\title{
Wagner and "Grand" Opera: Performing the Nation Through Embodied Sonorous Spectacle
}

\author{
by \\ Daniel James Sheridan \\ B. Mus. (Honours) Music (McMaster University), M.A. Music Criticism \\ (McMaster University)
}

A thesis submitted to the Faculty of Graduate and Postdoctoral Affairs in partial fulfillment of the requirements for the degree of

Doctor of Philosophy

in

Cultural Mediations

Carleton University

Ottawa, Ontario

(C) 2013

Daniel James Sheridan 
Library and Archives

Canada

Published Heritage

Branch

395 Wellington Street

Ottawa ON K1A ON4

Canada
Bibliothèque et

Archives Canada

Direction du

Patrimoine de l'édition

395 , rue Wellington

Ottawa ON K1A ON4

Canada
Your file Votre référence

ISBN: 978-0-494-94556-8

Our file Notre référence

ISBN: 978-0-494-94556-8
NOTICE:

The author has granted a nonexclusive license allowing Library and Archives Canada to reproduce, publish, archive, preserve, conserve, communicate to the public by telecommunication or on the Internet, loan, distrbute and sell theses worldwide, for commercial or noncommercial purposes, in microform, paper, electronic and/or any other formats.

The author retains copyright ownership and moral rights in this thesis. Neither the thesis nor substantial extracts from it may be printed or otherwise reproduced without the author's permission.
AVIS:

L'auteur a accordé une licence non exclusive permettant à la Bibliothèque et Archives Canada de reproduire, publier, archiver, sauvegarder, conserver, transmettre au public par télécommunication ou par l'Internet, prêter, distribuer et vendre des thèses partout dans le monde, à des fins commerciales ou autres, sur support microforme, papier, électronique et/ou autres formats.

L'auteur conserve la propriété du droit d'auteur et des droits moraux qui protege cette thèse. $\mathrm{Ni}$ la thèse ni des extraits substantiels de celle-ci ne doivent être imprimés ou autrement reproduits sans son autorisation.
In compliance with the Canadian Privacy Act some supporting forms may have been removed from this thesis.

While these forms may be included in the document page count, their removal does not represent any loss of content from the thesis.
Conformément à la loi canadienne sur la protection de la vie privée, quelques formulaires secondaires ont été enlevés de cette thèse.

Bien que ces formulaires aient inclus dans la pagination, il n'y aura aucun contenu manquant. 


\begin{abstract}
Richard Wagner famously ridiculed French grand opera as "effects without causes." His censure was that grand opera privileged spectacle and opulence at the expense of genuine artistic inspiration, a demerit he intended to avoid in his proposed "artwork of the future." But despite his profession of disdain towards grand opera, Wagner's works demonstrate a number of musical and dramaturgical concurrences with the traits of grand opera, including extreme length, large orchestras, extensive use of the chorus, and elaborate and technologically sophisticated scenic spectacle. Grand opera remained a prominent part of Wagner's compositional and dramatic aesthetic throughout his entire career. This dissertation considers Wagner's adaptations and transformations of the dramaturgy of grand opera, arguing that grand opera was effective in staging narratives of German nationhood upon performing bodies, focusing its analysis on the use of the grand opera chorus and the solo male performing body as representative of nineteenth-century German nationhood.

The individual arguments can be encapsulated as follows: the first chapter examines the intersections between the chorus, the city, and nationhood through the lens of the Weimar premiere of Lohengrin and the debut of Tannhäuser at the Paris Opéra. Chapter Two considers the importance of the grand opera chorus in Die Meistersinger and Parsifal in terms of positioning both works as examples of nineteenth-century Kunstreligion. Moving on to the male body, Chapter Three explores the Ring cycle's employment of myth and allegory in order to position male bodies as integral to its staging of the destruction of and subsequent renewal of the world. Chapter Four follows up by examining the Wagnerian tenor in the context of the "Christian" operas and how it is presented as the idealized form of the nation. The final chapter returns to Meistersinger, using the characters of Walther and Sachs to draw together many of the preceding ideas. Taken as a whole, the dissertation aims to show that grand opera is an essential element in Wagner's endeavours to construct uniquely German art.
\end{abstract}




\section{Acknowledgements}

This dissertation is the end result of approximately three years worth of research and writing. Such a project could not have come into being solely through my own efforts: a significant degree of assistance and support from a number of sources was essential in order to guide the following document into its present form. All deserve my gratitude.

My greatest thanks go to my supervisor, Dr. James Deaville whose invaluable comments and suggestions helped refine and strengthen my arguments in addition to cleaning and tightening up what was a frequently unwieldly first draft. Beyond his supervisory work, Dr. Deaville's status as one of the most prominent and widely-known musicologists in the field of nineteenth-century music provided any number of opportunities to meet and converse with other renowned scholars at various conferences. I am eternally grateful that he has always taken the opportunity to introduce me to his peers.

I also extend my gratitude to the other members of my dissertation committee, Dr. Paul Theberge and Dr. Murray Dineen and to my internal and external examiners, Dr. Alexis Luko and Dr. Thomas Grey respectively, for their own important insights. But even before there was a committee, or even a completed thesis proposal, there were my earliest attempts to outline the goals and research questions of this project. And so I am indebted to the participants in the "Interdisciplinary Research Methods" course taught by Chris Faulkner and to the participants and observers of the ICSLAC third-year colloquium for providing helpful feedback which enabled me to develop and refine my ideas about this project, beginning the process of pushing it towards the directions it would ultimately go.

In working through the various requirements for the Cultural Mediations program, I have spent a significant portion of my life at Carleton University. That time would not have seemed worthwhile without an atmosphere of intellectual and personal support. The faculty and the department of ICSLAC as well as my fellow students have come through with both over the years. I am exceptionally grateful for the friendships I developed with several of the ICSLAC students including, but not limited to Jessica Aldred, Matt Croombs, Kyle Devine, Thom Everrett, Murray Leeder, Heather Igloliorte, Paul Jasen, Stacey Loyer, Jeremy Maron, Steve Rifkin, Margaret Rose, Ben Wright, and Alex Wetmore. To them and all my other unnamed colleagues, I could not have made it through the rigors of this program without the amity you all so readily granted to someone who arrived in Ottawa knowing not a single person. The faculty and staff of Carleton's music department must not be overlooked for their offerings of support during my infrequent excursions to that side of campus. I must also give sincere thanks to all who have worked at the Carleton library and the Interlibrary Loans office over the years: it almost goes without saying (even though I will say it anyway) that I could not have put this document together without your invaluable resources.

Last but certainly not least, my thanks as always go to my family, particulary my parents David and Arlene Sheridan. This project could not have been completed without your love and support. I dedicate this dissertation to you. 


\section{Table of Contents}

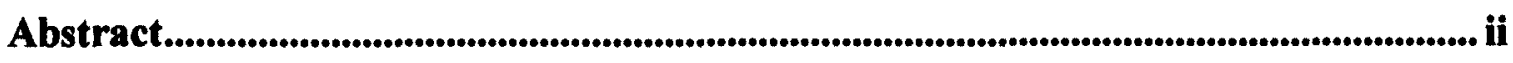

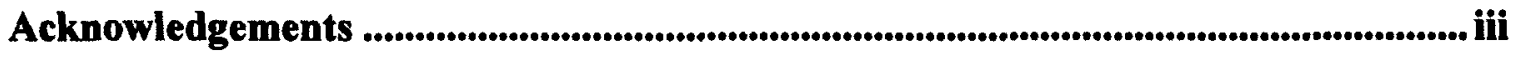

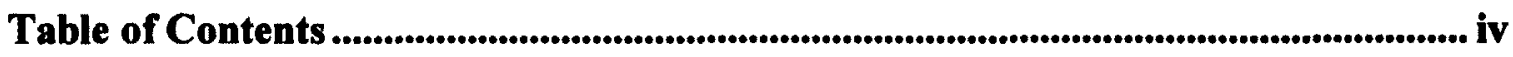

List of Abbreviations ................................................................................................................ vi

List of Illustrations............................................................................................................... vii

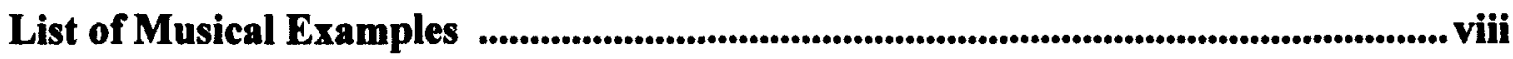

Introduction Wirkung mit Ursache?: Wagner's Grand Opera, the Body, and

German Nationhood .................................................................................................................................. 1

I.Vorspiel 1

II. The Nation $\quad 10$

III. The Body 25

IV. Volk Music $\quad 37$

V. Preview $\quad 49$

1 A Tale of Two Cities: The Weimar Lohengrin, the Paris Tannhäuser, and Choral

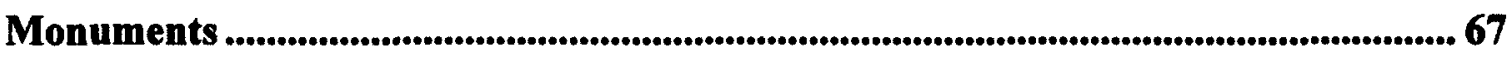

I. Monumental Premieres $\quad 67$

II. Paris and Grand Opera $\quad 78$

III. Wagner's Paris $\quad 91$

IV. Weimar's Two Golden Ages $\quad 97$

V. Weimar's Choruses $\quad 109$

VI. The Wartburg Comes to Paris 126

VII. Parisian Sickness and German Greatness 138

\section{Communal Sonorities: The Grand Opera Chorus, Kunstreligion, and Prolepsis}

in Die Meistersinger and Parsifal ........................................................................................... 157

$\begin{array}{ll}\text { I. Wagner's religious choruses } & 157\end{array}$

II. Nuremberg's proleptic Volk 165

III. Festspiel communities $\quad 180$

IV. Public benedictions $\quad 196$

V. Consecrating time and space 211 
3 Hearing the World End: Mythic Allegories and Male Bodies in the Ring ......... 235

I. Preliminary Remark $\quad 235$

II. Grand Myths 245

III. Grand Allegories $\quad 254$

IV. The Beautiful Hero 261

V. The God Says Goodbye $\quad 269$

VI. Uncanny Otherness $\quad 285$

VII. Heroic Apocalypse 302

4 Of the Tenor as Objet Petit a: The Imago, Heroism, and the Idealized Nation in

Lohengrin and Parsifal ................................................................................................................ 328

I. Wagner and Christianity 328

II. The Male Body as Imago 337

III. The Tenor and Grand Opera 347

IV. Wagner's Heroes $\quad 352$

V. Absolute Heroism 364

VI. The Pure Hero 383

VII. Dance of Regeneration 397

$\underline{5}$ "So alt, und war doch so neu": The Wisely Heroic and the Heroically Wise in

Die Meistersinger ............................................................................................................................... 414

I. Nuremberg's Two Heroes $\quad 414$

II. Walther Strikes Out $\quad 428$

III. Walther Wins 444

IV. And So Does Sachs 467

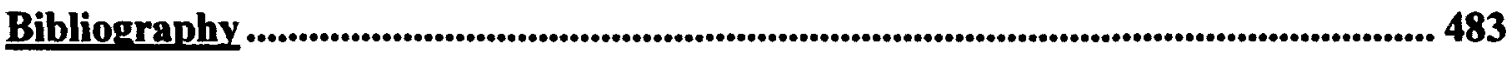




\section{List of abbreviations}

References to Wagner's various prose and epistolary writings are cited in the text using the following abbreviations:

CD Cosima Wagner's Diaries, ed. Martin-Gregor-Dellin and Dietrich Mack. Translated by Geoffrey Skelton; vol. 1: 1869-1877. London: Collins, 1978; vol. 2: 1878-1883. London: Collins, 1980.

CWL Correspondence of Wagner and Liszt, 2 vols. (1897). Translated by Francis Hueffer. New York: Greenwood Press, 1969.

DRW The Diary of Richard Wagner, 1865-1882: The Brown Book. Translated by George Bird. London and New York: Cambridge University Press, 1980.

ML My Life, ed. Mary Whittall (1983). Translated by Andrew Grey. New York: Da Capo Press, 1992.

PW Richard Wagner's Prose Works, 8 vols. (1892-1899). Translated by William Ashton Ellis. New York: Broude Brothers, 1966.

SL Selected Letters of Richard Wagner. Translated and edited by Stewart Spencer and Barry Millington. New York and London: W.W. Norton, 1988.

SSD Sämtliche Schriften und Dichtungen, Volks-Ausgabe, 16 vols. Leipzig: Breitkopf \& Härtel and C.F.W. Siegel (R. Linnemann), 1911 (vols. 1-12), 1914 (vols. 1316).

Page references throughout are given for the quotation's placement in both SSD and PW; although their stylistic deficiencies are well-noted, I have for the most part retained the translations from $\mathrm{PW}$.

WP Wagner Writes from Paris: Stories, Essays, and Articles by the Young Composer. Translated and edited by Robert L. Jacobs and Geoffrey Skelton. London: Allen and Unwin, 1972.

WR Wagner's Ring in 1848: New Translations of The Nibelung Myth and Siegfried's Death. Translated by Edward R. Haymes. Rochester, NY: Camden House, 2010. 


\section{List of illustrations}

3.1 p. 274 Drawing by Theodor Pixis, Munich 1869

(Wagner: A Documentary Study, Herbert Barth et al, eds. [New York: Oxford University Press, 1975], plate 169)

3.2 p. 280 Wotan - Franz Betz (1876)

(Wagner in Rehearsal 1875-1876: The Diaries of Richard Fricke, ed. James Deaville and Evan Baker [Stuyvesant, NY: Pendragon Press, 1998], plate 4)

3.3 p. 293 Alberich - Karl Hill

(Fricke, Wagner in Rehearsal, plate 8)

3.4 p. 294 Wagons in the first scene of Das Rheingold, viewed from behind the stage (Fricke, Wagner in Rehearsal, plate 29)

3.5 p. 324 Die Götterdämmerung III, 2 (final scene) (Josef Hoffmann)

(Fricke, Wagner in Rehearsal, plate 43)

4.1 p. 368 Illustrirte Zeitung, (Leipzig, April 12, 1851)

(Barth et al, Wagner: A Documentary Study [New York, 1975], plate 91)

4.2 p. 405 "Parsifal Healing Amfortas" (Franz Stassen)

(Oliver Huckel, Parsifal: A Mystical Drama by Richard Wagner Retold in the Spirit of the Bayreuth Interpretation by Oliver Huckel [New York, 1903], p. 57) 


\section{List of musical examples}

1.1 p. 115 Lohengrin $\mathrm{I} / 2$, mm. $384-390$

Vocal score arr. by Karl Klindworth (Mainz: B. Schott's Söhne, 1913)

1.2 p. 117 Lohengrin $\mathrm{I} / \mathrm{iii}, \mathrm{mm} . \mathbf{4 5 - 5 2}$

1.3a p. 142- Tannhäuser - Paris Version (1875) I/i, mm. 223-230

143 Vocal score arr. by Karl Klindworth (Mainz: B. Schott's Söhne, 1905)

1.3b p. 143 Tannhäuser - Dresden Version (1860), I/i, mm. 116-129

Vocal score arr. by Karl Klindworth (New York: G. Schirmer, 1895)

1.4 p. 150 Tannhäuser - Paris version II/iv, mm. 92-97

2.19 p. 184 "Dresden Amen"

2.1b p. 184 "Grail" theme from Parsifal

2.2a p. 185 Liszt, "Excelsior!" The Bells of Strasburg Cathedral

2.2b p. 185 "Communion" theme, Parsifal

2.3 pp. 203- Die Meistersinger von Nürnberg III/v, mm. 373-384

204 Vocal score arr. by Karl Klindworth (New York: G. Schirmer, 1904)

2.4 p. 210 Die Meistersinger III/v mm. 1092-1100

2.5 p. 219 Parsifal I/ii, mm. 42-47

Vocal score arr. by Karl Klindworth (Mainz: B. Schott's Söhne, 1902)

2.6 p. 222 Parsifal $\mathrm{l} / \mathrm{ii}, \mathrm{mm} . \mathbf{6 6 - 7 0}$

2.7 p. 225 "Mitleid" theme

2.8a p. $232 \quad$ Parsifal III/ii, mm. 248-250

2.8b p. $232 \quad$ Parsifal III/ii, mm. 251-254

3.1 p. 279 "Sword" motive

3.2 p. 296 Das Rheingold scene 1, mm. 178-185

Vocal score arr. by Karl Klindworth (New York: G. Schirmer, 1904)

3.3 p. 300 Das Rheingold scene $1, \mathrm{~mm} .672-683$ 
3.4 p. 308 Siegfried IV/ii, mm. 580-586

Vocal score arr. by Karl Klindworth (New York: G. Schirmer, 1904)

4.1 p. 369 Lohengrin $\mathrm{I} / \mathrm{iii} \mathrm{mm} .41-44$

4.2 p. 378 Lohengrin $\mathrm{IIL} / \mathrm{iii}, \mathrm{mm}$. 364-373

4.3 p. $400 \quad$ Parsifal $\mathrm{II} / \mathrm{ii}, \mathrm{mm} . \mathbf{1 4 0 - 1 5 5}$

4.4 p. $407 \quad$ Parsifal $\mathrm{III} / \mathrm{ii}, \mathrm{mm} .175-178$

5.1 p. 433 Die Meistersinger L/iii, mm. 721-728

5.2 p. 457 Die Meistersinger III/v, mm.825-841 


\section{Introduction}

\section{Wirkung mit Ursache?: Wagner's "Grand" Opera, the Body, and}

German Nationhood

\section{Vorspiel}

"Wirkung ohne Ursache," or "effects without causes": that is the descriptor Wagner uses in his 1851 treatise Opera and Drama to diagnose the prevailing characteristics of French grand opera." In a later essay, "A Glance at the German Operatic Stage of Today" (1873), Wagner maintains a streak of vituperation for French musical and theatrical practices. He observes that modern German singers all too frequently demonstrate absorption of the "lessons" of the "Meyerbeerian school" where thrilling "effect" prevails over all concerns with the dramatic integrity of the work. ${ }^{2}$ And yet, in A Communication to My Friends (1851), during a recounting of his composition of Rienzi (1840), Wagner recollects that " $\square$ 'Grand Opera' with all its scenic and musical display, its sensationalism and massive vehemence loomed large before me....” As such, when composing Rienzi, he resolved "not merely to copy" grand opera's opulence, "but with reckless extravagance to outbid it in its every detail." This goal became "the object of [Wagner's] artistic ambition." ${ }^{3}$ Clearly there was a time in Wagner's life when the precepts of French opera were not considered anathema to his aesthetic, and indeed grand opera's dramaturgy and its specific musical tendencies were seen as quite useful for Wagner's purpose. In other words, when Wagner was conceiving and composing Rienzi, grand opera was decidedly not a corrupting influence on "proper" German culture for him.

'SSD III, 301; PW II, 95.

${ }^{2}$ SSD IX, 271-276; PW V, 270-274.

${ }^{3}$ SSD IV, 258; PW I, 299-300. 
Wagner had a number of reasons, ranging from financial to personal and artistic, for not proclaiming the antipathy for French grand opera that would later manifest during the late 1830 s and early 1840 s. I will address some of those reasons later on, but before moving into any substantive discussions, it would behoove me to backtrack slightly and offer the reader a brief reminder of just what constitutes the musical and dramaturgical "ingredients" of grand opera. As has been well-documented by such scholars as M. Elizabeth C. Bartlet, David Charlton, Jane Fulcher, Hervé Lacombe and Karin Pendle among numerous others, "grand opera" denotes a form of musical theatre presented at the institution that bore several official names, but was colloquially known as the Paris Opéra. ${ }^{4}$ In short, the genre was dramaturgically quite rigid, generally consisting of a fiveact structure, utilizing a historically based plot, and calling for musically and scenically elaborate tableaux in the form of large orchestral forces (deployed in both the orchestra pit and through such effects as off-stage instrumentation) and choral scenes, a ballet in the third act, lavish costumes and sets, and extreme length. As Mark Everist notes, deviation from these codified components were done at the composer's and/or librettist's peril; speaking specifically of the necessity for a ballet, he observes that those that failed to conform to this requirement was subject to harsh disapproval from audiences and press alike. $^{5}$

\footnotetext{
${ }^{4}$ M. Elizabeth C. Bartlet, "Grand opéra," Oxford Music Online (accessed July 15, 2012); Karin Pendle, Eugène Scribe and French Opera of the Nineteenth Century (Ann Arbor, MI: UMI Research Press, 1979); Jane F. Fulcher, The Nation's Image: French Grand Opera as Politics and Politicized Art (Cambridge: Cambridge University Press, 1987); David Charlton, "On the Nature of 'Grand Opera," Hector Berlioz: Les Troyens, ed. Ian Kemp (Cambridge: Cambridge University Press, 1988), 94-105; Hervé Lacombe, The Keys to French Opera in the Nineteenth Century, trans. Edward Schneider (Berkeley: University of California Press, 2001); David Charlton, ed. The Cambridge Companion to Grand Opera (Cambridge: Cambridge University Press, 2003).

${ }^{5}$ Mark Everist, Giacomo Meyerbeer and Music Drama in Nineteenth-Century Paris (Aldershot, UK: Ashgate, 2005), 11.
} 
At first glance then, if grand opera requires specific musical and dramaturgical traits in order to be called "grand opera," it might appear to be wholly inappropriate to investigate Wagner's corpus of work through the lens of this form. Wagner's "canonized" works would appear to eschew as many conventions of grand opera as they embrace. ${ }^{6}$ Choruses, for example are either highly limited in their use or absent altogether in Tristan und lsolde and the first three stages of the Ring cycle; ensemble writing, quite ubiquitous in grand opera (and it must be admitted, most other operatic forms as well), is frequently avoided by Wagner; ballet is not obviously present in most of Wagner's work, with the clear exceptions of the Bacchanale in the Paris version of Tannhäuser and the prelude to the third-act song contest of Die Meistersinger. The typical Wagnerian opera/"music drama"/Bühnenfestspiel thus cannot be classified as grand opera, according to any textbook definition. Dieter Borchmeyer, in tracing the path of Wagner's aesthetic development that took him from Rienzi to so-called music drama, ${ }^{7}$ is rather adamant in divorcing Wagner's work post-Rienzi from grand opera, arguing that Wagner's turn towards myth as dramatic subject matter as opposed to history serves as a major signal that Wagner's work should not be included within the ranks of grand opera. ${ }^{8}$

But for as eager as Borchmeyer appears to be to divorce Wagner's compositions from grand opera, he nonetheless acknowledges that "the outlines of grand opera can still be glimpsed through the structures of his musical dramas." $\mathrm{He}$ could hardly argue otherwise, as it cannot be denied that Wagner's works clearly appropriate several aspects

\footnotetext{
${ }^{6}$ The "canonized" works are those from Der fliegende Holländer onwards; in other words those operas that are regularly performed to this day around the world, and particularly those that are sanctioned for performance at the annual Bayreuth Festival.

"Music drama" itself was a rather contentious label that Wagner would come to disavow in his essay "On the Name 'Musikdrama." See SSD DX, 302-308; PW V, 299-304.

${ }^{8}$ Dieter Borchmeyer, Drama and the World of Richard Wagner, trans. Daphne Ellis (Princeton, NJ: Princeton University Press, 2003), 72-78.

9'Ibid., 77.
} 
of grand opera, protracted length being the most obvious. Beyond matters of length, Wagner's musical dramas are characterized by other musical and dramatic qualities characteristic of grand opera: large orchestras and frequent use of off-stage instrumental effects, elaborate sets and technologically demanding stage effects and scene changes, and frequent employment of ceremonial crowd scenes and processionals that require a chorus. ${ }^{10}$ Patrick Carnegy, speaking more to the visual aspects than the music, writes that "the scenic virtuosity of grand opera was to have a much more lasting impact on both the conception and the scenic intention of Wagner's mature works than its carefully calculated texts and obedient music. Indeed, a large part of his persistent ambition was to achieve in German theatres the kind of scenic magic which had so impressed him in Paris."11 Wagner wished to repurpose what he saw as the empty extravagance of French opera, to place its theatrical grandeur and technological sophistication at the service of his aesthetic of the "drama of the future." In grand opera, Wagner saw a kernel of that which could be utilized to form a uniquely German work of art. If its immensity could amount to more than mere size, if its visual splendour could be mobilized for more than mere spectacle, and if its music could be epic without being overblown, then grand opera could be made into an all-encompassing drama that would serve as a monumental testament to the greatness of German art. Far from rejecting grand opera completely, it is my contention that in his expansion of the orchestra, his demanding new forms of solo and choral singing, and the complexity of his stagecraft, Wagner took grand opera further than anyone had previously imagined.

\footnotetext{
${ }^{10} \mathrm{Bartlet}$ establishes these aspects as characteristic of grand opera in the "Towards a definition" section of "Grand opéra."

${ }^{11}$ Patrick Carnegy, Wagner and the Art of the Theatre (New Haven and London: Yale University Press, 2006), 24.
} 
Wagner however purported to want no part of such supposed indulgences as size for the sake of size. And yet, Wagnerian drama evinces a penchant for the superlative as much as any other traditional grand opera. What is the difference? Principally, Wagner's post-Rienzi output, particularly those of Das Rheingold onwards, distinguish themselves in that each of them essentially pick and choose which aspects of grand opera that they intend to use; since some notable (and indeed vital) traits of the Parisian form are absent or at least not recognizable in these works, they cannot be classified as "grand operas" per se. This fact would allow Wagner to vouch for the originality of his creations. And yet, their massive scale continually acts as an element that pulls them back towards the realm of grand opera. Moreover, the clear debt that certain segments in each of these works show to numerous Parisian predecessors further clarifies that Wagner's statements of antipathy towards grand opera come across as examples of him protesting too much. Indeed, Thomas Grey notes that the legacy of French grand opera was a ghost "that had long haunted Wagner's memory" and that his relationship with the form was "a deeply conflicted one, artistically and psychologically" that stayed with him for much of his professional life. ${ }^{12}$ Grey's characterization of the form's lasting impact on Wagner as "haunting" is instructive and invites an interesting array of interpretations pertaining to his use of the genre's musical and dramaturgical conventions. As I shall argue throughout this document, Wagnerian "grand opera" is characterized not just by open embracement of its principles but also by adaptation and transformation of said principles. In more than one case that will figure into these discussions, the transformation is so extensive that one would be required to metaphorically squint in

\footnotetext{
${ }^{12}$ Thomas S. Grey, "Richard Wagner and the Legacy of French Grand Opera," The Cambridge Companion to Grand Opera, ed. David Charlton (Cambridge: Cambridge University Press, 2003), 322.
} 
order to register the lineage to grand opera. But nonetheless, that lineage is still there. As it so happens, Wagner's transformations cut to the heart of what I will argue was Wagner's project: I refer back to Carnegy's statement that Wagner was "impressed" by the elaborate spectacle of Parisian opera and saw potential use for it in fashioning a theatrical presentation that could similarly galvanize German audiences. In repurposing grand opera's dramaturgy, by incorporating and transforming certain elements and leaving out others, Wagner could press forward, secure in the conviction (not erroneous, I hasten to add) that he was putting together something altogether new and distinctive. In creating art that displayed the sheen of newness all the while steeped in the influences of prevailing forms - "so old and yet so new," to invoke Hans Sachs' diagnosis of Walther's Trial Song in Die Meistersinger - Wagner, I am contending, effectively hit upon a winning formula that he would continually deploy to varying degrees throughout his career in order to craft an ostensibly unique form of theatre that would stand as a representation of the spirit of German art.

By appropriating grand opera in this fashion, I will argue that Wagner took advantage of its dramaturgy and its various musical spectacles in order to stage German nationhood. The "grand" in grand opera is proved to be significant, to contribute vital political and cultural meaning in that such "grandness" is instrumental in placing a particular image of the German nation on the stage. This image revolves in large part around Alexander Rehding's study of "monumentality" in the music of nineteenthcentury Germany. ${ }^{13}$ Subsequent chapters of this dissertation will explore Rehding's ideas in greater detail, but at the present time, I will propose that one could posit that the

\footnotetext{
${ }^{13}$ Alexander Rehding, Music and Monumentality: Commemoration and Wonderment in Nineteenth-Century Germany (Oxford and New York: Oxford University Press, 2009).
} 
magnitude that Wagner's works display serve to bequeath a commensurate degree of scale to German art. Musical and dramatic "monumentality" essentially disseminates narratives of enormity to its prospective spectators, with that enormity being efficacious in constructing the work and its performance as an epoch, a pivotal moment that fundamentally changes the course of German art. However, it should be noted that such assertions act as a supplement, if not a corrective to Rehding's framework: in exploring the aesthetics of monumentality in the music and culture of nineteenth-century Germany, Rehding engages with the Wagnerian canon only indirectly. For example, Rehding deals with piano arrangements of selections from Tannhäuser rather than Wagner's score itself. $^{14}$ One would expect Wagner's dramatic works to be placed at the forefront of a study of the phenomenon of monumentality and commemoration in German music. Yet Rehding seems to sidestep the issue. Moreover, Rehding seldom annotates the exchanges with non-German forms of musical monumentality, French grand opera in particular. This is where my own study endeavours to fill those gaps: as I shall demonstrate, the "monumentality" of Wagnerian grand opera is thus set up to exploit its sense of size in order to function as a monument to the magnitude and grandeur of the German nation.

Of course, "size" and grand opera should not be understood as strict synonyms for each other, since it is quite possible for an opera to be of considerable musical and visual scale and yet not be grand opera, if it does not display enough of the requirements of the form. As such it is necessary to clarify that as one reads through this document, it should be kept in mind that my intent is to discuss Wagner's grand opera as "grand opera" and "grand" opera. Sometimes both mean the same thing, and sometimes not: in many cases, the musical and scenic examples I shall draw attention to emphasize their sense of ${ }^{14}$ Ibid., 84-105. 
magnitude at the expense of their connection to the typical hallmarks of Parisian dramaturgy. What unites all of my examples is the focus on that sense of size, whether the drama is enlarged by specifically "grand opera" or simply by "grand" opera. Grand opera/"grand" opera is employed by Wagner to stage depictions of Germanic myth and legend - another of Wagner's transformations of the genre, eschewing grand opera's traditional reliance upon historical settings for its plots - which serves to infuse said myths and legends with a sense of enormous scale. This, I will argue, complements Wagner's veneration of myth as a communicator of the "true" German spirit. Carnegy aptly summarizes Wagner's thoughts on the power of myth:

for Wagner the important thing about myth was that its truths were true for all time...the gods and demons of mythology were...the defining archetypes of human thought and feeling... Wagner hoped that myth-based drama was the most powerful means for addressing the deepest problems of the age and that it would help to bring about a new and better kind of society. ${ }^{15}$

In Wagner's estimation, myth was the stuff of social rejuvenation and reunification; by investing myth - and I am also including the medieval legends that incorporate Christian narratives and iconography under that banner - with the capacity to unify and transform society, Wagner ascribed to it a power, a magnitude that assigned a sense of all-encompassing size that allowed it to tap into a shared cultural consciousness. In representing that collective identity, a new social and political collectivity could be brought into being. By putting grand opera and its tendency towards enormity at the service of myth, Wagner effectively finds a musical and dramaturgical analogue for myth's cultural "size." Taken together, myth and grand opera combine to create a particular kind of "monumentality" that glorifies the "supremacy" of German mythology and the art used to transmit its transformative power to the people witnessing it.

\footnotetext{
${ }^{15}$ Carnegy, 47.
} 
One of the primary instruments in terms of disseminating this superlative state is that of the performing body; the two types of bodies that I will focus on are the mass body that is the grand opera chorus and the male body, with the Wagnerian tenor role positioned as a figure of particular gravity. In both cases, I intend to engage with these bodies as sonorities in order to interrogate how they function within the context of the aforementioned confluence of myth and grand opera. The contention that will thread itself through all of the discussions to follow is that by being placed within the superlative context of Wagnerian grand opera, these bodies are thereby magnified, enlarged to an appositely "grand" state that allows them to function as somatic vehicles for the transmission of narratives of German nationhood. In other words, the performing body serves as a constellation of spectacle that encompasses grand opera and German myth upon which the national identity is staged.

I have just laid the basic positions that this dissertation will take. The remainder of this introductory chapter will endeavour to account for various theoretical and historical modes of analysis that provide the basis for thematizing grand opera and the performing body as complementing strategies for bringing national narratives into being. These ideas provide the theoretical foundations that will inform the analyses and interpretations of the subsequent chapters of this dissertation; I will introduce them here in this introduction so that the chapters can proceed directly into their specific arguments without the added burden of establishing the theory. While the chapters will not always directly invoke the discourses introduced in the following pages, it should be understood that these ideas persistently thread themselves into the dissertation as subtexts that are ever-present. 
The introduction shall proceed along the following trajectory: I will begin by discussing various critical and theoretical frameworks that centralize the historicized, discursive, and performative qualities of the nation. I will follow up by demonstrating the performing body's efficacy as a stage for national identity. Following these more theoretical discussions will be a more historical-based analysis, focusing on the ongoing efforts in the nineteenth century to cultivate a uniquely "German" form of opera. After a preview of each of the subsequent chapters' specific arguments, this introduction will conclude with a brief discussion of Rienzi, the work that demonstrates the greatest propinquity to traditional grand opera. This appraisal will serve as a preview of some of the arguments that the rest of the dissertation will make. By the close of these introductory pages, it should be made clear that this project will be proceeding from the position that the nation is a discursive category that is primarily performed and produced, with Wagner's version of grand opera as staged upon the choral and male body acting as particularly potent agents in giving life to such a category.

\section{The Nation}

In proposing a model of analysis that situates the body as a stage for the production of nationhood, my forthcoming analyses are steeped within a number of critical frameworks that foreground the nation as a category that has no ontological basis. Rather than arising out of juridical, geographical, and/or political considerations, these hermeneutical models instead make a case for the nation as category that originates out of numerous historical and discursive issues. Delving into the varied paradigms that thematize nation as a category that is constructed out of strategies of historicization, we find the approach of the historian Eric Hobsbawm, whose contention that the concepts of 
discrete nations and nation-states are the result of "inventions of tradition." The invented tradition of the nation tends to situate nations as "rooted in the remotest antiquity, and the opposite of constructed, namely human communities so 'natural' as to require definition other than self-assertion." ${ }^{.17}$ Such inventions allow national identities to be framed as stable, strengthened by a common heritage that maintains lineage back centuries to the most inchoate periods of the culture's history, to the point that the nation more or less exists outside of history, so long-standing that it exists as an a priori fact.

Hobsbawm goes on to identify a number of common strategies for inventing traditions that are effective in crystallizing nationhood. They are, in order: "the development of a secular equivalent of the church"; "the invention of public ceremonies"; "the mass production of public monuments." Hobsbawm primarily uses France, particularly during the eras of the French Revolution and the Third Republic, to illustrate his concepts. I will bypass the first strategy and direct attention to the latter two, which both find expression in the Paris Opéra throughout the nineteenth century. Richard Taruskin notably claims that "the Parisian predilection for the 'monster spectacle' was a direct reflection of France's self-image as the great political monolith of Westem Europe." ${ }^{\prime 9}$ His words paint a picture of grand opera's function as an ostentatious display of the enormity and grandeur of French culture, which in turn would tend to position the institution that housed these productions as a major hub of Parisian and French society. Fulcher's and Lacombe's studies (among others) bear out such a supposition, with

\footnotetext{
${ }^{16}$ Eric Hobsbawm and Terence Ranger, eds. The Invention of Tradition (Cambridge and New York: Cambridge University Press, 1983); Hobsbawm, "The Nation as Invented Tradition," Nationalism, eds. John Hutchinson and Anthony D. Smith (Oxford and New York: Oxford University Press, 1994), 76-83.

${ }^{17}$ Hobsbawm, "The Nation as Invented Tradition," 76.

${ }^{18}$ Ibid., 77-78.

${ }^{19}$ Richard Taruskin, The Oxford History of Western Music - Volume 3: Music in the Nineteenth Century (2005) (Oxford: Oxford University Press, 2010), 206.
} 
Fulcher in particular detailing the state subventions and commercial popularity with the aristocratic and bourgeois classes that solidified the Opéra as a prominent political and cultural hub for French culture. ${ }^{20}$ As such, one could profitably map Hobsbawm's points onto the Paris Opéra in order to conceive of the grand opera as a "public ceremony" and the Opéra as a monument. Performances of grand opera can be thought of as serving a ceremonial function, a publicized celebration that allowed the Parisian citizenry (at least those who could afford tickets) to assemble in order to witness a multimedia celebration of France's artistic and cultural majesty, one that attracts talent from all over Europe. As the structure that houses these festivities, the Opéra functions as a public monument that stands as a symbol of the institution's hallowed place in French culture and of its importance as a representation of one of the pinnacles of achievement and success for European operatic composers, librettists, and performers.

Appropriately enough, given the intentions of my project, Hobsbawm offers up German inventions of tradition as a contrast to those practiced by France. In particular, he focuses on the practices of the Second German Empire (which found its initiation under Wilhelm I and the Chancellorship of Bismarck in the aftermath of the FrancoPrussian War of 1871), and to a lesser extent the invented traditions of pre-1848 Germany, not coincidentally the periods during which Wagner produced a significant portion of his most enduring work. However, Hobsbawm attributes much of the Second Empire's invention of tradition to the reign of Wilhelm II, who ruled during the late nineteenth century, after Wagner's death. Nonetheless, Hobsbawm's discussion merits some brief commentary. He maintains that the primary strategy on the part of Wilhelm II - the successor to Wilhelm I - for inventing tradition was to construct historical,

\footnotetext{
${ }^{20}$ Fulcher, $1-10$ and $47-121$.
} 
ideological, and spiritual continuities between the Second Empire and the original Holy Roman Empire, thereby naturalizing the Second Empire as a restoration of the nation's glorified history and "a realization of the secular national aspirations of the German people....".21 Part of this endeavour to link the two empires was an effort to legitimize the regime's Prussian origins by conflating Prussia with the entirety of the German nation through an invention of lineage between the Holy Roman Empire and the Prussian kingdom. ${ }^{22}$ Hobsbawm offers that the Second Empire's methods of inventing traditions functioned as a "fusion between the older romantic 'invented tradition' of pre-1848 German nationalism and [that of] the new régime" through its emphasis on buildings and monuments and their efficacy as symbols of German supremacy. As this dissertation unfolds, the characteristics of that "older romantic" model will be further explicated, but for the moment, let it suffice to summarize that one of the more significant of the preSecond Empire invented traditions is the foregrounding of art as expressive of the core of the German character; this tradition, as shall be shown, clearly manifests itself in Wagner's sundry essays and treatises, which advocate for art as being infused with the very essence of the German people and the best hope for the revitalization of German society.

Hobsbawm concludes his discussion of the nation as invented tradition with a comparison and contrast of the French and German models. I quote at length:

Both stress the founding acts of the new régime - the French Revolution in its least precise and controversial episode (the Bastille) and the Franco-Prussian war. Except for this one point of historic reference, the French Republic abstained from historical retrospect as strikingly as the German Empire indulged in it. Since the Revolution had established the fact, the nature and the boundaries of the French nation and its patriotism, the Republic could confine itself to recalling

\footnotetext{
${ }^{21}$ Hobsbawm, 79.

${ }^{22}$ Ibid., 79-80.
} 
these to its citizens by means of a few obvious symbols...Since the 'German people' before 1871 had no political definition of unity, and its relation to the new Empire (which excluded large parts of it) was vague, symbolic or ideological, identification had to be more complex and...less precise. Hence the multiplicity of reference, ranging from mythology and folklore...through the shorthand cartoon stereotypes to definition of the nation in terms of its enemies. Like many other liberated 'people', 'Germany' was more easily defined by what it was against than in any other way. ${ }^{23}$

Not all of this has much to do with Wagner - although Hobsbawm's underlining of the importance of mythology and folklore to the solidification of German traditions and heritage will prove to be quite central to Wagner's own politics and aesthetics, as Chapters Three and Four in particular will show. Hobsbawm's annotation of the various constructions of German heritage in the nineteenth century nevertheless amply demonstrates that his conception of the invention of tradition proves efficacious in transferring the category of nation from the realm of the ontological into that of the discursive and the historical. As I delve into Wagner's specific dramatic works and their engagement with various mythological and historical figures, it can be argued that through the creation and dissemination of these works, Wagner is doing his part to construct the German nation by (re)inventing traditions, strengthening the German people's connection to their collective heritage through his art.

Why would state powers and the populations they govern wish to invent traditions that solidify in national identities to begin with? To address that query, Benedict Anderson's noted study on the origins and spread of nationalism puts forth the postulate that the "nation" is an "imagined community." ${ }^{24}$ Anderson's paradigm contends that individuals collectively imagine that they "belong" to something larger than themselves,

\footnotetext{
${ }^{23}$ Ibid., 82.

${ }^{24}$ Benedict Anderson, Imagined Communities: Reflections on the Origin and Spread of Nationalism Revised Edition (London: Verso, 1991).
} 
that they are united in a common place of residency that comes to be defined as the "nation." As Anderson puts it, the nation is "imagined because the members of even the smallest nation will never know most of their fellow-members, meet them, or even hear of them, yet in the minds of each lives the image of their communion."25 By collectively "imagining" that they are constituent parts of the larger whole that is the nation, individuals are provided with a way in which they can "know" the "fellow members": even when personal relationships do not exist, the construction of the nation grants an imagined connection between its constituent members, they "relate" to each other as parts of this "community."

For Anderson, one of the crucial events that laid the groundwork for the concept of nation to take root was the development of "print capitalism" in the eighteenth century. Mass publication necessitated that printing be done in "vernacular" languages rather than Latin, which in turn allowed for the development of "official" languages. But of course, had print capitalism exploited each and every vernacular, "it would have remained a capitalism of petty proportions" and the concept of the nation might not have developed. ${ }^{26}$ Anderson further explains that "the various idiolects were capable of being assembled, within definite limits, into print-languages far fewer in number."27 The necessities of mass publication dictated that regional idiosyncrasies such as dialects, colloquialisms, etc. be filtered out in order to create a common vernacular understandable by the widest number possible. In doing so, official languages were created, with each particular nation-state (as it would come to be understood) having its own distinct print-language. Print-languages laid the groundwork for distinct national identities to be created in three

\footnotetext{
${ }^{25}$ Ibid., 6.

${ }^{26}$ Ibid., 43.

${ }^{27}$ Ibid.
} 
ways: first, "they created unified fields of exchange and communication below Latin and above the spoken vernaculars...[people] became capable of comprehending one another via print and paper." Secondly, language acquired a new fixity, "which in the long run helped to build that image of antiquity so central to the subjective idea of the nation." Finally, print-capitalism "created languages-of-power of a kind different from the older administrative vernaculars." ${ }^{28}$ Print-languages were distinctive to particular countries/states: while, for example, there were numerous German vernaculars, there was only an "official" printed German. As a result, the language was not Prussian German, or Bavarian German, but simply German. Print-languages helped define "national" borders by distinguishing one print-language from another.

It is not overly difficult to conceive of how Anderson's centralization of the emergence of print culture as a potent force in the development of nationalism could be extended to encompass other forms of "mass" communication as the eighteenth century gave way to the nineteenth. The most obvious example as it pertains to opera is that the language in which the work is sung denotes the country from which it originated. Obviously this was not always an iron-clad rule as operas in Italian from the genre's inception in the sixteenth century through the eighteenth did not automatically signal that they were Italian operas (Mozart's - an Austrian's - "Da Ponte" operas provided an apt example of works in Italian by non-Italian composers). Indeed, Italian's ubiquity suggested that, at least as far as opera was concerned, it was a cosmopolitan language. However, as time wore on, lines became more conclusively drawn: by the nineteenth century, operas composed in German identified it as a German opera, just as operas composed in Italian, French, etc. denoted that they were products of their respective

${ }^{28}$ Ibid., 44-45. 
nations as well. ${ }^{29}$ Certainly, by the time of Wagner, the concerns over the creation of distinctly "national" operas had long since taken hold. ${ }^{30}$

But in the specific case of Wagner, it is not just the use of German text that solidifies his work as "German": in combination with the setting of German texts, Wagner's dramas also exploit various facets of Germanic legend and myth. The blending of German singing and German mythology that characterizes so many of Wagner's works sets down what amounts to a more "multimedia" version of Anderson's underlining of print-languages and mass publication: like eighteenth-century print culture, Wagnerian opera could be theorized as solidifying "national borders" through its linguistic content and mythic subject matter, showing itself to be uniquely and "authentically" German. Wagner's "music dramas" can thus be profitably read as contributing to an "imagined community" that is based in a shared linguistic, artistic, and mythic heritage which in turn allows for the belief in a cohesive national identity to be solidified anew.

The fact that Wagner represents this imagined community through music is also significant. As Celia Applegate and Pamela Potter explain, the nineteenth century saw the development of a particular imagined community which positioned music as a potent

\footnotetext{
${ }^{29}$ I stress "composed" to make the point that it is the original language that identifies the work as belonging to a particular nation; obviously German theatres, for example, performing Italian works with the libretto translated into German would not be very effective in using the German language to identify a "German" opera. Just the opposite, I would contend: the translation of an Italian work into German uses language to identify it as a "foreign" work, through the contrast of the new German text with the Italian nationality of the composer. In that sense, language serves to demarcate national borders in a different way: German singing counter-intuitively solidifies the work as Italian. This phenomenon plays out in interesting fashion when one considers the practices of the Paris Opera, where all presentations were required to be in French; foreign works were translated - such as Wagner's Tannhäuser in 1861 - but most interestingly, the institution commissioned non-French composers to create works for the Opera in French, with Verdi's original five-act version of Don Carlos one of the more enduring examples (to say nothing of the Germanborn Meyerbeer's contributions). Here, one could almost say that the French language subordinates other nationalities by necessitating, in Verdi's case, that an Italian composer adopts the French language.

${ }^{30}$ For example, see Stephen C. Meyer, Carl Maria von Weber and the Search for a German Opera (Bloomington, IN: Indiana University Press, 2003) for an appraisal of Weber's works in the early nineteenth century, as a part of a larger concern for the development of a uniquely "German" opera.
} 
communicator of German identity, to the extent that Germans were thought of as "people of music" and music as the "most German of the arts." music as a vital component of the German character shortly. It will be shown in greater detail later that in the nineteenth century, music became a powerful form of national imagining, a way to construct a unifying thread that bonds the population together as distinctly "German." In putting music at the service of the German language and Germanic legends, Wagnerian drama can be interpreted as a powerful representation of the imagined community of the German nation, a community that is constructed as finding its unifying forces in music, the "official" German language, and German myth.

Anderson, of course, is not the last word on frameworks regarding the ostensibly discursive nature of the nation. Homi Bhabha argues that Anderson's model, although useful in its acknowledgment that the nation is predicated on discourse, is ultimately flawed in that it does not sufficiently account for the "meanwhiles" and "in-betweens" of representation, "failing to locate the alienating time of the arbitrary sign in his naturalized, nationalized space of the imagined community." 32 Bhabha seeks to rectify this problem by putting forth the nation as an ambivalent and indeterminate category, perpetually worked out and subject to redefinition. Bhabha characterizes "the nations 'coming into being' as a system of cultural signification, as the representation of social life rather than the discipline of social polity." ${ }^{\prime 33}$ The nation has no a priori existence; rather, it is in a constant state of being written. As Bhabha argues, the nation is

\footnotetext{
${ }^{31}$ Celia Applegate and Pamela Potter, "Germans as the 'People of Music': Genealogy of an Identity," Music \& German National Identity, eds. Celia Applegate and Pamela Potter (Chicago and London: University of Chicago Press, 2002), 1-35.

${ }^{32}$ Homi K. Bhabha, The Location of Culture (1994), (London: Routledge, 2004), 231.

${ }^{33}$ Homi K. Bhabha, "Narrating the Nation," Nationalism, eds. John Hutchinson and Anthony D. Smith (Oxford and New York: Oxford University Press, 1994), 306.
} 
constituted through discourse, specifically through "textual strategies, metaphoric displacements, sub-texts and figurative strategems." ${ }^{134}$ Metaphors and tropes are continually articulated and take on textual meaning as ideas upon which nationhood is based. It is through the deployment of these metaphors that the fantasy of the nation takes shape, eventually reaching the point where the existence of the nation becomes accepted prima facie. Bhabha's paradigm stresses that it is the repetition of narratives such as nation - and its associated metaphors including "homeland," "mother-toungue," "Fatherland," etc. - that grants them that sense of historical legitimacy. However, the point is that these metaphors only have meaning in a linguistic system. The nation also exists in that system; it is a function of language. In framing the idea of the "nation" as being seemingly stabilized as a consequence of repeated deployment of the language of nation and nationalism, Bhabha proposes that the nation is a fundamentally performative category.

Because of its performative status, the nation is perpetually transitory, characterized not as a homogeneous whole, but made of contradictions, complexities, and in-betweens. From this conception of the nation comes the notion of the "people" who are "not simply historical events or parts of a patriotic body politic... [but] are also a complex rhetorical strategy of social reference." ${ }^{, 35}$ The nation is an inherently liminal category in its status as being continually worked out and redefined, which can "no longer be signified as a 'sociological solidity' fixed in a succession of plurals... where social space is clearly bounded by such repeated objects that represent a naturalistic,

\footnotetext{
${ }^{34}$ Ibid., 307.

${ }^{35}$ Bhabha, The Location of Culture, 208.
} 
national horizon." ${ }^{36}$ As a consequence, the nation only has an illusion of stability; it is inherently unstable, subject to crisis as meanings become redefined through cultural and political shifts. It is for this reason that Bhabha posits the nation-space as existing "in the process of the articulation of elements: where meanings may be partial because they are in medias res. ${ }^{37}$ This is why Bhabha conceives of the nation as located within a series of "meanwhiles" and "in-betweens," residing in the interstices of representation, because it is in a constant state of being performed through language.

To relate the above to opera, we might interpret the processes of composition and performance as a form of "writing" the nation, where the use of certain musical gestures (the style of harmonic language, the use of thematic material, techniques of orchestration, etc.) are thought of as representing the character of a nation's music. But opera, like most musics, is created to be performed. Expanding Bhabha's framework somewhat, it can be argued that it is the repeated act of performing opera that brings nation into being. As an example, the annual performances at Bayreuth are simultaneously representative of and actively produce ideologies of German art and culture. ${ }^{38}$ Additionally, it is Bhabha's deconstructive framework, his argument for the liminality of the nation, which is productive for this project. His point that the modern nation emerged from exile, migration, and diaspora, is a reminder that the concept of nation "fills the void left in the uprooting of communities and kin, and turns them into the language of metaphor." ${ }^{39}$ In other words, the contention that the nation is continually "written," brought into being

\footnotetext{
${ }^{36}$ Ibid., 221.

${ }^{37}$ Bhabha, "Narrating the Nation," 308.

${ }^{38}$ Frederic Spotts provides a detailed account of the Bayreuth Festival's development into a German cultural institution in Bayreuth: A History of the Wagner Festival (New Haven and London: Yale University Press, 1994).

${ }^{39}$ Bhabha, The Location of Culture, 200.
} 
through discourse, is an argument for the nation's status as perpetually in transition and subject to redefinition. The repeated performances on the operatic stage similarly work to continually produce new images of the nation.

Bhabha's positioning of the nation as constituted through the repeated articulation of signs makes use of speech-act theory, specifically the performative statement which performs an action simply through its utterance..$^{40}$ These speech-acts require people - as individuals and as groups - to perform them in order for their meanings to be understood. The importance of performed actions by discrete persons in bringing concepts of nationhood into being opens a prominent window on another important aspect of the constructed nature of the nation. Barbara Gabriel explains that the nation is a "formation that serves an important mirroring function for the stability of the subject, in a relay of identifications that contributes to the fiction of coherence." Gabriel's statement is built upon the paradigm of the nation "as a phantasmatic or imaginary formation of the subject" which "remind[s] us that subjects do not so much belong to nations as nations belong to subjects." This formulation thematizes the nation as a "stabilizing fiction" for the subject, ${ }^{43}$ one which assists in granting the subject a sense of wholeness, plenitude, and coherence that was previously thought to be lacking. ${ }^{44}$ In the terminology of Jacques

\footnotetext{
${ }^{40}$ Speech-act theory finds origins in J.L Austen's seminal text How to Do Things With Words (Cambridge, MA: Harvard University Press, 1962).

${ }^{41}$ Barbara Gabriel, "The Wounds of Memory: Mavis Gallant's 'Baum, Gabriel (1935-),' National Trauma, and Postwar French Cinema," Essays on Canadian Writing 80 (Fall 2003): 200.

${ }^{42}$ Ibid., 212-123n6.

${ }^{43}$ Ibid., 212 n5.

${ }^{44}$ Discourses on "the subject," namely a being that is thematized as possessing a discrete consciousness and identity and is capable of having subjective experiences, are manifold. Kaja Silverman ably summarizes psychoanalytic conceptions of the formation of the subject (focusing on the models of Siegmund Freud and Jacques Lacan) in The Subject of Semiotics (New York and Oxford: Oxford University Press, 1983), 126193. Louis Althusser's seminal essay on ideology and the subject - which would prove to be influential on Lacan's own ideas - argues that subjects are formed by various "ideological state apparatuses" as a method legitimizing and naturalizing state power within the minds of subjects. See "Ideology and Ideological State Apparatuses (Notes Towards an Investigation)," Lenin and Philosophy and Other Essays (London: New
} 
Lacan, the nation functions as an example of the objet petit autre, the "little other," that unattainable object of desire that represents the "missing piece" that if acquired could make the subject whole again. ${ }^{45}$ Richard Dellamora and Daniel Fischlin effectively acknowledge as much when they state that "nations embody and refract desire." ${ }^{96}$ To go back to Anderson's framework, the desire for belonging to something larger than oneself speaks to a desire for a sense of selfhood that is complete and cohesive; for example, to say "I am Canadian" is as important to solidifying one's sense of identity just as much to say "I am male." To mythologize, imagine, or write the nation is to endeavour to find an avenue to stabilize subjectivity. Which is why much of this dissertation will focus on Wagner himself, studying how he "writes" the nation: textually in his various prose and epistolary writings and musically in his operas, with both foregrounding the body as a viable stage for German identity. One of the organizing principles of this project is that Wagner places performing bodies at the behest of his versions of grand opera in order to prop up his own subjective conceptions of German art and nationhood; this dissertation for the most part concerns itself with examining Wagner's own "stabilizing fictions" for performing bodies and the nation.

Left Books, 1971), 121-173. Michel Foucault has contended that subjects are formulated and extracted from the mass in order to create objects of knowledge as a method of naturalizing the mechanisms and practices of power. Paul Rabinow provides a handy summary of the various facets of Foucault's interrogation of the relationship between subjects and power in his introduction to The Foucault Reader, ed. Paul Rabinow (New York: Pantheon Books, 1984), 3-29. Foucault's own explorations of these issues may be found in The Order of Things: An Archaeology of the Human Sciences (1970) (New York: Vintage Books, 1994); Discipline and Punish: The Birth of the Prison, trans. Alan Sheridan (1977) (New York: Vintage Books, 1995); The History of Sexuality Volume I: An Introduction, trans. Robert Hurley (1978) (New York: Vintage Books, 1990).

${ }^{45}$ Jacques Lacan, The Four Fundamental Concepts of Psychoanalysis, ed. Jacques-Alain Miller, trans. Alan Sheridan (1977) (New York and London: W.W. Norton, 1981).

${ }^{46}$ Richard Dellamora and Daniel Fischlin, "Introduction," The Work of Opera: Genre, Nationhood, and Sexual Difference, eds. Richard Dellamora and Daniel Fischlin (New York: Columbia University Press, 1997), 2. 
The now-prevalent (and by no means limited to the previously cited authors) concept of the nation as a strategy for constructing personal and collective identities and subjectivities also finds expression in Pierre Nora's examination of what he calls "lieux de mémoire," or "places of memory," of which the nation could be considered an example. ${ }^{47}$ Nora defines a place of memory as "any significant entity, whether material or non-material in nature, which by dint of human will or the work of time has become a symbolic element of the memorial heritage of any community." between Nora's framework of memory as the preservation of a communal heritage and Anderson's notion of the imagined community as a construction of a shared heritage should not be hard to spot. It can be argued that in locating communities within individual and collective memories, Nora's model is more complex in its relationship to history than Anderson's, which tends to prioritize more concrete forms of dissemination, such as the aforementioned print culture, in order to solidify its narratives of nation and community. For Nora, the place of memory "is born out of a sense of crisis in the present.."49 Or as Nora puts it, "memory is constantly on our lips...because it no longer exists." 50 Places of memory represent our remaining opportunity to preserve the remnants of our past, to prevent them from disappearing completely from the present day and retreating forever into history. The place of memory then can be thought of as another avenue for the subject to construct a fiction of stability, by using memory to hold on to a sense of lineage to the past. This in turn imposes a feeling of continuity to one's

\footnotetext{
${ }^{47}$ Pierre Nora, "Between Memory and History: Les Lieux de Mémoire," Representations 26 (1989): 7-25; Realms of Memory: Rethinking the French Past (3 vols.), ed. Lawrence D. Kritzman (New York: Columbia University Press, 1996-1998).

${ }^{48}$ Realms of Memory, quoted in Rehding, Music and Monumentality, 12.

${ }^{49}$ Rehding, 12.

${ }^{50}$ Nora, Realms of Memory, quoted in Rehding, 12.
} 
history with the idea that connection to a continuing heritage adds a feeling of legitimacy to one's own selfhood.

Rehding adds that "it is these lieux de mémoire, which provide the community with a vital connection to its shared mythical past, that the idea of the nation could be built and sustained in the nineteenth century." ${ }^{11}$ This ostensible shared past coalesces into a narrative that underlines the connection that modern-day citizens maintain to the glorified past. The "nation" thus becomes a particularly powerful place of memory that fills the need for continuity with the subject's ancestry, both in terms of what $s /$ he shares with his/her forebears and what is shared with fellow subjects with whom $s /$ he interacts. Rudy Koshar expands upon the discourse of the nation as a product of memory writing: "memory serves not only to legitimize the nation historically but to give it a purchase on the future, to ground the nation in a historical narrative whose ending is even more ineffable than the beginning." 52 As Koshar sees it, memory imbues the nation with a sense of permanence, a fixture not only of the past - "real" and/or imagined - but of the future as well, to the point that its ending is completely unknowable, and indeed perhaps even unthinkable. To put it another way, "public memory looks forward as it directs its gaze backwards in time."’3 By looking back, collective memory locates within this shared mythic past a blueprint to ensure the endurance of that heritage well into the future, by constructing these places of memory that act as guarantors that the landmarks and epochs of the past cannot be forgotten.

\footnotetext{
${ }^{51}$ Rehding, 12-13.

${ }^{52}$ Rudy Koshar, Germany's Transient Pasts: Preservation and Memory in the Twentieth Century, quoted in Stephen McClatchie, "Performing Germany in Wagner's Die Meistersinger," The Cambridge Companion to Wagner, ed. Thomas S. Grey (Cambridge: Cambridge University Press, 2008), 136-137. See also Koshar, From Monuments to Traces: Artifacts of German Memory, 1870-1990 (Berkeley: University of California Press, 2000).

${ }^{33}$ Koshar, Germany's Transient Pasts, quoted in McClatchie, 136.
} 
Throughout this dissertation, we shall encounter numerous instances of Wagner and/or his compatriots making use of places of memory in order to insert his works into the supposedly-shared German heritage: Weimar, the Wartburg, Nuremberg and the Mastersingers' guild, the Rhine, the characters, locations, and events of Germanic myth and legend, all of these in one form of another will be thematized as "symbolic elements of the memorial heritage" of the German peoples. The Bayreuth Festspielhaus can also be framed as Wagner's venture to construct a German monument and place of memory of his own, one that houses the essence of the German artistic spirit, an idea that will manifest itself prominently during my discussions of the choruses in Parsifal in Chapter Two. I propose that Wagner exploits the power of these assorted German places of memory in order to build up the cultural significance of his own works. It could then be posited that Wagner "cashes in" the cultural prestige of those places of memory so as to elevate his operas to the level of German "memorials" in and of themselves, a supposition that gains plausibility when one observes some of the grandiose and epochal labels he affixes to his works: "drama of the future," "artwork of the future," Bühnenweihfestspiel, etc. As "places of memory," Wagner's operas act as commemorations of German identity through their assemblage of various pieces of cultural heritage and Wagner's own ideas about advancing German art. As such, theorizing Wagner as a place of memory can be grasped as another method of writing/performing the nation as a strategy for stabilizing the subject.

\section{The Body}

Locating the category of nation as a method of forming subjective identities sets up the next stage of my inquiry, which when combined with the earlier contention that 
nations "embody" desire and with Bhabha's framework of the performative status of the nation, opens a window on a potentially rich hermeneutical model. Bhabha's model offers the nation as that which requires a repeated act of writing and speaking in order to bring it into being. I propose that this model can be expanded to include repeated actions that serve to bring nation into being in addition to speech-acts; the nation is not just performative, it is performed..$^{54}$ Just as performativity necessitates repeated deployment of metaphors and tropes through writing and speech, the performed nation requires repetition of said performances in order to bequeath its image of the nation its fiction of coherence. Opera by its nature is predicated on the fact that it is conceived to be performed multiple times. In addition, opera is also of interest in its foregrounding of visible and audible performing bodies.

If we accept the framework that the nation is not an ontologically stable category but is instead brought into being through repeated performance, then it is not unreasonable to position the body as a viable stage for the production of nationhood. Supporting this contention are Richard Leppert's remarks at the outset of The Sight of Sound, where he observes that the body is both an object of vision as well as "a terrain, a land, as it were, both familiar and foreign...the geography of the body has both

\footnotetext{
${ }^{54}$ Such a distinction is based upon the understanding that "performativity" and "performance" are related but not synonymous: the former denotes an engagement in the activity of speech, specifically speech that performs actions, while the latter can encompass physical as well as verbal action. Being that both terms contain the root word "perform," the implication is that both contain a certain degree of artifice, neither portraying a "natural" state of being, but instead something that is "constructed" for display. The notion that "performativity" and "performance" are separate but related concepts is made manifest by the title of Andrew Parker and Eve Kosofsky Sedgwick's study of these two phenomena, especially their introduction, which endeavours to trace the potential distinctions and similarities between "saying" (performative) and "doing" (performance). Andrew Parker and Eve Kosofsky Sedgwick, eds. Performativity and Performance (New York and London: Routledge, 1995).
} 
topography and interiority, surface and depth, and all its levels are meaningful." ${ }^{55}$ The body having "geography" and "topography" are rather apt metaphors when contending that it can function as a stand-in for an entire land and its people, but most importantly such characterizations communicate the conception that the body is more than simply a physical presence and can be made to mean substantially more; the iconography of the body, how it is displayed, how one looks at it, and how one hears it in the case of musical performance, contains significant cultural and political currency. Mapped upon the images and sounds of bodies are the vicissitudes and complexities of sundry cultural tensions, encompassing such mutually implicated problematics as gender, race, class, age, and (dis-)ability, problematics that forthcoming chapters will show are all intertwined with the discourse of nation and nationalism.

Wagner himself positioned the body as vital ground for theorizing German nationhood. Marc Weiner summarizes that "for Wagner the body is the site in which the ideological becomes visible; it is both metaphor and physical reality, a vehicle for communicating abstract aesthetic and social concepts and, at the same time, a physiological manifestation of the purported veracity of the issues with which it is associated." 56 In terms of the visible body, Wagner used as his model the Ancient Greek theatre as a mirror for the audience, where spectators saw reflected in what was transpiring on the stage the essence of their own society. ${ }^{57}$ Wagner conceived of the drama of the future as operating along the same lines: authentic German art would be

\footnotetext{
${ }^{55}$ Richard Leppert, The Sight of Sound: Music, Representation, and the History of the Body (Berkeley: University of California Press, 1993), xix.

${ }^{36}$ Marc A. Weiner, Richard Wagner and the Anti-Semitic Imagination (1997) (Lincoln: University of Nebraska Press, 1995), 1.

${ }^{37}$ Ibid., 35-102. Wagner's idealization of the Greek Tragedy is also discussed by Jean-Jacques Nattiez in Wagner Androgyne: A Study in Interpretation, trans. Stewart Spencer (Princeton, NJ: Princeton University Press, 1993), 12-42.
} 
recognized by the Volk as such, creating an ideal community. The importance of seeing allows Weiner to argue that the bodies of the singers function as a map, a somatic image of the nation's essence. The performing body makes visible the German work of art, and by extension the German race. The audible body similarly provides an acoustic representation of the essence of the German people and their culture. The merging of both bodies in the context of operatic performance represents what could be considered a quintessential convergence of performance and the performative: the visual body provides the iconography and movements and gestures of performance while the audible body supplies the commensurate sounds that paint a sonorous picture of the nation's character. To reiterate, these account for the performance aspect. But the audible body uses sonority to transmit not just sound, but words as well, words that will be shown to communicate ideas and narratives about the nation. Proceeding from the position that singing represents a heightened form of speech, then the sonorous body performs the speech-acts that discursively bring tropes and ideologies of German nationhood into being and assist in granting them an illusion of stability. It is for that reason that I contend that the performing operatic body unites the performed and performative aspects of nationhood.

I will embark on a more detailed appraisal as to how the performing body potentially acts as a specifically acoustic stage for the production of nationhood especially as it functions within the context of grand opera - in the following chapters. Here I will provide some more general critical and theoretical discourses as to the body's import in the staging of the nation. Several of these ideas will not be specifically mentioned in this document; nonetheless the ideas presented here do serve to provide the 
critical, theoretical, and historical backbone that inform many of my interpretations and as such, it is necessary to account for them in these introductory passages so that they may be kept in mind as one reads through the investigations that follow. As stated earlier, this project will consider the national and nationalist implications of both the mass body of the grand opera chorus and the solo male body as particularly exemplified by the Wagnerian tenor role. In terms of the chorus, numerous scholars have underlined it in various forms of nineteenth-century opera as a particularly politicized instrument, one that was frequently mobilized to represent the voice of a collective with a political consciousness and will. Philip Gossett examines the chorus as exploited by the Italian opera of the Risorgimento and their tendencies towards statements advocating national unity, to the extent that the chorus could be considered as a sonorous embodiment of a mass movement towards Italian unification, or to paraphrase some of Gossett's own terminology, the voice of the massed citizenry. ${ }^{58}$ James Parakilas casts a broader net, drawing upon examples from Italian, French, German, English, and Russian opera in the nineteenth century to explore the political ramifications of the use of the chorus. ${ }^{59} \mathrm{He}$ examines the chorus both as a unified "voice of the people" and as a depiction of a divided citizenry, with competing (often violently so) political and social ideologies being given over to a chorus divided into contrasting sections. What links both Gossett's and Parakilas' readings are that they position the chorus as representative of "a whole people or nation, not a single class or party or profession; a people with a political destiny

\footnotetext{
${ }^{58}$ Philip Gossett, "Becoming a Citizen: The Chorus in Risorgimento Opera," Cambridge Opera Journal 2/1 (March, 1990): 41-64.

${ }^{59}$ James Parakilas, "Political Representation and the Chorus in Nineteenth-Century Opera," $19^{\text {sh }}$-Century Music 16/2 (Autumn, 1992): 181-202.
} 
of its own, not just a stake in the destiny of its ruler; a people whose political destiny is central to the dramatic action...."60

The chorus deploys multiple performing bodies on stage; given that both Gossett and Parakilas have characterized the chorus as a stand-in for an entire people, it is reasonable to thematize the chorus as an example of a mass body that performs and produces nationhood. Visually, the chorus displays the imagery of multiple bodies distributed across a circumscribed space creating the sight of a crowd, of a mass of people that one could interpret as a depiction of a population. However, in the chapters that follow I will direct my focus towards the chorus as a massed sonority, of a multitude of voices at once performing in harmony and counterpoint, the sound of an entire culture, often unified but just as frequently consisting of contrasting subcultures competing against each other. The sonority of society and community packages verbal (or performative) messages that bring the ideologies and narratives of nation into being, ranging from liberation from oppression to glorifications of community. The grandeur of the enhanced size of the grand opera chorus, the increased prominence and complexity of choral sequences, and the elaborate juxtapositions of choral and solo singing combine with their language (under Anderson's paradigm, one of markers of the nation's unique identity) and textual contents in order to push the political charge of the chorus's presence to the forefront, to conspicuously map the sights and sounds of the nation onto one massed body.

In The Artwork of the Future (1849), Wagner devotes a fair amount of space towards valorizing the beautiful male body as an ideal object for representation by art, and indeed as a work of art in and of itself. During the passage "The Art of Sculpture," ${ }^{60}$ Ibid., 189. 
Wagner writes that "the beauty of the human body was the foundation of all Hellenic Art, nay even of the natural State." He then goes on to state that sculptures representing the Doric Spartans, the "noblest" line of the Hellenic age exhibited the best of Ancient Greek society. "This beauteous naked man," Wagner writes, "is the kernel of all Spartanhood: from genuine delight in the beauty of the most perfect human body, that of the male, arose that spirit of comradeship which pervades and shapes the whole economy of the Spartan State." ${ }^{\prime 61}$ Clearly, in the beautiful male body, Wagner invests the very character of the Greek state and its culture. Extrapolating from the contextualization of this discussion within a blueprint for a proposed work of art that revitalizes the German culture through its engagement with the spirit of the German Volk, it is apparent that Wagner's aesthetic placed significant prominence upon the pulchritude of the male body as an emblem of the overall health of a society and its constituent art and culture. ${ }^{62}$ As 1 will demonstrate - particularly in Chapters Three and Four - the physical and acoustic excellence of Wagner's "heroes" provide the supplest stage upon which his narratives of the idealized form of the German nation may be mapped.

Wagner's ostensible foregrounding of the male body in his paradigm of nationhood effectively prefigures the many critical and theoretical discourses that have examined the points of contact between constructions of gender and those of the nation. In terms of music, Ian Biddle has been a prominent scholastic voice in exploring issues of

\footnotetext{
${ }^{61}$ SSD III, 134; PW I, 168.

${ }^{62}$ Uli Linke's study of the prevalence of blood in numerous historical European conceptions of race and nationhood notes that in the Germanic discourses of the eighteenth and nineteenth centuries, the health of the body was frequently coded as a representation of such qualities as spiritual and moral health (or lack thereof). "Unhealthy" bodies and were frequently linked with corrupt and "degenerate" races (typically associated with an anti-Jewish agenda), while "pure" blood resulted in a suppler body, externalizing an altogether more virtuous race. Linke's study demonstrates a historical basis for the framing of the body as a representation of the health of a society. See Blood and Nation: The European Aesthetics of Race (Philadelphia: University of Pennsylvania Press, 1999), 157-196.
} 
masculinity in Western classical music. His volume (with Kirsten Gibson) Masculinity and Western Musical Practice endeavours to make clear music is and has been a prominent avenue for demonstrating that "masculinity and nation-state are inexorably linked in the modern European consciousness...."63 As Marcia Citron's essay therein makes clear, mutually implicated discourses of masculinity and nationalism were threaded into a great deal of the reception of music in nineteenth-century Germany. ${ }^{64}$ Although her primary focus is on the reception of Brahms, her insights are nonetheless instructive. Citron notes that one of the prominent legacies of Beethoven through the nineteenth century was as a musically masculine and "heroic" icon for the German identity, a legacy that subsequent German musicians were tasked with carrying on. ${ }^{65}$ Notably, Citron sheds light on the reception of Brahms' First Symphony, particularly on the part of Eduard Hanslick, who as she observes thematized the work as upholding an appropriately "masculine" ideal for German music in the symphonic realm. She also notes that "the First Symphony appeared shortly after The Ring tetralogy inaugurated Bayreuth, the shrine to Wagnerian music drama. This becomes another reason for Hanslick to position the masculine Brahms at the centre of the new nation and thereby

\footnotetext{
${ }^{63}$ Ian Biddle and Kirsten Gibson, "Introduction," Masculinity and Western Musical Practice, Ian Biddle and Kirsten Gibson, eds. (Farnham, UK and Burlington, VT: Ashgate, 2009), 135. See also Biddle, Music, Masculinity, and the Claims of History (Farnham, UK and Burlington, VT: Ashgate, 2011).

${ }^{64}$ Marcia J. Citron, "Gendered Reception of Brahms: Masculinity, Nationalism and Musical Politics," Masculinity and Western Musical Practice, Ian Biddle and Kirsten Gibson, eds. (Farnham, UK and Burlington, VT: Ashgate, 2009), 141-159. See also Citron, Gender and the Musical Canon (Cambridge: Cambridge University Press, 1993).

${ }^{65}$ Citron, "Brahms," 147. The troping of Beethoven's musical "heroism" is discussed extensively by Scott Burnham in Beethoven Hero (Princeton, NJ: Princeton University Press, 1995). Beethoven's "masculinity" has also been discussed by Sanna Pederson in "Beethoven and Masculinity," Beethoven and His World, eds. Scott Burnham and Michael P. Steinberg (Princeton, NJ: Princeton University Press, 2000), 313-331. See also K.M. Knittel, "Wagner, Deafness, and the Reception of Beethoven's Late Style," Journal of the American Musicological Society 51/1 (Spring 1998): 49-82 and Raymond Knapp, "Reading Gender in Late Beethoven: An die Freude and An die ferne Geliebte," Acta Musicologica 75/1 (2003): 45-63.
} 
fend off Bayreuth as a stronghold of national identity." ${ }^{66}$ The preceding quote is productive not only in underlining the apparent premium that nineteenth-century German critics placed on masculinity as an expression of national character, but also to situate Wagner's music and attendant dramatic iconography as a potential "stronghold" within which tropes of masculinity can be fused with musical performance in order to produce German nationhood.

Links between narratives of gender and those of the nation extend beyond that of music criticism of course. For example, Citron points to Klaus Theweleit's Male Fantasies, which endeavours to explore the concurrences between German conflations of manhood and national identity. ${ }^{67}$ While primarily concerning himself with the Nazi-era, particularly the right-wing Freikorps group, Theweleit nonetheless aims to demonstrate the historical and discursive importance of the virile male body as a symbol of a triumphant German nation. His locates linkages between manhood and nation within a "battle for the German [nation]," which "resembles the men's own battle to become men; it takes place on the 'most monstrous settings' in the body: a battle between life and death, masculinity and femininity, fulfilment and void, sense and insanity." Theweleit is primarily discussing early twentieth-century Germany, his words nonetheless suggest some more generalized ideas about the prevalence of masculinity and the male body in the construction of the German nation, ideas that will be shown to have significant currency in the mid-to-late nineteenth century of Wagner's time.

\footnotetext{
${ }^{66}$ Ibid., 151.

${ }^{67}$ Klaus Theweleit, Male Fantasies ( 2 vols.), trans. Stephan Conway et al. (Minneapolis: University of Minnesota Press, 1987-1989).

${ }^{68}$ Theweleit, Male Fantasies vol. 2, quoted in Citron, 150.
} 
In the introduction to his study of the construction of national subjects throughout the world's literatures, Allen-Carey Webb notes that "none of the major theorists of the rise of European national identity... allow the question of gender to enter their analysis. ${ }^{\prime 69}$ Webb characterizes this as a significant oversight which he notes was begun to be rectified (although he curiously does not mention Theweleit's contribution) by George Mosse's 1985 book Nationalism and Sexuality. ${ }^{70}$ In that volume, Mosse argued that an image of "respectability" for the nation was normalized throughout Europe through veneration of masculinity "as the foundation of the nation" with "a version of manliness that rejected 'degeneration' into effeminate practices... [being considered] essential to the respectable 'norm' that regulated admittance to the national fraternity." "11 Mosse's model of "respectability" was primarily focused on discourses of domesticity, of hearth and home, but Webb makes a crucial observation when he states that "Mosse finds the key to the successful hegemony of nineteenth-century nationalism to be its normalcy, its assertion not only of the universality but its assumption that honorable social existence was only possible inside its discourse." 72 While my readings of Wagner's centralization of male bodies in his particular formulations of German nationhood do not prize "domesticity" or "respectability," Mosse's (and Webb's) points are nonetheless of great interest in providing an intellectual basis for the foregrounding of the male body in the

\footnotetext{
${ }^{69}$ Allen-Carey Webb, Making Subject(s): Literature and the Emergence of National Identity (New York and London: Garland Publishing, 1998), 22.

${ }^{70}$ George L. Mosse, Nationalism and Sexuality: Respectability and Abnormal Sexuality in Modern Europe (New York: Howard Fertig, 1985).

${ }^{71}$ Webb, 24.

${ }^{72}$ Ibid. It should be noted that while manhood was defined as the "foundation" of the national identity, women also played a crucial role in the gendering of the nation: "woman as national symbol was the guardian of the continuity of and immutability of the nation, the embodiment of its respectability" (Mosse, quoted in Webb, 24). But it cannot be overemphasized that as powerful as the image of woman was for staging nationhood, it was to provide "a background for the activity of men who determined the national fate" (24).
} 
troping of German nationhood. Moreover, Mosse's point about the normalization of nationhood is also instructive: I would submit that the performance of Wagner's music dramas may be thought of as a strategy towards constructing a sense of normality surrounding Wagner's particular iconographies and sonorities of the male body, of implanting the idea that these particular masculinities are exceptionally efficacious in disseminating the essence of the German character to the public.

Consistent with Webb's criticism that prevailing frameworks for discussing the construction of nationhood in the nineteenth century and beyond is Bhabha's performative model, which similarly eschews discussions of gender. This would appear at first glance to be problematic considering it is one of the key discursive paradigms for my reading of Wagner's staging of the nation. Coming to the veritable rescue is another more or less contemporaneous intellectual framework which handily provides a link between discourses gender and Bhabha's conception of the narrated/written nation. This would be Judith Butler's work in the seminal Gender Trouble and her subsequent tome Bodies That Matter. ${ }^{73}$ These works lay out her provocative case that the category of gender represents a particular deployment of speech-act theory, such that gender - like Bhabha's framework of nation - is neither biological nor ontological, but performative. Gender is the result of "the cultural meanings the sexed body assumes."74 Those meanings, like any other performative utterance, are granted meaning through speech: to repeatedly speak one's gender is to continually bring it into being in order grant it a fiction of coherence. Butler's paradigm is more expansive in that the performativity of

\footnotetext{
${ }^{73}$ Judith Butler, Gender Trouble: Feminism and the Subversion of Identity (1990) (New York and London: Routledge, 1999); Bodies That Matter: On the Discursive Limits of "Sex" (New York and London: Routledge, 1993).

${ }^{74}$ Butler, Gender Trouble, 10.
} 
gender is reliant not only upon literal speech-acts, but in a series of actions that give life to the discursive signs of gender:

As in other ritual dramas, the action of gender requires a performance that is repeated. This repetition is at once a reenactment and reexperiencing of a set of meanings already socially established; and it is the mundane and ritualized form of their legitimization...Gender ought not to be constructed as a stable identity or locus of agency from which various acts follow; rather, gender is an identity tenuously constituted in time, instituted in an exterior space through a stylized repetition of acts. The effect of gender is produced through the stylization of the body and, hence, must be understood as the mundane way in which bodily gestures, movements, and styles of various kinds constitute the illusion of an abiding gendered self. ${ }^{75}$

The performativity of gender, like that of the nation, functions as a strategy for granting the subject a fiction of stability and coherence. Because of gender's importance to the attempt to stabilize the subject, it is no surprise that according to Butler gender, while not ontologically stable, is also not generally a matter of individual volition either: social strictures have cultivated a "tacit collective agreement to perform, produce, and sustain discrete and polar genders" to the point that "punishments... attend not agreeing to believe in them. ${ }^{, 76}$ Subjects are enjoined to perform and produce within culturally codified systems; the "nation" is arguably one of those systems that provide a circumscribing frame within which subjectivities are formed. But it is a system that feeds back on the subject, itself functioning as a performative and performed method of propping up the subject's identity. It is the ostensibly performative bases for gender and nationhood that allow the two categories to be linked. In the specific case of Wagner, the link could be framed thusly: the male bodies of Wagner's operas perform and produce gender. At the same time, Wagner's performative "writing" of the German nation through both his music and his prose writings foregrounds the beautiful male body as the

\footnotetext{
${ }^{75}$ Tbid., 178-179.

${ }^{76}$ Tbid., 178.
} 
physical manifestation of the nation. The somatic "topography" of the Wagnerian body is thus troped to encompass the mutually implicated problematics of masculinity and the German nation, each thematized as sonorous reflections of the other.

\section{Volk Music}

For the time being, I shall set aside issues of French grand opera (although I will return to it at the end of the chapter when I discuss Rienzi) in favour an examination of the historical backing for Wagner's endeavours to create uniquely "German" art. Throughout the nineteenth century, one of the prevailing tropes mobilized in order to formulate a narrative of the German nation was that of the centrality of art to the definition of the national identity. This narrative arguably culminated in the German historian Friedrich Meinecke's (1862-1954) work on the German intellectual histories of the eighteenth and nineteenth centuries, where he branded "pre-unification Germany" as a "Kulturnation...an entity characterized by a common culture (language, literature, religion, etc.) rather than a common social order, politics, or history." ${ }^{\text {"77 }}$ Clearly, it is not a significant leap from the idea of Kulturnation as the unifying element for the German people to that of the imagined community, as the notion of a common cultural heritage is defined as that which creates the sense of large-scale "belonging" that unites a population under the banner of a German nation. Most importantly, this imagining is centralized around the conception that it is culture that conveys the fundamental character of the German nation; by necessity, art is thus framed as an essential aspect of this "common social order" that allows German citizens to imagine themselves as belonging to a shared culture.

\footnotetext{
"McClatchie, "Performing Germany in Die Meistersinger," 136.
} 
The Kulturnation trope as Meinecke defined it functioned as one strand in a network of discourses that framed nationhood as a significant concern for later nineteenth-century Germans. ${ }^{78}$ A number of those discourses were political, particularly the Revolutionary thought of the 1840s advocating for German unification under a Republican banner; the political discourse of nationhood following unification in 1871 took a monarchial turn as the German states were assembled under imperial rule. The development of German nationalism as a political tool from the late eighteenth century through to unification is traced ably by Hagen Schulze. ${ }^{79}$ Many of those political discourses do implicate themselves in the conception and creation of several of Wagner's works, and I will address them in forthcoming chapters when they are relevant to their constituent arguments. However, I wish to redirect focus back towards the cultural and intellectual aspects of this network. As Chapter One will further clarify, the latter eighteenth century saw a rising push towards national consciousness on the part of the intelligentsia, one of the most potent tropes being Johann Gottfried Herder's (1744-1803) conception of Volksgeist, which as Hannu Salmi summarizes "was the creative force of the nation." ${ }^{80}$ The Volksgeist narrative contended that the German people were united by a shared "spirit" which in turn found expression in people's art, its literature, and all other such human activities. The notion of Volksgeist can be interpreted an example of an imagined community as it is centralized around the construction of a narrative that instills

\footnotetext{
${ }^{78}$ Meinecke discusses Kulturnation in Cosmopolitanism and the National State, trans. Robert B. Kimber (Princeton, NJ: Princeton University Press, 1970).

${ }^{79}$ Hagen Schulze, The Course of German Nationalism from Frederick the Great to Bismarck, 1763-1870, trans. Sarah Hansbury-Tenison (Cambridge and New York: Cambridge University Press, 1991).

${ }^{80}$ Hannu Salmi, Imagined Germany: Richard Wagner's National Utopia (New York: Peter Lang, 1999), 39; Johann Gottfried Herder, Philosophical Writings, trans. and ed. Michael N. Forster (Cambridge and New York: Cambridge University Press, 2002).
} 
a sense of belonging to a larger (and communal) reality into the hearts and minds of individuals.

The Volk aspect of Volksgeist connoted a populist bent, that "the people" were the most "authentic" representation of the national spirit (as opposed to social and economic elites such as the aristocracy), and as such, all forms of human expression that demonstrated propinquity to that spirit were expressive of the essence of the German character. ${ }^{81}$ Indeed, so potent was this apparent shared affinity for the "folk-like" in the arts that an entire movement developed a significant foothold in the artistic tapestry of the nineteenth century: the Volkstümlich aesthetic was predicated on the creation of art that consciously adopted the appearance of being inspired by chronologically "older" cultures, art that was attuned to such conditions as the "rustic" and the "pastoral" and was expressive of the "peasantry." The motivating force behind Volkstümlichkeit ("folklikeness") was essentially a "recycling of an ancient idea, that of 'primitivism,' the belief that the qualities of technologically backward or chronologically early cultures are superior to those of contemporary civilization, or more generally, that it is those things that are least socialized, least civilized...that are closest to truth."82 In other words, the desire for the Volk represents a longing for the conditions of the pre-modern, when the Volk were supposedly more in touch with nature. Herder's ideas laid down a discursive template that positioned Volkstümlich values as the Ursatz of German society and culture, values that were maintained through the nation's creative spirit. By upholding the link to that more "authentic" past, the contemporary nation could continually revitalize itself through

\footnotetext{
${ }^{81}$ David Gramit discusses the prevalence of the Volk in German musical discourse of the eighteenth and nineteenth centuries in Cultivating Music: The Aspirations, Interests, and Limits of German Musical Culture, 1770-1848 (Berkeley: University of California Press, 2002), 63-92.

${ }^{82}$ Taruskin, Music in the Nineteenth Century, 123.
} 
its art. In the first half of the nineteenth century, the Volkstümlich aesthetic naturally gravitated towards a more simplistic musical language and utilizing folk melodies and setting folk poetry. As Philip Bohlman points out, Achim von Arnim and Clemens Brentano's two-volume collection of folk songs Des Knaben Wunderhorn (1806 and 1808) was particularly emblematic of the practice of situating folk-song anthologies as a summation of the German Volksgeist:

Connecting folk songs to the nation with acts of naming was first possible when the songs themselves demonstrated...the traits of a collective. Predicated on some kind of stylistic and linguistic unity, the anthology of national songs possessed some of the same properties of collective cohesion as the nation whose name they bore...The Germanness of the first editions of Des Knaben Wunderhorn lay primarily in their language, which itself was the stylized product of folk poetry in local dialects and variants...[D]uring the course of the nineteenth century the anthology entered the intellectual history of Germany through successive editions, constant editing and adaptation, and by the century's end, ethnographic documentation that identified the folk songs where the nationalist imagination believed them to be: in the oral traditions that confirmed the Germanness of the published anthologies. ${ }^{83}$

Bohlman is discussing the act of anthologizing folk poetry and folk song more than he is musical content. Nonetheless, what shines through in the above quote is the emphasis placed on the anthology's folk origins as a potent strategy for defining a distinctive German identity. ${ }^{84}$ I do not wish to belabour the point about folk song as it does not figure greatly in forthcoming discussions. However, I invoke it in order to point to folk song as an instance of the nineteenth-century prizing of Volkstümlichkeit as a method of troping German nationhood. Moreover, the Volkstümlich aesthetic would prove to also be quite influential on Wagner's own thought, as shall become clear as

\footnotetext{
${ }^{83}$ Philip V. Bohlman, The Music of European Nationalism: Cultural Identity and Modern History (Santa Barbara, CA: ABC-CLIO, 2004), 46-47.

${ }^{84}$ Wunderhorn in particular would continue to be a favoured target for composers - including Weber, Mendelssohn, Schumann, and Brahms - throughout the nineteenth century; perhaps most notably, Mahler would set a number of Wunderhorn poems as orchestral lieder - his cycle Lieder eines fahrenden Gesellen is a prominent example - and as movements of his Second, Third, and Fourth Symphonies.
} 
future chapters endeavour to analyze the importance Wagner placed on das Volk in both creating and understanding the German "artwork of the future." Not only do the nationalizing tropes surrounding the Volk implicate themselves in Wagner's own aesthetics and ideologies, but they also resonate within his adoption of myth. The framing of "folk" qualities as a representation of authenticity bears no small resemblance to Wagner's own position that myth represented a more "truthful" depiction of the German past, a truth that provided a more "authentic" portrait of the enduring legacies of the German identity.

Digressing from music briefly in favour of a wider-ranging cultural current, Celia Applegate's study of the German conception of Heimat offers a number of intriguing windows of insight into the increasing national consciousness of German citizens. ${ }^{85}$ Heimat is of course a complex concept: the word roughly translates to "homeland," but as a cultural trope, significantly more meaning is attached to the term. In its application, the term Heimat tends to bear out the contention that the nation functions as a strategy for propping up the subject. Applegate observes that scholarship tends to associate Heimat not so much with the land itself, but with the sense of allegiance and pride citizens invest into the place of their birth, either on a local or national level ("hometown" and "national" pride, in other words); the languages and customs of their homelands become one of the building blocks of an individual identity, to the extent that the affinity for the "homeland" becomes one more avenue for the sense of selfhood to be strengthened. Heimat then is not simply a descriptive term evoking one's home, but is instilled with a series of values, ascribing to the nation the capacity to be more than a series of borders

\footnotetext{
${ }^{85}$ Celia Applegate, A Nation of Provincials: The German Idea of Heimat (Berkeley: University of California Press, 1990).
} 
drawn on a map, to be capable of arousing such sentiments as loyalty, pride, and love for the nation.

The Heimat movement arguably gained its greatest cultural traction in the twentieth century, particularly between the two World Wars. However, as Applegate notes, the movement began to flower in the latter nineteenth century, in the wake of unification; as the Prussian state assumed political dominance over Germany, a need to maintain the provincial identities of the individual states arose. "For the incomplete nation of 1871, the invented tradition of the Heimat bridged the gap between national aspiration and provincial reality," Applegate writes, observing that Heimat drew its power not from an endeavour to cultivate loyalty to the state. ${ }^{86}$ Heimat arose from the "desire to have both community and nation, not the latter masquerading as the former." Put another way, the desire was for nationhood not to be completely displaced onto purely external forces such as state authority but to register as something more interior, so that the nation could be personally observable and felt by subjects through interaction with their immediate surroundings and with fellow citizens.

This post-1871 movement tended to be centralized around the Pfalz - or "Palatinate" in English - region of Germany, which lay on the banks of the Rhine. However, Applegate notes that the discourses of Heimat that proliferated in the late nineteenth and early twentieth centuries found antecedents in narratives that circulated in the mid-nineteenth century. Applegate writes,

The Heimat of numerous novels and poems about the countryside and village life was an idyll of local communities, close family harmony, and a domesticated, friendly nature...Heimat stood in opposition to the city; it was the seat of folk

\footnotetext{
${ }^{86}$ Ibid., 13.

${ }^{87}$ Ibid., 14.
} 
customs and speech, the place where the old ways were remembered and preserved. ${ }^{88}$

Applegate effectively links the mid-nineteenth century notion of Heimat to the aforementioned Volkstümlich aesthetic in its privileging of the pastoral and the traditional as the foundation of the German essence. Furthermore, the veneration of the domestic would appear to be a remnant of the Biedermeier aesthetic that prevailed in the German art of the early nineteenth century. ${ }^{89}$

What the above demonstrates is that many of the ideologies, if not always the terminology, of Heimat were part of the German national consciousness during the years Wagner was active and which were available for the composer to tap into in both his stage works and his prose writings. ${ }^{90}$ Additionally, Heimat's situating of the nation as a source of emotional investment for the subject shows that the discourse of Heimat can be theorized as positioning the nation as an example of a lieux de mémoire. I offer a segment of Wagner's own writing to illustrate this point: the final sentence of his "Autobiographical Sketch" of 1843 describes his return to Germany following his unsuccessful sojourn to Paris thusly: "I left [Paris] in the spring of 1842 For the first time I saw the Rhine - with hot tears in my eyes, I, poor artist, swore eternal fidelity to my German fatherland." ${ }^{91}$ This is an after-the-fact recollection and as such, rather difficult to corroborate. Regardless of its veracity (or lack thereof), Wagner's words paint an evocative picture. Contained within this statement is an expression of deep emotional connection to the German land that is consistent with the desire for Heimat;

\footnotetext{
${ }^{88}$ Ibid., 9.

${ }^{89}$ Simon Williams accounts for the tendencies of Biedermeier art and culture, particularly in its contrast to the subsequent move to adopt artistic depiction of the "heroic" in Wagner and the Romantic Hero, 5-19.

${ }^{90}$ In his discussion of Der fliegende Holländer, John Deathridge touches upon the issue of Heimat as one of the forces motivating the work's conception. See Wagner - Beyond Good and Evil (Berkeley: University of California Press, 2008), 29-30.

${ }^{91}$ SSD I, 19; PW I, 19.
} 
that outpouring of emotion functions as a consequence of Heimat existing as a "place of memory" within Wagner's being. Upon seeing the "fatherland" for the first time in several years, this "place" surfaced from the recesses of memory, triggering the flow of "hot tears" and a renewed loyalty to Germany that would drive so much of Wagner's creative energies.

I have previously alluded to the discourses that foregrounded music as a vital expression of Germanness. In the nineteenth century, the legacy of Beethoven was instrumental in solidifying the centrality of music to the construction of a "mythology" of German nationhood. Beethoven's funeral in 1827 - a highly public event with numerous Viennese citizens gathered - provides an illustrative vignette: during the oration, written by dramatist Franz Grillparzer and delivered by actor Heinrich Anschütz, Beethoven's death was proclaimed to be a devastating loss for the German people. Moreover, Beethoven was characterized as "the hero of verse in German speech and tongue...the heir and amplifier of Handel and Bach's, or Haydn and Mozart's immortal fame is now no more...." ${ }^{92}$ Contained within this expression of mourning is an encapsulation of how vital music had become to the Austro-German character, which would resonate strongly within many of the activities that would follow in the years to come.

As Applegate and Potter note, several German composers demonstrated an awareness of "their place in a national culture" although they often expressed this interest "through activities other than composition." ${ }^{93}$ They emphasize Felix Mendelssohn as one of the exemplary historical figures in terms of cultivating pride in Germany's musical

\footnotetext{
${ }^{92}$ Elliot Forbes, ed. Thayer's Life of Beethoven, quoted in Richard Taruskin, The Oxford History of Western Music - Volume 2: Music in the Seventeenth and Eighteenth Centuries (2005) (Oxford and New York: Oxford University Press, 2010), 689.

${ }^{93}$ Applegate and Potter, "Germans as the "People of Music," 9.
} 
heritage as a national asset. One of his seminal activities was his leading of a performance of Bach's St. Matthew Passion in Berlin in 1829, an event that has been frequently credited with "reviving" the work in the national consciousness. ${ }^{94}$ More than that, the historical significance of the event speaks to something that Grillparzer references in his speech: the importance of the significant composers of the past as revered figures, symbols of the ostensible greatness of Germany's heritage. The "Bach revival" was part and parcel out of "[Mendelssohn's] generation's concern for the future of a specifically German musical heritage that Beethoven's death had rendered vulnerable and in need of both preservation and renewal."95 Mendelssohn's efforts towards maintaining a German musical heritage also found expression during his directorship of the Leipzig Gewandhaus Orchestra, during which he frequently programmed concerts to include both canonized older works and premiered new compositions (many of which were his own).

Significant as music was to the cultivation of a distinct German identity in the nineteenth century, it was hardly the first time that music had been granted such cultural vitality. Applegate and Potter summarize:

By the end of the eighteenth century...claims for music's importance to German national culture grew increasingly bold. For instance, Friedrich Rochlitz, the founding editor of the long-running Allgemeine Musikalische Zeitung in Leipzig, committed his new journal almost from the outset to articulating the exclusively German of certain music, as well as its crucial contribution to national culture. ${ }^{96}$

Rochlitz's advocacy in the AMZ fit comfortably into a number of cultural currents gathering momentum throughout the eighteenth century. One of those currents was the

\footnotetext{
${ }^{94}$ Celia Applegate, Bach in Berlin: Nation and Culture in Mendelssohn's Revival of the St. Matthew Passion (Ithaca, NY and London: Cornell University Press, 2005).

${ }^{95}$ Applegate and Potter, "Germans as the 'People of Music," 9.

${ }^{96}$ Ibid., 4.
} 
investment in the creation and performance of German-language operas. As John Warrack recounts in his historiography of German opera, the period between the end of the Seven Years' War in 1763 - with the Pomeranian and Third Silesian Wars being the theatres that pertained to Germany - and the attendant period of relative peace saw a surge of operas composed in the German language. ${ }^{97}$ These were the Singspiele, with the most outstanding composer of the form during this period arguably Johann Adam Hiller, with Die Jagd (1770) as a particularly emblematic work. The Singspiel increased its cultural ubiquity during the era of the "Viennese Singspiel" inaugurated by Joseph II's institution of the Deutsches National-Singspiel in 1778, devoted to the purpose of performing German-language opera (and the theatre's very title carried the implication that vernacular opera and Singspiel in particular were national concerns). ${ }^{98}$

Because of its contextualization within a movement to foster the creation of specifically German operas, the eighteenth-century Singspiel can be considered a progenitor of what Stephen C. Meyer calls a "search" for a distinctive German opera in the early decades of the nineteenth century, a search that will have noticeable influence on Wagner's own efforts. Meyer acknowledges the influence of the operas of the eighteenth century and the intellectual and political currents that precipitated them, but the thrust of his study essentially frames this period as something of a prelude to the nineteenth-century discourses and practices that sought to create new definitions of what constituted the German nation, and of an opera that would reflect these notions. ${ }^{99}$ The first decades of the nineteenth century saw a number of prominent figures producing

\footnotetext{
${ }^{97}$ John Warrack, German Opera: From the Beginnings to Wagner (Cambridge: Cambridge University Press, 2001), 86-123.

${ }^{98} \mathrm{Ibid} ., 124-143$. The company would close in 1783 , reopened in 1785 and closed for good in 1788

${ }^{99}$ Meyer, Weber and the Search for a German Opera, 28-75.
} 
German opera, including Lortzing, Marschner, and Spohr, but it is Carl Maria von Weber who has remained the most enduring. Weber's work would leave a lasting impression on Wagner, as Part I of Opera and Drama attests, which contains a multi-page critique of Euryanthe, where he lauds Weber's melodic gifts while simultaneously criticizing what he saw as the work's dramatic and poetic deficiencies (arising in large part from the fact that Weber made his melodies the principle draw of the work with the poetry nearly an afterthought). ${ }^{100}$ This appraisal is altogether more tempered than the one he provided in his 1834 essay "German Opera," where he censured the opera's ostensible musical and poetic incoherence. ${ }^{101}$

Despite Wagner's apparent skepticism towards Euryanthe, the amount of attention he devotes to it indicates that he considered Weber to be a composer of particular significance. This supposition is borne out by an essay written during his Paris residency where he subjects Der Freischütz (he is reviewing an 1841 performance staged at the Paris Opéra) to rapturous praise for a not insignificant number of pages. In fact, he goes so far as to write the following opening statement: "oh, my dear German fatherland, how can I help adoring you, even if only because it was your soil that produced Der Freischütz! Must my heart not go out to a people that loves Der Freischütz?"102 With those words, Wagner situated Weber's opera as a matter of national pride, something that demonstrated the best qualities of the German land: its people. Indeed, as Nicholas Vazsonyi points out, Wagner's tribute argues that the opera was a product of the spirit of the Volk and that moreover, Weber's work could bring about a restoration of "a utopian

\footnotetext{
${ }^{100}$ SSD III, 289-293; PW II, 83-87.

${ }^{101}$ SSD XII, 2; PW VIII, 56. Interestingly, the Trauermusik that Wagner had composed in 1844 to accompany the procession that interred Weber's remains in Dresden after having been transferred from London incorporated a number of themes from Euryanthe.

${ }^{102} \mathrm{WP}, 138$.
} 
Volk spirit," an idea that Wagner resurrects in that "most German of operas' Die Meistersinger von Nürnberg."”103

The ostensible Volkstümlich nature of Freischütz is one of the reasons it has been thematized as one of the quintessential "national" operas of nineteenth-century Germany. ${ }^{104}$ For that reason and for its clear influence on Wagner, the opera is worthy of annotation, even if it has no discernible connection to grand opera. This leaves an opening for Wagner to add something to earlier endeavours: I propose that grand opera's aforementioned "haunting" of Wagner played a significant role in his own "search" for a German opera. Wagner retained from Weber a commitment to communicating the spirit of the Volk through music. What he added in his "artworks of the future" that were designed to revitalize German art and culture was a repurposed, but undeniably recognizable injection of grand opera, refracted through the narrative lens of myth and legend, rather than history. ${ }^{105}$ Wagner follows up from the cultural currents that produced the eighteenth-century Singspiele and the nineteenth-century endeavours of Weber, Lortzing, Marschner, etc. in striving to produce operatic works that are infused with and

\footnotetext{
${ }^{103}$ Nicholas Vazsonyi, Richard Wagner: Self-Promotion and the Making of a Brand (Cambridge: Cambridge University Press, 2010), 53-54.

${ }^{104}$ Wolfgang Wagner, Carl Maria von Weber und die deutsche Nationaloper (Mainz: Schott, 1994); Michael C. Tusa, "Cosmopolitanism and the National Opera: Weber's Der Freischütz," The Journal of Interdisciplinary History 36/3 (Winter 2006): 483-506.

${ }^{105}$ Returning to Weber momentarily, Euryanthe is labeled a große heroisch-romantische Oper, or a "grand heroic-romantic opera." As Meyer observes, the category of große Oper - referring to a form of German opera of the late eighteenth and early nineteenth centuries - typically made use of exalted subject matter for its plots, which were generally derived from ancient or more recent history. Große Oper should be thought of as more of a German analogue to opera seria than as a signifier of enormous musical and scenic spectacle like grand opéra. As a "grand romantic opera," Euryanthe was intended to integrate the "serious" and elevated material of große Oper with the "romantic" predilection for such ostensibly Volkstümlich elements as the rustic and the supernatural. Although German "grand opera" is quite different in many respects from Parisian grand opera, both forms do share a fascination with the elevated and the historical in terms of glorifying their respective cultures. Wagner's works, in their frequent combinations of the exalted (gods, the divine, "great" heroic figures), the "romantic" (the natural world, the supernatural, and the mythical), and the musically and dramatically grandiose, can be thought of as a synthesis of große Oper, romantische Oper, and grand opéra. Definitions of große Oper and große romantische Oper are provided in Meyer 30-31 and 116-118, respectively.
} 
communicate to the unique German spirit. But as this dissertation will set out to show, Wagner's various frameworks consistently incorporate the choral crowd scenes and processionals, the "heroic" tenor roles, the grandiose pageantry, the elaborate scenic spectacle so prevalent in grand opera. Wagner's search for a German opera distinguished itself from that of Weber et al in that Wagner quest led him to adopt and adapt aspects of French musical culture, incorporating them into a new context that supposedly spoke to and was infused with the inimitable German character of the Volk.

\section{Preview}

This dissertation explores the constellation of Wagner's versions of grand opera, performing bodies, and the production of German nationhood along the following trajectory: the first part consists of two chapters that delve into Wagner's use of the grand opera chorus as a mass sonorous body in order to act as stand-ins for the German people, while the second part encompasses three chapters that shift their focus to the individual male body, with the so-called Heldentenor (a term that Wagner himself does not use) situated as a particular locus. In these chapters, I will consider the male body primarily as sonority. This structure will result on more than one occasion in the same works being discussed in multiple chapters. This is by design: I have eschewed a structure that emphasizes a discussion of individual works in order to direct my focus towards ideas and topics, using selected works that I feel illustrate said ideas in the most interesting ways. Additionally, this format allows me to analyze multiple operas in one chapter, accounting for the complimentary and differing ways in which these works function within the hermeneutic frameworks I have selected for each chapter. 
The table of contents reveals some notable exclusions from this document, as discussions of Der fliegende Holländer and Tristan und Isolde are conspicuously absent. These exclusions are primarily the result of space limitations, as keeping this dissertation to a reasonable length disallows subjecting all of Wagner's works to detailed analyses. But there are also specific reasons why I have chosen these two particular operas for omission. Tristan is a fairly obvious choice for exclusion as it is the "mature" work that is furthest removed from grand opera: the chorus is only employed for a brief portion at the end of the first act and elaborate tableaux are generally not called for. The work's connections to grand opera mostly lie in its great length and its full orchestra (supplemented by some off-stage instrumentation in the second act, and similarly distanced vocalizing from Brangäne). The greatest debt the piece owes to grand opera, as Grey comments, is the extensive second-act duet between the titular lovers, which is reminiscent of the "grand duos" of many a Parisian work. ${ }^{106}$ Nonetheless, the degree of remove that Tristan displays from the hallmarks of grand opera makes it justifiable to exclude. Likely more attention-drawing is the absence of discussion of Holländer. The propinquity of that work to grand opera is more obvious, with its extensive choral writing and the opening storm scene as a piece of appositely spectacular tableau as but two examples. Additionally, its injection of supernatural forces (in the form of the Dutchman) into a rustic Norwegian setting, creating a romantic intrigue (also involving Senta and Erik) effectively renders the opera as a romantische Oper in the manner of Der Freischütz. Even so, Holländer is ultimately too ancillary to the specific lines of inquiry of each chapter to be convincingly worked into the proceedings without expanding this

${ }^{106}$ Grey, "Wagner and Grand Opera," 340-341. 
dissertation's length beyond reasonable proportions. ${ }^{107}$ For example, Holländer does not mobilize Christian-based legends like Lohengrin and Parsifal; it does not incorporate explicitly Germanic myth like the Ring; and its plot is not an exegesis on German art like Meistersinger. Additionally, its premiere in Dresden in 1843 is not situated within historical and cultural discourses surrounding that city's artistic legacy as with the Weimar Lohengrin and the Paris Tannhäuser. Rienzi will also not be examined in the subsequent chapters. However, as I have already established at periodic points earlier on, I will offer a few words on this opera at the end of this chapter.

The interrogation of Wagner's adaptation of the grand opera chorus commences with Chapter One, which focuses on two different premieres: the 1850 debut of Lohengrin in Weimar under the directorship of Franz Liszt, and that of Tannhäuser at the Paris Opéra in 1861 . This chapter aims to situate these two premieres within the cultural legacies of their respective cities, with the chorus thematized as a method of glorifying German nationhood. Overall, the chapter argues that the grand opera chorus is used to create a sense of "monumentality" (per Rehding) for these works in an endeavour to elevate German art and nationhood. For Lohengrin, the work's monumentality is aligned with the mythology of the city of Weimar in order to construct a narrative of the premier as a pivotal event in German artistic history, part of an ongoing endeavour to create a new "golden age" for Weimar. In contrast, I will argue that the Paris Tannhäuser appropriates the "urbanized" dramaturgy of French grand opera in order to simultaneously delegitimize French culture on the stage of a hallowed French institution and glorify Germanness before a Parisian audience, a gambit that I will argue played no

\footnotetext{
${ }^{107}$ The composition and performance history (including insight into the various biographical, historical, and mythological sources that inform the libretto) is extensively documented in Thomas Grey, ed. Richard Wagner: Der fliegende Holländer (Cambridge: Cambridge University Press, 2000).
} 
small part in the work's hostile reception among the city's vocal anti-Wagnerian contingent.

Contrasting this exploration of the intersection of cities and the nation is the discussion of Chapter Two, which directs its attention to the use of the chorus in Die Meistersinger and Parsifal. Central to the arguments of this chapter is Arthur Groos' contention that Wagner's depiction of sixteenth-century Nuremberg as a "proleptic community," that is the contemporary nineteenth-century Germany is transplanted into the past so that the appearance is that the conditions of the present are depicted as having already taken place. ${ }^{108}$ I will contend that the chorus in Parsifal, representing the denizens of the Grail temple, also function as a proleptic community: the Grail community of medieval Montsalvat stands in for the contemporary "community" of the Bayreuth Festspielhaus. The chorus as proleptic community will be situated within the discourse of Kunstreligion, the framing of art as a religion. ${ }^{109}$ In doing so, I will take the position that the Volk of Meistersinger and the Bühnenweihfestpiel that is Parsifal use the grand opera chorus as a strategy for "consecrating" German art.

Chapter Three commences the insight into the male performing body with an interrogation of the sonorities of the Ring; it is here that I will also examine in detail the importance of myth to nineteenth-century conceptions of German nationhood. ${ }^{110}$ In this

\footnotetext{
${ }^{108}$ Arthur Groos, "Constructing Nuremberg: Typological and Proleptic Communities in Die Meistersinger," $19^{\text {th }}$-Century Music 16/1 (Summer 1992): 18-34.

${ }^{109}$ Adolf Nowak, "Wagners Parsifal und die Idee der Kunstreligion," Richard Wagner: Werk und Wirkung, ed. Carl Dahlhaus (Regensburg: G. Bosse, 1971), 161-175; Glenn Stanley, "Parsifal: Redemption and Kunstreligion," The Cambridge Companion to Wagner, ed. Thomas S. Grey (Cambridge: Cambridge University Press, 2008), 151-175.

${ }^{110}$ George S. Williamson, The Longing for Myth in Germany: Religion and Aesthetic Culture from Romanticism to Nietzsche (Chicago and London: University of Chicago Press, 2004). Mary A. Cicora has published extensively on Wagner's employment of myth. See for example Mythology as Metaphor: Romantic Irony, Critical Theory, and Wagner's Ring (Westport, CT: Greenwood Press, 1998); Wagner's Ring and German Drama: Comparative Studies in Mythology and History in Drama (Westport, CT:
} 
chapter, I argue that the intersection of the male body and grand opera creates a "mythic allegory" of the progression of the German nation from an old, corrupted order to the beginnings of a newly redeemed one. Through the figures of Wotan and Alberich, we see forms of flawed identities that are externalized upon their bodies that compel them to commit "crimes" against the natural world, bringing about societies built on lust for power and violence and provoking cultures of human and world suffering. In Siegfried, we are shown the ostensibly greatest of all the world's heroes, given voice by the new kind of sonority that is the so-called Heldentenor, a physical and sonorous embodiment of the "artwork of the future" that will ostensibly ensure the supremacy of German art and nationhood. However, one of the central tragedies of the Ring is that even Siegfried's seeming heroic ideal ensures his own destruction through his own flaws of character; even Wagner's Siegfried is an example of a flawed masculinity, although one that manifests through conduct rather than sound or iconography. As the tetralogy careens towards its eschatological climax, Siegfried's death becomes an example of martyrdom, an unwitting sacrifice that acts as one of the events that sets the stage for a better society to emerge from the ashes of the old one. The Ring, I will argue, fuses Germanic myth, grand opera, and male bodies in order to stage an allegory of the history of the world; as the curtain falls on the cycle, a new world full of possibility is the last thing seen and heard. Placed within the confines of the Bayreuth stage, it represents the potential future of a reborn German nation and its constituent art. The mythical setting of the cycle sets these flawed masculinities in a distant past, as if they were long since Wagner's Music Dramas (Westport CT: Greenwood Press, 2000). 
surmounted, thereby setting the stage for the male body and the nation to progress towards its conclusive triumph.

In Chapter Four, I provide the next stage of this process - in the sense of the temporality of Wagner's thought, rather than the chronological order of composition - as the idealized form of the German nation is brought "closer," but not yet attained. This idea is illustrated through the "Christian" operas, primarily Lohengrin and Parsifal. The chapter picks up the discussion of the Heldentenor from the previous chapter, situating the titular characters' sonorous bodies within the discourse of both Simon Williams' models of the "epic hero" and the "messianic hero" the male imago figure, which is the representation of an aspirational, yet unattainable image of bodily perfection. In these works, the body of the Heldentenor operates within the dramaturgy of grand opera in order provide a somatic and acoustic stage for a perfected form of manhood that stands in for an idealized image of the German nation that remains out of reach.

Moving onward from the medieval milieu of Chapter Four to the Renaissance setting of Chapter Five, I return to Die Meistersinger in order to bring the dissertation to a close. Befitting its status as the closing section, I re-incorporate several of the ideas from previous chapters - among others, Kunstreligion, the proleptic community, history and myth, the Heldentenor, the hero, and the male imago - in order to tie everything together. Central to the chapter's argument is the thematizing of the characters of Walther and Hans Sachs as complementing figures that together embody sonorously the ideal to which German art aspires. In being embraced and fully accepted into the Nuremberg (proleptic) community, Sachs and Walther demonstrate that the heroic ideal

${ }^{111}$ Williams, Wagner and the Romantic Hero, 13-19. 
of German art and nationhood is no longer unattainable. Wagner's Nuremberg functions as the site where the German nation achieves triumph, where the male body performing grand opera is used to elevate German art (and the spirit of the Volk that inspired it) to its status of cultural supremacy. In essence, the progression that arises from this dissertation's ordering of chapters points to Walther and Sachs as the fulfillment of the promise that Siegfried's martyrdom had put forth so many generations before in the annals of myth: the potential for art to fundamentally reshape the destiny of the world, and in doing so, bring about a superior German culture.

It should be quite apparent that one opera is notably missing from the above cataloguing of the principle works to be discussed; Rienzi is not granted an extended analysis. This is in part due to its reputation as "minor literature" in Wagner's corpus of work. ${ }^{112}$ But the most obvious reason for this exclusion is the fact that this dissertation intends to interrogate Wagner's adaptations and transformations of traditional grand opera dramaturgy. Rienzi for all intents and purposes is not a transformation, but a straight grand opera in terms of musical and dramaturgical content. However, as the work most closely associated with French grand opera, it is necessary to make a few comments, if only to demonstrate how elements of this opera anticipate some of the points of discussion that will be further discussed in subsequent chapters.

\footnotetext{
${ }^{112}$ Gilles Deleuze and Félix Guttari, Kafka: Toward a Minor Literature (1975), trans. Dana Polan (Minneapolis: University of Minnesota Press, 1986). Deleuze and Guttari put forth the term "minor literature" as that which gives voice to the culturally marginalized, in opposition to the "major" literature of the dominant culture, with the idea that minor literature provides potentially greater insight into the makeup of a culture than major literature. Essentially, the argument is that the fringes are what define the culture rather than the normalized.
} 
Even as far back as such "Paris" writings as "Traps for Unwary Germans in Paris" and "The Opéra Lies Dying," Wagner expresses skepticism, even disdain towards the city and its myriad cultural institutions. ${ }^{113}$ However, both of those writings came at a time when it was becoming increasingly clear for Wagner that he would not be able to convince the Opéra to stage Rienzi. An essay written at an earlier period of his residency, "A First Night at the Opéra," recounting a performance of Halévy's La Reine de Chypre, is altogether more charitable towards the grand fare staged at the Opera. ${ }^{114}$ Even more interestingly, the piece was published several months after "Traps for Unwary Germans," which clearly indicates a hardly dogmatic view of grand opera, and indeed a not insignificant admiration for its dramaturgy. Such an admiration could have been instilled well before he ever set foot in Paris: as Grey points out, Wagner had dealings with $L a$ muette on numerous occasions, rehearsing the work "as choral répétiteur for his older brother Albert in Würzberg; later he took up [Auber's opera] on his own as conductor in Magdeburg in 1834-36, and again in Riga in 1837-38."115 Such affinity might well have motivated him to compose Rienzi as a grand opera, upon which he had begun serious work in 1838, well before his relocation to Paris. Wagner, of course, also possessed more mercenary reasons for fashioning his new work along these lines: a successful run of performances at the Paris Opéra would go a long way towards securing his reputation throughout Europe for the foreseeable future, the Opéra and the city of Paris had built up so much cultural prestige. Indeed, Grey characterizes the work as being "conceived as Wagner's ticket to international success via Paris,"116 a supposition lent support by

\footnotetext{
${ }^{113}$ WP, 18-35 and 109-116.

${ }^{114}$ Ibid., 163-177.

${ }^{115}$ Grey, "Wagner and Grand Opera," 323.

${ }^{116}$ Tbid., 326.
} 
Wagner's own recollections in A Communication to My Friends, where he states that upon arrival in Paris that he "busied [himself] in every way to make [himself] known in the world's metropolis." 117 These efforts initially required that he set the "half-finished" Rienzi aside, but eventually he worked his way towards showing portions of his score to Meyerbeer, who as Barry Millington recounts "received [Wagner] kindly, listened with interest to the libretto as it was read to him, and promised to provide letters of recommendation to Charles Edmond Duponchel, the director of the Opéra, and François Habeneck, the conductor."118 Wagner's eagerness to get his proverbial foot in the door in Paris is as clear an indication as any regarding why Wagner was so sanguine as to cast his opera in a form for which he would later profess such antipathy.

The initial seed of inspiration for what would become Rienzi is generally thought to be Wagner's reading of Edward Bulwer-Lytton's 1835 novel Rienzi: The Last of the Tribunes in 1837. However, John Deathridge notes that Wagner states in the "Autobiographical Sketch" that Bulwer-Lytton's tome "brought him back to a 'favourite idea' he had already been considering," and goes on to point out that a letter to Theodor Apel, dated September 20,1840 "clearly indicates that the idea for Rienzi originated at a time when he was still seeing a good deal of his friend, i.e. before he first read the novel in Blasewitz in the summer of 1837 when their ways had already parted."119 From this letter, Deathridge plausibly argues that the initial idea for Rienzi came from Apel. ${ }^{120}$ Nonetheless, the novel cannot be underestimated as a crucial signpost in the opera's

\footnotetext{
${ }^{117}$ SSD IV, 260; PW I, 301.

${ }^{118}$ Barry Millington, Wagner - Revised Edition (Princeton, NJ: Princeton University Press, 1992), 21.

${ }^{119}$ John Deathridge, Wagner's Rienzi: A Reappraisal Based on a Study of the Sketches and Drafts (Oxford: Clarendon Press, 1977), 24.

${ }^{120}$ The letter contains a passage where Wagner refers to the opera as "our" Rienzi and in attempting to account for who had the initial idea writes "I believe we have worked together on it!" See SL, 72.
} 
gestation. As Wagner recollects in "A Communication" regarding his exposure to the novel:

From the misery of modern private-life, whence I could nowhere glean the scantiest stuff for artistic treatment, I was borne away by the picture of a great historico-political event....This Rienzi with great thoughts in his head, great feelings in his heart, amid an entourage of coarseness and vulgarity, set all my nerves a-quivering with sympathy and love; yet my plan for an artwork based thereon sprang first from the perception of a purely lyric in the hero's atmosphere. The "Messengers of Peace," the Church's summons to awake, the Battle-hymns, these were what impelled me to an opera: "Rienzi.",121

This version of the tale of Rienzi's origins (which appears to expunge Apel's involvement from the record) positions the novel as partially consisting of a series of setpieces that Wagner realized could be quite productively dramatized in the operatic realm. The set-pieces he lists all make heavy use of the chorus, in manners quite common to both grand opera in general and to the way Wagner will tend to deploy the chorus in future works. Wagner's treatment of the chorus in Rienzi, on the whole, is in line with grand opera's tendencies towards using the chorus to depict "the people." In Rienzi, the chorus gives voice to the various conflicts between the ruling classes of Rome, with the citizenry placed in the middle. As such, the opera takes advantage of the grand opera chorus' tendency to exploit the massed performing bodies on stage in order to depict the populace in conflict.

The scenes Wagner lists above are illustrations of Parakilas' observation as to how nineteenth-century opera, and grand opera in particular, stage political and social conflict: "in scenes of battle, public ritual, and political assembly, nineteenth-century opera presented a new image of political struggle, an image of all the constituencies of a society (represented by differentiated choral groups) assembling in one place to contend

${ }^{121}$ SSD IV, 257; PW I, 298. 
with each other for political power." ${ }^{\prime 22}$ Wagner points to examples of all three types: perhaps the largest scale of the "battle-hymns" is the third-act cry of "Santo Spirito, Cavaliere!" that accompanies the army assembled by the nobles to attack Rienzi, an army that is met by Rienzi's procession of senators and armed citizens, with "Santo Spirito, Cavaliere!" reiterated as a prelude to the following battle. The "Church's summons" of the first act and the "Messengers of Peace" of the second both function as scenes of "public ritual" and "political assembly," as both scenes showcase competing attempts by the conflicting political forces to use spectacle to curry public favour: the former features Rienzi entering the church to declare himself before the assembled throng as Rome's protector, while in the latter, the "Messengers" are a chorus of patrician youths celebrating the nobles' success in bringing peace throughout Italy. The importance placed upon ceremonial scenes in Rienzi points towards how Wagner will frequently deploy the chorus in the works that will be discussed in subsequent chapters, while also pointing up how much differently Wagner will characterize the chorus in those later works compared to Rienzi.

During the course of those works, Wagner will frequently use the grand opera chorus to stage a processional into a public and then a depiction of such an event; where these differ from Rienzi is that quite often religious and/or political aspects are conspicuously absent. Frequently, these ceremonies are artistic in nature, such as in the song contests in Tannhäuser and Die Meistersinger. Even in instances where the gathering is somewhat political, such as the first and third acts of Lohengrin, which take on the character of public tribunals, there is a decidedly lesser sense of conflict and strife amongst the "crowd"; the Brabant citizens are not exactly clamoring for Elsa's blood

\footnotetext{
${ }^{122}$ Parakilas, "The Chorus in Nineteenth-Century Opera," 199.
} 
during some sort of auto-da-fé (as in Verdi's Don Carlos), and they raptly anticipate Lohengrin's revelation of his name and origins. And as for the choral scenes in Parsifal, which could not serve more obviously as examples of processional and ceremonial scenes, they distinguish themselves from Rienzi's in two major respects: firstly, the cloistered nature of the Grail community is as far away from being "public" as it can possibly be. ${ }^{123}$ Secondly, the knights' commitment to their ritualistic Grail ceremonies when they are not concerning themselves with Amfortas' sufferings and Klingsor's machinations - indicates that their representative chorus is not politicized in any conventional definition of the term, certainly not in the fashion that Rienzi's chorus is.

The fifth act of Rienzi - where the fickle Roman public burns down the Capitol, having turned against Rienzi - demonstrates another typical aspect of grand opera: using the chorus to characterize the crowd as a "destructive mob." 124 This is of course one of the quintessential strategies of dramatizing political and social conflict. It was also a convention that Wagner would rarely capitulate to in subsequent works; the closest would have to be the riot that closes Act II of Meistersinger, but even that is given a comedic edge as it happens and its aftermath provokes the Wahn monologue from Sachs, mourning the madness and delusion that precipitates such public outbursts. Wagner's portrayal of crowds in general is significantly less incendiary than such offerings as Les Huguenots or even Rienzi; in works like Tannhäuser, Lohengrin, and Parsifal, the crowd takes on more of an observational function, while the vassals of Götterdämmerung do not engage in any actual combat themselves, instead reduced to backdrop in the intrigue involving Siegfried, Hagen, Gunther, and Brünnhilde. In Meistersinger, the crowd is

\footnotetext{
${ }^{123}$ Indeed, as Gurnemanz demonstrates, only a select number of persons can even find the temple.

${ }^{124}$ Gerhard, The Urbanization of Opera, 9.
} 
portrayed as something approaching benevolent, simultaneously giving voice to the public benediction of Walther's art, while also collectively containing the life-force of the community that feeds artistic inspiration. This encapsulates the key distinction between Wagner's treatment of the grand opera chorus in Rienzi and how he will tend to use it later: in those "mature" works, Wagner frequently aims for a more optimistic portrayal of the crowd, less prone to violent conflict, more eager to embrace a common cause, and more sanguine about rallying around and remaining loyal to the singular heroic figures who enter their midst. As I will show in the next two chapters, this more positive treatment of the crowd (especially in Meistersinger) will serve Wagner's purpose in framing the greatness of the German people as laying not so much in aggressive political action, but in the common, supple spirit of the Volk.

The other aspect of the Rienzi story that Wagner recalls as having stirred his interest is the titular character himself, who Wagner characterizes as being given over to "great thoughts." Wagner posits Rienzi to be a quintessentially heroic figure. As such, it is hardly surprising that the titular role is performed by a tenor. As Grey contends, "the role of Rienzi...is regarded as the starting point of the Wagnerian Heldentenor as vocal Fach, however much the melodic idiom differs from roles like Siegfried or Tristan." Different as Rienzi may be, it does arguably set the template for Wagner's future dramas which, Holländer and Rheingold aside, casts the principal tenor role as a pivotal character in the work. In Rienzi, so crucial was that tenor sonority as a distinguishing characteristic for his "heroic" nature that "to avoid a competing heroic tenor role, Wagner casts the

\footnotetext{
${ }^{125}$ Thomas S. Grey, "Meister Richard's Apprenticeship: The Early Operas (1833-1840)," The Cambridge Companion to Wagner (Cambridge: Cambridge University Press, 2008), 35.
} 
young patrician Adriano as a mezzo-soprano trouser role." ${ }^{126}$ Wagner's casting of a tenor in the central role of his bid to beat Parisian grand opera at its own extravagant game should not come as a great surprise. After all, the assignment of the tenor to the "hero" role was a conventional practice of French grand opera: Masaniello of La muette (with Alphonse providing an example of a tenor cast as the romantic rival), Raoul of Les Huguenots, Eléazar of La Juive, Don Carlos of the opera of the same name, and Énée of Les Troyens are but a few examples. So critical was the principal tenor role to grand opera that, as Mary Ann Smart documents, the tenor became nearly as much of a star at the Opéra as the soprano, with Adolphe Nourrit and Gilbert-Louis Duprez being the two outstanding figures, who each premiered several of the iconic grand opera tenor roles. ${ }^{127}$

Several of these heroic tenor roles placed the characters either at the centre of or as the initiators of political conflict and upheaval, so it is no surprise that Rienzi would follow suit. But Wagner's Rienzi goes further than mere heroism and politicization, and will have implications on how Wagner will treat his future heroic tenor roles. As Paul Lawrence Rose argues, Rienzi serves as an early example of Wagner's revolutionary heroes, a "Great Leader," champion of Republican thinking and enemy of tyranny and aristocratic repression. In the opera, "Wagner developed his revolutionary theme around the relationship between the revolutionary leader and the people"; Wagner's Rienzi

was a messianic redeemer of the people striving for the 'good state.' Rienzi was not a king of the conventional type but the charismatic leader of a republic, the 'Tribune' who was above the ordinary politics of class. Nor was the republic of

\footnotetext{
${ }^{126}$ Tbid.

${ }^{127}$ Mary Ann Smart, "Roles, Reputations, Shadows: Singers at the Opéra, 1828-49," The Cambridge Companion to Grand Opera, ed. David Charlton (Cambridge: Cambridge University Press, 2003), 117122. See also Lacombe, The Keys to French Opera, 45-48.
} 
Wagner's Rienzi a liberal form of representative government, but rather one of mystic unity between ruler and people. ${ }^{128}$

Taking such descriptors into account, Rienzi would appear to be something of a progenitor for many of Wagner's "great men," almost all of them - Hans Sachs and possibly Wotan excepted - given voice by tenors. Like Lohengrin, Rienzi commits himself to service to and protection of the people while at the same time presented as "above" said people; Parsifal and Walther will be framed as "messianic redeemers," the aspirational models for their communities to follow in order to preserve and heighten their greatness.

Rienzi's heroic qualities are not without blemishes, however. Millington observes that Baroncelli's and Adriano's accusation that Rienzi has colluded with the nobles is never definitively refuted, leaving open a window of potential for doubt in Rienzi's integrity. ${ }^{129}$ Rose concurs, writing that "Rienzi is not a simple hero, but rather a violent idealist, using terror to slaughter his opponents, and he seems to symbolize the fundamental destructiveness of all politics." 130 In a sense, Rienzi is not far removed from Siegfried in that in both cases their attributes (political idealism for Rienzi, fearlessness for Siegfried) also prove to be tragic flaws that seal their doom. Beyond Rienzi's seeming capacity to embrace the tyranny he was attempting to fight, the character distinguishes himself from Wagner's later heroes in the following fashion: "Rienzi marks the high point of Wagner's Young German phase, when his revolutionism was at its most universal and least German."131 This was due to the fact that "at this time, the Young

\footnotetext{
${ }^{128}$ Paul Lawrence Rose, Wagner: Race and Revolution (New Haven and London: Yale University Press, 1992), 25.

${ }^{129}$ Millington, Wagner, 152.

${ }^{130}$ Rose, 25.

${ }^{131}$ Ibid., 26.
} 
Germans were dedicated to a cosmopolitan, international view of revolution rather than a specifically German one, ${ }^{132}$ which helps account for why Wagner adapted a novel by an English author and based upon an Italian historical figure. In Wagner's future compositions, his heroic tenors will physically and sonorously embody the "great men" of Germanic history and legend - and despite Tristan und Isolde's Cornish setting, Wagner's poem is based upon a German rendering of the legend by Gottfried von Strassberg - foregrounded as uniquely German heroes. Furthermore, as Wagner becomes more invested in the concept of the Volk, he will increasingly incline to show his heroes and the Volk in tune with and supportive of each other: Wagner will become more and more loathe to portray the people, as voiced by the grand opera chorus, so fickle as to profess allegiance to their hero in the first act and then turn on him in the fourth, as the Romans do to Rienzi. Even when the crowd censures Tannhäuser, it is due to being scandalized by the lascivious content of his song; by the opera's end, the overall mood is that of celebration over the sign of his (admittedly posthumous) redemption.

Despite these not insignificant differences between how Wagner conceives of and deploys his chief tenor in Rienzi and his later dramas, what remains constant is that Wagner places his "heroic" tenor in the thick of the elaborate musical and scenic constructions of grand opera. Through the triumphant pomp of the Act I finale in which Rienzi proclaims himself tribune (No. 4), to his pardoning of the conspiring nobles (No. 7), his leading of the forces into battle and their subsequent triumph (No. 10), and finally his solo prayer (No. 13), duet with Irene (No. 14), and final, fatal confrontation with the citizens (No. 16), Rienzi's voice stands tall. With its lack of timbral competition (Baroncelli is the only other tenor role of any significance), the tribune's heroic tenor acts ${ }^{132}$ Tbid., 24. 
like a resounding sonority that holds its own in maintaining its "identity" amidst the voluminous din of grand opera pageantry. This could be thematized as Rienzi's act of musical "heroism." Such musical heroism on the part of Wagnerian tenors will continue to manifest themselves in future works, whether this sonority is tasked with cutting through a multitude of voices, solo or choral, or simply the massive sound of the Wagnerian orchestra. As the following chapters aim to show, the tenor's sonorous heroics will take on increasingly nationalistic implications in his embodiment of a constellation of discourses concerning German myth, art, and nationhood.

Although the composition of Rienzi was, according to Rose, motivated by more cosmopolitan than national aims, apparently like Wagner's efforts to get the opera accepted for performance at the Opéra, Rienzi's subsequent path can still be used to position the work as a prelude to Wagner's nationalistic goals. Recall Wagner's claim at the conclusion of the "Autobiographical Sketch" of tears welling up in his eyes upon his return to Germany from Paris. This statement comes immediately after his notation that Rienzi had already been accepted for performance at the Dresden Court theatre. As a consequence, this "cosmopolitan" grand opera, initially conceived to secure an international reputation, had now been inserted into the fabric of German musical history. Upon its 1842 premiere, Rienzi had effectively become a "grand opera for the Germans,"133 Wagner's first public success which implanted his name into the German musical scene. Wagner had endeavoured to outdo all previous forms of grand opera with Rienzi, and by premiering it in Dresden, one could say that he did so on German soil. Having now "topped" Parisian extravagance with Rienzi, Grey claims that "Wagner was at least able to purge himself of the impulse. Now he had absorbed, synthesized, and

\footnotetext{
${ }^{133}$ Grey, "Wagner and Grand Opera," 326.
} 
'outdone' all the available models and could turn his efforts toward becoming the figure we think of today as Wagner." 134 While Wagner may indeed have exorcised the need to mobilize the tendencies of grand opera within the traditional Parisian mould, I maintain that he never truly "purged" the drive to "absorb" and "synthesize" grand opera into his own aesthetic. And through his continued efforts to maximize the musical, scenic, and technological means within the confines of his own custom-designed theatre - the Festspielhaus - in such works as the Ring and Parsifal, it can be argued that Wagner's urge to outdo previous forms of grand opera never truly subsided either. The following chapters will individually set out to make a case that Wagner's "music dramas" took advantage of choral and male performing bodies in order to continue what the Dresden Rienzi started: an effort towards creating and staging grand opera for the Germans.

\footnotetext{
${ }^{134}$ Grey, "Meister Richard's Apprenticeship," 36.
} 


\section{Chapter One}

\section{A Tale of Two Cities: The Weimar Lohengrin, the Paris Tannhäuser. and Choral Monuments}

\section{Monumental premieres}

Two premieres, two entirely different circumstances: on August 28, 1850, Lohengrin received its first performance at the Hoftheater in Weimar, under the directorship of Franz Liszt; ${ }^{1}$ on March 13, 1861, a substantially revised version of Tannhäuser debuted at the Paris Opéra under the baton of Pierre-Louis Dietsch. ${ }^{2}$ The unveiling of Lohengrin took place within a municipality limited to an understaffed court orchestra and chorus. The "Paris" version of Tannhäuser marshalled the extensive forces of the Paris Opéra in a bustling metropolis deemed by Walter Benjamin to be the "capital of the nineteenth century." ${ }^{33}$ The former performance was considered an overall (but not unqualified) success, and an occurrence that Richard Taruskin refers to as "the very event that led to the christening of the music of the future." Such hyperbole owes itself not insignificantly to the fact that the premiere functioned as a proverbial "meeting of the

\footnotetext{
'David Trippett recounts the historical and political significance of the Lohengrin premiere in "Lohengrin at the Weimar Hoftheater: the Politics of a Premiere," Journal of the American Liszt Society 61-62 (20102011): 135-158.

${ }^{2}$ The various versions of Tannhäuser - there are generally considered to be four: the 1845 original premiered in Dresden, an 1847 revision of this score, the "Paris" revision of 1861, and finally a minor revision of the Paris version prepared for an 1875 performance in Vienna - are accounted for by Werner Breig in "The Musical Works," Wagner Handbook, trans. John Deathridge, eds. Ulrich Müller and Peter Wapnewski (Cambridge, MA and London: Harvard University Press, 1992), 422-427. Carolyn Abbate studies the Paris version in detail in "The Parisian 'Vénus' and the 'Paris' Tannhäuser," Journal of the American Musicological Society 36/1 (Spring 1983): 73-123 and "The Parisian Tannhäuser" (PhD diss., Princeton University, 1984).

${ }^{3}$ Walter Benjamin, "Paris, the Capital of the Nineteenth Century" (1935), The Writer of Modern Life: Essays on Charles Baudelaire, trans. Howard Eiland, Edmund Jephcott, Rodney Livingstone, and Harry Zohn, ed. Michael W. Jennings (Cambridge, MA and London: Belknap Press, 2006), 30-45. See also The Arcades Project (1999), trans. Howard Eiland and Kevin McLaughlin, ed. Rolf Tiedemann (Cambridge, MA and London: Belknap, 2002).

${ }^{4}$ Richard Taruskin, The Oxford History of Western Music - Volume 3: Music in the Nineteenth Century (Oxford: Oxford University Press, 2005), 479.
} 
minds" for two of the figures (Liszt and Wagner) who would come to be framed as crucial to the advancement of German music. ${ }^{5}$

Conversely, the Paris Tannhäuser was an infamous fiasco, the performance itself subjected to numerous derisive hoots and whistles from the members of the Parisian "Jockey Club." Indeed, the public and critical opposition to Tannhäuser was so great that Wagner withdrew the work after only three performances. As Steven Huebner writes, the opposition to Wagner played no small part in the fact that no Wagner opera was staged at the Paris Opéra until the performance of Lohengrin in September of 1891 (although Wagner's music had made frequent appearances in the Parisian concert repertoire), which precipitated a drastic turnaround in Paris' reception of Wagner's works, resulting in Wagner becoming the most staged composer at the Opéra by the end of the nineteenth century. ${ }^{7}$ The chasm that separates the reception of the two works provides a handy encapsulation of what I intend to accomplish in this chapter: above all else, the following discussions are fundamentally about these two cities, Weimar and Paris, their artistic and cultural legacies, their importance to the creation of respectively

\footnotetext{
${ }^{5}$ The Liszt-Wagner relationship, both personal and musical, has been examined along several trajectories, a selection of which include (but are by no means limitied to): Gerhard Winkler, "Liszt und Wagner: Notizen $\mathrm{zu}$ einer problematischen Beziehung," Österreichische Musikzeitschrift 41/2 (1986): 83-89; Susan Bernstein, "In Formel: Wagner and Liszt," New German Critique 69 (Autumn 1996): 85-97; Rainer Kleinertz, "Liszt, Wagner, and Unfolding Form: Orpheus and the Genesis of Tristan und Isolde," Franz Liszt and His World, ed. Christopher H. Gibbs and Dana Gooley (Princeton, NJ and Oxford: Princeton University Press, 2006), 231-254; Kenneth Hamilton, "Wagner and Liszt: Elective Affinities," Richard Wagner and His World, ed. Thomas S. Grey (Princeton, NJ and Oxford: Princeton University Press, 2009), 27-64.

${ }^{6}$ As Hervé Lacombe explains, the "Jockey Club" was a group founded in 1834 that brought together members of the Parisian aristocracy and bourgeoisie; their public expressions of discontent was in part the result of Wagner's failure to include a ballet in the second act, "which was the time when these gentlemen would habitually come, after dinner, to admire their protégées among the ballerinas" (40). See The Keys to French Opera in the Nineteenth Century, trans. Edward Schneider (Berkeley: University of California Press, 2001), 39-40 and 358n16.

'Steven Huebner, French Opera at the Fin-de-siècle: Wagnerism, Nationalism, and Style (Oxford and New York: Oxford University Press, 1999), 17-21.
} 
German and French identities, and how the premieres of two of Wagner's operas (and their respective receptions) fit within those legacies and identities.

Despite the exceptional circumstantial differences that separate the two stagings, there are also a number of commonalities: as the preceding remarks should indicate, both premieres resulted in a marked increase in public consciousness of Wagner, both for good and for ill. In the case of Lohengrin, the performance - the first debut of "new" Wagner material since the Dresden premiere of Tannhäuser in 1845 - was efficacious in putting Wagner's music back in the public eye, in the wake of the composer's "exile" in the aftermath of the 1849 Dresden uprising. Of course, Wagner was already quite wellknown in Germany, but as will be made clear shortly, the highly publicized nature of the 1850 performance in Weimar provided a spike in exposure (national and international) to Wagner, which also saw a commensurate increase in critical attention as the performance was covered by the music press. As Annegret Fauser documents, the Parisian premiere of Tannhäuser served as something of a culmination of a lengthy critical debate surrounding Wagner's aesthetic theories as laid out in the "Zurich essays." reception to the performances only intensified the debate between anti and pro-Wagner voices (with Charles Baudelaire providing perhaps the most enduring panegyric to Wagner), ${ }^{9}$ the increased public presence of Wagner's name and theories (and eventually his music on the concert stage) arguably setting the stage for the fin-de-siècle explosion of popularity of Wagner's works.

\footnotetext{
${ }^{8}$ Annegret Fauser, "Cette musique sans tradition: Wagner's Tannhäuser and Its French Critics," Music, Theater, and Cultural Transfer: Paris, 1830-1914, eds. Annegret Fauser and Mark Everist (Chicago and London: University of Chicago Press, 2009), 228-255.

${ }^{9}$ Charles Baudelaire, "Richard Wagner and Tannhäuser in Paris," The Painter of Modern Life and Other Essays $-2^{\text {nd }}$ Edition, trans. and ed. Jonathan Mayne (London: Phaidon Press, 1995), 111-146.
} 
Another point of concurrence is that both premieres showcased works that owed a significant debt to grand opera. ${ }^{10}$ Tannhäuser proved ideal for adaptation for Paris' dramaturgical requirements. As Thomas Grey observes, in the opera "it is easy enough to recognise many of the basic structural lineaments of grand opera...."11 Grey points to the "scene-based dramaturgy"12 in which smaller structural units (such as recitatives, arias, ensembles, etc.) are absorbed into a larger-scale continuous musical argument as an example of said "lineaments," in addition to the presence of elaborate processional and ceremonial scenes. Huebner notes that the efforts to return Wagner to the Opéra were centred on Lohengrin likely because of the post-Rienzi operas, it was considered to be the one that arguably bore the greatest resemblance to conventional grand opera. ${ }^{13}$ Like Tannhäuser, it also contains the scene-based dramaturgy of grand opera as well as prominent processional, ceremonial, and crowd scenes. It is those processionals and crowd scenes so characteristic of works performed at the Paris Opéra that are most germane to this chapter: such scenes prominently exploit the services of the grand opera chorus. In its assemblage of multitudinous voices and performing bodies on the stage, the grand opera chorus (in its traditional Parisian guise) can be theorized as a prime example of the genre's reflection - according to Anselm Gerhard - of its status as a product of the increasingly urbanized conditions of nineteenth-century Paris. ${ }^{14}$ Following the logic of this paradigm (and as the following pages will endeavour to explicate in greater detail), the amassed bodies of the chorus would then function as an effective

\footnotetext{
${ }^{10}$ Thomas S. Grey, "Richard Wagner and the Legacy of French Grand Opera," The Cambridge Companion to Grand Opera, ed. David Charlton (Cambridge: Cambridge University Press, 2003), 331-336.

${ }^{11}$ Ibid., 332.

${ }^{12}$ Ibid.

${ }^{13}$ Huebner, 16.

${ }^{14}$ Anselm Gerhard, The Urbanization of Opera: Music Theater in Paris in the Nineteenth Century, trans. Mary Whittall (Chicago and London: University of Chicago Press, 1998).
} 
stand-in for the dense population of the city outside the walls of the opera house. The densely "populated" chorus employed by the Opéra explicitly demonstrates the genre's preoccupation with size and opulence which - as James Parakilas points out - functioned as a strategy for glorifying the French nation. ${ }^{15}$ The scale of the operatic spectacle put on display, personified in large part by the size of the chorus, ostensibly demonstrated the grandeur, immensity, and power of the French identity. If we accept Gerhard's contention that grand opera's opulence arose out of the attempt to come to terms with the conditions of urban expansion, it would be plausible to posit that French pride in the immensity of the Opéra's musical and technical resources spoke on some level to a certain pride in Paris's urban sophistication (and the ensuing discussion will strive to provide ample support for why such a contention is so): the chorus represented the city and the city, in turn, encapsulated the modern conception of the nation.

In the Paris version of Tannhäuser, Wagner exploits the "urbanized" dramaturgy of grand opera to advance a critique of Parisian culture by essentially setting grand opera against itself. Wagner positions the grand opera trappings of Tannhäuser as a sign of the "inauthentic" nature of Parisian life in order to underline the superiority of German culture. In formulating this argument, to be developed during the following pages, I paraphrase Lawrence Kramer, who observes that "as a national [German] opera set in the Middle Ages, with real historical figures among its characters, Tannhäuser associates authenticity with ancestry and mobilises the prestige of the national patrimony against a debased modernity."

\footnotetext{
${ }^{15}$ James Parakilas, "The Chorus," The Cambridge Companion to Grand Opera, ed. David Charlton (Cambridge: Cambridge University Press, 2003), 76-92.

${ }^{16}$ Lawrence Kramer, "Wagner's Gold Standard: Tannhäuser and the General Equivalent," Cambridge Opera Journal 21/2 (2010): 145-146. Kramer's readings are informed by a long extant interpretation of the
} 
As a sidebar, "modernity" is of course a notably polysemous term, but for the purposes of this chapter, it should be understood to be derived from Marshall Berman's observation that the nineteenth-century conception of modernity was borne out of attempts to come to terms with that era's experience of the rapid proliferation of technology and the concomitant expansions of urbanization, industrialization, and capitalism and the increasingly prevalent concept of the nation-state. ${ }^{17}$ In Berman's estimation, to be "modern" in the nineteenth century was to negotiate a multitude of complex and frequently contradictory experiences. This condition is akin to what the sociologist Georg Simmel ascribed to the experience of the modern city in his 1903 essay "The Metropolis and Mental Life," which characterized the city as a profusion of physical, emotional, and intellectual stimuli. ${ }^{18}$ With its expanding size and population and the accompanying increase in technological, industrial, and mercantile sophistication, the nineteenth-century city could then be thematized as an illustration of Berman's conception of modernity. As I shall make clear shortly, the make-up of Paris in the nineteenth century went a long way towards justifying David Harvey's characterization of the city as the "capital of modernity."19

Kramer locates the "debased modernity" of Tannhäuser primarily in the "sensuous orchestration and chromatic harmony of the Venusberg music" positioning this

\footnotetext{
Venusberg's ostensible debasement and decadence, which is influenced by a number of treatments of the Tannhüuser legend by various late-eighteenth and nineteenth century German poets and thinkers, including Heinrich Heine ("Die Götter im Exil," 1853), Ludwig Tieck (Der getreue Eckart und der Tannhäuser, 1799), and E.T.A. Hoffmann ("Der Kampf der Sänger," 1819-1821). Wagner recounts his experience with Hoffmann's story in ML 212-213. Dieter Borchmeyer accounts for the influences of these three writers on Wagner and for the popular interpretations of Venus in Drama and the World of Richard Wagner, trans. Daphne Ellis (Princeton, NJ and Oxford: Princeton University Press, 2003), 101-146.

${ }^{17}$ Marshall Berman, All That is Solid Melts into Air: The Experience of Modernity (New York: Penguin. 1988), 18-19.

${ }^{18}$ Georg Simmel, "The Metropolis and Mental Life" (1903), The Sociology of Georg Simmel, trans. and ed. Kurt H. Wolff (New York: The Free Press, 1964), 409-424.

${ }^{19}$ David Harvey, Paris, Capital of Modernity (New York and London: Routledge, 2003).
} 
realm of sensual pleasure "as ultramodern and decadent as possible." ${ }^{20}$ The association of the sating of the senses with modernity finds some resonance in Michel Foucault's reading of Baudelaire's conception of modernity: as Foucault puts it "modernity" is an attitude, a way of experiencing the present, rather than a temporal epoch. This attitude is that of an endeavour to "grasp the 'heroic' aspect of the present moment."21 Baudelaire's conception of the "modern" man is one who is constantly on the move, continually inventing and discovering himself, always searching for new experiences. ${ }^{22}$ As such, the Venusberg's veneration of sensation might be seen as an example of Baudelaire's "heroizing" of the present, its restless activity being actively sought out by the perpetually active modern individual..$^{23}$

The Venusberg scene as reworked for Paris contains a recomposed ballet and chorus as couleur locale, hallmarks of grand opera used to portray a den of iniquity that Wagner apparently associated with the decadent sensuality of modernity, a modernity that Tannhäuser must conclusively reject if he is to have any hope of achieving salvation. Examining Kramer's reading, "modernity" essentially becomes synonymous with the conditions of the "big city" that is nineteenth-century Paris, with its preponderance of physical and emotional stimuli, a sign of the ostensible "inauthenticity" of French culture. The conception of the city as a repository of commoditization, devoted to little more than

\footnotetext{
${ }^{20}$ Kramer, 146. Stephen C. Downes provides a more thorough reading of the musical representation of decadence in Music and Decadence in European Modernism: The Case of Central and Eastern Europe (New York: Cambridge University Press, 2010). Walter Frisch discusses the relationships of Wagner's music with late nineteenth-century conceptions of German modernism in German Modernism: Music and the Arts (Berkeley: University of California Press, 2005), 7-35.

${ }^{21}$ Michel Foucault, "What is Enlightenment?" The Foucault Reader, ed. Paul Rabinow (New York: Pantheon Books, 1984), 40.

${ }^{22}$ Tbid., 41-42.

${ }^{23}$ Baudelaire lays out his paradigm of modernity in "The Painter of Modern Life," The Painter of Modern Life and Other Essays - $2^{\text {nd }}$ Edition, trans. and ed. Jonathan Mayne (London: Phaidon Press, 1995), 1-41. Andrea Gogroff-Vorhees further explores nineteenth-century conceptions of modernity (specifically those of Baudelaire and Nietzsche) in Defining Modernism: Baudelaire and Nietzsche on Romanticism, Modernity, Decadence, and Wagner (New York: Peter Lang, 1999).
} 
tawdry thrills and mercantilism was nothing new to Wagner, as should be apparent in for example his 1841 essay "Traps for Unwary Germans in Paris,"24 where he characterizes the bustle of Paris, its sights and sounds, as fundamentally at odds with the German identity. He ascribes a falseness to Parisian city life that unhappily isolates Germans living in Paris, who cannot partake in the city's hustle and bustle because it is so contrary to their character.

In the Paris version of Tannhäuser, it can be argued that the dramaturgy of grand opera is mobilized in order to negate grand opera. This urbanized dramatic form is exploited in order to present its urbanity as fundamentally false, as decadent and depraved, a veritable hothouse incapable of genuine artistic inspiration. But this characterization only really applies to the Venusberg scene: the chorus is most prominent in the crowd scenes and processionals that are ubiquitous in the second and third acts. In fact, Kramer specifically contrasts the "Pilgrim's Chorus" - introduced at the beginning of the overture, and reprised in the third act procession - with the music of the Venusberg, arguing that the latter "mocks and seeks to obliterate the severe piety" of the former. ${ }^{25}$ This is not to say that the opera unequivocally endorses one position over the other, but it is clear that these two forces are established as in conflict from the overture. The dramaturgy of grand opera is used in furtherance of a narrative that exploits the "premodern" (as in, pre-urbanization, pre-industrialization, and pre-capitalism) milieu of German history and legend. ${ }^{26}$ As this chapter will endeavour to show, the Paris production of Tannhäuser makes use of grand opera on the genre's proverbial home turf

\footnotetext{
${ }^{24} \mathrm{WP}, 18-35$.

${ }^{25}$ Kramer, 146.

${ }^{26}$ Mary A. Cicora interrogates Wagner's adaptations of his various medieval German sources in From History to Myth: Wagner's Tannhăuser and its Literary Sources (Bern and New York: Peter Lang, 1992).
} 
in order to showcase a struggle of ideologies between the pre-modern "authenticity" of medieval Germany and the decadent and debased modernity of France, with Germany eventually declared the victor. As shall become apparent, the discourse in the Parisian press leading up to and in the aftermath of the premiere indicated awareness of what was at stake in terms of the Tannhäuser debut forcing a struggle between "French" and "German" conceptions of opera, which played a significant role in the opera's catastrophic failure. ${ }^{27}$ For my inquiry into the Paris Tannhäuser, I will situate the contrast between Wagner's writings on the performances and on French opera and culture in general, and the Parisian reception to the staging as a site of contestation between German and French nationalisms.

Such a contest played no part in the discourse surrounding the earlier premiere of Lohengrin in Weimar. As such, the circumstances of the 1850 performance suggest the potential for a different reading of the convergences of narratives of the grand opera chorus, the city, and national identity. The fact that the Lohengrin premiere took place in Weimar will be central to my argument, which will position "the city" as a venerated receptacle for artistic and cultural heritage. Lohengrin was premiered during a festival celebrating the anniversary of the birth of Johann Gottfried Herder. As Alan Walker points out, the festival brought a significant influx of visitors into Weimar for the festivities, with the Lohengrin performance in particular drawing a significant

\footnotetext{
${ }^{27}$ In addition to Fauser, this contention will also draw upon inquiries into Wagner's reception in France as carried out by: Gerald D. Turbow, "Art and Politics: Wagnerism in France," Wagnerism in European Culture and Politics, eds. David C. Large and William Weber (Ithaca, NY and London: Cornell University Press, 1984), 134-166; Katharine Ellis, "Wagnerism and Anti-Wagnerism in the Paris Periodical Press, 1852-1870," Von Wagner zum Wagnérisme: Musik, Literatur, Kunst, Politik, eds. Annegret Fauser and Manuela Schwartz (Leipzig: Leipziger Universitătsverlag, 1999), 51-83.
} 
international audience. ${ }^{28}$ That international presence is ultimately less important than the fact that it took place in Weimar, a city with an already rich artistic and intellectual tradition. ${ }^{29}$ Indeed, as my forthcoming analysis will show, Liszt's staging of Lohengrin played a significant role in his ongoing efforts as Kapellmeister to build upon the enduring legacies of such revered figures as Goethe and Herder in order to re-solidify Weimar's standing as a centre of activity for German art and culture. In that sense, the city represented the German nation just as Paris' urbanity supposedly did for French nationhood.

This chapter's central arguments will proceed along the following trajectory: I will begin by exploring the "urbanization" of Paris in the nineteenth century more thoroughly before discussing intersections between the grand opera chorus, the city, and nationhood in France. Space considerations can permit me to offer only a sampling of the extensive literature on Paris' and grand opera's resources, but what I shall provide will hopefully adequately sketch out what the experience of that city was like in the nineteenth century. Following up, I will contrast the French ideas about the city and nationhood with Wagner's critiques of French culture and his commensurate ideas about German art and culture as a corrective to France's cultural and aesthetic excesses. From there, the discussion will move into an examination of the Weimar Lohengrin and the Paris Tannhäuser, positioning both premieres as constellations of discourses surrounding the chorus, their respective cities, and the nation. With Lohengrin, I situate the performance within the specific cultural context surrounding the city of Weimar and the

\footnotetext{
${ }^{28}$ Alan Walker, Franz Liszt - Volume Two: The Weimar Years, 1848-1861 (1989) (Ithaca, NY: Cornell University Press, 1993), 125.

${ }^{29}$ Detlef Altenburg, "Franz Liszt and the Legacy of the Classical Era," $19^{\text {th }}$-Century Music 18/1 (Summer 1994): 46-63; Altenburg, ed. Liszt und die Weimarer Klassik (Laaber: Laaber-Verlag, 1997); G. Kraft and Dieter Hărtwig, "Weimar," Grove Music Online (accessed December 30, 2012).
} 
Herder Festival of which the performance was a part; specifically, I will argue that the cultural and artistic history of Weimar and its importance to the formation of German culture was strategically exploited by Liszt in order to grant the Lohengrin premiere a lineage to that history, thereby framing the performance as the latest contribution to Weimar's cultural heritage. Complementing Liszt's activities is the critical reception of the performance by Wagner's supporters (notably Franz Brendel and Theodor Uhlig), whose reviews of the performance argued that it was a momentous event that represented a major advance for German music. It is my position that such a reception was in part derived from the premiere's status as a constellation of Liszt's and Wagner's artistic and cultural reputations, and the legacy of Weimar.

Following that will be a reading of the Paris Tannhäuser that will foreground the aforementioned contestation between French and German conceptions of nationhood, with Wagner using the Parisian stage to broadcast a "victory" of German culture of that of the French. Threading itself through discussion of both premieres will be a series of readings of the grand opera choral scenes (primarily in the form of large-scale crowd and ceremonial scenes) in both works. Key to my examination of both works is Alexander Rehding's discussion of musical "monuments" as a central element in the commemoration of German culture in the nineteenth century..$^{30}$ The "metropolitan" grand opera chorus, I will contend, was efficacious in framing both premieres as "monuments" to German history, mythology, art, and nationhood. For the Weimar Lohengrin, the choruses were imbued with a sense of apposite "monumentality" that fit comfortably within both Weimar's own status as a German monument and Liszt's own intentions to

\footnotetext{
${ }^{30}$ Alexander Rehding, Music and Monumentality: Commemoration and Wonderment in Nineteenth-Century Germany (Oxford and New York: Oxford University Press, 2009).
} 
use the Herder festival to simultaneously commemorate the city's cultural history and celebrate its future. The "monumental" choruses of the Paris Tannhäuser, meanwhile, will be interpreted as part of a "grand" tribute to the superiority of German art and heritage, using an instrument of French culture in order conclusively reject it before French spectators.

\section{Paris and Grand Opera}

Grand opera as staged at the Académie Royale de Musique (the official name of the Paris Opéra during much of the first half of the nineteenth century) was the site of what Gerhard calls the "emancipation of the chorus." 31 In grand opera, Gerhard argues, the chorus began to be liberated from being limited to "self-contained choral numbers or [to joining] in arias and ensembles in a purely accompanimental function" of the type that Gerhard identifies even in Auber's La Muette de Portici, well recognized as one of the progenitors of the genre." The chorus' "emancipation" from ornamental duties was also critical to its increasing politicization throughout the nineteenth century. As Parakilas notes, this era saw the rise of the operatic chorus being employed to represent an entire people on stage, with a will to political action. ${ }^{33}$ In Chapter Two, I will further deal with the political dimension of the idea of the chorus as a miniaturization of the nation, but at the present moment, I wish to isolate the notion of the chorus as a representation of an entire people: to rephrase that in slightly different terms, the chorus under this paradigm is constructed as standing in for the population, for the public. Applying such terms to Parakilas' framework suggests a potential reading of "the people" that specifically

\footnotetext{
${ }^{31}$ Gerhard, 82-90.

${ }^{32}$ Ibid., 85.

${ }^{33}$ James Parakilas, "Political Representation and the Chorus in Nineteenth-Century Opera," $19^{\text {th }}$-Century Music 16/2 (Fall 1992): 181-202.
} 
situates them within cities, a reading that gains increasing plausibility when considered within the context of nineteenth-century Paris. In the following pages, I shall endeavour to demonstrate how the conditions of Paris might be considered efficacious in locating "the people" specifically within "the city."

Setting aside grand opera for a moment and focusing on the city itself, the Paris of Wagner's residency in the late 1830 s and early 1840 s and that of the premiere of the Paris Tannhäuser both provide significant portraits of the conditions and experiences of urbanity in the French capital. Baron Haussmann's renovation programs - begun in 1853 under the auspices of Napoléon III - represent the most extensive period of the city's urbanization, to the extent that many of the designs and layouts of the "Haussmann" Paris have endured to the present day. ${ }^{34}$ This was the city that housed the Paris Tannhäuser, but even before that, Paris was a metropolis of considerable magnitude. David P. Jordan paints the following portrait of the city's grandeur:

Long before Haussmann, visitors were amazed at the city in the bend of the Seine. Paris first seen etched a sharp and sometimes monstrous image in the memory. The city was larger than life, beyond the limits of perception. Its size, density, complexity, both wonderful and terrific when viewed from a distance, were confirmed in the days of more intimate examination that followed the first glimpse. Once experienced at street level, its particular charms and beauties singled out from the overwhelming whole, the city could become Paris remembered, the most familiar form of celebration in memoirs, letters, novels, poetry, and song. ${ }^{35}$

Jordan's hardly dispassionate appraisal telescopes several centuries' worth of experiences of city life into a single summational (and introductory) paragraph. Citations of select historicizations of the makeup of Paris during the first half of the nineteenth century should reveal that Jordan's effusive prose is not entirely without historical justification.

\footnotetext{
${ }^{34}$ David P. Jordan, Transforming Paris: The Life and Times of Baron Haussmann (New York: The Free Press, 1995), 10.

${ }^{35}$ Ibid., 13.
} 
The Paris that existed under the July Monarchy - that is, during the reign of LouisPhillipe that resulted from the overthrow of Charles $\mathrm{X}$ of the Bourbon Dynasty during the 1830 "July Revolution" - is illustrative. On the most prosaic level, there are these figures provided by Colin Jones: 'the city's population of 550,000 to 600,000 in 1801 had risen to 700,000 in 1817 , and was nearly 800,000 in 1831 . By mid-century Paris contained in excess of a million individuals. ${ }^{.36}$ Such a growth in residency in a relatively short period of time indicates that the Paris of the 1830 s and 1840s was indeed the busy metropolis that Jordan portrays in the above quote. The city that these residents were exposed to demonstrates that such a supposition is in many ways correct.

In Christopher Prendergast's study of nineteenth-century Paris, he observes that Benjamin's characterization of Paris as the "capital of the nineteenth century" has precedent in a number of writings on the city during the first half of the century. For example, Balzac's essay "Paris en 1831" refers to Paris as "the capital of the world" and "unrivalled in the world." ${ }^{37}$ This is not the only example Prendergast offers, but I isolate it due to the time period to which Balzac's writing refers: namely the 1830 s, only a few short years before Wagner's arrival. The Paris of this era provoked such encomia in part by offering a wide range of experiences. One of those experiences might have been the famed arcades, which as Benjamin points out mostly "[came] into being in the decade and a half after $1822,{ }^{, 38}$ and notably served for Benjamin as as a particularly potent image of Paris as the quintessential European city. Quoting an excerpt from an Illustrated Guide to Paris, Benjamin characterizes these glass and iron-covered passages

\footnotetext{
${ }^{36}$ Colin Jones, Paris: The Biography of a City (New York: Viking, 2005), 282.

${ }^{37}$ Honoré de Balzac "Paris en 1831," quoted in Christopher Prendergast, Paris and the Nineteenth Century (Oxford and Cambridge, MA: Blackwell, 1992), 6. Prendergast quotes the original French ("la capitale du monde" and "sans égal dans l'univers"); translations are my own.

${ }^{38}$ Benjamin, "Paris, the Capital of the Nineteenth Century," 30.
} 
lined with shops as "a city, a world in miniature." As Patrice Higonnet's history of Paris states, the arcades functioned as the symbol of Paris' "true economic originality" in its centralization of consumption over production. ${ }^{40}$ Invented in the late eighteenth century by Phillipe d'Orléans - father of the king of the July Monarchy, Louis-Phillipe the arcades would become a hub of Paris' mercantile sector, with more than a hundred standing by the end of the $1840 \mathrm{~s}^{41}$ Furthermore, the arcades represented "the latest ideas in industrial design" with the Passage des Panoramas becoming in 1816 "the first public space in Paris to be illuminated by gas." ${ }^{.42}$ So prominent were the arcades that they influenced intellectual thought: the utopian Charles Fourier (1772-1837), according to Benjamin saw the arcades as an example of his concept of the "phalanstery," a structure that assembles individuals into a co-operative community: although the arcades initially serve "commercial ends," they eventually become "places of habitation. The phalanstery becomes a city of arcades. ${ }^{\$ 43}$ Higonnet concurs with Benjamin's interpretation, positing that Fourier's analysis of the "gallery-streets" as an example of the phalanstery refers to the arcades, ${ }^{44}$ while Jonathan Beecher's study of Fourier is less certain, granting that Fourier knew of the arcades, but only willing to speculate that his utopian "street gallery"

\footnotetext{
${ }^{39}$ Illustrated Guide to Paris, quoted in Benjamin, 31. Graeme Gilloch examines Benjamin's writings on Paris and the Arcades Project in particular in Mtyh and Metropolis: Walter Benjamin and the City (Cambridge: Polity Press, 1996).

${ }^{40}$ Patrice L.R. Higonnet, Paris: Capital of the World, trans. Arthur Goldhammer (Cambridge, MA: Belknap Press, 2002), 195.

${ }^{41}$ Ibid., 195-196.

${ }^{42}$ Ibid., 196. As Prendergast notes, gaslight was "a novelty" (31) in the 1830 s but would become a major part of the urban experience in Paris by the 1850s. See Prendergast, 31-33.

${ }^{43}$ Benjamin, "Paris," 33. Benjamin further discusses Fourier in Convolute W of The Arcades Project, 620650.

${ }^{44}$ Higonet, 197.
} 
may have been influenced by the arcades. ${ }^{45}$ Nonetheless, it is still clear that the arcades were a ubiquitous presence in Parisian life in the first half of the nineteenth century.

Beyond the arcades, the Paris of the 1830 s and 1840s reflected Jordan's characterization in other ways: Prendergast devotes a not insignificant amount of space towards parsing various writings from the era that characterized Paris as a cacophonous den of noise and activity. Even as early as 1830 , the conditions of the city were characterized as displaying "the intolerable noise that twenty thousand vehicles make day and night in the streets of Paris. ${ }^{" 26}$ Clearly this example is not altogether positive towards the city's perceived flurry of activity. As Prendergast observes, poetic and literary writings on nineteenth-century Paris (in particular Baudelaire) demonstrated a pronounced ambivalence towards the effects of noise and cacophony on the experience of the city. ${ }^{47}$ Nonetheless, the "noisy" city was clearly perceived as an intrinsic part of Paris' daily life, a part that would become even more pronounced as the "Haussmann" Paris took shape. Futhermore, the perception of the city's noisiness feeds into the narrative that Jordan alludes to of Paris as this "larger-than-life" and "overwhelming" space, teeming with excitement and sensation. Regarding the characterization of Paris' noise as indicative of excitement and energy, Jones quotes the Polish publicist Frankowski whose diagnosis of the city in the 1830 s reads as follows:

[Paris] is rapid, it is ardent, it is seething...In the streets, in the passages, in the gardens, on the squares, on the quais, on the bridges, and under the bridges, men, animals, carts and boats walk, run, roll, and slide. The air vibrates. It is torn by brusque notes and long notes, and it is worn out by blasts of bizarre sound that

\footnotetext{
${ }^{45}$ Jonathan Beecher, Charles Fourier: The Visionary and His World (Berkeley: University of California Press, 1986), 245.

${ }^{46}$ Amédée de Tissot, Paris et Londres compares (1830), quoted in Prendergast, 127. The page reference is to the French original that Prendergast quotes ("l'insupportable bruit que font nuit et jour vingt mille voitures paticulières dans les rues de Paris"). Prendergast's translation, provided above, appears on p. 267.

${ }^{47}$ Prendergast, 126-163.
} 
suddenly erupt and suddenly vanish. The street is always babbling, and the paving stones groan or complain, grind or hiss..... ${ }^{48}$

As opposed to the previous quote lamenting the perceived unceasing clamour of the city, Frankowski attributes an intoxicating effect to Paris' constant bustle. Beyond the city's "sheer urban spectacle," the Paris of the July Monarchy also became "an international Mecca for all young scholars, scientists, engineers and physicians with vision and ambition." Furthermore, Paris solidified its reputation "as a maelstrom of intellectual and artistic activity" as "the Louvre remained the most renowned art gallery in the world" and the city "took over from Vienna as world capital of music," having attracted "most of Europe's greatest composers." ${ }^{\text {O }}$ All of these points combine to portray Paris in the 1830 s and 1840s as thrilling in its multivalence, offering all manner of physical, emotional, and intellectual pleasures.

After the inauguration of the Second Empire in 1852 under Napoléon III, Paris experienced a veritable transformation through the aforementioned renovations supervised by Haussmann. So influential was Haussmann's work that Jones was motivated to title the chapter of his history of Paris dealing with this period "Haussmanism and the City of Modernity." s1 Such a title implies a "before and after" effect to the "Haussmanization" of Paris, to the extent that Paris was a different city after the renovations had been implemented. Of course, David Harvey makes sure to note that the idea of Haussmann's Paris as a "radical break" from the "old" Paris is a piece of enduring mythmaking initiated by Haussmann and Napoléon III, as numerous plans for

\footnotetext{
${ }^{48}$ L.S. Kramer, Threshold of a New World: Intellectuals and the Exile Experience in Paris, 1830-48 (1988), quoted in Jones, 277.

${ }^{4}$ Jones, 277.

${ }^{50}$ Ibid., 276-277.

${ }^{31}$ Jones, 299-343.
} 
urban renewal of the city had been bandied about in the 1840 s under the July Monarchy. ${ }^{32}$ Nonetheless, it was during the Second Empire that the renovation programs were realized. The most obvious change to the city was the widening of the narrow streets that had endured since medieval times, which produced the "broad new boulevards along which traffic was to circulate henceforward...."533 But the Paris of the Second Empire saw more changes than just the width of the streets: for example, while the arcades were a ubiquitous presence in the 1830 s and 1840 s, they entered a period of decline during the Second Empire, many of them having been demolished as part of the renovations. Harvey encapsulates the "before and after" as such: "before, there were small stores along narrow, winding streets or in the arcades; and after came the sprawling department stores that spilled out onto the boulevards." ${ }^{\prime 4}$ The arcades did not disappear entirely of course, but as Jones notes they seemed "tawdry and lilliputian" compared to these stores, or grands magasins. ${ }^{5 s}$

The "sprawling" nature that Harvey attributes to these grands magasins, "spilling" out onto the boulevards as if the streets could not contain their magnitude, indicates that spectacle was a notable concern vis-a-vis the design of this "new" Paris: just in terms of the city's size, "the surface area of the capital rose from less than 3,500 hectares to nearly 8,000 by the $1860 \mathrm{~s}$ " while "the population increased from roughly one million at the fall of the Second Republic in 1851 to 1.9 million in $1872 \ldots . . .966$ These increases played no small part in rendering Paris a more "spectacular" city. The concept

\footnotetext{
${ }^{52}$ Harvey, Paris, the Capital of Modernity, 8-9. See also Nicholas Papayanis, Planning Paris Before Haussmann (Baltimore: Johns Hopkins University Press, 2004) for more detailed discussion of the various plans for "modernizing" Paris in the decades before Haussmann's project.

${ }^{33}$ Gerhard, 20.

${ }^{54}$ Harvey, 3.

s5 Jones, 288.

${ }^{36}$ Tbid., 299.
} 
of the city as spectacle notably manifested itself in the "Universal Expositions," the first of which took place in 1855. Inspired by London's Great Exhibition of 1851, the Universal Exposition sought to show off the "new" Paris, to solidify the city as the "capital of the world, the shining light of the modem age." made their way to the Champ-Élysées for the 1855 Exposition, to "view the merchandise" as Ernest Renan remarked, clearly not without some degree of skepticism. ${ }^{58}$ Benjamin further adds that the Expositions functioned as "places of pilgrimage to the commodity fetish." Higonnet writes that the "merchandise" was fetishized as such: the 1855 Exposition was a peaen to "the cult of mechanization and the idea that the key to the future of humanity lay in industrialization, in a universal technological modernization of which Paris would be the beacon." impressive iron architecture in which the exhibits were displayed, and the almost demonic energy of the machines and installations in place...." ${ }^{\circ 1}$ In many respects, what was for "sale" at the Expositions was an image of Paris as the most advanced, most spectacular, and the grandest city in Europe. ${ }^{62}$ Space has only permitted these few vignettes to provide a sketch of the narratives that Second Empire Paris endeavoured to put forward about itself; it was within the context of this version of Paris that the Tannhäuser premiere took place.

\footnotetext{
${ }^{57}$ Ibid., 301.

${ }^{58}$ Benjamin, The Arcades Project, quoted in Jones, 335. Benjamin erroneously attributes this quote to Hippolyte Taine in "Paris, Capital of the Nineteenth Century," 36.

${ }^{59}$ Benjamin, "Paris," 36.

${ }^{60}$ Higonnet, 353.

${ }^{61}$ Jones, 334.

${ }^{62}$ Gerhard argues that the aesthetics of the Expositions demonstrated a distinct similarity to those of grand opera, in that both distributed large crowds of people within a lavish and technologically sophisticated scenic space (389).
} 
Bringing things back to grand opera, Gerhard positions the popularity of the kaleidoscope in 1820s Paris as an effective metaphor for the social significance of grand opera as a reflection of the experience of the "spectacular" nineteenth-century Paris. As the device gained traction, the term "kaleidoscope" gained "the additional meaning of a rapidly changing succession of sensations and impressions...."63 The implantation of the kaleidoscope into Parisian life functioned as an apt metaphor for the experience of life in the modern city, one that was similarly "kaleidoscopic" in its multitude of competing emotional, mental, and physical stimuli. The kaleidoscope of urban modernity found expression in grand opera: as Gerhard argues, grand opera's frequent endeavours to "transcend" the mundane qualities of the everyday, an as a consequence "the 'real world' was subsumed in phantasmagorias." ${ }^{94}$ Gerhard submits that the troping of the city as a kaleidoscopic multiplicity of stimuli finds a central analogue in the conception and reception of grand opera: the "multiplicity of the genre's motives and conventions"65 and the manifold competing and complementing forms of spectacle on its stage can be productively situated as what amounts to an encapsulation of particular perceptions/fantasies of the city. ${ }^{66}$ These perceptions and fantasies of Paris "as an endless

\footnotetext{
${ }^{63}$ Gerhard, 15.

${ }^{64}$ Ibid., 14.

${ }^{65}$ Tbid., 15.

${ }^{66}$ The troping of grand opera as a procession of stimuli, particularly in its propensity towards partitioning into spectacular tableaux invites comparison to Tom Gunning's noted characterization of early cinema as a "cinema of attractions" where narrative was altogether avoided in favour of films that were designed to exhibit the capabilities of the technology. "Attractions" were in effect exciting spectacles designed to titillate the spectator, ranging from camera tricks and visual effects to erotic images. Two of the most famous examples of the early "cinema of attractions" that Gunning offers are the Lumières' L'Arrivée d'un train en gare de La Ciotat (1895) and Georges Méliès' Le Voyage dans la Lune (1902). Attractions, according to Gunning, were incorporated into narrative cinema, with the myriad spectacles and set-pieces parceled out during the course of the film's storyline. In a sense, one might posit that grand opera, with its propensity towards lavish set-pieces, functions as an antecedent of the cinema of attractions in that grand opera's "attractions" are similarly designed to astonish audiences and flaunt the Paris Opera's musical, dramatic, and technological capabilities. See "The Cinema of Attractions: Early Film, Its Spectator and the Avant-Garde" (1986), Early Cinema: Space, Frame, Narrative, ed. Thomas Elsaesser (London: BFI, 1990),
} 
adventure and feast for the eyes" were "basic to the more optimistic side of the nineteenth-century urban imagination," ${ }^{67}$ and as such tend to sublimate the various political and social upheavals that took place in the years of both the July Monarchy and the Second Empire. The persistent problems of poverty and crime ${ }^{68}$ are also covered over by this narrative as were the various demolitions, displacements, and expropriations of property - "devastating urban surgery" in the words of Jann Pasler" ${ }^{69}$ - necessary for Napoléon III and Haussmann to implement their vision of a new Paris. However, as I shall clarify momentarily, it is this optimistic narrative of the spectacular Paris that props up the image of the city as a source of French pride, and it is arguably that same optimistic image that Wagner reacted to during his residency, which is why I have focused on it.

Redirecting attention to the grand opera chorus in particular, Parakilas provides the following figures: "by the beginning of the grand opera period, around 1830, the Paris Opéra chorus numbered sixty or seventy; in 1836 - the year of the premiere of Les Huguenots - it numbered eighty-two." ${ }^{\prime 0}$ These were numbers that other major opera houses in Europe could not hope to match: in 1836, "only five German opera houses could muster choruses of fifty to sixty; St. Petersburg had a chorus of forty-eight; and the San Carlo in Naples - the great rival of La Scala among Italian houses - had a mere thirty six." $"$ As such, on the most prosaic level, it can be said that the grand opera chorus is

56-62; "An Aesthetic of Astonishment: Early Film and the (In)Credulous Spectator," Art and Text 34 (Spring, 1989): 31-45.

${ }^{67}$ Prendergast, 31. Emphasis added.

${ }^{68}$ Prendergast discusses the issue of poverty and crime in Paris through the lens of literary representations of Paris' sewer system, pp. 74-101.

${ }^{69} \mathrm{Jann}$ Pasler, Compasing the Citizen: Music as Public Utility in Third Republic France (Berkeley: University of California Press, 2009), 17.

${ }^{70}$ Parakilas, "The Chorus," 77.

${ }^{71}$ Ibid. 
reflective of Parisian city life in that the expanded "population" of the operatic stage functions as an analogue to the aforementioned population explosion of the city itself. ${ }^{72}$ The crowd scene, perhaps the most emblematic of grand opera's conventions and the chorus's proverbial shining moment, is positioned in many a work as the very voice of the city: using the examples of Angélique Bertin's La Esmerelda and the final three acts of Les Huguenots, Gerhard underlines the prominence of scenes set in the street, surely one of the principal geographical markers of the city. ${ }^{73}$ The crowds that populate the city streets find their musical representation in the crowd scenes that exploit the chorus. Carl Dahlhaus writes that "the crowd scenes in [grand opera] plots betray the temperament of an age which still believed that major political decisions are made in the street," making the connection between the Parisian chorus and the city explicit. ${ }^{74}$

So far, significant effort has been undertaken to draw out the points of contact between grand opera and narratives of the city; the question not yet addressed is what do the city and the Opéra have to do with the nation? Observe this report from the directors of the Opéra, composed early in 1848 after the inception of the Second Republic:

The Opera is still, one has to say, one of the glories of Paris. It is the theater of the greatest artistic magnificence. The Republic, in its advent, cannot repudiate the superb heritage of luxury, of elegance, and poetry that has been bequeathed to it....The Opera is clearly one of the sources of Parisian prosperity, it is the most beautiful fleuron of the crown that has made Paris the capital of Europe. ${ }^{75}$

These words indicate that by 1848 , there was a longstanding perception that the Opéra held an honoured place in Parisian culture and that Paris was the crown jewel of not just

\footnotetext{
${ }^{72}$ Beyond the chorus, Parakilas also notes that such elaborate tableaux as "the wedding-boat finale in Les Huguenots [involved] hundreds of singers, dancers, and instrumentalists" (78).

${ }^{73}$ Gerhard, 222-227.

${ }^{74}$ Carl Dahlhaus, Nineteenth-Century Music, trans. J. Bradford Robinson (Berkeley: University of California Press, 1989), 125.

${ }^{75}$ Archives Nationales - $\mathrm{AJ}^{13} 181$, quoted in Jane F. Fulcher, "French Grand Opera and the Quest for a National Image: An Approach to the Study of State-Sponsored Art," Current Musicology 35 (1983): 34. 
France, but of the entirety of the continent. Jane Fulcher adds that the report indicates that the Opéra "symbolize[d] French civilization in its most capacious and majesterial sense, and as such, [was] as essential to the national credibility abroad as it [was] within France." 76

The above diagnoses are generalized and do not refer specifically to the time periods of Wagner's greatest activity in Paris. Nonetheless, they provide a convenient entry point for an appraisal of Paris' and the Opéra's prominence in the French national imagination. During the reign of Louis-Phillipe, Paris' aforementioned active artistic, intellectual, and mercantile scenes were foregrounded as demonstrative elements of the city's greatness, with an 1846 tourist guidebook essentially echoing the sentiments of the directors of the Opéra in referring to Paris as "the heart of Europe, the capital of civilization." Put another way, it was the Paris' urbanized spectacle that functioned as a source of pride. In terms of governance, it is notable that since the days of the First Empire under Napoléon, the French governments/regimes were based in Paris, rather than Versailles, the major seat of power of the Ancien Régime's Bourbon Dynasty. ${ }^{78}$ This suggests that in the nineteenth century, Paris was positioned as the veritable keystone for the French government and its consitutent nation. As both Fulcher and Sarah Hibberd note, during the reign of Louis-Phillipe, the Opéra served as a prominent vehicle for promoting narratives that not only glorified national identity but also endeavoured to legitimize the regime's authority as that which ensured the perseverance

\footnotetext{
${ }^{76}$ Ibid.

${ }^{71}$ L.S. Kramer, Threshold of a New World, quoted in Jones, 277.

${ }^{78}$ Jones, 263-266.
} 
of the nation. ${ }^{79}$ What I wish to draw out here is the thematization of Paris, specifically its urban life, as a leader in European culture to the extent that this city was positioned as what amounted to a synecdoche for the entirety of France, the singular representative of the majesty of the French identity. If one accepts Gerhard's framework that the dramaturgy of the productions staged at the Opera reflected the urban "spectacle" that was promoted as an element that made Paris the nominal envy of Europe, then it is clear why Fulcher would observe that grand opera publicized the most "majesterial" demonstration of French civilization. The grand opera chorus, the voice of the city, of the "street" then could be believably foregrounded as a prime demonstration of Parisian and French grandeur.

The grand opera chorus of Second Empire Paris, the Paris of the 1855 Exposition, carries on this sonorous exhibition of the ostensible lavishness of Parisian and French culture. Just as Napoléon III's regime endeavoured to put forth their revitalized Paris as the proudest achievement of European culture, so too did they set out to exploit the Opéra's outsized pageantry to resolidify the institution's "politically crucial symbolic position in France" to glorify "the Empire's relation to France's great past and thus to emphasize the regime's legitimacy...." ${ }^{80}$ Like the Expositions, the grands magasins, and all the other aspects of the "Haussmann" Paris, grand opera flaunted size, spectacle, and technological sophistication. All of these could be said to serve complementing purposes: to at once venerate Paris as an urban marvel and to exploit their capacity for wonderment in order to provide the grandest vision of French culture and its governing

\footnotetext{
${ }^{79}$ Jane F. Fulcher, The Nation's Image: French Grand Opera as Politics and Politicized Art (Cambridge: Cambridge University Press, 1987), 47-122; Sarah Hibberd, French Grand Opera and the Historical Imagination (Cambridge: Cambridge University Press, 2009), 114-152.

${ }^{80}$ Fulcher, The Nation's Image, 165-166.
} 
body possible. Once again, with its assemblage of large crowds of performing bodies on stage, the grand opera chorus may be thematized as a sonorous embodiment of the "spectacular" conditions of the city. Only in the case of Tannhäuser, the ostensible grandeur of the urban chorus may be read as doing something quite different than glorifying Parisian extravagance, as we shall soon see.

\section{Wagner's Paris}

Needless to say, Wagner was not exceptionally receptive to any notions of Paris being the "capital of Europe," nor was he open to the idea of grand opera as a symbol of French cultural supremacy. As has been previously stated, Wagner's earliest rebuke of Parisian culture came during, and in the immediate aftermath of his nearly three-year residence in the city, from August 1839 to April 1842. Possibly the harshest of these reprimands was the aforementioned "Traps for Unwary Germans in Paris," which was written in 1841 "by which time Wagner had abandoned all thought of succeeding in Paris and pinned his hopes on productions of Rienzi and The Flying Dutchman in Germany."81 As such, Wagner's recriminations should be read at least partially through the prism of apparent bitterness at his failure to achieve any sort of success on the Parisian stage, which would have "gain[ed] access to the stages of the whole world, and not least to the many court opera houses in Germany," so great was Paris' reach in terms of operatic production. ${ }^{82}$ Additionally, Robert Jacobs and Geoffrey Skelton, editors and translators of Wagner's collected Parisian writings, characterize Wagner's prose as consisting of

\footnotetext{
${ }^{81}$ Robert L. Jacobs and Geoffrey Skelton, "Introduction," WP 16.

${ }^{82}$ Tbid., 11.
} 
"rueful references to naïve idealistic Germans struggling to cope with wily and cynical Parisians ...."

In "Traps for Unwary Germans," published in the summer 1841 issue of the Stuttgart-based journal Europa, Wagner offers this following opening salvo, which I quote at length:

Go and ask those shops in the Palais Royal, gleaming in their silver and gold, their silk and gaslight, what they are there for; ask the gardens of the Tuileries with their elegant, well-kept paths; ask the Champs Elysées with its splendid carriages and its powdered coachmen; the boulevards with their rich mixture of bustle and extravagance; the balconies of the theatres with their ravishing toilets and breathtaking coiffures; the opera balls with their irresistible grisettes in satin bodices and their expensive femmes entretenues in exclusive black velvet dominoes; and finally when summer comes, ask the chateaux, the parks, the gardens, the hermitages and all the other fine pastoral pleasures the Parisian so innocently enjoys; ask all these things what they are there for. Is it, you may enquire, simply to provoke yawns of boredom? They will first protest and then scoff. What a stupid question! And yet there is a whole race of people in whom all these marvellous things can produce nothing but the most profound ennui. They are the Germans who live in Paris. ${ }^{84}$

Contained within this introductory statement of a somewhat humorous account of Parisian life is essentially a précis of the previously discussed narratives of city life in Paris: that of the city as a bustling metropolis teeming with a multitude of stimuli, a celebration of spectacle and luxury. Whereas Paris' self-image set forth these qualities as representative of the greatness of Parisian and French culture, Wagner identifies these characteristics instead as that which betrays the fundamental "falsehood" of Paris and its concomitant urbanized lifestyle. Indeed, Wagner underlines the essential "honesty" of the German person as contrary to Paris' mendacity couched in a façade of hospitality. ${ }^{85}$

\footnotetext{
${ }^{83}$ Ibid., 16.

${ }^{84} \mathrm{WP}, 18$.

${ }^{85}$ As an example of Paris' supposed dishonesty, observe the episode described in My Life in which Wagner recounts the loss of his and Minna's dog, Robber, whom they had made the effort to bring with them to Paris. Wagner reminisces about the dog's popularity with Parisian citizens, whom he entertained with his
} 
Because the extravagance of the big city is so essentially inauthentic, the "unwary" German must regard its trappings with distaste, as such an apparent celebration of conspicuous consumption is so antithetical to the German character, which is ostensibly immune to the lure of such superficialities.

In essays such as "German Music" (published in the July 12 and 26, 1840 issues of the Parisian Revue et gazette musicale) and "The Opéra Lies Dying" (a report submitted to the Dresden-based newspaper Abendzeitung in February, 1841), Wagner extends his critique of Parisian modernity to the music and theatre that it produced. The former essay is the source of Wagner's contention that "the Italian is a singer, the Frenchman a virtuoso and the German - a musician." ${ }^{96}$ I will endeavour to explicate the implications of this statement, particularly the German-as-musician trope, in Chapter Five, but at present time, I offer this framework as an example of the "authenticity" of German music as a corrective to the deficiency of French music. Wagner's skepticism towards French "virtuosity" is particularly telling, considering that virtuosity is predicated on the exhibition of technical skill. As such, we can consider virtuosity as a form of musical spectacle designed to dazzle the senses of the spectator; in that sense, virtuosity functions in the capacity of another example of the type of extravagant spectacle that Wagner characterized as intrinsic to city life in Paris, which is fundamentally distasteful to the German character. Consequently, it can be argued that

efforts at retrieving lost articles of clothing from the bottom of the Quai du Pont-Neuf. Given Robber's ostensible superior qualities, Wagner blames the dog's disappearance on being lured into the home of one of those citizens so taken with his exploits. Wagner's perspective on this incident speaks to his expressions of resentment at what he saw as Paris' essential falsehood: the city expressed a veneer of appreciation for Wagner's "contribution" to its culture, all the while biding time until it could "betray" him by stealing from him. See ML, 177-178.

${ }^{86}$ WP, 37. 
Wagner's apparent animus towards French "virtuosity" is of a piece with his similarly stated disdain for Paris' conspicuous exhibition of luxury and spectacle.

In "The Opéra Lies Dying," Wagner is surprisingly charitable towards Parisian culture, especially given his later vituperations. In this piece, Wagner foregrounds the Opéra as a rapidly desiccating institution, mired as it is in a succession of mediocrities. "The public," Wagner notes in an expression of unexpected magnanimity towards the Parisian citizenry, "is capricious and will bestow its favours only on worthwhile things a point which, I must admit, has done much to raise it in my estimation. Brilliant reputations and illustrious names may suffice to impress opera directors and impresarios, but the public does not allow itself to be so easily blinded." ${ }^{87}$ Wagner states that only works from Meyerbeer (who was not yet a target of Wagner's ire, as he was still pinning hopes on him to use his influence to convince the Opéra to stage one of his works) will satisfy the public's demand for quality. Moreover, it was Meyerbeer's then-current absence from the scene that had precipitated the Opéra's stagnation, which only a new work from Meyerbeer could hope to reverse. The report's tone lacks the disdain for Parisian culture displayed in "Traps for Unwary Germans" and "German Music" as well as the extreme invective of later writings such as Opera and Drama and "Jewishness in Music." However, despite Wagner's proclamations of respect for the Parisian public's unwillingness to countenance mediocrity, his report maintains a sense of weariness with the machine of the Paris Opera, one that seems preoccupied with exhibiting operatic "stars" and opulent stagecraft over genuine artistic worth. Given the Opéra's previously explicated status as a function of Paris' urbanized conditions, we might infer that Wagner's growing disenchantment with the Opéra as an institution - beyond his

\footnotetext{
${ }^{87}$ Ibid., 111.
} 
increasing bitterness at not being able to enter its inner circle - could possibly have fed into his later stated antipathy for the city as a whole.

Wagner maintains his aversion to Parisian urbanity, and its commensurate expression in the grand operas he saw performed there in his reflections on that time period in My Life. Wagner's autobiographical writings should be approached with care, given his well-known propensity for revisionist history. ${ }^{88}$ Nonetheless, Wagner's recollections - factually unreliable as they may be - are valuable in that they assist in constructing narratives that position Paris, the city, and French opera as fundamentally foreign to the more "authentic" German culture. In the following lengthy quote, Wagner describes mounting disillusionment with Paris, using a performance of Meyerbeer's Les Huguenots as the primary illustration of the deficiencies of Paris' urbanized conditions:

I had serious reasons for keeping away from Parisian artistic or social life. In part it was my painful experiences, but also in part the growing antipathy, deeply rooted in my inner development, toward the entire artistic and social bustle I had once found so attractive, that had driven me with truly frightening speed away from any contact with it. The production of Les Huguenots, which I had heard here for the first time, had dazzled me very much indeed; the beautiful orchestral playing and the extremely meticulous and effective staging gave me an enticing foretaste of the great resources inherent in such well-trained artistic means. But curiously enough, I was not impelled to attend repeat performances of such works; I soon found the singing style a caricature of itself and developed the knack of mimicking the latest Parisian singing techniques and their tasteless excesses, thereby delighting and entertaining my friends exceedingly. The composers themselves, who achieved their successes by pandering to these ridiculous fashions, could not fail in time to attract my critical mockery. ${ }^{89}$

In this passage, Wagner characterizes Les Huguenots (and presumably the Paris Opéra's offerings in general) in terms that are reminiscent of his opening remarks to "Traps for

\footnotetext{
${ }^{88}$ John Deathridge addresses Wagner's approach to autobiography and its attendant efficacies and difficulties in recovering an understanding of the "real" Wagner in "Wagner Lives: Issues in Autobiography," in Wagner - Beyond Good and Evil (Berkeley: University of California Press, 2008), 317. ${ }^{89} \mathrm{ML}, 197$.
} 
Unwary Germans." Grand opera, like Paris itself, offers a multitude of sensual delights that are seductive upon first exposure, but on reflection ultimately prove to be hollow and unfulfilling, and indeed deserving of contempt and mockery. The big city and its constituent bustle and baubles are distasteful to the German, and the only way to accommodate its excesses is to respond to it with boredom, as Wagner prescribes in "Traps for Unwary Germans." It is not surprising that Wagner later characterized his eventual departure from Paris as one of release from abject misery. ${ }^{90}$

As a postscript, one can surely interpret that Wagner's bitterness over his experiences in Paris continually surface as revenants throughout much of his comments in the essays advocating operatic reform written during his post-1849 "exile" in Zurich ("Art and Revolution," "The Artwork of the Future," Opera and Drama, "Jewishness in Music," and "A Communication to My Friends"). Opera and Drama, in particular contains a revealing series of passages that express pronounced hostility to La muette de Portici, which interestingly enough, Wagner will regard significantly more generously in his later essay "Reminiscences of Auber" (1871). ${ }^{91} \quad$ In Opera and Drama however, Wagner's profession of distaste for Auber's prototype for grand opera starts, according to Mary Ann Smart, "from a position of self-righteousness nationalism." "92 Wagner writes that "this [Muette] was the dumb-struck Muse of Drama, who wandered broken-hearted between the singing, raging throngs, and tired of life, made away at last with herself and her hopeless sorrow in the artificial fury of a stage volcano! — ${ }^{93}$ Smart elaborates on

\footnotetext{
${ }^{90} \mathrm{Ibid} ., 216$.

${ }^{91}$ SSD IX, 42-60; PW V, 35-55. Maribeth Clark addresses Wagner's fluctuating views on Auber's opera at the outset of "The Body and the Voice in La Muette de Portici," $19^{\text {th }}$-Century Music 27/2 (Autumn 2003): 116-131.

${ }^{92}$ Mary Ann Smart, Mimomania: Music and Gesture in Nineteenth-Century Opera (Berkeley: University of California Press, 2004), 32.

${ }^{93}$ Opera and Drama, quoted in Smart, 32-33.
} 
Wagner's dismissal, writing that "this is, of course, a declaration of war against the guiding aesthetic of French opera. The 'singing, raging throngs' and the 'artificial fury' of the volcano represent the despised extremes of mere operatic entertainment, tuneful song and extravagant staging." What Smart's comments suggest is that Wagner's writings in the years immediately following the completion of both Tannhäuser and Lohengrin as well as those leading up to and following Lohengrin's premiere in Weimar serve to position French grand opera and its assorted cultural values as antithetical to the German identity. In the following pages, I shall endeavour to situate Wagner's music, specifically his use of the grand opera chorus, within a city that does ostensibly express German cultural and artistic values.

\section{Weimar's Two Golden Ages}

Wagner's expressions of alienation from Parisian culture actually find some resonance within the next phase of discussion, as his lack of direct involvement in the debut performance of Lohengrin practically consigns him to a role of peripheral player. Due to the still-outstanding warrant for his arrest in the aftermath of the 1849 uprisings in Dresden, Wagner was not able to travel to Weimar to attend the performance; his only avenues for keeping tabs on the preparations, the performance itself, and the reception thereof were through correspondence with Liszt as well as reports from figures such as Karl Ritter, whose description of "scenic deficiencies in the performance, as well as...[the] highly unfortunately casting of the title role" marring an "on the whole successful outcome" filled Wagner with some apprehension until he received Liszt's far more optimistic reflection. ${ }^{95}$ Even taking Wagner's physical absence into account, the

${ }^{94}$ Smart, 33.

${ }^{95} \mathrm{ML}, 453$. 
fact that it is his music that was performed on that fateful day in Weimar assures that Wagner is heavily implicated in the issues of the city's legacies and the importance of those legacies to German art.

The event that ultimately made the Lohengrin premiere possible was Liszt's acceptance of the position of Kapellmeister of the Weimar Hoftheater in $1842 .{ }^{96}$ This was initially little more than a perfunctory ceremonial position, ${ }^{97}$ but in 1848 he and the Princess Carolyne von Sayn-Wittgenstein would eventually relocate to Weimar, whereupon Liszt would make leading the court orchestra a genuine career. During his tenure in Weimar, Liszt would expand the meagre performing forces - which as Walker notes, Liszt had become acquainted with and dismayed by when he conducted a performance of Beethoven's Fifth Symphony in January of $1844^{98}$ - and transform the orchestra into a representation of "the midcentury state of the art," effectively turning Weimar into "the centre of the German avant-garde."100 Liszt accomplished this by exploiting his position as Kapellmeister to perform and promote "progressive" music by composers such as Wagner and Berlioz (not to mention his own cycle of "symphonic poems"). The centralization of the German musical "avant-garde" in Weimar precipitated the city's anointment as the home of the so-called "New German School," with Liszt functioning as its spiritual leader. ${ }^{101}$

There was a reason why Liszt made his way to Weimar and why it became the centre of German musical progressivism. In the late-eighteenth/early-nineteenth century,

\footnotetext{
${ }^{96}$ Allan Keiler, "Liszt and the Weimar Hoftheater," Studia Musicologica Academiae Scientarium Hungaricae 28 (1986): 431-450.

${ }^{97}$ Walker, 94-98.

${ }^{98}$ Ibid., 98-99.

${ }^{99}$ Taruskin, 418.

${ }^{100}$ Kraft and Härtwig, "Weimar."

${ }^{101}$ Detlef Altenburg, ed. Liszt und die Neudeutsche Schule (Laaber: Laaber-Verlag, 2006).
} 
Weimar was home to a vibrant artistic and intellectual scene popularly known as "Weimar Classicism," centred on Johann Wolfgang von Goethe, Johann Gottfried Herder, Friedrich Schiller, and Christoph Martin Wieland, with the former two individuals figuring prominently in the discussions to follow. ${ }^{102}$ As Gert Theile observes, the "Weimar myth" positioned the legacy of "Weimar Classicism" as a central piece of German heritage, a key location to the thematization of the German identity as one based upon culture. ${ }^{103}$ Put another way, the narrative of "classical" Weimar positioned the city as a prime example of Friedrich Meinecke's concept of Germany as a Kulturnation. ${ }^{104}$ Detlef Altenburg notes that Goethe's death in 1832 was "for Weimar and Germany as a whole an event of historic import...."105 The poet Heinrich Heine predicted in 1831 that Goethe's death would mark the "end of the art era" in Weimar. ${ }^{106}$ Granted, as James Garratt points out, Heine's forecast was expressive of the "Young Germany" movement's line of thought that "the artistic principles which governed the art of the Weimar classicists and the Romantics were no longer valid." ${ }^{107}$ Even so, Heine's ascription of a conclusion of an age to Goethe's eventual death indicates that he and his Weimar

\footnotetext{
${ }^{102}$ Studies of Weimar Classicism are multitudinous: two fairly recent examples (one in German, the other in English) are: Dieter Borchmeyer, Weimarer KJassik: Portrait einer Epoche (Weinheim: Beltz Athenăum, 1994) and Simon Richter, ed. The Literature of Weimar Classicism (Rochester, NY: Camden House, 2005). Richter's introduction to his volume makes sure to emphasize that the tendency to refer to "Weimar Classicism" as both a distinct literary and intellectual movement and a historical epoch is problematic not only for its somewhat arbitrary periodization of history but because the aesthetic characteristics of the work produced by this "movement" is not exceptionally distinct from those of other Romantic writers throughout Europe. Nonetheless, Richter acknowledges that the designation "Weimar Classicism" has endured, for the term's proponents and detractors alike. See Richter, 3-44.

${ }^{103}$ Gert Theile, "The Weimar Myth: From City of the Arts to Global Village," Unwrapping Goethe's Weimar: Essays in Cultural Studies and Local Knowledge, ed. Burkhard Henke, Susanne Kord, and Simon Richter (Rochester, NY: Camden House, 2000), 311-312. See also Gerhard J. Winkler, "Liszt's 'Weimar Mythology,"' Liszt and His World, ed. Michael Saffle (Stuyvesant, NY: Pendragon Press, 1998), 61-73

${ }^{104}$ Friedrich Meinecke, Cosmopolitanism and the National State, trans. Robert. B. Kimber (Princeton, NJ: Princeton University Press, 1970).

${ }^{105}$ Altenburg, "Franz Liszt and the Classical Era," 47.

${ }^{106}$ Karl Robert Mandelkow, Goethe in Deutschland: Rezeptiongeschichte eines Klassikers (1980), quoted in Altenburg, 47.

${ }^{107}$ James Garratt, Music, Culture, and Social Reform in the Age of Wagner (Cambridge: Cambridge University Press, 2010), 46.
} 
compatriots cast a long cultural shadow, even if it is ultimately a shadow from which it is needed to escape. Altenburg elaborates that this "end of an era for the Weimar court" threatened the court's and the city's "very identity as the center of German art and scholarship," in no small part due to Goethe's and the Weimar Classicists legacy, which created a heavy artistic and intellectual burden that would be difficult for future generations to live up to. ${ }^{108}$

In a letter to Marie d'Agoult, dated January 23, 1844, Liszt seems to tacitly acknowledge that the end of "Weimar Classicism" represented the end of an age for the city, writing:

Not "Carthage is to be destroyed," but "Weimar is to be constructed." Under the late Grand Duke Karl-August, ${ }^{109}$ Weimar was a new Athens. Let's dream today of building a new Weimar. Let us renew openly and boldly the traditions of KarlAugust. Let us allow talents to move more freely in their sphere. Let us colonize as much as possible. ${ }^{110}$

Liszt's letter perpetuates the narrative of Weimar during the time of Goethe, Herder, etc. as an intellectual and artistic beacon. In likening the "classical" Weimar to Athens, Liszt claims for the Thuringian city a lineage to the Hellenic era's rich intellectual legacy. But in calling for a "new" Weimar to be constructed, Liszt implicitly concedes that that era has past. However, a commitment to restoring the cultural climate that permitted Weimar to flourish could result in the creation of a new "golden age" for the city. In this letter, Liszt imagines himself as one who could potentially initiate this rejuvenated Weimar by cultivating the same atmosphere of creative freedom that Karl August ostensibly did, so

\footnotetext{
${ }^{108}$ Altenburg, 47.

${ }^{109}$ Karl August was the Grand Duke of the court of Saxe-Weimar-Eisenach during the "Weimar Classicism" era. He died in 1828.

${ }^{110}$ Franz Liszt - Marie d'Agoult: Correspondence, quoted in Altenburg, 48.
} 
that the city may be "colonized" by the kind of talent necessary initiate a new age of greatness for Weimar.

Liszt's endeavours to implement that vision of a rejuvenated Weimar were manifold. Beyond the aforementioned performances of musically progressive works, Liszt was also at the forefront of a pair of festivals that celebrated Weimar's heritage. The first of these was a Goethe centenary that began on the hundredth anniversary of Goethe's birth, August 28, 1849. As Walker notes, Liszt's plans for the festivities commenced on the heels of Wagner's departure from Weimar, where Liszt had harboured him from the Dresden authorities (over his actions in the uprising) before Wagner fled to Zurich. ${ }^{111}$ Liszt's concert programming for the festival centralized musical settings of works by Goethe, including Liszt's own composition based upon a scene from Goethe's Faust. ${ }^{112}$ Altenburg comments that the centenary was overall "an event of national significance and afforded Liszt the welcome opportunity of introducing the artistic ideals of the new Weimar to the public."'113 The following year, from August 24 to 26, the city mounted a similar festival commemorating the anniversary of the birth of Herder, Goethe's Weimar Classicist compatriot. The festivities culminated in the unveiling of a statue of Herder. Immediately following the festival on the $28^{\text {th }}$ was the Lohengrin premiere.

One of the planned aspects of the festival was a performance of Herder's Der entfesselte Prometheus, to which Liszt was to set incidental music for orchestra and chorus (the overture was later substantially reworked to form the basis of Liszt's

\footnotetext{
${ }^{111}$ Walker, 119. Wagner describes his plight in a lengthy letter to Eduard Devrient, dated May 17, 1849. See SL, 146-153.

${ }^{112}$ Altenburg, 52.

${ }^{113}$ Ibid. Liszt reflects on the festival in his essay "Die Goethe-Feiern" (1849), Sämtliche Schriften III, ed. Detlef Altenburg and Britta Schilling-Wang (Wiesbaden: Breitkopf \& Härtel, 1997), 3-19.
} 
symphonic poem Prometheus). The Munich theatre director Franz Dingelstedt was to provide a prologue for this performance. ${ }^{114}$ Liszt's letter to Dinglestedt (May 13, 1850) regarding this prologue is revealing: "in my opinion, this prologue should relate more to Weimar, to its past and its future, than to Herder, for whose anniversary it scarcely would have seemed desirable to propose a theatrical celebration." 11 With those words, Liszt indicated that his efforts as Kapellmeister were intended to celebrate the significance of Weimar itself, although Paul Bertagnolli adds that Liszt's apparent desire to subordinate Herder in favour of a testament to the city as a whole arose from the fact that he considered Goethe and Schiller more representative of "the power of talent and genius in Weimar circles." 116

Liszt's veneration of Goethe as the outstanding figure of Weimar's artistic tradition found a major outlet in a lengthy essay Die Göthe-Stiftung, published in $1851 .{ }^{117}$ This piece advocated for the creation of a Goethe Foundation based in Weimar, which would award prizes for German works of art. The essay devotes a significant portion of its length towards "a history of Weimar" in which Liszt "parad[es] the illustrious personalities who lived and worked there,"118 clearly with the intent of demonstrating the city's rich traditions in order to lend his proposed foundation an apposite sense of

\footnotetext{
${ }^{114}$ Liszt reproduces this prologue in "Lohengrin: Große romantische Oper von $\mathbf{R}$. Wagner und ihre erste Auffuhrung in Weimar bei Gelegenheit der Herder- und Goethe-Feiern 1850," (1851), Sämtliche Schriften IV, ed. Rainer Kleinertz (Wiesbaden: Breitkopf \& Härtel, 1989), 19-21.

${ }^{115}$ Franz Liszt to Franz Dingelstedt (May 13, 1850), quoted in Paul A. Bertagnolli, "Liszt, Goethe, and a Musical Cult of Prometheus," Liszt and the Birth of Modern Europe: Music as a Mirror of Religious, Political, Cultural, and Aesthetic Transformations, ed. Michael Saffle (Hillsdale, NY: Pendragon Press, 2003), 183.

${ }^{116}$ Bertagnolli, 184.

117"Die Gơthe-Stiftung" (1851), Sämtliche Schriften III, 23-151. Page references are to the Germanlanguage version; this volume of Liszt's collected writings includes the French-language version ( $\mathrm{De}$ la Fondation-Goethe à Weimar) on opposing pages, 22-150.

${ }^{118}$ Walker, 127.
} 
prestige. ${ }^{119}$ Altenburg adds that "what Liszt planned was no more and no less than a National Endowment for the Arts in Weimar where he had, not least, provided a culturalpolitical function to the backdrop of the unresolved German question." 120 In other words, Liszt's plan effectively proposed a means for the various German states to be unified under the banner of art, with Weimar and its prestigious past and potentially brilliant future serving as the nucleus for this "unified" Germany.

To summarize, Weimar was situated as a revered repository of German heritage. To reinvoke Rehding's framework, the city was a "monument," a commemoration of its significance to German history and culture. Indeed, Rehding notes that Weimar "was the center of cultural commemoration in Germany" in the nineteenth century. ${ }^{121}$ In consistently evoking the enduring "spirit" of Goethe and his fellow Weimar classicists as the inspirational building blocks of the "new" Weimar, I would propose that Liszt (and the Grand Duke Carl Alexander) effectively thematized the city in a manner similar to what Frankowski wrote about Paris: Frankowski characterized Paris as perpetually "alive," teeming with consistent energy. Weimar is also a "living" city. While hardly the kind of veritable juggernaut in terms of population, size, and availability of manifold forms of physical, emotional, and intellectual experiences that Paris was, Weimar nonetheless teemed with an "energy" of its own, that energy being its once and future commitment to the furtherance of art and culture.

\footnotetext{
${ }^{119}$ Sämtliche Schriften III, 25-65.

${ }^{120}$ Altenburg, "Franz Liszt und die Erbe der Klassik," Liszt und die Weimarer Klassik, 24: "Was Liszt hier plante, war nicht mehr und nicht weniger als eine Nationalstiftung der Kunst in Weimar, der er vor dem Hintergrund der ungelösten deutschen Frage nicht zuletzt auch eine kulturpolitische Funktion zugedacht hatte."

${ }^{121}$ Rehding, Music and Monumentality, 80.
} 
The festivals of 1849 and 1850 were prominent expressions of Weimar's monumentality; the mounting of these celebrations illustrates Rehding's fairly cynical comment that "Weimar's culture of commemoration was a well-oiled machine. ${ }^{122}$ But they are also indicative of a prevailing trend in nineteenth-century German culture: namely the ubiquity of festivals as a celebration/commemoration of national identity. ${ }^{123}$ In terms of music, only a few short years earlier in August of 1845, there was the festival held in Bonn to celebrate the unveiling of a statue of Beethoven (during which Liszt conducted a cantata he had composed for the occasion). ${ }^{124}$ The ceremonies both commemorated Bonn as Beethoven's birthplace and the composer's enduring importance to German artistic heritage. In that sense, the Bonn festival (along with other festivals before it) provided a precedent for the later Goethe and Herder festivals in Weimar in its celebration of outstanding individual(s) as representative of the German spirit. These German festivals, I propose, serve a function not overly removed from that of the previously discussed "Expositions" in Second Empire Paris: whereas the Expositions were designed to showcase the French capital's grandeur and opulence in order to glorify its place as the ostensible pinnacle of European culture, the festivals (the Weimar ceremonies in particular) display to their attendees (local, national, and international alike) their artistic heritages, promoting them as a source of enduring cultural pride. And as Walker observes, the Goethe and Herder festivals were not without pageantry in the form of processions and the display of decorative flags. ${ }^{125}$ These injections of spectacle

\footnotetext{
${ }^{122}$ Ibid., 74.

${ }^{123}$ George L. Mosse, The Nationalization of the Masses: Political Symbolism and Mass Movements in Germany from the Napoleonic Wars Through the Third Reich (New York: Howard Fertig, 1975), 73-99 and 100-126. See also Garratt, 84-127 for insight into the national significance of various German music festivals through the mid-1840s.

${ }^{124}$ Rehding, 54-69.

${ }^{125}$ Walker, 121-122.
} 
into the proceedings could be interpreted as an endeavour to put the proverbial "best foot forward" for the city, to exploit visual and scenic spectacle in order to exhibit not only the significance of the specific occasions, but to provide appropriate visual corollaries to the enduring magnitude of Weimar's celebrated legacy. With these considerations in mind, one can profitably thematize these festivals as "Expositions" in their own right.

In a letter to Wagner written before the Herder festival, Liszt demonstrates awareness of the import of the performance date for Lohengrin: "the special date of August $28^{\text {th }}$, on which Lohengrin will be performed, cannot but be favourable to it...the first performance being fixed for August $28^{\text {th }}$, the anniversary of Goethe's birth, and three days after the inauguration of the Herder monument, which will take place on the $25^{\text {th }} .126$ As the scholarly literature has established, it was a conscious strategy on Liszt's part to have Wagner's music performed on the anniversary of Goethe's birth. Bertagnolli succinctly states that the Lohengrin premiere was intended as the "inaugural event" that "helped celebrate the founding of the Goethe-Stiftung" that Liszt would advocate for in his aforementioned manifesto. ${ }^{127}$ In fact, Liszt's letter specifies that "the delegates of the Goethe foundation are convoked [on the $28^{\text {th }}$ ] to settle the definite programme of that foundation at [Weimar]."128 But beyond matters of the Goethe-Stiftung, Liszt's choice of date illustrates Altenburg and Britta Schilling-Wang's observation that since at least 1849, Liszt's ideas for a "new" Weimar centralized around the notion that the "WagnerLiszt era" would take up the mantle of the era of Schiller-Goethe. ${ }^{129}$ This ostensible era of "Wagner-Liszt" feeds into the point I made at the outset of this chapter: that part of the

\footnotetext{
${ }^{126} \mathrm{CWL}$ I, 71.

${ }^{127}$ Paul A. Bertagnolli, "Amanuenesis or Author? The Liszt-Raff Collaboration Revisited," $19^{\text {th }}$-Century Music 26/1 (Summer 2002): 25.

${ }^{128} \mathrm{CWL}$ I, 71.

${ }^{129}$ Sämtliche Schriften III, viii: "die Ära-Schiller-Goethe durch die Ära Wagner-Liszt abgelöst werde."
} 
Lohengrin performance's historical significance was derived from the "meeting of the minds" it represented. Commenting retrospectively on the premiere and the festival as a whole, Liszt maintains that the premiere of Lohengrin was "in every respect a worthy choice to celebrate the memory of Goethe...." ${ }^{130}$ In his efforts to link Wagner with the legacy of Goethe, Liszt effectively sought to use Goethe's and Weimar's prestige, their "symbolic capital" - to invoke a concept from sociologist Pierre Bourdieu - in order to bestow an apposite degree of consecration upon Wagner's work. ${ }^{131}$ Put another way, Liszt endeavoured to insert Lohengrin into that monumental tapestry in order to make a case for the opera's own monumentality.

Befitting of "Liszt's aspirations for a new golden age in post-Classical Weimar,"132 Wagner's work was, in the words of Altenburg and Rainer Kleinertz, "to be premiered both as a festival opera and as a paradigm for the new artistic ideal." ${ }^{{ }^{\prime 133}}$ In his noted essay on Lohengrin - originally written in French in the latter half of September of 1850, with a German translation from Karl Ritter and Hans von Bülow appearing in Leipzig's Illustrierte Zeitung in April of 1851 - Liszt extensively proselytized for Lohengrin's remarkable musical and dramatic innovations. Liszt argued that these advances set a new standard of excellence for opera, displaying a distinctly "German

\footnotetext{
130"Lohengrin von R. Wagner," 23: "die Wahl des Lohengrin in jeder Beziehung würdig war, das Gedăchtnis Goethes zu feiern...." The debut of an opera on Goethe's birthdate could be considered quite the appropriate tribute when one considers that from 1791 to 1817 , Goethe had been in charge of both the Weimar court theatre and the opera. See Altenburg, "Liszt and the Classical Era," 49.

${ }^{131}$ Pierre Bourdieu, The Field of Cultural Production: Essays on Art and Literature, ed. Randal Johnson (New York: Columbia University Press, 1993), 75-77.

${ }^{132}$ Franz Liszt, "Liszt on Lohengrin (or: Wagner in Absentia)" (Part 1), ed. David Trippett, The Wagner Journal 4/1 (March, 2010): 6. The second and third parts of this translation appear in issues 4/2 (July, 2010): 28-38 and 4/3 (November, 2010): 43-57 respectively of The Wagner Journal.

${ }^{133}$ Liszt, Sämtliche Schriften IV, vii: "Wagners Lohengrin als Festoper und zugleich als Paradigma des neuen Kunstideals uraufgefuhrt werden."
} 
premeditation." ${ }^{134}$ Nicholas Vaszonyi elaborates upon Liszt's praise for Wagner's music, writing that in the essay "not only does Liszt replay the distinction between FrancoItalian superficiality versus German complexity, he also demonstrates how Wagner had found the suitable formal method for developing a German art form that no longer bears any relationship to the Italianate genre." ${ }^{135}$ Liszt explicitly thematizes innovation as an expression of the intrinsic spirit of German art. His identification of Lohengrin's significance as a major advance for German music functions as an endeavour to situate the work as a monument to German culture. ${ }^{136}$ As Rehding notes, a musical monument tends to be constructed to be observed as a "self-sufficient musical object that radiates greatness as though out of itself...."137 Liszt's panegyric essentially aims to ascribe just such qualities to Lohengrin: it "radiates" greatness and in doing so, it announces itself as a work of significant cultural magnitude that commemorates the wondrous possibilities of German art. Furthermore, in situating this performance as one of his ongoing efforts to create a new golden-age for Weimar, Liszt creates what amounts to a closed loop of consecration: Weimar's longstanding symbolic capital grants the Lohengrin performance a degree of prestige in being premiered in this particular city on this particular date. The symbolic capital that Liszt locates in the opera's artistic quality would then be

\footnotetext{
${ }^{134}$ Franz Liszt, "Lohengrin und Tannhöuser von Richard Wagner" (1850), quoted in Vazsonyi, Richard Wagner, 117.

${ }^{135}$ Vazsonyi, 117.

${ }^{136}$ In praising Lohengrin as representing a major advance for German art, Liszt effectively positioned himself as the type of commentator that Wagner expressed such exasperation over in such writings as Opera and Drama and especially $A$ Communication to My Friends. In the latter, Wagner inveighs against analyzing such works as Holländer, Tannhäuser, and Lohengrin as examples of his proposed "artwork of the future." Indeed, Wagner seems to regard these works throughout the essay as somewhat passé, necessary stepping stones towards the project that would eventually become the Ring. In a letter to Adolf Stahr (May 31, 1851), Wagner would go so far as to characterize Lohengrin as a mere "cast-off skin" to be left behind in favour of more mature works (SL, 224). Nonetheless, since Wagner had produced no new dramatic work to go along with his theories of operatic reform, critical discourse tended to latch on to the operas that did exist by default. Trippett summarizes this problem in Wagner reception in "Liszt on Lohengrin (Part 1), 4-5.

${ }^{137}$ Rehding, 26-27.
} 
subsequently "reinvested" back into Weimar, assisting in solidifying the city's renown as representing the vanguard of German art and culture so that Weimar's new age may arise.

With the Herder festival having only concluded two days prior, and with many of the visitors still present in Weimar, Liszt had a significant national and international audience who would serve as witnesses for Lohengrin's "monumental" unveiling. Walker summarizes:

The performance...attracted much attention, and Weimar, which was already full of visitors for the Herder festival, now had to cope with a fresh wave of pilgrims curious to hear this opera. Among the well-known musicians, artists, and critics who converged on the theatre were Jules Janin and Gérard de Nerval from Paris, Joseph Fétis from Brussels, Henry Chorley from London; and Meyerbeer, Robert Franz, Franz von Dingelsteldt, Christian Lobe, Bettina von Arnim, Adolf Stahr, Franz Kroll, [Joseph] Joachim, von Bülow, Raff, Theodor Uhlig, Franz Abt, and Karl Ritter, the last of whom lived in the closest contact with Wagner in Zürich and knew every note of the score. ${ }^{138}$

Of course, despite the presence of all of these prominent figures, some degree of creativity had to be carried out in order to drum up the necessary public attendance:

By contrast, the ordinary citizens of Weimar were scarcely interested in Wagner and his latest work, and had it not been for the generosity of Maria Pawlowna, who bought up a great many of the unsold tickets at the last moment and distributed them free of charge, the premiere might have been a flop. ${ }^{139}$

The apparent ambivalence (at best) of Weimar's citizenry towards Lohengrin indicates the existence of notable gaps between the Weimar "legend" of an artistic haven that Liszt sought to harness and the reality of its day-to-day life. Nonetheless, for the performance, Liszt had managed to secure a reasonably full auditorium at the Hoftheater, extracted from the population of Weimar that had gathered for the previous festivities. In that sense, through the combination of "regular" citizens and national and international visitors, the city had gathered to witness this hopeful musical monument.

\footnotetext{
${ }^{138}$ Walker, 125.

${ }^{139}$ Tbid.
} 


\section{Weimar's Choruses}

Which now brings us back to the grand opera chorus: the sheer size of the typical chorus staged at the Opera contributes to the opulence that lends grand opera its sense of grandeur, or its "monumentality." In employing the types of crowd and ceremonial scenes and processionals that exploit the grand opera chorus, Lohengrin injects a sense of size and magnitude into its dramaturgy. Of course the reality of the Hoftheater's available resources was something of an impediment to the realization of the score's musical size, a reality of which Liszt demonstrated an acute awareness. In the final paragraph of his essay, Liszt clarifies that the number of performers were scarcely adequate in terms of satisfying the musical and dramaturgical demands contained in Wagner's score and libretto. ${ }^{140}$ But for Liszt, those limitations were compensated for because he "'dared to believe' in giving the premiere in spite of the 'profound admiration' that had arisen from his studying the work." ${ }^{141}$ Furthermore, Liszt endeavoured to put the best face on the results of the performance despite the obvious shortcomings of the performing forces available to him, "perhaps because of his central role in the opera's realization, the historic-artistic value he saw in it, and the importance he ascribed to it for Weimar's resurgent cultural status...."142

I bring up the meagreness of Liszt's resources, the chorus included, for two reasons: firstly, as an acknowledgment that while Wagner's score calls for a full chorus, the reality of its performance in Weimar necessitated an assemblage of voices that in a certain respect more reflected the state of Weimar in 1850. Even with the increased traffic brought in by the Herder festival, it was still a small city in terms of population

\footnotetext{
${ }^{140}$ Franz Liszt, "Lohengrin von R. Wagner," 91.

${ }^{141}$ Trippett, "Liszt on Lohengrin (Part 3)," 57n36.

${ }^{142}$ Trippett (Part 1), 8.
} 
and geographical size, especially when compared to places such as Berlin, Vienna, London, and of course Paris. Secondly, the fact that the performance went on in spite of the shortcomings of its performing roster because of Liszt's "belief" in the work's significance as an artistic epoch furthers the "monumental" narrative of both the performance and Weimar: for one thing, part of the story of the opera's staging is one of effort expended to surmount limitation. Liszt states in a letter that he has expanded the orchestra, with the violins increased to "sixteen to eighteen" players. ${ }^{143}$ Furthermore, as Walker points out, Liszt carried out forty-six rehearsals, "a number without precedent for an opera, and an indication of his determination to succeed."144 Contextualizing these endeavours to "monumentalize" the performance within Liszt's previously established goal of revitalizing Weimar's cultural prominence, one might profitably infer that Liszt aspired to position the "new" Weimar as a place where artistic innovation will carry on in the face of such inhibitors as an undermanned (and underskilled) performing roster and a skeptical and/or disinterested public. The deployment of an undersized chorus in order to perform music steeped in grand opera dramaturgy might thus be theorized as an example of the performance's "monumentality," even if the sonorities actually produced did not convey a sense of commensurate magnitude.

A significant portion of the first act's content takes the form of a crowd scene, as the Brabantian nobles and citizens, gather to witness Elsa answer her accusers before King Heinrich and accompanying members of his court. This setup has all the makings of a prototypical grand opera tableau, as the individual is brought before the masses, which are in position to witness the official judgment and resultant meting out of

\footnotetext{
${ }^{143} \mathrm{CWL}$ I, 70.

${ }^{144}$ Walker, 125.
} 
"justice." As such, the scene bears some resemblance to the following set-pieces: the finale of Halévy's La Juive (1835), where Eléazar and Rachel are brought to the gallows for a public execution; Act IV of the same composer's La reine de Chypre (1841), where Gérard is saved from being killed by the crowd by the King of Cyprus, the very man Gérard had initially intended to assassinate; the fourth act of Wagner's own Rienzi, wherein Rienzi is excommunicated from Rome in front of the citizens and is deserted by his followers (no. 12), not to mention the final scene (no. 16), where Rienzi fruitlessly attempts to quell the crowd's bloodlust.

The scenes depicting Elsa's public tribunal, Lohengrin's arrival, and his triumph over Friedrich in ceremonial combat are also reminiscent of grand opera in how they arrange the chorus: as Parakilas points out, one of grand opera's distinguishing musical features is the division of the chorus into a number of discrete units representing different (and frequently opposing) social groups. ${ }^{145}$ In Lohengrin's first act, Wagner distributes his chorus in order to give voice to a number of contrasting groups. Quoting from the stage direction accompanying the beginning of Act $I$, the scene is populated by the following: as part of King Heinrich's court are "Saxon and Thuringian counts, nobles, and soldiers....Opposite them are Brabantian counts and nobles, soldiers and people."146 Note that Wagner specifies that the Brabantian masses are to be placed opposite

\footnotetext{
${ }^{145}$ Parakilas, "The Chorus," 80-84. As Parakilas notes elsewhere, the division of the chorus into contrasting groups as a method of dramatizing political, social, or cultural oppositions was a trend that prevailed through opera in general in the nineteenth century. It should be noted many of Parakilas' non-French examples - such as Wagner's Der fliegende Holländer (1843), Verdi's Simon Boccanegra (1857, rev. 1881), and Mussorgky's Boris Godunov (1869, rev. 1872) - date from well after grand opera had established itself. One can draw one of two conclusions from this: that these works' treatment of the chonus display a tacit debt to grand opera, or that grand opera's dramaturgy fits within a wider ranging development vis-à-vis the opera chorus, one that cut across numerous cultures. See Parakilas, "Political Representation and the Chorus," 197-200.

${ }^{146}$ Unless otherwise noted, all quotations and translations from the Lohengrin libretto are from Chris Wood (Decca 421 053-2, 1987).
} 
Heinrich's entourage, seemingly in accordance with the grand opera tendency of dividing the chorus into opposing groups. But Wagner will not keep them in opposition for long: as the act unfolds, Wagner will exploit the potential for different combinations of the choral forces. Indeed, the chorus is only separated into "Brabantians" and "Saxons and Thuringians" for a brief portion at the act's outset. Once the action moves to Elsa's judgment, the typical division is between "all the men" and "all the women" as they react to Ortrud and Friedrich's charges, Elsa's recounting of her visions of her champion, and the eventual arrival of said champion.

Wagner's recombination of his choral groups builds towards the act's finale, where all of the soloists and the entire chorus sing out in praise of the champion's heroism. This represents one of Wagner's notable variations of grand opera's prevailing tendencies, as he conspicuously eschews the "destructive mob" aspect of the crowd scene - such as in the finale of Les Huguenots, where Raoul, Valentine, and Marcel are murdered by the marauding Catholics - in favour of something notably more celebratory. In Lohengrin's first act, the divided chorus is deployed to give voice to complementing rather than opposing ideologies. This is not an unprecedented type of variance of course. The use of the chorus to express political and social solidarity amongst the masses also finds several examples in the traditional French repertoire, such as in the finale of Halévy's Charles VI. Nonetheless, the essential point to be extracted is that Wagner adopts tendencies associated with the grand opera chorus in order to populate the stage with massed voices representing different social groupings. In Lohengrin these groupings come together to express astonishment at the miraculous occurrence that is the emergence of Elsa's champion, their words of amazement effectively positioning 
Lohengrin's presence as a monumental moment in history. I would suggest that the crowd's perception of an epochal historical occurrence effectively parallels Liszt's own perception of Lohengrin itself as a work of similar historical significance, a notion that shall inform my own readings of the opera's use of the chorus.

As Lohengrin's swan-pulled barque makes its way to shore, the assembled male chorus provides this reaction:

Ein Wunder! Ein Wunder!

Ein Wunder ist gekommen, ein unerhörtes, nie gesehnes Wunder!

Ein Wunder! Ein Wunder! (I, ii)
[A miracle! A miracle! A miracle has happened, a miracle never before seen or heard! A miracle! A miracle!]

The crowd proclaims the knight's arrival, and the attendant answering of Elsa's prayers to be a miracle. After Lohengrin disembarks and bids farewell to the swan, the entire chorus continues:

Wie faßt uns selig süßes Grauen! Welch holde Macht hält uns gebannt! Wie ist er schön und hehr zu schauen, den solch ein Wunder trug ans Land! (I, iii)
[What sweet and blissful trembling comes over us! What blessed power holds us spellbound! How fair and noble to behold is he whom such a miracle brought ashore!]

It is important to annotate their profession of astonishment at Lohengrin's arrival. The crowd had gathered in an open forum ostensibly to witness an accused individual face a public tribunal, but instead this "city" becomes collectively dazzled by the wondrous arrival of an emissary of seemingly divine origins (confirmed in the third act), whose very presence instills feelings of overwhelming bliss in them. In proclaiming the unprecedented nature of this miracle, the crowd anoints Lohengrin's appearance as a historical epoch, a monumental event that can irrevocably change their history. 
In his commentary, Liszt provides the following observations about Wagner's choral writing, using this particular scene to illustrate Wagner's approach to the operatic chorus throughout the opera as a whole:

Wagner treats his choruses with extreme care. They are generally written in eight real parts, and this one, which is the most wonderfully conceived and the most happily graduated, is the more remarkable on account of the picturesque truthfulness resulting from this distribution of the voices. The curious surprise of some, the pious and naïve faith of the astonishment of others, their terror and shock to all, are expressed like individual exclamations, and the motive being full of pomp and majesty acquires in the crescendo of its immense development a power which perhaps makes this instant appear the most opposed to this new style of music must find themselves carried away and enraptured by this admirable morceau. ${ }^{147}$

Liszt makes no mention of grand opera. There is no evidence to suggest that he is being disengenous regarding the music's supposed lack of precedent, so we should conclude that he genuinely does not see Wagner's choruses as demonstrating lineage to grand opera. Nonetheless, Liszt's tributes to the music's proclaimed superiority emphasizes its "majesty" and "pomp," playing up its capacity for grandiose pageantry. In doing so, Liszt argues that the music radiates the sufficient greatness to make it a musical monument. Wagner's choral scenes, according to Liszt, are of such overwhelming impact that to hear it is to be "carried away" and "enraptured": no other response on the part of the audience is feasible, as Liszt describes it. To hear Liszt tell it, the audience upon hearing the music of Lohengrin, must deem it a miracle, just as the citizens of Brabant do for the arrival of Lohengrin.

\footnotetext{
${ }^{147}$ Liszt, "Liszt on Lohengrin" (part 2), 32.
} 


\section{Ex.1}

(Lohengrin $\mathrm{I} / \mathrm{ii}, \mathrm{mm} .384-390)$

Both chornse together.
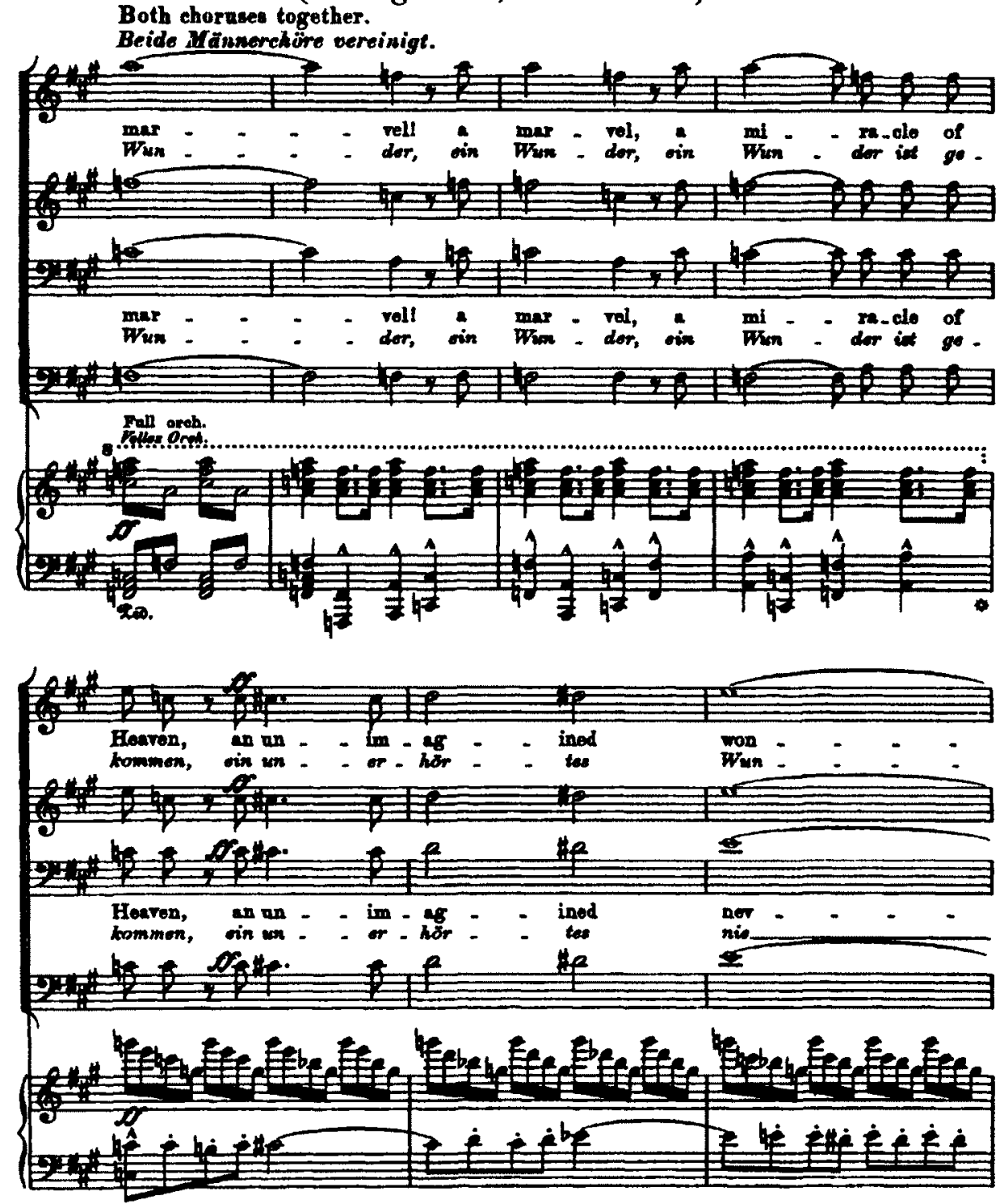

Liszt's praise is directed primarily towards the first choral passage that I have quoted (Ex. 1). Wagner sets the "shock" and "terror" amongst the male chorus through a concentration of note-against-note part-writing, emphasizing octaves and simple triads, alternation of sustained whole and half-notes and repeated eighth-notes. All of these are declaimed at a dynamic of fortissimo and accompanied by an orchestral tutti that accentuates martial dotted-rhythms and triadic arpeggiations in the bass. In contrast, the female chorus concentrates on expressions of piety, deploying mostly unison voicings 
and harmonized thirds and sustained whole and half-notes. Again, their parts are declaimed fortissimo so that their proclamations of spiritual gratitude are combined with the same degree of astonishment contained in the male parts. In doing so, Wagner provides a prelude to the strategy of choral writing that will expand in complexity as the act reaches its conclusion: the crowd is subdivided into distinct groups that disseminate discrete poetic and musical blocks that nonetheless fit together to convey an overall unified message.

This facet of the scene's crowd-based dramaturgy takes on added levels of intricacy during the setting of the second passage quoted (Ex. 2): while the pious mood is highlighted through the lowering of the dynamic to a serene pianissimo, the setting becomes more ornate with an expansion to the full eight-part chorus and a contrapuntal texture that initially separates the different timbres with distinct motivic material. The altos and falsetto tenors declaim a triadic theme that imitates Lohengrin's immediately preceding words of gratitude to the swan in its use of dotted and triplet rhythms. This triadic theme also recalls the string-based theme that opens the act one prelude, while the low tenors and basses concentrate on quarter-note arpeggiated figures. The melodic material is eventually distributed amongst each voice in order to functionally unify musically what already bonds them textually. In doing so, the scene positions the chorus as the series of "individual exclamations" that Liszt sees as key to the choral writing's musical and dramatic power. 
Ex. 2

(Lohengrin I/iii, mm. 45-52)

I pitu doloe posaiblle.
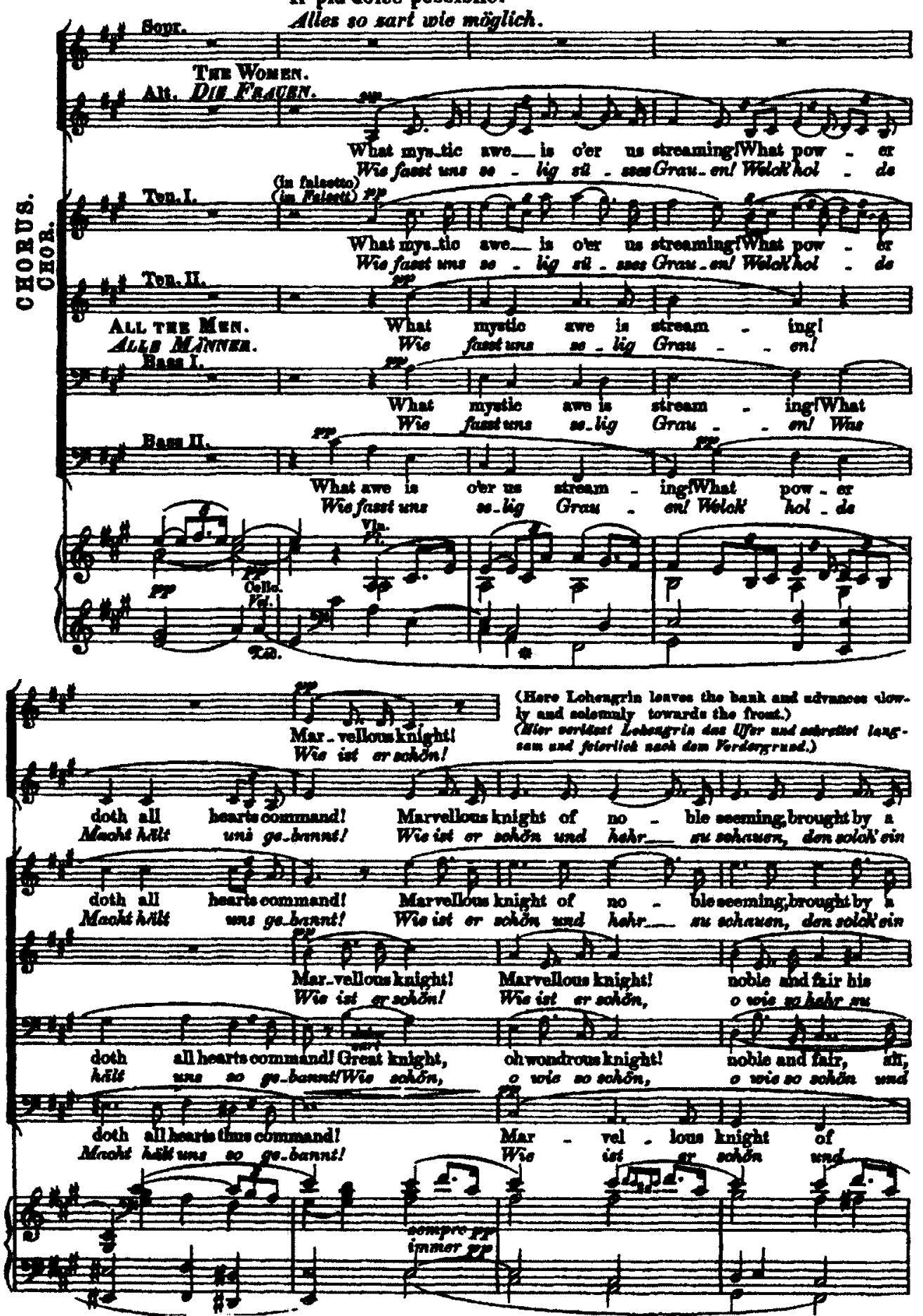

The chorus as an aggregation of discrete but complementary groups culminates with the

climax of the first act, as this crowd scene has progressed from a public tribunal, to an

expression of collective piety and astonishment, and ultimately concluding with a 
ceremonial spectacle, as Lohengrin engages Friedrich in single combat on Elsa's behalf, while all and sundry watch and comment. In the aftermath of Lohengrin's victory (and his sparing of Friedrich's life), the first act comes to its conclusion with the elaborate ensemble so typical of a grand opera finale. It does so with the chorus "express[ing] the joyful satisfaction and surprise of the king and people, who were loth [sic] to believe this beautiful woman guilty of monstrous crimes...."148 The men's celebration includes this passage:

Du hast gewahrt das Recht der Frommen, Preis deinem Kommen, Heil deiner Art! Dich nur besingen wir, dir schallen unsre Lieder! Nie kehrt ein Held gleich dir zu diesen Landen wieder! (I, iii)
[You have defended the right of the meek, praise be to your coming, all hail to your origin! We sing the praises of you alone, our songs ring out to you! Never again will a knight of your stature return to these lands!]

Meanwhile, the women proclaim the following:
Wo fänd' ich Jubelweisen, seinem Ruhme gleich, ihn würding zu preisen, an höchsten Lobe reich! (I, iii)
[Would that I could find tunes of jubilation equal to his glory, worthily to praise him, tunes rich in the highest praise!]

Both groups invoke the importance of singing in order to properly praise Lohengrin's heroism and majesty, but the women make it clear that no song that they can conceive can possibly honour this knight in a way that sufficiently conveys the feelings of joy that he has aroused in them. Lohengrin is so magnificent that his spectators cannot find words and tones that could hope to match the splendour to which they have been exposed. These poetic blocks are not kept separate for long, as both the male and female

\footnotetext{
${ }^{148}$ Ibid., 35.
} 
choruses exchange and take up the other's stanzas, bringing the entire "population" together with a unified message. As such, the act as a whole fulfills Parakilas' description of one of the grand opera chorus' typical functions: to give voice to the "people" in which a multitude of overlapping voices, divided into individual "personalities" come to be bonded in their jubilation, sharing each other's thoughts and expressions, at once a multiplicity and a singularity, simultaneously individual and collective, a heterogeneous homogeneity. This collective is emphatically not the frenzied mob of many a French grand opera, but a mass celebration of a divine presence within the midst of the Brabant citizenry.

To sum up, the "urbanized" chorus is deployed in order to give voice to a population that announces the onset of a monumental moment in their history. Wagner exploits the "pomp and majesty" (Liszt's words) of that chorus in order to bequeath his score a commensurate sense of musical and dramatic grandeur, providing the necessary sonorous "size" to the scene so that it may properly reflect the epochal nature of the event it is assigned to represent. Contextualized within the Weimar premiere, the musical magnitude that Wagner injects into his score for Lohengrin provides a fine parallel to the monumentality that Liszt had ascribed to both the city of Weimar and the importance that Lohengrin would hold in helping to usher in a new artistic golden age for the city. The importance that Liszt placed upon initiating his hoped-for "Wagner-Liszt" era of Weimar was such that even if the badly short-handed chorus available was incapable of adequately realizing the pageantry written into the score, the necessity of celebrating Weimar's enduring creative spirit by pointing the way forward was sufficient to surmount such shortcomings. In Liszt's own words, despite these not insignificant obstacles the 
benefits of having the "enthusiastic efforts of patient and determined workers [and] the steadfast resolve of all the artists who had the honour to lead us" allowed the "performance of the opera to make everyone forget everything that was missing." 149 In other words, the sheer determination of all involved to mount a work of art of such "grand scale" ("großartigen Maßstab") in spite of their limitations made such inhibiting factors ultimately meaningless, thereby successfully establishing "the entire celebration" as the "inauguration of the most important works of poetry and new music."150 According to Liszt's formulation, the efforts to stage as monumental a work as Lohengrin in the face of such adversity effectively granted the performance itself monumentality befitting Weimar's status as an artistic beacon. Therefore, one might posit that even if the Hoftheater's resources could not sufficiently instill the "grand" into Wagner's grand opera choruses, the choruses of the Weimar Lohengrin were nonetheless imbued with that city's artistic spirit.

Liszt's own conviction that Lohengrin's premiere represented a paradigm shift in the history of German art was hardly unanimously shared amongst the performance's specatorship. Wagner has already been quoted as having received less than flattering reports pertaining to the orchestra's and assembled singers' inadequacies in terms of convincingly bringing the contents of the score to life. Even more scathing was the review from Dingelstedt, who wrote in the Ausburger Allgemeine Zeitung:

\footnotetext{
${ }^{149}$ Liszt, "Lohengrin von R. Wagner," 91: "haben die enthusiastischen Anstrengungen, die geduldige und beherzte Arbeit, der beharrliche Wille aller Künstler, die zu leiten wir die Ehre hatten, wahrend der Vorstellung der Oper alles vergessen lassen, was noch fehlen konnte."

${ }^{150}$ Ibid: "die ganze Feierlichkeit, welche bei der Inauguration einer bedeutendsten Schð̈pfungen der Poesie und der Musik der Gegenwart vorwalten mußte."
} 
Here already the boundaries of art have flowed over into each other to such an extent, their means are so undifferentiated and arbitrarily jumbled that it is hard to say where poetry stops and music takes over. Instead of singers, the instruments declaim and subsist unawares; flutes coo about love, violins argue, contrabasses and timpani grumble against each other [...]. This goes on without a break until the curtain falls: no recitative, no andante, no cabaletta, also no duet, rather only a vocal exchange between two people, also no ensemble piece in the old style, never a point of rest, movement everywhere. ${ }^{131}$

Dingelstedt's pan was particularly devastating in that it "[ensured] that no sympathy for Wagner's music would help redress his compromised political profile," meaning that the review "essentially crippled Wagner's last hope for rapid political redemption in Saxony." 152

Liszt already seemed aware that resistance would surely arise to Wagner's work, and not just because of the fact of the overall inadequacy of his assembled musicians: what Liszt saw as Wagner's innovations would naturally engender a certain degree of opposition. This suspicion was borne out by the aforementioned disinterest on the part of the Weimar citizenry. In a letter to Wagner written shortly after the festival, Liszt made it clear that many an audience member will need to fundamentally change the way they approach and consume music in order to recognize Wagner's greatness: the public must eventually develop the capability to "[associate] itself by sympathy and intelligent comprehension with conceptions of a higher order than that of the lazy amusements with which it feeds its imagination and sensibility at our theatres every day."153 Furthermore, "this must be done, if need be, by violence, for, as the Gospel tells us, the kingdom of heaven suffers violence, and only those who use violence will take it."154 These are

\footnotetext{
${ }^{151}$ Franz Dingelstedt, "Weimarischer Festklander" (October, 1850), quoted in Trippett (part 1), 9.

${ }^{152}$ Trippett (part 1), 9.

${ }^{153}$ Liszt to Wagner (Sept. 16, 1850), quoted in Trippett (part 1), 9.

${ }^{154}$ Ibid. Walker states that by May 11, 1851, Liszt would have staged Lohengrin five times in Weimar, "thus insuring its place in the repertory" (126). Liszt's advocacy would culminate in the Wagner Festival
} 
notably martial terms, but not overly surprising when one considers that Liszt was taking on the role of public advocate in his decision to stage Lohengrin in Weimar. As Trippett observes with regards to Liszt's essay, "Liszt felt compelled to argue that the initial performances were only the first stage in an ongoing campaign, one that must involve critical advocacy as well as performance. The wider public now had to be persuaded through prose of the new art's validity and integrity."15s The effort to build up the reputations of both Wagner and the "new" Weimar was a matter of winning the proverbial hearts and minds, and a certain degree of force would be required in order to ensure that a resistant public, including that which was situated in Weimar itself, would eventually catch up with the spirit of innovation that Liszt continually endeavoured to cultivate and promote in Weimar.

But despite the prominent dissenting voices, there were still several figures (admittedly already allegiant to Liszt and/or Wagner) whose reaction to Lohengrin matched Liszt's conviction that the work was an artistic landmark. In the September 3, 1850 edition of the Leipzig-based Neue Zeitschrift für Musik, noted Wagner disciple Theodor Uhlig commenced a series of articles entitled "Three Days in Weimar: The Herder Festival. Richard Wagner's Opera Lohengrin." The series (encompassing six issues of the journal) examined both the opera and its Weimar premiere. ${ }^{136}$ Throughout these articles, Uhlig hardly lacked for superlatives, notably declaring the opera to be "the most important work of the most significant contemporary composer of German

of 1853, where between February 16 and March 15, performances of Der fliegende Holländer, Tannhäuser, and Lohengrin were all given.

${ }^{155}$ Trippett (part 1), 8.

${ }^{156}$ Theodor Uhlig, "Drei Tage in Weimar: Das Herderfest. Richard Wagners Oper Lohengrin" (1850), Musikalische Schriften, ed. Ludwig Frankenstein (Regensburg: G. Bosse, 1913), 324-341. The essay was originally published in NZfM 33/19 (Sept. 3, 1850), 33/21 (Sept. 10, 1850), 33/22 (Sept. 13, 1850), 33/25 (Sept. 24, 1850), 33/28 (Oct. 4, 1850), 33/30 (Oct. 11, 1850). 
opera." Uh7lig continues that "the libretto can stand boldly alongside the best that corresponding genres of modern German literature can offer,"158 while also applauding Wagner's mastery of compositional technique, emphasizing the complex and sophisticated use of musical motifs. ${ }^{159}$ The end result is a work that effectively illustrates Uhlig's claim that Wagner's works meet a higher standard than a typical opera, providing audiences with musical dramas that are "more vivid in their detail and psychological interest," befitting Wagner's ostensible reputation as one whose music is able to "look into the depths of the souls of speaking and acting persons." ${ }^{\text {Un }}$ Uhlig's review underlines the opera's sophistication, its stylistic, aesthetic, and psychological complexities, in effect, its "newness" as the source of its greatness and cultural import.

Regarding the actual performance, Uhlig also concedes that the orchestra and chorus were understaffed. ${ }^{161}$ Uhlig is quick to play down such barriers, only giving them an obligatory acknowledgment in the middle of the review and going so far as to blame the less than ideal performing conditions on the fact that the other major theatres in Germany have to date not found space in their schedule to add Wagner's latest works to their repertory. ${ }^{162}$ Indeed, the quality of the actual performance comes across as nearly an afterthought to Uhlig in his zeal to glorify Wagner's musical achievement and its significance for German art. Beyond the actual content of the essay, Uhlig's devotion of

\footnotetext{
${ }^{157}$ Uhlig, "Drei Tage in Weimar," 325: "das bedeutendste Werk des bedeutendsten deutschen Operndichters der Gegenwart."

${ }^{158}$ Ibid., 326: "Die Wortdichtung darf sich...kuhn neben das Beste stellen, was die moderne deutsche Literatur in den entsprechenden Gattungen aufzuweisen hat...."

${ }^{159}$ Ibid., 333-337.

${ }^{160}$ Tbid. 327: "in ihrem Detail ein mehr plastisches und psychologisches Interesse bieten...." and "in die tiefste Seele der redenden und handelnden Personen blacken zu lassen." Uhlig attributes the second quotation to something a "simple musician" at the Weimar church ("einfacher Musiker der Weimarschen Kapelle") told him about Wagner's music.

${ }^{161}$ Ibid., 336-337.

${ }^{162}$ Ibid., 337.
} 
six issues of written material to the opera would appear to register as a move to underline the opera's importance: such a monumental work requires a similarly significant piece of criticism to properly account for its significance, a piece that cannot be confined to a single issue. Vazsonyi contends that Uhlig's essay acts as a significant instance of "branding," building up Wagner as a key figure in modern German music. ${ }^{163}$

Liszt's own panegyric resembles Uhlig's in that they both prize Wagner's innovation. Liszt explicitly thematizes innovation as an expression of the intrinsic spirit of German art. Wagner's perceived significance as a musical and dramatic innovator also figures into the viewpoint of then- $N Z f M$ editor Franz Brendel, who was noted as a tireless advocate for the musical progressivism of the Weimar faction and would eventually coin the "New German School" moniker at the Leipzig Tonkünstler-Versammlung of $1859 .{ }^{164}$ His Geschichte der Musik in Italien, Deutschland und Frankreich von den ersten christlichen Zeiten bis auf die Gegenwert (History of Music in Italy, Germany, and France from the Earliest Christian Times to the Present) - initially published in 1852, and reached nine editions by 1906 - was perhaps his most enduring critical platform. ${ }^{165}$ In that tome, Brendel devoted the better part of two chapters towards touting Wagner as "the genius who, emerging from the recent progress of the arts, had the determination to break with the previous requirements to build up a new foundation, a new edifice" of

\footnotetext{
${ }^{163}$ Vazsonyi, 114.

${ }^{164}$ Franz Brendel, "Advancing an Understanding" (1859), Richard Wagner and His World, trans. James Deaville and Mary A. Cicora, ed. Thomas S. Grey (Princeton, NJ and Oxford: Princeton University Press, 2009), 316-332.

${ }^{165}$ Franz Brendel, Geschichte der Musik in Italien, Deutschland und Frantreich von den ersten christlichen Zeiten bis auf die Gegenwert - Siebente, neu durchgesehene und vermehrte Auflage (Leipzig: Heinrich Matthes, 1889).
} 
music. ${ }^{166}$ Elsewhere in the book (specifically the seventh edition, posthumously published in 1889), Brendel will refer to the "Wagner-Liszt school" as a stand-in for the term "New German," a gambit that Brendel claims is taken on for no other reason than to "eliminate malignant memories of the absurd term 'Zukunfstmusik."'167 Nonetheless, Brendel's rhetorical gesture serves to portray both Wagner and Liszt as nuclei for German musical progressivism, complementing Liszt's earlier stated goal to initiate a "Wagner-Liszt" era of Weimar. Brendel's thoughts on Wagner's standing as the idealized musical representative of contemporary Germany can be encapsulated in his article "Ein Ausflug nach Weimar" (An Excursion to Weimar) - a review of a performance of Lohengrin held in Weimar, published in the January 23, 1852 edition of the $N Z f M$ - where he writes that Lohengrin amply demonstrates that "right now, the Wagnerian path is the only correct one to take" in order to ameliorate the sorry state contemporary opera is in. ${ }^{168}$

Uhlig's, Liszt's, and Brendel's reception of Lohengrin provides the final piece of the puzzle in terms of the situation of the Lohengrin premiere as a major cultural event in the struggle to define the course of German music in the nineteenth century. The performance put forth a number of complementing discourses: firstly, the premiere was essentially the aforementioned "meeting of the minds" for two of the figures (Liszt and Wagner) who would come to be framed as crucial to the advancement of German music;

\footnotetext{
${ }^{166}$ Ibid., 546: "der Genius, welcher die Bestimmung hatte, heraustretend ans dem bisherigen Gange der Kunst und brechend mit den bisherigen Voraussetzungen, auf neuen Grundlagen ein neues Gebaude aufzufuihren...."

${ }^{167}$ Ibid., 593-594: "Es ist das grosse Verdienst der Wagner-Liszt'schen Schule - die bekanntlich den Namen der neudeutschen angenommen hat, aus keinem anderen Grunde, als um gehăssig Erinnerungen, die an das abgeschmackte Wort "Zukunfstmusik" sich knüpfen, zu beseitigen...."

${ }^{168}$ Franz Brendel, "Ein Ausflug nach Weimar" (1852), Gesammelte Aufsätze zur Geschichte und Kritik der neuren Musik, ed. Allgemeiner Deutscher Musikverein (Leipzig: C.J. Rahnt Nachfolger, 1888), 133: "daß der Wagner'sche Weg als der einzig richtige jetzt ist...."
} 
Liszt would then mobilize the legacy of Weimar to consecrate Lohengrin as a vital new addition to the city's prestigious lineage, while Brendel and Uhlig would concurrently work to mythologize various combinations of Liszt, Wagner, Lohengrin, and Weimar as prominent representatives of the cutting-edge of German art. ${ }^{169}$ As a consequence, it can be argued that despite the documented flaws in the work's performing conditions as well as in the performance itself, the Weimar Lohengrin was indubitably successful in that it provided a platform for Liszt and Uhlig to discursively situate it as a musical monument, the proverbial "next phase" in the advancement of German art, as part of the effort to bestow symbolic capital upon Weimar as the home of the progressive movement in German music. As the preceding discussion has hopefully made clear, the prominence of the grand opera chorus as an expression of musical monumentality played a sonorous and dramaturgical role in making that symbolic capital possible.

\section{The Wartburg Comes to Paris}

In the years following the Weimar Lohengrin, Wagner would become a source of great controversy in French musical discourse of the 1850s, despite the fact that precious little of his music had actually been heard in France. This was the result of the publication of the "Zurich essays" which made him "one of the most discussed composers alive."170 As Fauser notes, François-Joseph Fétis' series of articles published between June and August of 1852 in the Revue et Gazette musicale de Paris, devoted to discussing Wagner's aesthetics and reformist advocacies "would shape the discussion in France for several decades." ${ }^{\prime 11}$ Fétis would renew his attacks on Wagner with an

\footnotetext{
${ }^{169}$ While Brendel venerated both Liszt and Wagner, Uhlig's writings demonstrated no interest in Liszt, only Wagner.

${ }^{170}$ Fauser, "Tannhäuser and Its French Critics," 233.

${ }^{171}$ Ibid.
} 
additional three-part series of articles in the $R G M$ in 1853 and 1854 . Fétis' attack made sure to mention "the attention [Wagner's] music was gaining in Germany,"112 even going so far as to state that significant parts of Germany were "preoccupied by Wagner." striving to reveal the speciousness of Wagner's ideas, Fétis "hoped to prevent a comparable reception in France."174 The invocation of Wagner's supposed popularity in Germany is revealing: by foregrounding Wagner's ostensible growing cultural ubiquity in Germany, Fétis would appear to be situating Wagner as an outsider, a purveyor of "foreign" ideas that are at odds with those of France. This sort of chauvinism is made more explicit in Paul Scudo's review of Wagner's essays in the Revue de deux mondes of 1860 and his later contributions to L'Année musicale from 1860-1862. In the latter, Scudo invokes the "nationalistic opposition of the classic (and Classical) qualities of French culture and traditional complaints about the metaphysical obscurantism of German culture," with "ugliness" being attributed to German music. ${ }^{175}$ In both Fétis' and Scudo's admonishments, Wagner's Germanness is (implicitly or explicitly) underlined as a signifier of the manifest inferiority of his art and its potential to act as a pernicious influence that would threaten the integrity of French culture.

Fétis and Scudo were by no means the only voices in the French press that weighed in on the Wagner issue during the $1850 \mathrm{~s}$, but their hostility provides an evocative sketch of the temperament of the opposition and the type of atmosphere Wagner would have to contend with as he returned to Paris in 1859 in another attempt to

\footnotetext{
${ }^{172}$ Turbow, "Wagnerism in France," 138.

${ }^{173}$ François-Joseph Fétis, Revue et Gazette musicale de Paris (June 6, 1852), quoted in Turbow, 138.

${ }^{174}$ Turbow, 138.

${ }^{175}$ Ellis, 59.
} 
achieve stardom in its vaunted musical and operatic scene. ${ }^{176}$ This was of course after he had already stated such pronounced antipathy towards Parisian culture in his writings of the 1840 s, but clearly the chance to establish himself in Paris was too great to pass up, especially considering his status as an exile from his native Germany. Nor was this necessarily a case of reluctant acquiescence to the realities of Paris' status as a hub of artistic activity: in a letter to Ludwig II, dated July 18,1867 , Wagner makes the following statement:

[s]trangely enough, Paris has become the only city, for which I hold interest of curious sympathy... and even today, I prefer it to all other places in the world...I could bring myself, as a cultural historical study, to go to a new opera by Meyerbeer or Gounod in a Parisian theater, for whose circumstances, abilities, and audience it is calculated; in Berlin, Vienna and Munich I would find this impossible. ${ }^{17}$

These are not the words of someone who has maintained a consistent level of disdain for a city that had rejected him on two occasions, vociferously so in the second instance. But even then Wagner remains guarded in his praises, restricting his affinity for Paris to "curious sympathy" and framing his potential partaking of works by Meyerbeer and Gounod as something more akin to an anthropological project than that which could arouse emotional or spiritual contentment. So, even though Wagner professes admiration for Paris, there is still a significant qualification as though there were still something

\footnotetext{
${ }^{176}$ This was not the first time that Wagner had set foot in Paris during his "exile": Wagner made lengthy stays there in 1849 and 1850 after fleeing Dresden on a falsified passport. He found the city no more artistically or personally inspiring than he had during his initial residency there. In a letter to Uhlig, dated October 22, 1850 (written after he had returned to Zurich), he makes his feelings about Paris plain, writing that he "no longer believe[s] in any other revolution save that which begins with the burning down of Paris" (SL 219). Wagner also briefly visted Paris in 1853, accompanying Liszt; it was during this six-week stay that he first met Liszt's daughter Cosima. See also Barry Millington, Wagner - Revised Edition (Princeton, NJ: Princeton University Press, 1992), 39-40 and du Quenoy, Wagner and the French Muse, 20-26.

${ }^{177}$ Letter to Ludwig II (July 18, 1867), quoted in Fauser, 228.
} 
fundamentally "inauthentic" about Paris. This ambivalence about Paris will inform my forthcoming reading of the Paris Tannhäuser.

Nonetheless, Wagner had made his choice to rejoin Paris' musical scene, and thus set about endeavouring to implant himself in the public consciousness. One of his first "strikes" was to conduct three concerts at the Theâtre-Italien in January and February of 1860 , consisting of excerpts of several of his works, with a series of selections from Tannhäuser forming the centre of gravity for the program. ${ }^{178}$ There are a number of reasons why Wagner would emphasize Tannhäuser during this Parisian excursion: in My Life, Wagner claims that Léon Carvalho, the director of the Théâtre-Lyrique "would hear of absolutely nothing but Tannhäuser" and that if he were to stage any of Wagner's works, it would only be that one, for that opera's name supposedly "was inextricably tied with [Wagner's] by the Parisian public...."179 This might have convinced Wagner that Tannhäuser represented his greatest chance for success in Paris. But even before that, there was the matter of the French writer Théophile Gautier and his exposure to the work in 1850; his enthusiasm for the opera led to him publishing an article in the September 29, 1857 issue of Le Moniteur universel, where he advocated for the opera's greatness, emphasizing "the desirability of performing Tannhäuser in Paris." Whether or not Wagner actually saw this article, it provides a handy illustration of the prominence that Tannhäuser apparently enjoyed amongst pro-Wagner voices in Paris.

\footnotetext{
${ }^{178}$ Fauser, 233-234.

${ }^{179} \mathrm{ML}, 593$.

${ }^{180} \mathrm{du}$ Quenoy, 28. Gautier's daughter Judith would notably become involved with Wagner following her attendance of the 1876 Bayreuth festival. They would soon exchange a number of passionate letters, with Wagner sending her a copy of the libretto for Parsifal in December 1877. See Peter Wapneski, "The Operas as Literary Works," Wagner Handbook, 91-92 and Joachim Köhler, Richard Wagner: The Last of the Titans, trans. Stewart Spencer (New Haven, CT and London: Yale University Press, 2004), 575-591.
} 
Aside from the veneration it enjoyed from such figures as Carvalho and Gautier, Tannhäuser was already an ideal choice for adaptation for the dramaturgical requirements of the Paris Opéra, as scenes such as the Venusberg, the singing contest at the Wartburg, and the procession of Pilgrims presented the capacity for the kinds of scenic spectacle and ceremonial and processional crowd scenes so inherent to grand opera. The plot foregrounded a romantic intrigue between Tannhäuser, Elsa, and Wolfram von Eschenbach set against the historical backdrop of the German Minnesingers. The work already bore a clear lineage to grand opera, and in making a number of revisions to bring the opera more in line with the dramaturgical expectations of the Opéra, Wagner would intensify those pre-existing connections.

Wagner additionally sought to cultivate interest in his work and ideas amongst the Parisian intelligentsia and those with significant political and social capital through the city's well-established "salon" culture. As Gerald Turbow notes, the salons that Wagner frequented and eventually the one he created were attended by several cultural and political luminaries. ${ }^{181}$ Wagner's salon, along with the already-prominent support of such figures as Gautier, Baudelaire, and Champfleury played no small role in positioning Wagner as the "darling of the progressives" in Paris. ${ }^{182}$ Wagner secured supporters amongst members of both the legitimist Right and the republican Left with a specific purpose: he "had created his salon and played the social game in order to secure a Tannhäuser production in Paris."183 Wagner's networking efforts eventually proved successful, as the prominent support of the Princess Pauline von Metternich, wife of the Austrian ambassador, played a role in Napoléon III's order - issued on March 12, 1860 -

\footnotetext{
${ }^{181}$ Turbow, 142-147.

${ }^{182}$ Ibid., 147.

${ }^{183}$ Ibid., 146.
} 
that Tannhäuser be performed at the Operra. ${ }^{184}$ Wagner appeared on his way, but as shall become apparent, the Emperor's decree created no small degree of hostility towards Wagner that led to the fiasco surrounding the production.

To repeat, Wagner undertook a number of revisions to Tannhäuser in order to prepare it for its debut at the Opéra. The most prominent (and as it turned out, the most controversial) of these revisions was a significant expansion of the opening Venusberg scene, which included an extensively recomposed ballet sequence (the Bacchanale) that followed the overture and led into the first act. ${ }^{185}$ Here is how Wagner recounts the revision to the Bacchanale and the Venusberg scene in My Life:

In accordance with a need I had always felt, I had seized the opportunity presented by this carefully prepared production of Tannhäuser to expand significantly the first scene with Venus...[M]y annoying arguments with the management concerning a ballet had also induced me to extend the introductory Venusberg scene to a length far greater than it had previously possessed, whereby, as far as I could see, the corps de ballet was afforded such a vast choreographic challenge that there would no longer be any grounds for complaint about my lack of compliance in the matter. ${ }^{186}$

To reiterate, My Life can hardly be taken as a document of unvarnished truth, but even with that caveat, Wagner's reminiscence is of interest for portraying a man who could hardly be less annoyed to adapt his work to the requirements for the Opéra. Rather, he "was delighted to use the opportunity to make changes to the Venusberg scene...."187 Wagner does make mention of irritation over disagreements over the placement of the

\footnotetext{
${ }^{184}$ As Fauser notes, the staging of foreign-language works at the Opera was not a new phenomenon. She gives as an example an 1857 production of Verdi's $I$ Trovatore. However, whenever a work was given at the Opéra, regardless of whether the opera was composed by "Verdi or Weber, Mozart or Donizetti," the libretto had to be translated into French. See Fauser, 237-238. Abbate details the translation of the Tannhäuser libretto into French in "The 'Parisian' Tannhäuser, 133-209.

${ }^{185}$ Wagner's initial plan for the Paris version was to shorten the overture and have it seamlessly segue into the Bacchanale. This was not realized, as the overture remained as a self-contained piece. It was not until the 1875 Vienna version that Wagner would carry out his original intention to join the overture and the ballet. See Breig, "The Musical Works," 427.

${ }^{186} \mathrm{ML}, 624$.

${ }^{187}$ Fauser, 238.
} 
ballet (in the first act as opposed to the second), which in part precipitated the fury of the Jockey Club at the performances. ${ }^{188}$ But even then, the popularized narrative of Wagner's adamant refusal to bend to the institution's demands and "compromise" the "integrity" of his work has been revealed as an enduring piece of mythmaking: as Fauser writes

[Wagner] was far more amenable to the question of the act 2 ballet than later events might imply. Early on, [Alphonse] Royer has suggested that the finale of act 2 - after the arrival of the guests at the Wartburg and before the song contest would be an ideal place for the traditional act 2 ballet. Although Wagner had refused categorically to include a ballet within the opera, he agreed to the intercalation of a newly composed ballet divertissement by Théodore Labarre, Graziosa, after act 2. Wagner could have avoided a great deal of controversy had he not made his disdain for the local custom known in an article about the ballet question published in the Journal des Débats in July 1860, and had he not demanded that the first few performances of Tannhäuser be given without the intercalation of Graziosa. ${ }^{189}$

Wagner's (possibly unreliable) recollection in My Life indicates a degree of acquiescence to the Opéra's demands as well as the soon-to-be revealed erroneous belief that the first-act Bacchanale would be considered an acceptable compromise. But the point is that Wagner was not quite as recalcitrant regarding the Parisian expectations as the legend would have us believe. For all of Wagner's various public protestations about the entrenched musical and dramaturgical customs of grand opera, he was still quite willing to adopt many of them in order to give the Parisian premiere a better chance for success.

In the previous discussion of the Lohengrin premiere, I explicated how the "urbanized" elements of grand opera bequeathed the work a sense of magnitude that when contextualized within the cultural legacy of Weimar and the Herder Festival

\footnotetext{
${ }^{188}$ Mark Everist ably explores the prominence of ballet in nineteenth-century grand opéra in "Grand Opéra - Petit Opéra: Parisian Opera and Ballet from the Restoration to the Second Empire," 19 $9^{\text {th }}$-Century Music 33/3 (Spring 2010): 195-231.

${ }^{189}$ Fauser, 238-239.
} 
situated the piece as a musical "monument" to German culture. Even before its revision for Paris, Tannhäuser held a similar function as a German musical monument. The most obvious aspect of the work's monumentality is the centrality of the Wartburg castle (located in the Thuringian city of Eisenach) to its setting. In the nineteenth century, the castle became an important symbol of German identity. Rehding explains:

[Tannhäuser's] subject matter was of great symbolic relevance to the Weimar dynasty: reconstruction work on the Wartburg...had begun in 1838 under the management of was what nowadays be called a lieu de mémorie [place of memory ${ }^{190}$ holding a special place in the German national imagination. Not only had Luther translated the Bible into German while hiding there from prosecution, laying in the same stroke the foundation stone for a standardized German language, but it also had become a cultural-political symbol for German unity more recently, with such important events as the 1817 national students' meeting, celebrating simultaneously the three-hundredth anniversary of the Reformation and the fourth anniversary of the victory over Napoleon. ${ }^{191}$

In creating a work that set a significant amount of its action at the Wartburg, Wagner was clearly exploiting the castle's enduring vitality as a German monument as a benediction of his own work as another hopefully important piece of German culture. The Wartburg's importance to the legacy of the "Weimar dynasty" - presumably meaning the Grand Duchy of Saxe-Weimar-Eisenach - played a central role in Liszt's decision to stage the work in February 1849, the performance serving a dual function as part of Weimar's Goethe centenary and as part of a commemoration of the birthday of Maria Pavlovna, Grand-Duchess of Saxe-Weimar-Eisenach. Liszt made sure to use the Tannhäuser performance and the opera's medieval sources - namely the Tannhäuser legend and the tale of the singing contest at the Wartburg, both said to have taken place in the thirteenth century - to underline a connection between the Goethe celebration and the

\footnotetext{
${ }^{190}$ Pierre Nora, "Between Memory and History: Les Lieux de Mémoire," Representations 26 (Spring 1989): 7-24 and Nora, ed. Realms of Memory: Rethinking the French Past (3 vols.), trans. Arthur Goldhammer (New York: Columbia University Press, 1996-98).

${ }^{191}$ Rehding, 78.
} 
push to restore the Wartburg. ${ }^{192}$ In its original version, Tannhäuser centralizes a German monument. Placed within the halls of the Paris Opéra, the revised Tannhäuser mobilizes the urbanized dramaturgy of grand opera to stage a musical monument to German culture before a French spectatorship.

I submit that this strategy played no small role in provoking the hostility of the anti-Wagnerian contingent of the Parisian music press. This was but one example of the types of tactical "errors" committed by Wagner that incited opposition according to a number of scholars. Fauser summarizes:

From a Parisian standpoint, Wagner made one tactical mistake after another during the lead-up to the premiere, gambling away any general goodwill toward the controversial musician of the future. He demanded to conduct the first three performances of his opera in lieu of Louis Dietsch, the house conductor, whom he found wanting. Rehearsal time was excessive by any contemporary standards. He was rude to the musicians and singers and was perceived as arrogant by the Parisian press because he refused to pay the traditional visits to important journalists. He snubbed the professional claqueurs, depriving them of their income, then hastily brought some of them in at the last minute. His negative views of French composers such as Auber, Halévy, and Berlioz were widely circulated and found offensive. ${ }^{193}$

Clearly there were a number of extra-musical dimensions, personal and/or political, to the "anti-Wagner" contingent's resistance. As both Turbow and Fulcher argue, the Imperial order to perform Tannhäuser practically invited invective. ${ }^{194}$ In benefitting from the largesse of Napoléon III, Wagner opened himself up to the perception that he tacitly supported the authoritarian rule despised by so many. Indeed, the infamous derisive disruptions carried out by the Jockey Club were motivated as much by their legitimist leanings as by outrage at Wagner's refusal to capitulate to their expectations $v i s-\grave{a}-v i s$ the

\footnotetext{
${ }^{192}$ Liszt explains the importance of the Minnesingers and the Wartburg to German history in "Die GötheStiftung," 25-33.

${ }^{193}$ Fauser, 239.

${ }^{194}$ Turbow, 148-150 and Fulcher, 190-194.
} 
placement of the ballet. Turbow recounts a telling anecdote, where a member of the aristocratic opposition explained to Princess Metternich: "it's superb, this Tannhäuser, but what can I do? I whistle, for I am of the conspiracy."195 In many cases, the hostility towards Wagner was borne out of political and dramaturgical considerations, with the music itself practically a footnote.

Beyond matters of France's internal political conflicts and Wagner's perceived involvement therein (no matter how tenuous), Wagner's own conduct was considered a sufficient provocation to stir up such animosity in the press. For many, the proverbial gauntlet was thrown down by the circulation of Wagner's Lettre sur la musique addressed to Frédéric Villot (published in German as "Zukunfstmusik"), which prefaced French translations of the poems for four of Wagner's operas (Der fliegende Holländer, Tannhäuser, Lohengrin, and Tristan und Isolde). ${ }^{196}$ In this, Wagner summarized his positions on the unity of music and poetry in the name of the drama. The letter's distribution "managed to revive the controversy that had earlier surrounded his name in France. By offering his theories to the French, he gave them a new chance to compare his words and deeds, as Fétis and Scudo had done in 1852."197 The letter reiterates his earlier calls to cast off the shackles of the traditional forms of opera. Most germane to this discussion, Wagner speaks of Rienzi in quite dismissive terms: "I had the glittering Grand Opéra before me, and was insane enough to flatter myself with the wish to see my work produced there." ${ }^{\text {198 }}$ By using more flattering terms to characterize his subsequent opera Der fliegende Holländer, which Wagner characterized as eschewing

\footnotetext{
${ }^{195} \mathrm{H}$. Rewbel, "Wagneriana" (1913), quoted in Turbow, 150.

${ }^{196}$ SSD VII, 87-137; PW III, 293-345.

${ }^{197}$ Turbow, 148.

${ }^{198}$ SSD VII, 119-120; PW III, 327.
} 
Parisian influence, this portion of the letter likely stood out to anti-Wagner Parisian critics regarding his attitude towards Parisian culture and its musical and dramatic customs. Fauser summarizes the stakes thusly:

By blatantly and openly disregarding the tastes of his audience and the conventions of French grand opéra, according to his critics, Wagner had made himself a target of both the audience's disapproval and the journalists' attack; therefore, the reviews turned to lessons on the institution of French grand opera and its audience. Much was at stake, because if Wagner was successful in his critique of convention, then the central position of Paris as a musical capital was in jeopardy. ${ }^{199}$

She continues that "the Parisian journalists responded in [such] strong and concerted fashion not only because Wagner had offended French taste, but because his competing aesthetics called into question everything they prized." ${ }^{200}$

Oscar Comettant's review could not be less clear that such concerns were paramount in terms of motivating his critique:

Of course, if Mr. Wagner had not shown, in his numerous writings published in Germany and in France, his disdain for the works of the great masters past and present, and if he had not sustained with such incredible pride his system of opera composition as the nec plus ultra of the beautiful, and if he had not made his operas out to be the only ones worthy to be listened to by serious minds, the Parisian public - naturally benevolent and polite - would have been content to remain silent before the misshapen, dull, and wrongheaded work of the unfortunate composer. But to a pretension without limits and which nothing justifies, an exemplary lesson needs to be taught. ${ }^{201}$

With regards to the music, it is the "wrongheaded" epithet that is most telling:

Tannhäuser was considered such an affront to French taste because it was considered so manifestly "incorrect" in its approach. But the question remains, would Wagner's work have been considered so "wrongheaded" without the foreknowledge that Wagner had attacked their beloved grand opera and positioned his own work as an antidote?

\footnotetext{
${ }^{199}$ Fauser, 242.

${ }^{200}$ Tbid., 243.

${ }^{201}$ Oscar Comettant, “Académie Impériale de Musique: Tannhäuser” (1861), quoted in Fauser, 243.
} 
That Tannhäuser itself owed more than a small debt to grand opera's dramaturgy in its musical and dramatic construction seemed to offer little consolation to Wagner's critics. Indeed, I consider it a plausible speculation that the debt to grand opera that the work displayed may have amplified the insult. Recall the following factors previously discussed: Gerhard's framework for grand opera as a reflection of the urbanized conditions of nineteenth-century Paris; Wagner's professions of disdain for the supposed "inauthenticity" of Paris; Kramer's observation that scenes from Tannhäuser such as the Venusberg represent a criticism of the "debased" nature of a "decadent" culture. With these notions in mind, it is possible to thematize Wagner's use of grand opera, the dramaturgy of the city, as a strategy to stage grand opera and the city's essential falsehood before the spectatorship of the Parisian audience. In setting grand opera's dramaturgy against itself, Wagner stages the "defeat" of French culture in favour of Germany using a revered element of the French identity to carry it out. In the Venusberg scene, grand opera is used as a signifier of the genre's fundamental debasement, while in a scene such as the second-act entry of the guests into the Wartburg, grand opera is exploited to stage a German monument on the Parisian stage. In both of these examples, the grand opera chorus, the voice of the city, plays substantial roles in creating musical monuments respectively to the ostensibly grotesque decadence of France's musical and urbanized culture and the magnificence of German history and legend. If such a reading is accepted, perhaps that accounts for the anti-Wagnerian's investment in revealing Wagner's "wrongheadedness" to all and sundry: whether they were conscious of it or not, they would appear on some level to be responding to Wagner attempting to turn their heritage against them in this performance. 


\section{Parisian Sickness and German Greatness}

Since the opening Venusberg scene was the one most emblematic of the "Paris" Tannhäuser, it is only natural to begin there. To reiterate, Wagner considered this segment the one that lent itself most readily to be remoulded to suit the expectations of the Opéra. As he states in "A Report on the Production of Tannhäuser in Paris," published in the April 7, 1861 edition of the Deutsche Allgemeine Zeitung and the NZfM five days later: "I thought the first act, at the voluptuous court of Venus, would afford the most apposite occasion for a choreographic scene of amplest meaning, since I myself had not deemed possible to dispense with dance in my first arrangement of that scene."202 In a letter to Mathilde Wesendonck, dated April 10, 1860, Wagner expressed dissatisfaction with the original Bacchanale, feeling he had not adequately depicted the Venusberg's status as a sanctuary of earthly delights, and that the forthcoming Paris performances gave him the opportunity to make significant improvements. ${ }^{203}$

Musically, while the reworked Bacchanale retained much of the original version's basic thematic material, the surrounding music was almost entirely recomposed, reorchestrated, and significantly expanded in length. As Werner Breig notes, the new ballet sequence employed the techniques of "chromatic combinations of chords" and "free modulations" that Wagner had recently adopted for Tristan (completed in 1859). ${ }^{204}$ These kinds of harmonic colourations are combined with a rhythmic activity that frequently borders on frenetic. Together, these qualities provide the kind of "decadent" and "ultramodern" soundscapes alluded to by Kramer. Laurence Dreyfus points out that

\footnotetext{
${ }^{202}$ SSD VII, 141; PW III, 351-352.

${ }^{203} \mathrm{SL} 486-491$. Abbate summarizes Wagner's issues with the original Venusberg scene in "The 'Parisian' Tannhäuser," 272-273.

${ }^{204}$ Breig, "The Musical Works," 427.
} 
the Dresden original also exploited chromaticism and rhythmic agitation in order to portray the Venusberg's abandon. ${ }^{205}$ However, the Paris revision greatly intensifies those qualities. According to Millington, "orchestral textures are richer, more voluptuous, and transitions are negotiated with the assurance of Wagner's mature style."206 As such, the Parisian Bacchanale bears practically no resemblance to the original version. ${ }^{207}$

The ballet itself is not the primary focus of my discussion, but its status as the most iconic aspect of the new Venusberg scene necessitates that it be addressed. Furthermore, its often frenzied music casts an undeniable shadow over the rest of the scene, so that everything that follows the Bacchanale is informed by it. Wagner's efforts to musically draw out the Venusberg's sensuality and sexual abandon in this new version were not lost on Paris' pro-Wagner voices, such as Baudelaire, who professed great admiration for Wagner's sonorous images of "fevered and agonized delights, ceaseless returns towards an ecstasy of pleasure which promises to quench, but never does quench, thirst...."208 The multitudinous sexual couplings described in the lengthy stage direction that establishes Venus' grotto effectively illustrate Baudealaire's point. ${ }^{209}$ With the Venusberg's apparent promotion of unchecked carnality, it is not surprising that Emst

\footnotetext{
${ }^{205}$ Laurence Dreyfus, Wagner and the Erotic Impulse (Cambridge, MA and London: Harvard University Press, 2010), 84-88.

${ }^{206}$ Barry Millington, "Tannhöuser," Oxford Music Online (accessed January 16, 2013).

${ }^{207}$ As Abbate notes, the ballet for the Paris version was put together in an unusual fashion: the music for a grand opera ballet was typically composed first, with the choreography following the contours of the score. For Tannhäuser, something akin to the reverse was true, as the choreographic scenario contains detailed suggestions for blocking and for types of dances with the only musical accompaniments consisting of single-line excerpts of thematic material. This indicated that the overall plan for the Bacchanale was in place before any kind of detailed musical rendering was completed. This anomalous procedure demonstrates that the ballet for Tannhäuser was essentially reverse-engineered, as Wagner started with the required result (dancing) and worked backwards to provide the accommodating music. See "The Parisian "Vénus,"” 82-83.

${ }^{208}$ Baudelaire, "Tannhäuser in Paris," 126.

${ }^{209}$ Unless otherwise stated, all quotations and translations of the Tannhäuser libretto are derived from Andrew Huth (Decca 470 810-2, 1985).
} 
Bloch attributed to the work the "glitter of a high-class brothel, with a rose of hell."210 Theodor Adorno similarly likens the Venusberg (along with the realm of the FlowerMaidens in Parsifal) to "dreamland brothels." then Venus is its "madam," controlling her realm through the offering of a space where its inhabitants are encouraged to pursue unending physical pleasure. ${ }^{212}$

Retreating from the music to the libretto for a moment, Wagner's evocation of "magical, rosy lights," and "wonderful, coral-like tropical growths" as the setting for the revelry of the gathered Nymphs, Cupids, and Sirens serves to play up the "dreamland" aspect that Adorno had alluded to. According to Adorno, the grotto's apparent magical qualities helps position the Venusberg as "the phantasmagoria par excellence" in Wagner's oeuvre. ${ }^{213}$ For Adorno, the Venusberg's phantasmagoria privileges magical illusion; quoting Paul Bekker, it is the "illusion of the absolute reality of the unreal."114 But as shall become clearer momentarily, this is not a progressive act in Adorno's view: the transformation of illusion into reality in Wagner's music and dramaturgy are deleterious distractions, creating a situation where "art doesn't reveal; it obfuscates and regresses to the status of fetish."215 While Adorno's diagnosis does not make specific reference to either the Dresden or Paris versions, I submit that the "voluptuous" music of the Parisian reworking, spearheaded by the new Bacchanale, accentuates the

\footnotetext{
${ }^{210}$ Ernst Bloch, quoted in Eva Rieger, Richard Wagner's Women, trans. Chris Walton (Woodbridge, UK and Rochester, NY: Boydell Press, 2011), 42.

${ }^{211}$ Theodor Adorno, In Search of Wagner (1952), trans. Rodney Livingstone (London and New York: Verso, 2005), 83.

${ }^{212}$ In Benjamin's exegeses on nineteenth-century Paris, the figure of the prostitute was situated as one of his central metaphorical "characters" in his exploration of the mythology of the city. She is part of the tapestry that makes up the modern city's phantasmagoria. The prostitute's body is the commodity made flesh, offering the "dream" of limitless pleasure provided one is able and willing to pay for the service. As such, the prostitute is the embodiment of the city's intoxicating mask. See The Arcades Project, 489-515.

${ }^{213}$ Adorno, In Search of Wagner, 75.

${ }^{214}$ Paul Bekker, Wagner, Das Leben im Werke (1924), quoted in Adorno, 79.

${ }^{215}$ Richard Leppert, "Commentary," Theodor W. Adorno, Essays on Music, ed. Richard Leppert (Berkeley: University of Califormia Press, 2002), 533.
} 
simultaneously magical and sensual properties of the Venusberg, lending credence to the "phantasmagorical" reading of the scene. As such, the dream-like unreality of the Venusberg can be thematized as an effective parallel to Benjamin's characterization of nineteenth-century Paris as phantasmagorical. ${ }^{216}$ For Benjamin, the city similarly traded on the reification of spectacular illusion that concealed the labour required to produce it. Paris' "kaleidoscope of lights and perspectives, its cacophony of sound and noise, its mass of diverse artefacts and distractions" provided an anesthetizing effect that dulled one's critical capacities. ${ }^{217}$ Benjamin's study of Paris was to "unmask" the city's mythologized grandeur, to reveal the unpleasantness that lurked below the surface of the city's illusory dreamscape. Specifically contextualized within Tannhäuser's Parisian reworking, one might offer that Adorno's reading of the Venusberg's phantasmagoria functions as something akin to an allegory for Benjamin's critique of Paris' illusory dream world.

The chorus does not play an exceptionally prominent role in the Venusberg scene, as the ballet is the central "attraction" for the Bacchanale. Rather than forming the backbone for the elaborate tableau of a processional or ceremonial scene, the chorus is relegated to a pictorial role more akin to couleur locale. Nonetheless, arriving on the heels of the major set-piece that is the reworked Bacchanale, the choral passages of the opening scene - brief though they may be - are illustrative of many of the points catalogued above. The chorus is identified as "Sirens" in the score, and they accompany Venus' entrance with the following:

Naht euch dem Strande!

Naht euch dem Lande,
[Draw near the strand! Approach the land, where, in the arms of

\footnotetext{
${ }^{216}$ Benjamin, "Paris, the Capital of the Nineteenth Century," 40.

${ }^{217}$ Gilloch, Myth and Metropolis, 103.
} 
wo in den Armen glühender Liebe selig Erwarmen still eure Triebe! glowing love, let blissful warmth content your desires!]

(I, i)

The chorus of Sirens - consisting solely of female altos and sopranos - provide a beckoning call to all who approach the Venusberg, and envoice a promise that any and all desires shall be fulfilled. Addressed to no character in particular within the confines of the narrative, the Sirens' invitation seemingly breaks through the boundary separating narrative and spectator, entreating those in the audience to give themselves over to the embrace of the opera's myriad delights. They are the spokeswomen for this "brothel," "advertising" its seductive wares in order to entice potential patrons. Placed within the specific context of the Parisian performances, these veritable pitchwomen might be understood as calling out to the French audiences, announcing that the revelry they have just been exposed to in the form of the new Bacchanale is an example of the sensual pleasures into which they may partake.

Ex. 3a

(Tannhäuser - Paris version $\mathrm{V} / \mathrm{i}, \mathrm{mm}$. 223-230)

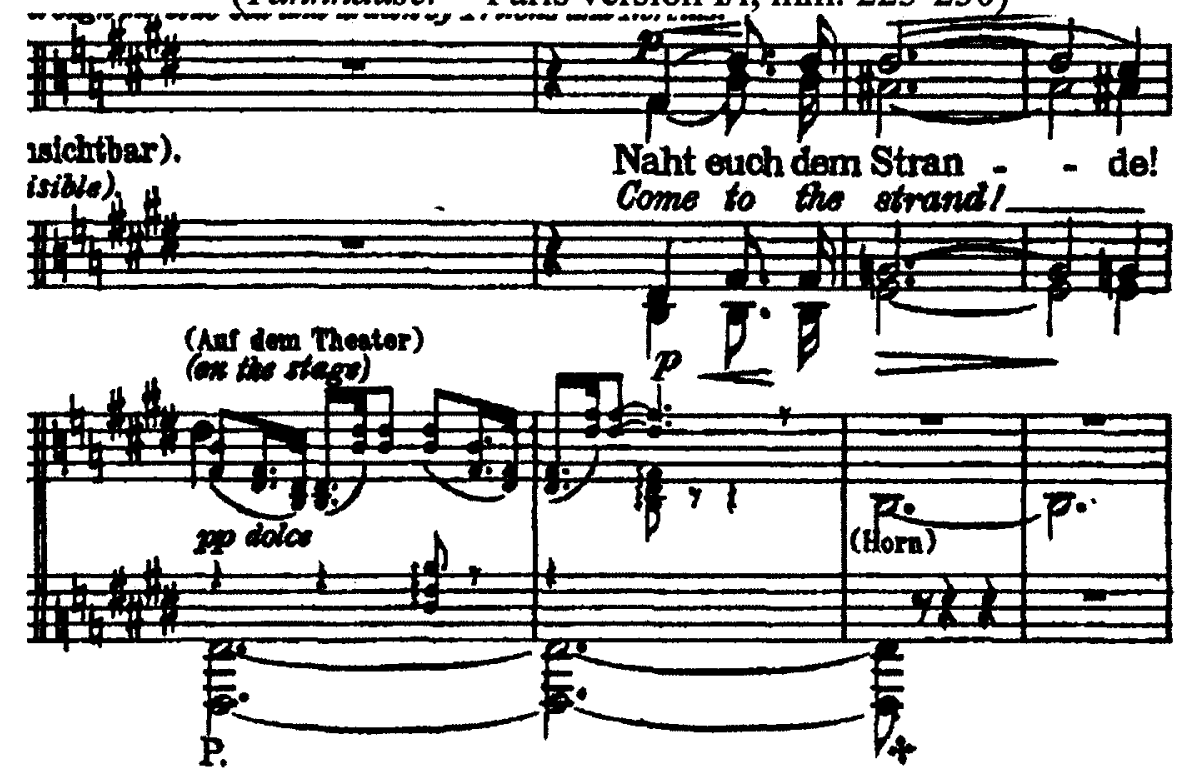




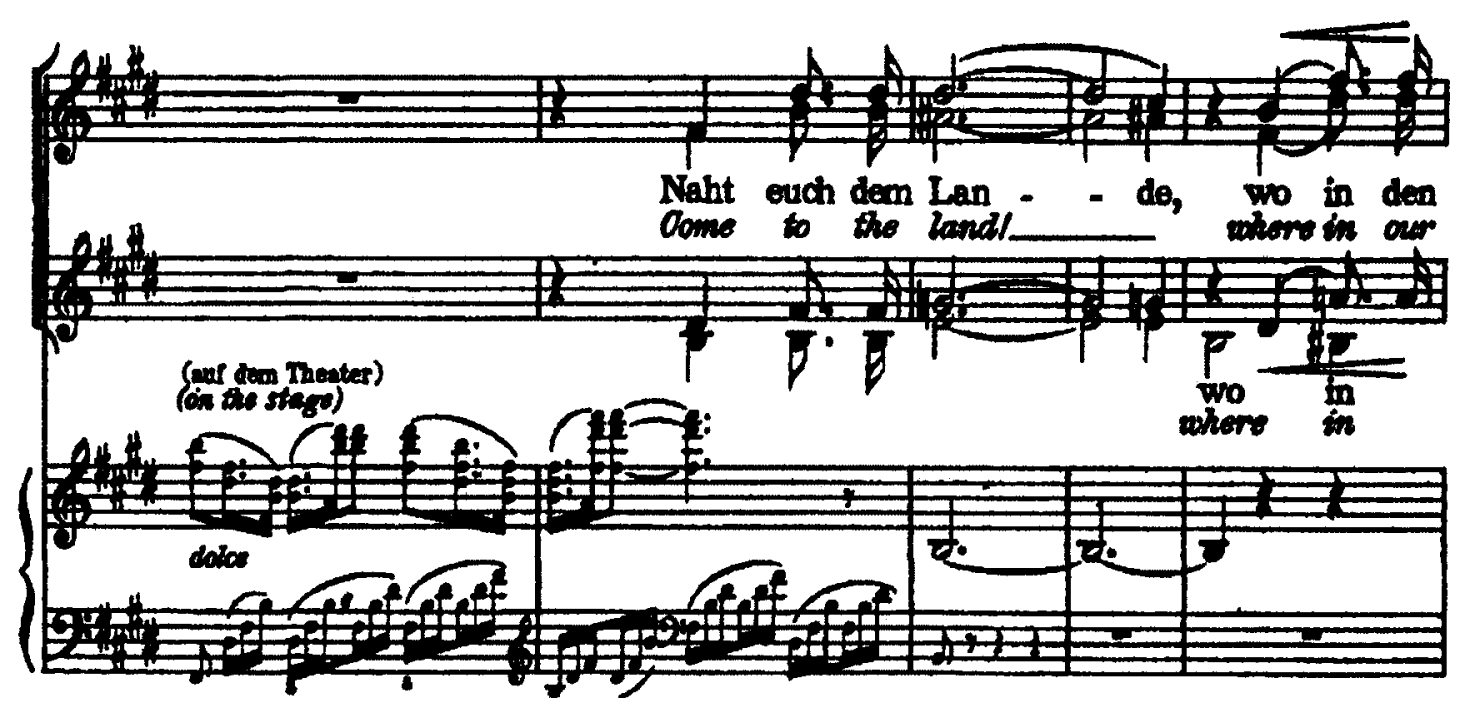

Ex. 3b

(Tannhäuser - Dresden version $\mathrm{V} / \mathrm{i}, \mathrm{mm} .116-129$ )

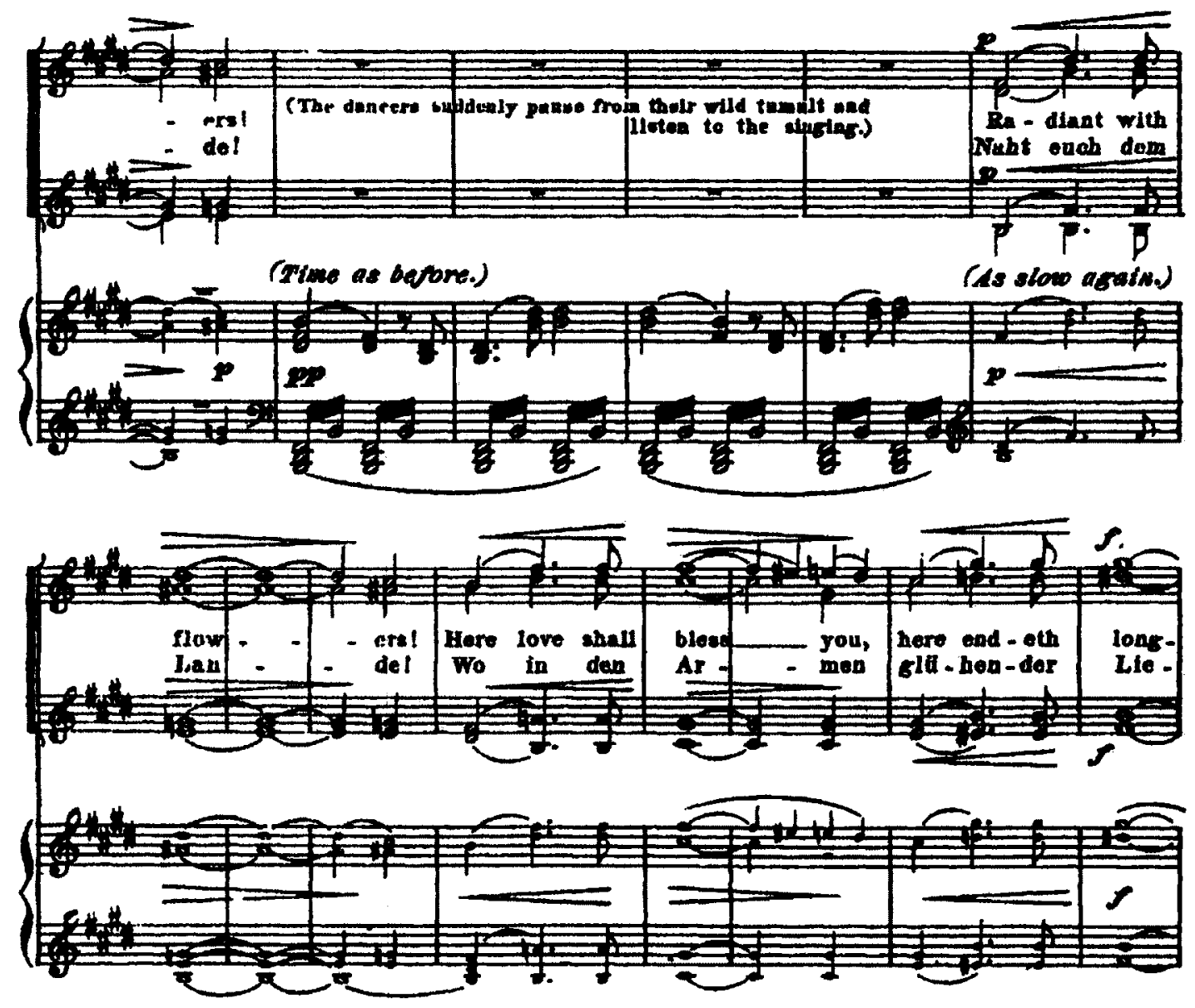


It needs to be acknowledged that there is also a chorus of Sirens in the Dresden version, intoning much the same text as above. In both versions, the Sirens seductiveness is emphasized, their voices never rising above a soothing piano; there is nothing confrontational about their vocalizations. Everything is constructed for maximum beguilement. Leaps of major-sixths and perfect-fifths are accompanied by small crescendos, as if to add the subtlest hint of insistence to their entreaties. Even then, these insistences are softened by smoothing out most of these leaps through slurs, as if to prevent the seductive mood from being negated by "hard" articulations. Chromaticism is increasingly injected into the melody lines and inner voices in order to offer an enticing "taste" of the sensuousness promised by their invitations. To reiterate, these comments apply to the choral writing in both versions. However, the original chorus is not imported wholesale from the Dresden score, as there are subtle alterations made for Paris. The most obvious change is that in the original, the first choral passage interrupts the carousing, prompting the dancers to stop and listen to the singing; the dancing then resumes before a second choral strophe assists in moving the scene from the Bacchanale to the subsequent duet between Tannhäuser and Venus. ${ }^{218}$ In the Paris version, the chorus does not enter until the ballet has concluded. The most apparent musical change is that the Dresden version sets the chorus in $4 / 4$ meter, while the Paris version uses $3 / 4$. Additionally, the Paris version employs a slightly faster harmonic rhythm - quarter and eighth-notes as opposed to half and quarter notes - as if to inject a very subtle increase in urgency into the proceedings. But despite those changes, the overall effect of sonorous

\footnotetext{
${ }^{218}$ The Dover edition (Mineola, NY: Dover, 1984) provides the full "Dresden" score (originally published in 1860 and incorporating Wagner's various revisions made between 1845 and 1852), with the Paris variants (derived from the 1875 "Vienna" score and including its modifications to the "Paris" version) printed in an appendix in order to helpfully facilitate comparison between both the music and texts of both versions.
} 
beguilement remains consistent between both versions. However, I would maintain that the musical effect of this chorus takes on an altered meaning when contextualized within the revised Parisian framework: the Sirens' touting of the Venusberg's myriad pleasures now come in response to a full ballet that marshalls the resources of the Paris Opéra. Thanks to Wagner's changes, the chorus - at least at the 1861 performances - can be considered fully enveloped by a Parisian milieu.

Consistent with Adomo's conception of the phantasmagoria, there is also a sense of dream-like unreality to how Wagner stages the chorus. The most obvious example lies in the fact that these are off-stage voices (Wagner designates them as "invisible" in the score). Moreover, the stage direction specifies a "rosy mist" that gathers and dissolves over the course of the scene. The mist provides an obscuring haze that gives the Venusberg a sense of dream-like indistinctness. Complementing that miasma is the "invisible" chorus; its unseen nature combines with the soft, seductive sonorities in order to grant it a sense of the untouchable, far away, simultaneously present and not-present. The Sirens are perpetually out of reach, giving voice to a dream of ceaseless pleasure, promising to quench a "thirst" that cannot actually be quenched.

The "unreal" nature of the Venusberg is subsequently underlined during the confrontation between Tannhäuser and Venus. On the heels of the reworked Bacchanale, Tannhäuser cries out "zu viel!" ("too much!") This outburst is carried over from the original version, but like the preceding chorus, it becomes recontextualized by the changes made to what precedes it. In the Paris version, Tannhäuser is now reacting to a display of sonic and dramaturgical licentiousness that is of a significantly greater scale than what he observed in the original. Coming on the heels of the revised Bacchanale, 
one might conclude that Tannhäuser's outburst gains greater dramatic power than in the original, in that he is now more convincingly responding to "too much."

Regarding the substance of Tannhäuser's censure, Adorno notes that Tannhäuser comes to regard the Venusberg's decadent excess as a facilitation of unfreedom. He has accepted that its myriad pleasures are ultimately illusory because, as Baudelaire concluded, the pursuit of pleasure is a perpetual thirst that can never be satisfactorily quenched. The Venusberg's seductive allure must be "unmasked" for the deceptive illusion that it is in order to escape that realm's imprisonment, no matter how enticing its cage might be. Indeed, Adorno further notes that Tannhäuser's desire to be free of the Venusberg's falsehood is an expression of a theme that recurs throughout the composer's work:

The socially determined experience of pleasure as unfreedom transforms libido into sickness, and so we see how, with the cry of "Too much!", Tannhäuser becomes conscious of his own enjoyment as a weakness while he is still in the kingdom of Venus. The experience of pleasure as sickness permeates Wagner's entire oeuvre. Those who refuse to resign themselves - Tannhäuser, Tristan, Amfortas - are all "sick". 219

The salient issue for the purposes of this discussion is that Tannhäuser's expression of "too much" positions the Venusberg's surfeit of pleasure as a virulent (but seductive) malady. Placed within the specific context of grand opera's dramaturgy and within the confines of the Operra, one might read Wagner's "excessive pleasure as sickness" equation as a rebuke to Paris' own culture: grand opera is exploited as the instrument of its own critique, with its musical and scenic opulence being shown to be an intoxicating obfuscation, a parade of sensual pleasures that turns unreality into reality. In transplanting Tannhäuser's cry of "too much!" and his subsequent abjuring of the

${ }^{219}$ Ibid., 82 
"sickness" of the Venusberg's decadence from the Dresden original into this new Parisian context, perhaps Wagner is using these Dresden holdovers to provide a "German" counterbalance to the "French" aspects of his new Venusberg scene. ${ }^{220}$ Taking both the new music and choreography together with the repurporsed Dresden material that now reacts to it, one might posit that the reworked Bacchanale essentially stages a barelyconcealed censure to the "decadent" tastes of the French audience. In constructing this new Venusberg (with all of its various new and repurposed parts), Wagner exploits grand opera's resources possibly as a move towards demonstrating Parisian culture's fundamental "illness" in its demand for a never-ending proliferation of sensual intoxicants in their operatic entertainments. By "gorging" themselves on the phantasmagoria of grand opera, Paris as a culture is making itself "sick." Therefore, the revised Venusberg employs grand opera in order to stage a "monument" to Paris' own debasement.

If we consider it plausible that Wagner employed grand opera in such a way as to negate the integrity of the form, as well as that of the culture/nation that countenanced it, then it might account for reactions such as Paul Scudo's:

It's hard to imagine in what sort of music Wagner has wrapped this voluptuous scene, one of the most familiar, often repeated clichés in the poetics of opera. Neither the dancing of the nymphs nor the interminable dialogue of the two lovers - who quarrel without understanding each other or letting their voices join in any sort of reasonable ensemble - has inspired the composer with a single rhythmic, harmonic, or other sort of musical idea able to distinguish itself over the vast ramblings that leave the listener's wandering ear quite adrift. I do not exaggerate here, when I say that this whole first scene of Tannhäuser, written here in Paris in

\footnotetext{
${ }^{220}$ Of course, this notion could also be applied to the Venusberg of the original version, given that it also demonstrates a clear lineage to grand opera and the ballet in particular. The fundamental difference is that in the 1861 version, Tannhauser's "too much!" is reacting not just to dramaturgy inspired by grand opera, but to music specifically written for a Parisian institution to be performed before Parisian spectators.
} 
the composer's most recent manner, can really not be compared to any sort of music now extant. This is a chaos, a void - but a scientific chaos and void. ${ }^{221}$

Scudo's harangue makes no mention of being directly motivated by a reaction to Wagner using aspects of Parisian musical culture to criticize that culture. However, his reprimand of the scene's supposed incoherence - to the degree that it cannot even be recognized as proper music - functions in part as an attack on Wagner's twisting of grand opera into something unrecognizable, which is seen as a flagrant affront to their culture.

Much more successful with Parisian critics was the processional of Act II, Scene 4 which brings the various guests into the Wartburg for the song contest. As Fauser writes,

Even [Wagner's] harshest critics heaped lavish praise (albeit sometimes grudgingly) on those segments of Tannhäuser that conformed to the conventions of French grand opéra...The march in act 2 was compared to similar compositions by Auber, Meyerbeer, and Halévy, to whom Wagner was sometimes judged a close second and at other times an equal. ${ }^{222}$

Scudo's review is representative of Fauser's point:

The Thuringian lords and ladies proceed into the great hall of the Wartburg and it is during this entry that the march with chorus is performed, the most notable piece in the score of Tannhäuser. This march is beautiful, if not very original. It is broadly designed and succeeds in producing the effect intended by the poetcomposer. ${ }^{223}$

For Parisian critics, the success of the second-act processional and ceremonial scene was seen as validation of French musical forms and in turn a refutation of Wagner's own claims for the ostensibly disreputable nature of grand opera. As Fauser writes, "by thus homing in on the traditional aspect of the score - whether in terms of form or musical texture - these critics responded to Wagner's own declarations in the Lettre sur la

\footnotetext{
${ }^{221}$ Paul Scudo, "Tannhäuser by M. Richard Wagner" (1861), Richard Wagner and His World, trans. and ed. Thomas S. Grey (Princeton, NJ: Princeton University Press, 2009), 359-360.

${ }^{222}$ Fauser, 249.

${ }^{223}$ Scudo, 361.
} 
musique, where he claimed that he no longer made concessions to the frivolous tastes of the audience." ${ }^{224}$ In fashioning a scene that in fact did end up appealing to French tastes, and which was deemed one of the most effective in the entire opera, Wagner tacitly rebuked his own theories of reform in the estimation of the anti-Wagnerians, basically admitting that French music was not so "frivolous" after all. ${ }^{225}$ However, the Scene 4 that the Parisians saw was in fact unchanged from the Dresden version. The changes to Act II are confined to the song-contest itself, and those are quite minor, especially when compared to the alterations to the first act. ${ }^{226}$ So, even though the entrance into the Wartburg bore a notable resemblance to scenes from such venerated composers as Auber, Meyerbeer, and Halévy, the Parisian critics were in fact praising a set-piece that had in fact been originally composed for the German stage.

In acclaiming Wagner's adoption of grand opera's traditional procedures, perhaps the Parisian critics missed something, and in doing so provided Wagner with a victory by stealth. It is true that the entrance into the Wartburg has all the makings of a grand opera ceremonial scene: a lengthy orchestral march accompanies the procession of knights, nobles, pages, and women into the hall. The arrangement of the chorus is such that it resembles a "population" of multitudes in its division into distinctive groups, in this case a male chorus of knights and nobles and a female chorus of noble ladies. The differing "levels" of "society" are brought together for a common purpose, to celebrate the creation and presentation of art within a hallowed space. The pageantry and opulence of the scene

\footnotetext{
${ }^{224}$ Fauser, 249-250.

${ }^{225}$ Scudo, 361-362.

${ }^{226}$ For the Paris production, Wagner eliminated Walther von der Vogelweide's solo number, which resulted in Tannhăuser's previously two separate interruptions of Wolfram's and Walther's respective songs being combined into one, with a new orchestral transition being composed to lead into his now composited interjection. The final measures of the act's finale were also recomposed. Abbate summarizes the changes made to the Song Contest for the Paris version in "The 'Parisian' Tannhäuser," 367-392.
} 
combined with the number of voices on stage create a tableau of a city that has assembled within the halls of a "monument" that stands as a symbol of their common heritage as residents of Thuringia (a "city hall" if you will). As such, the scene is imbued with a sense of size that "radiates" its "greatness" to its spectators. This grand opera crowd scene thus is another instance of a musical monument.

It is that to which the scene is a monument that is telling. As the crowd enters the hall, the two choruses intone the following words:

Freudig begrüßen wir die edle Halle, wo Kunst und Frieden immer nur verweil, wo lange noch der frohe Ruf erschalle:

"Thüringens Fürsten, Landgraf Hermann, Heil!" (II, iv)
[Joyfully we greet the noble hall, where may art and peace alone linger ever, and the joyous cry long ring out: "To the Landgrave of Thuringia, Count Hermann, hail!']

Following the Landgrave's welcome, the masses proclaim:

Heil! Heil! Thüringens Fürsten Heil!

Der holden Kunst Beschützer Heil! Heil! Heil!

$$
\text { (II, iv) }
$$

[Hail! Hail! Hail to Thuringia's Prince! Hail to the protector of the gracious art! Hail! Hail!]

Ex. 4

(Tannhäuser - Paris version II/iv, mm. 92-97)

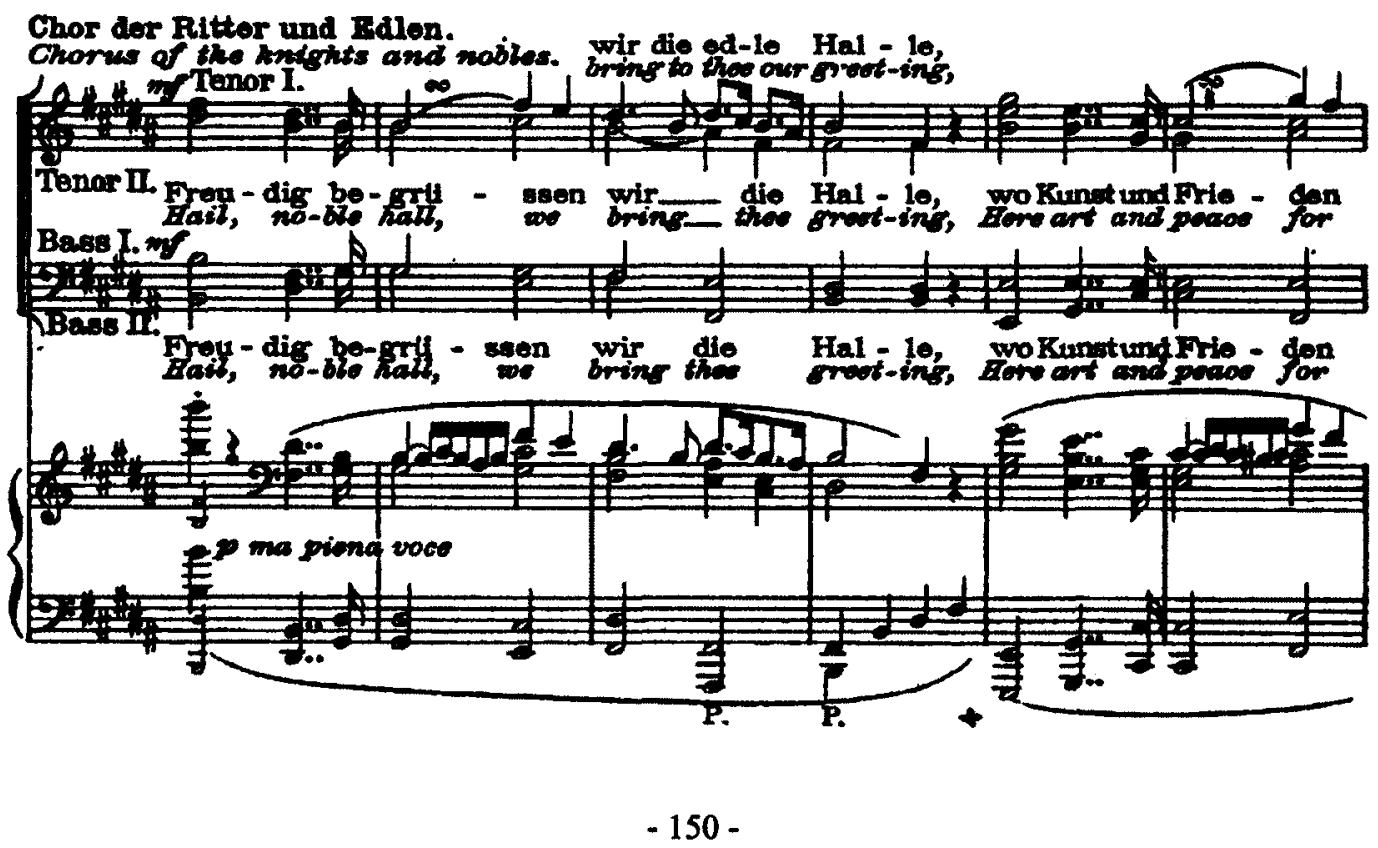


The chorus pays tribute to the "nobility" of the hall and expresses joy at the presence of the Landgrave and concomitant fealty to Thuringia's importance as a protector of their "gracious art." The music conveys joyfulness through its emphasis on bright B-major sonorities and sprightly turn figures on such words as "begrüßen" and "Frieden" while the prominent dotted march rhythms and frequently chorale-like counterpoint convey the formal, ceremonial nature of the proceedings. When performed by the immense complement of the Opera chorus the processional takes on the appropriate level of magnitude to imbue the scene with the requisite monumentality. Wagner applies the enlarged forces of the Opéra to his pre-existing music, marshalling those resources in order to astonish Parisian audiences, filling them with wonderment at the magnificence on display.

This scene of "astonishing" theatrical grandiosity centralizes the Wartburg and its surrounding Thuringia. In Tannhäuser, the musical monumentality of grand opera serves a commemorative function: Tannhäuser's choral crowd scene of Act II stages the scene as a musical monument that celebrates the significance of the Wartburg and Thuringia as testaments to German history. This is similar to the choral crowd scenes in Lohengrin which assisted in constructing a monument to German history and culture while being performed in the midst of another momument in the form of Weimar. Like the chorus of sirens and Tannhäuser's "too much!" in the first act, the music for the Wartburg, originally composed for Dresden, opens up a potential new window of meaning when recontextualized within the Parisian performances. Grand opera's "aesthetic of astonishment" (to re-invoke Tom Gunning) is exploited by Wagner for Paris in order to inject into his already-existing music a sense of size and majesty worthy of the 
Wartburg's cultural legacy. In combining the "old" music, which was already steeped in grand opera's compositional aesthetic, with the "new" lavish staging in Paris, the scene musically and scenically conveys the historical greatness of what the "citizens" refer to as a hallowed sanctuary for German art. One form of monument is used to erect another monument. Similarly, by taking place inside the Wartburg and having adopted grand opera's opulent spectacle, the song contest is staged before the French spectatorship as an epochal moment in Germany's cultural history.

This is what I refer to when I propose the Parisian Tannhäuser as a stealth "success" for Wagner: for these performances, Wagner appropriated the resources of a beloved French institution in order to construct a musical monument that commemorated the historical greatness of German art and culture and then "radiated" that greatness to French audiences. The fact that even his detractors praised the Wartburg scene might be interpreted as that which made Wagner's actions all the more subversive: in praising the scene for its conformation to the traditional strictures of grand opera, which in their estimation proved the artistic "truthfulness" of French forms and the speciousness of Wagner's competing aesthetic paradigm, Wagner's critics perhaps overlooked (willfully or not) exactly what it was they were praising. Of course, the medieval German setting would likely not have provoked any undue alarm on the part of Parisian audiences or critics, as foreign and/or "exotic" locales (seventeenth-century Naples for La muette de Portici, medieval Palermo for Robert le diable, sixteenth-century Germany for Le prophète to list but three examples) were hardly uncommon in grand opera, nor would French audiences have necessarily seen a conflict between their pride in their own heritage and their praise of a musical depiction of a German "monument." However, 
when considered in context with the extremely contentious and partisan critical discourse between Wagner and the French press that constructed a veritable "culture war," Tannhäuser's staging of a musical monument to German heritage on a French stage potentially carries an intriguing political subtext. ${ }^{227}$ That anti-Wagnerian voices seemingly looked past this subtext - or genuinely did not notice it - in order to direct their ire towards Wagner's aesthetic theories as the true "threat" to the sanctity of the French theatre suggests that Wagner achieved a minor victory in the midst of one of his most notable public failures: inducing French audiences to indirectly laud German heritage by ostensibly "capitulating" (well before the fact, of course) to Parisian musical and dramatic expectations.

The move to theorize the Parisian Tannhäuser as something of a "successful failure" is lent some credibility when one observes Wagner's perspective on the work's disastrous performances and his eventual decision to have the opera withdrawn. ${ }^{228}$ In recounting its failure in his report, published less than a month after the three performances concluded, one detects a certain degree of smug satisfaction at the opera's vociferous rejection by the Parisian establishment, personified most prominently by the disruptive hoots and whistles of the Jockey Club. In fact, he characterizes the whole affair as a "great victory," as the Jockey Club's efforts to capsize the performances did not deter the musicians from putting on superlative displays. Wagner seems to suggest

\footnotetext{
${ }^{227}$ As William Gibbons observes, the critical reception of a production of Gluck's Alceste (1767) at the Opéra, which debuted in October of 1861, demonstrated that Wagner continued to function as a lightning rod of discussion amongst the Parisian musical press, even months after the Tannhäuser fiasco had concluded. Gibbons notes that a significant portion of the praise for Alceste production served to situate Wagner as antithetical to French artistic values. The opposition of Wagner with Gluck highlighted how the German Gluck had since been effectively adopted as a valued contributor to the legacy of French opera. See "Music of the Future, Music of the Past: Tannhäuser and Alceste at the Paris Opera," $19^{\text {th }}$-Century Music 33/3 (Spring 2010): 232-246.

${ }^{228}$ SSD VII, 143-149; PW III, 354-360.
} 
that the efforts of his opponents to disrupt the proceedings amounted to an act of clear desperation, as if all in the theatre were aware that a profound event was taking place before them and that the Jockey Club's efforts were motivated by the perceived "danger" that Wagner's music and ideas might gain a foothold in Parisian culture. Indeed, Wagner notes that the audiences themselves greeted the initial performance with a substantial ovation in seeming defiance of the self-appointed arbiters of French taste. Wagner notes that several more scheduled performances had been sold out when he decided to withdraw the work. To hear Wagner tell it, withdrawing the score and halting future performances functioned as conclusive proof of the philistine nature of the Parisian establishment, i.e. the Jockey Club, the poverty of its taste, and its resolute intolerance towards the prospect of new artistic horizons. Wagner's report insinuates that having conclusively proved his point about the artistically arrested nature of the Opéra and its assorted claques, he could triumphantly take his work back, secure in the knowledge that the Parisian public's interest demonstrated how much of a threat his ideas truly were to the hidebound forces of Paris' artistic status quo. Wagner's narrative has all the makings of an endeavour to put a face-saving spin on an event that most conventional interpretations would deem a catastrophic public humiliation. Nonetheless, even when taking into account the after-the-fact nature of the essay, Wagner's self-serving reportage does serve to construct a narrative similar to what I have posited regarding the Wartburg crowd scene, namely that Wagner saw the Parisian Tannhöuser as partially a deliberate provocation that appropriated some of the most emblematic traits of French grand opera for subversive ends. 
Given the above parameters, it is possible to characterize the Weimar Lohengrin and the Paris Tannhäuser as successes for similar reasons. Although neither would ever be mistaken for an unqualified triumph in terms of quality of performance and/or critical reception, both can be considered successful in their endeavours to construct narratives of German art and culture that foregrounded its purported historical greatness. Both performances made use of the grand opera chorus in order to create the necessary degree of musical monumentality that would grant them significance to German culture. The chorus of the Weimar Lohengrin situated its musical monuments as a sonorous and scenic parallel to the historical and cultural monuments that made up the city of Weimar, the result being that the Lohengrin premiere was constructed to function as a constellation of the various narratives of Weimar and as a consequence a commemoration of the legacy of German art, its prestigious past and its potentially brilliant future. Meanwhile, the chorus of the Paris Tannhäuser used its monumentality in order to simultaneously celebrate the legacy of German culture and critique the ostensible failings of Parisian culture, specifically its hollow and "sick" nature. The Weimar Lohengrin's ultimate success is that its construction as a musical monument contributed towards Liszt's ongoing project of creating a new golden age for the city. For the Paris Tannhäuser, its failure was arguably the root of its success, as the outrage it and Wagner's aesthetics in general provoked among a vocal contingent of the Parisian musical establishment demonstrated that Wagner's infiltration into French musical life was drawing figurative blood, that Wagner's ideas had cultural potency and could potentially establish a presence in France, a proposition that would eventually be borne out during as the fin-de-siècle approached. Ultimately, it was grand opera as an 
expression of the magnitude of the contemporary city that played a vital role in allowing the Weimar Lohengrin and the Paris Tannhäuser to assume their places as monuments in the history of nineteenth century German opera. 


\section{Chapter Two}

\section{Communal Sonorities: The Grand Opera Chorus, Kunstreligion, and Prolepsis in Die Meistersinger and Parsifal}

\section{Wagner's religious choruses}

The years immediately following the composition of Tannhäuser and Lohengrin saw a significant shift in Wagner's thoughts on the place of the chorus in his vision of an ideal operatic presentation. In particular, Opera and Drama is notable in that it demonstrates a rather conspicuous reversal from an aesthetic that produced the plentiful choral writing found in those previous "Romantic" operas; Wagner proselytizes for the irrelevance of the chorus in his proposed "drama of the future" because the chorus represents not the idealized collective voice of the Volk, but a "mass" and "a mass can never interest, but only dumbfound us...." For Wagner, "the massive Chorus of our modern opera is nothing else but the stage machinery set into motion and song," a "dumb pageant" that amounted to little more than "nimble noise." The chorus was ultimately deleterious to drama in that their multiplicity of voices inhibited the transmission of the story's and characters' complexities and mythological underpinnings. Moreover, the operatic chorus was a relic of the dramaturgy of the very forms that Wagner sought to surmount, most prominently the French grand operas of Meyerbeer. The chorus could no longer function as a vox populi, because its sight and its sound had been subsumed under the banner of spectacle; it had long since become an attraction, effectively dissipating its potential for political and/or mythical resonance. The chorus ceased to fulfill the

\footnotetext{
${ }^{1}$ SSD IV, 162; PW II, 304. Wagner makes similar sanctions against ensemble singing in these passages.

${ }^{2}$ SSD III, 270; PW II, 63.
} 
"meditative and reflective" ${ }^{3}$ as well as commentating role that bequeathed it lineage back to the ancient Greek chorus (recalling that Wagner's aims were to rejuvenate what he saw as the abandoned virtues of the Greek theatre). In the "drama of the future" the orchestra was intended to supplant the chorus on multiple levels: in what Thomas Grey calls the "symphonic interlude," the orchestra would function as "processional" music, effectively providing the "voice" of the population on stage. This was accomplished through what Carl Dahlhaus called the symphonic "web" of leitmotivs, each of which accrued musical, narrative, and psychological histories which not only formed the basis of a connective tissue that provided musical continuity over the course of the course of a single act, but also provided the reflection and commentary on the drama that the chorus ostensibly no longer could. ${ }^{6}$

However, Wagner did not always practice what his theory preached. Although the use of the chorus in much of his output post-1849 was heavily circumscribed or absent altogether (Das Rheingold, Die Walküre, the first two acts of Siegfried, and Tristan und Isolde), the works at the greatest temporal remove from the writing of Opera and Drama saw the reincorporation of extensive choral composition. In fact, the choruses in Die Meistersinger von Nürnberg and Parsifal are arguably of a scale and complexity - musically and dramaturgically - that surpasses those earlier works. In these two works, Wagner once again mobilized one of the defining traits of grand opera,

\footnotetext{
${ }^{3}$ Thomas S. Grey, Wagner's Musical Prose: Texts and Contexts (Cambridge: Cambridge University Press, 1995), 81.

${ }^{4}$ Grey, 81-92. Grey's examples are the funeral processions for Siegfried and Titurel in the third acts of Götterdämmerung and Parsifal respectively.

${ }^{3}$ Carl Dahlhaus, Nineteenth-Century Music, trans. J. Bradford Robinson (Berkeley: University of California Press, 1989), 196-201.

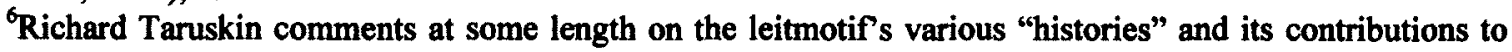
musical continuity in The Oxford History of Western Music Volume 3 - The Nineteenth Century (Oxford: Oxford University Press, 2005), 502-520.
} 
namely the ubiquity of large-scale choruses deployed to envoice the political consciousness of an entire community. ${ }^{7}$ The re-emergence of the grand opera chorus can potentially be traced to Wagner's Schopenhauer-influenced aesthetic shift that granted music primacy amongst the arts, ${ }^{8}$ which would seem to have resulted in Wagner embracing many of the tropes that he previously inveighed against. But it is the mobilization of the grand opera chorus in these two particular works that are of interest to me in this chapter. There is significance in the fact that grand opera dramaturgy is prominent in dramatic works that were created within the context of specific burgeoning ideas on the relationships between art and German nationhood during the latter stages of Wagner's career, ideas that shall be expounded upon shortly.

The resurrection of the chorus as a significant component of Wagner's dramatic intentions in Die Meistersinger and Parsifal opens up intriguing windows of insight into the treatment of the chorus, a treatment that displays both notable concurrences and divergences from the approach - both in terms of Wagner's compositional and dramaturgical methods and my own intellectual framework in Chapter One - towards massed voices displayed in Tannhäuser and Lohengrin. These concurrences and divergences form the basis for the arguments to follow. In terms of similarities, both the choruses discussed in the previous chapter and those in this one use the chorus to give voice to populations, to communities. The Lohengrin chorus is to the people of Brabant as the Meistersinger chorus is to the people of Nuremberg, just as the Tannhäuser chorus is to the spectators assembled in Thuringia as the Parsifal chorus is to the residents of the

\footnotetext{
'James Parakilas, "Political Representation and the Chorus in Nineteenth-Century Opera," 19th-Century Music, 16/2 (Fall 1992): 181-202 and "The Chorus" in The Cambridge Companion to Grand Opera, ed. David Charlton (Cambridge: Cambridge University Press, 2002), 76-92.

${ }^{8}$ This shift may be traced through several of Wagner's later prose writings, most notably "Beethoven," SSD IX, 61-126; PW V, 57-126 and “The Destiny of Opera," SSD IX, 127-156; PW V, 127-155.
} 
temple of Montsalvat. In all cases, these choruses are used to depict multitudes assembled for communal purposes, be those purposes civic, artistic, political, or religious. Whereas the previous chapter emphasized the "urban" aspects of the chorus and the relationships between the city and the nation, this chapter in contrast thematizes the chorus as illustrative of communities that are less sprawling and closer-knit than that of the proverbial "big city." The communities of Meistersinger and Parsifal, like those of Tannhäuser and Lohengrin, instill a distinctly religious flavour into the words they intone. As with Chapter One, the forthcoming arguments engage with that invocation of the sacred not to position these works' dramatic and thematic content as an expression of religious doctrine, but to examine the potency of the sacred as a metaphor for the power that art wields in defining culture. The forthcoming discussions of the choruses of Meistersinger and Parsifal distinguish themselves from those of Chapter One in that they will underline the importance of the communities formed out of the grand opera chorus in formulating art as a religion, and how this "art as religion" motif functions as a potent trope of nineteenth-century German nationhood. These general statements serve as a prelude to a cataloguing of the specific ideas regarding the chorus, community, and religion and art that inform this chapter's lines of inquiry and its ultimate statement of purpose.

In the Meistersinger score, the chorus in the climactic scene on the Festival Meadow - representing the Nuremberg populace - is identified as das Volk (the people), a prominent shift from its designation as die Gemeinde (the community) for the first act congregation. As shall be demonstrated, das Volk identified the aggregated voices as much more significant than an undifferentiated mass, of more political import than a 
mere operatic "crowd scene." Das Volk identified not just a gathering of individuals, but "a collective with a consciousness of itself and a will to action." This was similar to traditional grand opera in that the choral crowd frequently stood in for an entire body politic, "a whole people or nation, not a single class or party or profession; a people with a political destiny of its own, not just a stake in the destiny of its ruler...." ${ }^{10}$ However, I contend that Wagner took this principle a step further: the characterization of the chorus as das Volk puts it forth as something more than simple representation. By referring to the ensemble as "the people," Wagner characterizes the chorus as a somatic and sonorous image of the "spirit" of the nation: the chorus is Germany. The dramaturgy of the grand opera chorus is re-worked so that rather than voice allegorical commentary on political and social upheaval, it places the essence of German nationhood on stage in the form of a mass body, a contention that the following pages will endeavour to prove.

In Meistersinger, this is accomplished by staging sixteenth-century Nuremberg as what Arthur Groos calls a "proleptic community," which employs the device of prolepsis wherein characters, places, etc. from a later period are transplanted into an earlier one, creating the impression that the present and/or the future have already taken place in the past. As Groos explains, the sixteenth-century setting "[contains] the contemporary nineteenth-century [that] it is designed to anticipate." 11 Groos notes that the third-act contest is designed to resemble a modern (circa 1867) festival rather than a gathering more typical of the type in which Hans Sachs, et al would have actually participated. Within this proleptic mise-en-scene, the assembled throng lavish praise upon Walther's

\footnotetext{
"Arthur Groos, "Constructing Nuremberg: Typological and Proleptic Communities in Die Meistersinger," in 19th-Century Music 16/1 (Summer 1992): 27.

${ }^{10}$ Parakilas, "Political Representation," 189.

${ }^{11}$ Groos, 26.
} 
Prize Song, crowning it as the model for future works of German art to follow before taking up Sachs's exhortation to honour and protect German art of the past and future. The chorus as das Volk is effectively an embodiment of the proleptic community in that they place Germany's forthcoming artistic and cultural rebirth within its mythologized past. Furthermore, recalling the introduction which established Homi Bhabha's contention that the nation is not ontological but performative, the chorus functions as one of the very instruments that brings the nation into being: announcing the redemption of the nation effectively performs and produces a redeemed nation.

Although the chorus in Parsifal is not identified as das Volk, I will argue that the Grail Knights function comparably (but not exactly) to the Volk of Meistersinger. The brotherhood is the nation in miniature, and at the work's conclusion they bear witness to a miracle - the redemption of their order as Amfortas' wound is healed and the ascendency of their new King - and announce that miracle through the combined sonority of the chorus. As with the earlier work, Parsifal invokes a mythologized past here, Montsalvat in medieval Spain - which is then populated by a proleptic community, although in this case the community is at a further allegorical (and geographical) remove from a real (albeit romanticized) period in German history. Nonetheless, my position in this chapter is that the choral forces in the Grail scenes of the first and third acts may be interpreted along somewhat similar lines to Wagner's conception of das Volk; as with the spectators in Meistersinger, the inhabitants of the Grail Temple are stand-ins for the contemporary German people placed within the mythologized past. Where the earlier piece used a proleptic collective to announce the triumph of German art, Parsifal employs such a community in order to perform and produce a redeemed and rejuvenated 
Volk, the voice of a newly exultant national consciousness inscribed upon the mass body of the grand opera chorus.

But the somatic image of das Volk is not the only register upon which the chorus produces an ascendant German nation. Meistersinger's final chorus has the Nuremberg populace intoning an encomium to "holy German art," while Parsifal centralizes specifically Christian-based legends. In both operas, religion is vital to their artistic and cultural significance although "religion" should not be limited to purely liturgical concerns. Meistersinger's invocation of "holy German art" in the context of an elaborate choral finale is crucial to an interpretation that aligns religion with the staging of nationhood upon the choral body. The elevation of art to the level of the divine resonates within the nineteenth-century idea of Kunstreligion, the notion that art took on such cultural import that it became akin to religion in and of itself. ${ }^{12}$ Wagner himself never specifically uses this term in his 1880 essay "Religion and Art," but nonetheless would seem to inform his proclamation that when "religion becomes artificial it is reserved for art to save the spirit of religion...revealing [its] deep and hidden truth through an ideal presentation." ${ }^{13}$ Furthermore, the transformation of art into religion supposedly reveals the deepest truths about the national "spirit." For Wagner, music is the ideal vehicle to rescue religion and the nation from corruption and decay. While Meistersinger brings music's religiosity into the discussion, Kunstreligion has frequently been "advanced as

\footnotetext{
${ }^{12}$ Adolf Nowak, "Wagners Parsifal und die Idee der Kunstreligion," Richard Wagner: Werk und Wirkung, ed. Carl Dahlhaus (Regensburg: G. Bosse, 1971), 161-175; Glenn Stanley, "Parsifal: Redemption and Kunstreligion," The Cambridge Companion to Wagner, ed. Thomas S. Grey (Cambridge: Cambridge University Press, 2008), 151-175; Wolf-Daniel Hartwich, "Deutsche Mythologie": Die Erfindung einer nationalen Kunstreligion (Berlin: Philo Verlagsgesellschaft, 2000); Nicholas Vazsonyi, "Eine Pilgerfahrt zu Wagner: Kunstreligion und ihre Vermarktung," Wagnerspectrum 5/2 (2009): 199-218.

${ }^{13}$ SSD X, 211; PW VI, 213
} 
the aesthetic foundation of Parsifal....14 The Christian-themed narrative is one reason for this, but also key is Wagner's famous characterization of the work on the title page of the score as a Bühnenweihfestspiel (festival play for the consecration of the stage). The "consecration" of the stage in effect positions the Bayreuth Festspielhaus (recalling Wagner's intention that the work be exclusive to this venue) as a sanctified shrine, a monument to the supremacy of German art. ${ }^{15}$ In the final Grail scene, the amassed choral forces proclaim their community reborn, a rebirth metonymous with the renewal of Germany and its people. The Festspielhaus is the nation in microcosm; its stage is beatified by what has just transpired. Kunstreligion and the proleptic community merge through the vehicle of the grand opera chorus to create a mass body that as sonority, produce "holy" German art. The aesthetics of grand opera are mobilized not solely to astound the senses, to reinvoke Wagner's critique of grand opera, but to sanctify all that transpires between the proscenium arches, to transmute the stage into holy ground.

As should be clear, this framework considers the issue of the mass body of the chorus from a different angle than the previous chapter: there I foregrounded the body of the grand opera chorus in Tannhäuser and Lohengrin as a point of contact between discourses of German nationhood and urbanized conditions. Here, I consider the mass body more as sonority, with sonority functioning as a strategy for transforming art into an object of religious worship. My contention in this chapter is that if Meistersinger's Volk represents a nascent stage of the proleptic community as Kunstreligion, the Bühnenweihfestpiel of Parsifal is where it finds full flower. In repurposing hermeneutic concepts conceived for one work and applying those to the other - Kunstreligion,

\footnotetext{
${ }^{14}$ Stanley, 154.

${ }^{15}$ Frederic Spotts, Bayreuth: A History of the Wagner Festival (New Haven: Yale University Press, 1994), 79.
} 
typically theorized in the context of Parsifal, being applied to Meistersinger; the proleptic communities of Meistersinger reworked for Parsifal - I aim to simultaneously provide new perspectives on each of these two works while building upon established frameworks. In doing so, this chapter endeavours to demonstrate that both of these works are related both in their uses of the grand opera chorus and how this massed body foregrounds the "religious" qualities of German art.

\section{Nuremberg's proleptic Volk}

Wagner's pre-occupation with the Volk as an expression of the national spirit crystallizes in the Zurich essays, particularly The Artwork of the Future (1849). In that essay, Wagner contends that the vitality of this proposed work of art emanates from the spirit of the Volk. For Wagner, das Volk is nothing less than "the epitome of all those men who feel a common and collective Want."16 In Wagner's view, that Want is borne out of "Need," but only "a common and collective need is the...true Need."17 Unpacking the potential subtext of these statements, one surmises that the Need is on one level a desire for commonality and collectivity. Das Volk is united by a collective yearning for a common sense of belonging. Referring back to remarks made in the introduction ( $\mathrm{pp} .20$ 22), we can put forth the Volk as a subset of the trope of the nation as a discursive category, a mirroring function for the subject that expresses the desire for an identity bound up with a sense of unity and continuity with other subjects, unity that may be found through a spiritual link to the essence of a "homeland." Wagner's invocation of

\footnotetext{
${ }^{16}$ SSD III, 48; PW I, 75.

${ }^{17}$ Ibid. As William Ashton Ellis remarks in his introductory note at the outset of his translation of the essay (69), Wagner's references to such terms as "Need" and "Want" pre-date his exposure to Schopenhauer's The World as Will and Representation by several years. Nonetheless, Ellis points out that Wagner's terminology overlaps in terms of overall meaning with Schopenhauer's: "Need" in Wagner has more than a little similarity to the concept of the "Will," the ceaseless force of irrepressible longing that drives all of human activity.
} 
Need and Want and their localization around the concept of the Volk suggests his own desire as a subject for the German nation to be stabilized by the common need of the German people for a collective heritage. When reading the interpretations that will follow about the chorus as an embodiment of the Volk, one should always keep in mind that those readings are refracted through the prism of Wagner's own desire: in a sense, the chorus is the externalized performance of Wagner's hopes and needs for a clearly defined German nation. The posited "spirit" of the Volk is imbued with a plenitude that represents the wholeness of the nation which in turn stands in for Wagner's search for that which will make his subjectivity cohere. Such an interpretation would appear to be made manifest when Wagner channels the collective Need and Want of the Volk into art:

[In] fellowship shall we taste their genuine joys, and grow up in communion to veritable men. In common, too shall we close the last link in the bond of holy Necessity; and the brother-kiss that seals this bond, will be the mutual Art-Work of the Future...Necessity's vicegerent in the flesh,- the Folk, will no longer be a severed and peculiar class; for in this Art-work we shall be one.... ${ }^{18}$

Indeed, Wagner's sub-heading for a section of the essay outright identifies "The Folk as the Force conditioning the Art-Work." 19 Throughout this and the other "Zurich" essays, it is not explicitly stated that the Art-Work of the Future or the "Folk" are uniquely German, although the subtext is unmistakeable (especially given that the writing of these manifestos align temporally with his exile from Germany in the aftermath of the events of 1849), and it likely scarcely required clarification to begin with. However later essays, particularly "What is German?" (1865) and "German Art and German Policy" $(1867),{ }^{20}$ unequivocally situate the virtues of the German nation as a constellation of the spirit of the Volk, German art, and the ways in which the two inform each other (these are

\footnotetext{
${ }^{18}$ SSD III, 50; PW I, 77.

${ }^{19}$ Ibid.

${ }^{20}$ In SSD X, 36-53; PW IV, 149-169 and SSD VIII, 30-124; PW IV, 35-148 respectively.
} 
also the essays that are most aligned with the primary period of Meistersinger's composition). In the early pages of the latter essay Wagner writes that "the resurrection of the German Folk itself has emanated from the German Spirit..."21 The essence of Germany radiates from the Volk and it was art that gave voice to that essence long before the political will to mobilize that spirit in order to create a unified Germany existed. Even when the leaders of the various German states were scarcely concerned with matters of solidarity and national identity, according to Wagner, it was the artistic output, feeding off of the inspiration of the Volksgeist (spirit of the Volk) that was carrying the torch for the German character. ${ }^{22}$

According to Stephen McClatchie, "Wagner saw the Volk as both the impetus and the requirement for art." ${ }^{23}$ McClatchie's observations should be familiar from Chapter One, particularly in his references to Johann Gottfried Herder's conception of the Volksgeist as the central unifying force of the German people and its culture. As can be surmised, the importance of the Volk and the Volksgeist to artistic production was considered extensively greater than a matter of mere ideas influencing creative activity. As Hannu Salmi points out, even if Volksgeist was conceptualized in the eighteenth century it had not "emerged in the eighteenth century," the Volksgeist being seen as "having existed as long as the nation herself." ${ }^{24}$ In other words, the idea of Volksgeist was only introduced to explicate a presence that always-already existed from the earliest

\footnotetext{
${ }^{21}$ SSD VIII, 33; PW IV, 40.

${ }^{22}$ Wagner quotes a poem by Friedrich Schiller that verbalizes an encomium to German art and notes that the rebirth of German art came at a time "at which...the German Folk was scarcely recognisable outside its royal families...[A]ll capacity to move in any walk or sphere of life lay in the Prince's hands alone...." (SSD VIII, 33; PW IV, 40-41)

${ }^{23}$ Stephen McClatchie, "Performing Germany in Wagner's Die Meistersinger von Nürnberg, in The Cambridge Companion to Wagner, ed. Thomas S. Grey (Cambridge: Cambridge University Press, 2008), 139.

${ }^{24}$ Hannu Salmi, Imagined Germany: Richard Wagner's National Utopia (New York: Peter Lang, 1999), 41.
} 
history of the German land to the present. The German nationalists of the eighteenth century and onwards "saw nationalism as a latent force...[F]rom ancient times, the phases of the nation were seen to have been characterized by a striving for the realization of the idea of a nation, the Volksgeist."2s Since the existence of the Volksgeist ostensibly predated its linguistic codification, it stands to reason that this spirit was considered so all-encompassing that it had long since inculcated itself into the very fabric of society, an intrinsic part of every German citizen. So powerful and ubiquitous was this spirit of the Volk that in "The Artwork of the Future," Wagner foregrounded the Volksgeist as the coherent unifying force of the nation. The concepts 'Volk,' 'Nation' and 'Geist' were the cornerstones of his theory of art."26 For Wagner, it was the goal of art to tap directly into the Volksgeist itself, every aspect of any given German artwork's being having been instilled to its very core with this spirit. By doing so, the Volk are bestowed a unified voice granting them the best hope for the formation of a singular and cohesive nation. Authentic German art cannot exist without infusion of the voice of the Volk, and commensurately, the nation cannot hope to be solidified without a suitable vehicle for that voice. Lydia Goehr accounts for the power that the Volk was purported to have over German art: the "individual artist" and the "metaphysical Volk...share the function of keeping society open: the artist creates only in so far as he expresses the artistic spirit of the Volk."27 Goehr's reading suggests that because "true" art is inherently attuned to the Volksgeist, it can never be truly autonomous. ${ }^{28}$ The creative urge driving the artist is

\footnotetext{
${ }^{25}$ Ibid.

${ }^{26}$ Ibid.

${ }^{27}$ Lydia Goehr, The Quest for Voice: Music, Politics, and the Limits of Philosophy (Berkeley: University of California Press, 1998), 67.

${ }^{28}$ Such a reading would tend to rebuke the nineteenth-century critic Eduard Hanslick's noted position that music contains no "content" beyond its own form: music's "beauty" arises from the relationships between the tones, from the sound of musical form in motion. As such, Hanslick's aesthetic framed him as one of
} 
always the spirit of the Volk. As previously stated, such a conception makes the case for what is akin to psychic and spiritual connections between the artist and the quintessence of the nation. Being a part of the Volk, the artist has an inherent connection to that spirit, if properly fulfilling his duty, will channel that spirit into the work of art. It is artists who fail to heed the call of the Volk who produce mediocre art.

I am not prepared to endorse such a position wholesale, as it reduces the role of the artist to one that bears too much propinquity to mere transcription of an abstract (and rather contingent) concept in addition to situating the artist as one whose primary function is to satisfy popular taste. Even given those reservations, Goehr's framework is useful in that it underlines just how powerful a concept the Volk was to both German art and nationhood in the eighteenth and nineteenth centuries. Given the discursive and performative model of nationhood I have previously put forward, I submit that musings on art, Volksgeist, and nation feature cause and effect feeding back on each other into something of a Moebius Strip: it is the performative invocation of Volk and Volksgeist that ultimately produces those nationalist tropes and normalizes them in the German collective consciousness. According to Wagner, these tropes are ultimately the instruments that produce German art. However, we might take things a step further and posit that the public nature of the performances of Meistersinger, with its abundant references to the Volk and Sachs' declarations of music's connection to the people of Nuremberg, is what "legitimizes" the concepts of Volk and Volksgeist. These acts of

the most historically significant champions of "autonomous music." He advanced this philosophy in his famed treatise Vom Musikalisch-Schönen, which went through nine editions between its initial publication in 1854 and 1896. The eighth edition (1891) is translated as On the Musically Beautiful: A Contribution Towards the Revision of the Aesthetics of Music, trans. and ed. Geoffrey Payzant (Indianapolis: Hackett, 1986). Many of Hanslick's reviews (including several of Wagner's stage works, Die Meistersinger and Parsifal among them) provide further insight into his outlook on musical aesthetics. See Music Criticisms - 1846-99, trans. and ed. Henry Pleasants (Harmondsworth: Penguin, 1963). 
"writing" the Volk "normalize" the notions of a collective spirit with works such as Meistersinger intending to amply demonstrate an example of art that has properly tapped the Volksgeist. As such, we might conclude that the Volksgeist as it pertains to art has no precise point of origin: the concepts of the Volk are realized on stage, but that realization also produces the Volk in and of itself through its own performance. The Volk and the Volksgeist exist in a perpetual loop where ideas beget performance and performance begets ideas. But it is that perpetuity that grants these discourses the appearance of stability. The continual repetition of the cycle is part of what allows nationhood to take on the veneer of plenitude that it would not otherwise possess.

Perhaps one of the most provocative deployments of the Volksgeist narrative in the context of Wagner is Arthur Groos's aforementioned characterization of Nuremberg as a proleptic community. Groos uses two quotations as primary entry points: the first is Carl Dahlhaus's observation that the music of Meistersinger "interlock[s] the wilfully archaic and the modern." 29 The other is Friedrich Nietzsche's appraisal of the Act One prelude in Beyond Good and Evil, which contends that the music seems

alternately ancient, alternately foreign, bitter, and overly modern...a true emblem of the German soul, simultaneously young and ancient, too ripe and still very rich with future. This kind of music best expresses what I think of the Germans: they are of the day before yesterday and the day after tomorrow - they still have no today. ${ }^{30}$

The commonality between both points is that they put forth the dramatic and musical setting of sixteenth-century Nuremberg as a city out of time, which has "no real place," to invoke Michel Foucault's characterization of utopia. ${ }^{31}$ Past and future merge to create a

\footnotetext{
${ }^{29}$ Carl Dahlhaus, Richard Wagner's Music Dramas, quoted in Groos, 18.

${ }^{30}$ Friedrich Nietzsche, Beyond Good and Evil, quoted in Groos, 18.

${ }^{31}$ Michel Foucault, "Of Other Spaces: Heterotopias" (1967), trans. Jay Miskowiec, http://foucault.info/documents/heteroTopia/foucault.heteroTopia.en.html. To encapsulate: for Foucault, 
space that is akin to a dreamscape, "so old and yet so new," as Sachs characterizes Walther's "Trial Song." The art of tomorrow is woven into the fabric of the art of yesterday, but the resultant hybrid means that the setting displays no sense of now. Musically, this occurs according to Dahlhaus through the marriage of "old-fashioned" tropes such as four-part chorale writing, cantabile-like vocal lines, and diatonic melodies with more modern techniques such as the prolongation of resolution of dissonance through "intermediate chords," chromatic inner voices accompanying the aforementioned diatonic themes, and the employment of "descriptive" music in the guise of cantabile. ${ }^{32}$ For Dahlhaus, the result is that the music of Meistersinger is "somehow dreamlike, not quite real in the $1860 \mathrm{~s}$ : not so much restoration as reconstruction. It is a 'second' diatonicism...."33 This is arguably the most basic level on which Meistersinger operates as something existing out of phase with the "now," which has a day before yesterday and day after tomorrow, but still no today. Groos takes matters significantly further with his reading of Wagner's Nuremberg as a site of prolepsis.

To reiterate, Groos's framework foregrounds Nuremberg of the sixteenth century as a site that concurrently anticipates and contains the culture of the nineteenth century. Groos centralizes the concluding Festival Meadow scene and traces its lineages to the public festivals that were a ubiquitous element in the discourses of nineteenth-century German nationalism. As George Mosse recounts, the public festival in the nineteenth

utopias are an idealization, but that idealization renders them as fundamentally unreal spaces. Utopia is an impossible dream, but it is to be strived for because of its coherence, the way it rationally arranges objects and individuals into a cohesive totality. Foucault contrasts this with "heterotopia," which is "outside of all places, even though it may be possible to indicate [its] location in reality." Heterotopias are threatening because they overturn conventional wisdoms regarding social norms and shatter attempts to construct historical and social continuities. Foucault lists as examples of heterotopias insane asylums, prisons, and retirement homes. See also The Order of Things: An Archaeology of the Human Sciences (1970) (New York: Vintage Books, 1994), xviii.

${ }^{32}$ Dahlhaus, Richard Wagner's Music Dramas, 72-75.

${ }^{33}$ Ibid., 75. 
century (with the Wartburgfest of 1817 underlined as an event of particular historical gravity) was positioned as a happening that encouraged a sense of community amongst the populace and historical continuity with their ancestral roots. ${ }^{34}$ Mosse also notes that public festivals strategically fused the discourse of the sacred with notions of a shared national consciousness in order to position the festival as a benediction of the spirit of the Volk. ${ }^{35}$ Speaking specifically of music festivals, James Garratt similarly observes that festivals of the Vormärz period - that is, the years leading up to the revolutions of 184849 - had notable cultural impact in terms of publically celebrating the Volk and/or German musical history. ${ }^{36}$ Groos takes up Mosse's historicizing, adding that these mass movements "follow[ed] a model provided by the emergence of collective will in the French Revolution [with] mass national culture in nineteenth-century Germany...approximat[ing] the liturgy of a secular religion." ${ }^{, 37} \mathrm{He}$ adds,

In the dialogue between...national events and local historical festivities there developed a loose secular liturgy for celebrating the Volk, a variety of activities that began with a procession of participating groups, usually in festive or archaic costume with flags, often representing crafts, to the location of the festival. The location, usually a meadow or hall large enough to accommodate the mass of people celebrating themselves, also frequently used a "sacred national space" such as already existing historical buildings or newly created monuments for a mise-en-scène. Often set on a date of historical importance or one considered "Germanic"...the activities included dancing and parades in historical costume, singing of Protestant and patriotic hymns, and speeches and sermons. ${ }^{38}$

\footnotetext{
${ }^{34}$ George L. Mosse, The Nationalization of the Masses: Political Symbolism and Mass Movements in Germany from the Napoleonic Wars Through the Third Reich (New York: Howard Fertig, 1975), 73-99. ${ }^{35}$ Ibid., 74-79.

${ }^{36}$ James Garratt, Music, Culture, and Social Reform in the Age of Wagner (Cambridge: Cambridge University Press, 2010), 84-127. Garratt clarifies that organizers and participants of Vormärz-era music festivals, despite their designation of "people's festivals" did not necessarily think of Volkstümlichkeit as inherent qualities of the proceedings, nor were they significantly concerned "that their participants and listeners were drawn almost entirely from the educated classes" (87).

${ }^{37}$ Groos, 27.

${ }^{38}$ Ibid.
} 
As Groos notes, the climactic scene of Meistersinger bears more than a slight resemblance to the traits of a nineteenth-century public festival: in addition to the processional that brings the citizenry of Nuremberg to the Festival Meadow, the song contest is also held on "Johannistag" (June 24) or, the Feast of St. John, noted throughout the story as a day of celebration of the arrival of midsummer. In the nineteenth century, several events held in Nuremberg on this and surrounding dates served to position "midsummer" or "Johannistag" as particularly important to the culture of Nuremberg. For example, Groos observes that the second pan-German Song Festival was held in the city on July $21-24$ of 1861 , which featured participation from over 5000 singers and an audience of around $14000 . .^{39}$ Stephen Brockmann points out that a number of festivities that took place in the months following Die Meistersinger's Nuremberg premiere in 1874 included a parade through the city on June 24 , followed by the unveiling of a statue of Hans Sachs. ${ }^{40}$ Beyond matters of the date's Biblical significance or the city's Midsummer celebrations, the importance placed on "Johannistag" by the libretto represents in many ways a projection of nineteenth-century Nuremberg's cultural investment in this date back into the sixteenth century. For Groos, this scene is an example of prolepsis in that it takes elements of then-contemporary culture and places them in the context of the historical, essentially presenting the present as though it had already occurred some time ago. As such, under Groos's framework, the sixteenthcentury garments worn by the populace in the opera register as the "festive or archaic costumes" of the nineteenth-century festival. ${ }^{41}$

\footnotetext{
${ }^{39}$ Ibid., 28.

${ }^{40}$ Stephen Brockmann, Nuremberg: The Imaginary Capital (Rochester, NY: Camden House, 2006), 112.

${ }^{41}$ Groos hastens to add that the mise-en-scène of the Festival Meadow should not be interpreted as a direct transplant of a public festival into the historical setting as the magnitude of the "increasingly nationalized
} 
To demonstrate the proleptic nature of the Festival Meadow, Groos compares Meistersinger to a scene in Albert Lortzing's 1845 opera Hans Sachs, where the celebratory gathering takes place outside the city gates and "simply enumerates the various pastimes to which the citizens devote themselves, activities that lack the historicist and nationalistic consciousness pervading Wagner's scene....,42 In other words, Lortzing's dramaturgy stages the choral crowd more as couleur locale than as a miniaturization of the populace as a whole and an embodiment of the national character. But Wagner does not simply eschew Lortzing's staging of the community in favour of his own. As Groos puts it, Wagner's Nuremberg is a proleptic community not because it transposes the festival culture of his time wholesale into the arcane setting, but because it takes recognizable markers of that culture and re-moulds them into something more attuned to the realities of the story's specific temporal location. Simply put, "Wagner followed Lortzing's scenic precedent of placing his festival scene in an open space outside the city gates, elaborating it considerably with historically more appropriate, i.e., less massive and nationalistic, elements of nineteenth-century festival culture....,43 Wagner's Nuremberg is a community where yesterday and tomorrow merge into a culture that is the living embodiment of Sachs's exhortations to embrace the new while preserving the legacy of the past.

mass celebrations of the $1860 \mathrm{~s}$ " (28) such as the aforementioned pan-German Song Festival were frequently greatly out of proportion to the comparatively modest festivities presented in the opera.

${ }^{42}$ Ibid., 28.

${ }^{43}$ Ibid. While Lortzing placed his gathering just outside of the city gates, Wagner locates his Festwiese well outside the city limits ("Nuremberg in the distance" as the stage directions read), adjacent to the River Pegnitz. In David's "Spruchlein" of III/1, the Pegnitz is revealed as the end-point of a Biblical teleology beginning with St. John's baptism of the world at the River Jordan, thus situating Nuremberg as a modern "promised land." In exploiting Groos's insights into the Biblical resonances of events, characters, and places in Meistersinger, one can frame the processional to the Festival Meadow as a pilgrimage to the "sacred national space" that Groos notes was so desired by the organizers of public festivals. 
Groos's model of Nuremberg as proleptic community has proven to be influential on other scholars. For example, in putting forth Wagner's Nuremberg as the site of dialectical processes where the idealized image of musical perfection is arrived at through several instances of negation, Goehr demonstrates notable fidelity to Groos's arguments at several junctures. She frames Wagner's project in Hobsbawmian terms where Nuremberg functions as the site of

the invention of a German and a Romantic tradition of art...us[ing] a threecenturies-old Lutheran tradition of mastersinging to serve as its authoritative past. The story is set in the sixteenth century; the argument belongs to the nineteenth...The opera itself contributes to the actual invention of what Wagner claims is a newly emergent German tradition of art, by virtue of the relation in which the opera stands to a tradition of historical treatments of the mastersingers and so by association with Germany's actual Lutheran past. ${ }^{44}$

Goehr's essential argument invokes the work of Groos and Dahlhaus among others, in order to maintain that Wagner mobilizes arguments (historical, political, aesthetic, and philosophical) about the role and nature of the ideal artwork in society contemporary to the 1860 s and places them within the anachronistic context of the sixteenth century. ${ }^{45}$ In doing so, according to Goehr, Wagner invents a tradition where modern concerns about German art and its relationship to the people (and indeed, to the Volk) may be traced back to one of the most prominent pieces of early German musical heritage: through the placement of the aesthetics and politics of the present within the mythologized past, the artistic life of the mastersingers are staged as the beginning of a teleological progression leading to the ultimate realization of the future of German art. In Wagner's Meistersinger, Nuremberg is situated as the inception and the end result, the sixteenth

\footnotetext{
${ }^{44} \mathrm{Goehr}, 52$.

${ }^{45}$ The ideal, according to Goehr, is invariably arrived at through acts of negation of those regressive elements holding back artistic progress.
} 
century providing the setting and the story, the nineteenth century the philosophical framework. In other words, Goehr proposes another example of a proleptic community.

Groos and Goehr's hermeneutic models both foreground the city of Nuremberg as vital to the historicizing and mythologizing of the Volksgeist and the concomitant progression of German art. By the nineteenth century, Nuremberg had been held up as central to discussions of "German-ness." This notable passage by Ludwig Tieck and Wilhelm Heinrich Wackenroder from their Herzensergießungen eines kunstlieben Klosterbruders (Heartfelt Outpourings of an Art-Loving Monk) of 1797 is particularly instructive:

Nuremberg! $O$ town of erstwhile universal fame! How gladly I wandered through your narrow crooked streets; with what childlike love I observed your ancestral houses and churches, which bear the firm imprint of our fatherland's ancient art! What heartfelt love I feel for the creations of that age, creations that speak so vigorous, powerful, and true a language! How they draw me back to that gray century when you, Nuremberg, were the life-teeming school of our fatherland's art and when a truly fruitful and prodigal spirit flourished within your walls.... ${ }^{46}$

Tieck and Wackenroder specifically associate the city's architecture and its artistic life (he mentions Hans Sachs as one of the exemplars) with the identity of the "fatherland." Lortzing's and Wagner's dramatic efforts provide quite handy examples that illustrate that nineteenth-century discourse granted significant prominence to art's importance to the German character while constructing a nationalist mythos around Nuremberg. As Groos puts it, the city was framed as the site of "a cultural unity projected backward onto the period of the Reformation by the middle-class intelligentsia and intended to figure as a model and inspiration for both present and future. ${ }^{47}$ Furthermore, Nuremberg's

\footnotetext{
${ }^{46}$ Ludwig Tieck and Wilhelm Heinrich Wackenroder, Herzensergießungen eines kunstlieben Klasterbruders (1797), quoted in Borchmeyer, Drama and the World of Richard Wagner, 184.

${ }^{47}$ Groos, 19.
} 
importance was "epitomized by its geographical - and simultaneously symbolic location in the 'center' of Germany, a topos in early modern encomia of the city...."48 One of these "early encomia" came from the German poet-laureate Conrad Celtis, whose 1495 poem Norimberga described Nuremberg "as a city at the heart of the Holy Roman Empire, close to the source from which the four rivers of Paradise flowed, a city that derived its culture from the wisdom of the ancient druids." ${ }^{\$ 49}$ Groos notes that the location of Nuremberg as Germany's spiritual centre is given particular prominence in Sach's "Wahn" monologue of Act III, Scene 1:

Wie friedsam treuer Sitten, getrost in Tat und Werk, liegt nicht in Deutschlands Mitten mein liebes Nürnberg! ${ }^{50}$
[How peaceful in faithful customs, content in deed and works, lies in the middle of Germany my beloved Nuremberg!]

Also essential to the mythologizing of Nuremberg is the aforementioned architecture of the city. As Stewart Spencer writes:

During these three centuries - from the heyday of the Reformation to the annexation of Nuremberg by Bavaria in 1806 - the face of the inner town remained largely unaltered. Partly the geographical layout of the old town, partly the conservative outlook of the town council had ensured that visitors to Nuremberg in the late eighteenth and early nineteenth century were confronted by a town that was essentially unchanged since the sixteenth century. ${ }^{51}$

\footnotetext{
${ }^{48} \mathrm{Ibid}$., 19-20. Note that Groos places "center" in quotation marks, as if to emphasize that this trope is metaphorical, as consultation of a map of Germany will reveal that Nuremberg clearly does not literally lie in the geographical centre of Germany.

${ }^{49}$ Charles Zika, Exorcising Our Demons: Magic, Witchcraft, and Visual Culture in Early Modern Europe (Leiden and Boston: Brill, 2003), 555. Groos observes that the troping of Nuremberg as the "heart" of Germany may have originated in chapter 39 of Aeneas Sylvius Piccolomini's Europa and continued with the Nuremberg Chronicle of 1493, among several other sources (20).

${ }^{50}$ Quoted in Groos, 20.

${ }^{51}$ Stewart Spencer, "Wagner's Nuremberg," in Cambridge Opera Journal 4 (1992): 23.
} 
In retaining its "neo-Medieval" flavour, ${ }^{52}$ the city was lent a sense of pre-industrial "purity" that supposedly acted as a "living museum," 53 a direct conduit to the essence of the German identity. In a letter to Ludwig II dated July 24,1866 , Wagner wrote:

Nuremberg, the old, true seat of German art, German uniqueness and splendour, the powerful old free city, well-preserved like a precious jewel, reborn through the labours of its serenely happy, solid, enlightened and liberal populace under the patronage of the Bavarian throne. ${ }^{54}$

Nuremberg remained untouched and "uncorrupted" by the technological impositions of modernity and as such would allow the German spirit and its attendant art to flourish unhindered..$^{s 5}$

That Nuremberg is the "true seat of German art" is also critical to the city's status as what Sachs considers the "centre" of Germany. According to Dieter Borchmeyer, the city and its constituent Volk register as an "aesthetic utopia." He writes:

Wagner's Nuremberg...is wholly depoliticized...the town of Nuremberg lacks any municipal authority. And the mayor...does not appear onstage at all, an absence particularly striking in the Festival Meadow scene. That such a key event in the civic life of the community should take place without the mayor and town councillors is utterly without precedent in the history of municipal culture. It is impossible to escape the conclusion that Nuremberg has been transformed into a kind of "aesthetic state"...."

Borchmeyer continues that "the new art that triumphs on the Festival Meadow in the person of Walther is no longer maintained by a privileged few but by the townspeople as a whole...Art and artists alone set the tone in this totally aestheticized community....".57 The citizenry of Nuremberg are inherently attuned to matters artistic, with little attention

\footnotetext{
${ }^{52}$ Ibid., 24.

${ }^{53}$ Groos, 19.

${ }^{54}$ Selected Letters of Richard Wagner, quoted in Spencer, 36.

${ }^{55}$ Peter Uwe Hohendahl further explores Wagner's mythologizing of Nuremberg in "Reworking History: Wagner's German Myth of Nuremberg," Re-Reading Wagner, eds. Reinhold Grimm and Jost Hermand (Madison WI: University of Wisconsin Press, 1993), 39-60.

${ }^{36}$ Borchmeyer, 191-192.

${ }^{57}$ Ibid., 194.
} 
paid to political or financial concerns. Although the mastersingers all have middle-class occupations (Sachs as cobbler, Kothner as a baker, etc.), as Wagner presents them they are merely means to support the guild and the enrichment of the city's artistic life. Furthermore, the guild is venerated by the community, with Sachs singled out for special idolatry ("Nümbergs teurem Sachs!" as the townsfolk proclaim at the opera's close); the song contest on Johannistag brings out the entire populace. As previously noted by Borchmeyer, all political figures from the municipal authority all the way up to the Emperor have no presence and might as well not exist: the mastersinger's art is purely an exchange between the artisans and their attendant public. Indeed, at the climax of his summation, Sachs maintains that "even if the Holy Roman Empire should dissolve in mist, we'd still be left with holy German art." Borchmeyer's analysis maintains that in Wagner's Nuremberg, matters of empire and its constituent issues of politics and commerce are completely exterior to this community. This aesthetic utopia, located in the "spiritual center of Germany," 58 is an enclosed community, hermetically sealed to prevent anything not concerned with art from infiltrating the culture. The eventual symbiosis between artist and Volk isolates the city, but at the same time puts it forth as a test case, a municipality containing the enlightened few who provide the model for future German art to follow. As will be seen shortly, the issue of Nuremberg's status as an

\footnotetext{
${ }^{58}$ Groos, 26. Comparison must be drawn at this point between the prevailing theorizing of Nuremberg as the "spiritual" and artistic hub of German identity and the discourse surrounding Weimar that I discussed in the previous chapter. While the legacies of such figures of Goethe and Herder and the centrality of the city to the "New German" musicians and their musically progressive aesthetics effectively positioned Weimar as a nucleus for German artistic activity, one should not forget Wagner's quoted letter to Ludwig II, characterizing Nuremberg as the "old, true seat" of German art. Perhaps the distinction can be framed as such: Weimar's ostensible status as a German "spiritual centre" in the nineteenth century arises out of relatively recent history from the eighteenth and nineteenth centuries, while Nuremberg's legacy lies in the endurance of its traditions, the "old" that stretches back several centuries. So, because of that enduring heritage, the artistic "spirit" of Nuremberg has seeped into the fabric of Germany's being, if Wagner's statement is to be believed. The contrast of the legacies of Nuremberg and Weimar could possibly be stated in terms of one of Die Meistersinger's central theses: while veneration of the "new" (Weimar) is important, it should not be done at the expense of the "old" (Nuremberg).
} 
enclosed aestheticized space will resonate within discussions of Kunstreligion and the points of contact between the Volk of Nuremberg and the hermetic Grail community of Parsifal.

\section{Festspiel communities}

To this point, I have significantly referenced Meistersinger and comparably less Parsifal. This is because much of the terminology and theories find their origin in the former work. Indeed, nowhere in the libretto to Parsifal is the Grail community identified as das Volk. Also, the prose writings of the 1870s and 1880s contain few mentions of the Volk or Volksgeist. It would be an overstatement to contend that the discourses of the Volk are amenable to direct transposition into the Grail Knights of the later work. However, there are similarities between how the Volk functions in Meistersinger and how the communities of Parsifal register. While the chorus in Parsifal might not be particularly analogous to the Volk, I propose that they nonetheless function as a different form of proleptic community, albeit one at a greater temporal, geographical, and allegorical remove from Germany. Granted, Groos does not specifically make this comparison himself. However, he does note that Parsifal builds upon Meistersinger's precedent in that both present communities based upon "semi-Biblical typologies." Parsifal, this contributes to "institutionalizing [Wagner's] replacement of religion by art...that retrospectively validates his preceding operas by 'consecrating' an already existing theater at Bayreuth." ${ }^{90}$ Furthermore, in the course of his own reading of the

\footnotetext{
${ }^{59}$ In Meistersinger, these typologies liken Sachs to John the Baptist and the River Pegnitz to the Jordan. For Parsifal, a letter dated September 7, 1865 to Ludwig II equates Amfortas, Kundry, and Parsifal with Adam, Eve, and Christ, respectively. See SL, 664.

${ }^{60}$ Groos, 26.
} 
work, James Treadwell draws a specific comparison between the conclusion of Meistersinger and Parsifal, writing that

The end of Parsifal fulfils what is only a prophecy in Sachs's closing speech, as he issues a warning against imminent invasion and degeneration, and envisions 'holy German art' as the only impervious force of resistance. That vision comes true (or at least presents itself as having come true) in the closing act of Wagner's last opera, where art - Wagner's art of course - has clothed itself in the rituals and iconography of Christianity, and celebrates the restoration of a sacred brotherhood. The impure element (Kundry, who is at once female, Semitic, and unchaste) is baptized on stage, as if opera had taken on itself the role of administering the rites of purification. This too had been anticipated in Meistersinger, whose third act also contains a baptism in the domain of art: but whereas Sachs half-jokingly christens a song, in Parsifal it's music - the opera itself - that claims to be the actual site of the Christian sacrament. ${ }^{61}$

Treadwell's remarks provide a basis for what my own readings of the chorus in Parsifal. As I shall endeavour to explicate shortly, the "consecration" of Bayreuth can be reframed as proleptic by thematizing the community of the Grail as the embodiment of the nineteenth-century Bayreuth "community," projected back into a medieval setting. Similarities between Wagner's Nuremberg and his Grail kingdom do not end with Biblical "typology." Like Nuremberg, Montsalvat is presented as a cloistered community where the vagaries of politics and commerce are absent (and it is when politics, in the form of the various intrigues with Klingsor and Kundry, is allowed to infiltrate that the order's decline is initiated). Where Nuremberg was solely devoted to the creation and consumption of art, the Grail Knights are concerned entirely with Communion and the safeguarding of the holy relics entrusted to them. Once the external destructive forces are permanently obliterated and Amfortas's wound is healed, Montsalvat is rescued from its decline and re-emerges as a utopian community.

\footnotetext{
${ }^{61}$ James Treadwell, Interpreting Wagner (New Haven, CT and London: Yale University Press, 2003), 206.
} 
This community is not identified as explicitly German in the libretto or the score. However, because of the context of the work's conception and production, it is not overly difficult to infer a degree of accord with the issues surrounding modern German culture. Firstly, this work was specifically conceived for performance at Bayreuth, the venue intended as the space where Wagner's theories about the theatre and art were to be realized. In his 1873 speech after the laying of the Festspielhaus's foundation stone, Wagner refers to the Bayreuth project as fulfillment of his promise to "found for the Germans a Theatre of their own," ${ }^{62}$ one that will rescue German art from the pernicious influence of foreign (particularly French) theatrical and artistic traditions. For Wagner, the construction of the Festspielhaus will be bolstered by the German "spirit" and its walls will contain that spirit once completed. I quote the following at length:

I trust in the German Spirit, and hope for its manifestment in those very regions of our life in which, as in our public art, it has languished in the sorriest travesty. Above all, I trust in the spirit of German Music, for I know how glad and bright it burns in our musicians so soon as e'er a German master wakens it with them; and I trust in our dramatic mimes and singers, for I have learnt that they could be as if transfigured to new life when once a German master led them back from idly playing at a harmful pastime, to true observance of their lofty calling. ${ }^{63}$

In his reflection on the event, Wagner added that "if my Hans Sachs in the 'Meistersinger' lauds Nuremberg as lying in the heart of Germany, with still more right I now could claim that kindly lot for Bayreuth." ${ }^{\prime 64}$ Clearly such a statement was in part influenced by fealty to his Bavarian benefactor Ludwig II, but the point remains that Wagner discursively located his theatre within the metaphorical centre of Germany, granting it status as a point of origin from which the spirit of German art would

\footnotetext{
${ }^{62} \mathrm{SSD}$ IX, 326; PW V, 324.

${ }^{63}$ SSD IX, 327; PW V, 325. With these words, Wagner appears to be referring simultaneously to the incipient Festspielhaus as well as the upcoming performance of Beethoven's Ninth Symphony that was to be given later that day.

${ }^{64}$ SSD LX, 332; PW V, 329.
} 
outwardly flow. The Festspielhaus was to be the living testament to the sanctity of German art, its underlying spirit radiating from its walls touching all that were witness to its contained performances. With that in mind, I propose that the concept of the proleptic community may be modified in order to include the inhabitants of the Temple - the Knights and the off-stage denizens of the upper dome - arguing that in Parsifal the contemporary German culture that "consecrates" the Bayreuth stage is placed within the mythologized framework of medieval Christian ritual.

The contention that Parsifal might be read as a "German" opera regardless of its Spanish setting is also made more plausible under strictly musical terms, given the prominence of the "Dresden Amen" motive (Ex. 1a) - composed by Johann Gottlieb Naumann for use in church services in the late eighteenth century in his capacity as Kapellmeister in Dresden ${ }^{65}$ - whose rising harmonized sixths make up the second half of Wagner's "Grail" theme (Ex. 1b). So prominent did the "Amen" eventually become that many German musicians considered it "emblematic of Catholic church music." Its use extended to Lutheran services as well, so it is quite likely that many, if not all, in the audience at Bayreuth would have recognized this motive. Furthermore, the "Amen" was included in Mendelssohn's Fifth Symphony ("Reformation"), granting the theme a cultural ubiquity that could potentially situate it as a piece of German heritage. Importantly, a musical motive associated with German religious culture is married to music associated with several elements of the Christian "mythos," effectively framing the

\footnotetext{
${ }^{65}$ Wagner assumed this post from 1842 to 1849.

${ }^{66}$ William Kinderman, "Introduction: The Challenge of Wagner's Parsifal," in A Companion to Wagner's Parsifal," ed. William Kinderman and Katherine R. Syer (Rochester, NY: Camden House, 2005), 19. Kinderman further discusses the music of Parsifal from its initial sketches to its completed form, devoting especial attention to the first-act "Transformation" music in "Die Entstehung der Parsifal - Musik," Archiv für Musikwissenschaft 52/1 and 52/2 (1995): 66-97 and 145-165.
} 
heritages of German artistry and religion as one and the same. German art is granted a sense of religious splendour through this fusion. ${ }^{67}$

Ex. 1a

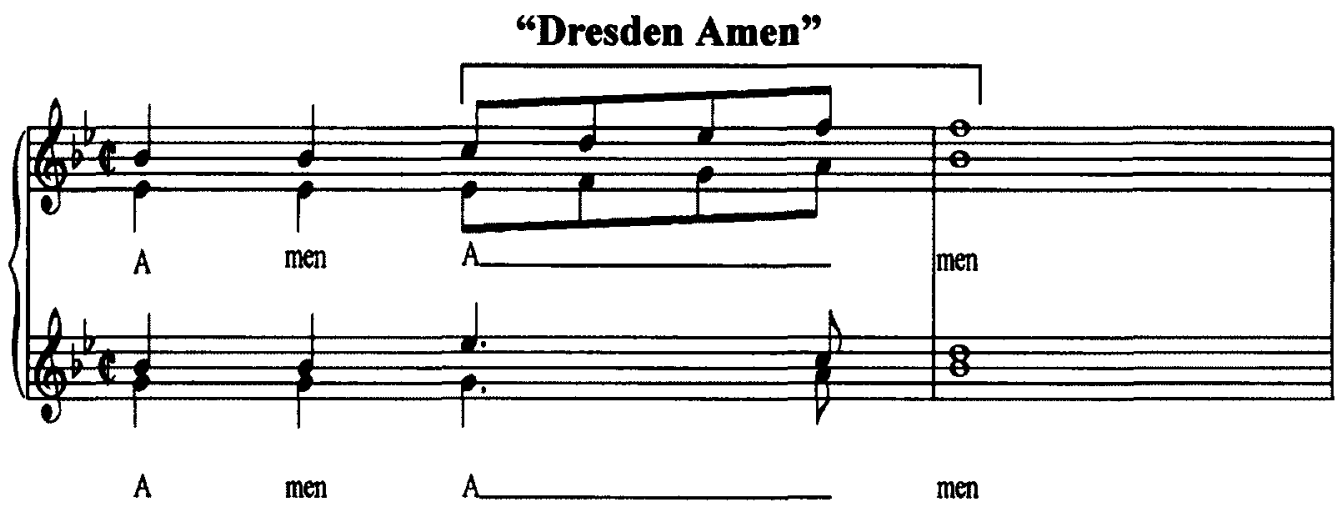

Ex. 1b

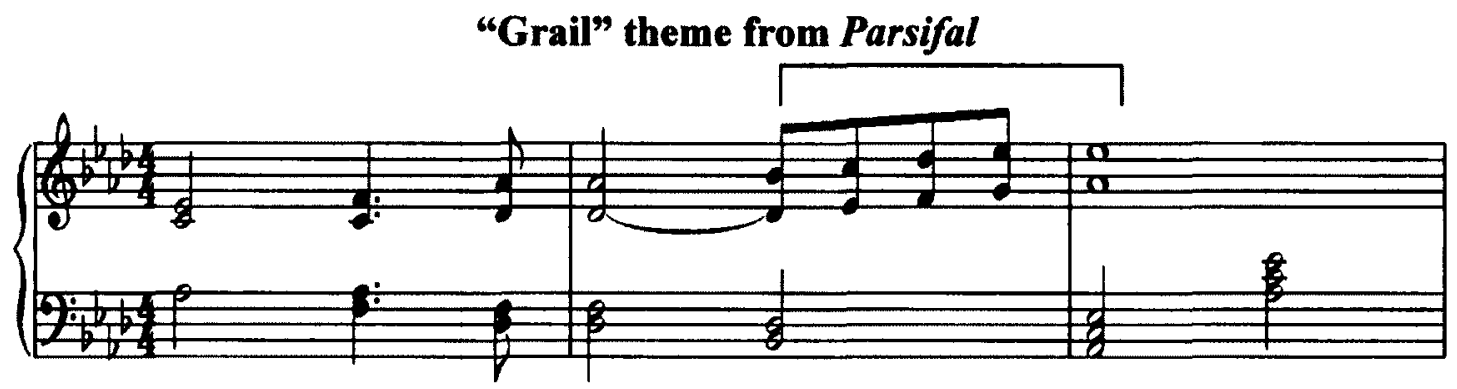

William Kinderman further notes that the main "Communion" theme (Ex. 2a) greatly resembles the "Excelsior!" motive from Liszt's 1874 cantata The Bells of Strasburg Cathedral (Ex. 2b), the score of which had been sent to Wagner and Cosima in $1875 .^{68}$ The similarity lies in that both motives begin with a rise through the interval of a major-sixth primarily via a series of ascending thirds. Also observe that the "Communion" theme is also reminiscent of the pre-"Dresden Amen" half of the "Grail"

\footnotetext{
${ }^{67}$ As Volker Mertens notes, the Grail as depicted in Parsifal is representative of the opera's overall synthesis of a number of different religious traditions, particularly Christianity, Hinduism, and Buddhism. This reflected Wolfram's own "inter-religious" conception of the Grail in the Parzival legend. I would extrapolate from this point by offering that in constructing the Grail as a vessel for a more allencompassing religiosity and using a musical motif that incorporates a well-known fragment of German musical culture, perhaps Wagner is amplifying Parsifal's and German art's connection to the sacred: German art's religiosity is of a more "universal" type. This potentially invests German art's ostensible spiritual power with a more totalizing quality in that its "divinity" cuts across numerous cultural borders. See "Wie christlich is Wagners Gral?" Wagnerspectrum 4/1 (2008): 91-115.

${ }^{68}$ Kinderman, "Introduction: Wagner's Parsifal," 21.
} 
theme, in that both feature a melodic ascent through the interval of a perfect fourth, emphasizing the rising major third. Although this piece was not as well known as the "Dresden Amen" (and took a French cathedral as its programmatic source), it is nonetheless intriguing that a notable portion of the thematic material in Parsifal makes a number of allusions to various pieces of nineteenth-century Germanic musical history, all related in some fashion to the liturgy, essentially elevating German music to the level of the sacred.

\section{Ex. 2a}

Liszt, "Excelsior!" The Bells of Strasburg Cathedral

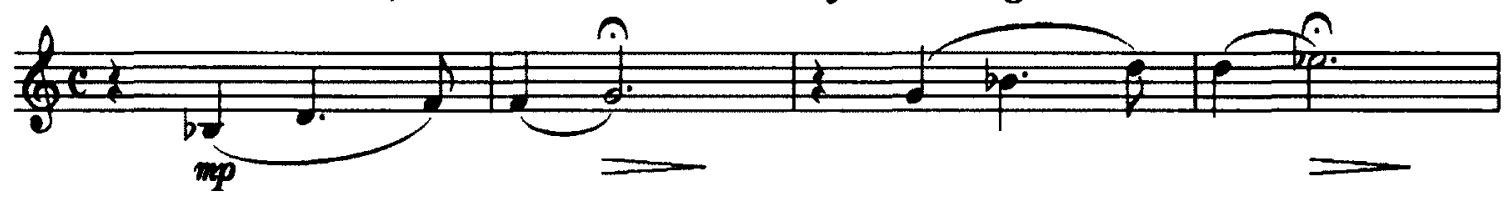

Ex. 2b

"Communion" theme, Parsifal"

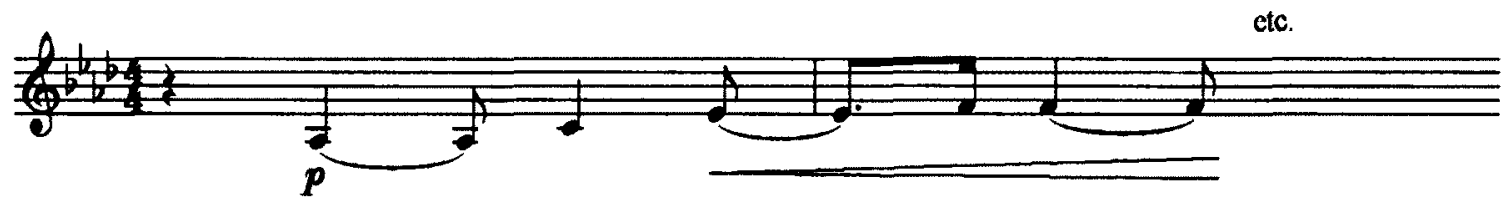

The ideology behind Wagner's aforementioned claim in "Religion and Art" that it is art that can rescue religion from its culturally contaminated status can be traced back to the aesthetic of Kunstreligion, which as Glenn Stanley notes first flowered in Friedrich Schleiermacher's 1799 essay On Religion: Speeches to its Cultured Despisers. ${ }^{70}$ There Schleiermacher contends:

If it is true that there are sudden conversions whereby in men, thinking of nothing less than lifting themselves above the finite, in a moment, as by an immediate, inward illumination, the sense for the highest comes forth and surprises them by

\footnotetext{
${ }^{69}$ Examples $2 \mathrm{a}$ and $2 \mathrm{~b}$ are both taken from Kinderman, "Introduction: Wagner's Parsifal," 21.

${ }^{70}$ Stanley, 154; Friedrich Schleiermacher, On Religion: Speeches to its Cultural Despisers, trans. John Oman (New York: Harper \& Brothers, 1958).
} 
its splendour, I believe that more than anything else the sight of a great and sublime work of art can accomplish this miracle. ${ }^{71}$

For Schleiermacher, the impact of a great work of art is akin to the transcendence of the strictures of the everyday that comes with religious illumination. Both bring the individual into contact with the divine. ${ }^{72}$ Schleiermacher's conception of art's religiosity has implications on the troping of German nationhood: as Stanley writes, Schleiermacher "linked his call for religious revival to Volksgeist theories of national culture (Herder)...."73 Indeed, Leopold Nowak's essay quotes H.A. Korff's claim that "the Goethezeit [was] "the time of true Kunstreligion."'74 Wolf-Daniel Hartwich further underlines the late eighteenth century's "belief in a divine inspiration of the poet in archaic cultures" the myth of which "formed now a constitutive element of Romantic Kunstreligion."7s The benediction of art is an expression of the German spirit: it is part of the Volksgeist to transmute art into religion. However, Stanley notes that the definition of Kunstreligion is "slippery...variously used to describe art in the service of religion, replacing religion as an outlet for devotion, or simply appropriating religious themes."76 It is that second definition that is of greatest interest to me, and one which Hegel in The

\footnotetext{
"Schleiermacher, 139.

${ }^{72}$ Schleiermacher's words contain more than a slight similarity to a great deal of philosophizing in the early nineteenth century about music and its relationship to the opposed concepts of the beautiful and the sublime (with E.T.A. Hoffmann's essays on Beethoven as a notable example). These early Romantic theories about (German) music are summarized in "The First Romantics" in Taruskin, Oxford History - Vol. 2, 641689.

${ }^{73}$ Stanley, 154.

${ }^{74}$ H.A. Korff, Geist der Goethezeit (1966), quoted in Nowak, "Parsifal und Kunstreligion," 162: "H.A. Korff nannte die Goethezeit 'die Zeit einer wahren Kunstreligion."”

${ }^{73}$ Hartwich, "Deutsche mythologie," 20: "Der Glaube an eine gottliche Begeisterung des Dichters in den archaischen Kulturen, die von den Mythen bezeugt wird, bildete fortan ein konstitutives Element der romantischen Kunstreligion." Hartwich had earlier referred to the Edda as one of his examples of mythic writing and poetry from "archaic" cultures that subsequent thought attributed "divine inspiration" to.

${ }^{76}$ Stanley, $309 \mathrm{n} 9$.
} 
Phenomenology of Spirit observes as one of the qualities of Hellenic society. ${ }^{77}$ In Meistersinger, as Treadwell observed we see a form of this type of Kunstreligion in the dedication to "holy German art." The elevation of art to the level of religion is part of what frames this community as an example of Borchmeyer's "aesthetic utopia": art is their religion, and it is that commitment to the sacredness of art that identifies the Volk as German.

But even before Meistersinger, Wagner's thought included generous amounts of invocations of Kunstreligion. As Nicholas Vazsonyi observes, Wagner's writings of the 1840 s often served to situate him within a "divine" lineage of German composers that culminated in Beethoven, positioning himself as Beethoven's chosen successor, thereby rhetorically bestowing a sacramental quality upon his own artistic ideas. ${ }^{78}$ The very title of his short story "A Pilgrimage to Beethoven" (1840) strongly insinuates that Beethoven is the end goal of a sacred journey. ${ }^{79}$ Another story, "An End in Paris" (1840) has the dying artist "R_" state that he "[believes] in God, Mozart and Beethoven," obviously intending to ascribe divinity to those two composers through their invocation alongside a deity. R - further professes belief "in the Holy Ghost and in the truth of the one and indivisible Art," proclaiming "this Art to be an emanation of God that dwells in the hearts of all enlightened men...." ${ }^{\text {so }}$ Some forty years before he put pen to paper on "Religion and Art," Wagner had already made a case for art's sacred properties.

However, as previously stated by Stanley, it is Parsifal that is frequently considered a locus classicus in Wagner's repertoire for the staging of Kunstreligion. He

\footnotetext{
${ }^{7}$ Georg Wilhelm Friedrich Hegel, The Phenomenology of Spirit (1807), trans. A.V. Miller (Oxford: Clarendon Press, 1977), 424-453.

${ }^{78}$ Vaszonyi, "Eine pilgerfahrt zu Wagner," 206-211.

${ }^{79} \mathrm{WP}$, 64-83.

${ }^{80} \mathrm{WP}, 101$.
} 
maintains that typically the invocation of the term in the context of Parsifal emphasizes "content, that is, how it embodies religious ideas, rather than on agency, how it propagates ideology and galvanizes opinion." ${ }^{\text {81 }}$ In other words, Stanley suggests that the prominence of Christian trappings in the work frequently motivates the application of Kunstreligion even though in Stanley's estimation the ideological issue is of greater significance. Commenting on "Religion and Art," Jürgen Kühnel observes that for Wagner "religion must fade before the reality of utopia - which for Wagner is also an aesthetic utopia - can be achieved. The age of religion and its priestly agents is over....Religion has lost its function as an exciter of the senses. In this it has been replaced by art, or, better, it has been preserved and saved in art." ${ }^{\text {82 }}$ It must be noted however that in the third chapter of the essay, Wagner prominently pivots back to the issue of Christianity: with art as its impetus "the great regeneration [of the German race] can spring from nothing but the deep soil of a true religion." ${ }^{\text {"83 }}$ Stanley adds that "in the context of this essay by Wagner, that true religion can only be Christianity." despite the fact that earlier in the essay, Wagner had underlined religion's ostensible irrelevance. One could attribute this seeming iconsistency to Kühnel's observation that these essays from late in Wagner's life tend to demonstrate a dearth of "clear line[s] of thought" tending to "proceed largely by association of ideas...." ${ }^{\text {"s }}$ Even so, Wagner's reasoning makes it clear that for him it is art that drives Christianity's revival. Therefore,

\footnotetext{
${ }^{81}$ Stanley, 154.

${ }^{82}$ Jügen Kühnel, "The Prose Writings," Wagner Handbook, trans. John Deathridge, eds. Ulrich Müller and Peter Wapnewski (Cambridge, MA and London: Harvard University Press, 1992), 615.

${ }^{83}$ "Religion and Art," quoted in Stanley, 156.

${ }^{84}$ Stanley, 156.

${ }^{85}$ Kühnel, 614.
} 
it is for that reason that Parsifal can be considered an example of Kunstreligion rather than because of its employment of Christian narratives and iconography.

Parsifal's status as Kunstreligion is further solidified by its designation as a Bühnenweihfestspiel. ${ }^{86}$ The stage to be consecrated is not in a traditionally liturgical space, but in a specially constructed venue, erected as a monument to Wagner's art. The synthesis of religion and the "festival play" that is the Bühnenweihfestspiel is particularly instructive in that it goes back to the importance of festivals to the formation of national identity. As Mosse writes,

not only were [Wagner's] works to be played at certain months of the year, but they had a deeper meaning closely related to the tradition of national festivals. Performances of his works were to be removed from the cares of daily life and given an extraordinary, cultic setting in order to transform them into actual rites. Eventually Bayreuth became a national pilgrimage center. ${ }^{87}$

By positioning the performances of his works within the context of a festival, Wagner claimed for his dramas a heridity with the national spirit. Moreover, the invocation of the religiosity of the "festival play" creates a link between the sacred, the festival and national identity. ${ }^{88}$

However, Wagner's artistic and discursive efforts to glorify German art and culture did not translate to a wholesale reverence for the German people. His essay

\footnotetext{
${ }^{86}$ In fact, the Bühnenweihfestspiel designation is what prompts Nowak to position Parsifal between two of the historical methods he identified as thematizing art as an object of worship, between "religious cult" and "aesthetic cult." See Nowak, 167. Even earlier than Nowak's essay, Theodor Adorno states that Wagner's identification of Parsifal as a Bühnenweihfestspiel situates the work within the Kunstreligion aesthetic, which Adorno notes dates back to Hegel. See "On the Score of Parsifal" (1956), trans. Anthony Barone, Music \& Letters 76/3 (August 1995): 386.

${ }^{87}$ Mosse, 106-107.

${ }^{88}$ As Stanley notes, such links between festival culture, religious-based music, and German nationhood had been forged several years previous, during the "three decades until the revolutions of 1848" (154). "The emphasis on oratorios" during these festivals, featuring works by composers such as Handel, Haydn, Mendelssohn, Louis Spohr, and Friedrich Schneider "perfectly accommodated Kunstreligion theory with respect to subject matter, and crucially, to performance ensemble. Choral societies, the driving force behind music festivals, embodied Kunstreligion like no other group could. Individuals participated in collective activities that supported religious-national agendas, as well as the survival of church music itself, in crisis since the late eighteenth century." (155)
} 
"Public and Popularity" (1878) - written while he was composing the music for Parsifal - adds a necessary complication to the survey of Wagner's views on German art and its relationship to the Volk. ${ }^{89}$ There, Wagner is considerably more skeptical of the German spectator's ability to comprehend and process great works of German art. "Everything, except the good, has its Public," ${ }^{90}$ Wagner writes contemptuously, an attitude seemingly out of step with his apparent veneration of the Volk in the Meistersinger libretto. Wagner's estimation in this essay is that the German "public" only has taste for the mediocre and superficial, a deficiency caused by their constant exposure to second-rate art. The "public" has been failed by all and sundry, ranging from artists to performers, critics, theologians, and academics. As a result, the public has no capacity to truly appreciate "genius" and "good" art. Such art under the current climate has no chance of achieving popularity.

Wagner's diagnosis in this essay provides a noticeable contrast with his earlier populist rhetoric surrounding art's expression of the spirit of the people. However, one should note that at the essay's end, he draws a distinction between the "public" and the Volk: the ubiquity of mediocre art has effectively divorced the public from the spirit of the Volk. As rectification, Wagner calls for a reinvigoration of that spirit

to prepare the ground for cure of ills inevitable in the evolution of the human race...might fitly be the mission of a true Art appealing to the Folk itself, to the Folk in its noblest, and at present its ideal sense. Again, to even now prepare the ground for such an Art, sublimely popular, and at all times to prepare it that the links of oldest and of noblest art shall never wholly sunder, our instant efforts may not seem altogether futile. In any case, to such works of art alone can we ascribe ennobling Popularity; and none save this dreamt-of Popularity can react

\footnotetext{
${ }^{89}$ Although as Borchmeyer points out, the essay's composition was also partially motivated by the dissolution of the friendship between Wagner and Nietzsche, as the essay carries out "a covert but for that reason all the more unpleasant polemic" against Wagner's former disciple (339). See Borchmeyer, "Wagner and Nietzsche," Wagner Handbook, 327-342.

${ }^{90} \mathrm{SSD} X, 61 ;$ PW VI, 53.
} 
on the creations of the present, uplifting them above the commonness of what is known to-day as popular favour. ${ }^{91}$

With these words, Wagner maintains that only art that is attuned to the genuine spirit of

the Volk will properly reconcile the German public with that shared consciousness; only art that manages such a reunification will be truly worthy of popularity. ${ }^{92}$

Given the above quote, it is quite possible that Wagner intended Parsifal to be expressive of the Volksgeist. Even so, it would still be problematic to frame the Parsifal chorus as an embodiment of the Volk. What unites Meistersinger and Parsifal is their presentation of self-contained communities that stage the contemporary nineteenth century in the guise of the mythologized past. The Grail community is a hermetically sealed society located by the narrative in the distant past, but embodied on stage within another cloistered community, a shrine to German art and a site of pilgrimage for spectators to witness the sanctified spectacle. ${ }^{93}$ These purported figures of the Middle

\footnotetext{
${ }^{91} \mathrm{SSD} X, 90 ; \mathrm{PW}$ VI, 81.

${ }^{92}$ Goehr's analysis of Meistersinger essentially makes this point in that she observes that it is the judgment of the Volk that ultimately guides the Mastersingers towards their acceptance of the "Prize Song" as a genuine Mastersong. The Masters are reminded that their status does not separate them from the Volk: artisans they may be, but they are still Volk themselves. The song attains "popularity" with the "public" while at the same time "educate[s] or re-educate[s] masters through the experience of art," reminding them of what their guild's rules and traditions were designed to promote. Because of the Prize Song's ability to unite both the artists and the "public," it would appear to be an example of the kind of artwork that Wagner will call for in "Public and Popularity," one which channels the very essence of the Volk and in doing so unites the entirety of society, thereby achieving "true" popularity. See The Quest for Voice, 68.

${ }^{93}$ Wagner's famous prohibition on performances of Parsifal outside of Bayreuth I would argue serves to enhance Bayreuth's status as a centre of "national pilgrimage." The limitation of the work to a specific place located outside of one of Germany's major metropolitan centres lends a sense of remoteness to both Bayreuth and Parsifal, so that experiencing them requires a dedicated effort on the part of their spectators. This resonates within Walter Benjamin's concept of the "aura" exhuded by a work of art. The aura is defined as the work's uniqueness, its "one-of-a-kind" nature that lends it a sense of distance and unapproachability. The aura is thus framed as a marker of the artwork's "authenticity" in that it is accessible to and appreciated by only the select few that have made the effort to understand the work's greatness. For Benjamin, the byproduct of the artwork's aura is the tendency to fetishize that ostensible authenticity and the "cult value" assigned to it. Technological reproduction strips the artwork of its aura, which Benjamin deemed a worthwhile sacrifice as the resultant widening of availability democratized the work of art, allowing it to be accessible to a wider potential spectatorship. By limiting Parsifal to Bayreuth, Wagner essentially endeavoured to maintain the work's aura, to ensure that it was only accessible to the Bayreuth "cult." As such, Wagner could retain Bayreuth's prestige as a "national pilgrimage" centre and by extension its value as a shrine to the sanctity of the German artistic spirit. See
} 
Ages, by the nature of their performing space and the ideologies implanted into that space, effectively come across as the embodiment of modern concerns regarding the work of art in German culture. The Grail community, functioning as an element of a "stage-consecration festival play," will be analyzed as an example of Kunstreligion, a nineteenth-century concept mapped upon a medieval society and projected into the distant past as if it had already taken place. A community that allegorically devotes itself to Kunstreligion, I will argue, is as proleptic as Nuremberg's Volk, a community that also reframes religion as a function of art rather than theology. In both works, the discourses of Volksgeist, the festival, and Kunstreligion are all exploited to merge the sacred and the secular; in Parsifal, the Grail Knights consecrate the stage through the fusion of Christianity and staged drama, transforming the theatre into holy ground.

The final piece of this puzzle before proceeding to the operas themselves is the use of the grand opera chorus to stage the population of the nation. As previously alluded, James Parakilas has commented on the significance of the nineteenth-century opera chorus as a politicized voice of a community. Of particular interest is what Parakilas calls the "processional and ceremonial scenes" in grand opera. ${ }^{94}$ In these ceremonial crowd scenes, "the people of a nation are brought together, often in a sacred space, to join with their religious authorities in affirming or celebrating the legitimacy of their secular authorities...."95 According to Parakilas, what makes these scenes "grand" "is that the illusion of a whole nation on stage is created, not simply by huge

\footnotetext{
"The Work of Art in the Age of Its Technological Reproducibility - Second Version," The Work of Art in the Age of Its Technological Reproducibility and Other Writings on Media, trans. Edmund Jephcott, Rodney Livingstone, Howard Eiland, eds. Michael W. Jennings, Brigid Doherty, Thomas Y. Levin (Cambridge, MA and London: Belknap Press, 2008), 19-55. Stephen C. Meyer discusses the issue of aura in performance and recordings of Parsifal in "Parsifal's Aura," $19^{\text {th }}$-Century Music 33/2 (Fall 2009): 151172.

${ }^{94}$ Parakilas, "The Chorus," 86.

${ }^{95}$ Ibid., 87.
} 
numbers... but by representatives of every estate and group of the society." 96 The sonic and visual pageantry of such sequences are intensified by their tendency to alternate with the solo and ensemble pieces that carry the main narrative forward. As Carl Dahlhaus puts it, the choral scenes of grand opera function as politicized tableaux, the visual and sonic image of the assembled mass serving as an opulent counterpoint to the soloists. The "private" (plot and character) contrast with the "public" (tableau) and "it is characteristic of grand opera, that in the work as a whole, the 'private' plot that motivates the arias and duets is overshadowed by the 'public' plot manifested in tableaux." "97 For example, the political conflict between the Catholics and the Protestants in Meyerbeer's Les Huguenots is initially the backdrop for the central romantic triangle between Raoul, Valentine, and Nevers. Eventually, the private romantic plot is overtaken by the public, political one.

Dahlhaus's appraisal carries a somewhat pejorative undertone, ${ }^{98}$ but perhaps his apparent dismissiveness is erroneous: it can be argued that the processional and ceremonial scenes, resplendent set-pieces that ostensibly sublimate the drama in favour of sonic and pictorial effect, are actually crucial to the production of nationhood upon the stage. The representation of all castes of society, giving voice to the strife that is uniting (or dividing) the populace is what provides the illusion of an entire nation on stage. It is the staging of a representation of the public inside a public arena that permits notions of

\footnotetext{
${ }^{96}$ Ibid.

${ }^{97}$ Carl Dahlhaus, Nineteenth-Century Music, 128.

${ }^{98}$ And one that is not wholly accepted among grand opera scholars as David Charlton for example submits that a public-political dimension is not necessarily a taken-for-granted element of grand opera. However, Steven Huebner disputes Charlton's point by noting that two of his supporting examples (Gustave III and L'Africaine) clearly contain prominent public-political strands in their plots, although Huebner grants that Charlton's other example (Robert le Diable) is "relatively apolitical." See David Charlton, "On the Nature of 'Grand Opera," Hector Berlioz: Les Troyens, ed. Ian Kemp (Cambridge: Cambridge University Press, 1988), 99 and Steven Huebner, "After 1850 at the Paris Opéra: Institution and Repertory," The Cambridge Companion to Grand Opera, ed. David Charlton (Cambridge: Cambridge University Press, 2003), 454n10.
} 
shared cultural and political consciousness to gain a sense of solidity. When the public and private plots in grand opera fold into each other, it is a performative demonstration of the conception of the individual as part of a larger totality. The private intrigues engaged in by the soloists - such as the aforementioned love triangle in Les Huguenots - are ultimately but elements contributing to the greater reality of the collective voice of an entire community.

Even brief glances at the choral passages of Meistersinger and Parsifal reveal that they function quite effectively as examples of the processional and ceremonial scenes so common to grand opera. ${ }^{99}$ In the third act of Meistersinger, the Nuremberg citizens congregate on the banks of the River Pegnitz to witness musical performance, certainly a sacred space under at least one of the tenets of Kunstreligion. Every level of this society is brought together and by the scene's end will have celebrated their/its commitment to retaining the vitality of the city's artistic life, with praise of Sachs legitimizing him as its "secular authority." As will be demonstrated in detail below, the progression of this scene, consistent with the dramaturgy of grand opera, alternates the private with the public as the resolution of the central storyline and the various character arcs are juxtaposed with commentary from the choral crowd. But in this work, the private and public plots do not oppose each other and neither is ultimately subordinated to the other: the crowd is the ultimate arbiter that decides that Walther has won the contest, which is the payoff for Sachs' (rejected) suggestion at the earlier guild meeting at the end of the

\footnotetext{
${ }^{99}$ As Huebner observes, Parsifal proved itself to be quite musically influential on French composers as a part of Fin-de-siècle France's general embracing of Wagner. Two examples he singles out (admittedly neither composed as grand operas, nor staged at the Operra) are Vincent d'Indy's Fervaal (1895) and Gustave Charpentier's Louise (1900). See French Opera at the Fin-de-siècle: Wagnerism, Nationalism, and Style (Oxford and New York: Oxford University Press, 1999), 334-341 and 447-451. Anya Suschitszsky further discusses Parsifal's influence on d'Indy's composition of Fervaal in "Fervaal, Parsifal and French National Identity," $19^{\text {th }}$-Century Music 25/2-3 (Autumn 2001/Spring 2002): 237-265.
} 
first act. By confirming Walther's triumph, the crowd also effectively resolves the tensions of the romantic plot between Walther and Eva. Walther, Eva, and the Masters' guild then join the chorus in its praise for Sachs, a reminder that they are part of the Volk as well; the chorus has the last word, but they repeat the words that Sachs had given to them moments earlier. Contrary to Dahlhaus' characterizations of grand opera, in Meistersinger private and public are two sides of a single coin: the actions of both are predicated by those of the other and both stories ultimately work to resolve each other.

Parsifal assembles an entire society in the very definition of a sacred space: the resting place of the Holy Grail. Ritualistic processionals are intoned as the Knights enter for Communion and Titurel's funeral, before commemorating the restoration of their order to its once and future status of glory. Unlike in Meistersinger, the choral scenes take over the musical and dramatic texture for lengthy periods of time, with the soloists (Gurnemanz and Parsifal) reduced to silent bystanders. However, the private and the "public" stories - "public" being relative as in Parsifal, the ostensibly public grand opera chorus is used to depict a cloistered group located far away from human society - are integral complements of the other rather than juxtapositions. The choral processionals and crowd scenes are no mere backdrop to Parsifal's character progression and Amfortas's perpetual suffering. Rather, the private and public are once again two halves of the same story, in that both parts are ultimately about the rejuvenation of the Grail kingdom. Parsifal's journey from "pure fool" to newly-crowned king serves to restore the glory to the Grail kingdom that the chorus continually clings to through their adherence to the Communion ritual. When Parsifal heals Amfortas's wound and reveals the Grail, he banishes the miseries that had long tormented the entire community, which 
the Knights lament only moments before during Titurel's funeral procession. Meanwhile, had the Grail kingdom not been in such turmoil, Parsifal would not have had the opportunity to grow beyond that of an impetuous dullard that did not even know his own name. In setting up the contrasting performing forces of grand opera to feed into rather than oppose each other, Wagner makes a case for the population of the operatic stage in its totality as a dramatization of a nation, with soloists and chorus alike functioning as a unified organism. In the following pages, I will examine select choral scenes in Meistersinger and Parsifal, demonstrating their musical and dramaturgical links to grand opera, and accounting for how they stage proleptic communities. I will then demonstrate how the combination of grand opera, prolepsis, Kunstreligion beatifies German art and the nation.

\section{Public benedictions}

Before delving into the "Festival Meadow" scene of Meistersinger, I wish to devote some attention to the chorale opening the first act, as its musical and textual content has some implications on what occurs at the opera's end. As previously mentioned, the opening congregation is identified by Wagner as die Gemeinde (the community) rather than das Volk. Insight into the importance of this distinction might be gleaned from Wagner's stage direction:

The scene represents the interior of Saint Catherine's Church, in diagonal section; the nave is supposed to extend towards the back of the stage to the left; only the last few rows of pews are visible: in front is the open space of the choir which is later shut off from the nave by a black curtain. ${ }^{100}$

The fact that only a portion of the congregation is made visible to the audience perhaps functions as something of a tacit reminder that the participants in the service are only a

\footnotetext{
${ }^{100}$ Unless otherwise stated, all translations from Die Meistersinger are by Peter Branscombe (Decca 470 800-2, 1997). All quotations of the libretto are taken from the same source.
} 
smaller community: they are not the Volk entire. It will only be an artistic event rather than a traditionally liturgical one that will bring the entire Volk together. For Groos, the contrast between the designation of the choral forces in the first and third acts demonstrates "the change from the sixteenth-century community of the faithful represented as 'die Gemeinde' to the nineteenth-century cross-section of middle-class society, now designated as 'das Volk,' that gathers on the festival meadow."101 The congregation does not contain any signifiers unique to the nineteenth century, instead registering as couleur locale, namely "the ecclesiastical ambience of a church interior, a commonplace of Romantic opera." 102 Nevertheless this opening scene, in addition to carrying out the grand opera tendency of contrasting the public ceremonial scene of the congregational singing with the private affair that is the series of stolen glances between Walther and Eva, anticipates the musical and dramatic devices that will stage the Volk and the elevation of German art to the status of religion. I quote the text that the chorus sings during this opening segment:

Da zu dir der Heiland kam, willig deine Taufe nam, weihte sich dem Opfertod, gab er runs des Heils Gebot: daß wir durch sein' Tauf uns weihn, seines Opfers wert zu sein.

Edler Täufer!

Christs Vorläufer! Nimm uns gnäding an, dort am Fluß Jordan! $(\mathrm{I}, \mathrm{i})$
[When the Saviour came to thee, gladly took thy baptism, dedicated himself to the sacrifice of death, He gave us salvation's commandment: that we dedicate ourselves through your baptism, to be worthy of His sacrifice. Noble Baptist! Christ's predecessor! Receive us graciously by the River Jordan!]

The centralization of John the Baptist and the River Jordan in the chorale text becomes crucial to what transpires later: Groos notes that the chorale's - both the text

\footnotetext{
${ }^{101}$ Groos, 26-27.

${ }^{102}$ Ibid., 20.
} 
and the musical setting are newly composed by Wagner - identification of John the Baptist as the precursor of Christ prefigures the connection between Sachs and Walther, another example of the work's aforemention Biblical typologies "in which Biblical figures or events anticipate and are fulfilled by post-Biblical persons or activities." ${ }^{103}$ As St. John is to Christ, so Hans Sachs is to Walther von Stolzing. The opening chorale text's allusions to these Biblical figures as well as to the River Jordan functions as an anticipation of a connection that will be made more explicit during David's "Sprüchlein" in Act III, where

an explicit relationship between the names Johannes [the Baptist] and Hans [Sachs] is drawn, and the temporal gulf between the New Testament and early modern eras is transposed into the negotiable spatial pilgrimage between the Holy Land and Nuremberg, implying a typological relationship between the introductory chorale's promise of redemption at the Jordan and the promised land of the Pegnitz. ${ }^{104}$

The Biblical references of the opening chorale achieve their ultimate fulfillment in the quintet "Selige Morgentraum-Deutweise" in which Sachs "baptizes" Walther's Prize Song. I will return to this quintet shortly in the context of the public benediction of German art at the opera's end. However, the point I wish to underline here is that the mobilization of the style of the four-part Lutheran chorale in the context of a grand opera ceremonial crowd scene functions as a sonorous and dramatic anticipation of the opera's subsequent transmuting of art into religion, ${ }^{105}$ a development in which the crowd will play a crucial role in when the members of the congregation join the rest of the Volk. As

\footnotetext{
${ }^{103}$ Ibid., 24.

${ }^{104}$ Ibid.

${ }^{105}$ The use of liturgical music as a scene setting device is not uncommon in grand opera: the aforementioned Les Huguenots prominently features the Lutheran chorale "Ein feste Burg" in the first act (in both orchestral and vocal setting) to dramatize the plight of the titular group and their persecution by the Catholics.
} 
such, I contend that die Gemeinde also anticipates their eventual transformation into the proleptic community of das Volk and the commensurate triumph of Kunstreligion.

Act III, scene 5 begins with the processionals of the various trade guilds (shoemakers, tailors, bakers), followed by the Apprentices and finally the Mastersingers to the Festival Meadow on the banks of the Pegnitz. Each group enters as part of their own processional (their guild identified by name in the score). Once all have arrived the chorus is finally identified as "alles Volk" (all the people). The stage direction during this sequence specifies that "there is much merry-making," which distinguishes this gathering from the solemnity of the church service at the opera's outset. Yet, despite the jovial atmosphere (including a dance of the apprentices, approximating the customary ballet in grand opera), there remains a strong element of ceremony indicative of a nineteenth-century festival. The stage direction prescribes "ribbons and flowers" and "slender wands, also ornamented" for the Apprentices. Each group of tradesmen are portrayed as "marching up with flying banner." Compare what has just been described with Mosse's description of the processionals that opened the "Schillerfeiern" of 1859:

Sometimes such processions were enlivened by floats representing themes from Schiller's plays, and here the diverse groups carried symbols indicating their crafts. Flags were the rule of the day, and all members of the procession had to wear a common emblem. ${ }^{106}$

In similar fashion, each faction of attendees at the Festival Meadow bears a flag "indicating their craft." The various ornaments to the attendees' attire add to the sense of ceremonial festivity while also marking their status in the Nuremberg and Mastersinger hierarchy. What we witness is the makings of a grand opera crowd scene adapted to function as the dramatization of a contemporary festival placed inside the Renaissance

\footnotetext{
${ }^{106}$ Mosse, 88.
} 
backdrop. The song contest is quite distinct from standard sixteenth-century celebrations "such as imperial entries, liturgical processions, or Shrovetide parades,"107 designed to give praise to imperial and religious authorities. Instead, this festival is specifically organized to commemorate the middle-class tradesmen and artisans, subcultures that hardly carried much influence in a time-period still beholden to feudal customs.

In terms of the dramaturgy of the scene, it is significant that each group enters separately, coming across as reminiscent of the divided chorus, a ubiquitous device in nineteenth-century opera. Parakilas notes that divisions of the chorus into distinct subsets traditionally "embody the conflicting political and social forces of the drama." Typically divisions were made according to such categories as class, gender, religion, etc. According to Parakilas "in scenes of battle, public ritual, and political assembly, nineteenth-century opera presented a new image of political struggle, an image of all the constituencies of a society (represented by differentiated choral groups) assembling in one place to contend with each other for political power. ${ }^{109}$ This is closest to what occurs in the third act of Meistersinger in that all levels of the society, represented by unique choral groups, gather together in a single place. But compared to what Parakilas puts forth as one of the defining tropes of the grand opera chorus - the divided chorus as a dramatization of irreconcilable conflict between a society's constituencies - Wagner's choral divisions are rather unique dramaturgically and politically in that there are no impassable differences between Nuremberg's various cultural subsets. They come to be understood as component parts of a greater totality, a totality unified by devotion to the Mastersingers and to art. Each trade guild intones praise to their individual profession

\footnotetext{
${ }^{107}$ Groos, 29.

${ }^{108}$ Parakilas, "Political Representation," 197.

${ }^{109}$ Tbid.
} 
and their vitality to the city; that their focus is initially only on their respective trades indicates that the populace has not coalesced into a unified whole. This is complemented musically by the fact that only male voices (tenors and basses) sing out during each of these processions. There is something "missing" sonorously: the lack of female voices bespeaks an absence that demonstrates that the population has not yet become whole. The arrival of the apprentices adds altos to the mix, and then once the Mastersingers and Sachs take the stage, the entire chorus finally coalesces into das Volk. According to the stage direction and the following choral text:

(Sachs erhebt sich und tritt vor. Bei seinem Anblick stösst sich Alles an; Hüte und Mützen warden abgezogen: Alle deuten auf ihn.)

Ha! Sachs! 's ist Sachs! Seht, Meister Sachs! Stimmt an! Stimmt an! Stimmt an! (III, v)
[Sachs rises and steps forward. At sight of him all nudge each other; hats and caps are taken off: all point at him]

[Ha! Sachs! It's Sachs! Look, Master Sachs! Begin! Begin! Begin!]

The Volk react to Sachs as though he were a celebrity; in their excitement at seeing him, they are initially not able to settle down. ${ }^{110}$ Musically, their excitement is depicted through the short and terse proclamations in each voice placed in close enough proximity to create the effect of the crowd talking over each other. Finally, alles Volk manage to assemble into a cohesive sonority, greeting Sachs with a strophe from one of his own songs (Ex 3). This song is Wagner's slight modification of Sachs' Die wittembergische Nachtigall (1523), written in support of the Lutheran Reformation. ${ }^{111}$ At first hearing, the music resembles the introductory chorale in its primary use of a four-

\footnotetext{
${ }^{110}$ The Volk's excitement at seeing Sachs brings to mind Lutz Koepnick's discussion of the importance of vision in staging Meistersinger's communities in "Stereoscopic Vision: Sight and Community in Die Meistersinger," Wagner's Meistersinger: Performance, History, Representation, ed. Nicholas Vazsonyi (Rochester, NY: University of Rochester Press, 2003), 73-97.

${ }^{111}$ Groos, 30.
} 
part setting with the harmonies changing on every beat and the largely homophonic texture. But the setting diverges from standard chorale part-writing in its plethora of disjunct leaps in multiple voices, in addition to the fact that musical phrases do not come to a rest at the end of lines of text, and that the metre shifts between $4 / 4$ and $3 / 2$. The lack of caesuras after each line creates a "seamless melody, whose flow is propelled by means such as ending the first line on the leading tone and running its continuation into the next, or shifts in meter in the middle of a line." ${ }^{112}$ Metric and agogic accents also occur in the middle of phrases (an octave leap in the sopranos on "wonnigliche Nachtigall" which occurs at the beginning of the measure, but not the beginning of the line). The end result appears as an example of Dahlhaus's "yesterday and tomorrow" framework, where the sound quality of a choral harmonization is combined with more contemporary techniques of creating vocal melodies. As such, this Nuremberg is a space where the sixteenth and nineteenth centuries intermingle, lending the music a sense of temporal indeterminacy to us. In terms of dramaturgy, the presence of a chorale-like setting is consistent with grand opera: as I have previously mentioned, Les Huguenots employs the Lutheran chorale "Ein feste Burg" as a hymn of solidarity for the oppressed Protestants. This is but one example of grand opera using hymns sung by the chorus as a way to create communities on stage. However, as Parakilas notes, hymns in grand opera are typically elements of "operas that enact stories of religious strife...each side in the struggle - or at least the minority or oppressed side - is identified by its own hymn or hymns...A hymn, like a national anthem, unites a group - turns a crowd into a chorus at the same time as it marks that group off from others." 113 In Meistersinger, Wagner

\footnotetext{
${ }^{112}$ Ibid., 31-32.

${ }^{113}$ Parakilas, "The Chorus," 90-91.
} 
once again adapts a grand opera trope to serve his purposes: the Nuremberg Volk create a hymn by fusing a song/poem in praise of Sachs with some of the sonic markers of the four-part Lutheran chorale. But rather than singing this hymn as an expression of solidarity in the face of political turmoil, it is employed as a statement of commonality in the town's sincere veneration of their de facto artistic leader. The poem's and the music's associations with the Lutheran service further assists in transferring religious faith from the liturgy to the practice of art.

Ex. 3

(Die Meistersinger III/v, mm. 373-384).

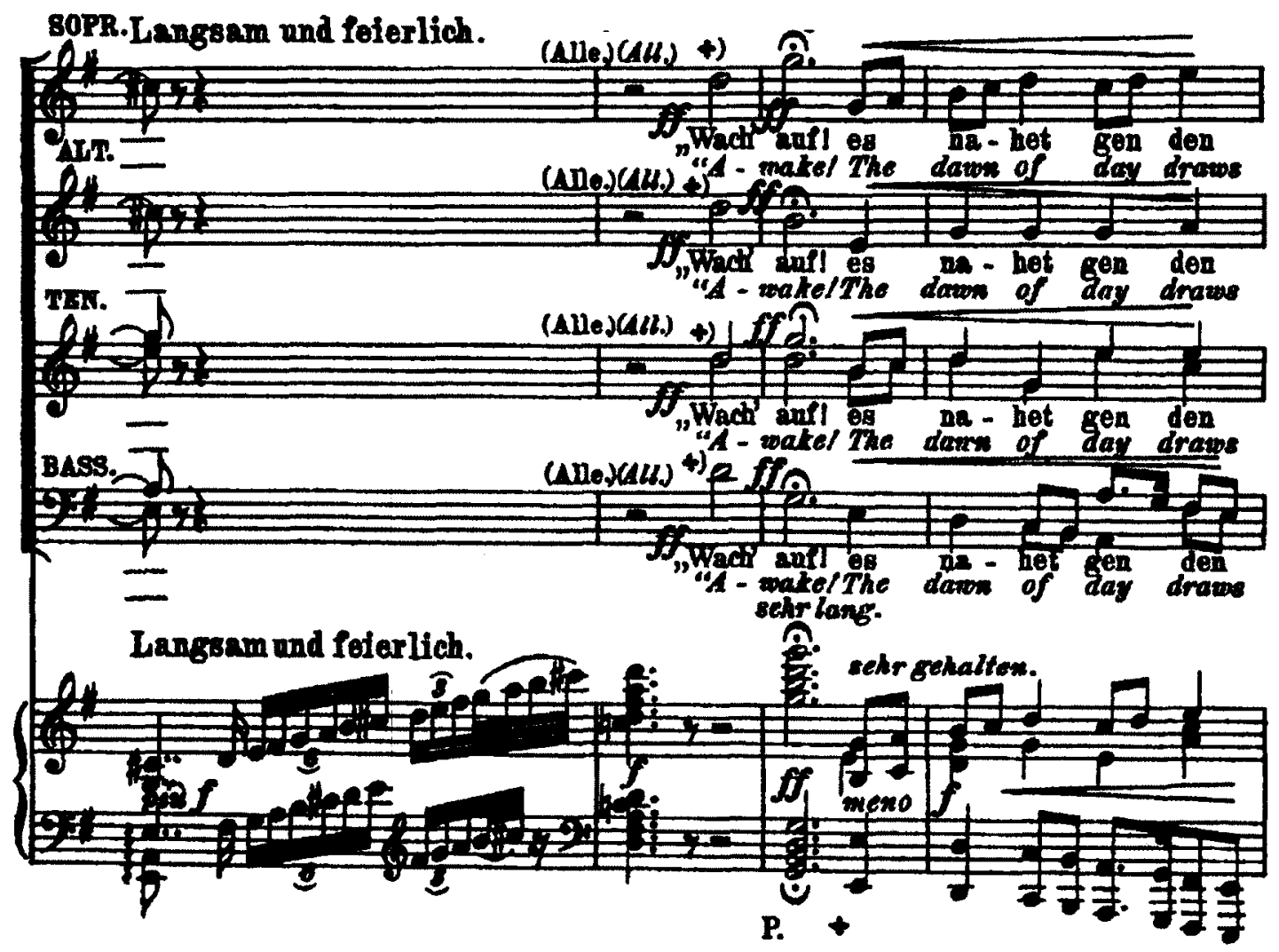



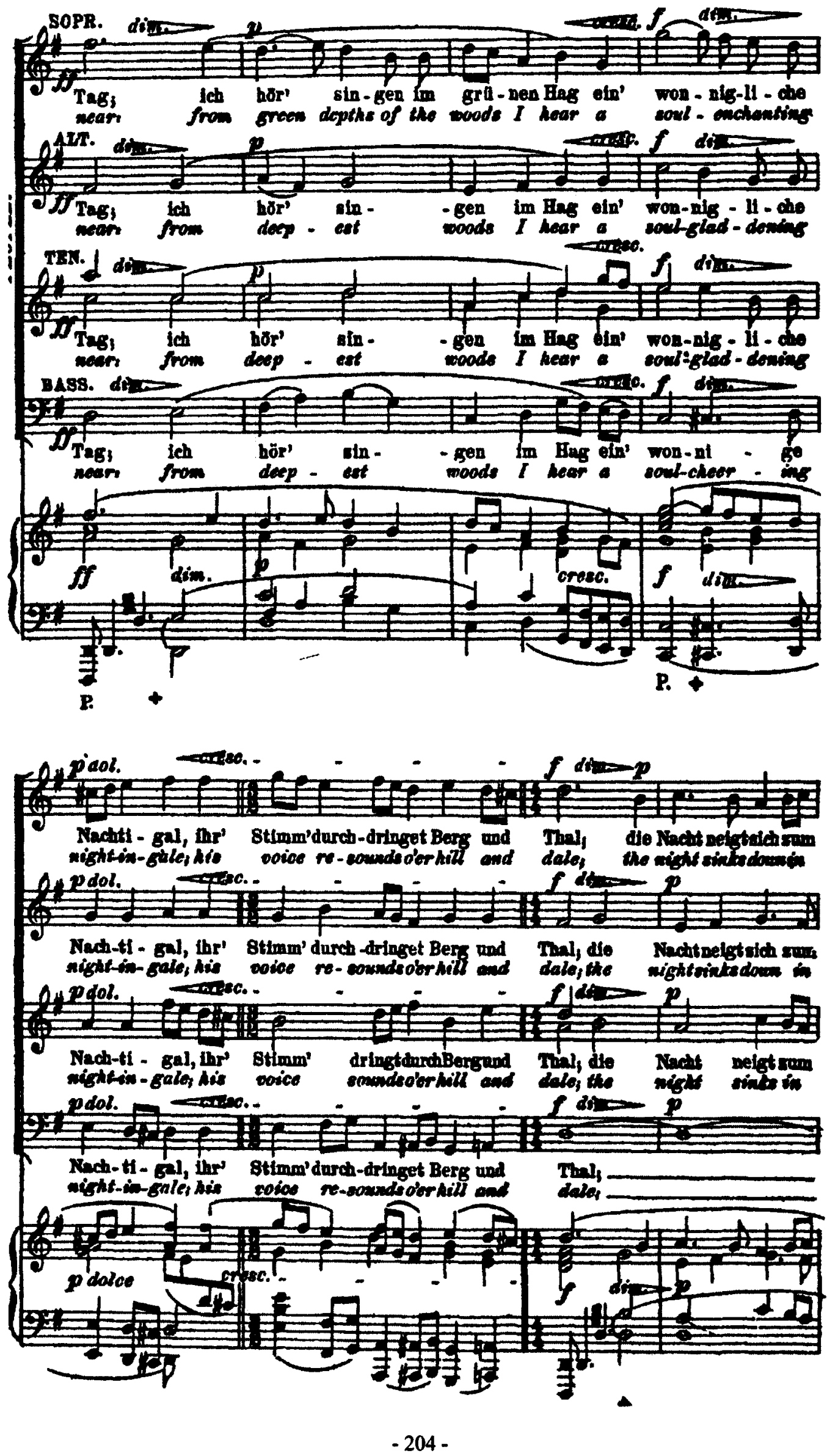
Between the strophes of Walther's Prize Song ("Morgenlich leuchtend im rosigem Schein"), the Volk voice their approval ("softly to one another") of what they are hearing. The Volk's diagnosis of the song ("so gracious and familiar, however far off it soars, but we seem to be experiencing it with him!") nearly matches Sachs's opinion of Walther's Trial Song in Act I ("so old and yet so new"). They envoice their unity with Walther by taking up the musical motives of his song in their own hymn of praise; both soloist and Volk are musically in tune with each other. The soft dynamic of the chorus shows the Volk's respect, while the melismatic vocal lines give life to the pleasure that Walther's music gives them. As they proclaim Walther the unequivocal victor, the constituent parts of the choral Volk (now divided into six parts) subject their demands for the Masters to grant Walther the prize to a series of repetitions accompanied by a gradual crescendo, while again repeating back to Walther the various musical phrases contained in the song. These musical effects suggest the collective bodily performance of a steady increase in excitement and joy.

In terms of staging, the performance and reception of the Prize Song is consistent with what Dahlhaus identifies as one of the prevailing dramaturgical traits of grand opera, the alternation of the soloists with the crowd in the guise of the chorus. But where Dahlhaus had contended that the alternation was for the purpose of juxtaposing the drama of the soloists with the tableau of the chorus, with the former eventually being folded into the latter, here they are constructed complements to each other: Walther and the Volk both play a role in resolving the central character conflict (Walther's need to prevail in the contest in order to win Eva's hand) and both have commensurate functions in the resolution of the opera's consideration of the place of German art in society. It is but 
another example of Wagner adapting grand opera conventions to suit his dramatic and aesthetic purposes.

As stated previously, the Volk's insistence that Walther has prevailed functions as the conclusion to Sachs's earlier recommendation that the citizens be the ones to judge the outcome of the contest. Borchmeyer notes that Sachs is adamant on this point because "he clearly feels that the art of the Mastersingers runs the risk of becoming fossilized and academic, and of losing its popular foundation." "114 What is more, "Meistergesang runs the risk of becoming an 'aristocratic' art, remote from the Volk, and hence of suffering the fate of all the noble arts, which is to die out."115 The only way to ensure the continued relevance of the Mastersingers, to maintain their connection to the Volksgeist and to make sure that "the festivities are not to be meaningless ceremonial and mere window-dressing...the townsfolk must be allowed to have a say...rather than simply acclaiming whatever decision the Masters have already reached."116 As it turns out, this is exactly what takes place: both the Volk and the Masters reach the same conclusions about the Prize Song simultaneously, they sing in counterpoint to each other - this is an example of the grand opera technique of the division of vocal forces once again being mobilized to dramatize consensus and unity rather than turmoil - but ultimately the judgment of the Volk holds sway, as Sachs is ultimately vindicated in his belief that only the Volk can properly determine whether art is correctly attuned to the Volksgeist. In terms of sonority, the chorus provides the more potent voice (numerically rather than dynamically) than the collected soloists that make up the Masters. Musically,

\footnotetext{
${ }^{114}$ Dieter Borchmeyer, Richard Wagner: Theory and Theatre, trans. Stewart Spencer (Oxford: Clarendon Press, 1991), 262.

${ }^{115}$ Ibid., 263.

${ }^{116}$ Ibid., 264.
} 
the more florid vocal lines of the Volk draw more attention than the rhythmically simpler contributions from the Masters. The chorus's elevated prominence serves to sonorously underline the point that it is their collective voice that prevails as the ultimate arbiter of the Prize Song's significance.

In his study of the building of the Wagnerian "brand," Vazsonyi offers a related reason for why it is essential that the populace have say over the winner. He situates the the Festival Meadow as the site of the Prize Song's "product launch," the "product" being an integral part of Wagner's brand, which promotes his music, Meistersinger in particular, as uniquely expressive of the German spirit. ${ }^{117}$ Like any publically and/or commercially distributed product, the Prize Song needs consumer support in order to be successful. For Walther to prevail, he must convince his spectators to "buy" his wares. Therefore, it is important that the Volk, embodied by the Nuremberg public provide the all-important benediction, for Walther cannot successfully build his brand as a genuine artist without the public's acceptance. To return to the language of "Public and Popularity," in Wagner's Nuremberg, the "public" have not been divorced from the spirit of the Volk, thus the art to which they grant "popularity" is not the "meaningless offerings of French and Italian opera"118 that the public Wagner complained about in the essay gravitates towards, but work demonstrating genuine creative inspiration. Vazsonyi further observes that Nuremberg's Volk is "no pre-modern body reacting 'spontaneously."'119 Instead, their behaviours and reactions are carefully constructed by Wagner to obey the needs of his storyline and concomitant ideology. In that sense, one

\footnotetext{
${ }^{117}$ Nicholas Vazsonyi, Richard Wagner: Self-Promotion and the Making of a Brand (Cambridge: Cambridge University Press, 2010), 160-165.

${ }^{118}$ Ibid., 164.

${ }^{119}$ Tbid.
} 
might look at the concept of the Volk as another instance of a carefully cultivated brand. Beyond the somewhat subversive value of discussing Wagner's peaen to art's socially revitalizing power using the language of business and commerce, Vazsonyi's framework also tacitly maintains that the Volk has no ontological basis: it is a discursive construction that requires consistent performance in order to give it life, in order to solidify its "brand."

All of the above has laid the necessary groundwork to a discussion of the opera's finale where the notions of prolepsis, das Volk, and Kunstreligion ultimately cohere in what Paul Lawrence Rose calls a "fertility rite, which not only celebrates the rebirth of the German race through German art, but also cements the Germans in racial solidarity." 120 After Walther is unequivocally crowned the victor by all and sundry and Sachs implores the entire crowd to honour the legacy of German art, the Volk repeat Sachs' words.

$$
\begin{gathered}
\text { (Alle Anwesenden - schließlich } \\
\text { auch Walther und Eva - schließen } \\
\text { sich dem Gesange des Volkes an) } \\
\text { Ehrt eure deutschen Meister, } \\
\text { dann bannt ihr gute Geister; } \\
\text { und gebt ihr ihrem Wirken Gunst, } \\
\text { zerging in Dunst } \\
\text { das heil'ge röm'sche Reich, } \\
\text { uns bliebe gleich } \\
\text { die heil'ge deutsche Kunst! }
\end{gathered}
$$$$
\text { (III, v) }
$$

[(All those present - finally also Walther and Eva - join in the people's song) Honour your German Masters, then you will conjure up good spirits! And if you favour their endeavours, even if the Holy Roman Empire should dissolve in mist, for us there would yet remain holy German art!]

The male voices commence the exhortation to honour the Mastersinger guild before being joined by the female singers. The initial phrase beseeching honour towards the Masters returns to the chorale-style four-part harmony along with the homophony,

\footnotetext{
${ }^{120}$ Paul Lawrence Rose, Wagner: Race and Revolution (New Haven: Yale University Press, 1992), 111.
} 
effectively bookending the opera by providing something close to a direct link between the finale and the opening congregation. To reiterate, where the earlier piece was an element of an explicitly liturgical context, the final chorus employs sonorities associated with the Lutheran tradition in order to illustrate the divinity of the city's artistic traditions. The chorus and the preceding monologue from Sachs serve as the final fulfillment of the Biblical allusions and prophecies voiced throughout the opera. As Groos puts it, the scene represents "the proleptic shift from the sixteenth to the nineteenth century, from religion to art, that takes place between the liturgical profession of faith at the beginning of the opera and the secular profession [of] faith in German art at its conclusion." 121

Additionally, the benediction of German art functions as the public complement to the private blessing of Walther's song in the previously-mentioned quintet "selige Morgentraum-Deutweise." Sachs's "baptism" discursively situates the Prize Song within a religious tradition, thereby attributing sacred qualities to Walther's art. As Sachs puts it:

Die "selige Morgentraum-Deutweise" sei sie genannt zu des Meisters Preise. Nun wachste sie groß, ohn Schad' und Bruch Die jüngste Gevatterin spricht den Spruch (III, iv)
["Blissful Morning-DreamInterpretation-Melody" let it be named to its Master's praise. Now may it grow big, without harm or hurt. The youngest godparent speaks the speech.]

${ }^{121}$ Groos, 30. 
Ex. 4

(Die Meistersinger III/v mm. 1092-1100)
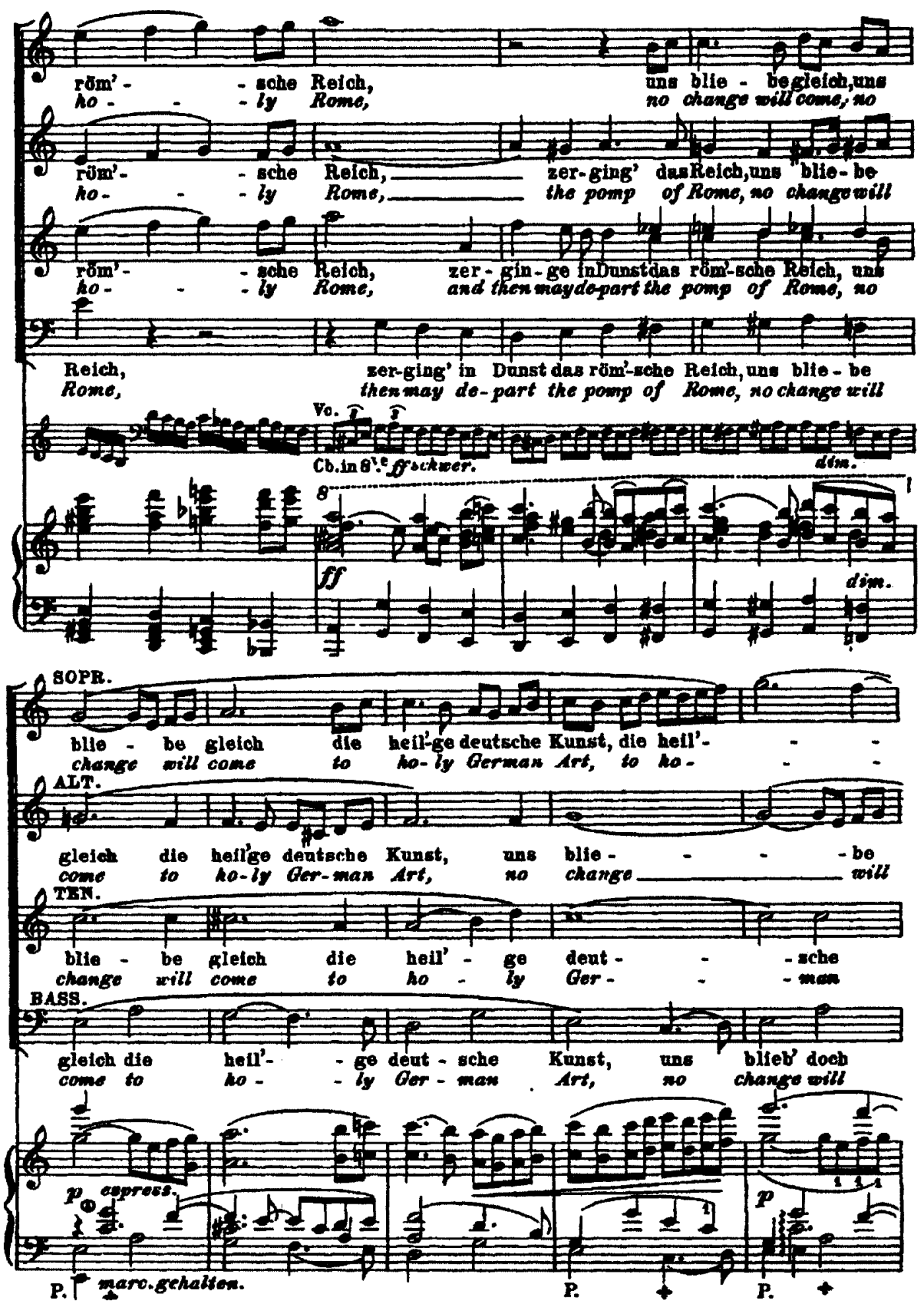
Sachs' private declaration that the work is a genuine Mastersong functions as a foreshadowing of the Volk's public utterance, which is the instrument that ultimately solidifies the notion of art's sanctity. Being a part of the Volk, Sachs can recognize the value of the Prize Song, but it is the public canonization that situates the work within the Volksgeist and constructs it as an instrument to move art into the religious realm. The necessity for the public's blessing demonstrates that Kunstreligion may be thematized as much of a "brand" as the Prize Song, the Volk, German art, etc. The initial command to honour the Masters is declaimed at the dynamic of forte, which when combined with the lower register of the male singers, conveys a perception of force and strength. The text "holy German art" features the altos and sopranos breaking out of the chordal texture and engaging in imitative figurations on the Meistersinger theme (Ex. 4), as if revelling in the joyful sounds they are producing. The effect is of a sonority that floats high above the rest, voices "elevated" into the heavens. The chorus contrasts two realms: the lower voices ground the artists within the world of the earthly, the corporeal while the upper voices raise their art to the level of the eternal, where it will acquire a majesty that will outlast the impermanence of its creators. The assembled body of the chorus produces contrasting sounds, at once powerful and graceful, earthly and heavenly. Through the sonorities of the Volk, German art is consecrated. The dramaturgy of grand opera serves to shift art into its destined role as object of worship, sacralising the secular and secularizing the sacred.

\section{Consecrating time and space}

The Grail Scenes in Acts I and III of Parsifal are at once subversions and clear examples of the dramaturgy of grand opera. In Thomas Grey's words: 
The hovering, ethereal nearly a-pulsatile music that evokes the mysteries of the Grail and its rituals is a true antithesis of the jaunty beat of those marches, chours dansés and lively ensembles that typically bring down the curtain of a grand opera...In other respects, however, even Parsifal is indebted to Wagner's earlier initiation into the world of Meyerbeer and Scribe: the central role of liturgical ceremony as a form of couleur locale, for instance, the deployment of instruments and voices off stage and on to develop a more realistic and imposing sense of theatrical space, or the elaborately painted 'cyclorama' that Wagner himself designed to illustrate the journey from the forest of Montsalvat into the temple itself in Acts I and III.... ${ }^{122}$

Even without a "jaunty" beat, the beginning of the Act I Grail scene displays an insistent quarter-note pulse of the bells and a dotted-note ostinato that accompanies the choral singing in Act I which musically suggests the parade of footsteps of the Knights as they enter the temple for Communion and the ritualistic unveiling of the Grail. Those musical steps give the scene the character of a processional. Those steps are very soft, which when combined with the aforementioned ostinatos and inexorable rhythm tend to efface a sense of forward momentum, which lends the scene the "a-pulsatile" quality that Grey discerns. These Grail rituals are also clear examples of ceremonial scenes, with the group gathered together in a sacred space. However, they are brought in concert to affirm the legitimacy not of a secular authority, but of their sacred customs. Parsifal's lineage with the traditional forms of grand opera is not difficult to ascertain, yet a case can be made that the work is many ways heightens that "grandness" especially as it pertains to the chorus. The numbers tell a significant part of the story: the 1882 performances at Bayreuth boasted a complement of 107 orchestral musicians (including off-stage brass), 23 soloists, and 135 choral singers. ${ }^{123}$ Length-wise, the first act Grail scene requires over a half-hour of performance time. Several permutations of contrasting

\footnotetext{
${ }^{122}$ Thomas S. Grey, "Richard Wagner and the Legacy of French Grand Opera," in The Cambridge Companion to Grand Opera, 342.

${ }^{123}$ Spotts, 81.
} 
sets of performing groups are spread across that time-span: solo and choral passages are interspersed with orchestral segments both short and long, and all of these contrast onstage and off-stage performing forces. Essentially Parsifal's processional and ceremonial scenes are examples of both Parakilas's and Dahlhaus's characterizations of how grand opera deploys its performers: the forces are divided into discrete groups and contrasted with each other, but unlike the (according to Dahlhaus) traditional opposition of drama and tableau (or private and public), Wagner creates something more complex. The various distinct factions do not contrast each other in schematic fashion, but are subjected to differing sequences of entries, the variety of permutations serving to present the temple as a space made up of multiple constituent parts. However, since the sundry choral groups do not engage in simultaneous vocalizing until the finale of the third act, it is a totality that has yet to achieve unity, a point that I shall explain shortly. Nonetheless, the case can be made that Wagner's division of the performers into multiple distinct blocks, continually combined and re-combined throughout the progression of the scene, represents one of the most large-scale, the most "grand" deployments of the grand opera tendency towards division and alternation of multiple groups of performers.

Gurnemanz's and Parsifal's entry into the temple in Act $I$ is preceded by Gurnemanz's famously cryptic proclamation that in the realm of Montsalvat "time becomes space," stated in response to Parsifal's observation "Ich schreite kaum/doch wähn' ich schon weit" ("I scarcely tread, yet seem already to have come far"). Gurnemanz's statement is crucial to the construction of the music that accompanies the following Grail scene. John Deathridge notes that the music throughout the opera, and in the ceremonial scenes in particular, is characterized by a sense of musical stasis: "the 
music seems purposefully to avoid forward movement, or rather to propose it at moments, only to take it back again...."124 This stasis can be read as bearing out Gurnemanz's claim for the meaninglessness of conventional conceptions of the passage of time and its commensurate relationship with the traversal through space. I submit that the protraction of time and the related dissolution of forward musical progress is an instance of portraying the Grail temple as a location that exists out of time in the same way that Wagner's Nuremberg was according to Nietzsche: the advanced compositional technique of the late nineteenth-century is placed within the context of the distant past. ${ }^{125}$ Yesterday and tomorrow concatenate, and as such there is no stable sense of a today. To reiterate, this feeds back into the notion that the residents of Montsalvat are essentially proleptic. On a more conventional level, the use of stasis for the purpose of prolongation also takes grand opera's fascination with length to another plateau. Finally, as I will demonstrate momentarily, musical distension also contributes to the Bühnenweihfestspiel's status as Kunstreligion.

As the Knights (voiced by the tenors and basses) make their entry into the temple for Communion, they initially sing about the ritualistic nature of the ceremony. This is but the latest in a long line of feasts, and that each feast will bring renewal:

Zum letzten Liebesmahle gerüstet Tag für Tag, gleich ob zum letzten Male es heut uns letzten mag.

Wer guter Tat sich freut, ihm wird das Mahl erneut: der Labung darf er nah'n
[At this latest love-feast, prepared day after day, as on the last occasion may it refresh us today.

The meal will renew him who delights in doing good: may he derive comfort, and receive the

\footnotetext{
${ }^{124}$ John Deathridge, Wagner - Beyond Good and Evil (Berkeley: University of California Press, 2008), 169.

${ }^{125}$ Anthony Barone discusses Parsifal's "advanced technique" through the lens of a consideration of Wagner's "late style." See "Richard Wagner's Parsifal and the Theory of Late Style," Cambridge Opera Journal 7/1 (March 1995): 37-54.
} 
die hehrste Gab' empfahn.

(I, ii)

supreme gift. $]^{126}$

These two stanzas are sung in their entirety doubled at the octave, and the tessitura of each couplet of text confined to an octave. Combined with the syllabic text setting and generally step-wise melodic motion, the sonorities convey an old-fashoned quality reminiscent of liturgical musics from the medieval era. The emphasis on quarter note motion puts the Knights' vocalizations in time with the constant pulse of the bells. The impression is that of the vocal music as an accompaniment to walking, what the Knights sing as they make their way into the temple and to the feast tables.

But it is the choral passages that immediately follow the initial declamations of the Knights that offer the first hint of the scenic complexity and of how the use of grand opera might end up consecrating the stage. Although the very beginning of the act employed off-stage brass, it is this scene that commences the most elaborate use of the contrast between on-stage and off-stage musical forces. Two additional choirs are called for: Jünglinge (youths), consisting of altos and tenors, and Knaben (boys), made up of sopranos and altos. These choirs are intended to be placed at differing heights above the stage, representing the different levels of the temple dome, with the Jünglinge choir designated as residing "aus der mitterleren Höhe der Kuppel" (from halfway up the dome) and the Knaben placed "aus der äußersten Höhe der Kuppel" (from the summit of the dome). These are unseen voices, which in Katherine Syer's words, convey the "sense that the meaning of the Grail extends beyond the phenomenal level, beyond the visible

\footnotetext{
${ }^{126}$ All translations from Parsifal by Lionel Salter (Decca 470 805-2, 1970). Quotations from the libretto are derived from the same source.
} 
and immediate realm of experience."127 The alignment of the various voices in terms of verticality is also instructive:

Anchoring the spectrum of vocal registers, and grounding the communal realm of the visible earth-bound knights (tenors and basses), is the bass Titurel. This framework of unseen voices is inextricably tied to the Grail: the choral conglomerate of voices in the dome functions as ambassador and even spokesperson for the Grail and the undisclosed redeemer with which it is associated, while Titurel, once keeper of the Grail, clings to life through its power...The extended musico-theatrical space reveals itself by this means to be an intricate system of interconnected levels through which we can overcome the barrier of the Grail's ineffability and feel its rejuvenating forces. ${ }^{128}$

Syer suggests that the "earth-bound" nature of the on-stage choir voicing the Knights is connected to the Grail through the "elevated" voices (both in terms of timbre and spatial location) in the dome, which because of their lack of visible performing bodies seem to emanate from a realm beyond the corporeal. Yet that ineffable realm is contained within the same physical structure as the Knights: the Grail temple in the context of the drama, and the Bayreuth stage in terms of the performance. In the former context, the Grail is the nexus between two seemingly separate spheres; in the latter case, I would contend that the "Grail" can be metaphorically transferred to the German artwork that will consecrate the stage through the ultimate union of these previously differentiated spheres.

But in the Grail scene of the first act, the spheres remain differentiated and the final consecration will have to wait. To quote Ryan Minor about the status of the chorus in Parsifal:

There is a notable contradiction, however, between the insignificance of the chorus in furthering the action and the significant amount of time it spends singing. As we shall see, the chorus's minimal dramatic contribution holds

\footnotetext{
${ }^{127}$ Katherine R. Syer, "Unseen Voices: Wagner's Dramatic Shaping of the Grail Scene of Act I," $A$ Companion to Wagner's Parsifal, 177. Syer's essay is a reworking of ideas presented earlier in Altered States: Musical and Psychological Processes in Wagner (PhD diss., University of Victoria, 1999), 137 187.

${ }^{128}$ Syer, "Unseen Voices," 178
} 
relatively true to Wagner's treatise Opera and Drama, whereas its steady vocal presence violates the treatise's tenets altogether. In fact, it is in the chorus's music that its unimportance as a dramatic participant is ultimately claimed as its supreme virtue. But such a claim is also one of contention, with two opposing ideals of the chorus represented by the knights of the Grail and the disembodied treble voices which periodically sound from the heights of the temple's dome. In a telling detail that illustrates this contended vision of choral agency, the knights' chorus veers off from the central musical narrative, whereas the treble voices from above strictly adhere to it. ${ }^{129}$

Minor's evaluation of the chorus's relative dramatic insignificance is dependent upon the fact that very little of what the chorus sings does much to contribute to the storyline, while consuming a considerable amount of performance time. I would propose to modify Minor's terminology and state that the chorus has little narrative importance, but is quite momentous in terms of dramaturgy. The contrast of on-stage and off-stage choruses is a prominent example of the techniques of grand opera being put to use, comparable to the Pilgrim's procession in Act III of Tannhäuser, which progressed from off-stage to onstage. Furthermore, the relatively miniscule narrative weight granted to the chorus aligns with Dahlhaus's identification of the tableau features of the grand opera chorus, which acts contrapuntally to the soloists carrying the story. However, these scenes do not function as a demarcation between private and public in the traditional sense. All participants are part of a cloistered community, with Parsifal and later Kundry (who remains silent during the third act) as the only outsiders. That both soloists and chorus take part in a secluded ceremony, performed on a public stage, offers a different relationship between private and public in the staging of grand opera, and as I will explicate shortly, it is the use of grand opera and its attendant tensions between private

\footnotetext{
${ }^{129}$ Ryan Minor, "Wagner's Last Chorus: Consecrating Space and Spectatorship in Parsifal," Cambridge Opera Journal 17/1 (2005): 3-4.
} 
and public that is especially important in staging a consecratory play. As such, the chorus plays a crucial dramatic role in Parsifal even if it does little to advance the story.

Having said that, Minor's identification of the "opposing ideals of the chorus" is important to how one interprets the relationship between the chorus and the eventual consecration of the stage. He points to the fact that while the upper voices in the dome almost exclusively employ the main motivic material from the opera, the Knights frequently diverge from it. This suggests that the earth-bound voices of the Knights are out of alignment with the otherworldly voices of the dome, a lack of unity that is borne out by the textual content of the service. But to backtrack to the initial entry of the offstage voices, the Jünglinge chorus sing about Christ's original sacrifice that redeemed the world's prior sins and how the ritualistic enactment of Communion keeps the spirit of the Redeemer alive (Ex. 5):

Den sündigen Welten, mit tausend Schmerzen, wie einst sein Blut gefloßen dem Erlösungshelden sein und mit freudigen Herzen mein Blut vergossen.

Der Leib, den er zur Sühn' uns bot, er liebt in uns durch seinen Tod. (I, ii)
[As once His blood flowed with countless pains for the sinful world - now with joyful heart let my blood be shed for the heroic Redeemer. His body, that He gave to purge our sin, lives in us through His death.]

The voices elevated by their physical location above the remainder of the ceremony are similarly elevated sonorously, with upper registers emphasized. In particular, the tenor voices of the Jünglinge sing in a notably higher tessitura, reaching a G-flat above middleC immediately after their initial entry: the tenor portion of the Knights has so far only reached a minor third above that particular pitch. As a result, the tenor voices in the 
dome are of a piece with the upper sonorities of the altos. ${ }^{130}$ The chorus' lack of any recognizable bass sonorities stage the Jünglinge as less "grounded," less earth-bound than the voices of the Knights. This sonorous gesture immediately contrasts the two choral forces, as the Jünglinge's elevated sounds grants them an ethereal, "heavenly" timbre, spatially removed from the Knights, a sonority so different from what had been previously heard that it seems to emanate from another realm entirely.

\section{Ex. 5}

(Parsifal L/ii, mm. 42-47)

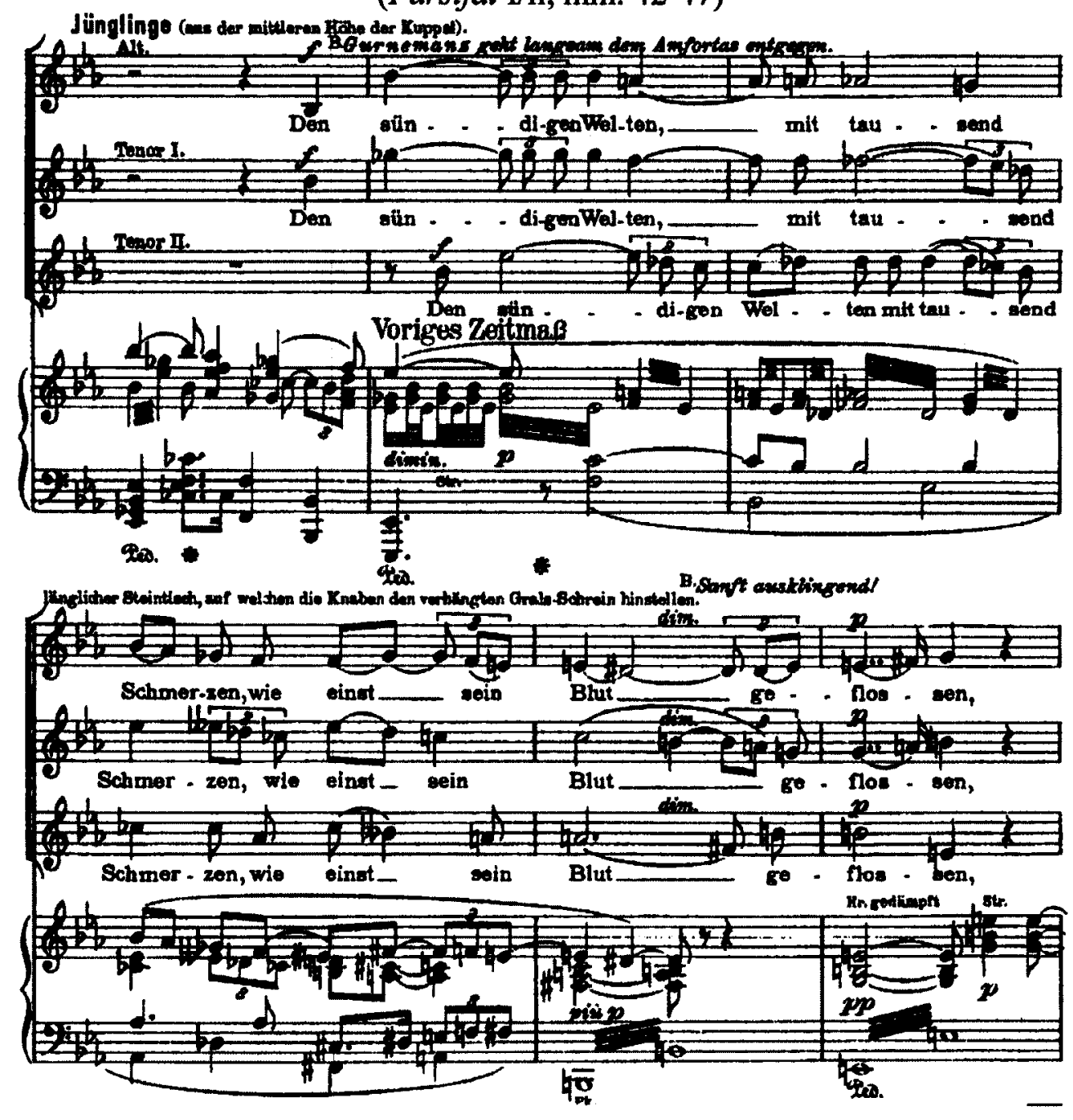

\footnotetext{
${ }^{130}$ This does not hold completely true throughout the entire scene, as for example the Jünglinge tenors will traverse some of the lower tessituras that the Knights do, but the point stands that the vocal range of the offstage voices at their initial entry strikes an immediate contrast with what has already been heard.
} 
As it turns out, the voices in the dome are removed in other manners: as stated by Minor, the vocal music of the Knights frequently veers away from the motivic material of the opera, while the dome voices adhere to it. This is borne out right away when the tenors, on the text "sündingen Welten" declaim a portion of what was dubbed by Hans von Wolzogen as the "Heilandsklage" (Savior's lament), which first appears in the Act I prelude and takes on the meaning ascribed to it "in connection with its texted appearance during Parsifal's identification with Amfortas in the second act." ${ }^{\text {131 }}$ In particular, the tenors take up the chromatic turn figure (albeit in rhythmic augmentation and with some of the melodic intervals modified) while the other voices mobilize the chromatic descents and triplets of the rest of the motive. The chorus repeats the Heilandsklage on the text "dem Erlösungshelden sei nun mit freudigem Herzen mein Blut vergossen." By connecting a musical theme that will soon to be associated with the suffering of Amfortas with Christ's original Passion, the voices of the dome link the suffering of one with that of another. As Ulrike Kienzle observes, a theme that Wagner had presented in the prelude as "a ponderous lament and in the Transformation music as a dramatic outburst now sounds in an atmosphere of mysterious sanctity and prophecy."132 The references to the flowing of the blood and the Redeemer presage the miracle that closes the opera as Amfortas's wound is closed by the very spear that inflicted injury on both him and Christ. In this sense, the Grail community mirrors what Groos referred to as the "typology" of the Nuremberg of Die Meistersinger: where the Prize Song functioned as the fulfillment of a Biblical prophecy that linked John the Baptist's blessing of the land at the River Jordan with the Song's redemption of German art, the disembodied voices of the dome

\footnotetext{
${ }^{131}$ Ulrike Kienzle, "Parsifal and Religion: A Christian Music Drama?" in A Companion to Wagner's Parsifal, 117.

${ }^{132}$ Ibid., 121.
} 
anticipate the physical healing of Amfortas and the concomitant spiritual renewal of the entire community. The redemption of the Grail community achieves its momentous status through its historical and symbolic continuity with the original redemption of mankind that laid the groundwork for the Monstalvat community in the first place.

As can be inferred through the fact that the dome voices intone texts that reach back to Biblical times, their sense of dislocation is also temporal as well as spatial: they exist outside of linear conceptions of time, keeping the distant past alive while linking it to the present. The voices of the dome are the primary embodiment of Gurnemanz's claim for time becoming space inside the temple. The slippery chromaticisms of the Jünglinge's vocal lines, combined with the harmonic instability as the tonality moves between E-flat and E, wavering between major and minor modes effaces any sense of forward progress. The restless harmonic motion creates a lack of a stable sense of musical place. Goal-directed progress is decentred, creating an example of what Deathridge calls "motion through motionlessness." ${ }^{\text {"133 }}$ Harmonically advanced music merges with text that references a moment from the distant past while speaking to that moment's prevailing redemptive power. Past, present, and future are fused by these invisible voices sonorously and textually and as a result their sense of temporal and spatial dislocation counter-intuitively grants them a sense of timelessness. Because time and space collapse into each other in their realm, with notions of directional motion effaced, they are eternal. They are thus separated from the procession of the Knights, who are concerned chiefly with the here and now of the current feast-day. ${ }^{134}$

\footnotetext{
${ }^{133}$ Deathridge, 170.

${ }^{134}$ At the end of the initial Jünglinge passage, the harmony will finally settle on E-flat major, but this will only serve as a pivot into the A-flat major tonality of the next section of music.
} 
Temporal, spatial, and musical dislocation is increased with the entry of the Knaben chorus situated at the upper level of the dome. Their initial proclamation explicitly ties the original redemptory act described by the Jünglinge with the Communion ceremony (Ex. 6):

Der Glaube lebt; die Taube schwebt, des Heilands holder Bote.

Der für euch fließt, des Weines genießt und nehmt vom Lebensbrote! (I, ii)
[The faith endures, the dove, the Saviour's loving messenger, hovers. Drink the wine poured out for you and take the bread of life!]

Ex. 6

(Parsifal L/ii, mm. 66-70)

Knaben (man der tubtersten Häbe der Kuppol).

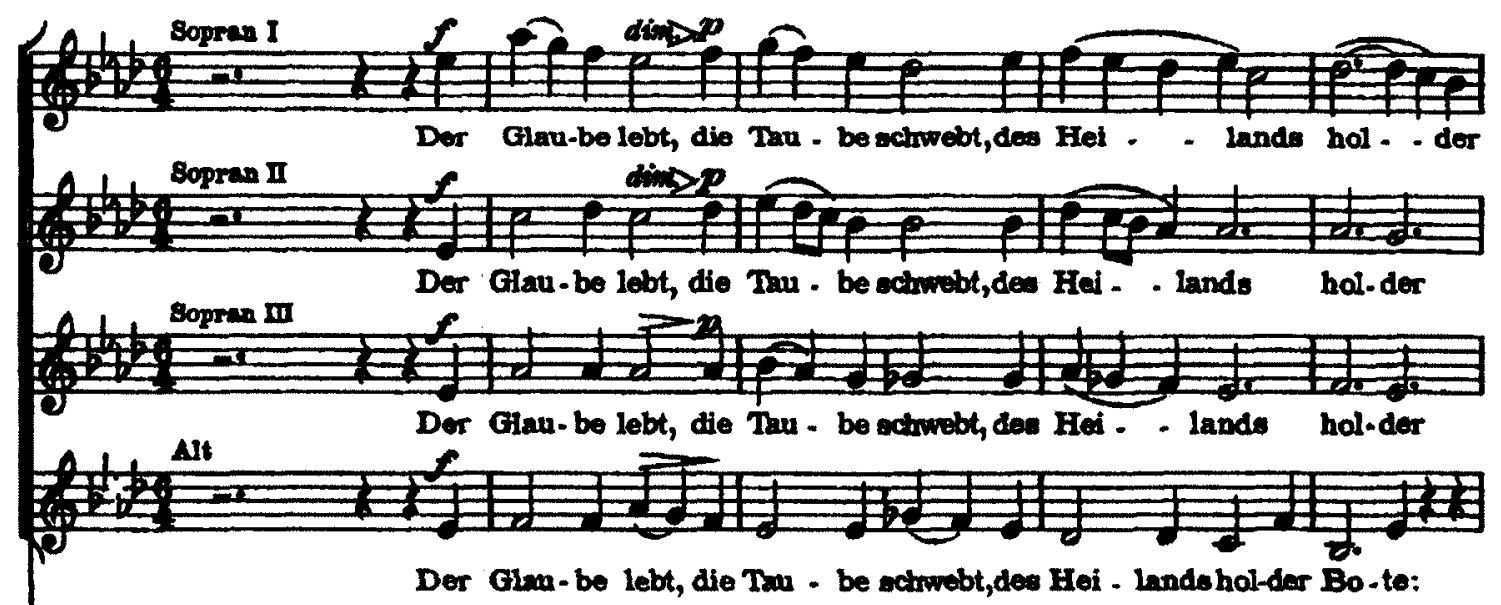

Appropriately enough, the Knaben employ the Faith motive throughout this passage,

bonding the feeling and expression of belief with the meaning of the Communion ritual, the endurance of the faith being the primary element that keeps the redemptive potential of the service alive. Once again, the association of thematic material with the off-stage voices contrasts with the so-far non-motivic music of the on-stage Knights. As the scene progresses, the dome voices will continually underline the symbolic import of the ceremony, while the Knights simply describe their actions as they perform the ritualistic activities that constitute the service. 
To return to the music, the Knaben, situated at the top of the dome, are comprised solely of sopranos and altos, divided in this particular passage into four parts (three soprano parts and one alto part). These are the highest voices heard so far, an appropriate sonorous analogue to their placement at the highest level of the set. ${ }^{135}$ The initial entry of the Knaben sings entirely a capella. Syer writes that the "extreme shift in instrumentation, following the unstable metrical and harmonic preparatory elements...calls attention to the shift from one unseen chorus to the other." ${ }^{\text {136 }}$ The entry of the Knaben is marked as an important sonorous event through the prominent shift in timbre and orchestration: that this chorus sounds so different from what has preceded bestows a dramatic import that will have implications on the rest of the opera, particularly in terms of the musical consecration of the stage and its attendant relationship to Kunstreligion, as we shall soon see. But for the present moment, the timbral change is efficacious in conveying a sense of further dislocation, a feeling of a greater remove from the other voices heard up to this point. Without the presence of an orchestra, the passage is completely absent of bass sonorities, which is in contrast to the Jünglinge section, whose orchestral accompaniment featured noticeable bass. As a result, these voices are even less grounded than what has been heard before, at a greater remove from everything heard before. They hover high above all and sundry, an acoustic trace of a non-terrestrial realm, voices simultaneously elsewhere and everywhere.

\footnotetext{
${ }^{139}$ As Minor points out however, "Wagner's division of the treble voices across various heights in the dome is a nice touch, suggesting levels of ethereal presence, but it is unintelligible in performance; the effect is simply one of treble voices from above (4n)." It is left to the sonorous distinctions between sopranos and altos to articulate the differences between the varying heights of the dome. The higher voices Knaben register as being at the top, and as such the Jünglinge come across as emanating from the mid-level of the dome.

${ }^{136}$ Syer, 190.
} 
The spatial dislocation is complemented by a displacement of temporality, albeit in a different manner than that employed by the Jünglinge. The first sopranos traverse a descending sequence based upon the aforementioned "faith" motive, essentially a reprise of a high-woodwind dominated sequence in the prelude. The other voices also make use of this motive at descending levels, but not in continuous sequence. A cadence on "Bote" is overlapped with an entry by the altos on "der für euch" that begins an ascending sequence of the "spear" motive, imitated at the octave one measure later by the top soprano voice. The apogee of that ascent brings the music in each voice back to the level of their initial entry and the descending "faith" sequence begins anew, culminating in a perfect authentic cadence as the orchestra re-enters. The sequential nature has the effect of seemingly breaking down conventional experiences of the progression of time: the sequence could conceivably continue indefinitely in an infinite loop that effaces forward motion. In terms of melodic and harmonic progression, time stands still. Complementing this effect is the ever-present G-flats in the inner voices throughout the passage, lending the music a Mixolydian tinge. When combined with the four-part harmony typical of a chorale setting (albeit in an arrangement distinct from the usual SATB) this brief passage is in a sense laden with the weight of the history of churchbased choral singing. Multiple eras of the musical past intermingle.

The musical, spatial, and temporal displacement of the unseen dome voices from those of the Knights is illustrative of a fissure that is ultimately deleterious to the wellbeing of the community itself. As has been previously mentioned, throughout the majority of the scene the Knights conspicuously avoid the use of motivic material, while the treble voices use it almost exclusively. We have already heard the Heilandsklage and 
the Faith motive; in due course, the treble voices will also intone the themes for Communion, "Mitleid" (compassion) and the Dresden Amen.

Ex. 7

("Mitleid" theme)

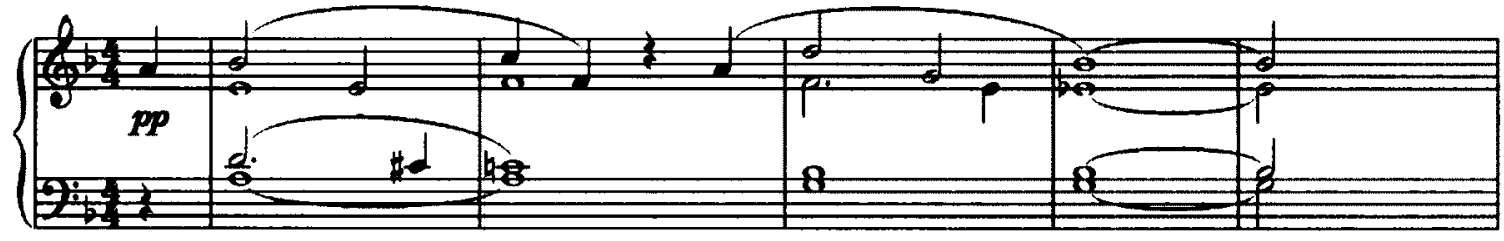

This musical detail maps onto the evident divergence of priorities that the sundry residents of the temple maintain with regards to the health of the Grail community. During the Act I communion, "the knights are entirely unconcerned about the 'Schmerzensfigur' in Amfortas's side, provided he perform his ritual duty." ${ }^{\text {137 The }}$ entirety of their texts concern themselves with the procedures of the ceremony, with no mention given to Amfortas's wound and his attendant suffering. Their indifference to the plight of their king is made even more manifest during the Act III processional, where the Knight's anguish is localized entirely around Amfortas's refusal to uncover the Grail during Communion. The words emanating from the dome offer a telling contrast: while they pay no obvious heed to Amfortas's continued torment, existing outside of conventional time as they do, their vocalizing emphasizes the symbolic links between the rituals of the present-day service and their forebears in the original communal and sacrificial acts. While the temporal-bound Knights vocalize their devotion to the carrying out of ritualistic actions to the exclusion of all else, the dome voices concern themselves with the metaphorical meaning of those acts, their historical lineage and their continued vitality to the world entire. Moreover, by not being bound to the strictures of

${ }^{137}$ Minor, 7-8. 
conventional time, the denizens of the dome consistently vocalize (textually and musically, the latter in the form of the aforementioned "Mitleid" motive) the prophecy of Montsalvat's redemption by the "pure fool enlightened through compassion," as though their existence outside of linear time grants them the knowledge that the culture's rejuvenation is inevitable. ${ }^{138}$ Minor summarizes thusly:

[The knights'] lack of interest or sympathy concerning Amfortas and his wound suggest that the knights, though clearly important members of the Grail community, have become disconnected from the Grail space and the affairs of its patriarch. Their only concern is that he continue to perform communion. Though unsympathetic to the wound, they are themselves its most damning product: avatars of time, out-of-sync congregants who sing not the infected, labile music of ruler and realm but their own transformation of it. Paradoxically, their lively march figures as the music of decay; its strong verve marks a communal vitality at odds with the prevailing sanctity - and sickness - defining Monsalvat. ${ }^{139}$

The posited fracture between the two spheres of the Grail community demonstrates a narrative example of the increasing decay and ossification of the culture that Deathridge attributes to the music's dissipation of forward momentum. ${ }^{140}$ Because of their physical removal from the main action, Minor sees "the treble voices of the dome as symbols of the fractured Grail space [while] the knights on stage function as agents of time."141 But as my own interpretations have suggested, the contrast of the two spheres is not quite so Manichean, as time and space mutually implicate in both realms. Musically, the general avoidance of thematic material on the part of the knights further underlines

\footnotetext{
${ }^{138}$ This prophecy is well known to the entire community, as Gurnemanz refers to it earlier in the first act (accompanied by the appropriate musical motive). But perhaps it is the increased numbers of the chorus combined with their described spatial and temporal dislocation that grants the prophecy a greater sense of weight, as if the disembodied, ethereal sonority conveyed a feeling that the redemption of the order was a matter of destiny.

${ }^{139}$ Minor, 9.

${ }^{140}$ Deathridge, 170.

${ }^{141}$ Minor, 9.
} 
the disharmony that currently plagues the community, ${ }^{142}$ dovetailing with the spatial and temporal displacement separating the two realms. That the dome voices present the major themes essentially in the guises originally heard in the prelude or earlier portions of the act, while the Knights avoid that material or heavily modify it suggests a sonic analogue of the narrative point that the unseen voices are attuned to the spiritual, mythological, and historical significance of the community, while the stage-bound voices are locked into matters of the present.

Such forms of dislocation hold true for most of the act, the gulf remaining unbridged. However, as the communion service and the act reach their conclusion, a betokening of what is to come at the opera's climax is offered: the Knights, the Jünglinge and the Knaben declaim permutations of the following text:

Selig im Glauben!

Selig im Glauben und Liebe!

$$
\text { (I, ii) }
$$

[Blessed in faith! Blessed in faith and love!]

These lines are set to the Grail theme, and sung by all the choral forces in imitation, progressing from the lowest voices to the highest, ascending from the earthbound, embodied voices to the disembodied, spiritual plane. The effect is reminiscent of that of the chorus at the conclusion of Meistersinger, where the upper voices similarly "floated" above the more earthly basses and tenors. According to Syer, "we are reminded that the Grail service symbolizes cyclical processes of renewal that richly unfold through time and space. Hence Wagner summarizes here the idea of registral ascent strongly

\footnotetext{
${ }^{142}$ Albeit with one major exception up to this point: during the initial procession as the knights enter the temple, they sing a form of the Communion theme, heavily transformed into the character of a march. Additionally, the theme is subjected to melodic inversion. As Minor notes, during the majority of the scene "the knights make the communion motif their own, whereas the voices in the dome repeat it unchanged." (10) For Minor, "that both choruses sing music based on the same theme underscores their essential unity and their essential difference."
} 
interconnected with the progression from visible to unseen sources of sound."143 Moreover, it is the only segment during the entire act when all choral forces are heard in simultaneity, a moment that anticipates the climax of the third act. As Minor writes, "the effect is one of elevation, symbolic of the uniting of earthly and heavenly spheres central to the act of communion." 144 The combining of vocal forces prefigures the re-unification of the fractured space-time of the Grail temple that will mark the community's rebirth under Parsifal's stewardship, a re-unification that will ultimately result in the consecration of the stage that the opera has been building towards, a benediction that ties into Kunstreligion. After the service has ended and the Knights (and Gurnemanz and Parsifal) have filed out, the dome voices get the act's last word, commencing with a solo alto voice "aus der Höhe" ("from the heights") restates the "Mitleid" theme, foretelling Parsifal's role in the upcoming renewal of the community. The dome chorus immediately follows, providing one last statement of the Grail theme, the mid-height voices supplying the "Communion" theme fragment while the upper voices take up the Dresden Amen, their final sustained pitches notated as "verhallend" (“dying away"), as if disappearing into the ether whence they came. That the "heavenly" disembodied sonorities bring the first act to a close suggests that it is these ethereal, off-stage voices that will be crucial to the upcoming consecration of the stage.

To sum up, for the majority of the first act, the grand opera tendency towards contrasting on-stage and off-stage forces is exploited to depict a culture that is fundamentally divided spatially and temporally. But the brief period at the act's conclusion where on-stage and off-stage, embodied and disembodied resound together

\footnotetext{
${ }^{143}$ Syer, 213.

${ }^{144}$ Minor, 9.
} 
anticipates a merging of distant past, present, and future into a contiguous whole. The placement of the choruses on the stage of the Festspielhaus is crucial towards allowing the community of Montsalvat to be framed as a proleptic stand-in for the contemporary German populace. Indeed, as I will argue shortly, the merging of on-stage and off-stage forces is what allows the boundaries between narrative and spectator spaces to be breached. As a result, the benediction of the Grail order and the Bayreuth audience occur simultaneously: the Knights and the audience effectively become one and the same. The distant past extends from the stage to the audience while conversely the contemporary audience is projected into the depiction of the past taking place on stage. Musically, that which lends and will lend credibility to the supposition that Montsalvat is essentially proleptic is the prominence of the themes for the Grail, "Mitleid," and Communion. The Dresden Amen portion of the Grail theme, a ubiquitous motive in nineteenth-century German musical culture, becomes associated with the Holy Grail and when placed within the Festspielhaus, can be regarded as a sonorous testament to the sacramental quality of German art, the "Grail" being thematized as the acoustic representative of the contemporary German artwork placed within the context of medieval Spain. The Mitleid motive is prophetic: the redemption of the Grail community occurring in medieval times anticipates the related redemption of the contemporary German culture. Finally, the Communion theme, present on its own and as a fragment of the Grail theme will tie all and sundry to the importance of community: the consecration of German art and the renewal of communities past and present will be shown to be mutually implicated. All of this is and will be accomplished through the deployment of grand opera dramaturgy. 
The final chorus of Act III, after Parsifal has healed Amfortas's wound and uncovered the Grail after its lengthy concealment, is arguably the moment where the stage is finally consecrated through the nexus of grand opera, the proleptic community, and Kunstreligion. In this sequence, all previous conflict and turmoil is dissipated; all of the preceding chromaticisms are banished in favour of what Deathridge calls "endlessly consonant harmonic progressions." ${ }^{145}$ The Knights, the Jünglinge, and Knaben choruses engage in numerous repetitions of the following text:

Höchsten Heiles Wunder! Erlösung dem Erlöser!

(III, ii)
[Miracle of supreme salvation! Redemption for the Redeemer!]

As it was at the close of Act I, the music is imitative with the points of imitation close enough for all registers to overlap at several junctures. The passage (Ex. 8) begins with the "Mitleid" theme as the divination of "holy fool enlightened through compassion" has finally come to pass. Tellingly, the downward leap of a tritone on "Höchsten," a sharp melodic dissonance that characterized previous declamations of the motive has been smoothed over into that of a perfect fifth for the finale, a melodic counterpart to the endless harmonic consonance that Deathridge alludes to and the concomitant expulsion of musical and narrative conflict. The text "Erlösung dem Erlöser" is set with a series of imitations on the ascending front portion of the Communion theme, the order of entries climbing from lowest to highest, complementing the similar sequence on the Dresden Amen at the conclusion of Act I: essentially, the two halves of the Grail theme are bookended. To reiterate, on-stage and off-stage voices are now no longer mobilized to

\footnotetext{
${ }^{145}$ Deathridge, 169.
} 
juxtapose contrasting spaces and opposing communities in the prototypical grand opera manner. Rather, at the work's climax, on-stage and off-stage merge as a unified choral body, a payoff to the foreshadowing provided by the conclusion of the first act. What was previously mutually divorced has now become a single unified space. Commensurately, the distinct temporalities of the two spheres have folded into each other: past, present, and future have fused, so that there is truly "no today" in this physically and spiritually replenished realm. Recalling Syer's point that the Grail space is portrayed as extending beyond immediate realms of experience, we might conclude that the consecration of the stage is achieved through the merger of embodied and disembodied voices, with the dramaturgy of grand opera employed to place sacred, otherworldly voices inside the theatre - magical sonorities that emanate from beyond the corporeal realm, "blessing" the stage with the majesty of their sounds and their ultimate message of redemption. In a similar tactic to Meistersinger, the register of the voices in the dome hover high above the rest, as though the metaphysical has encroached upon the physical. This point should not be underestimated, for as Minor notes, "if the chorus now sings as one, it is according to the terms of the voices from above."146 Ultimately the dome voices, out of phase with physical space and linear time, will be the instrument that sanctifies the Grail space and the Bayreuth stage. The transmuting of the metaphysical into sonority is the most vital element in the creation of the Bühnenweihfestspiel and the transformation of art into religion. Existing outside of the action, observing and commenting on it, the dome voices have the last word and as such, the opera effectively "closes with a chorus of spectators." 147

\footnotetext{
${ }^{146}$ Minor, 25.

${ }^{147}$ Ibid.
} 


\section{Ex. 8a}

(Parsifal III/ii, mm. 248-250)

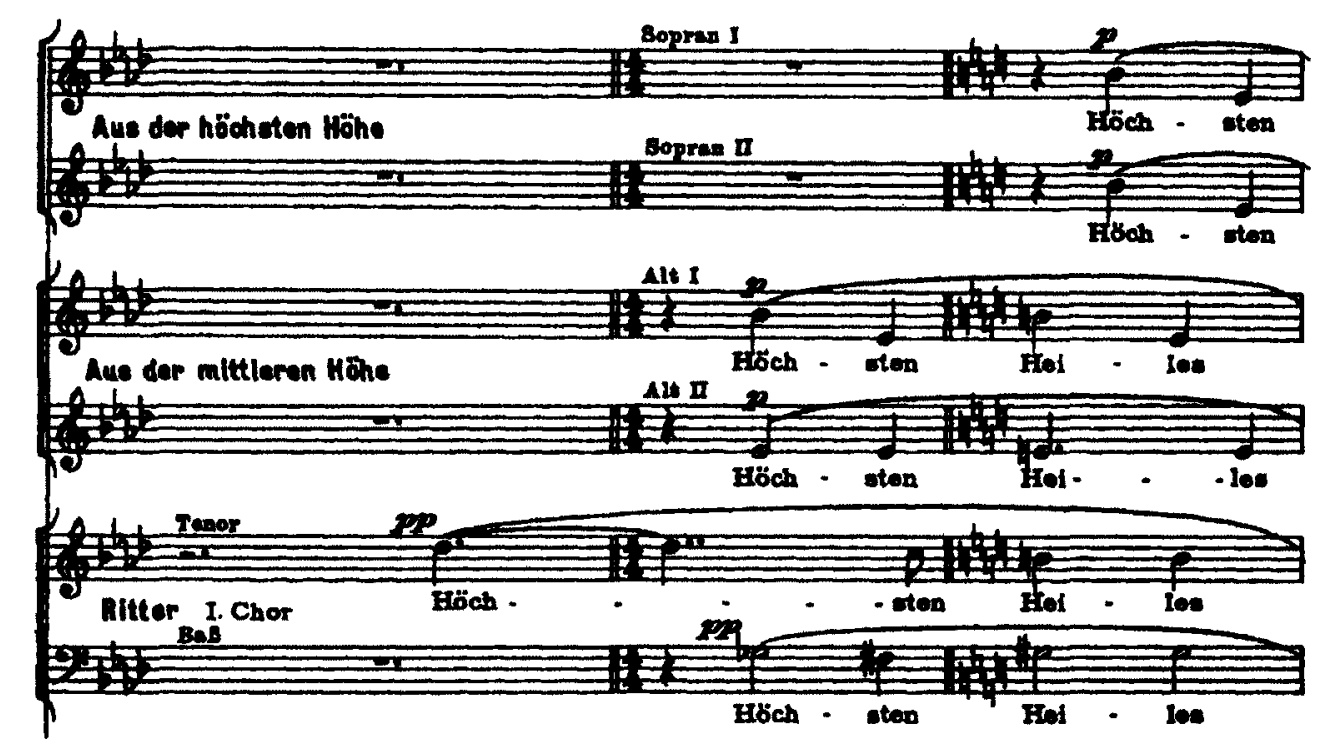

\section{Ex. 8b}

(Parsifal III/ii, mm. 251-254)

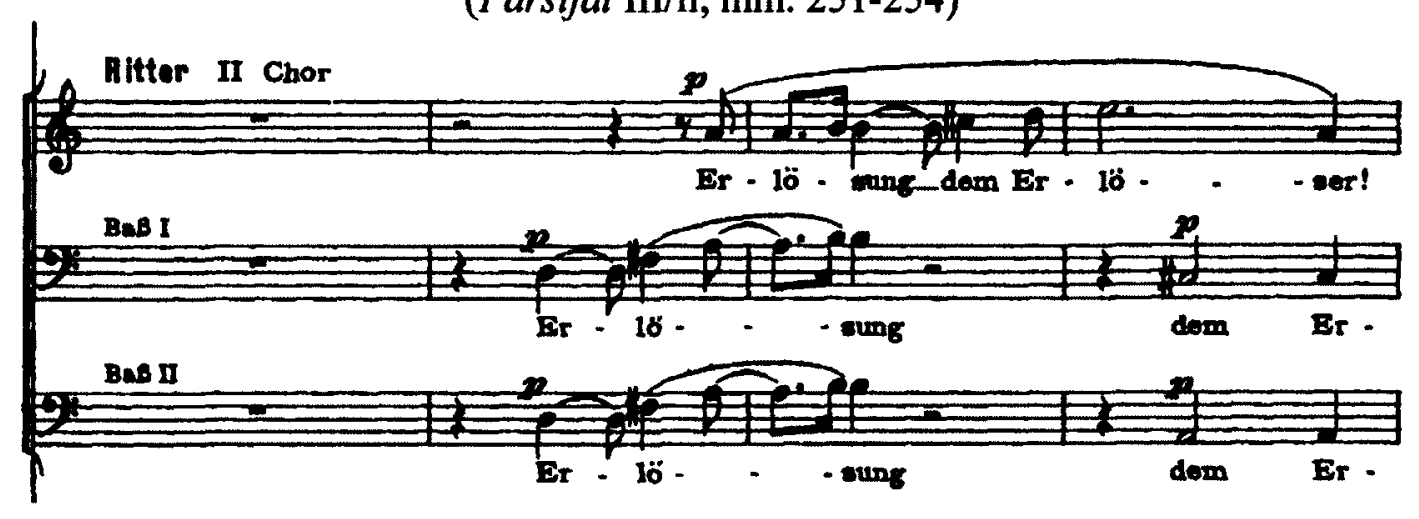

This last point suggests that the consecration of the stage occurs on a more realworld level. According to Stanley, "these voices help create a grand sonority...but their presence can also be interpreted symbolically, to the effect that a metacommunity, more ideal and abstract than the men and boys of the Grail community, seeks redemption. In this light, we can perceive a strongly articulated presence of a social collectivity...."148 The presence of a metacommunity and the chorus of spectators coalesces into Minor's framework for how the chorus ultimately functions as a consecrating agent. According to Minor, the contrast of embodied and disembodied voices placed on different levels of the

\footnotetext{
${ }^{148}$ Stanley, 152.
} 
stage is an instance where the performing bodies essentially break through the invisible barrier that separates the proscenium from the audience. ${ }^{149}$ If this contention is accepted, it is here that the relationship between the Communion and Grail themes attains their greatest significance. If the Grail theme's incorporation of the Dresden Amen marks the "Grail" as something of a stand-in for German culture of the nineteenth century, then the Grail theme's incorporation of the Communion theme positions art as communal in nature. That the Communion theme is so prominent to the opera's closing passages, and that it is one of the musical gestures that ultimately pierce the boundary between stage and audience, suggests that in the realm of the Festspielhaus, communities on stage and in the audience are complements of each other. It is that sense of concurrence between performing and spectating communities that renders Montsalvat as a proleptic community. In essence, the drama consecrates not only the stage, but also the audience as well. On stage, the Knights bear witness to and announce a miracle: Amfortas's healing and the concomitant rebirth of the order under the leadership of Parsifal, a rebirth metonymous with the renewal of Germany and its people. The Festspielhaus is the nation in microcosm, its stage having been blessed by what has just transpired. It is a blessing that reaches past the stage and into the audience so that the entire venue becomes a sanctified shrine to German art. In Parsifal, Wagner's use of the chorus as a collective social body is only the beginning. Mapped upon all in the theatre is the German nation with religious ritual mobilized to announce its salvation.

\footnotetext{
${ }^{149}$ Minor, 24-28. Minor's contention that this final chorus destabilizes the barrier between narrative and spectator essentially positions Parsifal's chorus as an example of Carolyn Abbate's concept of the "unsung voice." See Unsung Voices: Opera and Musical Narratve in the Nineteenth Century (Princeton, NJ: Princeton University Press, 1991).
} 
In the earliest pages of this chapter, I alluded to Wagner's thought that art was a reflection of the spirit of the Volk, which was in turn representative of the spirit of the nation. I wish to conclude the chapter by proposing a reversal of cause and effect: I refer back to the critical discourses expounded upon in the introduction, particularly Homi Bhabha's paradigm that foregrounds the nation as a performative category. In doing so, I submit that the act of consecrating German art through the convergence of grand opera, das Volk, the proleptic community, and Kunstreligion is the very instrument that brings the national "spirit" into being. The announcement of a redeemed society in these operas is that which bequeaths a sense of coherence to the idea of a redeemed nation. If the "holy German art" of Meistersinger represents a nascent stage of the benediction of art and the proleptic Volk, the Bühnenweihfestspiel that is Parsifal represents its apex: a ritualized repetition of consecration. Every repeated performance consecrates the Bayreuth stage anew, each successive group of spectators bearing witness to their own redemption. ${ }^{150}$ The intersection of the proleptic community and Kunstreligion represents possibly the most profound of Wagner's adaptations of the grand opera chorus: a case can be made that Wagner "topped" previous choruses by striving to create dramas more serious and further reaching than any previous works of theatre. In his bid to redeem the German people and German art, perhaps Wagner's proleptic choruses were instrumental in staging the grandest operas of all.

\footnotetext{
${ }^{150}$ I remind the reader that Parsifal was specifically composed for the Festspielhaus and was (a few exceptions aside) generally prohibited from being performed anywhere else until the embargo was famously "broken" by the Metropolitan Opera's staging of the work in 1903. Given Wagner's remarks quoted earlier regarding the importance that the theatre supposedly carried in terms of containing the spirit of German art, it is clear that Wagner considered it to be of the utmost national and cultural importance that the Bayreuth stage be the only one to receive this type of consecration. Syer discusses Parsifal's performance history from 1882 to present (as of the essay's publication in 2005) in "Parsifal on Stage," $A$ Companion to Wagner's Parsifal, 277-338.
} 


\section{Chapter Three}

\section{Hearing the World End: Mythic Allegories and Male Bodies in the Ring}

\section{Preliminary Remark}

A brief cataloguing of the statistics should tell the tale: four works (three full dramas, plus a Vorabend) performed over four evenings, resulting in nearly fifteen hours of music in aggregate. All of this music is performed by an orchestra that at its largest consists of 124 musicians, and expanded to include instruments designed by Wagner specifically for the purpose of performing these works (the "Wagner tubas" being the most enduring of these inventions). Over top of the orchestra are thirty-four different vocal roles, several of them among the most demanding in the operatic repertoire. Staging requirements are similarly daunting: thirty-seven different scenes, many of them requiring some of the most elaborate and technologically sophisticated scenic spectacle ever conceived for the stage, including but not limited to, dragons, rainbow bridges, flying horses, protective rings of fire, and a fortress consumed by fire in a climactic cataclysm. ${ }^{1}$ When considering these facts, it is not unreasonable to conclude that, taken in both its totality and its constituent parts, Der Ring des Nibelungen represents the ascension of opera to unprecedented heights of "grandness," further than any of the assembled composers, librettists, and regisseurs of the Paris Opéra could have ever conceived. It would appear that Wagner's professed desire to outdo the Opéra's extravagance with Rienzi (recounted in 1851's A Communication to My Friends) never entirely left him. ${ }^{2}$ In creating opera that is arguably more "grand" than even Paris' most

\footnotetext{
${ }^{1}$ Frederic Spotts, Bayreuth: A History of the Wagner Festival (New Haven and London: Yale University Press, 1994), 1-28; Patrick Carnegy, Wagner and the Art of the Theatre (New Haven and London: Yale University Press, 2006), 69-106.

${ }^{2}$ SSD IV, 258-259; PW I, 299-300.
} 
opulent offerings, Wagner could claim a victory over a nation that had chased him out of their musical scene twice.

The Ring's sheer size in terms of length and spectacle resonates within the issue of musical monumentality, previously discussed in Chapter One. There I noted that monumentality's pre-occupation with magnitude functioned as an expression of its historical "greatness," its status as a moment in history so epochal that the progression of history in its wake would be irrevocably changed. Indeed, Alexander Rehding states that the Ring "could justifiably be described as the single most monumental work in music history...." Rehding's claim restates that of Andreas Huyssen, who writes that "any discussion of monumentality...inevitably brings to mind the work of Richard Wagner: The Ring, the aesthetics of the Gesamtkunstwerk, the monumental artist, the history of the Bayreuth Festival." Granted, Rheding also notes that in A Communication to My Friends, Wagner professes an aversion to monumentality, characterizing the monument as a shrine to the past, like the marble statue that commemorates a long-dead figure. Wagner's reckoning proposes that the commemorative function of the monument fetishizes the past to such a degree that it bears no relevance to the present, which denied the "living spark" that was essential to the "forever-present work of art." Nonetheless, the Ring evinces a degree of musical and dramatic magnitude that had been heretofore unprecedented in the historical tapestry of musical theatre. If one accepts Wagner's interpretation of the monument as fundamentally ossified, a guarantor of "dead" art, than

\footnotetext{
${ }^{3}$ Alexander Rehding, Music and Monumentality: Commemoration and Wonderment in Nineteenth-Century Germany (Oxford and New York: Oxford University Press, 2009), 83

${ }^{4}$ Andreas Huyssen, "Monumental Seduction," New German Critique 69 (Autumn 1996): 181.

'Rehding, 84.
} 
perhaps a revision of the understanding of the term "monumental" is justified, whereby "magnitude" and "monumentality" should not necessarily be considered synonymous.

Clearly, despite his stated disdain for the monumental, musical and dramatic enormity remained important to Wagner's dramaturgy. Such a contention would likely have found sympathy with the German author Thomas Mann, who wrote that the "intellectual figure" of Wagner was "steeped in sorrows and grandeur, like the nineteenth century that he so perfectly epitomizes." ${ }^{6}$ The key to understanding Wagner's employment of operatic grandeur, I submit, is that he aims not to strip his work of the "living spark" by encasing it in the unchanging marble of the distant past. Wagner's dramaturgical dimensions were conceived as something more supple, more "alive" and expressive of the "forever-present." The magnitude of Wagner's form of "grand" opera as deployed in the Ring - for the purposes of these opening pages, I am focusing solely on scale and will discuss the specific resonances with Parisian dramaturgy later - thus took on a relationship to history distinct from that of the monument: rather than completely beholden to and worshipful of history, the size and "grandness" of the Ring makes history. This speaks to the aforementioned conception of monumentality as the commemoration of a historical epoch that fundamentally alters and overturns conventional wisdoms. In other words, Wagner's "monument" distinguishes itself in that it does not function as a shrine to an epoch that occurred in the distant past; the Ring itself is the epoch.

As the subsequent pages will endeavour to explicate, Wagner's adaptations of grand opera dramaturgy play no small role in troping the Ring as an epochal "monument"

\footnotetext{
6Thomas Mann, "The Sorrows and Grandeur of Richard Wagner" (1933), Pro and Contra Wagner, trans.
} Allan Blunden (London and Boston: Faber and Faber, 1985), 91. 
in German culture. As Patrick Carnegy writes, "a large part of [Wagner's] persistent ambition was to achieve in German theatres the kind of scenic magic which had so impressed him in Paris." Carnegy offers as an example the panorama mobile, introduced in Paris in 1829 and which provided an efficient method of transitioning from one painted backdrop to another through cloth unrolled on drums; this technique was notably deployed for the transformation scenes in the first and third acts of Parsifal as the forest scenery was gradually transmuted into the Grail temple. ${ }^{8}$ This is but one example; however the salient point is that according to Carnegy, the kind of "scenic virtuosity" that Paris routinely was something that Wagner considered a necessary ingredient to be introduced into German dramaturgy..$^{9}$ One can extrapolate from that observation that for Wagner, traits common to grand opera would lend his works a sense of size that would be beneficial to his ongoing project of creating the German "artwork of the future."

But while the kinds of musical and dramatic size that are emblematic of grand opera find ample representation throughout the Ring - as shall be demonstrated in detail shortly - there are also notable deviations from the genre's standardized precepts: the most prominent is in the tetralogy's exploitation of mythological sources as grist for its plots, rather than the historical backdrops that Parisian grand opera generally favoured. As the discussion of the Parisian premiere of Tannhäuser in Chapter One demonstrated, Wagner committed this type of departure over a decade before the full Ring saw its first performance on the stage of the Opéra itself, by eschewing history in favour of medieval Germanic legends as the primary source for its storyline. As Annegret Fauser remarks, this act of apparent "rebellion" against French custom assisted in heightening the

\footnotetext{
${ }^{7}$ Carnegy, Wagner and the Art of the Theatre, 24.

${ }^{8}$ Ibid., 24-25.

'Ibid., 25.
} 
controversy, adding fuel to the proverbial fire amongst the anti-Wagner voices in the Parisian press, who tended to argue that such a move only served to remove "human interest from his dramas." Wagner's estimation, the turn to myth away from history restored "human interest" to the drama. As I interrogate Wagner's affinity for myth and its deployment in the Ring in the following pages, I shall submit that in putting forth mythology as the foundation upon which the nation is built, infused with the life force that ostensibly unifies the German populace under the aegis of a collective spirit, Wagner reserved a specific form of "monumentality" for myth. As such, Wagner lionizes myth as the possessor of an allencompassing nature that speaks to its "historical greatness" and its capacity to serve as the basis for a culture-changing epoch. In putting the magnified scale of grand opera at the service of the culturally-unifying myth, Wagner found a musical and dramatic analogue to the cultural "scale" of myth; commensurately, the importance of myth to German identity lends a suitably "monumental" stage that elevates grand opera beyond simple pageantry into something that is of such magnitude that it is epoch-making.

One of the seminal texts of music criticism, George Bernard Shaw's The Perfect Wagnerite, went a long way towards popularizing another hermeneutic approach to the Ring beyond an examination of its mythical underpinnings. Shaw interpreted the work primarily as an allegorical critique of the increasingly industrialized conditions of the nineteenth century. ${ }^{11}$ Shaw's invocation of allegory in his commentary is of primary

\footnotetext{
${ }^{10}$ Annegret Fauser, "Cette musique sans tradition: Wagner's Tannhäuser and its French Critics," Music, Theater, and Cultural Transfer: Paris, 1830-1914, ed. Annegret Fauser and Mark Everist (Chicago and London: University of Chicago Press, 2009), 251.

"George Bernard Shaw, "The Perfect Wagnerite: A Commentary on The Nibelung's Ring," Shaw's Music: The Complete Musical Criticism in Three Volumes - Vol. 3: 1893-1950, ed. Dan H. Laurence (London: The Bodley Head, 1981), 408-545.
} 
interest to me for the purposes of this chapter. Numerous subsequent scholars have subjected the Ring to critical readings that devote significant attention to the perceived political subtexts to the tetralogy, with Mark Berry's being one of the most extensive and most recent. ${ }^{12}$ Like Shaw's, Berry's reading devotes much attention to the cycle as in part a critique of the advancement of industrial capitalism and its despoiling of the natural world, with Wotan's creation of his spear by ripping a chunk from the World Ash Tree put forth as one of the most potent examples. ${ }^{13}$

Both Shaw and Berry provide after-the-fact readings; what about Wagner's own intentions vis-à-vis allegory? In an endeavour to shed light on that issue, John Deathridge observes that Wagner possessed an enthusiasm for allegory that he never publicly discussed to any great degree, yet that enthusiasm led him "to drench his stage works with Christian images and clear references to modern social and philosophical ideas...."14 Deathridge reads Wagner's employment of allegory in his works through the lens of Walter Benjamin's study of the Baroque Trauerspiel. ${ }^{15}$ In doing so, Deathridge foregrounds Götterdämmerung, particularly its cataclysmic ending, as an allegory for the history of world suffering. ${ }^{16}$ I will delve into the issue of Wagnerian allegory in greater detail below, but I wish to underline Deathridge's point about how the Ring functions as the allegorical charting of the history of the world's torments in order to propose that Wagner's appropriation of allegory compliments his use of myth in that both tend

\footnotetext{
${ }^{12}$ Mark Berry, Treacherous Bonds and Laughing Fire: Politics and Religion in Wagner's Ring (Aldershot: Ashgate, 2006).

${ }^{13}$ Ibid., 57-78.

${ }^{14} \mathrm{~J}$ ohn Deathridge, Wagner - Beyond Good and Evil (Berkeley: University of California Press, 2008), 83.

${ }^{15}$ Walter Benjamin, The Origin of German Tragic Drama, trans. John Osborne (London: New Left Books, 1977). See also Samuel Weber, "The Ring as Deconstruction of Modernity: Reading Wagner With Benjamin," Sound Figures of Modernity: German Music and Philosophy, eds. Jost Hermand and Gerhard Richter (Madison, WI: University of Wisconsin Press, 2006), 106-123.

${ }^{16}$ Deathridge, 93-99.
} 
towards a sense of narrative scale that is matched by the dramaturgical scale of grand opera. The Ring's allegory ostensibly encompasses the entirety of world history, leading up to its climax when the "old" world is destroyed, making way for a new age. This speaks to a degree of narrative ambition that necessitates the magnitude of the grandest of grand opera in order to properly convey its immensity.

The primary instruments that put across the types of "mythic allegories" of German nationhood are performing bodies. As I have laid out in the introductory chapter, the body as sonority and as iconography was granted extensive primacy by Wagner as emblematic of the essential qualities of the "artwork of the future." Of especial prominence throughout the Ring are male performing bodies, ranging from Wotan, chief of the gods, to the giants Fafner and Fasolt, the Nibelungs Alberich and Mime, the Gibichungs Hagen and Gunther, and arguably the most significant male roles of them all, Siegmund and his offspring Siegfried. These two latter roles stand out because they are the prototypical Heldentenor roles in Wagner's oeuvre. As shall be illuminated in the following pages, the Heldentenor as a performing body was thematized by Wagner as disseminating an acoustic excellence that complimented the physical excellence of the characters he portrayed; that somatic splendour was put forth by Wagner as the emblem of the "artwork of the future," and by extension, of the German identity. ${ }^{17}$ In Art and Revolution, Wagner makes plain his notion of the male body as the essential symbol of this proposed new work of art: the pinnacle of the reunified society is the "strong fair Man, to whom Revolution shall give his Strength, and Art his Beauty!"18 This "strong Man" spearheads social and political change through the manifest

\footnotetext{
${ }^{17}$ Marc A. Weiner, Richard Wagner and the Anti-Semitic Imagination (1995) (Lincoln and London: University of Nebraska Press, 1997), 163-176.

${ }^{18}$ SSD III, 32; PW I, 56. Author's emphasis.
} 
excellence of his body: physical strength permits revolution, while art infuses the necessary pulchritude into his form that will entice followers with his radiance. Even taking into account that Wagner is likely speaking as much in metaphorical terms as he is literally, it is clear from this statement that he centralizes the somatic as a vital stage for the reform of German art and society, and it is the idealized male body that makes such reform possible.

Of course, not all male bodies presented in the Ring can be described in such elevated terms: the cycle is rife with characters that are grotesque in both their conduct and their physicality, with Alberich and Mime being perhaps the most notorious. The presence of these debased characters makes a degree of narrative sense: if the intent is to promote a character like Siegfried as a paragon of physical excellence, then it would seem necessary to present contrasting figures, whose manifest corruption throws Siegfried's superiority into sharp relief. ${ }^{19}$ Beyond matters of simple comparison, the contrast of types of male bodies in the Ring also speaks to the work's scope: in presenting such a wide range of manhood, from the elevated to the debased and practically everything in between, Wagner depicts a veritable cross-section of society. This, I submit, compliments Wagner's ambitions in terms of using myth and allegory to trace the history of German culture. Female bodies are quite prevalent throughout the cycle, but as we shall see the degree of variance between the types of male bodies is such that they offer the potential for more compelling readings with regards to the performing body as a sonorous and physical stage for myths and allegories of German nationhood.

\footnotetext{
${ }^{19}$ Any discussion of the grotesque characters in the Ring cannot avoid the issue of anti-Semitism, which I will touch upon later in this chapter. Weiner and Paul Lawrence Rose are the two most prominent recent scholars that have examined the issue of Wagner's debased characters as anti-Jewish caricatures at length. See Weiner, Richard Wagner and the Anti-Semitic Imagination and Rose, Wagner: Race and Revolution (New Haven and London: Yale University Press, 1992).
} 
However, despite the virility and beauty of Siegfried, ${ }^{20}$ and the rank unpleasantness of the likes of Alberich, Mime, Hunding, and Hagen, there is one constant that unites just about all of the male characters throughout the tetralogy: each possesses at least one flaw of character that brings about his ruin (a dramatic device befitting tragedy, of course). In general, those flaws are externalized upon the characters' body in some fashion: for example, Wotan's lust for power results in the loss of an eye; Alberich's physical hideousness reflects his moral impoverishment; Fasolt, Fafner, and Hunding are characterized as brutes, prone to resolve conflicts primarily through physical violence, which proves their undoing; even Siegfried is marked by a foolhardiness and arrogance that eventually results in his murder, as he fails to protect the one vulnerable portion of his body, his back. As such, a crucial part of the Ring's mythic and allegorical tapestry is a portrait of various forms of "flawed" masculinities, male identities and male bodies that fail in one manner or another to measure up to the standard necessary to ensure their ability to survive, let alone flourish.

The paradigm of flawed manhood that $I$ have proposed will prove to have significant implications on the forthcoming reading of the Ring as a "mythic allegory" of the German nation. Said reading will proceed along the following trajectory: I will begin by accounting for the importance of myth - specifically the Germanic and Icelandic myths that are the primary sources for the tetralogy - to Wagner's conception of German identity, and how Wagner's privileging of myth fit within a wider pattern of cultural tropes in nineteenth-century Germany. As an element of this analysis of Wagner's predilection towards myth will appraise Wagner's troping of the "artwork of the future" as a resurrection and rejuvenation of the practices of the Ancient Greeks, specifically

\footnotetext{
${ }^{20}$ Laurence Dreyfus, "Siegfried's Masculinity," The Wagner Journal 4/3 (November, 2010): 4-26
} 
their own adoptions of myth at the service of tragedy and the epic. ${ }^{21}$ I will then follow up with a brief consideration of allegory in the Ring, drawing particular attention to Shaw's and Berry's readings of the cycle. Subsequent to that, I will account for the importance Wagner placed upon the sonority of the body as a synecdoche for his proposed "music drama," which will in turn necessitate insight into Wagner's development of the Heldentenor role and its foregrounding as the primary symbol of his revolutionary work of art. All of this preliminary material will lay the groundwork for a series of analyses of male bodies in the Ring. During that section, I will direct attention to the respective bodies of Wotan, Alberich, and Siegfried as they perform within the context of the dramaturgy of grand opera, observing how grand opera is combined with embodied sonority to stage the cycle's multiplicities of manhood, with particular attention paid to how those sonorities serve to portray the "flawed" masculinities that precipitate their downfall.

As I will argue, the various forms of flawed male bodies are constructed to represent the old world that will eventually be washed away in order to set the stage for the birth of the redeemed society that gains life at the tetralogy's conclusion. This ending actualizes the prophetic vision that Brünnhilde notably describes during an earlier draft of her closing monologue: "I saw the world end." ${ }^{\text {"2 }}$ In the Ring, the male body serves as one of the primary stages for the cycle's mythic allegory, allowing us to hear the world end: the tracing of the history of German society and culture, through its manifold sufferings and mistakes leading up to a "revolution" that tears down the old, flawed society so as to

\footnotetext{
${ }^{21}$ Daniel H. Foster, Wagner's Ring Cycle and the Greeks (Cambridge and New York: Cambridge University Press, 2010).

${ }^{22}$ The entire deleted passage is quoted in the front matter of Deryck Cooke, I Saw the World End: A Study of Wagner's Ring (London: Oxford University Press, 1979).
} 
allow a "better" one to flourish. This is the Ring's ultimate Weltenschauung. ${ }^{23}$ Through the use of grand opera - specifically finales involving "spectacular" eruptions of the elements and "grand" duets - the cycle takes on the sufficient size and "monumentality" to establish itself and the performing bodies therein as a work of art that can chart that history and through its performance, fundamentally alter the course of German art. For that, I contend, is one of the work's fundamental allegorical projects: to situate the world's rebirth as a stand-in for the redemption and rebirth of German art, which is playing out on the operatic stage. By using myth as the primary sources of his narrative, Wagner strategically situates the world/nation's flaws, staged upon the male body, within the distant past. The rebirth of the world presented as part of the cycle's climactic cataclysm, I will argue, is thematized as that which sets the stage for a rejuvenation of German art and society that Wagner will take up as his mission in present and future dramatic endeavours.

\section{Grand Myths}

Part II of Opera and Drama, "The Play and Dramatic Poetry," contains a notable appraisal of the value of myth as subject matter for poetry and drama. After discussing the respective Ancient Greek and Christian "mythos," Wagner writes: "of the myths which have worked decisively upon the life-views and art-fashionings of the modern era we now come to the other circle, and that opposed to the Christian myths. It is the native Saga of the newer European, but above all the German peoples." ${ }^{24}$ As Wagner tells it, the various Siegfried legends function as a "primordial germ," part of "the enormous wealth of leaves and branches of the Germanic Folk-tree" that directly taps into and nourishes

\footnotetext{
${ }^{23}$ Hermann Danuser, "Musical Manifestations of the End in Wagner and Post-Wagnerian Weltenschauungsmusik," $19^{\text {th }}$-Century Music 18/1 (Summer 1994): 64-82.

${ }^{24}$ SSD IV, 38; PW II, 161. Author's emphasis.
} 
the enduring spirit of the German Volk. ${ }^{25}$ Similar claims about Germanic myth - those involving Siegfried in particular - find expression in A Communication to My Friends. In that manifesto packaged as a forward to a collection of the poems for his previous operas, Wagner draws an opposition between history and myth, finding in the latter an authenticity that the former decidedly lacks. As Wagner claims,

Since my return to Germany from Paris, my favourite study had been that of ancient German lore. I have already dwelt on the deep longing for my native home that filled me then. This Home, however, in its actual reality, could nowise satisfy my longing; thus I felt that a deeper instinct lay behind my impulse, and one that needs must have its source in some other yearning than merely for the modern homeland. ${ }^{26}$

The "modern" Germany could not satiate Wagner's desire for "home" because it carried the baggage of history, which as he had made clear in "Art and Revolution" had entrapped society in a lamentable state of "un-freedom" through its institutionalization of such elements as commerce and organized Christianity; even modern Germany had fallen prey to this form of historical "progress," and as such the German "spirit" was not to be found in the present day or in its historical antecedents. In Wagner's estimation, his longing for Heimat was salved by his engagement with the medieval Germanic legends and Nordic Sagas, for those mythic materials told of a time and a place untouched by the ravages of the history that led up to the present day. Moreover, "a myth was generated by the collective will of a people, and was therefore true, whereas (written) history had been formulated by individuals in their writing, apart from the tradition which had been preserved unbroken at the level of myths." ${ }^{27}$ In the Germanic myths, Wagner attested to finding an essential purity and authenticity:

\footnotetext{
${ }^{25}$ SSD IV, 38-39; PW II, 161-162.

${ }^{26}$ SSD IV, 311; PW I, 357.

${ }^{27}$ Hannu Salmi, Imagined Germany: Richard Wagner's Natonal Utopia (New York: Peter Lang, 1999), 32.
} 
In the struggle to give the wishes of my heart artistic shape, and in the ardour to discover what thing it was that drew me so restlessly to the primal source of old home Sagas, I drove step by step into the deeper regions of antiquity, where at last to my delight, and truly in the utmost reaches of old time, I was to light upon the fair young form of Man, in all the freshness of his force. My studies thus bore me, through the legends of the Middle Ages, right down to their foundation in the old-Germanic mythos; one swathing after another, which the later legendary lore had bound around it, I was able to unloose, and thus at last to gaze upon it in its chastest beauty. What here I saw, was no longer the Figure of conventional history, whose garment claims our interest more than does the actual shape inside; but the real naked Man, in whom I might spy each throbbing of his pulses, each stir within his mighty muscles, in uncramped, freest motion: the type of the true human being. ${ }^{28}$

Wagner paints the picture of having found within the realm of myth the representation of the idealized human, whose physical beauty represents the German essence in its untainted form. This "true" human being functions for Wagner as the singular embodiment of the value of myth in defining the German national consciousness; he portrays myth as untouched by such distraction as politics, commerce, religion, etc., and as such, that which conveys the "true" spirit of the German Volk. Wagner's characterization of myth is in many ways inspired by Johann Gottfried Herder's ideas about myth and the Volk. As Bruce Lincoln writes, for Herder "myths are the linguistic form that mediates between climate and Nationalbildung."29 Lincoln continues: "thus, if the environment impresses itself directly on the bodies of a Volk, it impresses itself on their customs and mores through the medium of myths, which Völker use to reflect on their surroundings and their history and to transmit ancestral traditions from one generation to another. ${ }^{930}$ For Herder, while physical location anchors the body to a specific place, myths serve to imbue that place with a distinct sense of character, of

\footnotetext{
${ }^{28}$ SSD IV, 311-312; PW I, 357-358.

${ }^{29}$ Bruce Lincoln, Theorizing Myth: Narrative, Ideology, and Scholarship (Chicago and London: University of Chicago Press, 1999), 53.

${ }^{30}$ Tbid.
} 
of identity, of "spirit." Therefore, myths are a valuable form of differentiation that allows each set of Volk to imagine a distinctive shared heritage and character. ${ }^{31}$ Therefore, Herder's model offers a precedent for Wagner's framing of myth as conveying essential truths about the German people. Furthermore, in connecting the spirit of myth with the body's location in a particular environment, Lincoln's commentary opens a window for thematizing the body as a mythic stage, which for Wagner is the aforementioned "true human being."

The ideal human being that Wagner discovered through the study of Germanic myth is subsequently revealed to be Siegfried. Wagner foregrounds him as the emblematic figure of the German myths that he had so inflamed his passion for "home." As Wagner writes, he had initially only known of Siegfried from his presence in the thirteenth-century Middle High German poem Das Nibelungenlied. ${ }^{32}$ As Barry Millington notes, the Nibelungenlied was an object of some fascination in Germany of the 1840 s as a "potent symbol in the struggle for national unification." ${ }^{33}$ Taruskin adds that in 1845 "none other than Franz Brendel...had called for an operatic setting of the myth, no doubt already thinking of Wagner...."34 Brendel's words serve to underline the import of taking on this task: "I believe the composer who could accomplish this task in an adequate manner would become the man of his era." ${ }^{" 35}$ Brendel was not alone in his conviction that an opera based upon the Nibelungenlied could be of vital import to fortifying German identity: for example, Friedrich Theodor Vischer had already

\footnotetext{
${ }^{31}$ Ibid., 54.

${ }^{32}$ SSD IV, 312; PW I, 359.

${ }^{33}$ Barry Millington, The Wagner Compendium: A Guide to Wagner's Life and Music, quoted in Taruskin, 492.

${ }^{34}$ Taruskin, 492

${ }^{35}$ Franz Brendel, Neue Zeitschrift für Musik, xxiii (1845), quoted in Taruskin, 492.
} 
suggested that a Nibelung opera could be a productive undertaking in Vorschlag zu einer Oper (Proposal for an Opera, 1844), while in 1845, the early feminist Louise Otto-Peters would publish a partial libretto for such an opera in the Neue Zeitschrift für Musik. ${ }^{36}$

It should be noted, however that Wagner identifies the text of the Nibelungenlied as of "medieval" origin, which as Edward Haymes notes, carried a pejorative connotation: "like most of his contemporaries [Wagner] felt that the Icelandic texts represented a far earlier, more 'primitive' version of the Nibelung legend, one that was far closer to the mythic roots of the story, than the "medieval' Nibelungenlied." ${ }^{37}$ In $M y$ Life, Wagner endeavours to illustrate the appeal the Nordic sagas held for him over the "medieval" poem, and their potential efficacy in forming the basis for his new work:

In my efforts to master the German myths more thoroughly than had been possible from my previous perusal of the Nibelungen and the Heldenbuch, I became especially attracted to the unusually rich pages of Mone's investigations of these heroic legends, ${ }^{38}$ even though stricter scholars have criticized them as overly audacious. This drew me irresistibly to the Nordic sources of these myths, and to the extent that it was possible without fluent knowledge of the Scandinavian languages, I now tried to get to know the Eddas, as well as the prose fragments comprising the basis for large parts of these legends. Viewed in the light of Mone's comments, the Wälsungasaga exerted a decisive influence on the manner in which I began to form the material to my own purposes. The consciousness of the close primeval kinship of these old myths, which had been shaping within me for some time, thus gradually gained the power to create the dramatic forms which governed my subsequent works. ${ }^{39}$

Wagner's stated affinity for the Norse myths would eventually reveal themselves in his gradual expansion of Siegfrieds Tod into the Ring, as the first three installments of the tetralogy draw extensively from the Poetic Edda and the Prose Edda (the material

\footnotetext{
${ }^{36}$ Stewart Spencer and Barry Millington, "Introductory Essay 1849-1858," SL 158-159. Spencer and Millington note that "it is assumed, but unproven, that Wagner was acquainted with the writings of Vischer and Otto" (159).

${ }^{37} \mathrm{WR}, 5$.

${ }^{38}$ Wagner is referencing Untersuchungen zur Geschichte der teutschen Heldensage (1836) by Franz Josef Mone (1796-1871).

${ }^{39} \mathrm{ML}, 343$.
} 
pertaining to the gods) and the Volsungasaga (the thread involving the family line of Siegmund, Sieglinde, and Siegfried), with the original Siegfrieds Tod of 1848 (eventually Götterdämmerung) owing the greatest debt to the Nibelungenlied. The Icelandic scholar Árni Björnsson has meticulously documented the Ring's borrowings from Nordic sources with an eye towards clarifying their uniquely Icelandic origin, as opposed to simply more examples of Germanic folklore. ${ }^{40}$ Even so, he nonetheless notes that Icelandic sagas became increasingly popular as an object of study amongst German scholars and writers, beginning in the latter eighteenth century and continuing into the nineteenth. ${ }^{41}$ Haymes adds that these sagas were absorbed by "Wagner and his generation" into the popular imagination of the German mythic past. ${ }^{42}$ Roberta Flack adds that Wagner's incorporation of the Nordic sources into his libretti serves to position the Ring as an expression of "pan-Germanism. ${ }^{\text {"43 }}$ Wagner's appropriation of the Scandinavian materials had a colonizing effect according to Flack, with his assemblage creating an enduring impression that "valkryies and norns, Valhalla and the twilight of the gods, Wälse and the Wälsunger, were timelessly German" when nothing could have been further from the truth. ${ }^{94}$

As previously mentioned, Wagner's gravitation towards the Nibelungenlied and his plundering of its antecedents in the Norse sagas was part of a wider-ranging troping of myth as an expression of the fundamental character of the German nation. As George Williamson encapsulates, the periods of early Romanticism and the Vormärz ("pre-

\footnotetext{
${ }^{40}$ Árni Björnsson, Wagner and the Volsungs: Icelandic Sources of Der Ring des Nibelungen, trans. Anthony Faulkes and Anna Yates (London: Viking Society for Northern Research, 2003).

${ }^{41}$ Ibid., 81-93.

${ }^{42}$ WR, 4.

${ }^{43}$ Roberta Flack, "Wagner's Ring, North-By-Northwest," University of Toronto Quarterly 74/2 (Spring 2005): 671.

${ }^{44}$ Ibid., 671-672.
} 
march," or the period leading up to the 1848 Revolutions) saw a preoccupation amongst German intellectuals with locating and cultivating a distinct national mythology. ${ }^{45}$ Perhaps the most significant voice in terms of exalting Germanic myth was the philologist Jacob Grimm, whose 1835 book Deutsche Mythologie could be considered one of the defining scholarly works of the era in its attempts to account for the "totality of Germanic religious experience, from the creation narratives of the Prose Edda to the superstitions of the German peasant." ${ }^{" 46}$ The work is notable for containing "alongside a detailed synopses of the sagas a description of the Norse theogony (the genealogy and history of the gods), as preserved in the medieval Icelandic epics known as the Eddas." ${ }^{947}$ Grimm's work thus did its part to solidify the Scandinavian sagas as a vital part of the German mythology and as such part of the national heritage. Flack suggests that Grimm did this to compensate for the fact that the "German-speaking lands lacked a heroic age," and that the "courtly epics and bridal quest romances of the Holy Roman Empire" would not be of sufficient grandiosity to create "a political entity called Germany" with a "glorious common national past." 48 In order to create this narrative of a "glorious" shared heritage, Grimm "borrowed" some elements from the Norse traditions.

Grimm's study also played a significant role in introducing the Volsungasaga and the Eddas to Wagner. As Elizabeth Magee notes in her study of Wagner's sources for the Ring, the second edition of Deutsche Mythologie (1844) was added to his personal library

\footnotetext{
${ }^{45}$ George S. Williamson, The Longing for Myth in Germany: Religion and Aesthetic Culture from Romanticism to Nietzsche (Chicago and London: University of Chicago Press, 2004), 74-120.

${ }^{46}$ Tbid., 104.

${ }^{47}$ Taruskin, 492.

${ }^{48}$ Flack, 671.
} 
in Dresden. ${ }^{49}$ Wagner's recollection of the work's effect on him in My Life portrays him as

spellbound by a marvellous enchantment: the most threadbare material spoke to me with the immemorial voice of my native land, and soon all my perceptive faculties were taken up with images, forming themselves in me with everincreasing clarity into an anticipation of recapturing a long-lost and constantly resought consciousness. ${ }^{50}$

Wagner ascribes to Grimm's work (and the myths it catalogued) a power capable of altering consciousness, suggesting that myth contained a degree of magnitude, or "monumentality," that he may have endeavoured to replicate in the Ring: as Germanic myth altered his perceptions of German identity, so too might his work for his potential audiences. On a more prosaic level, Deutsche Mythologie was "largely responsible for Wagner's ideas about valkryies, gods, and dwarves."'s1

However, Wagner's thinking did diverge from Grimm's in one notable aspect: "whereas Grimm focused on reconstructing a strictly 'Germanic' mythology, Wagner was interested in linking the legends and stories of the Middle Ages to a wider circle of Nordic and classical myths." 52 This led him towards the works of the aforementioned Franz Joseph Mone; in his Untersuchungen zur Geschichte der teutschen Heldensage (1836), Mone made the case "that medieval epics like the Nibelungenlied fused a timeless substrate of myth to the accidental events of history."53 As Mone writes, "one could say that the body of the heroic legend is history and its spirit is myth. The animating power lies in the spirit, and thus the historical events have attached themselves to the myth and

\footnotetext{
${ }^{49}$ Elizabeth Magee, Richard Wagner and the Nibelungs (Oxford: Clarendon Press, 1990), 27-28.

${ }^{50} \mathrm{ML}$, quoted in Magee, 12.

${ }^{51} \mathrm{WR}, 16$.

${ }^{52}$ Williamson, 188.

${ }^{53}$ Ibid.
} 
given up their own coherence." ${ }^{\text {4 }}$ Williamson adds that "in Mone's scheme, myth determined history, and the conflict described in the Nibelungen myth could be seen as underlying many of the fundamental polarities of German history."'ss But as Wagner's appraisal from My Life makes clear, Mone's interrogation of German myth also incorporated investigations into the Nordic sources of the Eddas and the Volsungasaga. Beyond his efforts to weave together the medieval German sources and the earlier Norse sagas, Mone's work is also important in that his advocacy for myth as the "true" history of Germany may be seen as forming an intellectual basis for Wagner's later professed notions of the authenticity of myth over that of history. ${ }^{36}$ Moreover, I propose that Mone's foregrounding of myth as essentially the unifying element of the German national identity bequeaths it an "all-encompassing" nature that speaks to its magnitude in terms of cultural vitality, a magnitude for which Wagner found a useful musico-dramatic analogue in grand opera, as I argue.

The presence of the three Norns at the outset of Siegfrieds Tod/Götterdämmerung, provides a clear indication that Wagner's preoccupation with myth extends beyond that of Germanic legend: as Taruskin observes, the Norns are "comparable to the three Fates of Greek mythology...." ${ }^{\text {? }}$ As Wagner maintained, the artistic pinnacle of Greek society was the tragedy, its artistic unity representing the perfected state of harmony of its originating culture. Tragedy's unified nature, according to Wagner, was the consequence

\footnotetext{
${ }^{54}$ Franz Joseph Mone, Untersuchungen zur Geschichte der teutschen Heldensage (1836), quoted in Williamson, 188.

${ }^{55}$ Williamson, 188.

${ }^{56}$ As Williamson notes, many of Mone's points about the relationship of myth to history would be reiterated by Wagner in his 1848 essay "Die Wibelungen." See Williamson, 189 and SSD II, 115-155; PW VII, 257. 298.

${ }^{57}$ Taruskin, 492.
} 
of poetry, music, and dance all operating together as a seamless whole. ${ }^{58}$ Central to the Greek tragedy was the employment of narratives steeped in the mythologies of Hellenic culture. As Wagner writes in Opera and Drama, "until now, genuine drama could issue only from the Greek view of the world. Its subject matter was myth, and only on the basis of the latter's innermost nature can we understand the supreme work of Greek art, the very form which so fascinates us... Greek tragedy is the artistic realization of the content as spirit of Greek myth." ${ }^{99}$ For Wagner, the trope of myth as the communicator of the human spirit originated in the society of Ancient Greece; in calling for the German "artwork of the future" to restore the lost unity of poetry and music and to exploit myth as its subject matter, Wagner positions his idealized German nation as that which inherits the spirit of the Greeks and carries it forward to cultural supremacy.

\section{Grand Allegories}

Despite the prominent lineage to various mythological sources in the Ring, and Wagner's well-documented fealty to the ostensible cultural authenticity of myth, Dieter Borchmeyer has cast some doubt as to whether the Ring itself can be considered a mythological work. For as steeped in folklore as the cycle's storylines are, the tetralogy is also marked a persistent modernity that manifests itself through such aspects as its advanced tonal language, musical and scenic complexity, and the technological sophistication required of its staging. It is "a modernity that although clothed in mythical symbols is sometimes so insistent that there have even been attempts to deny the work's

\footnotetext{
${ }^{58}$ Jean-Jacques Nattiez, Wagner Androgyne: A Study in Interpretation, trans. Stewart Spence (Princeton, NJ: Princeton University Press, 1993), 12-18.

${ }^{59}$ Opera and Drama, quoted in Nattiez, 17-18.
} 
mythical character altogether." ${ }^{\circ 00}$ Invoking Shaw's critique, Borchmeyer adds that "Shaw even permitted himself the conceit of transferring Valhalla, Nibelheim, and Riesenheim to London and of regarding Wagner's mythological society as a mirror of a British society in his own day." ${ }^{\circ 1}$ Even Wagner was not immune to such interpretations, as his 1881 essay "Know Yourself" attests (within the context of yet another anti-Semitic diatribe): he characterizes "the Nibelung's fateful Ring" as a "pocket-book" and an "eerie picture of the spectral world-controller." ${ }^{" 2}$ Taking these statements in mind, Borchmeyer proposes the possibility that "Wagner's myth, then seems to be not self-referential but merely an allegorical account of modern society."${ }^{93}$

Berry's analysis contextualizes the story and characters of the Ring within Wagner's exposure to various ideas about nature, politics, society, capitalism, and religion, among others. Regarding nature, one of the major themes that Berry identifies is what he calls "the natural world and its despoliation." ${ }^{94}$ In this section, Berry reads Wagner's setting of the natural world and the characters' relationships to it through the lens of such figures as Hegel, Feuerbach, Marx, and Engels. Perhaps the most significant event of the cycle's backstory - the "original sin" to use Berry's words ${ }^{65}$ - is the creation of Wotan's spear, which has all of his various binding contracts inscribed upon its shaft. As such, the spear and the treaties listed upon it grant him the power of governance over the world. In order to create this spear and to achieve this power, Wotan tore a branch from the World-Ash tree. The Norns recount this event during the prologue to

\footnotetext{
${ }^{60}$ Dieter Borchmeyer, Drama and the World of Richard Wagner, trans. Daphne Ellis (Princeton, NJ and Oxford: Princeton University Press, 2003), 213.

${ }^{61}$ Borchmeyer, 214.

${ }^{62}$ SSD X, 268; PW VI, 268.

${ }^{63}$ Borchmeyer, 214.

${ }^{64}$ Berry, 57-78.

${ }^{65}$ Ibid., 68.
} 
Götterdämmerung, noting in Shaw's words that "the tree withered after suffering that violence." Wo Wotan's act is characterized then as a violation of nature, the tree's subsequent shriveling functioning as the visualization of the unhealing "scar" of that initial defilement. Wotan's violation of nature arose out of a desire for knowledge and power, ${ }^{67}$ the former arising from drinking from the spring beneath the tree, and the latter from his cutting of the branch. The fact that power is granted him through treaties is important: by violating nature, "Wotan...has exchanged an independent state of nature for a political state based on a social contract. Nature is no longer the be-all and end-all but now has a rival that circumscribes what had previously been its sole right." ${ }^{168}$ Through the World-Ash's withering, "Wotan's new state already bears within it the stigma of a violation against nature. Every social contract presupposes a violation of the integrity of nature...."99

In committing his "sin" against nature in order to facilitate power, Wotan "will ultimately further his own destruction, not to mention that of manifold other victims." Once his spear is shattered by Siegfried, he will acquiesce in despair to the gods' prophesized demise, during which he will have "commanded his tamed heroes to cut down the withered boughs of the World-ash...Domination achieved, disaster has ensued, not least for Wotan himself, now surrounded by the ash-tree logs, awaiting their final allconsuming blaze."'1 Wotan's lust for knowledge and power compelled him to commit a crime against nature; in acknowledging his downfall, he compounds that initial

\footnotetext{
${ }^{66}$ Shaw, 484.

${ }^{67}$ Which as Berry notes via Theodor Adorno and Max Horkheimer in Dialectic of Enlightenment, are "synonymous in the modern world." See Berry, 70 and Theodor W. Adorno and Max Horkheimer, Dialectic of Enlightenment, trans. Edmund Jephcott (Stanford, CA: Stanford University Press, 2002).

${ }^{68}$ Borchmeyer, 228-229.

${ }^{69}$ Tbid., 229.

${ }^{70}$ Berry, 72.

${ }^{71}$ Ibid.
} 
transgression. The institution of Wotan's political system is predicated on an affront to the natural world that will demand and receive atonement by the time the curtain falls for the final time on the cycle. I note that Wotan's "rape of Nature appears to be purely Wagner's invention, with no warrant in his mythological sources." ${ }^{22}$ As such, we see in this portion of the story what appears to be a deviation from the devotion to myth that Wagner had previously professed. In its stead, we get what approaches the level of allegory: a critique of political power in the modern world. Through the character of Wotan, and the bass role required to perform it, Wagner situates a male body as the primary stage for that allegory; as I will aim to explicate, it is the dramatic size of grand opera that provides the necessary weight in order to map Wotan's ambition, arrogance, and eventual despair upon his performing body.

Wotan's encroachment upon the natural world for political gain finds a parallel in Alberich's theft of the Rheingold; like Wotan, the Nibelung robs from nature in order to gain financial and political power for himself. Alberich's and Wotan's despoliations of nature are but two examples of the type of allegorical reading that writers like Shaw, Borchmeyer, and Berry lay out. Deathridge's framework proposes something arguably more complex, dealing as it does in ideas less concrete than other interpretations that incline towards the allegorical. Deathridge's reading mobilizes Benjamin's The Origin of German Tragic Drama, specifically Benjamin's appraisal and critique of the Trauerspiel's (mourning play) use of allegory, with an eye towards rescuing allegory from the Romantics' dismissal in favour of the symbol. ${ }^{23}$ For Benjamin, the value of the

\footnotetext{
${ }^{72}$ Ibid., 71.

${ }^{73}$ To encapsulate, Deathridge interprets Benjamin as objecting to the Romantics' tendency to prize the ostensible multivalence of meaning offered by the symbol, on the understanding that allegory sought "access to the general through the particular, and as such artistically less worthy, since its expressive power
} 
allegory is its relationship with and depiction of history: the "allegorical way of seeing, of the baroque, secular explanation of history as the Passion of the world; it is significant only in the stages of its decline." ${ }^{.74}$ The mourning play in general and allegory in particular reflect "the view that life is an illusion that when dissipated, reveals nothing...Benjamin insists...that the knowledge that the world and life can afford us no true satisfaction is the essential, indeed the exclusive, characteristic of seventeenthcentury allegory."'s

Benjamin's pessimistic model of allegory, specifically the notion that allegory explains the "Passion of the world," informs Deathridge's interpretation of the ending of Götterdämmerung. By the time the climactic "immolation scene" unspools, the cycle has been instilled with an extensive sense of history, a history steeped in death and suffering, so that

despite the Ring's outward heroics, its allegorical vision of human existence is pervaded by melancholy...The ending [of Götterdämmerung] is not so much a text sung by a supposedly redemptive heroine, but instead the musical setting of a predominantly melancholic scene - and a scene with enough fire, water, animals, crowds, gods, and falling debris in it to rival the most ambitious theatrical extravaganza of the seventeenth century. The music acts as a kind of negative electrode that finally completes a highly charged circuit built up by previous parts of the Ring. ${ }^{76}$

The "previous parts" making up the "circuit" are the system of motifs that serve to provide a musical history to the cycle, charting the sorrows and melancholy that were initiated by Wotan's cutting into the World-Ash and Alberich's theft of the Rhine Gold. Deathridge observes that the final "twilight of the gods," the cataclysmic culmination of

is exhausted once its meaning has been revealed" (Deathridge, 82). In being supposedly less absolute, the symbol on the other hand, in being supposedly less absolute, offered greater hermeneutical richness, "express[ing] the inexpressible and open[ing] up an infinity of meaning that allegory cannot."

${ }^{74}$ Benjamin, German Tragic Drama, quoted in Deathridge, 82.

${ }^{75}$ Tbid., 83-84.

${ }^{76}$ Ibid., 94. 
all the sorrows that have been experienced throughout the cycle, is portrayed through a "conflict between symphonic development and the increasingly petrified landscape of Wagner's allegorical motifs." 7 The presentation of the motifs at the climax resist the urge towards development, fragmentation, or variation, instead declaimed in their most concrete and unadorned forms. By weaving together a number of motifs that reach back to the beginnings of the cycle, Wagner invokes the tetralogy and his world's history; but in presenting the motifs in their original, "undeveloped" forms, he strips the motifs of the potential for multiplicity of meaning that the symbol might provide, locking them in to allegorical emblems. As Deathridge writes,

Wagner's allegory may lack all symbolic freedom of expression, all classical proportion, even all humanity. But behind the glittering flames and the healing balm of the Brünnhilde motif, the secular explanation of history as World Passion is frozen musically into an allegorical form, which, precisely because of its sepulchral repose, can pose the enigmatic question of the nature of human existence it does. $^{78}$

Thus allegory is another method of effectively conveying the scale and magnitude of the Ring: namely that the cycle aspires to being in Adorno's words, "a metaphor of the totality of world history...." ${ }^{\prime 79}$ That, I submit, is the most engaging aspect of Deathridge's interrogation of allegory in Götterdämmerung: not in the attempt to come to terms with surface and hidden meanings, but in the endeavour to fashion a reading that takes into account the work's ambitions towards staging a world history. In undertaking such a massive project, the Ring's ostensible allegorical aspirations vis-a-vis the entirety of the

\footnotetext{
${ }^{77}$ Ibid., 95.

${ }^{78}$ Ibid., 100.

${ }^{79}$ Theodor Adorno, In Search of Wagner (1952), trans. Rodney Livingstone (London and New York: Verso, 2005), 119.
} 
history of the world complements the magnitude of its goal of staging German myth. ${ }^{80}$ Deathridge remarks that Wagner "claimed in his autobiographical writings to have preceded work on the Ring with a torturous debate with himself about the choice of history or myth as the focus of his future music drama"81 and that "he says he definitely came down in favor of myth." Nonetheless, it is rather apparent that "far from simply choosing myth over history, he actually blended the two." ${ }^{82}$ As evidence, he offers his "literary labors of 1848 and 1849" where "socialist ideas about love, power, and property wander from one subject to the next almost oblivious of their historical or mythical context. Wibelungs are Nibelungs. The Grail is the Hoard. Friedrich I is Siegfried. Siegfried is Christ." ${ }^{\text {"83 }}$ That would tend to contradict Wagner's previously expounded views that myth imparted a deeper and more resonant truth than history (or more specifically, historiography). But if, for a moment we take Wagner's intentions at face value (and that is of course always a risky proposition), perhaps the gap between purpose and effect with regards to his drawing of distinctions between myth and history only serve to underline the work's importance and "monumentality." If one goes along with the proposal that in the Ring, Wagner fuses history and myth, then he has arguably aimed for a work of art that is so far-reaching and "grand" that history and myth must be crosspollinated in order to properly realize its ambition. This is the "mythic allegory" of this

\footnotetext{
${ }^{80}$ Since Wagner's "world history" makes use of Germanic myth as its primary materials, it is not unreasonable to speculate that in doing so, Wagner sets up "world history" and German myth as effectively synonymous.

${ }^{81}$ For example, in "A Communication to My Friends," Wagner makes mention of some indecision over whether to use the historical Friedrich I ("Frederic Barbarossa") or the mythical Siegfried as the subject of his "artwork of the future." SSD IV, 312-314; PW I, 358-360. Barry Millington discusses Wagner's potential Friedrich I opera, along with various other uncompleted projects that Wagner sketched out during the time of the Ring's initial development in "After the Revolution: The Ring in the Light of Wagner's Dresden and Zurich Projects," University of Toronto Quarterly 74/2 (Spring 2005): 677-692.

${ }^{82}$ Deathridge, 93.

${ }^{83}$ Ibid.
} 
chapter's title, and the scale a fusion of two disciplines that Wagner had posited as divergent was such that it was necessary to appropriate the tendencies of grand opera in order to properly accommodate it. ${ }^{84}$ In the next section, I shall re-introduce the other crucial element in the Ring's staging of grand opera as a "mythic allegory": that of the male body.

\section{The Beautiful Hero}

Wagner's autobiographical writings centralize Siegfried, both as an individual and as an emblem of the mythic sources of the Nibelungenlied and the Volsungasaga, as the inspiration (taking into account Wagner's profession of simultaneous consideration of the Holy Roman Emperor Friedrich I) for his "artwork of the future." Siegfried as a character and as a dramatic role can be thematized as one of the crucial elements in the preceding concept of the "mythic allegory," namely that the figure of Siegfried is appropriated from the annals of myth and placed within the form of grand opera in order to stage an allegory about the rebirth of German art. ${ }^{85}$

As Laurence Dreyfus notes, Siegfried has tended to be troped as "the quintessence of the new German man of the future." ${ }^{96}$ Central to this conception is the character's uncommon virility, physical strength, and utter lack of fear. The veneration of the

\footnotetext{
${ }^{84}$ With Benjamin's discussion of allegory in mind, it would be productive to offer a brief comment on Adorno's critique of Wagner's appropriation of myth. Adorno could scarcely be less impressed by the presence of myth in Wagner's work, ridiculing it as "bourgeois" pretension. Myth, for Adorno, strips away any potential for human interest: characters are divested of nuance and psychological complexity in favour of simplified, archetypal forms; political and social relevance are similarly blunted through fealty to the arcane and the archaic. Simply put, for Adorno, Wagnerian myth does not communicate any fundamental truths about the German character. Instead, it plays a fundamental role in constructing "music drama" as a dazzling, but hollow phantasmagoria. See In Search of Wagner, 103-118.

${ }^{85}$ Wolf-Daniel Hartwich exploits Siegfried's potential as a redemptory figure, finding him a kindred spirit with Jesus, a comparison that takes on additional power when one considers that both Siegfrieds Tod and the never-realized opera Jesus of Nazareth were conceived with notable temporal propinquity. See "Deutsche Mythologie": Die Erfindung einer nationalen Kunstreligion (Berlin and Vienna: Philo Verlagsgesellschaft, 2000), 149-159.

${ }^{86}$ Dreyfus, "Siegfried's Masculinity," 5.
} 
character was not unique to Wagner among nineteenth-century Germans; as Simon Williams notes,

for those familiar with Nibelungenlied, he was the acme of the epic hero, a paragon of courage and strength, whose exploits strengthened the bonds of a chivalric society. His blond hair, rubicund complexion, and imposing stature, as well as his centrality to a work that was acquiring the status of a national poem, made Siegfried into a German national hero. ${ }^{87}$

Nonetheless, as his various prose and epistolary writings attest, Wagner maintained a particularly strong degree of affection for the character over the course of the long gestation of the work. Dreyfus speculates that some of Siegfried's appeal to Wagner lay in that the character was something of an "antipode" to Wagner: Siegfried's unabashed physicality and ruggedness stood as a marked contrast with Wagner's own predilections towards such "feminized" sensual pleasures as pink satin, silk, and other fabrics, scented perfumes, and a general aversion to physical discomfort. ${ }^{88}$ Wagner's sensual proclivities were, as Dreyfus notes, "unusual and received a good deal of exposure in the $19^{\text {th }}$-century

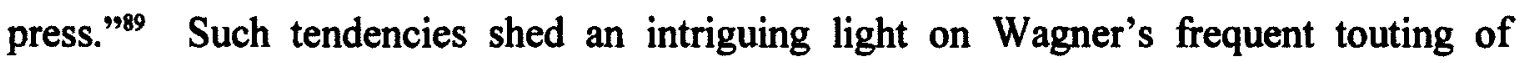
Siegfried's virtues: Siegfried represents all that Wagner is not. Siegfried's imposing manhood cuts a figure of an ideal to which the admiring Wagner cannot measure up. ${ }^{90}$

In Wagner's writings during the planning stages for the Ring, his extolling of Siegfried's physical superiority is implicated in his advocacy for a new form of German drama. As Marc Weiner writes, "Siegfried, and especially his body, was to provide an aesthetic model for the world of the future...."91 In "A Communication to My Friends,"

\footnotetext{
${ }^{87}$ Simon Williams, Wagner and the Romantic Hero (Cambridge: Cambridge University Press, 2004), 86.

${ }^{88}$ Dreyfus, 18-25. See also Wagner and the Erotic Impulse (Cambridge, MA and London: Harvard University Press, 2010), 133-155 and 178-179, by the same author.

${ }^{89}$ Dreyfus, "Siegfried's Masculinity," 19.

${ }^{90}$ This notion of a male body as an image of unattainable perfection will be discussed further in Chapter Four's discussion of the Wagnerian tenor as a male imago figure.

${ }^{91}$ Weiner, Richard Wagner and the Anti-Semitic Imagination, 60.
} 
Wagner's conception of the "strong Man" who exemplified the aesthetic attributes of the new German art was conclusively linked to his valorization of the physically superior male body of Siegfried:

What I recognized here was no longer the historical conventional figure, whose attire must interest us more than his true appearance, but rather the genuine naked human being, in which I could recognize every surge of blood, every twitch of the powerful muscles in unfettered, freest movement: the true human being per se. ${ }^{22}$

With words such as these, Wagner identifies outstanding physical specimens such as Siegfried as the somatic benchmarks for the "truest," most authentic form of human being, the visualization of physical and human excellence that provides the ideal stage for a new age of German art. The sight of Siegfried's body on stage precipitates recognition in German audiences that they are bearing witness to the embodiment of the essential qualities of their collective German-ness. Weiner summarizes the point thusly:

When Siegfried appears on stage before the gaze of the German audience, his image and his sounds provide a hierarchy of metaphors based on his superior physiology: as the locus in which rhythm and movement converge...he represents the reunification of aesthetic elements that were once indistinguishable of the Greek Total Work of Art... ${ }^{93}$

Furthermore, the reunified work of art that Siegfried's performance conveys "constitutes the deep interior 'essence of German art" that the German audience ostensibly recognizes as manifestly superior to all other forms of contemporary art. ${ }^{94}$ Although Weiner does not do much to conclusively establish that the "German audience" would receive Siegfried in the manner he suggests, he does manage to underline the importance that Wagner places upon Siegfried as an embodiment of his ideas what would become the Ring and of operatic reform in general.

\footnotetext{
92،"A Communication to My Friends," quoted in Weiner, 60.

${ }^{93}$ Weiner, 61 .

${ }^{94}$ Tbid., 61.
} 
As a part of his inquiry into the ubiquity of the metaphor of androgyny in Wagner's music and writings, Jean-Jacques Nattiez explicitly reads Siegfried as a representation of an artist, as part of his overall troping of the Ring as an allegory of the history of music. Specifically, Nattiez argues that Siegfried is situated by Wagner as the singular representation of the poet of the future that will restore the lost unity of the work of art. As Wagner writes in "A Communication to My Friends," Siegfried is "the male embodiment of the spirit of eternally and uniquely creative spontaneity, the doer of true deeds." ${ }^{\circ 9}$ In Nattiez's estimation, Siegfried functions as a "true" artist for Wagner in his ability to create new forms, to reshape the remnants of what had come before into something innovative and altogether meaningful. Wagner (and Nattiez) foreground Siegfried's reforging of Siegmund's shattered sword into Nothung as the primary metaphor for the power of his creativity. I invoke Nattiez's interpretive model for its efforts to underline the points of contact between Wagner's veneration of Siegfried as a physical paragon and the quintessence of heroism and his efficacy as an allegory for the idealized poet and artist.

Additionally, Nattiez's foregrounding of the Siegfried/Brünnhilde love duet as the culmination of the androgynous union of poetry and music is important in terms of thematizing Siegfried as representative of the German artist of the future. Most obviously, the introduction of music into the equation serves to position - under Nattiez's paradigm - the sonorous as an essential attribute vis-a-vis defining the new German artist. On a related level, Nattiez observes that upon her awakening Brünnhilde gazes upon Siegfried and recognizes her "masculine" half in his being, and moreover that she contains Siegfried's own "feminine" half. The duet concludes "with a celebration of the

\footnotetext{
95"A Communication to My Friends," quoted in Nattiez, 72.
} 
perfect union between them, a union rendered possible by the sexual complementarity of the two partners involved...." I I recognize the necessary centrality of the body to Nattiez's interpretation: the complementing "halves" of each other that will find blissful union are concealed by the outer shell of their physical bodies. Those bodies will emanate acoustic sounds that bring those hidden "male" and "female" halves out into the open, in the process of merging poetry and music into a unified, "androgynous" whole that ostensibly mirrors the physical and spiritual union of the two individuals. It is the fact that the body radiates sonority that is of interest to me for the purposes of my forthcoming discussions: the body of Siegfried, functioning simultaneously as the enactor of heroic deeds, a vision of iconographic splendour, and as producer of sound, is put forth as a vital stage for the advancement of German art and consequently for the German nation.

Crucial to the troping of Siegfried as an audible symbol of the German artist of the future is the fact that he is constructed as the locus classicus of a unique type of operatic role and sonority. As Weiner recounts, Wagner's endeavours to create a new type of singing style that would acoustically communicate the essence of the German land and its peoples culminated in his ostensible invention of what would come to be known as the Heldentenor, which he argues "constituted a daring and revolutionary event in the history of operatic composition." ${ }^{.97}$ It should be noted that this specific term does not appear in any of Wagner's essays, nor did he use it in any of his other autobiographical or epistolary writings. As such, subsequent uses of Heldentenor in this and following chapters should be qualified as helpful shorthand for its type of sonority,

\footnotetext{
${ }^{96}$ Nattiez, 78.

${ }^{97}$ Weiner, 164
} 
not an endorsement of the term's historical veracity. Weiner's claim of the Heldentenor's supposedly unprecedented sonority is not fully accurate either: as the article on the Heldentenor in the New Grove Dictionary of Opera attests, the role "was an extreme manifestation of the new dramatic tenor that appeared in the 1830 s and 40 s, especially in such Parisian operas as Meyerbeer's Robert le diable (1831) and Berlioz's Benvenuto Cellini (1838). ${ }^{, 98}$ Jens Malte Fischer even goes so far as to say that the Heldentenor as we know it "was not introduced into the history of music by Wagner," citing tenor parts written by Spontini, Auber, and Meyerbeer as precedents for Wagner's model. ${ }^{99}$ However, Wagner was "adamant in dissociating his tenor parts from the 'socalled dramatic-tenor roles of recent times'...especially citing Robert le diable," evidently to ensure his tenor writing bore a sufficient distance from the legacy of those despised French roles. ${ }^{100}$ Wagner's efforts to distance his tenor roles from those of earlier composers combined with the "extreme" nature that the Grove article attributes to them partially rescues Weiner's claim to the extent that the so-called Heldentenor can be framed as a Wagnerian innovation if not an outright invention.

Weiner notes that many a Heldentenor actually began his career as a baritone before moving on to the Wagnerian tenor roles. He quotes Shirlee Emmons, biographer of the Danish singer Lauritz Melchior, one of the outstanding Wagnerian tenors of the early twentieth century: "the Heldentenor Fach"101 demands a tenor voice of large size,

\footnotetext{
${ }^{98}$ Owen Jander and Ellen T. Harris, "Heldentenor," Oxford Music Online (accessed May 7, 2012).

${ }^{99}$ Jens Malte Fischer, "Sprechgesang or Bel Canto: Toward a History of Singing Wagner," Wagner Handbook, trans. John Deathridge, eds. Ulrich Müller and Peter Wapnewski (Cambridge, MA and London: Harvard University Press, 1992), 541. Emphasis added.

${ }^{100}$ Jander and Harris, "Heldentenor."

${ }^{101}$ Literally meaning "compartment" or "subject," the Fächer refers to a German system of classifying the different types of singing voices along with the operatic roles that are suited to that voice. Rather more detailed than other classification systems, the $F a c h$ not only includes the main categories (i.e. soprano, alto, tenor, baritone, bass), but also various sub-categories for each, with the Heldentenor Fach obviously being
} 
exceptional stamina, and more strength in the lower register than other tenors can summon."102 According to this prescription, the Heldentenor is a sonority that "in Wagner's time was new, darker, and deeper"103 and richer than any other tenor voice previously heard, one that generally eschewed the high tessituras (in particular, the top $\left.c^{\prime \prime}\right)$ and vocal ornamentation so favored in the tenor parts produced by Italian and French composers. Rather than a high-C, a Heldentenor was more likely to be called upon to sing a low-C. Weiner associates the characteristics of the Heldentenor with the tenor roles written after Wagner's prescriptions for simultaneous political and artistic revolution in his writings of 1849-51. As such, he tacitly excludes earlier tenor parts such as Tannhäuser and Lohengrin from the "canon" of Wagnerian Heldentenor roles. I take some issue with this tactic, as the similarities displayed in those earlier roles in terms of tessitura, contour, and sonority are quite conspicuous (and in Chapter Four, I will examine those parts as proto-Heldentenor roles). Even so, I acknowledge that it makes sense that Weiner would take this position: the years immediately following the completion of Lohengrin were a musically fallow period, with the void being filled with extensive theorizing about the intersections of political and operatic reform. The musical works to follow these prose writings were Das Rheingold, Die Walküre, and the first two acts of Siegfried, with the roles of Siegmund and his offspring Siegfried being the two significant tenor roles that resulted from Wagner's endeavours to implement his theories into his compositional practice. ${ }^{104}$

a subdivision of the tenor category. See J.B. Steane, "Fach," Oxford Music Online (Accessed May 9, 2012).

${ }^{102}$ Shirlee Emmons, Tristanissimo: The Authorized Biography of Heroic Tenor Lauritz Melchior (1990), quoted in Weiner, 164.

${ }_{103}^{10}$ Weiner, 166.

${ }^{104}$ Overall, Weiner's framework for the Heldentenor as a radical invention should be approached with care: for one thing, the vocal stylings of Siegmund and Siegfried are not quite the clean break from previous 
I propose that what gives the sound of the Heldentenor its power is not its supposed lack of precedent but who is singing them. Weiner appears to suggest as much when he writes that "the conceptualization of this new vocal category was an aesthetically revolutionary act" which inscribed a "vision of a different kind of singer into the scores of his music dramas" following which he will specifically tie Siegfried to this "new" brand of tenor:

Siegfried, let us recall, is the revolutionary, metaphorical representation of a future Germany and of its artwork. Because the Total Work of Art represents the new utopian collective order, it is only fitting that the physiological properties of its paradigmatic emblem - Siegfried will be different from those Wagner deemed inferior...The Heldentenor voice as the acoustical icon of Siegfried's body is the mirror in which a similarly voiced, physiologically heroic collective would see itself - 'know' itself reflected. ${ }^{105}$

Weiner's claim that Germans understood themselves as "similarly voiced" to Siegfried is somewhat dubious, but his tying of Wagner's admiration for Siegfried to the acoustic sounds produced by his body is significant. The fact that those sonorities emanate from Siegfried's body contributes significantly towards solidifying the Heldentenor as the emblematic voice of the new world that the artwork of the future will ostensibly bring about. This alignment of Siegfried's voice with his vouched for qualities as an optimum human allows the sound of its Heldentenor sonority to vouchsafe a portion of the mythical Siegfried's physiological beauty, transferring it to the performer assigned to portray him on stage. As a producer of musical sound, Wagner's Siegfried can plausibly be read as a primary example of how important the male body as aural iconography

practices that he claims, as the tenor parts for Tannhăuser and Lohengrin are not too far removed from the type of writing he will adopt for the Ring. Weiner also makes too much of the ubiquity of the Heldentenor's "low" sounds, as those low-Cs he lists as a necessity are not exactly a constant presence. In terms of tessitura, Wagner's tenor parts are in general not too far removed from those of other composers; what distinguishes them is the "deeper" timbre. Taken as a whole, Weiner's narrative of the invention of the Heldentenor should be treated on some level as more a piece of rhetoric than a statement of unvarnished fact.

${ }^{105}$ Weiner, 166-168. 
functions as a stage for a mythic allegory of the history and transformation of German art, with the dramaturgy of grand opera serving to give that allegory and the body the sufficient sense of grandeur in order to take on such a task. What that history is to be transformed from will provide the basis for the following analyses of other significant male bodies in the Ring, and how their iconographies and sonorities function as mythic allegories of their own.

\section{The God Says Goodbye}

If by chance one were only aware of the first two works in the Ring cycle (Das Rheingold and Die Walküre), one could be forgiven for concluding that it was not anyone from the Volsung line that was the most emblematic character of the entire saga, but the god Wotan. Even accounting for his gradual withdrawal from the storyline (from his "Wanderer" disguise in Siegfried to his outright absence from Götterdämmerung), Wotan is still arguably the prime mover of the cycle in that his actions have implications for several of the characters and their activities as the tetralogy pushes towards its apocalyptic conclusion. For those reasons, it is necessary to delve into Wotan's portrayal and its contribution to the mythic and allegorical tapestry that makes up the Ring's musical setting. Wotan is not the only male representative of the gods (there is also Donner, Froh, and most prominently Loge), but considerations of space will compel me to focus on their leader as the representative of that entire realm. Because of its prominent connection to grand opera dramaturgy, I will direct primary attention to one particular scenes - the finale of Das Rheingold whereupon the gods cross the rainbow bridge to enter Valhalla, appended with some brief remarks pertaining to how it foreshadows the conclusion of Die Walküre where Wotan bids farewell to Brünnhilde - 
with an eye towards explicating how Wagner stages Wotan's body in order to indicate the gods' increasing obsolescence, foreshadowing their eventual destruction.

The Ring's theogony foregrounds a male body that performs an action that originates the world, even though that action is also "original sin" that sets the world off on a course that ensures manifold suffering across all of its societies. Nonetheless, despite the harm that his ambition will precipitate, as a deity, Wotan maintains a sense of majesty and grandeur, which I shall shortly argue is played up by his presence within the dramaturgy of grand opera. As distasteful as Wotan's urge for power may be, he still bears the unmistakeable imprint of the magnificent and the "monumental." Paul Lawrence Rose essentially summarizes many of the above points, writing that Wagner conceived

of a flawed but magnificent Wotan as the personification of law, the upholder of bourgeois morality and society. Wotan is the god of contracts, bound to maintain the bourgeois marriage contract - based on financial interest - as in Die Walküre, no matter how much his nobler instincts go against it. In his less elevated moments, Wotan is also the god of power, of domination and of possession, willing to resort to trickery to secure the erection of Valhalla, that icon of worldly wealth and power. ${ }^{106}$

Wotan's drive for dominance is emblematic of a less "elevated" individual and his maintenance of "bourgeois" mores can tend against more "noble" impulses, yet he still manages to project a discernible magnificence that contributes to the compelling nature of the character.

Williams provides the following appraisals of Wotan that offers another angle in terms of diagnosing Wotan's complexities and failures:

Wotan...faces a tragic dilemma. He wishes to live in the natural freedom signified by the Rhinegold, but cannot because, if he does, his power as a ruler will be destroyed along with the order on which his authority is based. He has ideals, he

\footnotetext{
${ }^{106}$ Rose, Wagner: Race and Revolution, 67-68.
} 
is not just a harsh oppressor, but he is divided between his dependence on power and his desire to create a world free of the evil brought about by power. He has no choice but to submit to the obligations incurred through his exercise of power, though his desire to substantiate the ideal that will annul power grows correlative to his intensifying awareness of the trap in which he has caught himself. ${ }^{107}$

Wagner's Wotan is internally conflicted, afflicted with self-doubt, increasingly acquiescent to the reality that his own machinations have caught him in an inescapable bind that will set the stage for his eventual ruin. Wotan's conflicted impulses make for a more complex and arguably more sympathetic character than a simple power-hungry tyrant, but they also evince a decided lack of self-assuredness and discipline, qualities that one might expect an effective world leader to maintain.

To encapsulate, as the leader of the godly realm, Wotan functions as a singular representative of a flawed institution, an institution that covets and hoards state power. Even as his lack of personal discipline drives him to visit atrocities upon the natural world he also fails an emotional test that renders him unworthy of Wagner's idealized society. Indeed, Wagner specifically lays much of the conflicts that run through the Ring as precipitated by the decline of love in society. ${ }^{108}$ As such, Wagner paints Wotan as a figure doomed to obsolescence as a result of his failure to measure up to the demands of the "elevated" sphere as befitting a god of his stature, nor the conditions of a redeemed human society based upon the regenerating power of emotion. Because of his "magnificent" flaws, Wotan represents a culture whose time has passed and must be torn down, like the remains of the World-Ash he had wounded so long ago.

The flaws in Wotan's character enumerated above are externalized upon his body. The most obvious is of course his missing eye, which is initially attributed to the price

\footnotetext{
${ }^{107}$ Williams, 78.

${ }^{108}$ Magee, The Tristan Chord, 48-67; Barry Emslie, Richard Wagner and the Centrality of Love (Woodbridge, UK and Rochester, NY: Boydell Press, 2010), 26-32 and 55-127.
} 
Wotan had to pay to win Fricka's hand, and then by the Norns to the cost of gaining wisdom from drinking from the well beneath the World-Ash. ${ }^{109}$ As part of a conversation with Cosima in June of 1872, Wagner explains that Wotan's physical sacrifice "expresses the belief that intellectual force precludes regular physical beauty." A conventionally beautiful physical body, according to such a paradigm, demands that "the brain is reduced in potency." Borchmeyer elaborates, "in short, the loss of an eye and the resultant reduction in physical beauty means that for Wotan, conversely, his intellectual powers are immeasurably enhanced."111 Clearly, Wotan believes this to be the case, as his physical disfigurement becomes a precondition for his ascension to dominance of a world guided by treaties and contracts.

And yet, such a disabling lesion to the body could be plausibly read as that which will betoken a more urgent problem than that of mere physical injury. ${ }^{112}$ Borchmeyer more or less grants that for as much as Wotan's mutilation might have elevated his intelligence, it did not grant him the power of the divine. We might ascertain that the loss of Wotan's physical beauty might not have been the worthy sacrifice that it appeared to be: if, for all of Wotan's "wisdom," he is still not all-powerful, might the missing eye register as the somatic signifier of a potential vulnerability? Consider that the loss of an

\footnotetext{
${ }^{109}$ The apparently contradictory explanations for the loss of Wotan's eye (unless his wooing of Fricka and his drinking from the well occurred simultaneously, or perhaps he had simply pledged his remaining eye to Fricka) contribute, I would argue, to the backstory's folkloric nature: the loss of Wotan's eye happened so far in the past that multiple explanations have arisen in the prevailing years. The event is of such distant origins that even Wotan and the Norns have developed diverging memories about how it occurred.

${ }^{110} \mathrm{CD}$ (June 23, 1872), quoted in Borchmeyer, 227.

${ }^{111}$ Borchmeyer, 227.

${ }^{112}$ Wotan's missing eye is the sign of a deformed body. To invoke the "carnivalesque" discourse of Mikhail Bakhtin, Wotan's deformity suggests a possible lineage with Bakhtin's observations of "grotesque" and otherwise deformed bodies in the work of Rabelais. For Bakhtin, the grotesque body was the site of inversion of social hierarchy, with the authority of the "official" culture being laid out for ridicule. The infliction of deformity on Wotan's body might be processed in Bakhtinian terms as the iconography of Wotan's "uncrowning," the overturning of his social and political authority. See Rabelais and His World, trans. Hélène Iswolsky (Bloomington and Indianapolis: Indiana University Press, 1984).
} 
eye hinder Wotan's ability to see. As Martin Jay notes, the "ocularcentric" world view could be traced back to René Descartes, whose epistemological world was purely visual, privileging a method of scientific investigation that relied upon "visual observation of evidence... which could lead in a decidedly empirical direction." 113 Under the Cartesian paradigm, it was the empirical, the visible that functioned as the gateway to genuine knowledge and understanding of the world. The loss of an eye, in limiting Wotan's field of vision, serves to inhibit his sight, both literally and metaphorically. In his rush to obtain the knowledge necessary to seize power, Wotan "blinds" himself to any potential negative repercussions. As the words of Erda and Loge towards the end of Rheingold make clear, Wotan does not "see" what lies ahead for him, and by the time he does, it is too late: he has bound himself to his fate and his only choice is to resign himself to it.

The finale of Das Rheingold purposefully plays up the fissure between the gods' delusions of security and the reality that their imminent ruin is foreordained. Wotan boasts that the fortress that he will name Valhalla will protect them from "terror and dread," even though as Williams notes, "it is obvious his new castle will offer him no such security."114 Loge makes this point eminently clear, stating with clear disdain "they hasten to their end, though they think themselves strong and enduring. I am almost ashamed to share their doings...."115 This scenario of course makes the tragic dimension of the gods' downfall quite apparent: in attempting to escape fate, Wotan and the gods only serve to ensure that their doom will ultimately come to pass.

\footnotetext{
${ }^{113}$ Martin Jay, Downcast Eyes: The Denigration of Vision in Twentieth Century French Thought (Berkeley: University of California Press, 1994), 70-71.

${ }^{114}$ Williams, 81.

${ }^{115}$ Unless otherwise stated, all translations and quotations from the libretto are derived from liner notes to Das Rheingold (Decca 455 556-2).
} 


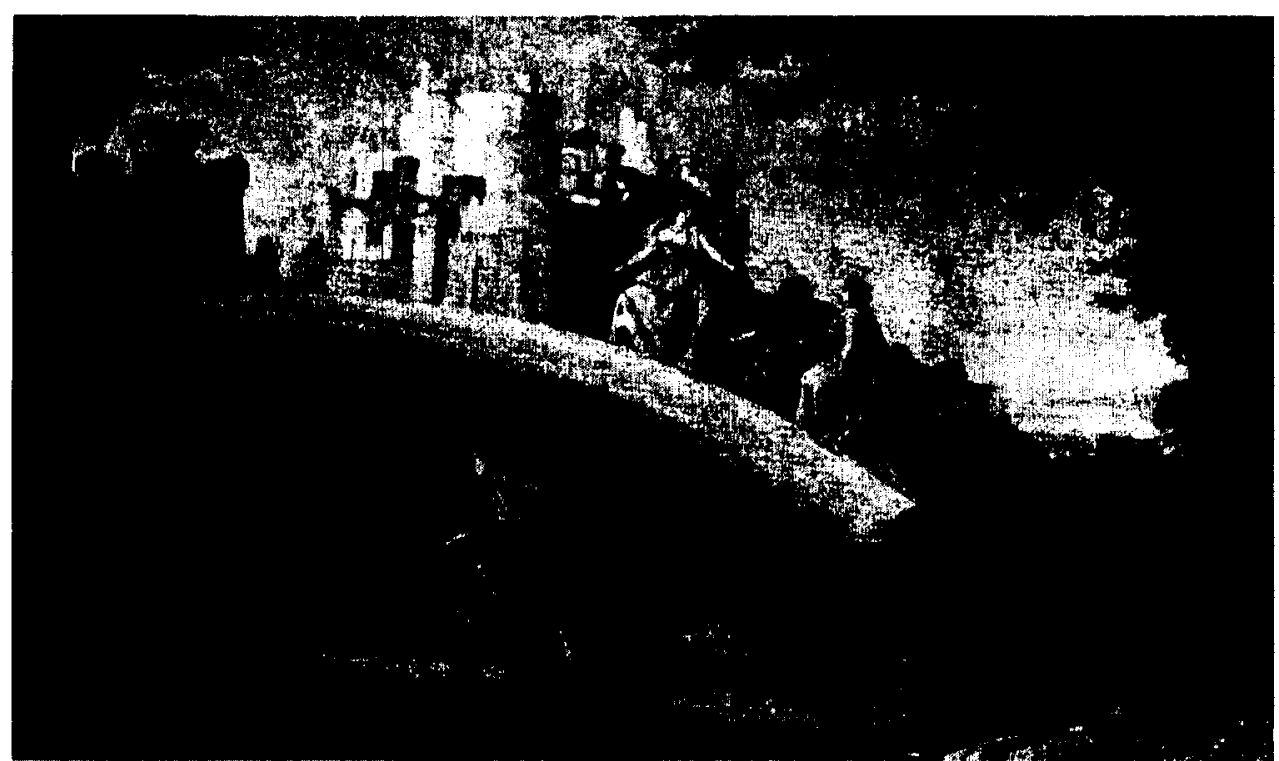

Fig. 1

Drawing by Theodor Pixis, Munich 1869

(Wagner: A Documentary Study, Herbert Barth et al, eds. [New York: Oxford University Press, 1975], plate 169)

In terms of dramaturgy, this finale also displays a prominent lineage to grand opera despite Thomas Grey's claim that Rheingold "is in many ways the antithesis of grand opera." ${ }^{" 16}$ Grey justifies this statement in part by noting that "visual display 'for its own sake,' ceremonial grandeur, ballet...and the operatic chorus" have no presence whatsoever in the first three works of the cycle (that is, those that were conceived and drafted in the wake of the project's expansion from Siegfrieds Tod). ${ }^{117}$ Even so, Grey concedes that these "'music dramas' benefited as much from an absorption of the grand opera genre as they did from his more recent critique of it." ${ }^{118}$ I submit that the finale of Rheingold is but one example of Wagner's "absorption" of grand opera's prominent musical and dramaturgical traits. The creation of a rainbow bridge for the gods to cross in order to enter Valhalla of course requires a fair degree of legerdemain and ingenuity on

\footnotetext{
${ }^{116}$ Thomas S. Grey, "Richard Wagner and the Legacy of French Grand Opera," The Cambridge Companion to Grand Opera, ed. David Charlton (Cambridge: Cambridge University Press, 2003 ), 337.

${ }^{117}$ Ibid.

${ }^{118}$ Ibid.
} 
the part of the production designers and technicians. But beyond matters of stagecraft, the scene resembles grand opera in other ways: musically, it is an ensemble finale, common (but not unique) to grand opera, which divides its forces between on-stage and off-stage voices (the Rhinemaidens providing the latter). Dramatically, the rainbow bridge is reminiscent of the type of elemental outbreak in the name of creating a grandiose scenic spectacle that harkens back to the climactic eruption of Mount Vesuvius in Auber's La muette de Portici, the arguable progenitor of the grand opera genre. Later examples of this tendency manifest themselves in the storm over Lake Lucerne that drives much of the fifth act of Rossini's Guillaume Tell and the climactic explosion that destroys the palace in Meyerbeer's Le prophète. ${ }^{119}$ What these scenes have in common is that they call for an elaborate stage effect that brings together the surviving characters in order to provide a spectacular resolution to the story. The rainbow bridge of Das Rheingold is certainly less sensationalistic than the other examples listed, and is less given to ornate tableaux, if only due to its lack of a chorus embodying the crowd. Nonetheless, a representation of the elements in order to create a stage effect lends the scene its grand opera resonances.

Rheingold's finale also represents a notable transformation of the grand opera "elemental" finale: whereas in the examples provided by Auber and Meyerbeer, such scenes are destructive in nature, providing a suitably catastrophic conclusion to the story that befits their downbeat outcome, Wagner reworks the manifestation of the elements as something altogether more triumphant. The visual beauty of the rainbow provides an uplift that is complemented by the exultant mood of the music. Both combine to depict the gods at the absolute pinnacle of their powers. Of course, as Loge's observation

\footnotetext{
${ }^{119}$ Although in that case, the elements are manipulated as the fire is set off by Jean.
} 
makes clear, it is quite the superficial triumph: Wagner's music and dramatic imagery provide the veneer of victory, which is then undermined by the knowledge that it is only fleeting. If we accept Grey's assertion that Rheingold is generally an antithesis of grand opera that had nonetheless absorbed some of its practices, then it is plausible to infer that Wagner exploits grand opera for a dual purpose: on the one hand, to provide an appropriately spectacular finale that sends the performance out on the proverbial high note, while at the same time providing a stealth critique of grand opera's traditions. In communicating to us that Wotan's proclamations of triumph and the accompanying resplendent music and staging only serve as the proverbial "pride before the fall," perhaps Wagner entreats us to realize that grand opera is steeped in shallow pageantry. Paradoxically, that "shallowness" serves as a potential demonstration of how the filtration of grand opera through Wagner's sensibilities is the very thing that "rescues" it from the genre's ostensible shortcomings: he aligns the scene's superficial sense of grandeur with the foreknowledge that the gods are in fact only taking another step towards irrelevance. ${ }^{120}$ Or as Heinrich Porges - who had been hired by Wagner to document the

\footnotetext{
${ }^{120}$ Proceeding from the premise that Rheingold is in fact indebted to the dramaturgy of grand opera, then it is an intriguing observation that Wagner's transformation of grand opera, especially in the first three works, was so thorough that few of the observers who published their accounts of that inaugural Bayreuth Festival in 1876 saw fit to annotate to a significant degree any connections between what Wagner put on stage and the type of scenic spectacle offered by the Paris Opera. Indeed, although Frederic Spotts notes that the various stage effects required for Rheingold made it the most challenging of the four works to realize colour-lit steam provided by a locomotive boiler is listed as a prominent piece of equipment - many of the various reviews from the period do not make any mention of the rainbow bridge scene, nor of how the illusion might have been presented. Was this omission simply a tacit statement that it simply was not considered a particularly notable bit of stage magic - and indeed, Eduard Hanslick's review, one of the few to comment on this particular stage effect, was rather derisive, writing that "the rainbow...was set so low that one could have taken it for a painted bridge in a flower garden" (84) - or could it also serve as an indication that Wagner had reworked an aspect of grand opera to such an extent that no one thought to note any similarities between the scene in Rheingold and the instances of elemental "outbursts" that had frequently occurred in previous Parisian works? See Spotts, Bayreuth, 63 and Robert Hartford, ed. Bayreuth - The Early Years: An Account of the Early Decades of the Wagner Festival As Seen by the Celebrated Visitors \& Participants (Cambridge: Cambridge University Press, 1980), 45-108. Gundula Kreuzer discusses the prominent use of steam in the Ring and other Wagner productions in "Wagner-
} 
rehearsals for the 1876 Bayreuth Festival - describes it in the closing sentence of his analysis of Rheingold, "the prelude to the world tragedy about to unfold."121

The elemental nature of Rheingold's finale lays down a template for the rest of the cycle, as each of the following three works will set down such "eruptions" as backdrops to their respective conclusions. Upon "construction" of the bridge, Wotan engages in a monologue that culminates him being seized by what the stage direction refers to as a "great idea."

(Wotan und die andern Götter sind sprachlos in den prächtigen Anblick verloren)

Abendlich strahlt der Sonne Auge; in prächtiger Glut prangt glänzend die Burg.

In des Morgens Scheine mutig erschimmend,

lag sie herrenlos hehr verlockend vor mir.

Von Morgen bis Abend in Müh' und Angst

nicht wonnig ward sie gewonnen!

Es naht die Nacht: vor ihrem Neid biete sie Bergung nun.

(Wie von einem grossen Gedanken ergriffen, sehr entschlossen)

So grüss' ich die Burg, sicher vor Bang' und Graun!

Folge mir, Frau:

in Walhall wohne mit mir!

(scene IV)
$[($ Wotan and the other gods contemplate the glorious sight, speechless) The sun's eye shed's its evening beams; in its glorious gleams the castle shines in splendour. In the radiance of the morning it glittered proudly but stood before me tenantless, grand and inviting. From morn to eve, in case and anxiety, not lightly it was won! Night draws on; from its envy it now offers shelter. (As if seized by a great idea, very firmly) Thus I salute the fortress, safe from terror and dread. Wife, follow me and dwell with me in Valhalla!]

Before delving into the music, attention should be paid to the initial stage direction, quoted above: the gods are struck "speechless" by the "glorious sight" of the formation of the rainbow bridge. In other words, the gods are prescribed by Wagner to be dazzled by

Dampf: Steam in Der Ring des Nibelungen and Operatic Production," The Opera Quarterly 27/2-3 (Spring/Summer 2011): 179-218.

${ }^{121}$ Heinrich Porges, Wagner Rehearsing the Ring: An Eyewitness Account of the Stage Rehearsals of the the First Bayreuth Festival, trans. Robert L. Jacobs (Cambridge and New York: Cambridge University Press, 1983), 39. 
the same stage illusions that are to ostensibly dazzle the audience; they are duly impressed by the type of scenic spectacle that is endemic of grand opera. Wotan initially sings of the morning light revealing the majesty of the fortress that lies across the bridge, the reference to morning loaded with implication: one could easily intuit that Wotan refers to the "dawn" of a new age wherein the gods ascend to new heights of glory having been "freed from the tyranny of time and allowed to reenter the ahistorical realm of nature...."122 And yet, the very same monologue also provides ample illustration of Deathridge's observation that in the "different worlds of his myth," things "are never quite what they seem."123 Wotan admits that the fortress was "not won lightly," reflecting his statement of unease made only a few moments prior where "when Fricka tries to wheedle him into delighting in the beauty of the fortress that is now theirs, he can only reply, gloomily, that he has bought it with bad money." ${ }^{24}$ Furthermore, he observes that night is approaching, from which he claims the new citadel will shield them. Whatever Wotan's reservations, they appear to be soon sublimated by his awe at Valhalla's majesty and erroneous assurance that it will protect them from the aforementioned twilight. Accompanying Wotan's oration is a constant and sprightly sixteenth-note figure in the strings which sonorously evokes the images of the dispersing mists and fogs and the rising sun shining upon the rainbow bridge and the fortress lying across from it. The passage builds towards Wotan's "great idea." At the moment he is seized by this thought, the trumpets articulate what Deathridge calls "one of Wagner's best ideas." 125 This is the C-major triad-based theme that will come to be known as the

\footnotetext{
${ }^{122}$ Deathridge, 52.

${ }^{123}$ Ibid., 51 .

${ }^{124}$ Cooke, I Saw the World End, 233.

${ }^{125}$ Deathridge, 52.
} 
"sword" motive (Ex. 1), introduced in Die Walküre to represent the sword that Wotan has left embedded in the trunk of the Hunding's house-tree for Siegmund to retrieve. Grey observes that the motive "belongs to the larger family of simple, noble, triadic motives usually associated with natural phenomena (the Rhine, Freia's apples of eternal youth, Donner's thunder, the rainbow bridge to Valhalla)."126 Sounding in concert with Wotan's idea, the insertion of the "sword" motive is thematized as an event that will have wideranging, indeed "monumental" implications on the events to come. When Wotan resumes his vocalizations, he aims to stake out a claim for that monumentality as the first note he sings upon resumption is an $\mathrm{F}$ above middle-C. In singing his highest note (of this sequence) immediately after the statement of the sword theme, Wotan aims for the same sort of brilliant clarion-call effect that the trumpet had just provided, a "ringing out" that announces that like the trumpet's motive, Wotan's "great idea" will have a significant influence on the world's course from here on out. This turns out to be very much the case, as Wotan's decision to christen the fortress as "Valhalla," a hall where slain heroes are gathered in order to protect the godly realm will play no small role in bringing about all of the events that take place over the course of the remainder of the cycle.

Ex. 1

("Sword" motive)

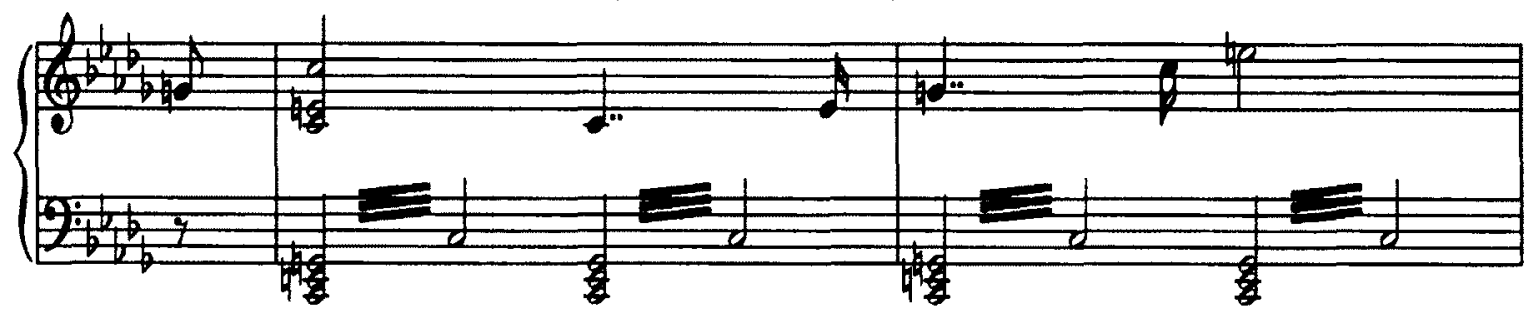

${ }^{126}$ Thomas S. Grey, "Leitmotif, Temporality, and Musical Design in the Ring," The Cambridge Companion to Wagner, ed. Thomas S. Grey (Cambridge: Cambridge University Press, 2008), 92. 
Wotan's vocal encomium to the "great idea" that is the naming of Valhalla and the intimations of its future purpose thus can be grasped as an attempt on Wotan's part to construct a sonorous body that projects a sense of regality, dignity, and majesty apposite to his godly position. An August, 1875 entry from Cosima's diary is potentially illustrative: she attributes a sonorous splendour to Franz Betz's voice that reflects Wotan's ostensibly "magnificent" qualities. During a rehearsal designed to test the tone of the orchestra, she extols Betz's singing as the source of a "heavenly sound [and an] overwhelming impression" with her husband being "very moved" by the performance. ${ }^{127}$

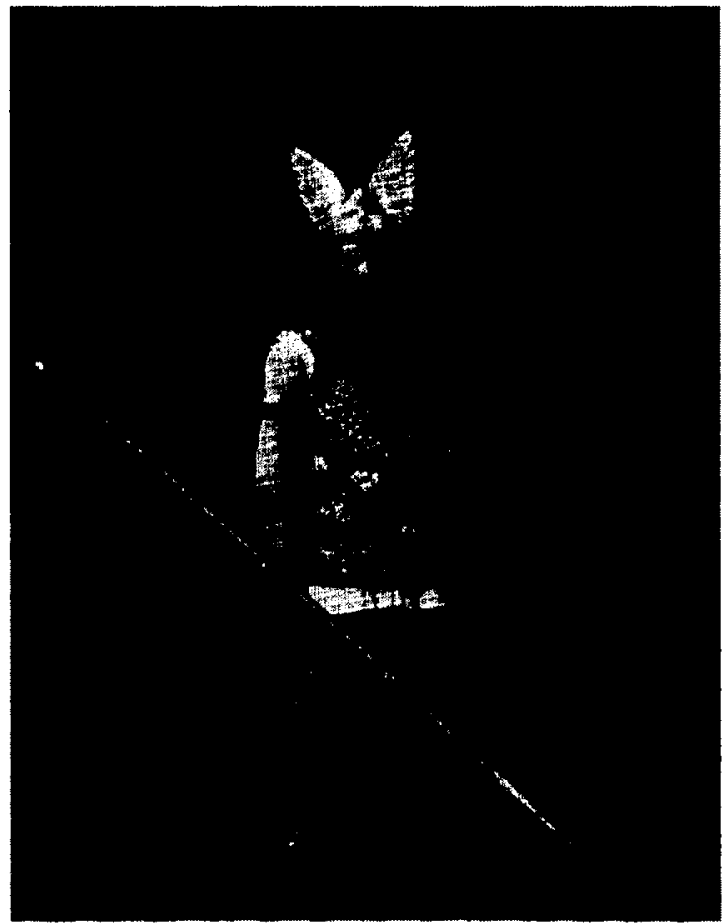

Fig. 2

Wotan - Franz Betz (1876)

(Wagner in Rehearsal 1875-1876: The Diaries of Richard Fricke, ed. James Deaville and Evan Baker [Stuyvesant, NY: Pendragon Press, 1998], plate 4)

\footnotetext{
${ }^{127} \mathrm{CD}$ I (August 1, 1875), 858. Wagner's relationship with Betz would eventually sour, as a letter to Lilli Lehamann, dated September 7, 1876 attests: Wagner states that Betz "casts a wholly repugnant shadow upon my memory! The wretch even went so far as to make fun of his part, more especially at the beginning of the last performance of the Valkryie." Wagner goes on to speculate that it might be necessary to "take steps to replace him as Wotan next year, since he tells me that in no circumstances would he ever again return to Bayreuth." Betz would eventually return to Bayreuth in 1889, performing in Tristan und Isolde alternately as Marke and Kurwenal, and as Sachs in Die Meistersinger. See SL, 859-860.
} 
Wotan's acoustic body attempts to align itself with the "ahistorical" natural realm in order to permanently enshrine those bodies as a somatic testament to the permanence of their majesty. The concluding measures put the finishing touch on this gambit: as the gods cross the bridge and into Valhalla, the orchestra underscores their ostensible triumph with effulgent brass repeatedly articulating the Valhalla theme in a manner that evokes overwhelming victory. The exultant sonorities of the brass, along with the prominent martial rhythms evoke the same sense of grandeur that Wotan attempts to claim for himself in both his words of praise for the newly-named fortress and the "great idea" that was so prominently announced by the brass. As such, one might say that the musical depiction of Wotan's body migrates in these final measures from his own voice to that of the orchestra. ${ }^{128}$ In doing so, the orchestra paints a sonorous image of splendour that befits Wotan's image of himself, the figure of "radiance" (to use the words of Loge's - admittedly sarcastic - rebuke to the lamentations of the Rhinemaidens) that has triumphed over nature and history.

But of course, that musical depiction of triumph is but a gloss: an effort to use the sonorities of victory to cover over the words that pierce that uplifting artifice. In terms of vocals, the last words are given over to the "plaintive cries from the invisible Rhine daughters" which "sully the triumphant march of the gods," a reminder to the audience "that the story is still incomplete." Loge's words of contemptuous rebuke function as a pointed rejoinder to Wotan and his fellow gods' misguided certainties of superiority and security, "hang[ing] on the air, after

\footnotetext{
${ }^{128}$ Note that the stage direction quoted above reads "Wotan and the other gods": that Wotan is placed in that primary position and is the only one specifically named lends a degree of credence to the hypothesis that Wotan is essentially staged as a synecdoche for the entire community of the gods.

${ }^{129}$ Deathridge, 52.
} 
the curtain has fallen, like an unanswerable denunciation." ${ }^{130}$ To visit those denunciations back upon Wotan's body, Wotan aspires towards godly beauty and control, but the censures of Loge and the Rhinemaidens remind us of the "missing eye" that his music has attempted to conceal. The contrast of Wotan's attempts to fashion himself as a figure of omnipotent majesty and Loge's and the Rhinemaidens words of recrimination is efficacious in solidifying the "magnificent, but flawed" trope. Even Wotan himself contributes to this characterization, as his proclamations of victory are coloured by expressions of anxiety over his duplicitous methods in securing the construction of Valhalla and the potential threat that Alberich's curse upon the Ring might pose, resulting in his decision to return to earth to consult with Erda. Those doubts paint a picture of an individual trying to convince himself of his magnificence and invulnerability, but at the same time becoming increasingly aware of his flaws. All of this is depicted musically and dramaturgically in the context of the "elemental" finale of grand opera, which both provides the theatrical audience with an appropriately exhilarating, large-scale concluding set-piece, but also affords a sufficiently "grand" stage for both Wotan's magnificence and flaws, to provide the necessary dramatic approximation of the scope of his power and of the world-changing reach of his prophesized downfall.

As a postscript to the above discussion, I submit that the finale of Die Walküre functions as an interesting complement to that of Rheingold. The libretto (and to some extent, the music) of the earlier work makes it clear that in traversing the rainbow bridge into Valhalla, Wotan is proceeding toward his eventual doom. That prophecy prefigures not just the conclusion of Götterdämmerung, but what occurs at the end of this second part of the tetralogy. The work's ending consists of a lengthy monologue from Wotan,

${ }^{130}$ Cooke, 244. 
wherein he bids Brünnhilde farewell, before summoning Loge to encircle his favorite Valkryie daughter with a ring of protective fire, through which only a hero who knows no fear may pass and claim her as his bride. This monologue effectively mirrors the earlier one he gives to Brünnhilde in the second act, in which he recounts to her the backstory behind his directive that she not intervene on Siegmund's behalf against Hunding. In that monologue, Wotan impressed upon her the historical weight of every event that had led up to that moment. ${ }^{131}$ The final monologue follows from that, showing a Wotan who is taking a major step in giving himself over to the consequences of his history, because his farewell to Brünnhilde simultaneously functions as his farewell to the world; in permanently taking leave of his daughter, Wotan signals that he is abandoning his power and position. Wotan's proclamations of "farewell," "no longer," and "never again" are addressed to both Brünnhilde and the theatre audience. At the same time that Wotan disowns his daughter, he also announces his abdication of his status as a deity, for when he is next seen by the audience, it is in the guise of an anonymous Wanderer, never again to actually be seen or heard as Wotan, chief of the gods. In abandoning his favored daughter and his godly duties, Wotan, to invoke the terminology of Theodor Adorno, migrates from god to "beggar." triumph that covers over the impending end of the gods' power and relevance, the end of Walküre follows up from that in showing where this end truly commences.

Musically, the scene is characterized by a mounting emotional intensity in both Wotan's singing and the accompanying orchestra which, as Porges prescribes, should

\footnotetext{
${ }^{131}$ Carolyn Abbate discusses this monologue at length as an example of musical narrative in Unsung Voices: Opera and Musical Narrative in the Nineteenth Century (Princeton, NJ: Princeton University Press, 1991), 156-205.

${ }^{132}$ Theodor Adorno, In Search of Wagner (1952), trans. Rodney Livingstone (London and New York: Verso, 2005), 119-131.
} 
never lose its "elegiac quality," despite the music's "passionate intensity."133 The emotional fervour of the music and its commensurate radiant sonority serve to acoustically cover over Wotan's missing eye, to create a sonorous body that resounds with emotion and genuine grandeur. ${ }^{134}$ It is a body that acoustically elevates Wotan, finally, into the realm of "greatness," right before he gives it all up. Wotan's sacrifice helps illustrate why Claus-Dieter Osthövener refers to the Ring as the "redemption of the gods." ${ }^{\text {33s }}$ In terms of dramaturgy, Wotan's farewell owes a debt to grand opera in two notable ways: Grey observes that many of Wagner's notable love duets are not far removed from the "grand duos" of Parisian opera, with Raoul and Valentine in Les Huguenots singled out as a prominent example. ${ }^{136}$ My position is that the confrontation between Brünnhilde and Wotan, which takes up nearly two scenes in Act III, constitutes a variation on the "grand duo," with the love aspect being of a paternal/filial rather than romantic/sexual nature.

The world - as Wagner presents it - has moved on from the gods to the point that it is understood that while they are part of the building blocks of the national identity, they only have a place in the modern world to the extent that they are preserved as figures from the mythological past. Wagner's simultaneous conception of Wotan and the gods as allegories for the influence of the lust for power and the resultant despoliation of the world is also instructive: as powerful, but corruptible figures, Wagner simultaneously foregrounds the gods as a diagnosis of the ills of "modern" society. In projecting that

\footnotetext{
${ }^{133}$ Porges, 75-76.

${ }^{134}$ Matt Bailyshea provides an analysis of this scene as an example of his exploration of the ways in which characters in the Ring can be said to "control" the orchestra, shaping it to reflect their emotional and psychological states in "The Struggle for Orchestral Control: Power, Dialogue, and the Role of the Orchestra in Wagner's Ring," $19^{\text {th }}$-Century Music 31/1 (Summer 2007): 3-27.

${ }^{135}$ Claus-Dieter Osthövener, "Konstellationen des Erlösungsgedankens," Wagnerspectrum 5/2 (2009): 6671.

${ }^{136}$ Grey, 337-338.
} 
allegory back into myth - as Borchmeyer notes, for Wagner "myth was not an allegory of the social conditions that obtained in the modern world" but was instead "these conditions are reactualizations of the events prefigured in myth"137 - Wagner effectively situates the corrupted modern world within the past, as something to be overcome and left behind. So, then the "mythic allegory" of the "magnificent, but flawed" performing body of Wotan is that said body represents a part of the nation's past, a past that contains many glories, but also "flaws" to be surmounted, left behind as part of a progression towards a revitalized state. To return to the "elemental" aspect of Walküre's grand opera finale, the stage direction indicates that Wotan gives one last look back towards Brünhilde as he leaves her behind, thus departing from power and consigning his godhood to history. He then walks through the magic fire that he has summoned, which he had prophesized that only Brünnhilde's suitor would do. Wotan's departure through the flame signals that the hero whom Wotan himself has proclaimed will be his better, the one who will represent the idealized human being and thus stand in for the promise of a rejuvenated German nation will possess the same "magnificent" qualities as himself, only more so. Wotan's emergence from the flame and commensurate withdrawal into myth uses the scenic spectacle of grand opera to set the stage for Siegfried's entry into said flame in order to cement his role as embodied mythic allegory for the nation.

\section{Uncanny Otherness}

Before delving into the most exalted male body in the Ring, it behooves me to address one of the other pieces of male sonority that are similarly thematized as that which has been left in the past. With Wotan, Wagner presented us with a figure that although flawed was nonetheless a valued part of the German mythic tapestry. In

${ }^{137}$ Borchmeyer, 221. 
contrast, I will now explore the male bodies that stage that which Wagner puts forth as the debased, the detritus of German myth and history. Without question, the most debased figures that Wagner presents in the Ring are the titular Nibelungs themselves, with Alberich being the most emblematic. It was not always the case that the term "Nibelung" carried a negative connotation in Wagner's framework, as his 1848 essay "Die Wibelungen" attests. That piece demonstrated that "in Wagner's view, the Nibelungs were identical with the old Frankish dynasty of the Wibelungs, or Ghibellines."138 Wagner also makes this observation about the Nibelung legend:

Here we find Siegfried as the winner of the Nibelung's Hoard and with it might unmeasurable. This Hoard, and the might in it residing, becomes the unmovable centre round which all further shaping of the saga now revolves: the whole strife and struggle is aimed at the Hoard of the Nibelungen, as the epitome of earthly power, and he who owns it, who governs by it, either is or becomes a Nibelung. ${ }^{139}$

Wagner in this essay essentially characterizes Siegfried as a Nibelung, if only as a consequence of having won the treasure for himself. Certainly, a hypothetical reader coming to this essay already familiar with the completed Ring would be surprised by such a statement, which is characteristic of one who sees them not as abject villains, but as examples of the old Germanic kings and tribes that the essay sets out to venerate.

However, by the time of "The Nibelung Myth," which essentially functions as a prose synopsis of both the dramatic action Siegfrieds Tod and its attendant backstory, Wagner's depiction of the Nibelungs had shifted to become more or less in line with what was presented in the completed tetralogy. Observe the opening sentence:

Out of the womb of the night and of death rose a race that lives in Nibelheim (Mist-Home) i.e. in subterranean dark crevasses and caves: they are called

\footnotetext{
${ }^{138}$ Ibid., 214. Berry adds that Wagner was able to take this position by alleging that the word "Nibelung" was etymologically linked with "Wibelung" and "Ghibelline" (80).

${ }^{139}$ SSD II, 119; PW VII, 263.
} 
Nibelungs; in irregular, restless activity they dig (like worms in a dead body) through the bowels of the earth: they melt, purify, and shape the hard metals. ${ }^{140}$

This passage ascribes altogether more grotesque imagery to the Nibelungs: they are borne out of the "womb of death" and their "restlessness" is verbally envisioned in exceptionally unpleasant terms: although they themselves are not likened to "worms in a dead body," in evoking that image as a descriptor of their activities, Wagner associates the Nibelungs with decay, disease, and death. Wagner's Nibelungs are thematized as symbols of corruption. In likening the industrial practices of the Nibelung to maggots feasting on the flesh of a corpse, Wagner provides an image designed to provoke revulsion, thereby identifying an ugliness to industrial capitalism that will spread said ugliness throughout the world, thereby soiling its natural beauty.

Alberich's outward appearance serves as a physiognomy, externalizing upon the body the repulsiveness of the Nibelung's society and their practices. Upon seeing him for the first time, Wellgunde and Woglinde exhort a disgusted "ugh!" before remarking "how frightful!" The Rhinemaidens will further play up Alberich's lack of physical appeal, referring to him as a "lascivious gnome." During her mocking "seduction," Flosshilde identifies Alberich's "toad-like form" and "croaking voice." All of these descriptors serve to paint Alberich as diminutive and grotesque, most definably "other." As Berry observes, the Rhinemaidens "proclaim [Alberich] to be a misfit in a world of cruel hedonism...."141 Such wording indicates a certain degree of sympathy for Alberich's plight, borne out by Wagner's admission to having "once felt every sympathy for Alberich, who represents the ugly person's longing for beauty." ${ }^{142}$ Even so, Wagner

\footnotetext{
${ }^{140}$ "The Nibelung Myth," in Haymes, 45.

${ }^{141}$ Berry, 64.

${ }^{142} \mathrm{CD}$ II (March 2, 1878), quoted in Berry, 64.
} 
makes it plain that Alberich is in fact physically repellent. But it is not just physical and moral corruption that contributes to Alberich's repellence: recall Flosshilde's observance of his "croaking voice." In addition to looking "other," he (and by extension his fellow Nibelungs) sound other as well, and that otherness is thematized as similarly ugly and characterized by "distorted music and...contorted words...."143

The congruence of Alberich's visual and sonorous ugliness and his avarice and lust for power cannot help but bring to mind Wagner's anti-Semitism. Especially when so much of the debased characteristics ascribed to Alberich correspond rather closely to those that Wagner assigns to Jews in his infamous screed "Jewishness in Music."144 Reading the Nibelungs as anti-Jewish caricatures has been a popular critical strategy, with Rose and Weiner providing the most prominent recent examples. I do not intend that paradigm to be a significant aspect of my own forthcoming interpretation, if only to avoid to needless repetition of what is already well-trod critical ground. However, the ubiquity of this particular line of inquiry, and the inescapability of the issue of antiSemitism when discussing matters pertaining to Wagner, necessitates that I acknowledge its existence. It would thus perhaps be beneficial to keep the anti-Semitism trope at least in the back of one's mind when reading any analysis of Wagnerian characters that underline physical and acoustic ugliness as an externalization of "inner" corruption, as my forthcoming reading of Alberich will do.

It would be tempting to conclude that Wagner tropes his various degraded characters as outliers, completely antithetical to the "true" German character, especially if

\footnotetext{
${ }^{143}$ Ibid., 69-70.

${ }^{144}$ SSD V, 66-85; PW III, 79-100. These page references are to the original 1850 version of the essay, published under the pseudonym "K. Freigedank." Wagner's 1869 addendum "Aufklarungen tuber das Judenthum in der Musik" ("Some explanations concerning "Jewishness in Music") may be found in SSD VIII, 238-280; PW III, 77-78 and 101-122.
} 
we take into account some of Wagner's writings that post-date the composition of the Ring poems - in particular "Know Thyself," an addendum to his 1880 essay "Religion and Art" - that characterize Jews as an "anti-race."145 The "anti-race" paradigm would certainly find some concurrence with Homi Bhabha's performative framework for the nation, a part of which posits that the "terror of the space or race of the Other" defines the undesirable elements that are to be exiled in order to stabilize the fantasy of nationhood. ${ }^{146}$ The "centre" (that is, the nation) is defined against that which exists on the margins, in other words. As an "anti-race," the Jews are efficacious in terms of underlining what Germans are not, so as to solidify a narrative of what the German nation is.

I offer the following introductory points in order to set up my framework for discussing the "undesirables" of the Ring: firstly, even though in the finished cycle the Nibelungs are presented as arguably the most loathsome of all persons and creatures dispersed throughout the storyline, they are still conspicuously centralized. Moreover, recall that the Nibelungenlied was considered by nineteenth-century artists and intellectuals to be one of the defining folkloric texts in terms of constructing a cohesive German national identity. Since they are identified in the title of what was considered an important piece of German heritage, one might plausibly extrapolate that the Nibelungs in fact play a significant role in defining German identity. Wagner's Nibelungs, I maintain, play that role in a manner related to, but perhaps more subtle than that of the

\footnotetext{
${ }^{145}$ SSD X, 271; PW VI, 271. Chapter Four will examine the Jewish anti-race concept as it pertains to Parsifal

${ }^{146}$ Homi K. Bhabha, "Introduction: Narrating the Nation," Nation and Narration (London and New York: Routledge, 1990), 2. See also The Location of Culture (1994) (London and New York: Routledge, 2004), 199-244.
} 
grotesque, marginalized Other, whose alterity provides the model against which the nation is constructed.

A clue to how this occurs may be found in another of the characteristics that Wagner assigns to the Nibelungs in "The Nibelung Myth": the Nibelungs are noted as residing in a "subterranean" realm and that their mining activities necessitate that they plow through the "bowels of the earth." It is this subterranean language that is significant, as it specifically locates the Nibelungs as existing and operating underground, beneath the surface of the earth. Put another way, such imagery suggests possible psychological underpinnings, for these residents who live in and burrow through the "bowels of the earth" bring to mind the workings of the subconscious, constantly operating below the surface that is the conscious mind. At the beginning of the cycle, Alberich ascends from the depths to the surface world, in a similar manner to the way in which the unconscious periodically manifests itself in the conscious. To invoke Freudian language, one particular instance of this manifestation of the unconscious is the "return of the repressed" that Freud associates with the condition of the uncanny. ${ }^{147}$ As Freud notes, it is that tendency towards recurrence that gives the repressed and the uncanny their capacity to frighten; the repressed can never remain buried indefinitely, it must eventually erupt into the subject's consciousness completely unexpectedly, resulting in great anxiety. One could say that in the subterranean depths of Nibelheim, Alberich functions as the "repressed," who at the outset of Das Rheingold emerges from those depths, provoking significant unease in the Rhinemaidens. Furthermore, this emergence of the unconscious - or the "repressed" - from the earth's bowels results in a serious

\footnotetext{
${ }^{147}$ Sigmund Freud, "The Uncanny," The Standard Edition of the Complete Psychoanalytic Works of Sigmund Freud Vol. 17, trans. and ed. James Strachey (London: Hogarth Press, 1953), 219-256.
} 
destabilization of the world, as Alberich makes off with the Rhinegold, setting in motion all of the upheaval to follow.

If we accept that Alberich, as a Nibelung, is in fact an important thread in the tapestry of German myth and nation, then the characterization of Alberich as an eruption of the unconscious which results in significant destabilization carries the suggestion that German identity submerges an unpleasant undercurrent, a collective "repressed" that recurs, resulting in a national "uncanny" and problematizing the phantasmatic of nationhood. The interaction of myth and allegory significantly resonates within this proposed problematic of nation and the repressed: earlier, I mentioned that Borchmeyer concluded that for Wagner, the allegorical functioned as a restatement, a recurrence of the events narrated in the annals of myth. Wagner himself comes close to stating this by subtitling the "Wibelungen" essay "World History from Legend": history - and allegory is at its fundamental level, a metaphorical staging of history - essentially extracts its first principles from mythic archetypes. Alberich's theft of the Rhinegold, the subsequent fashioning of the Ring, and his eventual curse, in its allegorical/historical guise, represent the inception of the world of capital and industry and the concomitant urge to obtain and hold onto power. But, in Borchmeyer's estimation, "the curse of the gold" does not simply represent the "curse of capital." In addition,

it also represents the recurrence of an archetypal mythical situation. After all, the motif is already found in the oldest of mythological sources. (Suffice it to recall the obsession with gold on the part of King Midas of Phyrigia.) Here Wagner based his account on the Reginsmál (The lay of Regin) from the Edda, where we already find the curse creating a constant succession of acts of cunning, deception, and murder, with the minds of participants poisoned by the greed for gold. And Alberich's curse on the ring is modeled on an episode in the life of the dwarf Andvari, whose last remaining ring is stolen by Loki and who thereupon curses its future owners. ${ }^{148}$

\footnotetext{
${ }^{148}$ Borchmeyer, 221.
} 
Borchmeyer's report bolsters his point that myth "contained within it the archetypes of all essential historical developments."149 His point may be extended to dovetail with my own arguments about myth, allegory, and the unconscious: in maintaining that for Wagner, history continually resurrected the mythic tropes and archetypes, Borchmeyer in a sense positions myth as the unconscious, and perhaps the repressed, of history which has a tendency to return, finding new expressions in "essential historical developments." Just as Alberich and the Nibelungs are situated as the world's dark underbelly, breaking through to the surface and upsetting the world order, myth similarly functions as the undercurrent running below the surface of history. As the Nibelungs themselves reside in mythic sources, there is the potential to infer that Wagner is portraying even myth, and by extension the nation, as having an ugly undertone lurking in the depths, ready to re-emerge at any point. Since myth remains a constant presence throughout history, then it stands to reason that the seamy underside to the nation is forever festering below the surface of any and all exalted constructions of nationhood, never fully submerged and impossible to dispose of entirely. As Borchmeyer points out, in the aftermath of the eschatological conclusion of Götterdämmerung, "Alberich appears to survive the disaster and will surely resume his struggle to regain the ring." 150 The corruption of the Nibelungs cannot be completely sublimated, but to reapply Bhabha's framework, it might not even be desirable to do so: Alberich's physical and moral depravity is efficacious in defining the marginalized Other that is necessary to centralize as that which is to be excluded in order to prop up a more "dignified" narrative of the nation. As such, it is actually advantageous to have such debased elements lurking

\footnotetext{
${ }^{149}$ Tbid.

${ }^{150}$ Tbid., 214.
} 
in the shadows of a cultural "repressed," and it is equally beneficial to the mythic allegory of the nation for that repressed to return periodically.

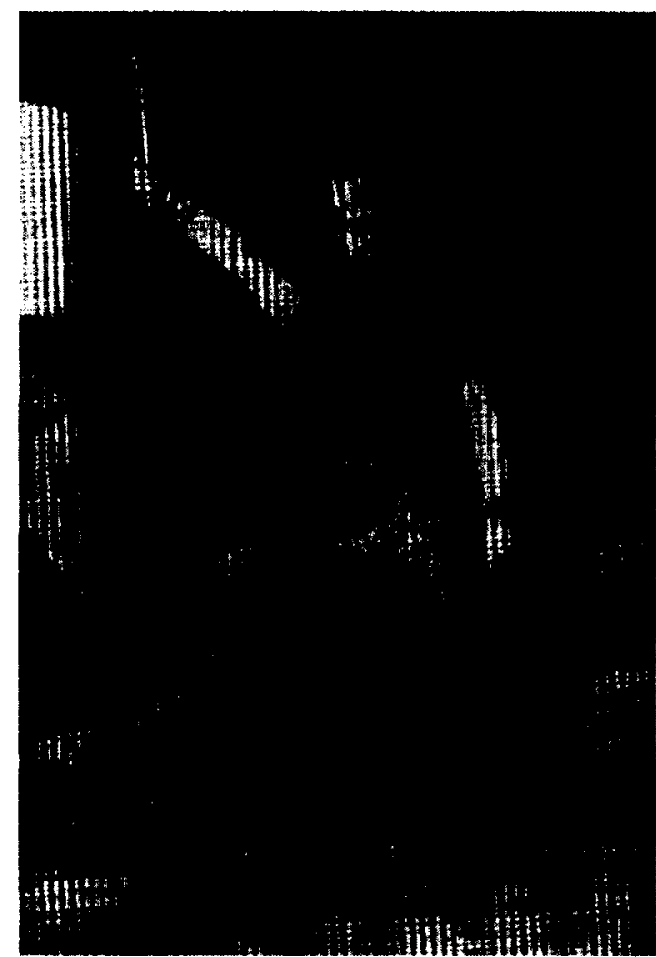

Fig. 3

Alberich - Karl Hill

(Fricke, Wagner in Rehearsal, plate 8)

As has been well established, Alberich's activities are the inciting incident for the entire cycle's intrigue. He implements these actions during the first scene of Rheingold, having first encroached upon the Rhinemaidens' revelry in the river's depths. As Spotts notes, the creation of a believable visual approximation of the Rhinemaidens swimming through the waters and around the rocks jutting from the depths was among the most challenging bits of scenography required for the Bayreuth performance. ${ }^{151}$ In addition to the stage and lighting effects designed to approximate underwater effects, ${ }^{152}$ the singers portraying the Rhinemaidens were strapped into "swimming machines" designed to

\footnotetext{
${ }^{151}$ Spotts, 63.

${ }^{152}$ Carnegy, 95.
} 
suspend them above the stage. ${ }^{153}$ To supplement these swimming machines was "a "bigdipper slide down which Alberich plunge[s] after stealing the gold...."'"154 The picture below (Fig. 4) depicts this setup from the backstage vantage point. Needless to say, a not insignificant amount of stagecraft and stage muscle was necessitated in order to implement all of these elements. As Dahlhaus notes in commenting on the swimming machines, Wagner, "the despiser of grand opera, did not hesitate for a moment to appropriate its stage machinery" adding that such use of technology was "a holdover from Baroque traditions." $155 \mathrm{He}$ adds that these devices "resemble flying machines transported to another element" and uses this particular example of Wagner's exploitation of elaborate stage machinery to illustrate his contention that "as a spectacle that gives the theater its full due, Wagner's Bühnenfestspiel or Bühnenweihfestspiel proves to be the heir of grand opera."156

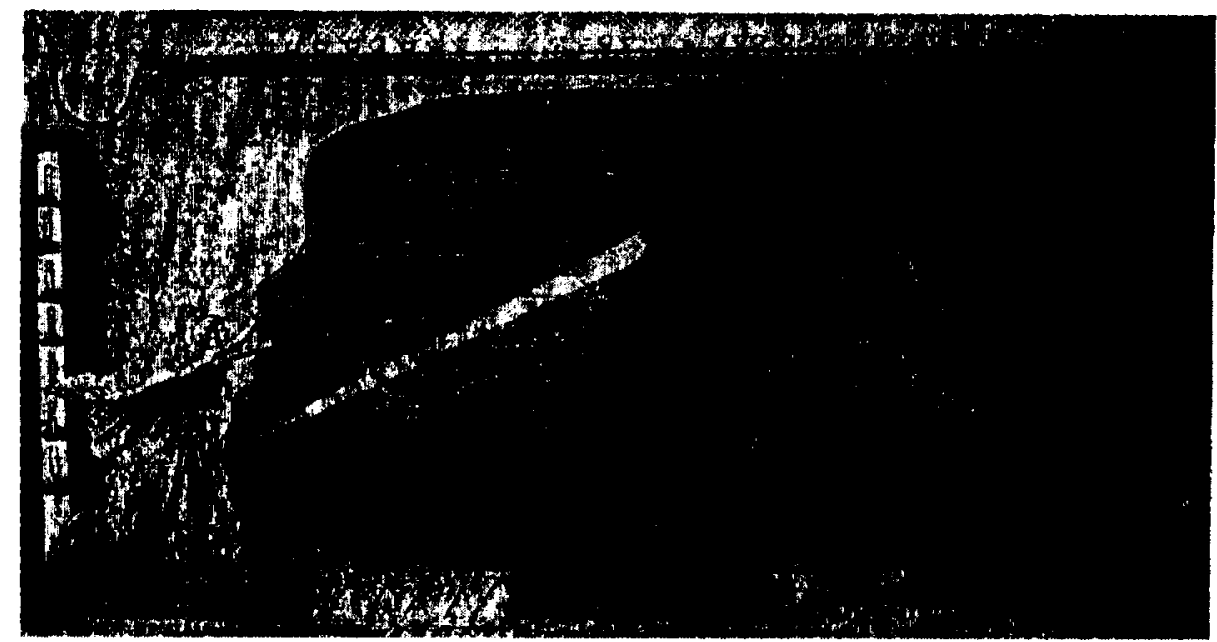

Fig. 4

Wagons in the first scene of Das Rheingold, viewed from behind the stage (Fricke, Wagner in Rehearsal, plate 29)

\footnotetext{
${ }^{153}$ Spotts, 63. Fricke describes his experiences with the "swimming machines" and the female singers in Fricke, Wagner in Rehearsal, 61-65.

${ }^{154}$ Carnegy, 87.

${ }^{155}$ Carl Dahlhaus, Nineteenth-Century Music, trans. J. Bradford Robinson (Berkeley: University of California Press, 1989), 201.

${ }^{136}$ Ibid.
} 
Into this "grandness" steps Alberich. Berry characterizes Alberich's introduction in the following terms: "the Rhinemaidens' inhumanity points to the cultural necessity to create humanity, not to restore it; they are no more human than the gods."157 Under that paradigm, it must be concluded that Alberich represents the basest form of humanity, stripped of all but the most primal urges: lust, greed, etc. If Alberich stands in for the origin of humanity, then the message is apparently these unsavory qualities are woven into the very fabric of humanity, what is left when the veneer of civilization is filtered out. Not an exceptionally optimistic view of human nature to be sure, but it fits with my own point that the Ring's presentation of myth and nation posits the existence of an ugliness hidden below the surface of even the most supple image of the nation, acting as something of a cautionary tale that points to the debasement that must be striven to be surmounted. The stage direction specifies that Alberich emerges "from a dark chasm" and climbs one of the rocks in order to observe the Rhinemaidens. The prescription for him to materialize out of an unlit crevice indicates that Alberich has made his way from a place that is hidden from conventional view, which is eventually borne out by the later revelation of his residence in a subterranean enclave of miners. Alberich's appearance then acts as the surfacing of the submerged, disrupting the prevailing order.

Alberich announces his alterity through his "darkened tonality and shifting rhythms" which "proclaim him to be a misfit in a world of cruel hedonism...."158 I am not fully endorsing Berry's characterization of the Rhinemaidens as given to "cruel hedonism," but the "misfit" description of Alberich's music is quite undeniable when

\footnotetext{
${ }^{157}$ Berry, 64.

${ }^{158}$ Berry, 64.
} 
comparing its timbres and rhythms in comparison to what preceded it. One need only observe the music (Ex. 2) that accompanies his initial address to the three water-nymphs:

He he! Ihr Nicker!

Wie seid ihr niedlich, neidliches Volk! Aus Nibelheims Nacht naht' ich mich gern, neiget ihr euch mir.

(scene 1)
[Hey, hey you nymphs! How inviting you look, enviable creatures! From Nibelheim's night I'd gladly draw near if you'd but come down to me.]

\section{Ex.2}

(Das Rheingold scene 1, mm. 178-185)
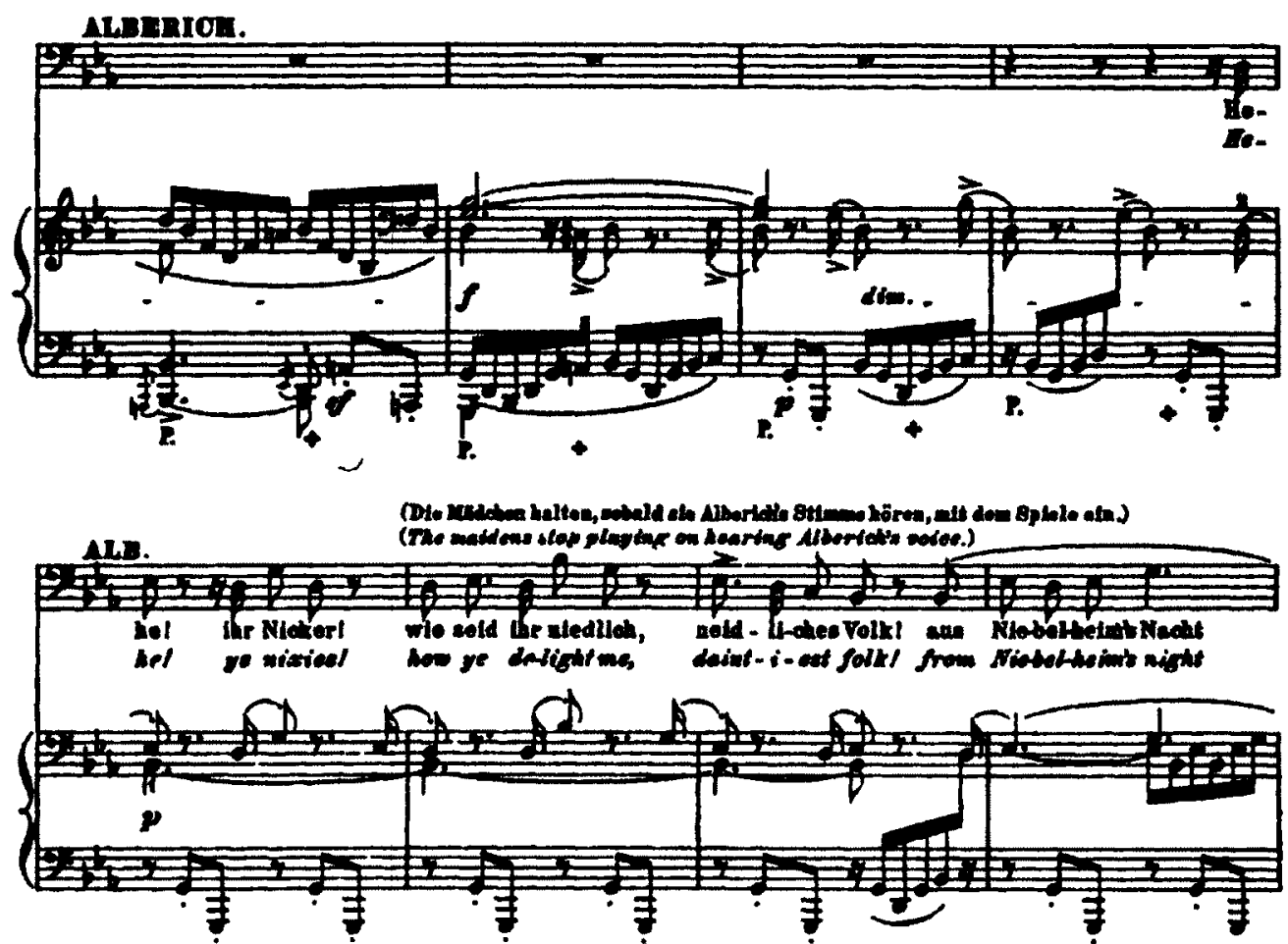

The rapid, clipped dotted rhythms combined with the prevalence of disjunct leaps

in the opening couplet convey a sense of uncouthness that provides a marked contrast to the more flowing lyricism of the Rhinemaidens' vocalizations. ${ }^{139}$ In terms of vocal sonority, Alberich's bass timbres instantly distinguish themselves from the soprano sonorities that had prevailed previously. What these sonorities sing contributes to their differing affects: in aligning the sopranos with the flowing rhythms, smooth articulations,

\footnotetext{
${ }^{139}$ Werner Breig analyzes the Rhinemaidens' singing in detail in 'Der 'Rheintochtergesang' in Wagners 'Rheingold,"' Archiv für Musikwissenschaft 37/4 (1980): 241-263.
} 
and diatonic melodies, that timbre becomes associated with those qualities and by extension with the "natural" beauty that surrounds them. Alberich's bass, in vocalizing those less "refined" rhythms and in tending (along with the accompanying orchestra) towards "syncopated, limping rhythms," 160 might be considered as made to sound more "brutal," more "primitive" than the sopranos' lyricism and diatonicism. In any case, it is such a manifestly different sonority from what has been previously heard that it would not be surprising that its difference would arouse such distaste amongst the Rhinemaidens.

Possibly the most interesting segment in terms of the scene's debts to grand opera comes during Alberich's fruitless attempt to secure the favours of Floßhilde, the final of the three Rhinemaidens. Here we are spectators to what is essentially a travesty of an operatic love duet. As Jean-Jacques Nattiez endeavours to demonstrate, this is quite strategic on Wagner's part. Nattiez specifically compares the words of love and devotion exchanged between Alberich and Floßhilde with that of the grand duo between Raoul and Valentine in Les Huguenots, noting pronounced similarities which are complemented by the device of having Floßhilde's vocal line doubled by the orchestra, the only passage during the work where this tactic is employed; as Nattiez observes, this device is also prominently displayed during a passage sung by Valentine in Meyerbeer's work. ${ }^{161}$ In exploiting some of the musical tendencies of the traditional grand opera love duet and putting them in the mouths of one character who is mockingly insincere and another who is stupidly suckered by such a seductive deception, Nattiez speculates that this is an example of Wagner staging an explication of grand opera's supposedly fundamental

\footnotetext{
${ }^{160}$ Jean-Jacques Nattiez, Wagner Androgyne: A Study in Interpretation, trans. Stewart Spencer (Princeton, NJ: Princeton University Press, 1993), 63.

${ }^{161}$ Ibid., 65-68.
} 
falsehood, made up primarily of superficially enticing, but ultimately artificial attractions.

To resurrect the spectre of anti-Semitism, if one inclines to accept the notion that Alberich is intended as a Jewish caricature, then presenting him as one who is foolishly enchanted by music inspired by grand opera (and Meyerbeer in particular) might induce one to speculate that in this particular scene Alberich functions as a disparaging portrait of Meyerbeer himself.

It does not seem all that likely that grand opera or Meyerbeer would be considered part of the subconscious of German myth and nationhood, even if the mobilization of grand opera appears to function as something of a "corruption" of the prevailing natural beauty. Once these love duet parodies have run their course, the sunlight illuminates the Rhinegold, announced by the introduction of the triadic "gold" motif in the trumpet which Porges notes should "radiat[e] a sublime Appolonian joy."162 The revelation of the gold returns the music to that "elemental" state that opened the scene, as the Rhinemaidens join together in a similar type of joyous song rife with sprightly rhythms and onomatopoeic evocations of elation as they pay tribute to the treasure that they are charged with guarding. As Wagner informed Nietzsche in a letter dated June 12, 1872, the ostensible "nonsense" words that they regale us with both at the scene's outset and during their encomium to the gold are transmitted via "a rootlike syllabic melody...by analogy with the 'eiapopeia' of our nursery rhymes." ${ }^{\text {163 }}$ Borchmeyer adds

but for whom are the Rhinedaughters singing their lullaby? Whose 'cradle' are they rocking? It is the 'sleeping gold' that they are guarding; playfully they keep watch over the 'slumberer's bed.' In the depths of the Rhine, a golden age still reigns, an age symbolized, in keeping with its name, by the gold that has not yet

\footnotetext{
${ }^{162}$ Porges, 10.

${ }^{163}$ Letter to Nietzsche (June 12, 1872), quoted in Borchmeyer, 219.
} 
been deprived of its mythical innocence and that expresses...the crucial point in cosmogonic myth. ${ }^{164}$

However, the innocence of this golden age conceals a corrosive underside that must eventually manifest out of the dark caves; deprivation of "mythical innocence" can only be deferred for so long. Borchmeyer again:

The gold in the Rhine is nature's most perfect gift. Its beauty promises to bring joy to our lives; it can bestow "radiant delight," proclaim the Rhinedaughters in a kind of dawn song addressed to the gold as it is woken to new life by the sun's rays. In short, the gold is not a piece of inanimate matter but a living mythological being whose "eye wakes and sleeps." It can smile and even laugh...But the gold conceals within it a demonic power. The man who curses the primeval cosmogonic power of life...can forge a ring from the gold...It is Alberich who pronounces this curse on love. With it, evil enters the world and destroys its mythological integrity. This evil poisons the world, turning the beneficent mythological personality of the gold...into a mere object that can be exploited, a reified force that destroys all human and moral ties. ${ }^{165}$

For all of the gold's supposed mythical integrity, its capacity to fill the world with resplendent delight, below its radiant patina lays something potentially corrupt. The gold's appearance of innocence and beauty sublimates that hidden capacity for monumental evil and destruction, just as the natural world that houses the gold sublimates the "bestial" urges of greed and power that is materialized by Alberich's "primitive" and "abhorrent" body. But in implanting Alberich the Nibelung into this mythic cosmogony, Wagner for all intents and purposes states that the destruction of the gold's original integrity and the resultant introduction of evil into the world is in actuality also a vital component of this mythic allegory of the history of the nation that he is constructing. It is essential that the corruption lurking within the innocent beauty of the Rhinegold and of the world be brought out in order for the world to be inundated with flaws from which to be eventually redeemed.

\footnotetext{
${ }^{164}$ Borchmeyer, 219.

${ }^{165}$ Ibid., 220-221.
} 
As before, Alberich's "brutal" bass sonority serves to interrupt the Rhinemaidens' playful lullabies, their "dithyrambic jubilant song in which their childlike is expressed with such charm,"1166 as if to sonorously play up the malice that lurks beneath the gold's surface radiance. Alberich's lines following the revelation of the gold's powers ("The world's wealth I could win for mine through you?') begins a change in vocal tone, that of one who "is no longer in the clutches of a tormenting passion, but is taking a decision to commit the dreadful act of cursing love." ${ }^{\prime 67}$ This is carried out in the following passage:

Das Licht lösch' ich euch aus; entreisse dem Riff das Gold, schmeide den rächenden Ring;

den hör' es die Flut: so verfluch' ich die Liebe!
[I will put out your light, wrench the gold from the rock, forge the ring of revenge; for hear me, ye waves: thus I curse love!]

\section{Ex. 3}

(Das Rheingold scene 1, mm. 672-683)
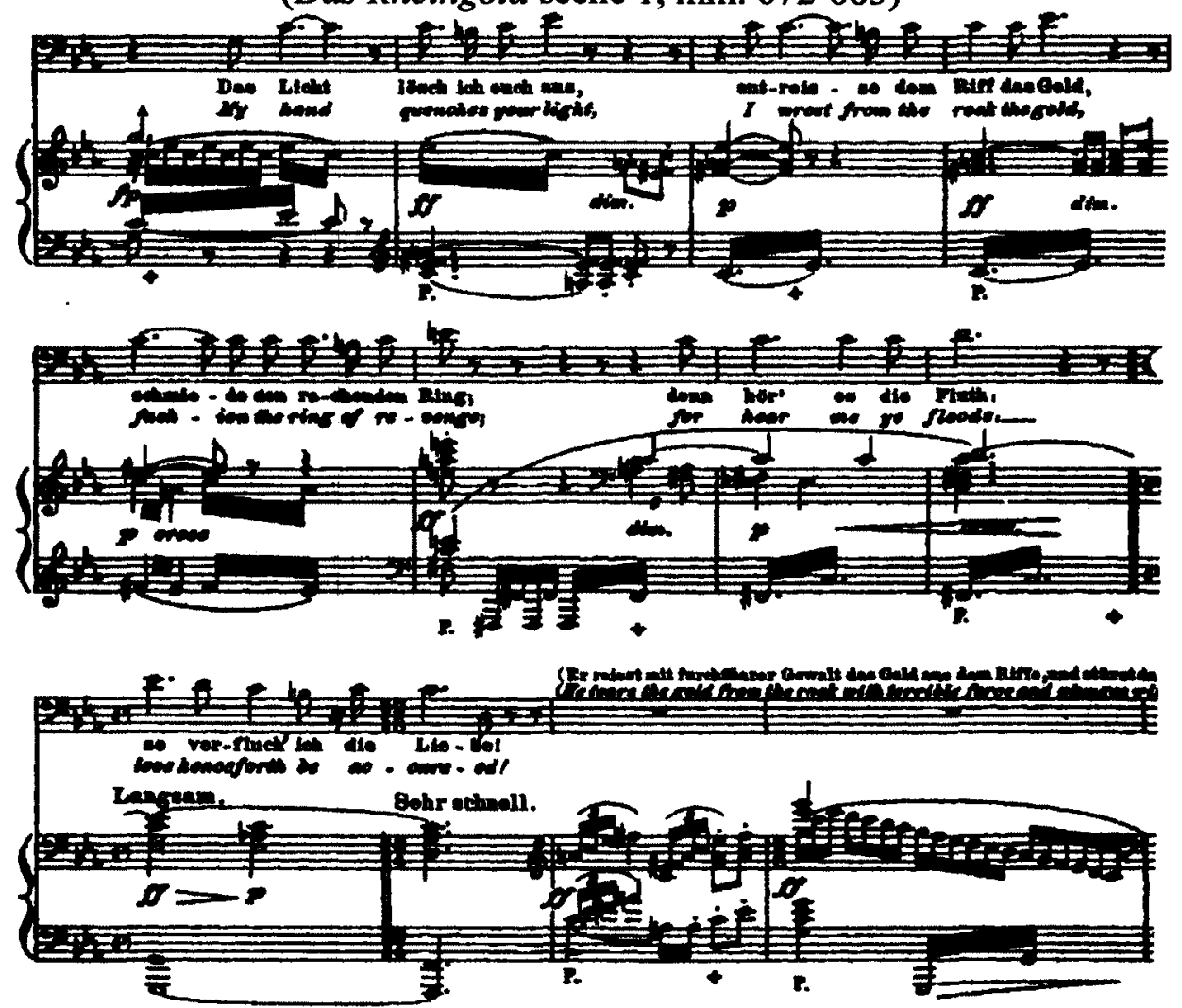

\footnotetext{
${ }^{166}$ Porges, 10.
}

${ }^{167}$ Ibid., 11. 
Porges makes the following prescription for performers of this passage (Ex. 3): Alberich's "uncontrolled outburst...must therefore be delivered not only with great power but with very sharply defined rhythmic accents (rhythmic accents are to music what alliteration is to verse)."168 Alberich's sonority should reflect the violence of the act of ripping the gold away from its abode in the rock, removing it from the "innocence" of the daylight and dragging it down into the darkness, which is itself reflected musically by the descent through the interval of a minor third - as a portion of the "renunciation of love" motif - and finishing with a downward leap of a minor seventh as Alberich announces "so verfluch' ich der Liebe": Alberich's sound descends into the depths just as he pulls the world's "golden age" into an era of darkness that will match that of Nibelheim. In tearing the gold from the rock, Alberich pulls its inner "demonic power" to the surface.

To conclude, the technology of grand opera is mobilized for the purpose of visualizing the graceful and joyous activities of the Rhinemaidens as they swim about the river's depths, protecting the gold that signifies the maintenance of a mythic "golden age" of purity. The elaborate stage wizardry creates a world of natural uncorrupted beauty. Into this realm of worldly and scenic magic enters the "primitive," "abhorrent" body of Alberich voiced by a "brutal" sonority that interrupts such revelry and pulls the greed, malice, and venality previously sublimated by that magic to the surface, despoiling the world. In engaging in a travesty of a grand opera love duet with the Rhinemadiens, this grotesque figure may also be understood as explicating the ostensible shallowness of Parisian grand opera's pleasures, which could be seen as a symptom of Alberich's introduction of evil into the world. But as with the preceding discussion of Wotan, the conspicuous thematizing of Alberich as residing in the realm of the long ago is ${ }^{168}$ Ibid. 
instructive: Alberich undeniably corrupted the world, but his iconography and sonorities of primitiveness also grants him temporal distance from the Bayreuth spectator. The Nibelung's deleterious actions may be framed as crucial to the German mythical past, yet it is still very much of the past, belonging to another age and therefore laying down the potential to be overcome. Indeed, as Nattiez states, the artistic, natural, and social unity that Alberich destroys through his theft of the gold and commensurate rebuke of love serves to set in motion a "laborious progress towards the restoration of unity that the Ring invites us to follow." ${ }^{169}$ The combination of this primitive and corrupt male body and the dramaturgy of grand opera stages a mythic allegory of the world's initial fall from grace; as shall become apparent soon enough, it will be grand opera and more exalted representations of the male body that will create the conditions of possibility for the world to revitalize itself and find a new unity.

\section{Heroic Apocalypse}

One of the pivotal actions that take place during the third act of Die Walküre occurs when Brünnhilde prophesizes that Sieglinde (having been impregnated by her twin Wälsung brother Siegmund) will soon give birth to the greatest hero of them all, whom she will name Siegfried. This begins the transition that will marginalize Wotan as the central figure in the drama of the Ring in favour of Siegfried. In specifically calling Siegfried a "hero" (both in her prediction and in her query in Act III of Siegfried, "who is the hero who woke me?"), Brünnhilde will effectively identify Siegfried as one who puts the Held in Heldentenor. As Siegfried's superior physique and his exemplary deeds will mark him as the ne plus ultra of heroism and as such a somatic emblem of the suppleness

\footnotetext{
${ }^{169}$ Nattiez, 68.
} 
of German myth and German identity, so too will the superiority of his vocal sonority render him as the hero of German art.

Siegfried's origins within the annals of Germanic and Norse myth are so well documented that they do not require a detailed reiteration. In all iterations, Siegfried/Sigurd acts as the prototypical "action hero," a physically superior specimen, utterly lacking in fear who is given to the commission of numerous acts of intrepidity that are beyond the capabilities of typical mortals. Drawn from the annals of myth, this paragon of heroic action is foregrounded as an embodiment of the enduring spirit of the German nation and its constituent Volk. Siegfried's role in myth, as Wagner recounts it, is to use his heroism to pull the world out from darkness and into the light, representing the triumph over fear and destruction and the dawning of a new and altogether more optimistic chapter in the existence of mankind. As the mythic hero, Siegfried brings about and stands in for a rejuvenated world. Borchmeyer follows up on Wagner's points, writing that "Wagner recognized with great clarity a point that modern mythographers have proved in detail, namely, that in heroic myth and the dragon fight that is central to it, cosmogonic myth - the original battle between god the creator and the monster of chaos - is reactualized." ${ }^{170}$ The Siegfried as portrayed in the Ring, according to Borchmeyer, retains cosmogonic significance, but "although he is no longer the light and sun god himself, it is he who reactivates the latter's creation of the world."171 However, as the forthcoming discussions shall hopefully elucidate, Siegfried's "reactivation" arises to a greater degree out of his death than the dragon fight, important as that will prove for his heroic deeds.

\footnotetext{
${ }^{170}$ Borchmeyer, 223.

${ }^{171}$ Ibid.
} 
In order to carry out such feats of heroism, Siegfried must be possessed of superior physiology. Dreyfus makes the following remarks about Siegfried's introduction in the drama that bears his name (quoting liberally from Wagner's stage directions): "to show off his physical prowess, he has 'tethered a large bear with some organic rope fibre' and 'with merry cockiness' sets the bear on Mime, egging on the animal to 'bite the dwarf' and do violence to him. There is surely not a soft bone in this boy's body." 172 In Siegfried's introductory scenes, his various feats of physical strength are emphasized in order to provide the clearest distinction between him and the pathetic and debased Mime. ${ }^{173}$ The Siegfried of Siegfried née Der junge Siegfried presents manhood in its "raw" form, physical strength and fortitude that has yet to be socialized in any conventional fashion. This primal version of Siegfried is all unbridled energy that is reflective of a youthful beauty, eliciting pleasure in the form of excitement at witnessing such vigour and virility and the seemingly endless potential of where it could go once developed and harnessed.

This primal version of Siegfried that derives much of his appeal from the display of raw strength and fearlessness reaches its zenith during his second act confrontation with Fafner. The imposing challenges of putting a dragon on stage render this scene, if only on the technological level, as a hoped-for example of the type of elaborate scenic spectacle endemic to grand opera. In terms of technical complexity, the creation of the illusion of a functioning dragon is not far removed from some of the other grand exhibitions displayed in grand opera, such as erupting volcanoes and exploding cathedrals. In fact it could be argued that in attempting to replicate a living entity that

\footnotetext{
${ }^{172}$ Dreyfus, "Siegfried's Masculinity," 5.

${ }^{173}$ Adrian Daub, "Mother Mime: Siegfried, the Fairy Tale, and the Metaphysics of Sexual Difference," $19^{\text {th }}$ Century Music 32/2 (Fall 2008): 160-177.
} 
directly interacts with one of the on-stage performers (Siegfried), and whose actions must be co-ordinated with the performance of the singer providing the voice, the visualization of Fafner functions as that much more demanding a piece of stagecraft. Siegfried's battle with Fafner represents the as-yet most impressive implementation of the strength and courage that has been well-ascribed to Siegfried's person, his most spectacular display of heroic action. Such heroism is carried out within the context of an exceptionally elaborate display of sceneography that owes more than a minor debt to grand opera. Consistent with many of Wagner's other transformations of grand opera, the scene's spectacle is placed within what is nominally a fantastical/mythological rather than historical narrative context. Of course, going back to the conception of the interlocking of myth and history as laid out in Die Wibelungen, the battle with Fafner is to be considered effectively a part of German history: the mythic confrontation with the dragon of "darkness" restages within the context of German lore similar altercations that go back to the Hellenic era. To extrapolate, it would appear that Wagner frames the "dragon fight" as an event that recurs throughout world mythologies, where an "enlightened" age experiences its birth pangs, which assists in solidifying the work's status as, according to Deathridge "an allegory of the movement from the 'dark ages' to the bright light of the future...."174 In that sense, Siegfried's defeat of Fafner could very well be thematized as a quasi-historical occurrence, the Germanic iteration of the use of myth to chart humanity's move out of the dark ages. As such, the scene finds a fit with grand opera's tendency towards the historical, at least from a certain point of view.

Into this "grand" tableau is inserted an act of heroism that centralizes the hero's physical attributes. By placing Siegfried's action on such a spectacular stage, his heroism

\footnotetext{
${ }^{174}$ Deathridge, 65.
} 
is concomitantly elevated to new heights of grandeur; Siegfried is as impressive a hero as the scenic spectacle upon which he acts. Crucially, Siegfried's valour is displayed by venturing into the forest, vanquishing the monstrous scourge haunting the woods, which plays no small role in his crowning as a "hero of nature." of Siegfried's physical body is a commensurately virile sound. Siegfried's Heldentenor sonority is crucial in terms of building him up as a figure of sufficient magnitude in order to prevail over the fearsome challenge of Fafner. It is his status as the Heldentenor that permits Siegfried's heroism to solidify him as the "'artist of the future' to lead humanity, the 'people' back to the heart of 'nature."'176 Siegfried's physicality banishes the dark age represented by Fafner from nature, allowing it to flourish once again, thereby encouraging humanity to enter an enlightened age of harmony with nature; complimenting his heroic iconography, Siegfried's sonority acts as the instrument that similarly leads German art out of its "dark age" into a new era of aesthetic prosperity, of renewed and undivided unity between the arts, nature, and society. Herein lays another aspect of the Ring's "mythic allegory" where myth is mapped upon a performing body in order to allegorize the rejuvenation of humanity through the revitalization of German art. The grand spectacle of the dragon fight, visualized with the most advanced operatic technology available, provides a stage of sufficient magnitude for Siegfried's physical and sonorous heroism to flourish in its full epoch-making monumentality.

The confrontation between Siegfried and Fafner proceeds, as Foster notes, through numerous stages, as Siegfried initially approaches Fafner as a potential playmate, like the bear at the work's outset, eventually leading to a boastful dare that the creature

\footnotetext{
${ }^{175}$ Ibid., 64.

${ }^{176}$ Tbid.
} 
teach him fear, which in turn provokes the physical altercation. ${ }^{177}$ Space permits only permits consideration of but one of those stages, where battle is joined and Siegfried slays the beast. As the exchange between Siegfried and Fafner intensifies, the vocal lines are prominently distinguished: Siegfried's part is rife with lines ascending through rapid rhythms and frequent wide downward leaps, musically conveying a sense of energy and enthusiasm. In contrast, Fafner's vocal contributions are more lugubrious in character, dominated by longer notes and frequent repeated pitches. Siegfried's passages are lengthy, frequently running to several measures, while Fafner is relegated to mostly brief declamations of two measures or less. The hero is musically portrayed as being in possession of boundless vitality and zest for adventure, while the monster comes across as tired, wishing only to go back to sleep.

This time however, it will not be enough. With bravado befitting his fearlessness, Siegfried issues his challenge "I've no desire to be digested by you; but it seems right and proper that you should die the death without delay...On your guard, growler! Here comes the braggart!"178 With that Siegfried "resolves to negate...this representative from the corrupt society of the past. With this decision, he reveals his revolutionary parentage."179 Siegfried's heroic nature compels him to action against the venality of the world as represented by Fafner, a world which will prove to be of no match for Siegfried's superiority. The battle is scored by a fairly extensive instrumental passage that mobilizes the forces of the full orchestra, with the brass prominently featured as it alternates between vigorously declaiming Siegfried's "hom call" motif and noisy chromatic lines (concentrated in the low brass) depicting Fafner's attempts to attack Siegfried. The stage

\footnotetext{
${ }^{177}$ Foster, 164.

${ }^{178}$ All translations are derived from liner notes to Siegfried (Decca 455 564-2).

${ }^{179}$ Foster, 164.
} 
directions however indicate that Fafner does not provide much of a threat as Siegfried handily avoids the dragon's attacks, and before long has plunged his sword into the creature's heart. As Siegfried proclaims his triumph (Ex. 4), much of the orchestra drops out, leaving only sustained chords in the low brass and the Fafner theme in the timpani, as if to showcase Siegfried's voice without any other sonorous distractions. Near unaccompanied, Siegfried sings out

Da lieg, neidscher Kerl: Notung trägst du im Herzen! (II, ii)
[Lie there, murderous beast: you have Notung through your heart!]

Ex. 4

(Siegfried II/ii, mm. 580-586)

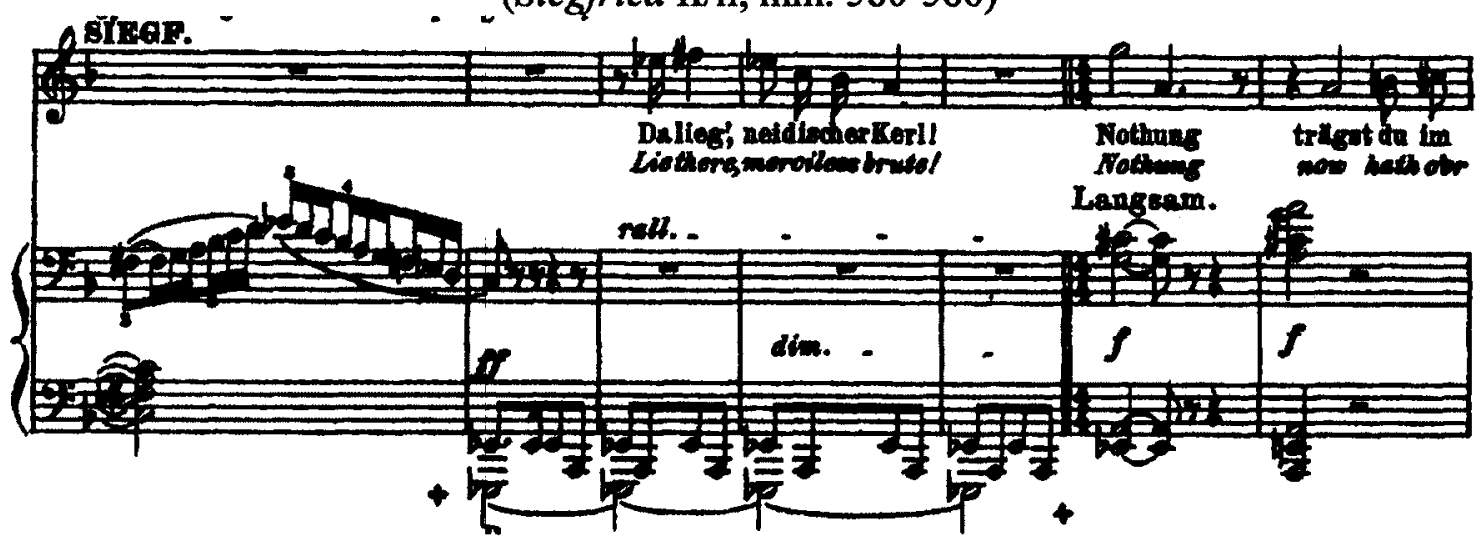

Once the word "Notung" is reached, Siegfried sings a triumphal rendition of the Notung motif, beginning on a half-note $g^{\prime}$, which drops down a minor-seventh to $a$; this downward leap on "Notung" is responded to on a downward-octave leap beginning on $d$ ". The presence of that sustained $g^{\prime}$ provides a potent statement of purpose: with only the most minimal of orchestral accompaniment, Siegfried's vocal sonority establishes uncontested dominance over the proceedings. The elevated note that this couplet begins on, in combination with the requisite vocal power of the Heldentenor sonority, creates an effect where the voice seemingly "rings out" around the entire auditorium. This exposed 
and reverberating sound provides the sonorous depiction of heroic action, an acoustic analogue to Siegfried's somatic suppleness and virility.

Siegfried finalizes his victory during his subsequent exchange with Fafner, where the dying dragon demands to know the identity of the one who defeated him, while at the same time intoning a warning about the cursed nature of the Nibelung treasure. In response to Fafner's request, Siegfried sings:

Woher ich stamme, rate mir noch; weise ja scheinst du, Wilder, im Sterben; rat es nach meinem Namen: Siegfried bin ich gennant.

(II, ii)
[Then tell me where I came from: in your death, dragon, you seem wise. You will know from my name: I am called Siegfried.]

In announcing his name to Fafner, it is ensured that the last thing this creature will know before expiring is that it was Siegfried who destroyed him. Siegfried's act of naming himself in the wake of his accomplishment serves a purpose beyond the confines of the narrative: his self-identification in effect serves notice that to all who have witnessed what has transpired (namely prospective audiences at the work's performances) that it is beyond all doubt that it is Siegfried who is the hero with the elevated physical aptitude, the one with the necessary courage and will to action to confront and overcome the corruption of the world's "dark age" in order to usher in a new era for humanity. In disseminating this message via his particular singing voice, Siegfried concomitantly serves notice that as the carrier of the Heldentenor sonority, his performing body is similarly possessed of a resplendent manhood that heroically carries German art out of its dark age and into an exciting new realm rife with tantalizing possibilities. But even so, there is an ominous undercurrent: immediately preceding Siegfried's C-major invocation of his identity is an E-minor statement of the "curse" motive in the orchestra. It is as if 
the orchestra drops in a foreboding anticipation of the grim fate to come, that for all of Siegfried's heroic vitality his "world" is nonetheless coming to an end, with his eventual death acting as a key inciting force for the eschatological climax that will conclusively wash away the remaining vestiges of the "old" order to make way for a newly revitalized one.

Circling back to grand opera, Foster offers an intriguing insight into the battle with Fafner. As Foster notes, in 1851 shortly before Wagner commenced work on the poem for Der junge Siegfried, Wagner expressed some appreciation for the visual spectacle of French theatre in his essay "A Theater at Zürich." In that essay, Wagner "praises French theater because it provides French poetry with a visual framework through public staging." ${ }^{180}$ Wagner explains:

what fits these [French dramas] out so bravely for the public eye, is altogether lacking for the freer development of native [German] art: namely a public artinstitute in keeping with our spirit, our forces, and our idiosyncrasies; an institute that not only should help our art-creations to the light of day, but, through offering the possibility of such a furtherance, should apply the first incitement to take dramatic art in hand at all. ${ }^{181}$

In the above passage, Wagner seems more enamored with France's subsidizing of institutions that allow art to publically flourish than the specific content that those institutions display. This of course goes back to Wagner's well-known criticisms of Parisian opera in such writings as "Traps for Unwary Germans in Paris," "The Opéra Lies Dying," and later "Opera and Drama," where he claims that Paris places a deleterious premium on visual spectacle at the expense of the drama. However, the French predilection for spectacle could be mobilized for useful purposes in order to infuse German "lyricism" with the public appeal that German art supposedly heretofore

\footnotetext{
${ }^{180}$ Tbid., 174.

181"A Theater in Zürich" (1851), quoted in Foster, 174.
} 
lacked, preoccupied with inwardness and "too personal to reach a popular or national audience." 182 In other words, giving the German audience a carefully measured amount of the proverbial razzle-dazzle would furnish its art with the necessary populist appeal in order to effectively function on a public stage and express the spirit of the Volk.

For Foster, this is where Fafner comes in: "like Fafner, the French are distinguishable by their use of spectacle and their dependence on the visual." ${ }^{83}$ The stage effect that is Fafner's realization is consistent with the type of visual spectacle that grants French theatre its public appeal. As such, in Foster's estimation, Fafner is put forth as an emblem of grand opera. The fact that Siegfried conclusively triumphs over this singular representation of Parisian theatre suggests a number of possible interpretations. Recalling that Fafner is thematized as a stand-in for a world that has been corrupted by greed, his own corruption would be thus associated with the supposed vice of Parisian culture, if his dragon form is indeed accepted as a representative of grand opera's visual and technical ingenuity. If Siegfried, as the idealized embodiment of the spirit of the German people, claims unambiguous victory over this figure, then it is not unreasonable to posit that the battle stages a triumph of "authentic" German art and culture over grand opera and French mores. However, Foster does not quite see it this way: it is crucial that once victorious, Siegfried does not cast the dead Fafner aside as worthless detritus, a mere obstacle on his heroic journey. Rather, by ingesting the dragon's blood, he gains the ability to understand the Forest Bird's song (which directs him to appropriate the Ring and the Tarnhelm and to venture to the Valkryie rock to claim Brünnhilde as his bride) as well as to hear Mime's true murderous thoughts towards him, concealed by

\footnotetext{
${ }^{182}$ Tbid., 174.
}

${ }^{183}$ Ibid. 
phony pleasantries. Siegfried takes a portion of Fafner into him, and in doing so is further empowered, is bettered. Foster explains the implication thusly:

Siegfried as Germany not only triumphs over Fafner as France, but also internalizes and transforms its peculiar virtues. He does not utterly vanquish Fafner, nor does he simply become Fafner. Instead, he is transfigured by Fafner. The meaning this scene had for Wagner should by now be clear. By imbibing the art of French theater, the art of German lyric could be projected to the entire German nation, not just the wealthy, the elite, and the educated, but to das Volk as well. ${ }^{184}$

This newly transfigured Siegfried thus represents a newly hybrid status for German art and nationhood: the "virtues" of grand opera are absorbed into the genetic fabric of the German character, its predilection for "effects without causes" filtered out so that spectacle is no longer an end unto itself but made to serve the needs of the Volk. This hybrid form of grand opera can now satisfactorily fulfill the function for which it has been specifically engineered, to use visual and musical sumptuousness in order to display the greatness and monumentality of German identity. As the singular embodiment of the "Artwork of the Future," Siegfried represents Wagner's ideal of the "perfected human being" whose battle with the grand opera dragon "will unite sight and sound, external and internal, national and personal, epic and lyric" into an organic dramatic whole that will represent the rebirth of the theatre of the Ancient Greeks within the borders of Germany. ${ }^{185}$ Thus, mapped upon the performing body of Siegfried are all of Wagner's hopes and intentions towards the revitalized German artwork: the strong, beautiful, and masculine body given voice by the heroic sonority of the Heldentenor. Having successfully woven grand opera once and for all into the fabric of the German

\footnotetext{
${ }^{184}$ Ibid., 176.

${ }^{185}$ Ibid., 177.
} 
"music drama," through both aspects of his performing body, Siegfried exits the forest as the unquestioned hero of German art and the German Volk.

Of course, as it turned out, it took Siegfried over a decade to finally complete his departure from the woods; Wagner set work on the Ring aside following the completion of Act II in 1857 and did not return to composition of Siegfried until 1869. Wagner's renewed commitment towards the Ring culminated with the climactic Act III, scene three wherein Siegfried penetrates the protective flames surrounding the Valkryie rock, awakens Brünnhilde after which the two embark upon a rapturous love duet to bring the work to an exhilarating close. This scene, like Wotan's farewell to Brünnhilde in Die Walküre, incorporates two aspects of grand opera dramaturgy: the "elemental" finale, envisioned by the magic fire, and the "grand duo." Technically, the flames are not part of the actual finale, as they are most prominent during the orchestral passage - a "powerful symphonic fresco"186 according to Porges - that acts as a transition between scenes two and three. The stage directions at the outset of scene three specify the flames as being in the distance, Siegfried having successfully broken through the barrier and making his towards the peak. Even if this eruption of the natural elements is not exactly an integral portion of the finale, it nonetheless provides a sufficiently opulent background that lends the subsequent duet extra majesty. The magic fire effect was praised by spectators as more convincing than the one offered in Walküre. Paul Lindau, dismissive of the previous attempt at approximating fire on stage, wrote of Siegfried's offering "the flamered gauze behind which the steam rose depicted the blazing fire in effective painterly

\footnotetext{
${ }^{186}$ Porges, 105.
} 
fashion." Joseph Kürschner described the effect as a "surging sea of flame which, beginning with the whole foreground, eventually spread to fill the whole stage."188

In anticipation of surmounting this grand opera approximation of quasi-natural phenomena, Siegfried states that he will "bathe" in the fire. Such a prediction speaks to what Lawrence Kramer observes as a demonstration of Promethean mastery over fire. ${ }^{189}$ Having broken through this obstacle by means of his superior physiology and courage (recalling that only one without fear would pass through the flames), Siegfried is now free and clear to awaken Brünnhilde. ${ }^{190}$ So begins a duet that, according to Nattiez, will function as an allegory for the restoration of the unity between poetry and music. As Nattiez tells it, this unification is realized through the formulation of an androgynous being: the male Siegfried and the female Brünnhilde being joined in sexual union is mapped upon the notion of poetry providing the fertilizing "masculine" seed for the "feminine" music in order to create a new hybrid form that is the drama, no longer purely male or female. Nattiez supports such a contention by noting that as Siegfried and Brünnhilde are introduced to each other, each recognizes themselves and by extension their gender, within the physiognomy of the other. ${ }^{191}$ In other words, the "feminine" exists within Siegfried and the "masculine" resides within Brünnhilde (which possibly provides some justification for his misrecognition of the armoured former Valkryie as a man). Their complementarity is made manifest throughout the scene as their sung texts

\footnotetext{
${ }^{187}$ Lindau, quoted in Carnegy, 100-101.

${ }^{188}$ Joseph Kürschner, Bayreuther Tagebuchblätter, quoted in Carnegy, 101.

${ }^{189}$ Lawrence Kramer, Opera and Modern Culture: Wagner and Strauss (Berkeley: University of California Press, 2004), 80-81.

${ }^{190}$ This includes one of the more ludicrous elements of the story, in that having removed Briunnhilde's breastplate, he expresses great shock that it is not a man lying before him. But why is he so surprised when he knew full well beforehand that a woman would be awaiting him there, and in fact was the very reason he had ventured to the Valkryie rock?

${ }^{191}$ Nattiez, 76-79.
} 
frequently parallel each other, for example: "s/he's mine forever, always mine, my heritage and own, my one and all!"192 This degree of overlap states that these two beings belong to each other, no longer fully autonomous, but strengthened by their joining in a matrimonial/sexual/artistic bond. As Wagner explains in an 1854 letter to August Röckel,

not even Siegfried alone (man alone) is the complete 'human being': he is merely the half, only with Brünnhilde does he become the redeemer; one man alone cannot do everything; many are needed, and a suffering, self-immolating woman finally becomes the true, conscious redeemer: for it is love that is really 'the eternal feminine' itself. ${ }^{193}$

Wagner's letter incorporates elements from the conclusion of Götterdämmerung into his paradigm, namely the necessity of the female's sacrifice in order to conclusively bring about redemption, which I shall deal with shortly. Nonetheless, attention should be paid to Wagner's claim that any one man, let alone Siegfried, cannot redeem the world on his own: a woman, indeed his female counterpart must join him. Of course, this woman and her feelings of love must be of a sacrificing sort; she must be willing to give everything to him. But this seeming subordination of the feminine even in the face of claims towards a merger finds some clarification when one takes into account Wagner's paradigm in Opera and Drama that "music is a woman."194 Nattiez uses Wagner's feminization of music to thematize Brünnhilde as the very embodiment of music during the duet. He quotes from the libretto examples of Siegfried's exclamations of delight at the sound of Brünnhilde's voice, placing especial emphasis on his use of the word singing to describe her vocalizations. ${ }^{195}$ In Opera and Drama, Wagner necessitates that

\footnotetext{
${ }^{192}$ Quoted in Nattiez, 78-79.

${ }^{193}$ Sämtliche Briefe (January 25/26, 1854), quoted in Nattiez, 79.

${ }^{194}$ Opera and Drama, quoted in Nattiez, 82.

${ }^{195}$ Nattiez, 79.
} 
woman surrender herself to love "without condition." 196 This plays out at the conclusion of Siegfried when Brünnhilde expresses lament over having permanently lost her Valkryie powers and immortality and commensurate anxiety over giving herself and her "music" to Siegfried and his "poetry." Siegfried is called upon once more to act the hero, to take the reins and quell her apprehension, to convince her to "surrender" her love to him, a demand to which she is eventually only too happy to acquiesce. In "taming" woman/music, Siegfried thus further demonstrates Wagner's stated faith in him as the optimal example of humanity.

And so, through their sexual/matrimonial coupling, Siegfried and Brünnhilde bring together poetry and music, merging them into the drama, the work of art that will rejuvenate the artistic spirit of the German Volk. But if Siegfried truly is supposed to represent the singular embodiment of the "Artwork of the Future," then perhaps it would be beneficial to frame the amalgamation of poetry and music in the following terms: having been enraptured by the sound of Brünnhilde's song, Siegfried takes music into his own being, using its sonorous beauty to transform his own expression, always-already infused with the spirit of creativity and poetic invention, into something more triumphant, more heroic. This is not to say that Brünhilde is rendered superfluous: this "grand duo" reaches its climax with both voices singing together, an acoustic representation of their inseparability and unity of purpose. ${ }^{197}$ Keeping the focus on the heroic model, it is reasonable to hypothesize that this duo is the sight of Siegfried's greatest triumph: by absorbing "music" into his expressive palette, Siegfried has now scaled to the pinnacle of

\footnotetext{
${ }^{196}$ Opera and Drama, quoted in Nattiez, 82.

${ }^{197}$ Although the counterpoint of the two vocal lines frequently demonstrates small difference that prevents them from being in lock-step with each other, as if to suggest that for as devoted to each other as they are, both retain minds of their own, which will have ramifications on the subsequent entry in the cycle.
} 
human achievement - and it goes without saying that Brünnhilde has allowed poetry into her being, which enables her to achieve new heights of expression - an accomplishment that manifests itself in the radiant sonorities and enveloping sense of exaltation that pervades these final measures of the work as the "mythic allegory" of the actualization of the German work of art reaches its conclusion.

The overwhelming joie de vivre of the music that Siegfried and Brünnhilde share serves to replicate their experiences of pleasure in the members of the German audience witnessing the performance. Siegfried channels his bliss into his Heldentenor sonority, which imbues the sound with a radiant sheen that instills commensurate satisfaction in all who hear it. ${ }^{198}$ As such, the Heldentenor gains another dimension to its musical "heroism": where the battle with Fafner played up the physical intrepidity, this grand duo injects a sense of emotional fulfillment into the Heldentenor sound. If it was not already apparent, the rapturous sound of the music makes it indubitably clear that the Heldentenor is to be enjoyed. Having braved vicious dragons, duplicitous dwarves, and magic fire in order to achieve this state of sonorous bliss, the ascendance of the Heldentenor sonority is demonstrated to well and truly earned, a genuinely "heroic" sound.

Wagner's well-established conception of Siegfried as the embodiment of the "artist of the future" already lends a German nationalist edge to his characterization. This conception gains an interesting new aspect from a remark that Wagner made to Cosima

\footnotetext{
${ }^{198}$ Or would have at the 1876 performances, had Georg Unger, the performer of the role, been up to the task. Although Cosima is overall generous to Unger's abilities in her diaries, Carnegy notes that "less tactful sources make it plain that Georg Unger was never truly inside the role of Siegfried, nor did he have the necessary vocal stamina. By Wagner's own account he had so little voice left for Götterdämmerung that [Albert] Niemann volunteered to sing in place of him...." (102) Wagner turned down this offer, but ended up regretting that decision.
} 
about the third act. "That is Gobineau music...that is race," Wagner is recorded as saying, invoking the racist theories of the Count Joseph-Arthur de Gobineau. ${ }^{199}$ But Wagner's observation indicates that he retroactively looked upon the grand duo between Siegfried and Brünnhilde as a musical staging of the essence of the German "race." Kramer proposes that the duo's depiction of an incestuous union between the two feeds into the troping of the bond as a guarantor of racial "purity." 200 This accounts for Wagner's claim that it was the music of "race": in preserving the purity of their bloodlines, Siegfried and Brünnhilde's coupling provides a mythic allegory for the protection of the purity of the German "race." Taking all of these ideas together, Siegfried's heroism leads him through the magic fire and into a grand duo, where his Heldentenor voice functions as a major element in an allegorical staging of the union of poetry and music into drama. Such a union instills a wave of joyous rapture within that voice which in turn aims to leave audiences with feelings of "sublime joy" in hearing these sounds. Both the bodies of the characters and those of the spectators witnessing their performance bask in the pleasure of the musical and dramaturgical staging of the purity of German art and the German race. The stage that is the grand opera elemental finale and grand duo provides the appropriate monumental stage in order for such delights to take on the appropriate scale commensurate to these tasks.

By all appearances, as the curtain falls on Siegfried, this free hero seems to have everything going for him. And yet, as Deathridge asks, "if our Nordic superman is the man of the future who leads us with phenomenal strength into a new age of light and

\footnotetext{
${ }^{199} \mathrm{CD}$ II (October 17, 1882), quoted in Kramer, 76.

${ }^{200}$ Kramer, 84-91.
} 
social harmony, why is he doomed?"201 Kramer, at a point in his reading where he entertains the substance of Nietzsche's critique, posits that Siegfried seals his fate the moment he departs from the encomium to free love that was the finale of his eponymous opera. "When Siegfried descends from Brünnhilde's rock he blunders into the modern world, the scene of social organization rather than mythic adventure, of kinship alliance rather than glorified incest."202 Under this paradigm, Siegfried exits the realm of mythic heroism and enters the world of political intrigue. Given Nietzsche's aversion to nationalist sabre-rattling in his writing of The Case of Wagner, it is no surprise that Kramer would state that, for Nietzsche

Siegfried...becomes a nationalist hero only when he becomes vain, stupid, brutal, and lecherous...Only in the world of Götterdämmerung, where political consciousness is mystified and sexual desire never recognizes its object, can the national hero come to be, and even then only on the condition that he come to grief. The national hero is born to be a martyr. ${ }^{203}$

These are Siegfried's "fatal flaws": his physical strength and fearlessness are matched by a complementing streak of superciliousness and stupidity, a lethal combination that ensures his demise. Indeed, these faults prompt him to turn away from an opportunity to stave off impending execution when he arrogantly refuses to turn the Ring over to the Rhinemaidens after they accuse him of being fearful. But these character flaws are conveyed through story: the heroic beauty of his Heldentenor sonority remains a constant, providing a musical covering over of those flaws until it is finally silenced with his death. But even such an inconvenience as dying does not stop Siegfried from playing a crucial role in the world's forthcoming destruction and rebirth.

\footnotetext{
${ }^{201}$ Deathridge, 65-66.

${ }^{202}$ Kramer, 77.

${ }^{203}$ Ibid., 78.
} 
As Brünnhilde prepares to immolate herself along with Siegfried's corpse on the pyre, she presages her imminent demise with a lengthy tribute to Siegfried's competing heroism and betrayal, and her anticipated reunion with him in the great beyond. This provides a strong indication that even in absence Siegfried casts enough of a shadow over everything that he remains a crucial figure in the resolution of the story. Kramer states as much, writing that

although this final Siegfried is strangely still capable of action - his dead hand rises up to prevent Hagen from taking the ring - he has no voice except, belatedly, Brünnhilde's voice in mourning for him. He becomes present, to her and to us, only in the music that expresses Brünnhilde's love and grief for him, music always tuned to absence rather than presence, whether at the beginning of Götterdämmerung with its love duet marking the parting of the lovers, or at the end, with its double threnody of funeral music and immolation scene. ${ }^{204}$

Siegfried is physically absent but his spiritual presence functions as a driving force in precipitating the long-awaited cataclysm. As the destructive/purifying fire rages on, the spirits of Siegfried and Brünnhilde hang over the proceedings, so that even though the closing minutes of music that bring the tetralogy to its eschatological close are purely orchestral, the intricate weaving together of motifs nonetheless has the trace of their "voices" firmly implanted into its fabric.

With its pronounced destructive streak, the finale has an unmistakeable connection to grand opera. Grey writes:

The conclusion of Götterdämmerung...takes the catastrophic final tableau of French grand opera - the volcanic eruption of La Muette, the explosion of the Münster palace in Le Prophète, the destruction of Pompeii ending Félicien David's Herculanum (1859) or the Last Judgement ending of Halèvy's Le Juif errant... - to new, and undeniably effective extremes. ${ }^{205}$

\footnotetext{
${ }^{204}$ Kramer, 79.

${ }^{205}$ Grey, "Wagner and Grand Opera," 339.
} 
The conclusion of Siegfrieds Tod was not nearly as cataclysmic as the final version, lacking as it did the burning of Valhalla. Grey again:

It was only in the final redaction of the text, as set to music, that these events were augmented to suggest a universal apocalypse encompassing the downfall of the gods and the symbolic purgation of humankind by fire and water - this well after Wagner had castigated Meyerbeer for his alleged operatic "effects without causes." ${ }^{206}$

Wagner's seeming endeavour to top all previous forms of grand opera opulence did not sit well with Shaw, who reserved several pages of his commentary for explaining that this retreat to conventional operatic dramaturgy played no small role in causing the allegory for industrial capitalism that he had been working with to break down. ${ }^{207}$ Leaving aside the obviously curious practice of censuring Wagner for failing to adhere to an allegorical framework that Shaw himself devised post-hoc, Millington explains that for Shaw, "the allegory collapses after the second act of Siegfried, degenerating formally into grand opera and philosophically from revolutionism toward what he called a "love panacea."'208 In Shaw's estimation, it is the trading of allegorical potency for grand opera effect that robbed the climax of the tetralogy of its power.

However, Shaw's conviction that Wagner abandoned allegory may be determined to be erroneous as the mobilization of a particularly intensified version of grand opera for the apocalyptic finale finds a powerful mythic resonance, which in turn maps onto an allegorical narrative quite distinct from the one Shaw grasped. Borchmeyer summarizes:

the fire that consumes the world at the end of the Ring not only recalls the Ragnarök of Norse mythology but also harks back to a myth, widespread in the

\footnotetext{
${ }^{206}$ Ibid.

${ }^{207}$ Shaw, The Perfect Wagnerite, 496-499.

${ }^{208}$ Barry Millington, "Der Ring des Nibelungen: Conception and Interpretation," The Cambridge Companion to Wagner, ed. Thomas S. Grey (Cambridge: Cambridge University Press, 2008), 80.
} 
ancient world, of an eschatological fire that purifies the earth. And in each case the world is reborn through the force of the fire. ${ }^{209}$

An entry in Cosima's diaries shows that Wagner was quite aware of the mythic implication of a great fire as the force that redeems the world, as he told Cosima of "the idea in Scandinavian mythology of a new world to follow the downfall of the gods." 210 The mythic narrative of the destruction of the old world in order to make way for a new one also has clear allegorical ramifications in Wagner's hands. As Borchmeyer explains, "in death, Siegfried and Brünnhilde rise above all sense of alienation and return to their state of mythological integrity, thus allowing us to hope for a better world of a kind suggested by the motif heard in the orchestra at the end of the work."211 It is significant that Borchmeyer's formulation has the two lovers ascend to their true greatness away from the strictures of the everyday world that they lived in: as residents of that world, they demonstrated fatal character flaws endemic of their surrounding society Siegfried's arrogance and foolhardiness, Brünnhilde's extreme vengefulness in response to Siegfried's betrayal. As such, it is only through their departure from the corporeal world and back into the realm "mythological integrity" that they can shed those flaws and become aspirational figures that provide "hope" for a better world. But only hope: although the world is purified of its "sins" by the funereal flames, that does not mean it is instantly fixed. A more just society must be built from the ground up, but the soaring "redemption through love" motive that the violins spread above the musical texture, and which is the last piece of thematic material heard as the curtain falls on the Ring provides as much optimism that this ideal world will come to pass as can be mustered.

\footnotetext{
${ }^{209}$ Borchmeyer, 235.

${ }^{210} \mathrm{CD}$ I (November 25, 1873), quoted in Borchmeyer, 235.

${ }^{211}$ Borchmeyer, 235.
} 
It could be said that this music takes its inspiration from Siegfried's and Brünnhilde's example in twofold fashion: from a commitment to staging history and its commensurate ambition. Recall that the dragon fight showed Siegfried foregrounded as an outstanding figure that continually makes history, consistently rewrites history as it happens. The orchestral finale of Götterdämmerung takes on a similar relationship to posterity: in recapitulating a number of prominent leitmotifs in close proximity, the orchestra weaves together what amounts a history of the world it has depicted over the course of these four nights with the intent of underlining that that world is coming to an end. Hermann Danuser underlines the potency of the finale's supposed "history of the world" (my words, not his): the merging of various motifs might be seen as an illustration of his point that "the farther the tetralogy progresses, the more powerful the force of memory, and the more significant the narration of past events." ${ }^{\text {212 }}$ Danuser is primarily talking about textual narration, but his point could just as easily be applied to the musical motifs, which also take on a "powerful force of memory" as the cycle approaches its end. In that sense, the orchestra looks backwards; with the prominence of the optimistic "redemption through love" theme, the orchestra simultaneously writes the opening phrases of a new chapter of history, the birth pangs of the new world. ${ }^{213}$ As such, it can be hypothesized that the orchestra takes up Siegfried's mantle, doing instrumentally what he achieved vocally and physically: create new historical and cultural epochs. This speaks to the music's ambition, to be tasked with what would seem to be such a

\footnotetext{
${ }^{212}$ Danuser, "The End in Wagner," 75.

${ }^{213}$ Danuser notes that the finale's key of D-flat major parallels that of the finale of Das Rheingold, essentially musically fulfilling the prophecy that the gods were "hastening towards their end." He also gleans a cyclical dramatic structure to the tetralogy, where "pure" nature in the form of the flow of the Rhine (represented by the sustained E-flat major chord) is returned to at the close of Götterdämmerung as the Ring is retrieved by the Rhinemaidens.
} 
Herculean goal. Wagner's apparent resolute belief in the ability of music to pull off such a feat in such a temporally circumscribed duration (about four minutes in an average performance) might find a kindred spirit in Siegfried, the hero who is constantly on the lookout for new challenges against which to pit his abilities, new adventures to add to his legacy, new ways to reshape the world's course. In short, Siegfried is a possessed of an ambition and a belief in his ability to realize ambitions that complements the music's aspiration towards using tone to stage the simultaneous eschatology and new cosmogony.

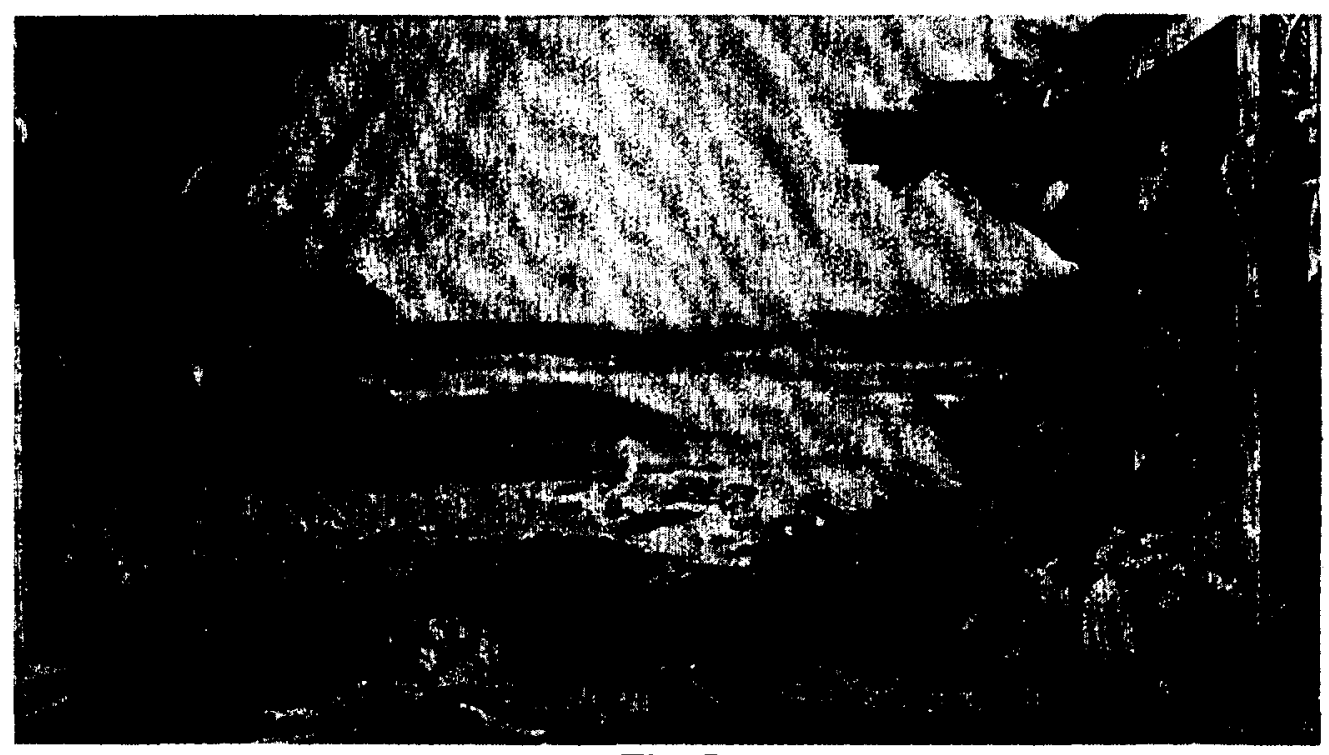

Fig. 5

Die Götterdämmerung III, 2 (final scene) (Josef Hoffmann)

(Fricke, Wagner in Rehearsal, plate 43)

Siegfried's ambition finds an appropriate dramaturgical outlet of expression in grand opera. Grey provides an apt summation: the conclusion "represents his capitulation to the imperative of grand-operatic dramaturgy inherent in this ending, in terms of both music and spectacle. In both regards he sought a maximum 'effect' as the most fitting way to conclude his sprawling mythic-allegorical epic." 14 In other words, the maximizing of musical and dramatic means that result from grand opera provided for

\footnotetext{
${ }^{214}$ Grey, "Wagner and Grand Opera," 339.
} 
Wagner a stage of sufficient magnitude for the desired world and art-changing effect to take place. Even though Siegfried is physically and vocally absent, the eschatological finale of the Ring, in its commitment to the portrayal of radical artistic and social change, demonstrates that the "spirit" of the Heldentenor carries on, its sonorous and physical grandeur leaving a trace within the prevailing symphonic sound. ${ }^{215}$

It is hardly insignificant that for all of the preceding talk of the Ring cycle serving as an allegorical dissertation on the nature of modern society and the state of contemporary and future German art, the story is nonetheless set in a mythic Pagan milieu. Everything that happens over the course of the tetralogy is positioned as having taken place long ago. As a result, one of the potential takeaways is that the cycle can present all of the forms of flawed masculinity that this chapter has discussed without having an overly adverse effect on the correlation between the male body and the character of the German nation. The tribal setting thus carries an implicit suggestion that all of these imperfect, primitive, or even reprehensible masculinities portrayed throughout are all vital components of the nation's historical and mythological background, but they are also distinctly in the past: improvement has, is, and shall continue to be carried out. Additionally, the openness of the ending, the fact that what amounts to only a tantalizing sketch of the new world and what it could entail is provided at the cycle's close is suggestive. The obliteration of the old, flawed society is placed in the past, but the openendedness as to what comes next implies that much work remains to be done: this newly redeemed world is but the raw material upon which a beauteous society populated by a

\footnotetext{
${ }^{215}$ Carolyn Abbate discusses the prominence of the "symphonic" in Wagner's music in "Opera as Symphony, a Wagnerian Myth," Analyzing Opera: Verdi and Wagner, eds. Carolyn Abbate and Roger Parker (Berkeley: University of California Press, 1989), 92-124.
} 
redeemed humanity may be built. The location of all of this in the distant past, essentially leaving an enormous gap between the world's destruction so long ago and the here and now (that is, the later nineteenth century of Wagner's time), and the questions of what happened in between can potentially be addressed by what Borchmeyer terms the "cyclical nature of myth" which "cannot conceive of the idea that the world will end once and for all" and that "for myth, the history of the world involves a perpetual cycle of destruction and renewal."216 Such a notion is productive, in that it can be seized upon to argue that the iteration of the cycle that occurred so many generations ago in the mythical-historical annals of the Germanic tribes is now recurring in allegorical form on the operatic stage in contemporary times, to present yet another renewal of German society, this time through art.

I propose to modify this idea in order to posit that the situation of an open-ended promise of a revitalized world in the distant past opens up a window into observing how the Wagnerian male performing body progresses through subsequent periods of German history and myth in the following two chapters. From the destruction of the flawed order of the Pagan era, we traverse through the era of medieval Christianity, with which figures of unattainable bodily perfection (Lohengrin and Parsifal) will briefly interact, showing an ideal of nationhood that is as-of-yet out of reach. From there, we arrive in a version of sixteenth-century Nuremberg that is specifically constructed to contain the Germany of the nineteenth century, where avatars of artistic progress (Walther) and innovation (Hans Sachs) combine to allow German art and nationhood to ascend to its long-awaited triumph, promised by the Ring's purifying fire. Such a progression, ahistorical as it may be, is useful as an organizing principle in order to connect the three different strategies I

\footnotetext{
${ }^{216}$ Borchmeyer, 236.
} 
employ for exploring how Wagner stages male bodies to create sounds of German myth, religion, and nation. As composed, Lohengrin, and Die Meistersinger do not follow Götterdämmerung (only Parsifal does), but the eras they depict do. Consequently, I find some justification in tampering with the chronology to account for what amounts to Wagner's own non-linear treatment of the transition from German redemption to triumph: temporally, the birth of a redeemed world occurs in the Pagan era and its ultimate victory takes place in the Renaissance, but as works of art, the latter precedes the former. Revising Wagner's chronology to place the Ring as the origin for what follows tacitly acknowledges that his ideas about the intersections between German history, myth, and art are manifold while at the same time finding a certain degree of sympathy with each other. But also, such a revision places a great deal of importance on the fact that Wagner conspicuously leaves the reborn world at the Ring's conclusion as but a tantalizing glimpse of yet-to-be realized potential. The following chapters then are situated as possible directions in which that virgin world might go (and indeed did go), depicting how German culture might ultimately rise to attain final victory. The "holy German art" praised by the Nuremberg throngs will be thematized as the payoff to the promise of a vital new society, prophesized so long ago in the annals of myth, even if the former was actually composed first. But before Grail Knights and Mastersongs can arise, the mythic cycle of destruction and renewal needs to have taken place to provide a blank slate from which they can emerge; before "holy German art" can properly flourish, it is first necessary to hear the world end. 


\section{Chapter Four}

\section{Of the Tenor as Objet Petit a: The Imago, Heroism, and the Idealized Nation in Lohengrin and Parsifal}

\section{Wagner and Christianity}

The Ring and its stew of Norse and Germanic folklore arguably loom most prominently in the discussion of Wagner's pre-occupations with the importance of myth in the creation of the German "artwork of the future." But as should be manifestly apparent from previous chapters, Wagner mined medieval Germanic legends based upon Christianity with nearly comparable alacrity. His apparent enthusiasm for mobilizing the artistic possibilities of Christian narratives stood in stark contrast to many of his prose writings, particularly those of the period that approximately coincided with the composition of Lohengrin. In "Art and Revolution" (1849) for example, Wagner argued that the modem institution of Christianity bore partial responsibility for art's divorce from nature and from the spirit of the people (a process that commenced with the ascendance of Imperial Rome and its commensurate emphasis on gladiatorial spectacle over communal fulfillment), a state of unity that had once existed during the era of the Ancient Greeks. ${ }^{1}$

For all of Wagner's professed disdain for Christianity as a contemporary institution, it clearly did not extend to its central "mythos" (meaning the collection of stories that form what amounts to the organizing principles of a system of belief). As Jean-Jacques Nattiez points out, for Wagner "there were two types of Christianity. First, there was early Christianity, with Christ's authentic message and its magnificent response

${ }^{1}$ SSD III, 15; PW I, 38. 
to the barbarousness of Roman civilization." It was the second Christianity, of the modern brand that had abandoned the original tenets which furthered art's and society's deterioration into aesthetic and spiritual abjection. Wagner took the figure of Christ with the utmost seriousness throughout his career. Notably, Wagner began drafting a scenario for an opera titled Jesus of Nazareth in 1849 which in essence sought to "rescue" Christ from the corruption of modern religion. In A Communication to My Friends (1851), Wagner draws a parallel between the Artist and the Christ figure of Jesus of Nazareth, which in turn also points to a concatenation between his notions of artistic and cultural unity and that of a communal form of love. ${ }^{3}$

Neither Jesus of Nazareth the man nor the proposed opera figure greatly into the discussion that is to follow, but I invoke it to provide an entry point into what will be the central theme of this chapter: Wagner's use of Christian narratives, specifically as employed in the Germanic legends of the Middle Ages as a strategy for constructing sonorous representatives of the "ideal" of German art and nationhood. We can glean a preview of how such a project might work by vaulting past the writings of a not-yetcompletely disillusioned revolutionary to those of his later life, where we see that Christ and the stories that flowered from his teachings maintained a lasting prominence in Wagner's politics and aesthetics. In "Heroism and Christianity," a supplement to his 1880 essay "Religion and Art," Wagner continues the argument from the main piece that the Germanic race has suffered from a long-term degeneration due to centuries of miscegenation. The "pure" blood of the German race has been compted through the mixture with "impure" foreign blood. In this supplementary paper, Wagner identifies the

\footnotetext{
${ }^{2}$ Jean-Jacques Nattiez, Wagner Androgyne: A Study in Interpretation, trans. Stewart Spencer (Princeton, NJ: Princeton University Press, 1993), 19.

${ }^{3}$ See SSD IV, PW I, 378-80.
} 
mythological figure of the "hero" as one of the progenitors of a potential German "regeneration" and then looks back at how discourses of heroism and blood have been conceptualized. Wagner describes the Christian formation of the hero in these terms: "for we now must seek the Hero where he turns against the ruin of his race, the downfall of its code of honour, and girds his erring will to horror: the hero wondrously become divine the Saint." Wagner notes that "it was a weighty feature of the Christian Church, that none but sound and healthy persons were admitted to the vow of total worldrenunciation; any bodily defect, not to say mutilation, unfitted them." underline a necessity of purity of the outer body to go along with purity of blood. Wagner also invokes the figures of the martyr and the Saviour in his framework of the Christian form of the hero. I will discuss Wagner's linkages between Christian rites, purity of blood, and heroism further when I discuss Parsifal in detail, but the point should be amply apparent that regardless of Wagner's criticisms of perceived institutional corruptions, Christianity remained vital to Wagner as subject matter for his aesthetic and political aims.

Beyond matters political and historical, Christian-based legends were also prime fodder for Wagner's dramas because of their mythological component. The fact that Lohengrin and Parsifal find their inspiration not in Biblical sources, but in thirteenthcentury medieval legends that mine ideas and iconography from Christian tradition is what moves them from the religious and/or liturgical into the realm of the mythological. Picking up from the discussions of Chapter Three, Wagner positioned Germany's mythologized past as the ideal dramatic stage for the German identity. Whereas the Ring

${ }^{4}$ SSD X, 279; PW VI, 279.

${ }^{3}$ Ibid. 
appropriated various Germanic and Norse myths, the "Christian" operas deploy the narratives and iconography of the sacred to interact with explicitly German characters and settings. In doing so, these legends - and Wagner's adaptations thereof - create a mythology of German history wherein the sacred has directly contacted the German land and its people.

In Lohengrin, Christian-inspired legend is framed as an intrinsic element of the "spirit" of Germany in its depiction of an interaction between an emissary of Christ. This in turn suggests an inference that the titular character's presence serves as a benediction of German history. Such an intertwining of myth and history is an example of Hannu Salmi's contention that "the amalgamation of myths and historical elements could be interpreted as evidence that Wagner saw no incongruity between myth and history...a myth, like history, could tell the truth, but the truth told by a myth was different in character: a truth concerning the past which sprang from the dimension of time across the centuries." In this nominally "Christian" opera, German history and sacred myth dovetail in order to present the "truth" that Germany was at a point in its distant past "touched" by the sacred, in essence consecrating the national identity as one that is part of a holy lineage that has threaded itself through any number of cultural histories. This mythological truth of Germany's hallowed background has survived "the dimension of time across the centuries," and its dramatic and musical depiction reinforces that truth and keeps it alive for contemporary audiences. In the case of Parsifal, something akin to the reverse is carried out: the setting itself is not explicitly German, the interaction of the sacred with the artistic occurs within the confines of the Festspielhaus itself, the "consecration" of the stage projected backwards in time to a mythologized

\footnotetext{
${ }^{6}$ Hannu Salmi, Imagined Germany: Richard Wagner's National Utopia (New York: Peter Lang, 1999), 32.
} 
version of a Christian setting. Instead of the German past being touched by the sacred, the benediction of German art occurs in the present and reaches back to be effectively twinned with that distant past: the sacrosanct of the past and present revealed as equals, each symbolic of the other.

The above serves to introduce the central grounding for what are the core arguments in this chapter. The conflation of German history, art, and myth in both of these works is centralized around the titular male characters, both portrayed by tenors. The previous chapter introduced the so-called Heldentenor (so-called in that Wagner himself never adopted the term) as an integral element in the creation of the Ring, with the role of Siegfried put forth as the primary aural and visual embodiment of the "Artwork of the Future." To repeat from that previous exploration, while the term Heldentenor should be approached with care, especially due to the after-the-fact nature of its designation, it does provide convenient shorthand for distinguishing Wagner's tenors from those of other composers. The sonorous characteristics of the Wagnerian tenor, to be detailed below, provide a prominent sonic advertisement of Wagner's musical and dramatic vision. As such, whether or not one is inclined to accept the Heldentenor label, the sonorities of Lohengrin and Parsifal function as significant markers of Wagner's efforts towards giving "voice" to German history and myth. Furthermore, as the following analyses will show, it is really the Held aspect of the label that is of greatest interest to me: Wagner's "heroic" tenor sonorities provide an acoustic signature of the body of the Germanic heroes of medieval legend.

In this chapter, I intend to analyze the "heroic" stature of these roles and their significance in reflecting and creating discourses of nation. In contrast to my discussion 
of the Ring, where I situated the tenor as one example of many male roles that served to illustrate the mythical and allegorical underpinnings of the German nation, here I centralize the body of the "heroic" Wagnerian tenor in its aural aspects as an instrument in the glorification of the nation. A theme of redemption runs through both of these operas, and it is through that theme that the importance of Christian legend and iconography is revealed. Both of the titular characters is either redemptive or achieve redemption through their interaction with the sacred: Lohengrin, a Knight of the Grail, performs as Elsa's champion in rescuing her from accusations of fratricide and then ultimately frees her brother Gottfried from magical captivity and declares him the new Duke of Brabant; Parsifal heals Amfortas' wound, frees Kundry from her cursed existence, and redeems the order of the Grail Knights. I will endeavour to posit the acts of sacred redemption in the narratives of these operas as a stage for the redemption of the German nation itself. From there, I will link the mobilization of the redemptory power of the Christian mythos with discourses of the heroic, making prominent use of Simon Williams' study of the modes of heroism displayed in Wagner's works. ${ }^{7}$

Williams' inquiry identifies the early nineteenth century discourses of heroism as crucial to the cultivation and flowering of nationalist movements in Germany: he notes that the constellation of Wagner's fascinations with heroism and nationalism created the conditions of possibility for the development of works of art that deviated from the prevailing paradigms of the "Biedermeier" movement of the early nineteenth century and

\footnotetext{
${ }^{7}$ Simon Williams, Wagner and the Romantic Hero (Cambridge and New York: Cambridge University Press, 2004).
} 
its valorization of interiority, domesticity, and the pastoral in German art. ${ }^{8}$ Williams writes,

In his youth, Wagner had read widely in early romantic literature and he returned to it in the $1840 \mathrm{~s}$ when he was establishing himself as a composer of national stature. He was therefore agreeable to the romantic image of Germany as a pastoral land where individuals were free to cultivate their inner life. But he also needed a means of articulating his bitterness and sense of isolation from a world in which he had little part. He found it in the literature of later romanticism...His ideas of heroic action as a means of saving humanity from the materialism, fear, and lovelessness that were destroying it arose first from this literature and were later enhanced by his return to an earlier romanticism oriented around nature. But they also derived from his reading, in the 1840 s, of medieval epics, whose heroes were embodiments of human strength and courage. ${ }^{9}$

In his consultation with the earlier literature of heroism, Wagner found effective prototypes for a framework that put forth an exceptional individual as a synecdoche of the collective, heroic spirit of the German people. In both "The Artwork of the Future" and "A Communication to My Friends," Wagner bequeaths significant import to the figure of the hero as the singular embodiment of the "artwork of the future," which in turn represents the artistic "voice" of German identity. The later essay "Heroism and Christianity" makes manifest that the narratives and iconographies of the hero remained vital to Wagner's conception of the national mythos, even as his musical and dramatic aesthetics had somewhat moved away from the ideals of "music drama." Even as his revolutionary politics and aesthetics had begun to recede, the notion of the hero as an idealized figure representative of the German essence remained.

Williams identifies three primary heroic "types": the "romantic", "epic", and "messianic" hero, positioning Lohengrin as an example of the second, and Parsifal as the third. I will not seek to meticulously analyze the historical and theoretical backgrounds

\footnotetext{
${ }^{8}$ Ibid., 5-6.
}

${ }^{9}$ Tbid., 7-8. 
of these "types" as that would not be particularly vital to my argument. However, how each of these characters fit into their respective types will shed some light on what will be one of the chief strategies of this chapter: to investigate these operas as a constellation of narratives of heroism, Germanic legend, and iconography, and nation aligned through the body of the Wagnerian tenor. My analyses will be centralized around the body as male imago figure for the nation, a psychoanalytic concept that can be encapsulated as a representation of the body into which is invested an unattainable fantasy of an idealized conception of manhood: the "heroic" tenor in these works aligns will be analyzed as the presentation of an acoustically "perfected" body. This idealized figure, I will argue functions as a somatic stand-in for the fantasy of an idealized German nation.

Both works will be demonstrated to thematize the heroic male body as stage for the idealized nation in their own individual fashion. As the plots and dramatis personae for Lohengrin and Parsifal find their origins in the thirteenth-century Parzival legend of Wolfram von Eschenbach, ${ }^{10}$ the convergences and divergences in the dramatic and musical content of these operas will consume the most significant portions of this chapter. The construction of the Lohengrin character is situated within Wagner's revolutionary politics of the 1840 s, particularly his fascination with the "messianic redeemer of the people striving for the 'good state."'11 This leader serves as a bellwether of Germany's possible future should it rise to the revolutionary call, a stand-in for the potentially brilliant future of the entire nation. The discourse of the revolutionary leader dovetails with the Christian trappings, framing the character's "beautiful" body as an

\footnotetext{
${ }^{10}$ Wolfram von Eschenbach, Parzival and Titurel, trans. Cyril Edwards (Oxford: Oxford University Press, 2006); Arthur Groos provides an extensive study of the Parzival legend in Romancing the Grail: Genre. Science, and Quest in Wolfram's Parzival (Ithaca, NY: Cornell University Press, 1995).

"Rose, 25.
} 
idealized image of plenitude that serves as a mirroring function for an idealized image of the nation. As its emissary, Lohengrin is positioned as metonymous with the Holy Grail, which Lawrence Kramer puts forth as a Lacanian objet petit autre, an unattainable object of desire, belonging to a "mythical past and...a constantly postponed future." ${ }^{12}$ As one of its protectors, Lohengrin may be seen as a similar unattainable object, a representation of a perfected male body that stands in for Germany's infinite potential that has not yet been reached.

The Parsifal of Parsifal - who will go on to father Lohengrin - may also be interpreted as an imago figure, but not completely along the same lines as his future progeny. The revolutionary leader aspect is conspicuously de-emphasized. Instead, the prophecy of the "pure fool enlightened through compassion" is foregrounded. Parsifal's purity of heart and purity from corruption concatenate with the notions of racial purity and purity of blood that took up a significant portion of Wagner's thoughts during the work's gestation. The German "race" had suffered centuries of "degeneration" by contaminating the blood-line through miscegenation. ${ }^{13}$ In the opera, the degeneration of the German race is depicted through the decline of the Grail kingdom, symbolized through Amfortas's wound. Jeremy Tambling expounds upon this wound as an injury to masculinity, where Kundry's seduction and Klingsor's magic reveals weakness in Amfortas (as well as numerous others knights). ${ }^{14}$ They are outside infiltrations that contaminate the blood of the Knights, an infection that is externalized though a bodily injury, with a singular lesion standing in for the German race entire. Parsifal's pure

\footnotetext{
${ }^{12}$ Lawrence Kramer, Opera and Modern Culture: Wagner and Strauss (Berkeley: University of California Press, 2004), 59.

${ }^{13}$ This race-based aspect of Wagner's thought is notably discussed in Rose, 135-169.

${ }^{14}$ Jeremy Tambling, Opera and the Culture of Fascism (New York: Oxford University Press, 1996), 47-60. 
blood, and - by extension - pure body, will heal the wound, an act of suture for the wounded nation casting out the infectious influences that lacerated it and allowing manhood and nationhood to flourish at its full potential. ${ }^{15}$

One final element of this chapter's tapestry has not yet been revealed. The Wagnerian tenor interacts not only with Christianity and Germanic mythology and discourses of heroism to create a visual and aural stage for nationhood, but with the dramaturgy of grand opera as well. Threaded throughout this chapter will be inquiries into how the tenor roles in these operas play off of elements of grand opera mobilized by Wagner. I will pay particular attention to the situation of the tenor role within Wagner's adaptations of grand opera crowd scenes and balletic sequences in both, in addition to how the Wagnerian tenor itself contributes to grand opera dramaturgy. What will become clear as the chapter's arguments progress is that the grandness of grand opera plays no small part in solidifying the mythic stature of the Wagnerian tenor; grand opera, Germanic legend, and heroism mutually imbricate to mythologize the Heldentenor, which in turn mythologizes those three discourses through its stated importance to Wagner's art. All and sundry effectively combine to foreground the Heldentenor as a somatic stage for the idealized sound of the German nation.

\section{The Male Body as Imago}

Before embarking on a detailed examination of the issues introduced in the above passages, it is necessary to backtrack slightly and account for the critical and theoretical backgrounds for the male body as imago figure, as well as adumbrate the role of the tenor in traditional grand opera and account for the cultural narratives localized around the

\footnotetext{
${ }^{15}$ James Kennaway discusses issues of degeneration and masculinity in the reception of Parsifal in "Degenerate Religion and Masculinity in Parsifal Reception," Current Musicology 88 (Fall 2009): 35-62.
} 
"heroic tenor" in other forms of opera. The concept of the imago has points of contact with several strands of psychoanalytic theory. In The Language of Psycho-Analysis, Jean Laplanche and J.B. Pontalis define the imago as an "unconscious prototypical figure which orientates the subject's way of apprehending others; it is built up on the basis of the first real and phantasied relationships within the family environment." that the concept was initialized in Jung's Psychology of the Unconscious, which described paternal, maternal, and fraternal imago figures. ${ }^{17}$ Under this framework, the imago functions as an idealized concept internalized by the subject as the locus classicus of the parental figure. Laplanche and Pontalis stress that Jung's conception of the imago need not be localized to a physical image, but rather grasped as "an acquired imaginary set rather than an image: as a stereotype through which, as it were, the subject views the other person." 18 Moreover, the imago is not necessarily "understood as a reflection of the real world, even in a more or less distorted form: the imago image of a terrifying father, for instance, may perfectly well be met with in a subject whose real father is unassertive." ${ }^{\prime 19}$ As such, the imago is not automatically an idealized concept in the most positive connotation of the word (although my readings of Wagner will use "ideal" in its traditional meaning), but idealized in that it represents a phantasmatic that transcends the boundaries of reality, so that the imago is the father, the mother, etc.

Jung's framework of the imago as a fantasy of the parental figure bears similarities to the Freudian model of the subject, in particular the concept of the super-

\footnotetext{
${ }^{16}$ Jean Laplanche and J.B. Pontalis, The Language of Psycho-Analysis (New York: W.W. Norton \& Company, 1973), 211.

${ }^{17}$ C.G. Jung, Psychology of the Unconscious: A Study of the Transformations and Symbolisms of the Libido (1911), trans. Beatrice M. Hinkle (New York: Dodd, Mead, and Company, 1925).

${ }^{18}$ Laplanche and Pontalis, 211.

${ }^{19}$ Tbid.
} 
ego, which emerges through the (male) subject's identification with the father. According to Kaja Silverman,

By taking the image of the father into himself, the male subject resolves both his original erotic feelings for that figure, and his subsequent hostility and jealousy... Not only does the subject identify with the father, he also accepts that there are ways in which he can never be like him. In other words, the male subject internalizes along with the image of the father an image of his own distance from the father. That distance is expressed through the creation of a psychic construct which stands to one side of the ego, as a kind of ideal version of it. This ego ideal or superego functions throughout the history of the subject as the mirror in which the ego sees what it should be, but never can be. ${ }^{20}$

Where the Freudian super-ego overlaps with the Jungian "father-imago" is in the idea of the psychological displacement of the father out of the realm of the corporeal into essentially a fantasy figure that resides as something of an "imaginary residue."21 In Jung, the father is effectively transmuted into "The Father," no longer simply an individual parent, but a conceptualization of what a father is and should be. For Freud, the father is the behavioural model for the subject to strive for, but can never fully attain. Both the imago and the super-ego lay the groundwork for the subject to define for itself the nature of its relationships and interactions with the family and with the external world.

Jacques Lacan expanded the Freudian models to include elements of linguistics and semiotics in his inquiries into the psychic formations of subjects. But he retained the notion of the importance of the father as an ideal. For Lacan, the father had a presence in each of his three orders, a "real" father, the paternal-imago figure belonging to the

\footnotetext{
${ }^{20}$ Kaja Silverman, The Subject of Semiotics (New York and Oxford: Oxford University Press, 1983), 134135.

${ }^{21}$ Laplanche and Pontalis, 211.
} 
Imaginary, and the Symbolic father. ${ }^{22}$ Where the Imaginary resides in a pre-linguistic network of feelings and visual and auditory images, the Symbolic belongs to the realm of language and signification. The Symbolic father is identified by Lacan, in something of a revision of the Oedipus complex, as a particular signifier known as "The Name of the Father." Similar to the Freudian ego-ideal, the Name of the Father trope posits that the child identifies with the father, but it can never become the father. The father serves as an ideal, a lack that the subject desires so that the father is no longer a material father, but has a father function. ${ }^{23}$

The ubiquity of the "father" trope in the provided summaries should not be taken as an indication that I intend to put forth the male body of the Wagnerian tenor as specifically a paternal figure for the nation. I draw attention to the prominence of the father in these discourses to underline the importance of the male figure in terms of how subjective identities are frequently theorized. In his essay on the paintings of Théodore Géricault, Norman Bryson specifically points to representations of the idealized male body as a visual representation of the male imago. ${ }^{24}$ Bryson identifies the idealized male body as a site of visual "magnificence," which he traces back to the Freudian discourses of the subject's internalization of the father as the ideal. ${ }^{25}$ According to Bryson, idealization is essentially "the gap between the actual body and that of the higher imago of the body that constitutes the masculine ideal, the identification to which the male

\footnotetext{
${ }^{22}$ The three "orders" are explained in Alan Sheridan's "Translator's Note" in Jacques Lacan, The Four Fundamental Concepts of Psychoanalysis, ed. Jacques-Alain Miller, trans. Alan Sheridan (1977) (New York and London: W.W. Norton, 1981), 279-280.

${ }^{23}$ The Name of the Father concept is encapsulated in Silverman, 181.

${ }^{24}$ Norman Bryson, "Géricault and 'Masculinity,"' in Visual Culture: Images and Interpretations, ed. Norman Bryson, Michael Ann Holly, and Keith Moxey (Hanover and London: Wesleyan University Press, 1994), 228-259.

${ }^{23}$ Ibid., 233-236.
} 
subject aspires and is also prevented from attaining. ${ }^{26}$ To view - or in the case of a Wagnerian tenor, to hear - a "magnificent" representation of the male body is to be confronted with that ideal to which the subject can never actually measure up. In Lacanian terms, the idealized male body can be thematized as an example of the objet petit autre, the "little other" that has been internalized within the subject as the "missing piece" that could make the subject whole, but is forever out of reach. ${ }^{27}$ Put another way, the idealized body of the male imago is perpetually deferred..$^{28}$

The idea of the subject as longing for a perpetually unavailable coherence was tied to the construction of nationhood in the introduction. To reiterate that idea, the category of "nation" operates as an "important mirroring function of the subject, in a relay of identifications that contributes to the fiction of coherence." ${ }^{29}$ Furthermore, "subjects do not so much belong to nations as nations belong to subjects." ${ }^{30}$ In terms of the body's link to the nation and to the subject, I also offer as a reminder Marc Weiner's work, which specifically underlines Wagner's theorizations of the male body as a stage for the essential "spirit" of the German nation. The performing body placed in the field of vision of the spectator stands as the external representation of the German artwork. But, as Weiner explains, Wagner's framework stages both performers' and spectators'

\footnotetext{
${ }^{26}$ Ibid., 234.

${ }^{27}$ Silverman summarizes this concept on p. 156. She ties the concept of the "missing piece" to the longedfor wholeness of the subject on p. 158.

${ }^{28}$ Compare this notion of the imago figure as a site of perpetual deferral with Jacques Derrida's concept of différance, where discursive meaning is continually deferred because words and concepts can only be defined through their relationships with other words and concepts. Just as meaning is continually put off, put out of reach by this diachronic chain of signification, the imago is similary unattainable, tantalizingly sighted but eventually deferred for another future engagement, until it is inevitably deferred yet again. In that sense, the male imago figure might be productively theorized as the somatic analogue of linguistic and discursive différance. See Jacques Derrida, Margins of Philosophy (1972), trans. Alan Bass (Chicago: University of Chicago Press, 1982), 1-28.

${ }^{29}$ Barbara Gabriel, "The Wounds of Memory: Mavis Gallant's 'Baum, Gabriel (1935- ),' National Trauma, and Postwar French Cinema," in Essays on Canadian Writing 80 (Fall 2003): 200.

${ }^{30}$ Ibid., 213 n6.
} 
bodies as part of a feedback loop where the relationship between the observed and the observer bring the German identity into being. The Artwork of the Future, according to Weiner is "couched in the metaphors of the bodies of those who perceive it, contains within its 'depths' the essence of those who innately know by viewing, and thus itself contains its focal point in the metaphor of ocular perception." ${ }^{\text {31 }}$ Bodies witnessing bodies is the central strategy for bringing the shared "knowledge" of the German essence into conventional view. But it is the apprehension of the performing body that is the primary instrument that surfaces the shared cultural heritage and solidifies the national identity. Wagner specifically positions the performance of music as central to this cultural revitalization, couching musical melody in distinctly somatic terms. To quote Wagner at length:

Just as the interior is probably the basis and the condition for the exterior, but only from the exterior does the interior clearly and decisively emerge, so harmony and rhythm are probably the formative organs, but only melody is the true shape of music itself. Harmony and rhythm are blood, flesh, nerves, and bones with all the inner organs, which like the former remain closed to the beholding eye in the contemplation of the completed, living human being; melody on the other hand is this completed human being in itself, just as it presents itself to our eyes. When we look at this human being we behold only the slender shape as it expresses itself to us in the form-giving delineation of the exterior coat of the skin. We immerse ourselves into the contemplation of the most expressive realization of this shape in its facial features and finally stop at the eye, the most lively and communicative realization of the entire human being, which, through this organ that derives its capacity for communication in turn only out of the most universal talent to receive the expressions of the surrounding world, at the same time communicates to us its interior in the most convincing fashion. In this way melody is the most perfected expression of the interior being of music, and every true melody determined by this innermost being also speaks to us through that eye which most expressively communicates to us this interior. ${ }^{32}$

\footnotetext{
${ }^{31}$ Marc A. Weiner, Richard Wagner and the Anti-Semtic Imagination (Lincoln and London: University of Nebraska Press, 1997), 42.

${ }^{32}$ Opera and Drama (1851), quoted in Weiner, $42-43$.
} 
Bound up in this description is essentially a series of encomia to the presence of the somatic in the production of the acoustic, the metaphor being that the eye perceives the exterior of the body, while the envoiced melody brings the concealed interior into view. Music as disseminated by the performing body reveals the entirety of one's being to the spectator. ${ }^{33}$ Weiner follows up from the above quote,

To the discerning gaze of the Artwork of the Future reveals its depths through its physiognomy - it is a being that mirrors the audience that beholds it, and the symbiosis of vision between artwork and community forms a link between the aesthetic construct as metaphorical body and the community as the body politic made up of real, human bodies with genuine physiognomies. ${ }^{34}$

In witnessing the performance of the Artwork of the Future, German audiences saw a reflection of the shared spirit of the Volk; they saw a piece of themselves up on stage. As such, the Wagnerian drama functioned as "both a model and as an anticipatory mirror of a future, superior world." 35

With the above kept in mind, I will endeavour to lay out a hermeneutic model that thematizes the male body as imago figure for the German nation. Wagner's dramatic works typically foreground the principal tenor role as the key male role. Weiner's analysis applies the category of Heldentenor to these roles, positing the Heldentenor (Siegfried in particular) as what amounts to a "mirroring function for the subject." Of course, since Wagner never employed the term Heldentenor himself, Weiner's

\footnotetext{
${ }^{33}$ Wagner's words demonstrate interesting resonances with Michel Foucault's tracing of the development of what he calls the modern "episteme" - the ideas that are accepted as constituting knowledge during a particular historical period - which he contends developed during the nineteenth century. The modern episteme located Man as an object of knowledge, and one of its goals was to construct methods of making the previously invisible visible. Foucault points to the development of the discipline of biology, which transferred scientific inquiry from the manifestly observable to the "hidden" interior workings of the body as one of the most significant intellectual developments of the modern episteme. Wagner's characterization of music's capability of unveiling inner essences might be seen as another example of the modern episteme's efforts towards revealing that which was previously hidden. See The Order of Things: The Archaeology of the Human Sciences (1970) (New York: Vintage Books, 1994), xv-xxiv and 303-343.

${ }^{34}$ Weiner, 43.

${ }^{35}$ Ibid., 49.
} 
framework should not be adopted without qualifications, especially when one considers that his characterizations of the Heldentenor are based in large part upon retroactive observance of Wagner's scores. ${ }^{36}$ Weiner's analysis demonstrates its greatest usefulness in underlining the importance the tenor would come to hold in sonorously defining Wagner's work. Moving on from that caveat, Wagner and Weiner frame in their own ways the reception of the performing body as an act of recognition on the part of the spectator, the apprehension of a previously concealed reality now made manifest: in Wagner's case, music emanating from the body reveals to the audience the inner essence of the "complete human being" while for Weiner, the German audience sees their collective spirit reflected back at them through the bodies performing on stage, the somatisation of the German work of art.

I propose a modification of these frameworks. First, let us begin with the premise that the sonority of the so-called Heldentenor communicates to its spectator the "essence" of the German artwork and the German identity through its ostensible physical and acoustic superiority ${ }^{37}$ By that reckoning, the sonorous body of the Wagnerian tenor acts as a supple stage for German nationhood by investing German art with an appositely "heroic" quality through the superiority of its sound, a feat of musical "heroism" (to be expounded upon below) that matches the valour of their attendant characters' deeds, deeds that only a blessed few can accomplish. ${ }^{38}$ In Lohengrin and Parsifal, the "heroic"

\footnotetext{
${ }^{36}$ Earlier in Chapter Three, I further enumerated some of the shortcomings of Weiner's interpretations of the musical and social characteristics of the Heldentenor. Those critiques should continue to be kept in mind as I discuss his analyses within the context of this chapter.

${ }^{37}$ Weiner, 163-176.

${ }^{38}$ In his 1865 reminiscence of the then-recently deceased tenor Ludwig Schnorr von Carolsfield, Wagner demanded that singers who interpreted his works be "thoroughly alive to their spiritual significance" (238). He then goes on to describe Schnorr's performances in terms that emphasize both the incomporable beauty of his tone and the vocal power and stamina necessary to achieve and sustain such beauty. Extrapolating from his words, Wagner essentially ascribes to Schnorr (and any other proper interpreter of his music) a
} 
tenor sonority is made to emanate from the bodies of characters that have connections to and/or origins in divinity. As my forthcoming analyses will show, those divine qualities frame the body as a site of unattainable perfection as both Lohengrin and Parsifal are fundamentally unavailable to human society: Lohengrin ultimately leaves Brabant to return to the Grail kingdom while Parsifal ends his story ensconced in a cloistered society accessible only to a select few. In that context, these heroic tenors may be thematized as male imago figures for the nation: sonic embodiments of a perfected nation that is aspired to but ultimately out of reach. In that sense, sound of the Heldentenor might be theorized in this context an an example of the aforementioned Lacanian "little Other" that embodies the desired plenitude that the subject lacks. ${ }^{39}$

It is of exceptional importance that these idealized sonorous bodies resound within the mythic context of Germanic legend. For just as the sound of the "heroic" tenor provides an acoustic portrait of an ostensibly "superior" human being, so does myth offer fertile ground upon which similary imposing persons can traverse. Myth, in its capacity for telling stories of world and cultural origins, provides a supple domain for the heroes that Wagner found so compelling to flourish, its stories and legends providing a suitably outsized canvas for their remarkable and world-defining feats. Lohengrin and Parsifal's

sense of "heroic" superiority, physical and musical skills that are beyond the capacities of "normal" men. So great are the skills of a Schnorr that he is able to comprehend and tap into a "spiritual" component to the music, to transcend the merely physical and acoustic. With these words, Wagner essentially demands that his singers (and particularly his tenors) amount to paragons, figures that astonish with their manifest superiority. See SSD X, 189; PW IV 238-239.

${ }^{39}$ Silverman, in her discussion of the cinematic use of the female voice to represent a "sonorous envelope," specifically thematizes music as a "primordial" source of auditory pleasure, where the child envelops itself in the joyful protective blanket of tone. Silverman identifies this as a specifically maternal fantasy, the "sonorous envelope" providing an outlet for the subject's longing for the pleasurable ensconcement in the womb. Silverman's analysis situates the pleasurable experience of sonority within the pre-linguistic Imaginary order, wherein the subject's construction of imago figures and the "little Other" also take place. As such, I would modify Silverman's sonorous envelope concept so that the sound of the Heldentenor voice resonates within the subject's conception of the male imago, an Imaginary idealization of coherence and plenitude that the subject cannot ultimately attain. See The Acoustic Mirror: The Female Voice in Psychoanalysis and Cinema (Bloomington: Indiana University Press, 1988), 84-85. 
heroic magnificence, resulting from their service to the divine vessel of the Holy Grail, lends them a sense of perfection unavailable to humanity, which finds a similar analogue in myth's relationship to society: to reiterate Salmi's point, myth tells essential "truths" about the essence of a culture that spans across centuries. However, it should not be forgotten that those truths are situated within the context of stories that are set within a mythologized version of the distant past, creating a sense of remoteness and displacement from the current culture. The heritage of the mythic past is part of the "truth" of Germany's essential identity, but at the same time it is presented as an untouchable remnant of the long-ago. The divinely empowered heroism of Lohengrin and Parsifal thus can be thematized as the singular embodiments of myth's capacity to provide the "anticipatory mirror of a future, superior world" that has yet to be attained. The "heroic" tenor sonorities, supposedly achievable by only the fortunate view serve as the acoustic analogue these legends presentation of divine perfection as an aspirational model that is ultimately unavailable to its spectators. For these reasons, I have proposed that the heroic tenors of Lohengrin and Parsifal serve as embodiments of male imago figures for the German nation. Given grand opera's well-established fascination with heightened emotional and dramatic gestures, specifically pertaining to the "spectacle of the past," it makes sense to postulate that the Heldentenor, performing within a Wagnerian version of grand opera dramaturgy, functions as a suitably "grand" stage to act as an embodiment of the mythic construction of an idealization of the German nation, projected into the distant past, as a tacit reminder that the "perfected" form of the nation is still out of the grasp of the contemporary nineteenth-century Germany.

\footnotetext{
${ }^{40}$ Simon Williams, "The Spectacle of the Past in Grand Opera," The Cambridge Companion to Grand Opera, ed. David Charlton (Cambridge: Cambridge University Press, 2003), 58-75.
} 


\section{The Tenor and Grand Opera}

The preceding remarks have sketched out the tenor's potential efficacy as an idealized image of the nation in Wagner's specific conception of the musical drama. It is now necessary to account for how the tenor has been mobilized as an element of grand opera's traditional dramaturgy. The logical starting point is the musical function of the tenor role in grand opera. Mary Ann Smart examines these Parisian roles by comparing and contrasting the parts written for the Paris Opéra's first "star" tenor Adolphe Nourrit with those composed for his successor Gilbert-Louis Duprez, who essentially rendered Nouritt obsolete by being the first Parisian tenor to sing up to a $c^{\prime \prime}$ in chest voice. She notes how the different musical qualities of each of their roles constructed differing notions of masculinity. Smart writes

One effect of Nourrit's innovation concerned dramatic verisimilitude and archetypes of masculinity. Accustomed as we are today to the blaring tones of a Pavarotti (or even a Caruso), we might guess that Duprez's ringing fully embodied high notes would inspire librettists and composers to create a new kind of tenor lead, more forceful, active - in short, more convincingly masculine. But in fact the movement was nearly in the opposite direction. Where the roles associated with Nourrit...tended emphatically towards the heroic and the revolutionary, those conceived for Duprez were likely to be defined more by loveinterest than by political conviction. ${ }^{4}$

Smart continues by noting that Duprez's roles tend to be "surprisingly restrained in their use of the newly forceful high notes, instead exploiting the warmth and breadth of tone for which Duprez was noted. ${ }^{, 42}$ In contrast, Nourrit's earlier roles "use their highest notes as clarion calls to action: Masaniello [of Auber's La Muette di Portici] sings a rabble-rousing duet with baritone studded with exuberant high notes... while Amold [of Rossini's Guillaume Tell] specialises in leaps of sixths and sevenths, triumphantly laying

\footnotetext{
${ }^{41}$ Mary Ann Smart, "Roles, Reputations, Shadows: Singers at the Opéra, 1828-1849," in The Cambridge Companion to Grand Opera, ed. David Charlton (Cambridge: Cambridge University Press, 2003), 117.

${ }^{42}$ Ibid., 118.
} 
claim to the Swiss landscape of Alpine yodeling." ${ }^{, 43}$ Both, according to Smart, position the principal tenor role of grand opera as an acoustical model of heroism and male identity, Nourrit's virtuosity reflecting the revolutionary spirit of his characters, while the beauty of Duprez's tone reflecting the "romantic" nature of his roles.

Nourrit and Duprez's musical achievements reflect a prevailing trend in nineteenth-century opera: as Carolyn Abbate's and Roger Parker's history of opera makes clear, the nineteenth century was the period of the tenor's "coming of age." Part of that coming of age was the prevalence of "heroic" tenors in multiple operatic cultures. Granted, Abbate and Parker place greater weight upon the tenors of Italian opera. However, they do locate in French grand opera one of the progenitors of the heroic tenor, the aforementioned Arnold from Guillaume Tell. ${ }^{45}$ Abbate and Parker observe that the gradual shift in the 1830s towards these types of "heroic" parts in Italy and then France placed notable prestige on what were thematized as its "manly" sounds, effectively restating Smart's observance that combinations of vocal power, dexterity, and richness of tone provided an acoustic model of the masculine and the heroic. Indeed, despite Rossini's apparent revulsion at the "extreme vocal machismo" that accompanied Duprez's interpretation of Arnold, Abbate and Parker note that posterity has frequently signposted those chest-voice high-Cs as a point of no return, a harbinger of the direction operatic vocal writing was headed. ${ }^{46}$ Despite the more "romantic" characters that were conceived for Duprez, the increasing popularity of grand opera "increased a sense, already felt in the Italy of Donizetti and Verdi, that force, with or without agility, would

\footnotetext{
${ }^{43}$ Ibid., 117-118.

${ }^{44}$ Carolyn Abbate and Roger Parker, A History of Opera (New York and London: W.W. Norton, 2012), 215-240.

${ }^{45}$ Ibid., 216.

${ }^{46}$ Ibid., 219.
} 
be the new fashion." ${ }^{47}$ In other words, power would come to be the quintessential vocal marker of the heroic tenor, and as we shall see, that wide-ranging predilection for vocal strength was amply exploited by Wagner's own aesthetic.

Musically, the grand opera tenor would at first glance appear to be quite distinct from the vocal tendencies of the Wagnerian Heldentenor in several respects: the higher tessituras of the French works as well as the ubiquity of ornaments were the very elements that Wagner professed to deplore. ${ }^{48}$ Indeed, because the French public "was fascinated by [the] preternatural achievement" ${ }^{\prime 49}$ of a tenor reaching those high-Cs, the "heroic" tenor would eventually become a draw unto itself. Regarding Duprez's performance in Guillaume Tell, Berlioz remarked that "for [the public], all the interest in the revival of Guillaume Tell...lay in that diamond of a C; that out-of reach C. The libretto, the score, the chorus, the orchestra, the singers are nothing - nothing but the framework that is unfortunately necessary for that pyramid of a C." ${ }^{50}$ As previously stated in Chapter Three, the Wagnerian tenor generally eschewed those uppermost registers. Furthermore, in place of significant ornamentation or coloratura, Heldentenor roles prioritize the vocal power necessary to project over a full Wagnerian orchestra and the stamina to maintain that power over an exceptionally dilated time scale, especially considering that the Heldentenor and the principal soprano roles were required to be singing on stage for a significant percentage of the considerable length of Wagner's

\footnotetext{
${ }^{47}$ Ibid., 266.

${ }^{48}$ Wagner states this position particularly forcefully in "On the Performing of Tannhäuser" (1852) in PW III, 202-203. In these passages, Wagner argues that prioritizing vocal flash above all else renders a tenor part as a "weak and unmanly character" (203). Wagner directs specific ire towards Meyerbeer's Robert le diable as an example of the type of superficial tenor part to which Tannhäuser is supposed to be a corrective.

${ }^{49}$ Herve Lacombe, The Keys to French Opera in the Nineteenth Century, trans. Edward Schneider (Berkeley: University of California Press, 2001), 45-46.

${ }^{30}$ Hector Berlioz, article in Le Journal des Débats (1837), quoted in Lacombe, 46.
} 
works. ${ }^{51}$ In contrast, as Richard Taruskin points out, in grand opera, extensive solo passages are often in short supply because "single characters rarely got to occupy the stage long enough to sing one." 52 Taruskin adds that "while every grand opera score contained its share of 'detachable' numbers...they are often throwaways, used for the purpose of narrative exposition rather than emotional effusion...."53 While Wagner's dramaturgy shared the de-emphasis of discrete arias and musical numbers, he deviated from that of grand opera in keeping his principal solo roles prominent throughout the score.

Despite the differences stated above, there are greater musical concurrences between the grand opera "heroic" tenor and the Wagnerian tenor than Wagner was apparently willing to give credit for. While, Wagner's musical "heroes" were constructed not to display their acoustic valiance through flashy technical display or by scaling seemingly insurmountable vocal heights as with the supposedly despised French and Italian singers, Wagner's writings in his reminiscence of Schnorr still suggest that he prized "preternatural achievement" from his singers in general and his tenors in particular. In his aforementioned encomium to Schnorr's gifts (see note 38 of this chapter), Wagner describes his reaction to Schnorr's reading of Lohengrin as one of astonishment at the unrefined yet substantial talent displayed in this portrayal of a "youthful Hercules." $"$ For Wagner, Schnorr's potential was fully realized with his performance of Tristan in 1865. In this, Wagner lauds Schnorr for having achieved a

\footnotetext{
${ }^{51}$ Wagner specifically emphasizes the necessity for vocal power and stamina as characteristic of his tenor roles in his tribute to Schnorr, lauding the singer's facility with navigating the demands of the Tristan role. PW IV, 229-230.

${ }^{52}$ Richard Taruskin, The Oxford History of Western Music - Volume 3: Music in the Nineteenth Century (Oxford: Oxford University Press, 2005), 219-220.

${ }^{33}$ Ibid., 220.

${ }^{54}$ SSD X, 178; PW IV, 228.
} 
"titanic deed" in rising to the demands of the role..$^{55}$ Indeed, Wagner then claims that in response to worries that Schnorr had "murdered" himself with the demands of the part, Anton Mitterwurzer (who portrayed Kurwenal) responded that "a man like Schnorr, who had shown himself master of his task in the fullest sense, could never overtax his physical powers...." Wagner adds that "neither during, nor after the performances was there ever detected the smallest fatigue in his voice, or any other bodily exhaustion...." ${ }^{96}$ Schnorr's musical and physical triumph, as Wagner tells it in this essay, represents the future of German art. So, while the Wagnerian tenor actively avoids the type of musical ostentation that made the grand opera tenor such a box-office draw in Paris, there is some overlap between the two types: both tend to locate their "heroic" qualities in their outstanding musical and physical feats. In the Wagnerian case, that achievement lies not in technical display or seemingly impossible high notes, but in pushing the body to the outer limits of its abilities in order to properly realize the "spiritual" core of the music. This conquering of physical and musical adversity is a "preternatural achievement" that for Wagner disseminates the spirit of German art through the display of a heroic male performing body. In that sense, the so-called Heldentenor is not far removed from that of the grand opera tenor after all.

Beyond musical matters, Wagner's principal tenor roles in both of the operas to be discussed also fulfill in some manner the narrative and dramatic functions of the typical grand opera tenor. In both works, the tenor is a participant in a romantic intrigue: Lohengrin weds Elsa, who is manipulated by Ortrud to ask the forbidden question of her husband's name; Kundry is dispatched by Klingsor to seduce Parsifal in order to thwart

\footnotetext{
${ }^{55}$ SSD X, 186; PW VI, 236.

${ }^{56}$ SSD X, 187; PW VI, 237.
} 
his quest to retrieve the Holy Spear. Lohengrin and Parsifal also provide heroic leadership that aims to inspire beneficial social and/or political changes in their respective communities. But unlike such political figures in previous grand operas - Masaniello in La Muette, Raoul in Les Huguenots, Jean in Le prophète, even Wagner's own Rienzi their leadership does not bring about disaster that claims their own life and those of their compatriots (although the conclusion of Lohengrin is admittedly not altogether happy). Before returning to the Grail kingdom, Lohengrin unites the masses under Heinrich and prophesizes that Germany will never be overtaken by its enemies, and then frees Gottfried from captivity and proclaims him ruler of Brabant. Parsifal redeems both Kundry and the Grail Knights, heals Amfortas, and then ascends to the position as the new king of the Grail. Lohengrin and Parsifal both will be shown to function to some extent within the context of specific aspects of grand opera, and as we shall soon see, all mobilize some combination of the romantic, the heroic, and the revolutionary, to situate the Wagnerian tenor as the bodily ideal for the nation.

\section{Wagner's Heroes}

As alluded to earlier, Simon Williams puts the character of Lohengrin forth as an example of an "epic hero," a type that was ideal to "serve as a mouthpiece for burgeoning German nationalism." ${ }^{57}$ The epic hero model became attractive to Wagner upon his return to Germany from Paris in the mid-1840s and his reading of the medieval German epics. The epic hero,

[A]lmost invariably a male figure, is distinguished by the degree to which he corporealizes the most admirable of human traits. His elemental feature is his immense strength and courage and his greatest ambition is to prove himself

\footnotetext{
${ }^{57}$ Williams, Wagner and the Romantic Hero, 13.
} 
superior to all other men. The epic hero defines himself not by thought but action and celebrates human strength. He has some connection to the divine. ${ }^{58}$

Although frequently possessing divine lineage, Williams notes that the epic hero does not employ actual magic to achieve his incredible feats. Also, the overwhelming physical and moral superiority of the epic hero assures that he must exist perpetually outside of society, regardless of how beneficial to that society he may be.

Wagner's interest in the intersections between the heroic and the national mythology makes itself apparent in his essay "Die Wibelungen" (1848), written the same year that Lohengrin was completed. ${ }^{59}$ This essay also lays groundwork for his exploitation of the Nibelungenlied as well as some the ideas of cultural and racial decline that will figure into the later gestation of Parsifal. In this essay, Wagner pinpoints Germany's decline as a result of the increasing distance from a veneration of the ancient kings and heroes that formed the basis for the great sagas. In "Die Wibelungen," Wagner called for a re-engagement with the old legends and a return to the valorization of heroism. For Wagner, "heroic action rather than systematic revolution seemed...to be more efficacious in undoing the ills of society. The epic hero might save a world dying from its own corruption." ${ }^{, 60}$

Wagner's presentation of Lohengrin imbues the character with numerous aspects of the epic hero. As Williams writes,

He is the first of Wagner's heroes to be hailed as "Held" and who is distinguished by conventional qualities of epic heroism. He comes accoutered with the glamorous mythological apparatus of the swan, he effortlessly saves a damsel in distress, he is prepared to lead German troops into war, and at the end he turns out

\footnotetext{
${ }^{58}$ Ibid., 15.

${ }^{39}$ SSD II, 115-155; PW VII, 257-298.

${ }^{60}$ Williams, 14.
} 
to be from the mysterious brotherhood of the grail whose purpose is to bring peace to a troubled world. ${ }^{61}$

Williams' description accounts for Lohengrin's actions and mythic origins as markers of epic heroism; those actions and origins may be productively extended to foreground Lohengrin's heroic qualities as an idealized figure of nationhood. To start with the work's narrative, despite the character's relative lack prominent stage time, Lohengrin functions as an integral element in the progression and resolution of each of the three levels of the opera's plot: the political turmoil that has brought King Heinrich to Brabant, the intrigue involving Ortrud and Friedrich, and the romantic relationship with Elsa. It is the first level that is arguably the most relevant in the portrayal of Lohengrin's heroism as an embodiment of a national ideal. Paul Lawrence Rose notes Wagner's preoccupation with the figure of the "revolutionary leader," which had first manifested itself during the composition of Rienzi and would continue through to Lohengrin. But Rose identifies King Henry as the central figure that makes the opera, in his view, to be a "revolutionary [opera], using images of the German past to presage the German future."62 Rose quotes a passage from Act One to support his point, where Henry announces

Now is the time to guard our Reich's honour.

From east and west, all men count equal in this.

Place armies wherever there is German land.

So that none shall disparage again the German Reich!

(Lohengrin - I, i) $^{63}$

Later, in Act Three, scene two, Henry proclaims

I thank you, good men of Brabant!

How my heart shall swell with pride

if on every acre of German soil I find

such mighteous throngs of troops!

\footnotetext{
${ }^{61}$ Ibid., 61.

${ }^{62}$ Rose, 28.

${ }^{63}$ Quoted in Rose, 28.
} 
Let the Empire's enemy now approach, we will meet him with courage: from the barren wastes of the East he shall never dare attack again! For German soil the German sword! Thus shall the Empire's might be proved! (III, ii) ${ }^{64}$

Such remarks would tend to posit Henry as the embodiment of the nation, the representative of "the idyllically free German society...led by a true German king...."65 Henry's words of pride and confidence at the inception of the opera's climax however, are a direct result of Lohengrin's intervention. Immediately following Heinrich's proclamation, the Brabant citizenry make plain their collective faith in Lohengrin and exhort him to lead the troops into the forthcoming battle against Hungarian invaders. They are distressed when Lohengrin ultimately declines and announces his departure; at the opera's close, his prayers transform the swan into the hitherto assumed deceased Gottfried and Lohengrin proclaims him the ruler of Brabant, who will presumably lead his people into battle with the Hungarians. In the opera's context, it is Lohengrin who unifies the people, which in turn inspires Henry's certitude in the stability of the German empire. By creating the conditions for Germany's prophesized triumph, Lohengrin's heroism effectively positions him as the nation's saviour. But like the typical epic hero, he cannot integrate into human society: while "Lohengrin as epic hero announces that the future prosperity will be guaranteed by the restoration of its leader, and...strengthens King Heinrich's authority over Germany by his prophecy that Germany will never be invaded by hordes from the East...he denies himself a messianic role: he is only the

\footnotetext{
${ }^{64}$ Unless stated otherwise, all translations from Lohengrin are by Chris Wood (Decca, 1987).

${ }^{65}$ Rose, 28.
} 
messenger, not the ruler." ${ }^{96}$ Elsa's forbidden inquiry of Lohengrin's identity permanently severs his earthly ties, requiring him to return to the realm of the Grail. Such a conclusion bestows a manifest streak of melancholy to the work's conclusion, as King and the populace alike cry "woe!" at Lohengrin's departure, in lamentation of "the disappearance of the divine element from a world that has been profaned and secularized." ${ }^{\circ 7}$ As Dieter Borchmeyer points out, "Wagner's last Romantic opera...is the only one not to end on a note of redemption or transfiguration."68 Borchmeyer's contention regarding the opera's lack of a redemptory conclusion is clearly in reference to the fates of the characters of Lohengrin and Elsa, as he admits that while the ending sunders the central romantic relationship, it also provides a last-minute rescue for Gottfried and a vision of the nation's future prosperity. However, the point remains that the nation's "redemption" comes at a steep price that casts a pall over the proceedings: the departure of Germany's hero. Lohengrin's inability to integrate with the people of Brabant and Germany contributes to the "out of reach" qualities that potentially identify him as the imago figure in addition to the idealized hero.

The interpretations of the opera provided in A Communication to My Friends and Wagner's programme note to the Act I prelude both paint textual pictures that might suggest that in these particular sources Wagner is troping Lohengrin as something akin to an imago figure (acknowledging that these are ex post facto readings of the work, and may not necessarily reflect Wagner's thoughts at the time of composition). The programme note focuses on Lohengrin's status as an emissary of the Grail and portrays

\footnotetext{
${ }^{66}$ Williams, 66.

${ }^{67}$ Dieter Borchmeyer, Drama and the World of Richard Wagner, trans. Daphne Ellis (Princeton and Oxford: Princeton University Press, 2003), 155.

${ }^{68}$ Ibid., 154.
} 
the music as a depiction of the nature of the Grail and Lohengrin's subsequent journey to the human realm:

So it was that the mystic imagination located the source of this intangible longing for love, and likewise its final destination, outside of the empirical world, ascribing to it a marvellous form... This object was imagined as really existing, though infinitely far away: it was believed in, longed for, and sought for under the name of the "Holy Grail"...This sacred vessel had been for some time removed from unworthy humanity when a host of angels from on high returned it to a band of devoted, loving men who lived withdrawn from the world. These pure ones were thus consecrated as its guardians, finding themselves marvellously strengthened and blessed by its presence, and so they became earthly champions of eternal love. The tone poet of Lohengrin chose this episode of the miraculous descent of the Grail accompanied by the host of angels, and their entrusting of it to these happy mortals, as the object of the introduction to his drama concerning the Grail-knight (Lohengrin). ${ }^{69}$

In A Communication to My Friends, Wagner provides the following appraisal of his opera's transplanting of the Ancient Greek myth of the god who comes to earth and falls in love with a human woman into a Christian milieu:

The ethereal sphere from which the god yearns to descend had expanded under the influence of Christian yearning to encompass the remotest corners of the universe. For the Hellene, it was still the cloud-locked realm of thunder and lightning from which the shaggy-haired Zeus came down to earth to mix with men in expert likeness; for the Christian, the blue firmament dissolved into an infinite sea of yearning ecstasy in which the forms of all the gods were merged until finally only his own image as yearning man rose up toward him from the ocean of his own imagination. An ancient, oft-repeated feature recurs throughout the legends of those nations that dwell beside the sea or beside rivers that flow into the sea: upon the waves' blue mirror there draws near an unknown being of utmost grace and purest virtue who wins all hearts through the irresistible spell that he casts on them; he is the embodied wish of the man who dreams of happiness in that far-off land that he cannot know. The stranger vanishes again, disappearing across the ocean waves as he is questioned about his true nature. ${ }^{70}$

The programme note bequeaths the Grail, its resting place, and those entrusted with its guardianship a verbal image of absolute perfection, but one that exists at a great

\footnotetext{
69"Prelude to Lohengrin" (1853), in "Wagner Introduces Wagner (and Beethoven)," Richard Wagner and His World, trans. and ed. Thomas S. Grey (Princeton and Oxford: Princeton University Press, 2009), 499500 .

${ }^{70}$ A Communication to My Friends (1851), quoted in Borchmeyer, 151.
} 
spatial remove from human society (and temporal, recalling Gurnemanz's claim in Parsifal that "time becomes space" in the realm of the Grail). ${ }^{1}$ Being the Grail's protectors, its knights are bestowed the Grail's purity and beauty. In the second quote, the divine sphere in which the Grail and its knights reside is associated with "yearning": as Wagner sees it, the multitude of gods has been essentially winnowed down to a central yearning figure that stands in for the yearning of mankind. The divinity of the gods represents that which is longed for by humanity but cannot achieve, a noumenal world that the individual can never truly know. Wagner uses water metaphors - "sea of yearning ecstasy," "the ocean of his own imagination," etc. - to locate the yearning for the divine within the restless waves and currents of bodies of water, essentially likening that oceanic activity with the similarly restless workings of an individual and collective subconscious.

When considering the above quotes in combination, the perfection of the gods and of the Grail may be grasped as narratives and images internalized within a simultaneously individual and shared cultural psyche that express a conception of an idealized humanity that is perpetually longed for, but forever out of reach. The divine maps onto the Lacanian discourse of desire as an expression of longing for the "lack," the "missing piece" that can make the subject whole. Lawrence Kramer takes up that line of thought, writing "[the Grail] holds the place of a structural impossibility. Because it embodies the

\footnotetext{
"As Volker Mertens notes, the Grail is actually a "Christianized" object, often considered to have originated in either Eastern or Celtic myths and not associated with Christianity until the turn of the twelfth into the thirteenth century when the legends of those such as Wolfram von Eschenbach, Chrétien de Troyes and Robert de Boron inserted the Grail into the Christian "mythos." See "Wie christlich ist Wagners Gral?" Wagnerspectrum 4/1 (2008): 91-92. For further (but by no means exhaustive) background on the Grail legend, see Emma Jung and Marie-Louise von Franz, The Grail Legend, trans. Andrea Dykes (1970) (Princeton, NJ: Princeton University Press, 1998); Volker Mertens, Der Gral: Mythos und Literatur (Stuttgart: Reclam, 2003).
} 
satisfaction of a desire that can never be satisfied, the Grail is in essence a lost object." The Grail's divinity, its status as an object of impossible beauty and perfection that is forever desired but destined to be unattainable marks it as an example of the objet petit autre, the "little Other" that is imbued with the power of suture, to salve what had previously seemed to be an irrevocable splitting of the subject.

As the Grail's earthly representative to the citizens of Brabant, Lohengrin is for all intents and purposes the somatic avatar for the Grail, and as such may be put forth as possessing the same divine qualities associated with the Grail. Those qualities are made manifest through the physical and sonic "perfection" of Lohengrin's body, perfections that are then inscribed upon the performing body of the Wagnerian tenor. The idealized beauty of Lohengrin's body aligns with Bryson's conception of the imago figure as displaying an image of the body that resonates within the spectator's imagination as the visualization of the perfected body, one that is desired but is seen as impossible to be achieved. This serves as the somatic complement to Lohengrin's epic heroism: in effectively saving Brabant, paving the way for the ultimate triumph of the German empire, Lohengrin's presence and subsequent actions position him as a national hero, a figure of veneration. Lohengrin's heroic nature is externalized sonically through a commensurately beautiful body whose sounds demand similar veneration. In Lohengrin, we find a figure that merges the heroic persona with the body as imago figure, so that the idealized body and the hero are expressions of each other. Just as the imago visualizes a bodily ideal that is unattainable, the epic hero must also be inassimilable within the society he has been summoned to serve/protect. The hero's perfection necessitates that

\footnotetext{
${ }^{72}$ Kramer, Opera and Modern Culture, 59.
} 
he must inevitably return to the realm whence he came upon realization that human society cannot adequately accommodate his "greatness."

Wagner's remarks regarding the Lohengrin legend in A Communication to My

Friends tend to frame the character as an ideal on another level. In this essay, Wagner conceives of the opera as an allegorical representation of the "artist [and] his troubled relationship with the modern world."73 For Wagner, "the knight of the grail" stands in for

[T]he artist who dwells in the highest realm of consciousness, but wishes to be part of humanity through the love of a woman; that love, however, must be directed toward him as a human being, not toward his "higher nature," to those imaginative capacities which produce his art. If woman loves the artist rather than the man, her love is akin to worship and cannot therefore nourish the man. Lohengrin... is concerned with the artist's predicament, not with the manner in which his art is created. Lohengrin's insistence on not revealing his name tells us much about the artist's nature...Although the urge to create arises from within the artist and is, particularly from the romantic viewpoint, self-expression, the artist can experience his creativity as an alien presence. The sources of romantic creativity are unknowable, and the ways in which the romantic artist comprehends the world and re-forms it in art are not subject to rational analysis. If they are, analysis will destroy them. The blind trust Lohengrin asks of other correlates to the uncritical acceptance of creativity that is required of the artist and those who experience his work. When that trust is broken, so too is the capacity of the artist to create and of his audience to accept that creation. ${ }^{74}$

Analyzing the preceding statement reveals intriguing concurrences between Wagner's notion of the artist in society and the conception of the imago figure. The artist ostensibly creates by tapping into otherworldly, noumenal forces that are beyond earthly comprehension. ${ }^{75}$ That the artist has the ability to function as a conduit between this rarefied realm and the human world grants him an exalted place in the culture; although

\footnotetext{
${ }^{73}$ Williams, 62.

${ }^{74}$ Ibid., 62-63. See also SSD IV, 294-302; PW I, 339-348.

${ }^{75}$ In this we witness another example of the type of thought that may have predisposed Wagner to Schopenhauer's philosophy upon his initial reading of The World as Will and Representation in 1854. Compare Wagner's model circa-1851 of art as influenced by that which transcends the bonds of the everyday with Schopenhauer's contention that music functions as an expression of the ceaseless longing of the ineffable "Will."
} 
the artist can neither directly grasp nor understand the forces that direct the creative process, his ability to transmit the feelings and the "character" of those forces to audiences grants the artist his "higher nature." That lofty nature places the artist on an elevated cultural plane that renders him beyond understanding of conventional humans. Both the artist and his art eschew rational analysis or understanding. Such thinking suggests the potential for the artist to be interpreted as an idealized cultural and societal figure. Keeping in mind the centrality that Wagner granted to art in the formation and expression of German identity, it stands to reason that the reading of Lohengrin as metaphor for the idealized artist is another productive avenue for interpreting the character as an imago figure for the nation: as the visual and aural image of the idealized artist, Lohengrin registers as the idealized avatar for the German identity. ${ }^{76}$

The staging of the performing body of the Wagnerian tenor as the imago figure for the nation is made possible in no small part due to its intersection with the dramaturgy of grand opera. Williams notes that Lohengrin distinguishes itself from such previous works as Der fliegende Holländer and Tannhäuser in that Lohengrin demonstrates "greater objectivity" in the portrayal of its hero. ${ }^{77}$ Such objectivity comes, according to Williams, through the comparative lack of self-pity on the part of the character. In addition, Lohengrin's musical and dramatic portrayal eschews the naïveté that threads itself even into Wagner's own interpretation of the character and the legend in $A$ Communication to My Friends. This increasing objectivity in the dramatic treatment of

\footnotetext{
${ }^{76}$ Arne Stollberg offers a different angle on the thematizing of Lohengrin as an allegorical representation of the artist: he argues that the Swan Knight can be read as an embodiment of "pure" music, so that when Lohengrin is ultimately banished from the human world, it enacts the decline and eventual vanishing of "absolute music," to be replaced by Wagner's proposed "music drama." See "Hartnäckig auf dem christlichen Standpunkte': Wagners Lohengrin am Ende der absoluten Musik," Archiv für Musikwissenschaft 65/1 (2008): 45-60.

${ }^{77}$ Williams, 63.
} 
the hero is "due, in part, to the utilization of the realistic, historicist milieu of grand opera." ${ }^{, 7}$ I will defer appraisals of the specific points of contact between Lohengrin's dramatization and the traits of grand opera for the moment, but suffice it to say, grand opera's historicist leanings are of particular present interest. Wagner's treatment of history in this opera stands as a particularly notable adaptation and modification of grand opera's general tendencies. In the typical Parisian opera, the principal tenor role is the male half of a romantic entanglement that will inevitably be crushed by the weight of the merciless progression of history, Meyerbeer's Raoul and Valentine perhaps being prototypical examples. Certainly a strong trace of this manifests itself in Wagner's work in that the marriage of Lohengrin and Elsa - a marriage that is ultimately torn apart takes place against the historical backdrop of King Henry's monarchy. But Lohengrin himself does not die in the literal sense: his earthly power is broken by Elsa's asking of the forbidden question and he is summoned back to Montsalvat. The French work that Lohengrin perhaps bears greatest resemblance to is Les Troyens: in both works by Berlioz and Wagner, mythological history is given greater primacy. ${ }^{79}$ In both operas, otherworldly forces pull the heroic tenor away from their respective romantic entanglements: in Berlioz, Énée's gods compel him to abandon Carthage and its queen Didon in order to fulfill his destiny of founding Rome. In both works, the necessities of myth are the agents that destroy the central romantic intrigue rather than the forces of conventional history.

But the entanglements between history, myth, grand opera, and the iconography of the male body are even more interesting than a mere substitution of myth for history in

\footnotetext{
${ }^{78}$ Ibid.

${ }^{79}$ Katherine Kolb writes about the complicated relationship between Berlioz and Wagner in "Flying Leaves: Between Berlioz and Wagner," $19^{\text {th }}$-Century Music 33/1 (Summer 2009): 25-61.
} 
grand opera's traditional dramaturgy. My contention is that in Lohengrin history, myth, and grand opera coalesce into a form of feedback loop with the idealized body of the tenor as a nucleus. The scenic and musical splendour typically associated with grand opera, I submit, elevate what transpires on stage to the level of myth through its intensified dramatic spectacle. Grand opera's sonic and scenic spectacularity essentially mythologize its performers irrespective of its narrative or musical content; upon consideration of those factors, one can contend that the concatenation of myth and history in turn mythologizes grand opera. To reiterate a point made earlier, the encroachment of the mythical upon the historical effectively raises German history to the level of myth: Lohengrin differs from the typical grand opera tenor in that he is not a constituent part of history. Rather, he originates from outside of history in the sanctified realm of legend and briefly descends upon the earthly, historical plane. German history is touched by the divinity of myth couched in the guise of Christian iconography, and as a consequence that history is elevated to the level of the divine and the mythic. Weaving through the mutually implicated problematics of history and myth is grand opera and the body of the Wagnerian tenor. In his role as a grand opera tenor, Lohengrin merges history and myth. Simultaneously, the mythic force of German legend creates the conditions for the character to be grasped as a vision of the divine, while Lohengrin's bodily sonorities infuse the legend with a beauty that aims to transmit the essence of the sacred to earthly spectators. Both sides of the equation feed each other in order to put forth Lohengrin as an idealized bodily stand-in for the nation, an aural image of somatic perfection that mobilizes the opulence of grand opera as the superlative stage for that perfected sonic body. 


\section{Absolute Heroism}

As previously pointed out, for an ostensibly principal character, Lohengrin surprisingly spends nearly more time off stage than on, and during those times he is on stage, he is frequently part of the crowd rather than a featured soloist. As it so happens, his placement within the masses is a vital aspect of the character's status as an element of grand opera dramaturgy: that of large-scale crowd scenes. In fact, a significant percentage of the entire opera consists of crowd and ceremonial scenes with the river bank tableau that heralds his arrival taking up almost the entire first act, while the complementary scene that culminates in his departure encompasses the second half of the third act. In both cases, the narrative intrigues carried out by the soloists are continuously subjected to interpolations from the choral crowd that witnesses all that transpires. The result of the enactment of the character drama in a highly public sphere, frequently punctuated by choral commentary, is that public and private dramas converge on a single stage, allowing them to be played out as essentially greatly extended crowd scenes. The extensively protracted nature of these crowd scenes renders them rather atypical of traditional grand opera, an example of the opera's tendency, according to Thomas Grey to deviate from grand opera's tendency towards discrete set pieces in favour of "more-orless continuous series of smaller musical and rhetorical units (of the sort Wagner provisionally named "poetic-musical periods in Opera and Drama)." units" consist of the aforementioned alternation of solo passages and choral counterpoints, which are organized into an ostensibly seamless and continuous whole.

\footnotetext{
${ }^{80}$ Thomas Grey, "Richard Wagner and the Legacy of French Grand Opera," in The Cambridge Companion to Grand Opera, ed. David Charlton (Cambridge: Cambridge University Press, 2003), 332. Grey discusses the "poetic-musical period" in greater detail in Wagner's Musical Prose: Texts and Contexts (Cambridge: Cambridge University Press, 1995), 181-241.
} 
Indeed, it is the emphasis on musical continuity extended over an entire act that leads both Carl Dahlhaus and John Deathridge to discern in the opera inchoate examples of the qualities that will come to define Wagner's "Artwork of the Future," with Deathridge going so far as to label the opera a musically progressive and advanced work that points towards a more "modern" aesthetic. ${ }^{81}$ The point that should ultimately be taken is that Wagner's expansion of the crowd scene evidently magnified an ingredient of traditional grand opera to such "grand" proportions that it tended to register as something altogether distinct: the scenes still make their grand opera roots plain, while in their blending of numerous dramatic and musical elements into an extended continuity, point the way towards the "poetic-musical periods" that would become a prominent part of Wagner's future style of vocal writing.

But it is Lohengrin's participation in these crowd scenes that sets the moments when he steps out of the mass to address the entire crowd entire into sharper relief. Lohengrin's status as simultaneously a part of grand opera's traditional pageantry and set apart from it is prefigured from the transition from the prelude to the beginning of the first act, "when the ecstatic music of Montsalvat is set off against the pronounced rhythms and vigorous melodies of the choruses and ensembles of Henry the Fowler's troops. ${ }^{182}$ The martial brass fanfares that announce the arrival of Henry and his legion in

\footnotetext{
${ }^{81}$ Carl Dahlhaus, Richard Wagner's Music Dramas, trans. Mary Whittall (Cambridge: Cambridge University Press, 1979), 35-48 and John Deathridge, Wagner - Beyond Good and Evil (Berkeley: University of California Press, 2008), 31-44. In my review of Deathridge's book, I take this argument to task somewhat in that the contention that Lohengrin contains a "progressive" core is part of an endeavour to rescue to opera's deteriorated critical reputation. My criticism was directed towards what I saw as Deathridge's tacit implication that Lohengrin's rehabilitation is contingent upon the location of that progressive heart, as if the work would not be worthy of rescue had that "modern" trace not been present. I otherwise have no quarrel with Deathridge's contention that Lohengrin's music displays incipient forms of the stylistic advances contained in Wagner's subsequent works. See Intersections: Canadian Journal of Music 30/1 (2010): 138.

${ }^{82}$ Williams, 63.
} 
Brabant functions as couleur locale and firmly situates them within the "historicist" and "realistic" milieu of grand opera. And it is Heinrich's presence that lends the opera its essential historical backdrop: upon Heinrich's arrival in Brabant, he intones to its citizens a call to arms to corral support from the Brabant nobles as part of his efforts to unite the German tribes into an army tasked with repelling the Hungarian invaders. This is the historical backdrop for the ensuing action that is so typical of grand opera.

Heinrich's subsequent dismay at the state of discord that is the Brabant leadership serves to provide a transition to Elsa's summoning to answer her accusers. It is here that she "falls into a trance, and with the open eyes of a somnambulist she sees a dreamlike image of the hero who brought heavenly solace to her suffering in days long past." ${ }^{, 83}$ During her trance, Elsa recounts the image witnessed in the dream of her defender arriving on the banks of the Scheldt:

$$
\begin{aligned}
& \text { In lichter Waffen Scheine } \\
& \text { ein Ritter nahte da, } \\
& \text { so tugendlicher Reine } \\
& \text { ich keinen noch ersah: } \\
& \text { Ein golden Horn zur Hüften, } \\
& \text { Gelehnet auf sein Schwert - } \\
& \text { so trat era us den Lüften } \\
& \text { zu mir, der Recke wert; } \\
& \text { mit züchtigen Gebarren } \\
& \text { gab Tröstung er mir ein; } \\
& \text { des Ritters will ich wahren, } \\
& \text { er soll mein Streiter sein! }
\end{aligned}
$$$$
\text { (I, ii) }
$$

[In splendid, shining armour a knight approached, a man of such pure virtue as I had never seen before: a golden horn at his side, leaning on a sword - thus he appeared to me from nowhere, this warrior true; with kindly gestures he gave me comfort; I will wait for the knight, he shall be my champion!]

In her recounting of the dream, Elsa externalizes the knight's virtue into something tangible that she can see. The purity of his character is mapped upon the sight of his body, its somatic perfection being a sign of his heroic nature. The emergence from

\footnotetext{
${ }^{83}$ Joachim Köhler, Richard Wagner: The Last of the Titans, trans. Stewart Spencer (New Haven and London: Yale University Press, 2004), 199.
} 
"nowhere" of a figure of such splendour indicates that her champion cannot be of this conventional earth, which would tend to suggest that her visions of a saviour to rescue her from peril is an expression of desire for the imago figure. As Joachim Köhler notes in his biography of Wagner, that Elsa has been granted such a vision places her on a privileged plane of humanity, likening her to "the visionary Senta...reborn in the Brabantine virgin." 84 Just as Senta was "gifted" with the ability of prophecy and to attract the otherworldly force of the Dutchman to the human realm and her person in particular, Elsa's vision will reach beyond the boundaries of the known world and summon a champion of uncommon virtue from "nowhere." But despite Elsa's own "purity" and elevated nature compared to her fellow humans, and Wagner's own analysis of Elsa as Lohengrin's "other half," 85 it would be problematic to reduce her to Lohengrin's strict distaff counterpart. Although her own virtue positions her as the conduit between the corporeal world and that of the Grail, the narrative still puts her in need of otherworldly assistance. Elsa is comparatively beatified on the earthly plane, but her vision speaks to a desire for an image of perfection that still resides outside of her own grasp.

Elsa's vision becomes reality as the swan-pulled barque arrives ashore at the beginning of scene 3. As Lohengrin disembarks in order to fulfill his aid to the "damsel in distress" aspect of his epic hero role, he is described in the following stage direction:

[The barque, drawn by the swan, reaches the bank in the middle of the background; Lohengrin, dressed in gleaming silver armour, a helmet on his head, a shield on his back and a small golden horn by his side, is standing in the boat leaning on his sword.]

\footnotetext{
${ }^{84}$ Ibid.

${ }^{85}$ See SSD IV, 301; PW I, 346 and Berthold Hoeckner, "Elsa Screams, or The Birth of Music Drama," Cambridge Opera Journal 9/2 (July 1997): 97-132.
} 
As Lohengrin exits the barque, he intones the following passage:

(neigt sich zum Schwan)

Nun sei bedankt, mein lieber Schwan!

Zieh durch die weite Flut zurück, dahin, woher mich trug dein Kahn, kehr wieder nur zu unsrem Glück! Drum sei getreu dein Dienst getan! Leb wohl, leb wohl, mein lieber Schwan! (I, iii) [(bending down to the swan) I thank you, my dear swan! Go back across the waters to whence your boat brought me, return again only to bring us happiness! Thus will you have carried out your duty faithfully! Farewell, farewell, my dear swan!]

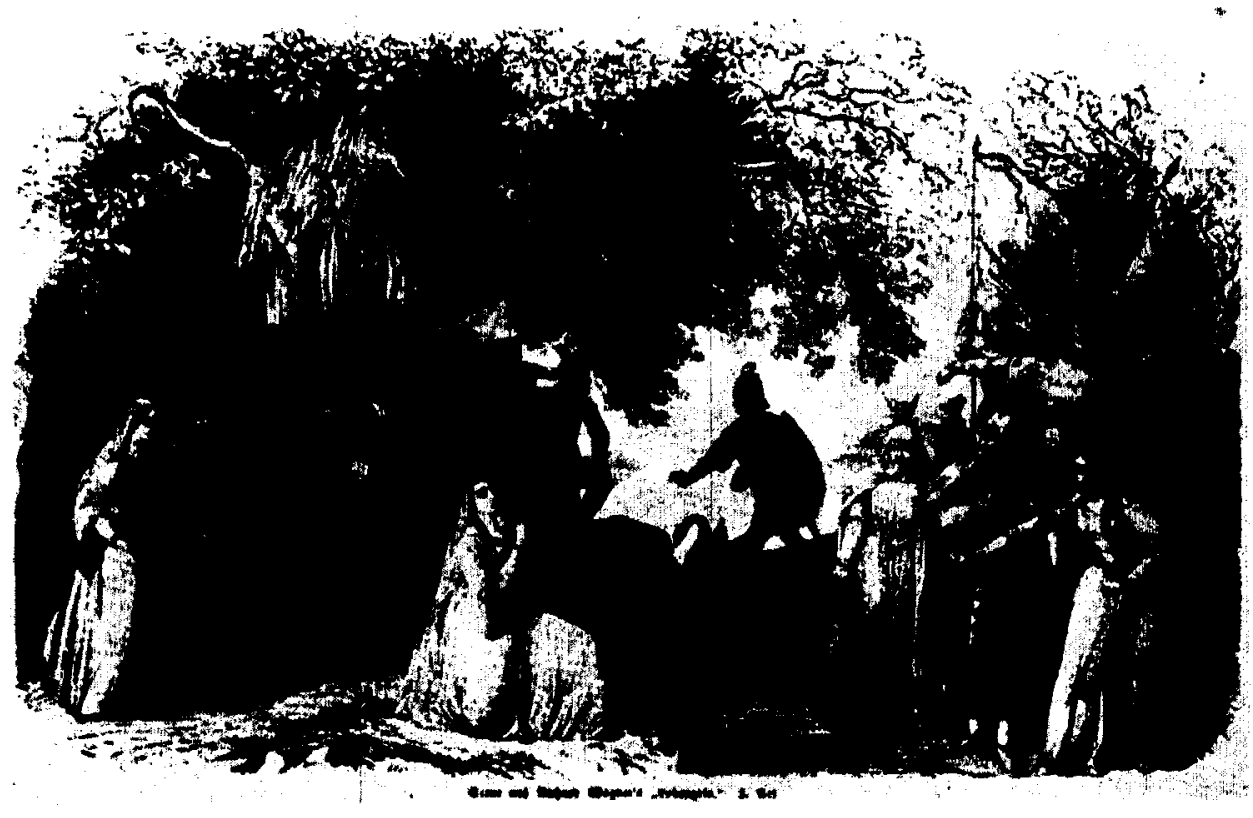

Fig. 1

Illustrirte Zeitung, (Leipzig, April 12, 1851)

(Barth et al, Wagner: A Documentary Study [New York, 1975], plate 91)

As mentioned previously, the dramaturgical proceedings leading up to this moment function as an extended grand opera crowd scene, with the final measures of scene two consisting of the choral crowd "shaken to the very depths of their being by the events unfolding before them...break[ing] down into individual voices, before merging together again with their increasingly rapid invocations of the hero and their shouts of joy 
that form a single hymn of triumph." ${ }^{\text {"86 }}$ So stunning is the hero's arrival that it temporarily halts the heretofore continuous flow of grand opera spectacle: all other voices cease and for the final three beats of Lohengrin's first measure of singing, the orchestra falls completely silent. Lohengrin is the only tenor role in the entire opera, so this is the first time that both the audience and the characters hear a solo tenor voice. The very first hearing of a solo tenor voice (Ex. 1) is unadorned, devoid of instrumental accompaniment. $^{87}$

\section{Ex. 1}

(Lohengrin V/iii mm. 41-44)

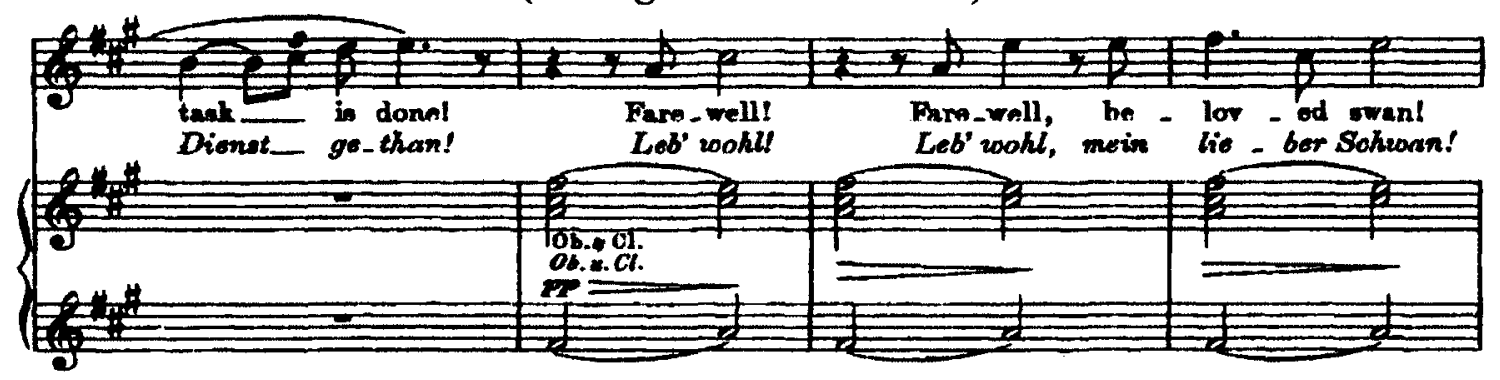

Until his cries of "Leb wohl!" to the swan, the only instrumental accompaniment is a whole-note A-C\# harmonic interval played by the violins every fourth measure. So momentous is the debut of the solo tenor voice that - with the exception of those two violin notes - it temporarily halts all other musical and dramatic activity that had been nearly constant throughout the act up to this point. The first appearance of the solo tenor in the work is of such dramatic import both within and without the context of the narrative that the forward motion of what had been essentially a magnified grand opera crowd scene is completely ceased for several measures. It is as if the thinking was that

\footnotetext{
${ }^{86}$ Köhler, 199.

${ }^{87}$ This is not the first time a solo voice has been heard completely unaccompanied: in scene one, Henry and Telramund both sing without orchestral accompaniment. Perhaps this conceit distinguishes each of the three characters as those who will play the greatest roles in determining Elsa's fate and the outcome of the entire story. But the point remains that the first hearing of a solo tenor voice is the only music heard is significant.
} 
before being integrated into the dramaturgical fabric of a grand opera crowd scene, it would be necessary for Lohengrin the character, and Lohengrin the singing voice to conspicuously puncture that fabric and cut out a unique role for him.

It is perhaps telling that upon completion of Lohengrin's farewell to the swan, the orchestra returns and the choral crowd resumes its commentary:

Wie faßt uns selig süßes Grauen! Welch holde Macht hält uns gebannt! Wie ist er schön und hehr zu schauen, den solch ein Wunder trug ans Land!
[What sweet and blissful trembling comes over us! What blessed power holds us spellbound! How fair and noble to behold is he whom such a miracle brought ashore!]

Musically, the chorus adopts the unhurried dotted rhythms and eighth-note triplets that Lohengrin employed upon his entrance, as though the awe at the knight's appearance expressed in the text compelled them to emulate his music. They account for the "sweet and blissful trembling" that overcomes them upon witnessing Lohengrin's appearance and state how miraculous the event is and conflate that miracle with the beautiful figure that the knight cuts. Taken in isolation, the text foregrounds merely the visually pleasing dimension of Lohengrin's presence, but in the context of the dramatic and musical performance, the passage directly follows a moment where they have heard the Swan Knight's voice for the first time, and simultaneously, we have heard the initial instance of a solo tenor voice singing. This context invites a question: is the visual image of the knight's body the only thing that fills the Brabantine spectators with feelings of bliss? Does the sound of the tenor voice conflate with the sight of the miracle they are collectively bearing witness to, so that they are hearing a miracle that "holds them spellbound" in addition to seeing one? 
Such questions invite a likening of the scenario to Carolyn Abbate's model of the "unsung voice" - itself a development of Roland Barthes' concept of the "grain of the voice" a body vibrating with musical sound - a speaking source - that is not the body of some actual performer. ${ }^{989}$ For Abbate, concealed beneath the somatically produced voices is another voice that periodically breaks through the carefully constructed artifice of the opera, threatening its logic. These moments demand interpretation in order to make sense of them. Gary Tomlinson has explicated these voices as

uncanny irruptions [that] cluster around the fault lines between two different musico-dramatic modes: phenomenal music - stage songs and the like portrayed within the drama as song which, as a result, the characters onstage are meant to hear as music - and all the other music of opera, which the characters hear problematically if at all. ${ }^{90}$

The first words that emanate from the crowd following Lohengrin's initial declamation refer to the blissful tremors that course through their bodies; until they specify the vision of the knight's form, were those quivers of joy in response to the sight or the sound of his body? The chorus does not explicitly state that they hear Lohengrin's words as music, so there is no manifest rupture of the boundary between narrative and spectator. Even without that clear irruption of "phenomenal" music into the piece's dramatic logic, does there still exist the possibility for the potential spectator to experience a fleeting moment of ambiguity? Was the chorus' elation in response to the sound of Lohengrin's voice? If it was, did they hear it as music, and was that the reason for their imitation of the

\footnotetext{
${ }^{88}$ Roland Barthes, "The Grain of the Voice," Image, Music, Text, trans. Stephen Heath (New York: Hill and Wang, 1977), 179-189.

${ }^{89}$ Carolyn Abbate, Unsung Voices: Opera and Musical Narrative in the Nineteenth Century (Princeton, NJ: Princeton University Press, 1991), 13.

${ }^{90}$ Gary Tomlinson, Metaphysical Song: An Essay on Opera (Princeton, NJ: Princeton University Press, 1999), 88.
} 
rhythmic contours of this otherworldly champion's words? If one accepts the possibility for the chorus' remarks to provoke a brief moment of doubt about what precisely they witnessed/heard, then it is perhaps permissible to posit Lohengrin's farewell to the swan and the choral reaction as forms of "unsung voices": while there is no instance where the music the audience hears is explicitly identified as being heard as music by the characters, which would be necessary to meet the strictest definition of Abbate's framework, I submit that this passage may nonetheless be productively read as a moment of slippage where the reactions of the in-story performers exhibits points of crossover with those of the opera's potential spectators. The audience first hears the timbre of a solo tenor voice at the same time that the characters first glimpse Lohengrin's body and hear his words. A moment that is conspicuously constructed as one of great importance to the drama registers within the narrative space as one that fills the characters with great elation. Is it plausible that the specific content of the chorus' reaction suggests to the audience that they should respond to the sound of the tenor with "blissful trembling," that the chorus' encomium to the knight's somatic beauty should be matched with a similar tribute to the singer's sonorous splendour? This brief segment of the act might be grasped as containing "unsung" voices in that it is a moment where spectator response within and without the narrative prospectively converge and mutually implicate. Such an interpretation might be lent credence by Joachim Raff's opinion stated in his 1854 book Die Wagnerfrage that the chorus in Lohengrin "often functions as a surrogate of the audience, playing a double role as both a character and commentator."91 Dramatically, the entrance of the tenor essentially cuts through the dramaturgy of a grand opera crowd

\footnotetext{
${ }^{91}$ Hoeckner, 103. Hoeckner cites Raff's Die Wagnerfrage, 123-124 as the section where Raff argues this point.
} 
scene, temporarily bringing it to a halt, thereby marking the tenor as the dramatic focal point of the opera; meanwhile the characteristic instrument of the crowd scene, the chorus, immediately expresses its jubilation at the seemingly idealized body that appears before them. The grand opera chorus fulfills its traditional function as a politicized vox populi to rally around a singular figure, to perform a mass recognition of the superior bodily image and sound that has appeared before them.

Having momentarily pierced the artifice of grand opera, Lohengrin will subsequently integrate into the dramaturgy, beginning with what amounts to a love duet with Elsa as he offers himself as both her champion and her husband. ${ }^{92}$ But unlike many other duets in grand opera between the central romantic pairing, this one is carried out in a highly public arena, an example of how all of the narrative threads and intrigues are carried out in this act under the auspices of an extended crowd scene. From there, Lohengrin seemingly progresses in stages through a series of dramatic sequences that are typical of grand opera. Firstly, Lohengrin issues his challenge to Friedrich on Elsa's behalf, the knight quickly routing his would-be wife's accuser. With the ever-present choral commentary running through the scene, the confrontation has all the makings of the type of public spectacle characteristic of the grand opera ceremonial scene (the Autoda-fé scene in Don Carlos is but one potential point of comparison). The chorus proclaims unwavering confidence in Lohengrin's abilities, swayed by the nobility and

\footnotetext{
${ }^{92}$ Deathridge interprets the Lohengrin/Elsa relationship through the lens of Otto Rank's 1911 analysis that privileges the Freudian implications of incest in the pairing, namely that in challenging Telramund, Lohengrin in effect saves his surrogate "mother" from an evil "father." (Deathridge, 34-35). The implications of the Lohengrin/Telramund/Elsa intrigue sheds potential light on the psychoanalytic conceptions of the imago as the unconscious phantasmatic of familial figures internalized within the subject: shifting from Freud to Jung, for Lohengrin, Elsa functions as the "mother-imago." But at the same time, if Elsa has projected her image of the idealized (male) protector onto the person of Lohengrin, might he function as a surrogate father for her? Lohengrin may be productively read as Elsa's "father-imago" figure.
} 
beatitude they see inscribed upon his body. And through its sonorous uniqueness, the sound of Lohengrin's tenor voice further distinguishes his body as one of noble beauty. As the Brabantian nobles entreat to Friedrich, any attempt to combat this divine champion would be a futile gesture ("he is protected by the highest power, so of what use is your brave sword?"). In other words the nobles, those who would be the most likely to cast their lot with Friedrich instead intuit the manifest greatness of Lohengrin's nature, and the inevitable fruitlessness of opposing him. Indeed, in the ensuing scene of ceremonial combat, Lohengrin conclusively demonstrates the physical qualities of the epic hero, complementing the moral righteousness that he displays in his resolve to act as Elsa's champion. By carrying out his heroism within the spectacle of what amounts to a grand opera ceremonial scene, his heroic qualities are consequently elevated to a greater level of grandeur, effectively placing the epic hero on a more mythic stage.

As Williams has noted, after Lohengrin "has bidden farewell to the swan and betrothed himself to Elsa," he sings much of the remainder of the act as part of an ensemble. ${ }^{93}$ In fact, this is perhaps the segment of the first act that displays the greatest lineage to traditional grand opera, as the act culminates in an ensemble finale. During this passage, we hear simultaneously Henry and the men praise Lohengrin's heroism and nobility, the women (Elsa included) express their inability to find tones that would adequately express their jubilation at what they have witnessed, Ortrud and Telramund express anger and despair respectively over their defeat, while Lohengrin proclaims that his victory was made possible through Elsa's innocence. After effectively puncturing the artifice of grand opera upon his entrance, Lohengrin re-integrates into its dramaturgy, becoming but one constituent part of a massed gathering that makes up the finale. And

\footnotetext{
${ }^{93}$ Williams, 62.
} 
yet, much of the content of the ensemble is devoted to singing Lohengrin's praises, to paying tribute to his magnificence. In terms of sonority, Wagner strategically has Lohengrin leap into a higher tessitura at periodic points in order to prevent the tenor voice from being subsumed within the mass, to make sure that his voice cuts through the vocal thicket so that our attention is drawn to his voice. For example, on the first exclamation of "Den Sieg," ("the victory") Lohengrin leaps from $e^{\prime}$ to $a^{\prime}$ (sounding rather than notated pitch), with "sieg" being sustained for an entire measure while the other voices are rhythmically active. This gambit essentially allows the tenor voice to stand out from the crowd. The point being is that in this ensemble finale, the tenor part is made to be heard, to be at times distinguished from the other voices, both by its sonorous uniqueness and by its melodic and rhythmic activity; the vocal sound is distinguished while the text intoned by Lohengrin's companions on stage commend the knight as the idealized vision of a hero.

Act III brings the opera's proceedings full circle to another extended crowd scene on the riverbank. It is in the third scene that Lohengrin is granted an extended solo passage where he explains his origins, and reveals the true nature of his divinity, commonly referred to as the "Grail narrative." In this passage, Lohengrin both fulfills the qualities consistent with the epic hero and the imago figure: in terms of the former, he reveals his outsider status that forbids him from assimilating into the culture he has been tasked to serve; that inassimilable quality feeds into his characterization as the imago, as his origin in the "far-off land" is an element of the unattainability that is part of the idealization that is invested into the imago figure. As a representative of the Grail and a resident of Montsalvat, Lohengrin embodies a magical, otherworldly beauty that humans 
cannot hope to grasp. The idealized beauty of the Grail and its knights must be forever out of reach of earthly inhabitants. Once Lohengrin reveals his divine origins he must depart Brabant and return to the Grail Temple whence he hailed. Lohengrin's unattainability is emphasized through his announcement that the anointed "hero of Brabant" will not lead the troops into battle. Lohengrin's refusal is greeted with cries of "hilf Gott! Welch hartes Wort er spricht!" ("God help us! What cruel words he speaks!") from the King and the citizens. Their distress at the knight's impending departure indicates that the people had invested Lohengrin with the survival of Brabant and the Empire. But Elsa's posing of the forbidden question has now eternally divorced them from their ostensible protector. Lohengrin's overwhelming physical and sonorous superiority eventually necessitates that he hew to the defining characteristics of the epic hero and the male imago figure by being ultimately "too good" for the community he has served and has positioned him as their model for their idealized state of being. ${ }^{94}$ Mirroring his arrival on the banks of the Scheldt, Lohengrin will carry out his departure from the human realm by making manifest his somatic and sonorous splendour in the context of the exceptionally public sphere of the grand opera crowd scene.95

\footnotetext{
${ }^{94} \mathrm{~K}$ ठhler's interpretation of what transpires is worth noting: in his view, Lohengrin's state of being is hardly considered ideal by the knight himself but more like a cursed existence. Kohler writes that "the knights of the Grail are lonely wanderers scouring the earth in search of salvation...For Lohengrin, [the] return [to Montsalvat] is a painful punishment, being less of a journey home than a relapse" (204-205). According to Köhler, Lohengrin considers the purported divine, ethereal beauty of the Grail kingdom more akin to a menagerie that binds him into an inescapable familial obligation in service of the Grail, and by extention, his father. For Lohengrin, freedom from the Grail kingdom and assimilation into human society is his unattainable object of desire. From his perspective, his otherworldly origins are decidedly not a sign of perfection, but of restriction. Marriage to Elsa is his objet petit a (recalling that Wagner saw Elsa as his "other half") that will grant his subjectivity the longed-for plenitude. But just as Brabant's and Germany's idealized champion is perpetually out of reach, Lohengrin's own idealized existence must also exist beyond his grasp, necessitating his return to the duties he longed to escape.

${ }^{95}$ Lohengrin's departure is what prompts Mertens to state that "the Grail myth in Lohengrin is not Christian because the chasm between [the human] world and transcendence proves to be unbridgeable as the human incarnation of Lohengrin fails and there is no redemption" ("Der Gralsmythos im Lohengrin ist nicht christlich, denn der Abgrund zwischen Diesseits und Transzendenz erweist sich als unuberbrlickbar, die
} 
Musically, one of the significant gestures of the Grail narrative is the fact that the orchestral accompaniment returns to the music of the prelude to the first act. As with the early measures of the prelude, the orchestration of the Grail narrative primarily consists of violins in the upper register and flutes. Kramer characterizes this sonority, combined with the slow harmonic rhythm, as an attempt at musically creating a trance-like state. ${ }^{96}$ I would complement this point by also contending that the music is designed to sound otherworldly, untouchable, something just out of the realm of our experience, just as Lohengrin reveals himself to be. This is accomplished through the aforementioned orchestration, which privileges "high" sonorities that seem to "float" in an elevated "ethereal" sphere without any bass sounds to "ground" them, and harmonic motion that seemingly suspends time through its apparent ceasing of forward motion. Berthold Hoeckner characterizes this gambit as "pure sound" gradually shaped into "distinct motifs," with that pure sonority seeming to "hover over [Lohengrin] like a halo."97 So it is as an accompaniment to the narrative describing his origins: the "pure sound" of the accompaniment betokens his forthcoming revelation that he is truly not of this earth, its "halo" a crown of otherworldly beauty that (as Wagner's own programme note about the prelude attests) approximates the splendour of the Grail to human ears.

Lohengrin's vocal line (Ex. 2) is one of steadfastness: always clearly enunciated, without being obscured by excessive ornamentation, and in unhurried rhythms of straight and dotted eighth notes that tend to fall on the beat. Overly disjunct leaps are minimized

Menschwerdung Lohengrins misslingt, es gibt keine erlosung"). This is, according to Mertens, unChristian because Christianity is predicated upon the closing of that gap, with the divine having lived amongst humanity, and eventually redeeming it. See "Wie christlich ist Wagners Gral?" 97.

${ }^{96} \mathrm{Kramer}, 65-69$. Taruskin discusses the various discourses in the first half of the nineteenth century about music's capacity to place listeners in a trance in Oxford History of Music, Vol. 3, 61-118.

${ }^{97}$ Hoeckner, 119. 
and most importantly, the vocal line never reaches higher than an $a^{\prime}$, thereby avoiding the $c^{\prime \prime}$ that stood for the "preternatural" physical and musical achievement of the Parisian tenor. Wagner presents a different form of an idealized male voice: where clarity of expression, vocal strength, and overall musicality are mobilized to serve both the scene's dramaturgical needs and to capture the "spiritual" importance of the music. But the "pure," trance-inducing, unearthly accompaniment would tend to paint that idealized voice as that which is out of phase with the corporeal, everyday world, that has not carved out a recognizable place within the musical and dramatic landscape of the present.

Ex. 2

(Lohengrin III/iii, mm. 364-373)
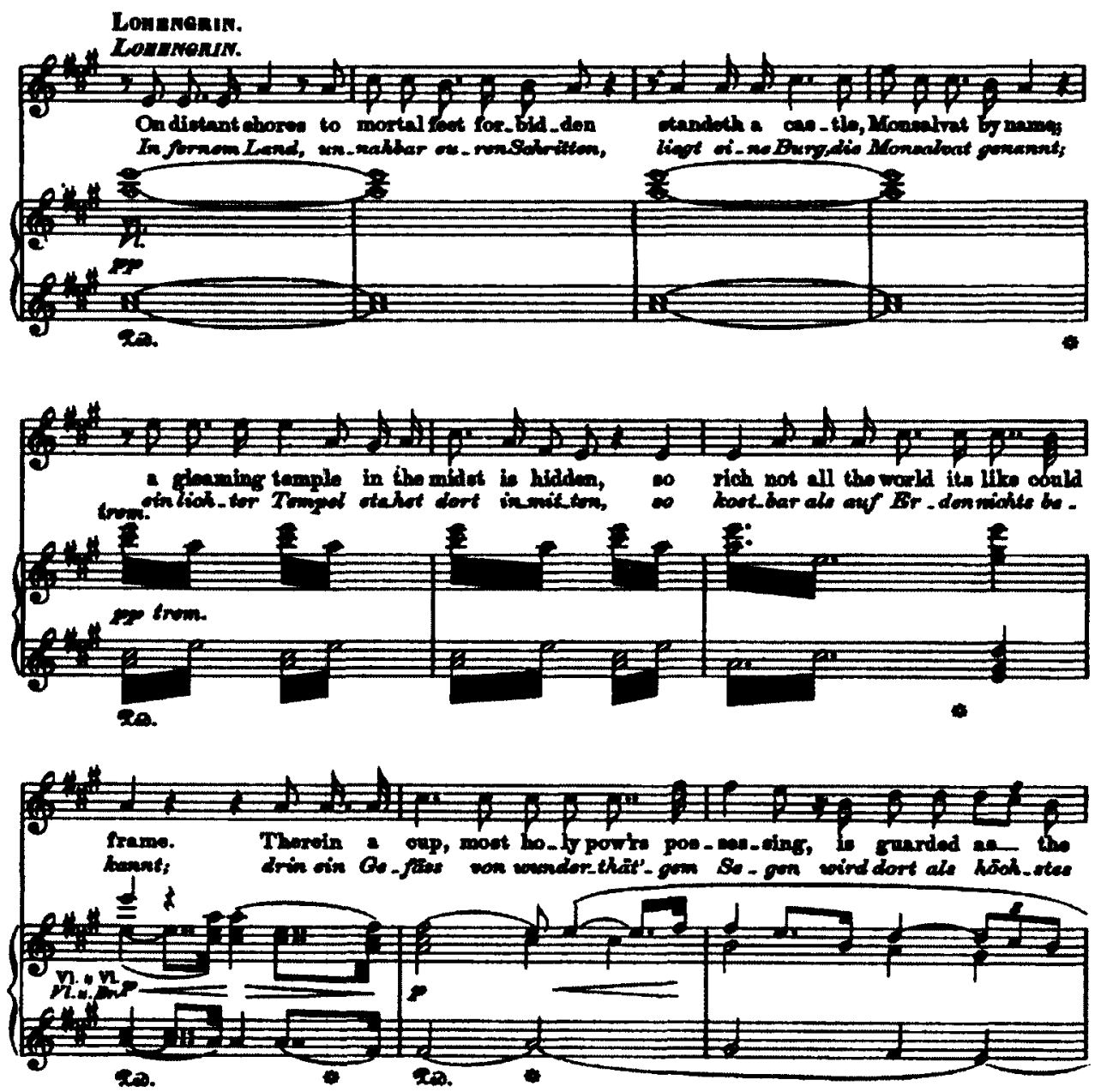
Once Lohengrin has completed his narrative and revealed his name, the mechanics of the grand opera crowd scene resume as the choral crowd recommences its prevailing function in the opera as a "voice of the people" that reflects both the will of the assembled onstage mass, and ostensibly that of the assembled crowd witnessing the dramatic performance. Upon hearing of Lohengrin's sacred origin, the crowd penitently intones,

Hör' ich so seine höchste Art bewähren, entbrennt mein Aug' in heil'gen Wonnezähren. (III, iii)
[To hear him thus attest his sacred origin causes my eyes to brim with tears of blessed joy]

The chorus' reaction may be read as another moment of an "unsung voice," in a similar fashion to their reception of Lohengrin's arrival in the first act. They collectively specify that it is the hearing of Lohengrin's story that induces tears of joy. This observation points to a moment of potential slippage: is the assembled mass so greatly moved by hearing Lohengrin's story or simply the sound of his voice? If it is the latter, is this choral couplet another case where the reception of the characters overlaps with the reception of the spectator? Does the former's reaction to the knight's words as a vessel for a sacred narrative parallel the latter's reaction to the tenor's voice as a vehicle for music? Does that parallel foster a situation where the spectators, inside the story and out, invest Lohengrin's vocalized narrative as sonority with the same divinity as the story conveyed by those sonorities? If that is the case, then the dissemination of the sacred Grail narrative by the Wagnerian tenor would be a feedback loop where the beauty of both the vocal sonority and its concomitant narrative infuse each other with the characteristics of the divine, constructing Lohengrin, the character, and Lohengrin, the performing voice as an idealized bodily figure. 
Backtracking to. Wagner's reading of Lohengrin as a dramatization of the tragedy of the "absolute artist" opens one more window to thematize Lohengrin as imago figure. Hoeckner frames this tragedy as part of a provocative argument that posits the interlocking stories of Lohengrin and Lohengrin as an encapsulation of the history of opera, and the documenting of the forthcoming transition from German Romantic opera to music drama. Hoeckner's contention foregrounds what he refers to as Elsa's two "screams," the first as the culmination of Elsa's recounting of her vision of the swan knight, and the second when she finally succumbs and asks her husband's name. According to Hoeckner, the first scream protests against the boundaries of Romantic opera, the acoustic rupture that will initiate the process of bringing music drama into the world. ${ }^{98}$ Elsa's scream against the increasingly obsolete operatic forms is what summons Lohengrin into the world, "born out of music: out of Elsa." embodiment of the artist that will transcend the limitations of opera and point toward the union of poetry and music that will come to be defined as music drama. This essentially provides a new dimension to the understanding of Lohengrin as epic hero under Williams' definition: just as he descends upon the earthly realm to act as saviour for Elsa, and later Brabant and the German nation, Lohengrin as synecdoche for the entire work is positioned as a saviour of sorts for German opera, by representing the forthcoming dramatic revolution that will irrevocably transform the art for the better.

But to reiterate, the "absolute" artist's existence is one of isolation, reflecting an inability (and often unwillingness) to be assimilated into conventional society. As a

\footnotetext{
${ }^{98}$ Hoeckner, 100-116. As Hoeckner notes, Lohengrin clearly resonated with Wagner as a significant transitional work in terms of the development of his musical and dramatic aesthetics, as he subjected Elsa's dream narrative to a musical analysis in his 1879 essay "On the Application of Music to the Drama," SSD X, 176-193; PW VI, 173-191.

${ }^{99}$ Tbid., 116.
} 
consequence, the absolute artist fits comfortably into the category of the epic hero. Ultimately, the arrival of Lohengrin is an example of the opera's overreaching itself. As Hoeckner argues, in compelling Lohengrin to reveal his origins, Elsa's second scream serves to illustrate Lohengrin's ultimate dramatic failure. That failure is located in the fact that the Grail narrative returns to the music of the prelude as its accompaniment. This was, according to Raff, the work's greatest folly. The Grail narrative is:

a miscalculation of the poet which he will pay for with the yawns from a large part of the audience and the silent curses of the singer... The mystic content of the narrative is exhausted in the prelude. The singer can do nothing more than declaim to the music of the prelude. ${ }^{100}$

For Raff, Wagner proves unable to successfully approximate in music the ineffable beauty of the Grail kingdom; the return to the prelude merely represents a retreat to that which has already been "exhausted." As Hoeckner adds, Elsa's scream "succeeds in creating Lohengrin, but she cannot save Lohengrin. Neither can Lohengrin. When he finally matches his name to the music in the Grail narration, its dramatic effect falls flat." 101 It should be noted that Wagner himself at several points professed antipathy for Raff. ${ }^{102}$ Moreover, as James Deaville points out in his entry on Raff for the New Grove Dictionary of Opera, Raff's criticisms in Die Wagnerfrage alienated Raff from many of his colleagues in the Weimar circle of musical progressives. ${ }^{103}$ This is to say that Wagner had no inclination to accept the validity of Raff's dismissal of the recapitulation of the

\footnotetext{
${ }^{100}$ Raff, Die Wagnerfrage, quoted in Hoeckner, 129.

${ }^{101}$ Hoeckner, 129.

${ }^{102}$ Wagner's aversion to Raff manifests itself in a letter to Liszt dated September 8, 1852 where he decries what he sees as Raff's lack of creativity. In a letter written to Peter Cornelius, dated March 4, 1862, Wagner expresses personal dislike for Raff. SL, 268-269 and 541-542.

${ }^{103}$ James Deaville, "Joachim Raff," Grove Music Online (accessed December 18, 2012). Alexander Rehding's account intimates that Raff's skepticism towards Wagner was received by his Weimar cohorts as something resembling apostasy: Raff's "apodictic lines on Wagner caused considerable embarrassment among his progressive colleagues...." See Music and Monumentality: Commemoration and Wonderment in Nineteenth-Century Germany (Oxford and New York: Oxford University Press, 2009 ), 93.
} 
prelude (and by extension, he would have to reject any interpretation that built off of it). Therefore, the supposed implications of the opera's "failure" on the future of German art are external and not built into the work itself. Nonetheless, Hoeckner's reading (and its employment of Raff's critique) is of interest for its adoption of the "absolute artist" interpretation in order historically situate Lohengrin as that which longs for new model for musical drama, but which ultimately cannot succeed in making that advance in absence of a worked-out paradigm. Consequently, the summoning of the absolute artist proves to be too soon to successfully bridge Romantic opera and "music drama." Elsa's dream can only imagine such integration, and her scream can only push against the circumscriptions of opera. Lohengrin's failure to conclusively bring absolute art or music drama into the world necessitates that he fulfill his final duty as both harbinger of operatic reform and as epic hero and vacate the realm of humanity.

And so Lohengrin/Lohengrin reaches its inevitable conclusion, with his marriage shattered, his bride dead, and his last hope of escaping the bonds of servitude to his father and the Grail dashed. But before his ordained departure, he informs Heinrich and the rest of the gathered throng that "never, not even in the most distant future shall the hordes from the East rise up in victory against Germany!" As the swan approaches the riverbank, Lohengrin's prayers release Gottfried from his imprisonment and the swan transforms into the man Lohengrin anoints the ruler of Brabant. Lohengrin as a physical and sonorous being may have been too perfect to remain as a resident of Germany, but his mystical properties in the end create the conditions of possibility for Brabant and the Empire to flourish. Furthermore, his sacredness as an element of Christian myth touches the mythos of German history, bestowing the nation with a trace of the sacred. This final 
act of benediction before his departure positions Lohengrin as a somatic and sonorous focal point where discourses of grand opera, the epic hero, the absolute artist, and the male imago figure imbricate in order to mythologize Germany's ostensibly divine lineage and heritage.

\section{The Pure Hero}

In Wagner's estimation, the prevalence of Christian narratives and iconography in Lohengrin was not an indication of endorsement of Christian doctrine. Rather, Wagner's stated strategy in mobilizing Christianity's "mythos" within the context of medieval legend was part of a plea "for a critical method that could reveal what is known in modern parlance as the 'deep structure' of all myths that relate them to each other."104 Borchmeyer proposes that Lohengrin, in its exploitation of Christian imagery, is an example of a "mythical palimpsest."105 As alluded to previously, the relationship between Lohengrin and Elsa is essentially written over top of that of Zeus and Semele. ${ }^{106}$ Borchmeyer and Deathridge both note that for Wagner, around the time of the composition of Lohengrin, Christianity's significance lay not in its own inherent religious truths, but in the fact that it was the contemporary culture's re-branding of mythological formations that stretched back to the Hellenic age. Christianity, specifically the Parzival and Lohengrin legends, was a strategy for maintaining the vitality of the myths of the Ancient Greeks, to continue to implant the "spirit" of those myths into the collective psyche of the modern age.

As Wagner neared the end of both his compositional career and his life, he revisited the Parzival legend, this time focusing on Lohengrin's progenitor, the Grail

\footnotetext{
${ }^{104}$ Deathridge, 33.

${ }^{105}$ Borchmeyer, 147-156.

${ }^{106}$ SSD IV, 289; PW I, 334.
} 
King himself. ${ }^{107}$ His return to the myth did not exactly signal a resurgence of religious faith, or even a recommitment to Christian doctrine (as Wagner's opening remarks to "Religion and Art" attest). But the exploitation of the Parzival saga also did not necessarily represent a veneer for the retelling of world myths in a Christian guise as it apparently did with Lohengrin. However, Parsifal still maintained something of the qualities of the "mythical palimpsest" that Borchmeyer identified in the earlier work. Chapter Two already expounded upon the presence of Christian narratives as a productive vehicle for discussions of Kunstreligion. In the following pages I will endeavour to demonstrate that in Parsifal, the nominally "Christian" story functions as a patina for the dissemination of ideas revolving around the intersections between narratives of the hero, his idealized body - theorized in terms of racialized discourses of "purity" - and the "heroic" tenor and grand opera. Specifically, I will situate the body of the tenor in the persona of Parsifal as a constellation of narratives of the "messianic" hero, racial "purity" and "degeneration," and the dramaturgy of grand opera that serves to frame the Grail King within the context of Christian mythology as a national imago figure, in manners both similar and unique to what was observed in Lohengrin.

Whereas Williams characterized Lohengrin as an example of an "epic hero," he places his father, Parsifal within the mode of the "messianic hero." According to Williams, it is the fact that Lohengrin ultimately does not lead the Brabantian troops into battle and function as their Duke that prevents Lohengrin from crossing the divide

\footnotetext{
${ }^{107}$ In My Life, Wagner claims to have made initial sketches for a drama based on Parzival in 1857 (ML, 547). He did not resume any serious work on it until August of 1865 , when he completed a prose draft of the work. Devotion to the completion of the Ring meant that an additional prose draft and the finished poem were not completed until 1877. See Lucy Beckett, Richard Wagner: Parsifal (Cambridge: Cambridge University Press, 1981), 1-24.
} 
between epic and messianic heroes. ${ }^{108}$ While the epic hero is ultimately alienated from the society he protects, the messianic hero is very much a part of society according to Williams. This mode of hero is derived from the work of nineteenth-century historian Thomas Carlyle, particularly as collected in his On Heroes, Hero Worship, and the Heroic in History. ${ }^{109}$ The hero in Carlyle's estimation "will lead humanity to an awareness of whatever is essential in life...."110 Carlyle's messianic hero is fundamentally a leader for humanity who has "a tangible impact on everyday life" providing "sterling moral examples." "Hero as King," who becomes "the Commander over Men; he to whose will are to be subordinated, and loyally surrender themselves, and find their welfare in doing so. [He] may be reckoned the most important of Great Men."112 This is a "hero as messiah, one who will lead society to utopia." 113

The concluding tableau of Parsifal provides a handy illustration of how the titular character can be interpreted as a messianic hero: Parsifal heals Amfortas's wound, uncovers the Grail, and is anointed Montsalvat's new king. Initially ensconced within the characteristics of the epic hero, demonstrating physical suppleness and superiority in battle, Parsifal "overcomes a mighty monster - Klingsor and Kundry - travels through

\footnotetext{
${ }^{108}$ Williams, 66.

${ }^{109}$ Thomas Carlyle, On Heroes, Hero Worship, and the Heroic in History (London: James Fraser, 1841). As Williams notes, Carlyle became a major influence on Wagner's thought upon his first reading of Carlyle's work in the 1870s (17). For example, at the outset of his introduction to "Art and Revolution" (1849), written for the 1872 publication of the third and fourth volumes of his collected writings (SSD III/IV), Wagner cites Carlyle's History of Frederick the Great, likening its characterization of the French Revolution as a "spontaneous combustion" of a corrupt social order to the transformative effect that Wagner hoped would result from his proposed fusion of revolutionary politics with art (PW I, 23). Later on, Cosima will account for Wagner's admiration for Carlyle and numerous points throughout her diaries. In her entry for April 12, 1879 (CD II, 291), she intimates that, in Williams' words "Wagner valued Carlyle as much as he did Schopenhauer" (17).

${ }^{110}$ Williams, 17.

${ }^{111}$ Ibid., 18.

${ }^{112}$ Carlyle, quoted in Williams, 18.

${ }^{113}$ Williams, 18.
} 
the world, engages in repetitive suffering and error, but continues to champion the ideals symbolized in the spear, and eventually becomes leader of a regenerated society." 114 But Parsifal will eventually transcend the shackles of the epic hero, and eventually ascend to a position as the apotheosis of all of Wagner's heroes: where the Dutchman, Tannhäuser, Lohengrin, and Siegfried were all to some extent unassimilable into society, Parsifal not only successfully integrates into the culture of the Grail kingdom, he becomes the "sterling moral example," 115 which will allow the brotherhood of knights to regain its exalted status, "ensur[ing] that the vital energies from the grail may spread through a regenerated humanity...."116 In siring Lohengrin, Parsifal works to ensure that his "sterling" example is continued so that the Grail's energies are properly distributed amongst humankind. This is done through a genealogy of knights birthed for the purpose of being dispatched into the human realm, to preserve peace and justice in the name of the Grail, provided that the humans they serve place their absolute trust in their champion. With their cries of "miracle of supreme salvation," the residents of the Grail Temple are only too sanguine about acquiescing to Parsifal's will; as the earlier opera makes plain, Parsifal's plans to lead the kingdom into utopia have been implemented many times over.

Williams' references to the "regeneration" of society effected by Parsifal's redemptory acts indicates a potential window into how the body of Parsifal may be theorized as that of an imago figure for the German nation. The resolution of all of the

\footnotetext{
${ }^{114}$ Ibid., 131.

${ }^{115}$ As Wagner writes about the performances of Parsifal at the 1882 Bayreuth Festival, "the significance of the kingship of this brotherhood we sought in the original meaning of the word "King" itself, as head of the race, a race here chosen to protect the Grail: nothing was distinguish him from the other knights, save the mystic import of the lofty office reserved for him alone, and his sufferings understood by none" (PW VI, 309). In other words, it is the office of king that will in the end mark Parsifal as possession of superior moral fibre to the brotherhood he is to lead.

${ }^{116}$ Williams, 141.
} 
work's dramatic conflicts comes out of Parsifal's fulfillment of the prophecy of the "pure fool enlightened through compassion" (the name "Parzival" of course roughly translating to "pure fool"). The implications of "pure" are quite productive in framing Parsifal as a somatic focal point in discussions of both societal regeneration and the image of the idealized body as stand-in for the nation. As both Paul Lawrence Rose and John Deathridge have noted, the primary period of composition of the music for Parsifal (the poem having been completed in 1877) was roughly concurrent with his exposure to the racial theories of the Count Joseph Arthur Gobineau as expounded in his Essay on the Inequality of Human Races (1853-55). ${ }^{117}$ Wagner first met Gobineau in 1876 and read the essay in 1880, which prompted him to publish an essay in the May/June 1881 issue of the Bayreuther Blätter lauding Gobineau's theories of race. ${ }^{118}$ Wagner in particular gravitated towards Gobineau's valorization of the Aryan race, of which the Germanic races were foregrounded as a part; indeed, as Wagner famously remarked to Cosima, "Gobineau says the Germans were the last card Nature had to play - Parsifal is my last card." 119 However, for Gobineau, the Aryan (and Germanic) races had been subject to decline: "races decayed through intermarriage, just as degeneration of the heroic occurred within a pure race by intermarriage between aristocratic stock and lower castes. This...was a tragic and irreversible process of history." ${ }^{20}$ As Gobineau would have it, the supremacy of the Aryan bloodline had been tainted through generations of miscegenation, and as a consequence that supremacy had been permanently and irrevocably lost.

\footnotetext{
${ }^{117}$ Rose, 138-141 and Deathridge, 164-166.

${ }^{118}$ SSD X, 33-35; PW VI, 38-40.

${ }^{119}$ Cosima's Diaries, March 28, 1881, quoted in Deathridge, 165.

${ }^{120}$ Rose, 139.
} 
Deathridge points out that several years before he had even heard of Gobineau, Wagner had expressed his own concerns about the preservation of the German race in "Die Wibelungen." There, Wagner explicated his conception of the history of the ancient Germanic tribes, the strongest of which possessed "the purest of blood from which entire people descended." ${ }^{, 21}$ But that purity was subject to constant dangers of "degeneration" through the mixture of that blood with those of "lesser" races; as Deathridge notes, "the essay floats the idea more than once that the Germanic races always had to be wary of foreign impurity." 122 This essay is important, as Wagner makes "prominent use of words like 'blood' (Blut), 'degeneration' (Entartung), and 'depravity' (Verderbtheit) to describe racial conflict and decay," more than three decades before he had read a single word of Gobineau's writings. ${ }^{123}$ If Wagner's interest in matters of the supposed degeneration of the German race had subsided in the intervening years, they would be re-ignited upon his reading of Gobineau's work. These resurrected interests would manifest themselves in what Rose refers to as the "regeneration" essays of $1877-81 .{ }^{124}$ In these writings, Wagner revealed that his diagnosis of the decay suffered by the German race was significantly less pessimistic than that of Gobineau. As Deathridge writes, Wagner

refused to accept [Gobineau's] view that the decline of the Aryan race was unstoppable. The 'absolute purity' of the Aryan race can indeed be aspired to...by the intervention of a divine hero, who, although himself the product of racial impurity, is capable of compassion and hence able to resist any further adulteration of blood through an intuitive understanding of human suffering. ${ }^{125}$

For Wagner, the Aryan (and by extension, German) bloodline has already been contaminated to the point that there is no possibility of the existence of a completely

\footnotetext{
121 "Die Wibelungen," quoted in Deathridge, 164.

${ }^{122}$ Deathridge, 164.

${ }^{123}$ Ibid., 165.

${ }^{124}$ Rose, 141-158.

${ }^{125}$ Deathridge, 167.
} 
"pure" hero. Nonetheless, by resisting any impulse towards further mixing of the races, the proposed divine hero can effectively halt further degradation of the bloodline, and provide one of Carlyle's "sterling moral examples" for others to follow, thereby laying down the conditions for an eventual regeneration of the Germanic blood and a resultant reclamation of its purity, thus allowing the race to once again flourish. Such was the theme of Wagner's "regeneration" writings. Most germane to this chapter is the aforementioned "Heroism and Christianity" (1881), which Rose argues "comes closest to providing an explicit programme for the racial content of Parsifal."126 In the essay, Wagner specifically identifies "corruption of blood" as the cause for the degeneration of the Aryan race. ${ }^{127}$ That corruption, resulting from miscegenation with the "LatinoSemite" races necessitates that the Aryan bloodline be rescued by a "revolutionary redeemer-hero." 128 For Wagner, it is necessary to bypass traditional Judeo-Christian doctrine (which precipitated the deleterious mixture of blood) and look to the Brahmin religions (the origins for the Aryan race) in order to locate such a hero. Only the blood of the Aryan Christ possesses the sufficient divinity to purify the infiltrations from the "degenerate" races, and restore the Aryan blood to its original pure state. The superiority of his blood is externalized through the superiority of his actions and moral character, for Wagner "sees the essence of nobility as lying in a superior, heroic capacity for suffering, pity and compassion." 129

It is not difficult to conceive of how all of the above pertains to Parsifal. At the opera's commencement, the kingdom of the Grail has been suffering a precipitous

\footnotetext{
${ }^{126}$ Rose, 155.

${ }^{127}$ SSD X, 275; PW VI, 275.

${ }^{128}$ Rose, 155.

${ }^{129}$ Ibid.
} 
decline: several knights have been lured into Klingsor's magic garden and wooed by his Flower Maidens. In response, Amfortas attempted to do battle with Klingsor, but was seduced by Kundry, which allowed Klingsor to steal the holy spear and inflict a wound on Amfortas that will not heal. The kingdom now awaits the coming of the prophesized "pure fool enlightened through compassion" who will finally defeat Klingsor, return the spear to the community, and heal Amfortas's wound, thereby redeeming him and the rest of the kingdom. The fall of the various knights through temptation into sexual licentiousness aligns fairly comfortably with Wagner's concerns about sexual activity with degenerate races leading to a contamination of the blood: Amfortas's wound that is the result of his succumbing to Kundry's sexual temptations is "located in the genitals, according to [Wolfram's] original source...a sexual wound, symbolic of racial sexual contamination." ${ }^{, 130}$ The wound functions as a synecdoche, a singular representation of the Grail community's decay as a whole, and as such also maps upon the theorized decline of the German race and the German nation. In their analysis of Parsifal, Linda and Michael Hutcheon foreground the wound as a representation of sexually transmitted disease (specifically syphilis, a ubiquitous malady in the nineteenth century). According to their interpretation, the presence of an open lesion on Amfortas's body that will not close, that bleeds constantly, and subjects him to intense pain that resulted from an act of sexual indiscretion maps onto the symptoms of syphilis as understood in the contemporaneous discourse. ${ }^{131}$ Whether or not one accepts that the wound is a metaphor for the effects of

\footnotetext{
${ }^{130}$ Rose, 164. For the opera, Wagner changed the area of the wound to Amfortas's side.

${ }^{131}$ Linda Hutcheon and Michael Hutcheon, Opera: Desire, Disease, Death (Lincoln and London: University of Nebraska Press, 1996), 68-76. Indeed, in this section, the Hutcheons observe the tendency of discourses on syphilis to position the disease as God's punishment for promiscuity. In that sense, Amfortas's wound is the penalty to be paid for failing to properly serve the Grail in succumbing to sexual temptation.
} 
syphilitic infection, the Hutcheons' reading is productive in terms of theorizing the wound as the externalized manifestation of an internal contagion, a bodily laceration that indicates the contamination of the blood contained within. Furthermore, the Hutcheons extend their inquiry into the points of contact between the opera's narrative and discourses of sexually transmitted infection by likening the loss of the sundry knights to the wiles of the Flower Maidens to narratives of soldier's dalliances with prostitutes. ${ }^{132}$ In support of their contention, they note that Theodor Adomo specifically identified a connection between Klingsor's magic garden and "dreamland brothels...simultaneously calumniated as places that no one could leave unscathed."133 Klingsor's realm is a den of iniquity that irrevocably contaminates the blood of those who partake of its pleasures; once "infected," knights can no longer return to the realm of the Grail, as they have divested themselves of their purity.

But what precise contaminants do Klingsor, Kundry, and the Flower Maidens carry that inject disease and decay into the Montsalvat bloodline? Such a question demands that the ever-present issue of Wagner's anti-Semitism be addressed: going beyond Adorno's own unambiguous proclamation that all of the unsavoury characters in Wagner's oeuvre are negative caricatures of Jews, ${ }^{134}$ Rose and Weiner both put forth Klingsor and Kundry as examples of the Jewish "anti-race," 135 which functions as the destructive antipode to the Aryan race. Micha Brumlik's analysis posits that Parsifal's "Christology" thematizes Parsifal as the Aryan ideal who redeems the world from the

\footnotetext{
${ }^{132}$ Ibid., 76-83.

${ }^{133}$ Theodor Adorno, In Search of Wagner, quoted in Hutcheon and Hutcheon, 77.

${ }^{134}$ Adorno, In Search of Wagner, 13.

${ }^{133}$ Rose, 153. Wagner himself characterizes the Jews as such in "Know Thyself" (SSD X, 271; PW VI, 271).
} 
destructiveness of Jews and Judaism. ${ }^{136}$ We have already noted Wagner's reference to the blood of the "Latino-Semite" races as an infection of the Aryan blood; in Parsifal, Klingsor "has castrated himself in his search for material power...Having foresworn the idealism of the Grail (as the Jews are incapable of appreciating German idealism), Klingsor now intends to destroy the Grail and with it the brotherhood of knights." ${ }^{137}$ The act of castration was intended to demonstrate Klingsor's commitment to chastity in order to gain acceptance to the kingdom of the Grail. Instead, it only served to hasten his exscription from the community. Klingsor's grotesque body is an outward sign of his grotesque character, both of which mark him as manifestly unfit to integrate into the brotherhood/race of the Grail knights. Klingsor's bodily/racial difference compels him to seek vengeance against Montsalvat and ultimately destroy it. His primary strategy in this endeavour is the deployment of Kundry, condemned to an existence as a seductress since mocking Christ's passion. ${ }^{138}$ Wagner himself identified Kundry's plight as akin to that of Ahasuerus, the "Wandering Jew" in the December 28, 1873 entry of his diary. ${ }^{139} \mathrm{Her}$ physical pulchritude and sexual availability (along with those of her fellow Flower Maidens) corrupt the knights, irrevocably divorcing them from the Grail, thereby causing the kingdom to rot from within. Kundry's intrinsic urges, her being controlled by emotion and libidinal drives has induced scholars to situate her within the discourse of

\footnotetext{
${ }^{136}$ Micha Brumlik, "Erlösung von der Erlösung: Richard Wagners Christologie," Wagnerspectrum 5/2 (2009): 98-104.

${ }^{137}$ Rose, 163.

${ }^{138}$ Slavoj Žižek argues that Kundry's laughter carries a more potent charge than mere blasphemy or lack of compassion: he contends that the most egregious transgression of Kundry's laughter lay in its undermining of male authority, revealing its impotence, a process that repeats throughout the opera via her relationships with her various "masters." Žižek asserts that her laughter is evinces both mockery and despair in her repeated inability "to find a reliable support in the master." Žižek and Mladen Dolar, Opera's Second Death (New York and London: Routledge, 2002), 162.

${ }^{139} \mathrm{DRW}, 54$. The "Wandering Jew" legend of course earlier implicated itself heavily into the plight of the Dutchman of Der fliegende Holländer, condemned to eternally sail the seas until redeemed by the love of a virtuous woman. Borchmeyer discusses the resonances of the Ahasuerus myth in Holländer (also linking the Dutchman to Kundry) in Drama and Richard Wagner, 79-100.
} 
hysteria: Catherine Clément's groundbreaking study of women's roles in opera analyzes the intersections between women in opera and hysteria, ${ }^{140}$ while Sander Gilman has provided insight on the tendency of nineteenth-century European thought to associate hysteria and nervousness with the body of the Jew. ${ }^{141}$ The point that I aim to make clear is that Kundry's sexual urges function as a complementary perversion to Klingsor's mutilated body, which mark them as distinctly alien to the persons of the Grail knights.

Of course, there are obstacles to directly associating Klingsor's and Kundry's racial difference with Jewishness; the first is Wagner's very conception of the Jew as an anti-race. As previously explicated, Wagner's position was that miscegenation had diluted and poisoned the Aryan/Germanic bloodline. But Wagner's essay "Know Thyself" makes plain that as an anti-race, Jews were incapable of miscegenation: "the Jew...is the most astounding instance of racial congruence ever offered by worldhistory...[E]ven commixture of blood does not hurt him; let Jew or Jewess intermarry with the most distinct of races, a Jew will always come to birth." ${ }^{.142}$ Deathridge expands upon this by writing, "that would mean, according to the historical dynamic of race as he saw it, that [Jews] are incapable of both civilization and genuine purity simply because the have never had to reclaim purity from a process of degradation."143 That Wagner invoked the "Wandering Jew" myth in discussing Kundry's origins does not automatically guarantee that she is a representation of a Jew. Indeed, Deathridge writes that in her wanderings through one guise after another, Kundry "seems about as far away

\footnotetext{
${ }^{140}$ Catherine Clément, Opera, or, the Undoing of Women, trans. Betsy Wing (Minneapolis: University of Minnesota Press, 1988).

${ }^{141}$ Sander L. Gilman, The Jew's Body (New York and London: Routledge, 1991), 62-63.

${ }^{142}$ SSD X, 271; PW VI, 271.

${ }^{143}$ Deathridge, 175 .
} 
from Wagner's idea of the consistent 'purity' of the Jews as she can be...."144 Strictly speaking, it is not interbreeding that is the cause of the brotherhood's woes as no hybrid offspring, Jewish or otherwise, is conclusively identified as having been produced over the course of the opera. It is the acts of sexual congress for purely hedonistic (rather than procreative) purposes that is the source of the knight's troubles. Even if one does not accept the presence of an anti-Semitic subtext to the characters of Klingsor and Kundry, as the Hutcheons point out, they are clearly examples of cultural (and possibly racial) "others" who carry virulent disease that contaminate the "pure" German blood of the knights through sexual contact. ${ }^{145}$ Whether Klingsor and Kundry are anti-race or lesser race, the intermingling of bodies and of blood has had disastrous consequences for the once-pure order of the Grail.

Parsifal's status as a "pure fool" is not the only avenue through which he will redeem Amfortas and the brotherhood. It is also his idealized manhood that will prove vital to revitalizing the community. As Tambling writes, "the wound is the mark of a break in the male subject."146 Wounds to the male body are quite prevalent in Wagner's work: for example, the final act of Tristan und Isolde is centralized around a wounded Tristan awaiting the arrival of Isolde and her healing potions. Parsifal features two prominent wounds to male bodies: Klingsor's self-inflicted castration and Amfortas's laceration received from Klingsor via the Holy Spear. Tambling contends that in both Tristan and Parsifal, a wound visited upon the male body is an externalization of "a masculinity which has lost its potency, which no longer exists in phallic

\footnotetext{
${ }^{144}$ Ibid. As Williams notes, Klingsor's castle is located in Moorish Spain, "suggesting that the culture that threatens the knights is Islamic, not Judaic" (133).

${ }^{145}$ Hutcheon and Hutcheon, 81.

${ }^{146}$ Tambling, 47.
} 
supremacy...."147 In Amfortas's case, he is the "son who has betrayed the patriarchy,"148 his masculine inadequacy resulting in his inability to resist Kundry's seduction, the wound making manifest that inadequacy for all to see. Amfortas's wound essentially functions as a stand-in for the declining manhood of the Grail community entire. As Susan McClary has noted, the sexually licentious woman leading men into ruin was a frequent trope in the latter nineteenth century. ${ }^{149}$ In the periods preceding and during Parsifal's primary gestation, Wagner himself remarked upon the ostensible threat femininity posed to male identity. For example, as Cosima writes in her diary, Wagner remarked (notably playing upon the concluding lines of the second part of Goethe's Faust) that "the eternal feminine drags one downward." 150 In any case, Amfortas and the fallen knights preceding him have succumbed to the lures of purely sensual pleasure, thus allowing the corruption of "degenerate" blood to infiltrate their heretofore pure bodies. The wound is the marker of "the defiled 'sanctuary' [that] is the pure male body and the Grail temple, both already spoiled by the otherness of the woman...A society bonded on the basis of male power rejects the woman as the source of tainted blood...."151 Kundry and the Flower Maidens then function as both racialized and gendered "others" to the Grail society, the infiltration of their difference effecting a precipitous decline in the culture's masculine health.

Into this scenario enters the "enlightened fool" that is Parsifal. During Act II, he happens upon Klingsor's magical garden and encounters the Flower Maidens and later

\footnotetext{
${ }^{147}$ Ibid., 48.

${ }^{148}$ Tbid., 51.

${ }^{149}$ Susan McClary, Feminine Endings: Music, Gender, \& Sexuality (Minneapolis and London: University of Minnesota Press, 1991), 99-101.

${ }^{150} \mathrm{CD}$ (Dec. 1, 1880), quoted in Nattiez, 168.

${ }^{151}$ Tambling, 49-50.
} 
has a lengthy duet with Kundry. In both passages, Parsifal is exposed to their seductive wiles, but with a significantly different result than what had previously transpired: the Flower Maidens are not able to entice him, and at the culmination of their duet, Kundry kisses Parsifal. But as Kramer observes, Parsifal's initial reaction to the kiss "is to feel neither pleasure nor desire, nor their counterpart, disgust. Those things come afterwards. What he feels at once is Amfortas's pain."152 Kramer argues that the wound itself at this moment is given voice, transmitting the agonies it inflicts directly into Parsifal's being. This is the moment where he is truly "enlightened through compassion": the ability to empathize with Amfortas's suffering grants him the fortitude to not only reject Kundry's sexual advances but to retrieve the spear from Klingsor and destroy his fortress. Furthermore, Parsifal's resistance of Kundry will sow the seeds for her eventual release from her cursed existence, culminating in her redemptory third act "baptism." Through these confluences of actions, Parsifal makes apparent his manifold superiorities to the remaining knights, an inability to be corrupted by the impurities of gendered and racial otherness.

In rejecting Kundry and reclaiming the spear, Parsifal merges two strands of heroism: the former action demonstrates moral certitude while the latter provides an example of the outstanding physical prowess and facility in battle characteristic of the epic hero. Additionally, his rebuffing of Kundry and refusal to allow his blood to be corrupted registers as the "sterling moral example" consistent with the messianic hero. Taken in aggregate, Parsifal's heroic qualities imbue him with the necessary physical and moral strength to redeem Amfortas and the rest of the brotherhood, liberate Kundry from

\footnotetext{
${ }^{152}$ Lawrence Kramer, "The Talking Wound and the Foolish Question: Symbolization in Parsifal," The Opera Quarterly 22/2 (2007): 208.
} 
her life of damnation, destroy the external threats to the Grail kingdom and cast out their commensurate contaminations of the noble blood, and finally be anointed the new king of the Grail. Metaphorically then, Parsifal is the "redeemer-hero" who will regenerate the Aryan bloodline, laying the groundwork for the Germanic race (and by extension, the German nation) to re-ascend to a level of racial and cultural supremacy. Like with his offspring, Parsifal's heroic character and actions are made manifest through his aesthetically idealized body. Recalling Wagner's own remarks in "Heroism and Christianity," the Christian formation of the hero called for a beautiful, unblemished physical form. And like Lohengrin, Parsifal's body is further positioned as superior due to its production of "heroic" tenor sonorities (consistent with much of Wagner's other work, Parsifal is the only solo tenor part in the piece); the body as a physical and sonorous object once again functions as a site of aesthetic perfection, the externalized representation of the idealized inner qualities that is Parsifal's pure blood. The somatic perfection is then mapped upon the character's heroic qualities. Both are expressions of each other, thereby framing Parsifal as the physical and acoustic ideal that will regenerate the bloodline and reinvigorate the German race. In healing Amfortas's wound, Parsifal takes the first step towards healing the nation.

\section{Dance of Regeneration}

Williams has this to say about the aforementioned Flower Maiden scene of the second act: "the Flower Maidens stand for lust and Wagner encases them in his most saccharine music, reminiscent of the ballets of French grand opera, with their scenes of voluptuous luxury in which the senses, and the senses alone are charmed."153 Grey additionally remarks that "the memory of the corps de ballet lives on in the Flower

${ }^{153}$ Williams, 137. 
Maidens (whose seductive mission in Act II is not unlike that of the nuns in Act III of [Meyerbeer's] Robert le Diable)." ${ }^{\text {154 }}$ Reaching back to an earlier era of scholarship, Adorno also observes that the scene "arose out of the ordinary theatrical requirements of the ballet." ${ }^{\prime 155}$ Interestingly, in his recounting of the work's performances at the 1882 Bayreuth Festival, Wagner writes, "as soon as it came to the question of a costume for Klingsor's magic Flower-maidens, we found nothing but models from ballet or masquerade...."156 Wagner only alludes to ballet vis-à-vis the costume designs rather than the music, and the given quote indicates that he considered that examples from ballet to be inadequate and/or inappropriate. However, this does not necessarily refute any contentions that the music and the staging bear some lineage to ballet. Note that Wagner's stage direction for Chorus I and the first group of maidens at one point reads "während sie, wie in anmutigem Kinderspiele, in abwechselndem Reigen um Parsifal sich drehen" (as they dance around Parsifal in ever-changing circles with the charm of children at play), ${ }^{157}$ indicating that the passage is intended to incorporate some form of dance. The placement of the sequence within Act II, roughly midway through the drama is reminiscent of the traditional location of the ballet in a typical grand opera: in a standard five-act presentation, the ballet would often take place during the third act, again approximately halfway through the performance. ${ }^{158}$ But to come back to the music, Williams' emphasis of the ostensible sensuousness of balletic music in grand opera is instructive, characterizing music that is to accompany bodily movement as itself having a

\footnotetext{
${ }^{154}$ Grey, "Wagner and Grand Opera," 340.

${ }^{155}$ Adorno, In Search of Wagner, 80.

${ }^{156}$ SSD X, 303; PW VI, 308.

${ }^{157}$ Unless otherwise stated, all translations from Parsifal are by Lionel Salter (Decca, 1970). German quotations of the libretto are from the same source.

${ }^{138}$ Mark Everist, Giacomo Meyerbeer and Music Drama in Nineteenth-Century Paris (Aldershot: Ashgate, 2005), 11 .
} 
somatic effect on the spectator, music for and of the body. Furthermore, the purported physical pulchritude and sexual desirability of the Maidens is in line with aspects of the reception of ballet at the Paris Opéra, where the dancers were often situated as objects of male spectatorship, to be ogled more or less. ${ }^{159}$ By tying the Maiden's sexual allures with "sensual" music, Wagner essentially foregrounds the bodies of his performers as objects of display. Williams' reference to luxury is similarly telling: as Lacombe notes, the presence of dance in grand opera "added to the glamour and contributed [its] own visual effect." $" 160$ The ballet was a display of musical and dramatic luxury, an exhibition of the extensive resources at the Opéra's disposal that contributed to the performance's opulent spectacle. As such, it would then appear appropriate that Wagner would adapt an operatic element associated with luxury and sensuality for a scene of an attempted seduction. ${ }^{161}$

As Parsifal enters the garden, the Maidens commence their attempt to entice him:

Chor I und I. Gruppe

(während sie, wie in anmutigem

Kinderspiele, in abwechselndem Reigen um

Parsifal sich drehen)

Komm, komm, holder Knabe!

Komm, komm! Laß mich dir blühen!

Holder Knabe, dir zu Wonn' und Labe gilt mein minniges Mühen!

(II, ii)
[Chorus I and $1^{\text {st }}$ group (as they dance around Parsifal in everchanging circles with the charm of children at play) Come, come, handsome boy! Come, come, I'll be your flower! Gentle boy, all my loving care is for your delight and bliss!]

\footnotetext{
${ }^{159}$ Marian Smith, "Dance and Dancers," in The Cambridge Companion to Grand Opera, ed. David Charlton (Cambridge: Cambridge University Press, 2003), 104-107.

${ }^{160}$ Lacombe, 53.

${ }^{161}$ Taken as a whole, Act II is reminiscent of grand opera in that it consists of a variety of elaborate scenic effects, ranging from the transition from Klingsor's castle to the magic garden to Parsifal's climactic destruction of the castle. The latter is the type of scenic cataclysm so typical of grand opera finales (i.e. the eruption of Mount Vesuvius in La Muette di Portici), and indeed in many of Wagner's previous works, most prominently Brilnnhilde's immolation and the subsequent destruction of Valhalla at the close of Götterdämmerung, or even the ring of fire that encircles Brulnnhilde at the conclusion of Die Walküre. For a recounting of the sundry challenges in staging Parsifal, see Patrick Carnegy, Wagner and the Art of the Theatre (New Haven and London: Yale University Press, 2006), 108-114.
} 
Ex. 3

(Parsifal IL/ii, mm. 140-155)
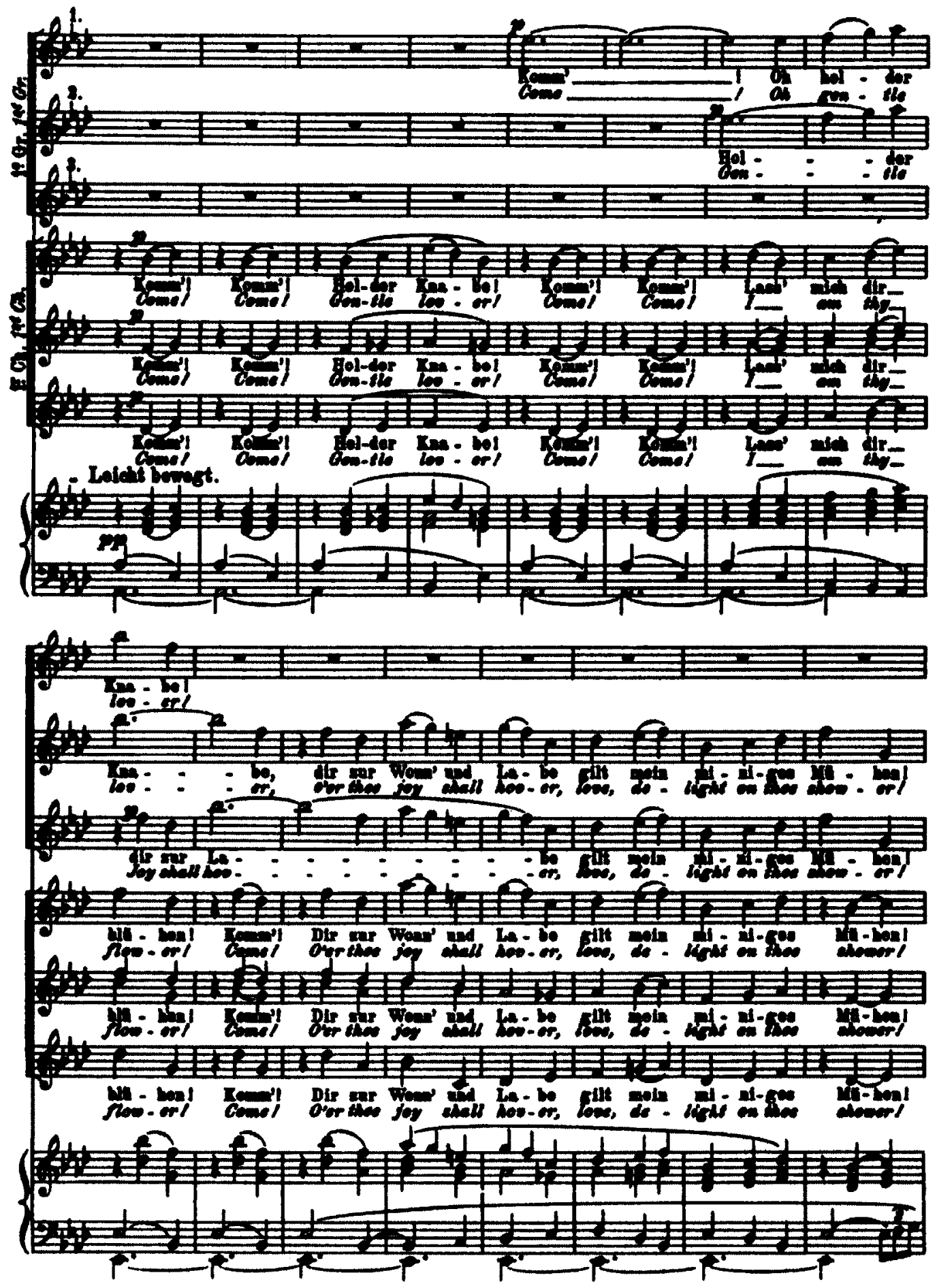

The music accompanying this action bears a vague resemblance to a waltz, with the low strings providing the downbeat of the $3 / 4$ meter, while the upper strings answer with 
chordal figures on the two off-beats. But if it is a waltz, it is the gentlest waltz imaginable, as the unhurried tempo and muted strings dissipate any sense of urgency and create a sense of insouciance consistent with the magic garden's encouragement of idle pleasure. Despite the stage direction, there can be little in the way of precisely choreographed dance steps, as the Flower Maidens are required to sing while on stage. ${ }^{162}$ But as Mary-Ann Smart has argued, Wagner's compositional technique gradually worked towards an emphasis on tracing bodily movements and gestures (whether they be physical or emotional) in the music, while the on-stage bodies remain comparatively static in their movements as part of an endeavour to stress the "inner drama" of the characters and the narrative. ${ }^{163}$ Under this paradigm then, it is possible to contend that the orchestra and the singer's vocal lines obviate the need for the on-stage performers to engage in anything beyond the most basic "dance" moves, as the music (vocal and instrumental) "dances" in their place. The downbeat in the bass combined with the upper sonorities of the off-beats provides the appropriate lilt for the type of playful dance specified in the stage direction. Similarly, the gentle quarter-note flow of the choral writing traces that lightness of movement. The pre-dominance of upper sonorities in the choruses and the orchestra and their attendant soft articulations disseminate an attractive,

\footnotetext{
${ }^{162}$ This was not an unusual feature in Wagner's work. Ballet-master Richard Fricke was hired by Wagner to choreograph not dance steps but "natural and fluid" (xv) movements for the singers and various other stage performers at the 1876 performances of the Ring at Bayreuth. Fricke's diaries recount several of his efforts to coach the singers in movements that would both fit within the surrounding stagecraft and sell the "reality" of their characters to the audience. One of these examples was his council of the three singers portraying the Rhinemaidens, who had to sing and mimic swimming while suspended above the stage in elaborate "swimming machines." See Wagner in Rehearsal, 1875-76: The Diaries of Richard Fricke, eds. James Deaville and Evan Baker, trans. George R. Fricke (Stuyvesant, NY: Pendragon Press, 1998), 61-65.

${ }^{163}$ Mary-Ann Smart, Mimomania: Music and Gesture in Nineteenth-Century Opera (Berkeley: University of California Press, 2004), 163-204. As Smart notes, this tendency caused Nietzsche much consternation, leading him to ridicule Wagner as a "mimomaniac," too concerned with the imitation of movement in his scores to create music with the necessary rhythmic fluidity to enable dance, Nietzsche's idealized condition for music. See "Nietzsche Contra Wagner" in The Portable Nietzsche, trans. and ed. Walter Kaufmann (New York: Penguin Books, 1982), 661-683 and "The Case of Wagner" in Basic Writings of Nietzsche, trans. Walter Kaufmann (New York: Modern Library, 2000), 601-653.
} 
sensuous sound designed to entice both Parsifal and the spectators in the theatre. The addition of sixteenth-note triplets encode greater ornamentation into the Maidens dance motions and gestures, while the chromatic descents in the vocal line (doubled in the orchestra) increase the sense of seductive decadence. To reiterate, these gestures in the music would appear to imitate the act of playfully seductive dancing, in order to avoid the necessity of choreographed steps that might interfere with the performer's ability to sing.

During their beckoning calls to Parsifal, their words attempt to infantilize him, referring to him as a mere "boy" that is no match for their charms. But his rejoinders to their entreaties prove, both dramatically and musically, to be something of a rebuke. Parsifal's first response is as such:

(heiter ruhig in der Mitte der Mädchen)

Wie duftet ihr hold!

Seid ihr denn Blumen? (II, ii) [(standing in happy calm amidst the maidens) How sweet you smell! Are you flowers then?]

The above quotation provides a template that will preside over much of Parsifal's reactions to the Maidens. His words throughout, in combination with the stage directions, make it quite apparent that he is doing little more than humouring the Maidens and is in no real danger of succumbing to them. ${ }^{164}$ Parsifal's contributions to the scene consist of periodic series of terse couplets that stand as a marked contrast to the intricate call and response and imitation of the various choral passages sung by the Maidens. While the choral parts are distinguished by a sense of continuous flow in their emphasis on a steady quarter-note pulse in mostly conjunct movement and chordal, perhaps even

\footnotetext{
${ }^{164}$ Žižek argues that Parisfal's resistance to Kundry's and the Flower Maidens' seductions renders him as Kundry's objet petit $a$, "the object-cause of Kundry's desire, yet totally insensitive to feminine charms." See "The Wound Is Healed Only by the Spear That Smote You': The Operatic Subject and Its Vicissitudes," Opera Through Other Eyes, ed. David J. Levin (Stanford, CA: Stanford University Press, 1994), 191.
} 
chorale-like texture, Parsifal's interjections are almost recitative-like in their display of sustained and repeated notes, and wide leaps. He eschews the old-fashioned, graceful melodicism of the Flower Maidens in favour of arioso-like declamation; he says his piece quickly and then falls silent. The orchestra continues with the triplet figures associated with the chorus, essentially pitting prurience against purity.

Parsifal never permits himself to be fully enveloped in the "saccharine" music of the Flower Maidens' ballet, remaining at arms length from this aspect of grand opera. The exceptionally brief interjections of his tenor sonorities essentially place him as "outside looking in," effectively cutting through the artifice from that exterior position, albeit in an exceedingly subtle manner: the brevity of his interpolations combined with the fact that they are packaged in no significant discordances in terms of timbre, harmony, or melody means that the sensual mood of the piece continues seemingly unabated. Yet those impositions of the tenor sonority are distinctive regardless. As Grey writes about the overall sensuality of the scene:

Kundry and the Flower Maidens could be said to represent the simple harmonies, lilting phrases, and self-contained forms of "pure" or absolute music as an illusion: an alluring vision without real substance, a seductive conjurer's trick in which artifice merely apes the ideal of nature. Thus the Flower Maidens, who are neither real plants nor real women, but the products of necromantic artifice; thus Kundry's disguise "in transformed shape," as Parsifal discovers her lying in a flowery bower. The Flower Maidens' music, with its little aromatic arabesques and sensuously mild chromatic inflections of a smooth harmonic exterior, is the music equivalent of the exotic Parisian scents and fabrics by which Wagner was seduced, particularly in later years - the commercial products of a culture he never tired of condemning from a higher moral ground. ${ }^{165}$

In its marked contrast of sonority and the comparative brusqueness of the text, the impositions of Parsifal's vocalizations come across as something resembling a sonorous rebuke to his surroundings. Those surroundings are the types of decadence described

\footnotetext{
${ }^{165}$ Grey, Wagner's Musical Prose, 174.
} 
above. Tellingly, Grey likens the sensuousness of the Flower Maidens' music to forms of physical stimuli found in Paris (and moreover that Wagner frequently succumbed to their wiles). Is it so much of a stretch to speculate that by localizing the magic garden's sensual delights within Paris, Grey tacitly situates them within the realm of grand opera, one of that city's most prominent cultural products, with ballet as one of its major commercial draws? Judged in that context, Parsifal's curt responses might be heard as the dismissive exclamations of a person who has evolved beyond the sort of kaleidoscopic funhouse of sensuality that Adorno referred to as "phantasmagoria."166 Indeed the fact that as Grey points out, Wagner himself was not able to match Parsifal's resistance to Parisian charms nicely makes the case that Wagner's divine hero was an unattainable idealization for himself. In contrasting the idealized sonority of the Wagnerian tenor against the commercialized phantasmagoria of the magic garden, perhaps Wagner has mobilized the dramaturgy of the grand opera ballet for the purpose of putting forth its ultimate negation.

Parsifal as male imago for the Grail kingdom and the German race is especially played up in the final tableau of Act III, where he heals the wound and uncovers the Grail for the enraptured knights. Chapter Two has already delved into how the third-act sequence in the temple is an example of a ceremonial crowd scene derived from grand opera, so that need not be repeated here. Rather, like with the discussion of the Flower Maidens scene, the focus will be on the insertion of the body of the tenor into grand opera. Preceding Parsifal's entry into the proceedings is a processional of uncommon bleakness: as Titurel's funeral cortege makes its way into the temple, the knights desperately plead with Amfortas to reveal the Grail, while Amfortas longs for death in

\footnotetext{
${ }^{166}$ Adorno, In Search of Wagner, 74-85.
} 
order to be released from his agony. As his plea for death culminates, Amfortas tears open his garment, revealing the wound to the gathered assembly (similar to how Tristan tears off the dressing of his wound upon learning of Isolde's arrival), referencing his "poisoned" blood. He proclaims that the Grail will only be revealed when one of the knights kills him as the final punishment for his sin of corrupting the bloodline of the brotherhood. Parsifal (accompanied by Gurnemanz and Kundry) then enters the temple:

(Parsifal ist, von Gurnemanz und Kundry begleitet, unvermerks unter den Rittern erschienen, tritt hervor und strecks den Speer aus, mit dessen Spitze er Amfortas' Seite berührt)

Nur eine Waffe taugt: die Wunde schließt der Speer nur, der sie schlug (III, ii)
[(Parsifal, accompanied by Gurnemanz and Kundry, has appeared unobserved among the knights and now steps forward and extends the Spear, touching Amfortas's side with its point) But one weapon serves: only the Spear that smote you can heal your wound.]

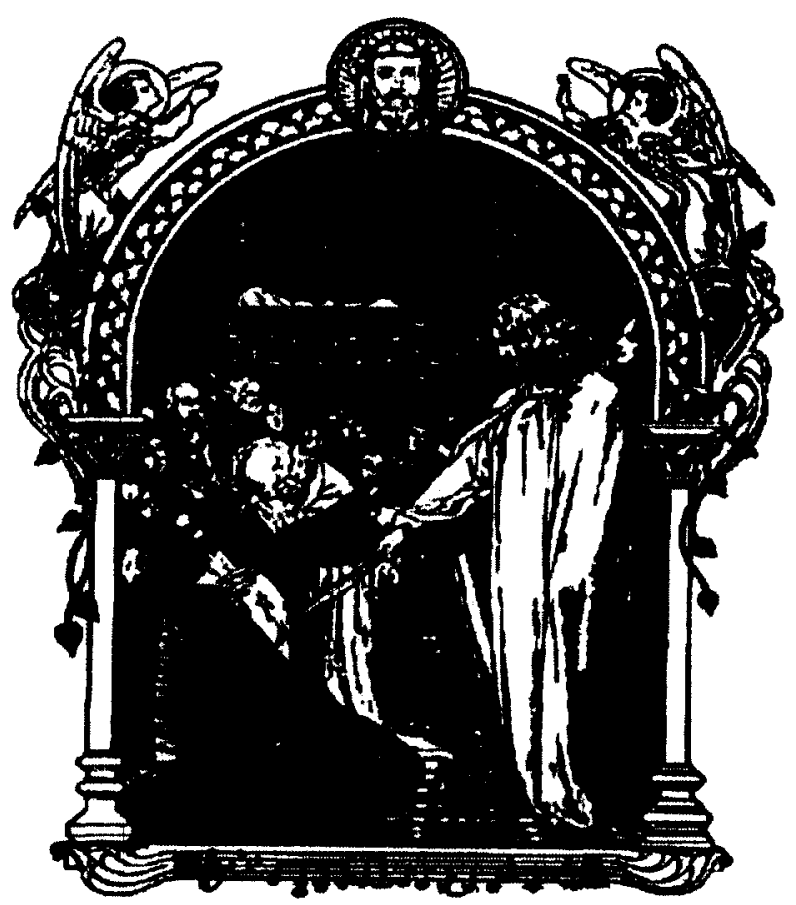

Fig. 2

"Parsifal Healing Amfortas" (Franz Stassen)

(Oliver Huckel, Parsifal: A Mystical Drama by Richard Wagner Retold in the Spirit of the Bayreuth Interptation by Oliver Huckel [New York, 1903], p. 57) 
This moment of healing is memorably represented in one of Franz Stassen's illustrations that accompany Oliver Huckel's retelling of the opera's story. ${ }^{167}$ In this image (Fig. 2), Parsifal is attired in an unblemished, flowing white robe stripped of any ornate accoutrements, with curled shoulder-length hair and beard, touching the spear against the wounded body of a somewhat emaciated-looking Amfortas. Parsifal is placed in the foreground of the image, the only figure standing and as such seems to tower over all and sundry who view the action with astonishment and supplication.

In terms of sonority, the music endeavours to frame Parsifal's body as acoustically superior, complementing his visual splendour. ${ }^{168}$ As Amfortas completes his proclamation that only his death will result in the Grail being revealed, the orchestra accompanies with the first half of the Grail theme; the first measure of Parsifal's entry is simultaneous with the "Dresden Amen" half of the theme, effectively underlining Parsifal's presence and actions as an important part of the German identity. The vocal line of his initial four measures (Ex. 4) outline respectively A major and C-sharp major chords, contrasting the agonized chromaticisms associated with Amfortas's suffering. But I offer the stage direction describing Amfortas's reaction as particularly suggestive: "Amfortas's features light up in holy ecstasy: he seems to stagger under overpowering emotion: Gurnemanz supports him." The surface reading of that description is that it naturally refers to Amfortas's feelings of euphoria in the wake of being healed, but at the risk of engaging in an exercise in post hoc ergo propter hoc, what if his feelings of

${ }^{167}$ Oliver Huckel, Parsifal: A Drama by Wagner Retold by Oliver Huckel (New York: Thomas Y. Crowell \& Co., 1903).

${ }^{168}$ Note a musical staff upon which the "Spear" motive is written is placed at the bottom of the image, as though the picture were reminding us that music is an element that is crucial to the action depicted. Stephen C. Meyer further discusses Stassen's illustrations and their incorporation of the opera's musical motifs in "Illustrating Transcendence: Parsifal, Franz Stassen, and the Leitmotif," The Musical Quarterly 92/1-2 (2009): 9-32. 
"overpowering emotion" are in response to something else? I propose a reading that interprets Amfortas's "holy ecstasy" as the type of "unsung voice" similar to the reception of Lohengrin's arrival and Grail narrative: Amfortas's jubilation does come immediately after his wound has been healed (and consequently, his blood being "purified"), but it also directly follows his hearing Parsifal's words and also the sounds that carry those words.

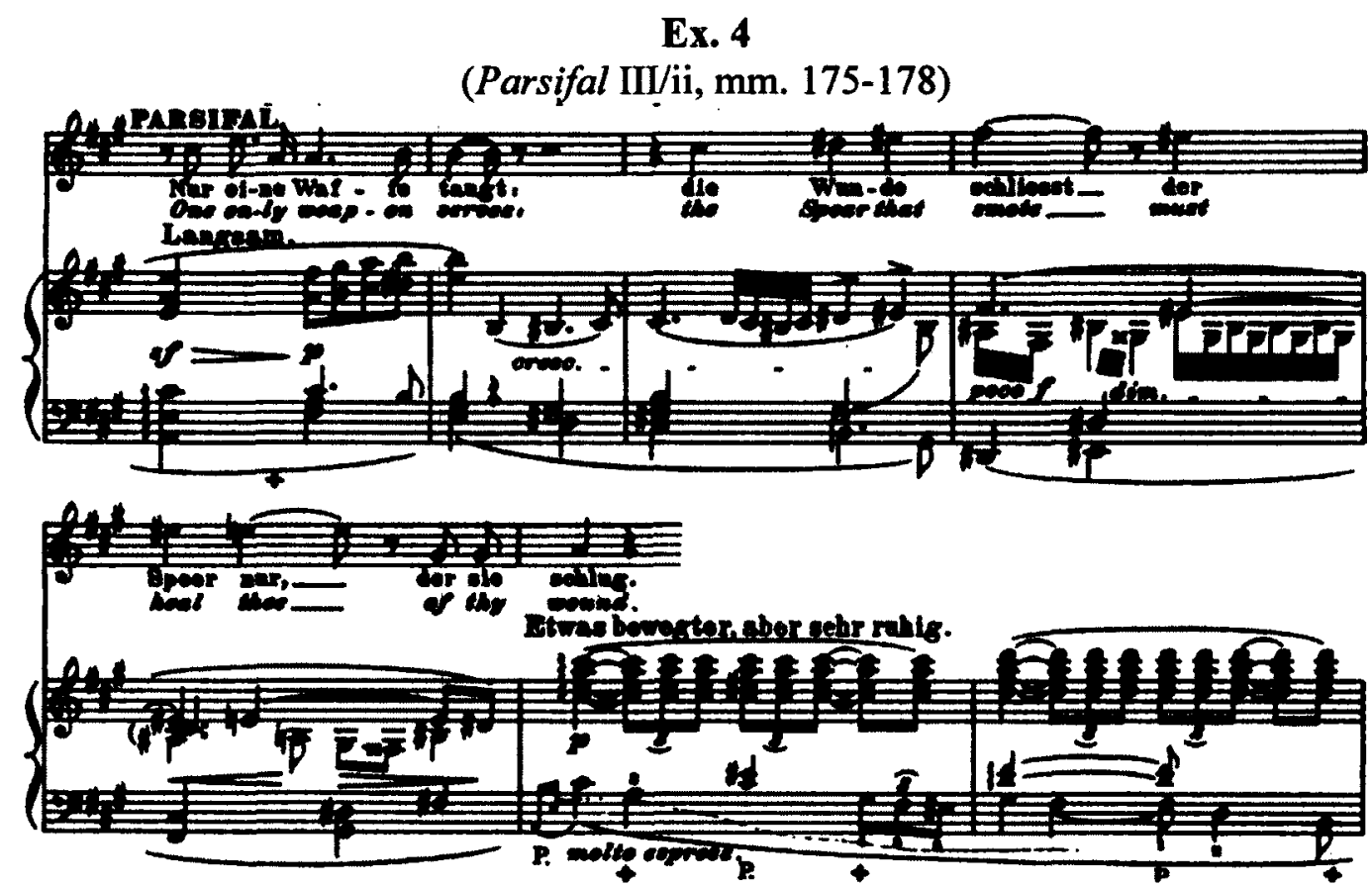

As I have just stated, this is something of a post-hoc observation, as there is nothing to definitively identify Parsifal's voice as a cause for Amfortas's joy beyond the fact that one occurrence directly follows the other. But consider the following observations in aggregate: firstly, the moment of Amfortas's healing coincides with what if for all intents and purposes his first hearing of the solo tenor sonority (he has no interaction with Parsifal during the first act); the import Wagner placed on the Heldentenor in defining the music drama; secondly, Wagner's writings in "Religion and Art" and the discourse of Kunstreligion (see Chapter Two), which elevated art to the 
level of religion to rescue Christianity from its longstanding corruption. Taken as a whole, I submit that it is Parsifal's voice, as a representative of the sacred power of German art, that is positioned as just as crucial to Amfortas's (and the kingdom's) revitalization as are his moral excellence and bodily purity. To hear Parsifal's vocal sonority simultaneously with his act of healing the wound essentially makes both complements of the other: the physical body cures Amfortas's ailment while the acoustic body declares him cured. Together, both aspects of Parsifal's body function as the instrument of Amfortas's salvation, which instils divine joy into his being. ${ }^{169}$

Subsequent to healing Amfortas, Parsifal proclaims that he will take up Amfortas's office and preside over the Grail ceremony from here on. He then presents the Spear to the knights and calls for the Grail to be revealed. The final stanza of Parsifal's oration arguably ties many of the work's dramatic themes together:

O! Welchen Wunders höchsters Glück! Der deine Wunde durfte schließen, ihm seh' ich heil' ges Blut entfließen in Sehnsucht nach dem verwandten Quelle, der dort fließt in des Grales Welle. Nicht soll der mehr verschlossen sein: Enthüllet den Gral, öffnet den Schrein! (III, ii)
[O supreme joy of this miracle! This that could heal your wound I see pouring with holy blood yearning for that kindred fount which flows and wells within the Grail. No more shall it be hidden: uncover the Grail, open the shrine!]

\footnotetext{
${ }^{169}$ Although not directly related to the preceding points, I nonetheless offer this remark from Wagner, towards the end of his appraisal of the 1882 performances of $P$ arsifal:

[W]e here were taught how much the German bandsmen's sense of beauty and fine feeling is susceptible of, when he knows himself released for a time from incompatible demands upon his faculties, to give his whole mind to the solving of higher tasks, imposed elsewhere in haste. Brought into through concord, with the singers by the proved acoustics of the installation, our orchestra attained a beauty and spirituality of expression already sadly missed by every hearer who returns to the gorgeous opera-houses of our great cities and has to suffer from their primitive arrangements for the band (SSD X, 307; PW VI, 311).
}

Although Wagner is primarily lauding the orchestra and the acoustics of the Festspielhaus, contained within the provided quote is an argument for the efficacy of sonorous beauty in cultivating spiritual rejuvenation of the German public. If beauty of tone within the confines of the auditorium is considered so vital to the health of the German people, I propose that there is a plausible basis for situating Parsifal's vocal production as part of Amfortas's healing process. 
The Spear, as Parsifal observes, drips with "holy blood": it was the instrument that pierced Christ's side during the crucifixion. But having just made contact with Amfortas's wound, the Spear also literally drips with the fallen knight's blood; the mingling of the blood of the two figures suggests that in healing the wound, Amfortas's literal blood has mixed with the blood of Christ that still symbolically adheres to the weapon's point. In mixing the two, Amfortas's blood is purified by the corruption from Klingsor's and Kundry's otherness, the first step in regenerating the (Aryan/Germanic) bloodline of the entire order. The regenerated blood longs to be reunified with the Grail, the chalice that caught Christ's blood after he had been pierced. That both holy relics have been touched by divine blood is instrumental to their power. In Wagner's adaptation of Wolfram's legend, the Grail itself is transformed from merely a ceremonial stone into "the final manifestation of [Wagner's] idea of an elemental energy that gives vitality and worth to life and is made accessible through the intercession of the hero. It incorporates the perfect unity of the subject and the world...."170 Wagner uses the Christian iconography of the Grail as a gloss to portray the object as a representation of the fundamental life-force of the German/Aryan race, the Grail's live-giving vitality having been bequeathed to it through its contact with pure blood.

Just as Parsifal has purged the sufferings of the brotherhood, the music is similarly purged of the emotional and psychological turmoil and physical agonies expressed in intense chromaticism and dissonance. As this Bühnenweihfestspiel comes to its close, its titular character has fulfilled his role as the messianic hero on two fronts: by revitalizing the Grail kingdom through regenerating Amfortas's blood and proclaiming

${ }^{170}$ Williams, 132. 
that the Grail shall never again be hidden away, ${ }^{171}$ Parsifal steps up to lead the knights with a sterling example. Meanwhile, his redemptory actions create the conditions for the music to be "rescued" from the chromaticism that heretofore delayed resolution. With chromaticisim (that is, tones and chords "in between" key centres) banished, Klingsor destroyed, and Kundry baptised and eventually dying, the end of Parsifal "can be construed as an allegory of the long-awaited conclusion of [the] process [of racial decay and regeneration]: the end of racial mixture that caused the whole problem in the first place - the welcome death of hybridity itself." 172 The erasure of hybridity is the ultimate moral example that Parsifal's heroism provides for the nation.

In terms of dramaturgy, these heroic acts are carried out under the auspices of the grand opera crowd scene. But like the "ballet" of the Flower Maiden scene, Parsifal approaches grand opera from a position of exteriority: Parsifal always remained at arms length from the Flower Maidens, never becoming a fully integrated part of the sequence. Here, Parsifal encroaches from outside on a ceremonial tableau that has been underway for several minutes, his entry essentially bringing the crowd part of the scene to a halt as he intones his monologue. Upon opening the shrine, Parsifal falls silent and the choral crowd resumes, this time joined by the ethereal, otherworldly sonorities of the Jünglinge and the Knaben voices high up in the dome (see Chapter Two). As the chorus listened to Parsifal, so too will Parsifal listen to the chorus, each showing the other respect. The difference between the two scenarios is that in the earlier one, Parsifal came from outside grand opera and remained outside as a rebuke to the most commercialized aspects of

\footnotetext{
${ }^{171}$ As Borchmeyer clarifies (239-240), this should not be inferred to mean that the Grail will be forever publically displayed, only that the ritual of opening the shrine during the Communion ceremony will no longer be refused, as Amfortas had done: the Grail will still be covered at the ritual's conclusion.

${ }^{172}$ Deathridge, 169.
} 
grand opera; for this finale, he traverses from outside to inside grand opera to effect the community's salvation. Parsifal comes before the public (in the guise of the chorus) to act as the conduit for the kingdom's redemption, and the public follows up by declaring themselves redeemed. Taken together, both sets of performing bodies mobilize the dramaturgy of the crowd scene to bring the divine into the theatre. Between the two scenes, we observe one aspect of grand opera used to critique its supposed decadence, and another used to carry out the final "consecration" of the stage that will regenerate both the German race and German art.

But Parsifal and Parsifal ultimately cannot be left as cut and dried as that: as with Lohengrin, the attainment of the perfected form of the nation must ultimately be revealed as a potent fantasy. The seed of such a revelation is planted in Parsifal's assumption of the duties of Amfortas's office. In doing so, Parsifal does not supplant Amfortas: in actuality, Parsifal for all intents and purposes vaults over Amfortas and stands in for the now-deceased Titurel, the father whose example Amfortas strove to follow but could not ultimately measure up. In assuming Titurel's role, Parsifal becomes the idealized Urfather that is the paternal imago figure, not only for Amfortas, but for the brotherhood as a whole. ${ }^{173}$ Parsifal is now the paternal figure against which the subservient knights define their identities. But of course, the imago is the unattainable object of desire: Parsifal's bodily perfection as an acoustic representation of the male imago must then be a phantasmatic that throws the fiction of a "regenerated," "purified" and plenitudinous German nation into relief. Parsifal's status as an imago is pointed up by the realization that the entire scenario that the opera's conclusion presents is fundamentally based upon an impossibility: according to "Religion and Art" and its supplements, the decay of the

\footnotetext{
${ }^{173}$ For more on Titurel as the paternal imago, see Kramer, "The Talking Wound," 214-216.
} 
German race is a process that is still ongoing, its proposed reversal not having happened yet. But recalling the arguments of Chapter Two, if we accept the denizens of the Grail temple as a proleptic community, then a proposed future for the nation is placed within a mythologized past: a regeneration that is theorized in one venue as not having happened yet is framed as having "always-already" occurred in another. This is consistent with what Borchmeyer identifies as one of the primary strategies in Parsifal's treatment of Christian narratives and iconography. He writes that "Christianity is stripped of its historicity in Parsifal and restored to the iterative structures of myth."174 Kramer also observes that through its origin in a medieval epic, "Parsifal not only uncovers a hidden historical trauma but also its cure. Parsifal's act of healing is 'historical,' but it has never entered history; it has no consequences. The modern world is anything but redeemed...."175 In his origins within the German mythos, Parsifal is both a part of German history and fundamentally ahistorical, in that he exists outside of history. He is recorded as having done something for the mythic German identity in its distant past that has not threaded itself into the "real world" tapestry of Germany's history. Parsifal and Parsifal locate a contradiction in German mythology and history where "always-already" and "not yet happened" both are presented as simultaneously true. As such, we might theorize the fantastic impossibility of Parsifal's idealized body standing in for the fictitious plenitude of the German nation as a focal point in a seemingly irreconcilable breach between myth and history: the unattainable impossibility of the body of the male imago finds its complement in the impossibility of a scenario where said body enacts a redemption of the German nation that is presented as part of history despite not having

\footnotetext{
${ }^{174}$ Borchmeyer, 239.

${ }^{175}$ Kramer, "The Talking Wound," 226.
} 
happened yet. In this we also see a particularly intriguing transformation of grand opera: where grand opera has typically exploited history as grist for its plots, Wagner has employed several of the musical and dramatic hallmarks of grand opera in service of a drama that on some level aims to fundamentally rewrite history. 


\section{Chapter Five}

\section{"So alt, und war doch so neu": The Wisely Heroic and the Heroically}

\section{Wise in Die Meistersinger}

\section{Nuremberg's Two Heroes}

The Ring and Parsifal were hardly unique as examples of Wagner's works that had a lengthy period of gestation from initial idea to completion. In My Life, Wagner claims that Hans Sachs and the Mastersingers' guild in sixteenth-century Nuremberg had begun to occur to him as fertile ground for a dramatic work during the same 1845 holiday in Marienbad that planted the initial seeds for Lohengrin and Parsifal. As Wagner recalls:

From a few remarks in Gervinus' History of German Literature, ${ }^{1}$ I had formed a particularly vivid picture of Hans Sachs and the mastersingers of Nuremberg. I was especially intrigued by the instruction of the marker and his function in rating master-songs. Without as yet knowing anything more about Sachs and his poetic contemporaries, I conceived during a walk a comic scene in which the popular artisan-poet, by hammering upon his cobbler's last, gives the marker, who is obliged by circumstances to sing in his presence, his come-uppance for previous pedantic misdeeds during official singing contests, by inflicting upon him a lesson of his own. To me the force of the whole scene was concentrated in two points: on the one hand the marker with his slate covered with chalk-marks and on the other Sachs holding the shoes aloft, completed as a result of his hammering the marks in, whereby both indicate that the singing has been a failure. To this picture I now added a narrow, twisting Nuremberg alley, with neighbors, uproar and a street-fight to close the second act - and suddenly my whole mastersingers comedy stood before me so vividly that, on the grounds that it was an especially merry subject, I felt justified in putting it on paper, despite the doctors' instructions. ${ }^{2}$

Both of the scenarios described above ended up in what ultimately became Die

Meistersinger von Nürnberg, both ending up taking place in the second act. ${ }^{3}$ Sachs notes

\footnotetext{
'Wagner is making reference to literary historian Georg Gottfried Gervinus' (1805-1871) Geschichte der poetischen National-Literatur der Deutschen, which was published 1835-1842.

${ }^{2} \mathrm{ML}, 303$.

${ }^{3}$ Wagner's recollection in My Life can on the whole be taken as accurate: John Warrack reproduces an outline dated July 6, 1845, its plot summary matching what was given in ML. Barry Millington further
} 
every error in marker Beckmesser's intended contribution to the song contest with a hammer-blow on his last (a foot-shaped form used by cobblers in order to mould shoes), finding so many faults that he is able to shape a completed pair of shoes, and the concluding riot that is precipitated when David, believing that Beckmesser is attempting to woo Magdalene, attacks Beckmesser. Wagner's first thoughts also suggest that one of the completed works' overriding conflicts - genuine creativity versus pedantic adherence to arcane rules - served a key element from its inception. Wagner's initial visions place Sachs at the forefront of a proposed Mastersinger drama; as Wagner later explains in $A$ Communication to My Friends (1851), he "took Hans Sachs as the last manifestation of the art-productive spirit of the Folk (Volksgeist)...." Perhaps conveniently, Wagner neglects to mention in "A Communication" that it was not exactly an original insight of his own to discern in Hans Sachs an outstanding representative of the intersection between the creative spirit and the collective identity of the German people. After all, Sachs was previously the subject of Lortzing's 1840 opera Hans Sachs, which Wagner mentions neither in My Life, nor "A Communication." The latter omission may owe to his assumption of knowledge of the earlier work on the part of the document's intended recipients (Liszt and Theodor Uhlig, most prominently) - as John Warrack notes, it is highly unlikely that Wagner was himself unaware of Lortzing's work. ${ }^{6}$ But Sachs's popularity as a dramatic figure extended even further back as both Lortzing and Wagner

corroborates the influence of Gervinus' text on the creation of that initial prose sketch. See John Warrack, Richard Wagner: Die Meistersinger von Nürnberg (Cambridge: Cambridge University Press, 1994), 3-5; Barry Millington, Wagner - Revised Edition (Princeton NJ: Princeton University Press, 1992), 246.

${ }^{4}$ SSD IV, 284; PW I, 329.

${ }^{5}$ In the latter text, Wagner grants Lortzing but a single mention in a footnote appending his account of the use of a "ready-made story" as grist for the libretto for Rienzi. Wagner's note observes that this was a common practice for Lortzing as well (SSD IV, 316n; PW I, 362n.).

${ }^{6}$ Warrack, 23. See Bernhard Schubert, "Wagners 'Sachs' und die Tradition des romantischen Künstlerselbstverständnisses," Archiv für Musikwissenschaft 40/3 (1983): 220-226 for an examination of Lortzing's opera in comparison to Wagner's. 
exploited the same dramatic source for their respective works: Johann Ludwig Deinhardstein's 1827 play, Hans Sachs. Additionally, at the play's 1828 performance in Berlin, it was prefaced by a 1776 poem by Goethe entitled Erklärung eines alten Holzschittes, vorstellend Hans Sachsens poetische Sendung ("Explanation of an old woodcut depicting Hans Sachs's poetic calling"). ${ }^{7}$ I do not intend to use these introductory pages to fully analyze the concurrences and divergences between Wagner's work and the earlier sources, but I invoke said sources to make the point that prior to Die Meistersinger, Hans Sachs had already been situated numerous times as a distinguished part of German cultural history; as a consequence, Sachs would plausibly appeal to Wagner as a productive symbol of Germany's artistic heritage and therefore an aspirational model for future efforts of creativity that would endeavour to be similarly infused with the collective spirit of the Volk.

Of course, Wagner's work conspicuously diverges from other representations of Sachs in that Wagner tasks the cobbler-poet with sharing the spotlight as principal character with another. In "A Communication," approximately ten years before the initial poetic drafts were put to paper, Wagner lays out a plot synopsis of his proposed Mastersinger drama that almost precisely matches that of the eventual finished opera: Wagner's nascent idea for the work envisions "a young nobleman who, inspired by the Heldenbuch and the songs of the ancient Minnesingers, forsakes the ruined castle of his ancestors to learn the Meistersingers' art at Nuremberg." In attempting to gain admittance to the guild, this nobleman baffles the assembly with his trial song and earns the enmity of the Marker, who sees in this stranger a potential romantic rival for the hand

\footnotetext{
${ }^{7}$ Ibid. and Dieter Borchmeyer, Drama and the World of Richard Wagner, trans. Daphne Ellis (Princeton and Oxford: Princeton University Press, 2003), 184-185.

${ }^{8}$ SSD IV, 285; PW I, 329.
} 
of the oldest Master's daughter, who has been promised to the winner of the forthcoming song contest. Only Sachs finds worth in this nobleman's song, and takes the young man under his wing. Through Sachs's tutelage (in combination with his own innate artistry), the nobleman is able to craft a song that is successful in guaranteeing him the woman's hand and prompts the Mastersingers to offer him entry into their guild.

All of the above plot elements found their way, without much alteration, into the eventually completed work, with the nobleman identified as Walther von Stolzing. The character is of Wagner's creation, but he is nonetheless made to bear a certain degree of lineage to prior sources: when the Masters inquire as to the identity of Walther's instructor, he claims that one "Walther von der Vogelweide" (who as we have seen, appears as a character in Tannhäuser) served as his teacher, a revelation that suitably impresses the artisans. Retreating momentarily from Wagner's fiction to real historical documents, Adam Puschmann's - a pupil of Sachs - Gründlicher Bericht des deudschen Meistergesangs (1571) contains a list of a dozen names identified as the first Mastersingers. The first name on this list is "herr Walther ein Landtherr von der Fogel weid," essentially the same name as the one Walther claims as his tutor. In making such an assertion, Wagner positions Walther as "already declaring an imaginative connection with the very origins of the art [of Mastersinging]." Walther's statement of artistic lineage resonates within Sachs's second-act observation that Walther's Trial Song sounded "so old and yet so new" to him: Walther's radical song scandalizes the conservative ears of the guild, and yet his professed artistic background grants him a connection to the essence of the Mastersingers' art. This connection manifests itself in the aforementioned Trial Song, which sounds incontrovertibly strange to most of the

\footnotetext{
${ }^{9}$ Warrack, 51.
} 
guild; however, discerning ears (such as those of Sachs) recognize concealed within the song's unconventionalities the distinct trace of the guild's poetic and musical traditions. Sachs recognizes that within Walther's offering lies the potential for a genuine Mastersong. With the proper nurturing, Walther's innate artistry can be mobilized to create a song that simultaneously advances the art of Mastersinging while preserving the enduring traditions of the guild that have granted it an artistic affinity with the spirit of the Nuremberg Volk.

Walther's part calls for a tenor, in contrast to Sachs's bass-baritone. Marc Weiner points out that Walther's vocal tessitura is generally higher than those of Tristan, Parsifal, and especially Siegfried. ${ }^{10}$ Indeed, Jens Malte Fischer's encapsulation of the history of singing Wagner conspicuously fails to include discussions of Walther in its section on the so-called Heldentenor." $\quad$ Carl Dahlhaus offers a potential explanation for Wagner's decision to adopt a more conventional musical language in order to give voice to Walther:

Wagner as a dramatist may have had the idea of furnishing Stolzing, as the representative of musical progress, with the kind of music that was recognized as progressive in the mid-1860s, but as an experienced man of the theatre he knew better: his triumphant heroic tenor needed music that would have an immediate appeal for the audience, who would identify with the crowd on stage. ${ }^{12}$

Dahlhaus's contention should not be taken as more than speculation. But it nonetheless demonstrate a recognition that Walther's music, his sound is of a more "conventional" brand than that of Siegfried, given as it is to a more traditional

\footnotetext{
${ }^{10}$ Marc Weiner, Richard Wagner and the Anti-Semitic Imagination (1995) (Lincoln and London: University of Nebraska Press, 1997), 173 and 381 n66.

${ }^{11}$ Jens Malte Fischer, "Sprechgesang or Bel Canto: Toward a History of Singing Wagner," Wagner Handbook, trans. John Deathridge, eds. Ulrich Maller and Peter Wapnewski (Cambridge, MA and London: Harvard University Press, 541-546.

${ }^{12}$ Carl Dahlhaus, The New Grove Wagner (1990), quoted in Weiner, 174.
} 
melodicism and lyricism. Yet, the fact that Walther - characterized as almost the prototypical artistic genius - is sung by a tenor is significant: Walther may not be the only solo tenor sonority in the opera, but his role grants him significantly more prominence than the rather minor roles assigned to the various members of the guild, and his specific timbre is noticeably "heavier" and more dramatic than the comparative sprightliness of David (whose position as an apprentice to Sachs clearly establishes him in a subordinate role). Moreover, Wagner's reference to the Heldenbuch - a collection of thirteenth-century German epic poetry - as a point of origin for his proposed nobleman's character and conduct is clearly intended to situate Walther within the discourse of the heroic. Of course, Wagner's outlook vis-à-vis the intersection between art and politics had shifted from the "revolutionist" thinking that informed his initial 1845 prose draft and the remarks in "A Communication," to the more monarchist leanings of the 1860 s when he was composing the libretto and the music. ${ }^{13}$ Nonetheless, a conception of Walther as a heroic figure survives into the final libretto. Walther's brash iconoclasm demonstrated during his initial trial, and his subsequent disdain for the perceived parochialism of the Mastersingers, resonates within Simon Williams' model of the individualistic "romantic hero," who is guided by his emotions and frequently situate themselves in opposition, if not outright defiance of "conventional" society. ${ }^{14}$ But as James Garratt notes, even as early as the 1845 prose draft (where Walther is only identified as a "Young Man"), the resolute non-conformist that is the romantic hero is not held up as the idealized embodiment of German culture:

\footnotetext{
${ }^{13}$ Paul Lawrence Rose, Wagner: Race and Revolution (New Haven and London: Yale University Press, 1992), 102-118 and James Garratt, Music, Culture and Social Reform in the Age of Wagner (Cambridge: Cambridge University Press, 2010), 192-196.

${ }^{14}$ Simon Williams, Wagner and the Romantic Hero (Cambridge: Cambridge University Press, 2004), 8-13.
} 
In the 1845 draft, the Young Man, son of an impoverished knight, spurns the outmoded world of chivalry only to embrace another superseded form; for him, the "beautiful poetic life" of the mastersingers serves as compensation for a "repugnant" reality. Aesthetically, therefore, this draft repudiates not one but two forms of art cut off from contemporary needs: one hidebound by old-fashioned rules and one which intentionally alienates itself from the community. ${ }^{15}$

In the final libretto, Walther's initial poetic and musical contribution follows no rule that the Mastersingers can discern, and indeed as Sachs subsequently notes in his offering of praise that the song seems to establish its own internal rules. In his second-act rumination, Sachs adds that although it followed no pre-determined rule, it contained no obvious fault either. However, this initial act of artistic radicalism is conspicuously not the site of his ultimate triumph, nor is it held up by even Walther's lone supporter in Sachs as the ideal Mastersong: it might be innovative and demonstrate an instinctive artistic talent, but it is also undisciplined in its newness. Walther's ignorance of the guild's poetic and musical rules and their traditions is decidedly not foregrounded as Walther's most admirable artistic trait, and his hostility to the guild and its membership is pointedly rebuked by Sachs as it momentarily resurfaces when Walther obstinately refuses membership after having won the song contest. Artistic radicalism that is undertaken solely for the purpose of defying convention will not produce art that is informed by the spirit of the Volk; in other words, art must not aim to intentionally "alienate itself from the community." In the third act, when Sachs guides Walther through the transformation of his dream into poetry, he maintains, in John Warrack's words, that "to sing when young is one thing, but to preserve art when older demands

\footnotetext{
${ }^{13}$ Garratt, 192.

${ }^{16}$ Garratt notes that in the 1864 essay "On State and Religion," Wagner identifies the purpose of singing as fostering communal health. However, Garratt also points out that in the final libretto of Meistersinger, Wagner essentially reverses positions, arguing that art is not necessarily created to benefit communities, but that communities better themselves through devotion to art (194-195).
} 
mastery; the Mastersinger's rules must be learnt early, for they had been formed so as to preserve what was good." ${ }^{17}$ For Walther to win the contest, he must craft a song that integrates the poetic traditions of the guild - preserving what is "good" about the Mastersingers' art - into the new. As Walther works his way through the Stollen and Abgesang of each Bar, ${ }^{18}$ Sachs continually counsels him on how to choose the poetic themes of each stanza and relate them to each other, and how to construct the melody. After Walther completes the first two Bars of the song (the third providing Walther with some difficulty and left until the contest), Sachs will "baptize" the song during the famed quintet, which goes on to greatly move the Mastersingers and citizens alike.

It is this relationship between Sachs and Walther, where the bass-baritone (Sachs) provides tutelage to the dramatic/heroic tenor (Walther) that is crucial to the central arguments of this chapter, which endeavours to synthesize the various strands of theory and history that have been introduced and discussed in this dissertation's previous chapters in order to bring it to a close. In Meistersinger, the bass role mentors the tenor role into tempering the latter's innate predilections towards innovation with a respect for and incorporation of tradition, not to reject convention solely for the sake of rejecting it. The implementation of Sachs' teachings creates the conditions of possibility for Walther's climactic crowning as the embodiment of the new breed of Mastersinger, who produces a song that the veteran Mastersingers acknowledge as artistically bold yet is still

\footnotetext{
${ }^{17}$ Warrack, 45.

${ }^{18} \mathrm{Bar}$ form is a poetic-musical structure favored by the original Mastersingers and adapted by Wagner for the opera. It essentially follows an $\mathrm{AAB}$ structure, with an Aufgesang consisting of two Stollen (stanzas) forming the A section, and a final stanza, the Abgesang, making up the B section. As Wagner presents the form, a Bar consists of a single stanza of a song, with Walther's Prize Song being made up of three Bars; for the original Mastersingers, a Bar made up the entire song. Bar form in Meistersinger is discussed in Warrack, 111-115. The early twentieth-century Austrian music theorist Alfred Lorenz argued in his fourvolume Das Geheimnis der Form bei Richard Wagner (1924-1933) that Bar form was one of the fundamental structures employed in Wagner's works. See Stephen McClatchie, Analyzing Wagner's Operas: Alfred Lorenz and German Nationalist Ideology (Rochester: University of Rochester Press, 1998).
} 
recognizable within their established forms. ${ }^{19}$ To reduce the relationship between Sachs and Walther to its barest essentials, the bass sonority comes to be aligned with tradition and the past, while the tenor stands in for innovation and the future.

Of course, while Walther reigns victorious in the song contest and gets the girl, he steps aside to cede the final public benediction to his mentor, Sachs. His plea for the citizens of Nuremberg to honour the Mastersingers as the protectors of "Holy German art" (and by extension, the protectors of the sanctity of German culture in general) is met with the public proclamation of "Nuremberg's dear Sachs!" The overwhelming public acclaim for Walther and then Sachs anoints them jointly as the ideal representatives of the city's artistic life: the latter as the guardian of tradition who nonetheless keeps on open mind towards new ideas, and the former as the genius who possesses the innate talent to carry out Sachs's ideals. Together, they stand before the Nuremberg community - and, recalling the discussion of the mythos of Nuremberg in the formation of German identity in Chapter Two, the nation entire ${ }^{20}$ - as the "sterling moral examples" for the populace; in coming to accept Sachs's teachings as wisdom, Walther makes the transition from the brash romantic hero of the first act to join Sachs as a messianic hero for the city/nation. ${ }^{21}$ As a consequence, unlike Lohengrin and Parsifal, Meistersinger foregrounds two characters and two performing bodies as triumphant figureheads of German art, each representing one side of the tradition/innovation dichotomy, coming

\footnotetext{
${ }^{19}$ Lawrence Kramer has noted that the issue of tutelage in the earlier nineteenth-century carried with it numerous instances of identity politics. In particular, Kramer observes that in the discourse of musical tutelage, the ideal that the student worked towards was to eventually declare independence from the mentor. Under this paradigm, Walther's triumph marks the moment where he has conclusively demonstrated that he has fully mastered the lessons of his teacher (Sachs), and thus is an individual artist. See Classical Music and Postmodern Knowledge (Berkeley: University of California Press, 1995), 150157.

${ }^{20}$ Borchmeyer, 183-184 and Stewart Spencer, "Wagner's Nuremberg," Cambridge Opera Journal 4/1 (March, 1992): 21-41.

${ }^{21}$ Williams, Wagner and the Romantic Hero, 16-19.
} 
together to bridge that divide. In this work, there are two figures who serve as the heroic flag bearers of "holy German art."

Walther and Sachs are constructed as ideal representatives of the poles of German art in scenes whose dramaturgy are clearly derived from grand opera. Indeed, of Wagner's later works, Die Meistersinger is arguably the one that owes the greatest amount to grand opera. As Robert Gutman remarks, Wagner's disciples were astonished that he had produced a "historical opera in the manner of Meyerbeer."22 Thomas Grey notes that Gutman's claim is somewhat overstated, but concedes the clear influence of the Parisian dramaturgy on the work, which is rife with "distinct arias, marches, choruses, a rousing crescendo finale, a ballet and elaborate ensembles topped by...a quintet."23 Grey singles out the numerous instances of ensemble and choral writing typical of grand opera, which Wagner "brought to a new and unsurpassed peak of complexity" in terms of

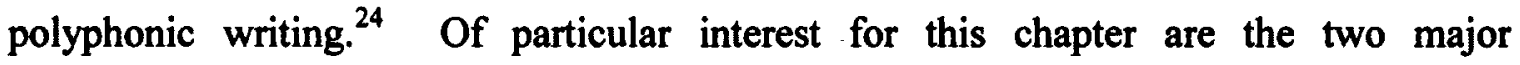
ceremonial/crowd scenes in the work: the first act's meeting of the Mastersingers' guild, culminating in Walther's Trial Song and the third act's climactic song contest (the former is not really a scene for the chorus, but the complex amalgamation of a large number of solo voices and ensembles renders this very much a crowd scene). Chapter Two has established how ceremonial and crowd scenes were employed as a strategy for creating the visual and sonorous image of a unified mass. In these two scenes, the solo voices of Sachs and Walther are set in contrast with the assembled throng, as much through the poetic content of their vocalizations as through their own sonorities. It is in part through

\footnotetext{
${ }^{22}$ Robert W. Gutman, Richard Wagner: The Man, His Mind, and His Music (1968), quoted in Thomas Grey, "Richard Wagner and the Legacy of French Grand Opera," The Cambridge Companion to Grand Opera, ed. David Charlton (Cambridge: Cambridge University Press, 2003), 341.

${ }^{23}$ Gutman, quoted in Grey, 341.

${ }^{24}$ Grey, 340.
} 
the ceremonial aspect of these respectively private and public gatherings that Walther and Sachs are elevated to their particular positions with regards to the function of art; in other words, it is their participation in this aspect of grand opera that solidifies their status as acoustic representatives for Wagner's ideal of German art.

As I will argue shortly, in the first act guild meeting, it is the force of numbers for the crowd that officially marks Walther as the representative of innovation. Through their stupefied and scandalized reactions, the assembled Masters and apprentices recognize Walther's music, his timbres, and his methods of melodic construction as completely beyond their comprehension. As the solo voice that precipitates this commotion, Walther's unique sonority as a "heroic" tenor is made to stand out from the crowd: its sonorous and musical uniqueness contrasts with the din of the ceremonial crowd scene and justifies itself as a sound previously unheard by the Mastersingers, one that is too original for the well-meaning but hidebound guild to understand. As the sole source of support for Walther's audition, Sachs similarly stands out from the crowd. In terms of sound, Fischer notably positions Sachs as an example of a "heroic" baritone, whose tessitura generally occupies the upper-third of the bass register. ${ }^{25}$ Moreover, Fischer singles out Sachs as a particularly demanding role amongst Wagner's baritones, not so much due to technical difficulty, but for the fact that Sachs is required to be on stage for a significant length of time, giving voice to a wide range of moods and emotional states. ${ }^{26}$ Beyond the "heroic" baritone sonority, Sachs is positioned as distinct from the grand opera crowd in his open-mindedness to new sounds and new poetic forms, because in Joachim Köhler's words, "Sachs is well aware of the [Mastersingers'] rules

\footnotetext{
${ }^{25}$ Fischer, "Singing Wagner," 531-532.

${ }^{26}$ Tbid., 533-535.
} 
but is also clear about their limitations."27 As such, Sachs constructs for himself a unique role within the din of this particular grand opera ceremonial scene: the voice of appreciation for Walther's new sounds, and an understanding that such newness could eventually be harnessed to make a comfortable fit within the guild's musical culture. Sachs takes advantage of grand opera to openly display his ear for innovation in front of a crowd.

The conflict that had been introduced during the guild meeting is paid off during the song contest, a more typical example of a ceremonial crowd scene due to the presence of the chorus. Walther steps before the crowd and delivers his Prize Song, which leads the crowd (consisting of both the Mastersingers and the assembled Volk) to acclaim the song's beauty and musicality; as the Mastersingers observe, the song is "bold and strange" but at the same time "well-rhymed and singable." 28 The Volk also observe that "so gracious and familiar, however far off it soars, but we seem to be experiencing it with him!" At the conclusion of the song, they exclaim "lulled as if in the most beautiful dream I hear it well, but scarcely grasp it!" The chorus acknowledges that the song is both familiar and new, and although they recognize its beauty, in saying that they can "scarcely grasp" the content of the song, they also concede that as accessible as the song may be, it is borne of a talent that is greater than any of their capacities to match for themselves.

In each of the scenic examples from the work, I will examine how Walther and Sachs are situated within the dramaturgy of grand opera as somatically idealized

\footnotetext{
${ }^{27}$ Joachim Kohler, Richard Wagner: The Last of the Titans, trans. Stewart Spencer (New Haven and London: Yale University Press, 2004), 491.

${ }^{28}$ Unless otherwise noted, all quotations and translations from the libretto come from Peter Branscombe (Decca, 1997).
} 
representatives of German art, in their capacities as producers of beautiful sonorities. These beautiful acoustic bodies intersect with the discourse of the heroic to frame Walther and Sachs as heroes of German art. Additionally, this chapter will re-incorporate the discussions of Kunstreligion, Borchmeyer's conception of Nuremberg as "aesthetic utopia," and the paradigm of the proleptic community from Chapter Two; as that chapter argued, the public reception of the Volk, envoiced in the form of the grand opera chorus was instrumental in situating the Prize Song as an outstanding example of German art and in constructing Nuremberg as the aesthetic utopia where art was elevated to the level of religion. In this chapter, I will examine the other half of the equation where the solo voices of Walther and Sachs, placed within the context of grand opera, sonorously make their case for Nuremberg as an artistic utopia devoted to Kunstreligion, a case to be validated by the ceremonial crowd. In the first act, the bafflement of the crowd underlines the newness of Walther's art and positions Sachs's forward thought in opposition to his fellow Mastersingers, while in the third act the validation is successfully attained.

The status of Nuremberg as proleptic community provides the greatest point of distinction between the argument of this chapter and that of the previous chapter. Chapter Four put forth the Wagnerian tenor as an acoustic example of a male imago figure for the nation, and as such a model of perfection that was perpetually deferred; this chapter mobilizes the concept of prolepsis to put forth the idealized performing bodies of Walther and Sachs as not an unattainable object of desire, but having been "alwaysalready" existing. By not aligning the performing body with the narratives of Christianity and issues of racial "regeneration," but with discourses of art and its own inherent 
religiosity, the opera is able to present a scenario where the idealized bodily image of the nation is not only attainable, but a manifest reality. Recalling that Meistersinger's form of prolepsis projects the nineteenth-century festival culture (presented in the form of a grand opera ceremonial scene) back into sixteenth-century Nuremberg, then the performing bodies of Walther and Sachs are simultaneously put on stage as crucial elements of a contemporary nineteenth-century performance while being implanted into German history. As such, the idealized performing bodies of Walther and Sachs effectively exist as messianic heroes of German art in the present and the past; in performing Die Meistersinger on the nineteenth-century stage, German art is elevated into religion in contemporary real-time while said elevation is concurrently presented as a part of the nation's mythic history. In contrast to the "Christian" operas, the somatic avatars of German art in Die Meistersinger are not presented as unattainable imago figures: at the work's conclusion they are not alienated from the Nuremberg they have endeavoured to serve, but are rather very much integrated into the community as beloved leaders. Nor do they represent a cultural or racial redemption that has not yet occurred in the "real" Germany. Sachs and Walther are rejuvenating German art both right now on the operatic stage and back then during the era of the narrative's setting. In transitioning the religious element from the traditional liturgy to that of art, the proleptic community of Wagner's Nuremberg arguably stages the nation at its most triumphant: rather than staging perfected performing bodies as a strategy for projecting the "redeemed" nation into a hoped-for but inevitably deferred future, I submit that the performances of the "heroic" Walther and Sachs bring into being a work of art, and therefore a nation that 
stands victorious always-already: the very existence of and the act of performing Die Meistersinger, I will contend, stands as the proof.

\section{Walther Strikes Out}

Before delving into Walther's Trial Song, it is necessary to make some remarks about Walther himself and how the opera establishes him as a character and a performer. Particularly interesting are remarks that Eva makes about Walther. As Köhler writes, "like Senta and the Dutchman, Eva first saw her Walther in a picture, in this case that of the biblical hero David - not, she insists the bearded king of the Jews who is emblazoned on the sign of the Mastersingers' guild but [painter Albrecht] Dürer's flaxen-haired youth who slew his adversary Goliath."29 Lydia Goehr has noted that Dürer in all likelihood never actually produced an image such as this. ${ }^{30}$ However, Eva's likening of Walther's physical appearance to this (invented) portrait simultaneously bestows upon the knight a physical beauty commensurate with that of the Biblical hero, but also what will amount to a prophecy: just as the Biblical David will overcome a seemingly implacable physical force, Eva's "David" (Walther) will pull off a miraculous feat in defiance of similarly overwhelming odds. "David"'s feat will be victory in the song contest with only the briefest amount of training. The giant to be felled is the increasingly hidebound nature of the guild's adherence to its rules and its skepticism (and in Beckmesser's case, hostility) towards Walther's abilities. David's triumph is borne of physicality, while Walther's is derived from artistry. But in comparing David's physical beauty as seen in the picture to Walther's, Eva will plant the suggestion that Walther's handsome visage might prove to be the outward representation of the innate artistic genius that will secure his victory.

\footnotetext{
${ }^{29}$ Köhler, 495.

${ }^{30}$ Lydia Goehr, "“-wie ihn uns Meister Dürer gemalt!': Contest, Myth, and Prophecy in Wagner's Die Meistersinger," Journal of the American Musicological Society 64/1 (Spring 2011): 52. 
Additionally, in her curt dismissal of the suggestion that the picture of David that she observed is the image of the long-bearded (read: "old") King David of the Old Testament adorning the coat-of-arms of the Mastersingers' guild, Eva suggests that the guild represents an agedness that she wishes to pass over in favour of the youthful beauty of Dürer's David in the form of Walther. This presages the opera's forthcoming conflict and eventual resolution, as the "old" in the form of the more reactionary elements of the guild's rules and traditions gives way to the "young" in the form of Walther's poetic and musical invention. ${ }^{31}$ The mythical young "David" that slew Goliath finds its embodiment in a Franconian knight who will eventually slay the forces of artistic stagnation, an embodiment that will share the pulchritude of Dürer's supposed picture. ${ }^{32}$

But as his audition piece in front of the guild will attest, it will not be an easy giant to topple. Before Walther even begins his Trial Song, the Masters express their doubts about his eligibility to even undergo trial, and demand justification of the legitimacy of his artistic lineage. As previously stated, ceremonial/crowd scenes such as this are frequently deployed in grand opera in order to bring a multitude of voices together in a display of inclusion and solidarity. Wagner conspicuously eschews that tendency during this scene. The Masters' skepticism of Walther's bid for membership acts as a prelude to a ceremonial scene that will display major divisions between the views expressed by the various participants in the scene, which can be boiled down to:

\footnotetext{
${ }^{31}$ Ibid., 56.

${ }^{32}$ In characterizing Walther's victory as the work of a "Prometheus-figure," Carl Dahlhaus further underlines the mythic resonance of Walther's achievement. In stealing the power of fire from the gods, Prometheus defies seemingly insurmountable opposition, just as David does in slaying Goliath. Walther's Promethean act is to appropriate the Mastersingers' traditions to reform it into a "'new art' that triumphs over the outmoded, fossilized rules of the guild of mastersingers" and present that new art to the Volk and the guild itself. Whether considered through the lens of Hellenic or Judeo-Christian tradition, Walther's triumph has positioned him as a figure with a lineage to Biblical/Classical narratives of heroism. See Carl Dahlhaus, Richard Wagner's Music Dramas (1971), trans. Mary Whittall (Cambridge: Cambridge University Press, 1979), 65.
} 
Walther's Trial Song itself, the Master's bafflement at said song, and Sachs's encouragement for Walther to continue in spite of the guild's recriminations. As the scene (and the act) proceeds towards its conclusion, each of these positions is set against each other in increasingly complex counterpoint. This is a scene where ceremony serves to reveal the schisms in the assembled group rather than its unity.

That sense of discord is intensified by the initial stanzas of Walther's offering. In announcing that the poetic theme of his song will be love, Walther lays the groundwork for his eventual ascendency as, in Goehr's words, "the estranged and individual artist who contributes to the mastersingers' art by virtue of his not obeying the rules, but, rather, of his either breaking or reinterpreting them as his love - doubly for woman and art - dictates." ${ }^{\text {33 }}$ However, as Nicholas Vazsonyi observes, Walther is not a complete outsider to the guild, as Kunz Vogelgesang notes that during his introduction to the Masters "Walther has just sung 'two nice verses' (zwei artige Stollen), i.e. that even when speaking informally Walther spontaneously communicates in traditional forms. ${ }^{.34}$ Even though Walther has no formal training in the art of mastersinging (and indeed, had no idea what it was before the beginning of the opera), Walther's inherent artistic sense still grants him a deep instinctive connection to the very essence of the guild's art (recall Walther's claim to have studied the poetry of Walther von der Vogelweide). It would appear that his devotion to art is so deep that even his everyday conversation bears the imprint of poetic verse.

\footnotetext{
${ }^{33}$ Lydia Goehr, The Quest for Voice: On Music, Politics, and the Limits of Philosophy (Berkeley: University of California Press, 1998), 57.

${ }^{34}$ Nicholas Vazsonyi, Richard Wagner: Self-Promotion and the Making of a Brand (Cambridge: Cambridge University Press, 2010), 154.
} 
Even given Walther's instinctive affinity for the Mastersinger traditions, the song he produces only succeeds in stupefying most of the guild. Carl Dahlhaus argues that Wagner's very construction of the Trial Song shows the notion of Walther's supposed intrinsic but unharnessed genius to be illusory. The "line and rhyme schemes are so complicated that the ability to compose a song to them as immaculately as Walther does presupposes the most intense effort and application." 35 As Warrack observes, the Trial Song in its entirety turns out to be a complex modification of the standard Bar form, where the first two Stollen (which encompass the song as it is heard up until Beckmesser's interruption) form an "A1-B1/A2-B2" structure; Walther sings an Abgesang as a $\mathrm{C}$ section following Sachs's encouragement. ${ }^{36}$ This is, as Warrack notes, a novel transformation of the traditional AAB structure, and indeed Beckmesser interprets the A1-B1/A2-B2 form as a completed ABA, which prompts his outburst. The quotation below provides four couplets that show the $\mathrm{A} 1 / \mathrm{A} 2$ and $\mathrm{B} 1 / \mathrm{B} 2$ parallel:

A1

So rief der Lenz in den Wald, daß laut es ihn durchhallt... A2

So rief es mir in die Brust, als noch ich von Liebe nicht wußt...
B1

Der Wald, wie bald antwortet er dem Ruf, der neu ihm Leben schuf...

B2

...Die Brust wie bald antwortet sie dem Ruf der neu ihr Leben schuf...
[A1: Thus spring cried to the forest so that it re-echoed loudly...A2: That was the call in my breast when it was still ignorant of love...]
[B1: The forest, how soon it answers to the call which brough it new life...B2: The breast, how soon it answers the call which brought it new life...

\footnotetext{
${ }^{35}$ Dahlhaus, 69.

${ }^{36}$ Warrack, 114.
} 
The song is too long to reproduce the entire text in this document, but I invoke Warrack's observations to bolster the observations that Dahlhaus makes about Walther's textual originalities. To return to Dahlhaus's appraisal, the fact that the complexities of Walther's text and its structure tend to problematize notions of instinctive invention should not be taken as an example of failure on Wagner's part. As Dahlhaus writes, the paradox of art professed to be produced effortlessly, yet clearly requires a great deal of effort

[I]s not, of course, an accidental oversight on Wagner's part; rather, it encapsulates the esoteric artistic philosophy of Die Meistersinger, as opposed to the exoteric philosophy represented by Sachs, to say nothing of the confrontations between Beckmesser and Walther or Sachs. Wagner's fundamental aesthetic conviction... was that art, in order to be art, must conceal itself and appear in the guise of nature. The means and expedients must not be allowed to be visible, reflection must be transformed into spontaneity, immediacy must be recreated and still be immediacy, and every trace of effort must be expunged. The paradox is that it takes technique to deny technique. But in Walther the contradictions are resolved in a utopian image: artistry is his natural lot, he improvises what can only be achieved by reflection. ${ }^{37}$

If the Trial Song is of sufficient textual complexity to baffle nearly all and sundry,

how is that complemented by the music? Vazsonyi offers this appraisal:

Carried by rising chromatic waves in the strings, he moves rapidly up the F-major scale, ending on a massive dominant-seventh chord - which even hints at a ninth chord - that sets up the roller-coaster ride to follow. Walther's song has a kind of pulsating momentum and an unending harmonic freedom not yet heard in the opera, so the rejection by the masters is quite understandable: they are shaken to the core...Walther's song seems like gibberish to [them].... ${ }^{38}$

Again, to reiterate Dahlhaus's point, the "unending harmonic freedom" and "pulsating momentum" of the music contained both in Walther's vocal line and in the orchestral accompaniment required a significant amount of compositional work on the part of Walther/Wagner. Nevertheless, its restless activity suggests an inference of the type of

\footnotetext{
${ }^{37}$ Dahlhaus, 69-70.

${ }^{38}$ Vazsonyi, 156-157.
} 
wild, "made up as he goes" quality that suggests an extended improvisation that follows the muse without consideration for any such matters as rules or traditions.

\section{Ex. 1}

(Die Meistersinger $\mathrm{I} / \mathrm{iii}, \mathrm{mm} .721-728)$
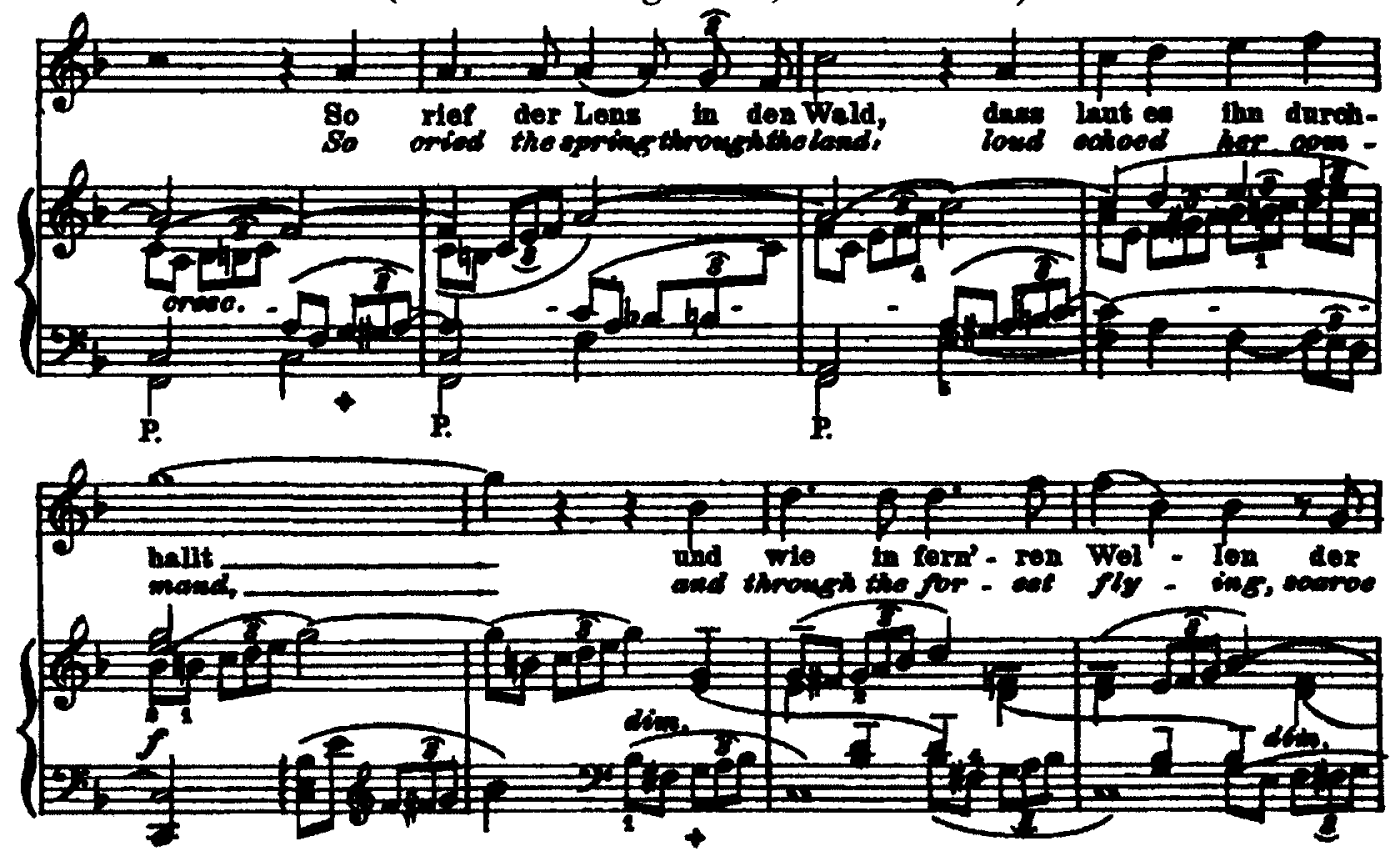

Beckmesser complains that the song contains "no coloratura anywhere and not a

trace of melody" (kein Koloratur, von Melodie auch nicht eine Spur!), the linkage suggesting that the two are complements of the other. Fellow Masters note their agreement saying "who calls that singing?" (Wer nannt das Gesang?) Weiner observes that for Wagner, coloratura (and other forms of florid vocal ornamentation) signified music that was antithetical to genuine German artistry; Beckmesser's propensity for a surfeit of ornamentation thus marks him as ethnically and artistically "other" to the Germans. ${ }^{39}$ Weiner goes on to note that the vocalization of the other Masters (Kothner is

\footnotetext{
${ }^{39}$ Weiner, 119-122. Weiner contends that Beckmesser's musical "otherness" is intended to be understood as a sign of his "Jewishness." This is consistent with Theodor Adorno's reading of the character of Beckmesser. It has also been argued that Walther's reference to himself as a magnificent bird - a bird that Beckmesser wishes to stop singing - in the final portion of his song invites one to compare Beckmesser to the titular figure in the Grimms' story "The Jew in the Thornbush," who endeavours to silence the singing of a songbird. The Jew's comeuppance eventually comes when he is forced to dance on the thoms. Compare this result to Beckmesser's public humiliation during the song contest. See Theodor Adorno, In
} 
singled out) during the scene also demonstrates a marked amount of ormamentation. Weiner considers this proof that "Wagner makes it clear that the very (to Wagner's mind, reprehensible) music Beckmesser champions has already, by the beginning of the work, begun to infiltrate the acoustical discourse of other members of the Meistersinger guild as well. Beckmesser's coloratura poses a danger to the future of German art....,40 As a consequence of this pernicious influence, the guild is presented as losing its way, drifting away from the essence of German art in favour of the trappings of the foreign. Grey has notably taken Weiner's tendency to characterize instances of vocal ornamentation in Wagner's work as representations of ethnic Otherness to task as an overly simplistic and superficial reading. ${ }^{41}$ Indeed, Beckmesser's "dangerous" influence need not necessarily be associated with "Jewishness" as Weiner insists, but simply with unartistic pedantry, "German or otherwise." ${ }^{" 2}$ These criticisms are well taken and hard to dispute, and to that I would add that Weiner assumes the veracity of his proposed cause-and-effect of Beckmesser's pedantry leading the guild down a primrose path without sufficiently considering that it is just as likely that the reverse may be the case, or even that the relationship between Beckmesser and the Masters apparent decline is altogether more

Search of Wagner (1952), trans. Rodney Livingstone (London and New York: Verso, 2005), 10-13; Barry Millington, "Nuremberg Trial: Is There Anti-Semitism in Die Meistersinger?" Cambridge Opera Journal $3 / 3$ (November, 1991): 247-260; David J. Levin, "Reading Beckmesser Reading: Antisemitism and Aesthetic Practice in The Mastersingers of Nuremberg," New German Critique 69 (Autumn 1996): 127146; Hans Rudolf Vaget, "'Du warst mein Feind von je': The Beckmesser Controversy Revisited," Wagner's Meistersinger: Performance, History, Representation, ed. Nicholas Vazsonyi (Rochester: University of Rochester Press, 2003), 190-208. A German-language consideration of the issue may be found in Reinhard Metzger, "Eine geheime Botschaft in Die Meistersinger von Nürnberg und Parsifal: Jüdisches, Christliches, und Antisemitisches in zwei Werken von Richard Wagner," The German Quarterly 80/1 (Winter 2007): 20-41. Borchmeyer has been a vocal critic of the reading of an anti-Semitic agenda in the characterization of Beckmesser, and in fact uses the specifics of the "Jew in the Thombush" story as evidence that Beckmesser cannot be understood as an anti-Jewish caricature. See Drama and the World of Richard Wagner, 196-211.

${ }^{40}$ Tbid., 127.

${ }^{41}$ Thomas S. Grey, "'Bodies of Evidence' - review of Richard Wagner and the Anti-Semitic Imagination by Marc A. Weiner," Cambridge Opera Journal 8/2 (July 1996): 190-191.

${ }^{42}$ Ibid., 191. 
symbiotic. Nonetheless, the Masters' concurrence with Beckmesser's bemoaning of the lack of coloratura and "melody" in the Trial Song indicates that the guild's collective tastes have significantly atrophied to the extent that Walther's strange new sounds are repellent to this group. At the present moment, it is Walther who appears "other" to the guild, to the extent that his sound fails to register even as proper singing.

The Masters' nonplussed reception to the Trial Song can be said to qualify Walther as a "heroic" tenor, at least in the romantic sense of the individualist who refuses to allow his creativity to be confined by convention. In this particular ceremonial scene, the tenor serves as a sonority that scandalizes the sensibilities of the conventional culture. ${ }^{43}$ Walther's tenor sonority is one of the instruments that will transform the grand opera ceremonial scene from an expression of the crowd's unity of purpose under the aegis of a charismatic leader into an expression of nearly chaotic tumult; in Act One, the crowd scene is turned into a site of controversy rather than concord. But the precipitator of that controversy is also the one who keeps the scene from falling into complete chaos: "in [this] complex ensemble, the anarchic delight of the apprentices, the hysterics of Beckmesser, and the worried fulmination of the Mastersingers are kept in a state of precarious unity only by the melody of Walther, which soars above them." ${ }^{44}$ Walther's tenor sonority is understood as the sound of originality, but it is not yet the ideal of German art because he is still "all intuition and spontaneous feeling"45 and as such has not gained an understanding of his art. That will only come from Sachs's tutelage. But the vitality and freshness of Walther's sounds, at the moment, would tend to come across

\footnotetext{
${ }^{43}$ Similar to the reaction that the Thuringians have to Tannhäuser's encomium to sensual pleasure; recall that the initial idea for Die Meistersinger came to Wagner in 1845, not long before Tannhäuser was premiered.

${ }^{44}$ Williams, 123.

${ }^{45}$ Ibid., 121.
} 
as the acoustic analogue to the youthful beauty and vigour that Eva saw in the bodies of Dürer's David and Walther, which will result in both slaying their respective giants.

The only Master who provides a sympathetic ear to Walther's song is the one who is introduced last during the meeting's role call, and as such would appear to hold a privileged position in the guild: Hans Sachs. Even before Walther takes his seat in the singer's chair, Sachs has made waves amongst the membership in his suggestion that the people have a say in crowning the victor of the song contest. Kothner is aghast that Sachs would propose that the guild's rules be "abandoned" to the people. Sachs acknowledges that he understands the rules, but offers that it might be productive "once a year" to reevaluate those rules in order to ensure that their strictures are not stifling creativity. The assembled Masters and apprentices regard this suggestion as wellintentioned but ultimately misguided. But Sachs's suggestion that the rules would do well to undergo periodic revision is an indication that "like Walther, [Sachs] disdains ossified musical conventions, believing that the artist's private inspiration justifies the creation of new forms appropriate to its individual expressive impetus....,46 For Sachs, traditions are not to be upheld solely for the sake of tradition, as that will only succeed in ensuring the stagnation of the Mastersingers' art. Only the reception of the Volk can prevent such a regression, as their lack of experience with the guild's myriad rules will compel them to rely on their own instincts in order to determine whether the guild's art truly speaks to their collective spirit. For it is the spirit of the Volk that must be the final arbiter of the worth of German art; this is what leads Williams to characterize Wagner's (and by extension, Sachs's) view of the function of art as "pragmatic and romantic." This view values art both "as the means by which the folk could understand themselves"

\footnotetext{
${ }^{46} \mathrm{James}$ Treadwell, Interpreting Wagner (New Haven and London: Yale University Press, 2003), 143.
} 
through the subconscious of their collective needs and desires, and as the "conduit by which nature challenged society, as it aroused the people's sense of their natural origins, giving them a common identity as a folk that lies outside the pale of social life." ${ }^{, 47}$ Art is created both in service to the Volk and helps to create the spirit of the Volk, which is why Sachs insists that the people's input is desirable both for determining the winner of the contest and in reviewing and revising the guild's rules. Sachs's suggestion sets him up as an iconoclast within this society, the one member most likely to be drawn to Walther's intuitive originality.

Indeed, when Walther's song is met with unanimous rejection from the conservative ears of the Masters, Sachs offers his rebuttal, maintaining that the song was "new, but not confused; if he left our paths he at least strode firmly and surely." Sachs adds that "if you wish to measure according to rules something which does not agree with your rules, forget your own ways, and first seek its rules!" These are exceptionally forward-thinking remarks, especially in comparison to what we have already heard. With these words, Borchmeyer observes that

Sachs shows great astuteness in stressing the fact that all artistic rules are historically determined, whereas the Masters are carrying on as though their norms will last forever, ignoring their origins and historical development. Sachs clearly senses that in this way the art of the Mastersingers runs the risk of growing ossified and, by becoming academic, losing its popular basis. ${ }^{48}$

Naturally, such concerns never so much as fleetingly enter Beckmesser's mind, and he rejects Sachs's words out of hand. Nonetheless, Sachs beseeches Walther to finish his song. Concurrent with Walther's final stanza and the Master's continued bafflement, Sachs persists in his view that the song displays "spirit" and "glow of inspiration,"

\footnotetext{
${ }^{47}$ Williams, 117.

${ }^{48}$ Borchmeyer, 192.
} 
whereas the rest of the Masters hear only cacophony and incoherence. Moreover, as Vazsonyi points out, Sachs is able to discern a connection to the traditions of the guild within Walther's song: Walther left the Mastersingers' path with confidence, which suggests there was a point that he started on that path. Only Sachs "realizes that Walther was initially on the same path, but has taken a different route."49 Sachs's openmindedness and attuned ear is part of what makes him both a critic and an artist, which as Williams points out, is the one aspect of Sachs's character that aligns with that of Beckmesser. ${ }^{50}$ Indeed, it is "as a critic not an artist that Sachs is of most importance, because he recognizes that Walther's poetry will be the medium by which the energies will be released into the community of Nuremberg." ${ }^{51}$ By that estimation, Wagner positions Sachs as a "good" critic in opposition to the creatively bankrupt pedantry of Beckmesser.

Sachs's respective insistences that the Volk should have a degree of input into the artistic practices of the guild and that Walther's song contains the seeds of a genuine Mastersong are thus put forth as demonstrations of the wisdom that will culminate in his climactic commendation as "Nuremberg's dear Sachs!" That wisdom is part of the reason why Sachs will come to function as, in Goehr's words, "the sobering teacher who recognizes the difference between art and craft...."52 Sachs realizes that slavish adherence to the rules inscribed in the Tabulatur renders Mastersinging only a craft; properly harnessed, Walther's flights of fancy could be infused with the guild's traditions to produce art, which would in turn revitalize Mastersinging and keep the guild relevant

\footnotetext{
${ }^{49}$ Vazsonyi, 158.

${ }^{50}$ Williams, 121.

${ }^{51} \mathrm{Ibid}$.

${ }^{52}$ Goehr, The Quest for Voice, 58.
} 
and creatively supple as it progresses into the future. As previously stated, it is my contention that the intersection of the text and Sachs's bass-baritone sonority allows that sonority to register as the bodily-produced sound of wisdom.

Fischer demonstrates that such an idea is not without historical precedent, with a foremost example being "basso profundo" roles going as far back as those of Monterverdi, their "essential features [being] the majestic, the solemn, and the manner of old age." 33 Fischer adds that in the nineteenth century, "the authority of a bass voice is best revealed in the figures of priests, kings, and fathers." ${ }^{.54}$ His primary two examples are Philip and the Grand Inquisitor in Verdi's Don Carlos, which between them encompass all three of "priests, kings, and fathers. To those, I would add Verdi's Simon Boccanegra and from Wagner, the Dutchman, Tannhäuser's Wolfram von Eschenbach, King Heinrich from Lohengrin, Wotan, and later Gurnemanz from Parsifal. Each of those characters is narratively made to evince some combination of authority, age, or knowledge, the "commanding" sonority of the bass/bass-baritone providing a timbral analogue to those character qualities. 35 That ostensible "authoritarian" and "aged" sound of the bass and the bass-baritone contributes to Sachs's credibility as a fount of artistic wisdom, its stentorian timbre carrying the weight of Sachs's years and experience. But unlike Weiner's framework, I do not necessarily proceed from the assumption that "low"

\footnotetext{
${ }^{33}$ Fischer, "Singing Wagner," 531.

${ }^{54}$ Ibid.

${ }^{55}$ Fischer hastens to note that the operatic bass is quite flexible in its function, as in addition to "solemn," "majestic," "aged," and "authoritarian" roles, it is also used to give voice to the supernatural and the evil (531). He lists Kaspar of Der Freischütz, Sparafucile of Rigoletto, and Wagner's own Hagen. I would also add the longstanding use of the bass to portray "bumbler" roles, such as Leporello in Don Giovanni, Verdi's Rigoletto and Falstaff, to provide just a few of any number of examples. Even Beckmesser functions in that capacity. The point is that the bass sonority has multiple histories and is dependent upon context in order to determine which one has been invoked.
} 
sounds signify German "authenticity." R6 Rather, I propose that the bass and baritone sonorities of Sachs and the rest of the Masters convey various combinations of age, authority, solemnity, and wisdom because of the history that its sonority carries with it,. Because of the endurance of the use of the bass/baritone to give voice to the "old," it thus makes sense that basses and baritones would be deployed by Wagner to perform the venerable institution of the Mastersingers.

But it is not just the sound of the voice that is of importance for Sachs's characterization: Sachs's particular vocal line during the Trial Song maintains a generally smooth melodic contour and rhythmic regularity that suggests "authoritative" and "confident" as key aspects of his character. Sachs also eschews coloratura, separating him from the sounds of Beckmesser's artistic poverty. It all sounds quite dignified, but there is little about the sound alone that makes Sachs stand prominently out from the crowd of fellow bass voices. Once joined with the text extolling the originality of Walther's song, however, Sachs's "heroic" bass-baritone timbre communicates wisdom to accompany authoritativeness and confidence. Even so, "age," "wisdom," "authority," and "dignity" do not necessarily translate into "inspiration," and that gap is instructive in terms of establishing the role for which Sachs will be most valued: to reiterate, it will not be Sachs's own artistry that will most endear him to the Volk, but his ability to recognize and nurture talent. That, as much as the expressive qualities of his vocal performance throughout the opera, is what thematizes Sachs as a "heroic" baritone.

To bring the discussion back to grand opera, Sachs's performance of the "voice of reason" ironically only serves to provoke discord, as the intransigence of the more conservative members of the guild causes them to dig in their heels regarding both

\footnotetext{
${ }^{56}$ Weiner, 106-117.
} 
Sachs's suggestions for reform of their rules and his insistence that Walther's song be given a fair hearing (meanwhile, the apprentices obtain youthful enjoyment from the spectacle of people making a scene). To repeat, this stands in contrast to the general tendencies of the narrative and dramaturgical functions of the grand opera ceremonial scene, its ceremonial spectacle typically gravitating towards unifying multitudinous voices in service of affirmation and inclusion, rather than division and dissension. Of course, the other major point of distinction is that ceremonial scenes in grand opera are frequently of a public nature, of which this one is decidedly not. Perhaps the cloistered nature of the guild's meetings and practices goes a way towards proving Sachs's point: is it a coincidence that a ceremony that is cut off from the public by design (with the conservative wing of the Master's completely aghast at the very notion of the citizenry being granted access to any part of their affairs) reveals a hidebound organization? Furthermore, is it any wonder that the meeting of such a change-resistant group eventually devolves into a veritable shouting match between (at this point) seemingly irreconcilable viewpoints? Tellingly, the next major ceremonial scene - the third-act song contest - which does foreground the input of the Volk, is very much the type of inclusive public event that brings the entire population together, united through the beauty of Walther's Prize Song and under the aegis of holy German art in general. ${ }^{57}$ The

\footnotetext{
${ }^{57}$ Parakilas notes, however, that many ceremonial scenes do in fact inject elements of conflict that will sow seeds of discord among the on-stage mass: the interruption of a public ceremony by a solo voice will frequently incite a public debate that will "eventually [draw] everyone in on stage" (88), resulting in an increasingly complex and contrapuntal choral texture. Parakilas uses the auto-da-fé scene of Verdi's Don Carlas and the first scene of Mussorgsky's Boris Godunov to illustrate his point. Under this paradigm, Walther is the interrupting voice that transforms a ceremony into a source for vigorous debate; the main difference is that it is a debate taking place during a private, rather than public ceremony. In the later public ceremony, that same solo voice will not provide an interruption, but rather lay the groundwork for unification between guild and Volk. Even the interruption in the Third Act (Beckmesser's disastrous attempt to perform Walther's song) provokes a unified response from all and sundry, that of mockery. This
} 
presence of the Volk during the song contest will draw out the distinction between public and private ceremony: the latter results in turmoil while the former succeeds in fostering social harmony. Clearly, such a result is engineered to prove Sachs's initial proposal about the importance of the people indubitably correct.

And so, as the act comes to its close, we are left with a grand opera ceremonial scene that conclusively lays out what will be the central conflict that will carry through to the work's end: the creativity of the newcomer pitted against the overbearing conservatism of the institution. The mediating voice will be Sachs. Together, the performing bodies of the innovator and the mediator will turn ceremony into strife. But this act of disturbance is for a decidedly noble purpose: to protect the Mastersingers' (and German) art from falling into a stagnant rut. Sachs's final gesture of the act, as the other Masters make their motions to leave the hall and the apprentices are busy dismantling the set-up, tells the story: he "remains alone in the front, looking pensively at the empty seat." Through the interaction of its novel poetic and musical construction and its heroic tenor sonority, Walther's song has introduced a sound that will not go away: Sachs fixes his gaze on the empty singer's chair, where Walther had been only moments before, as though the impact of his performance was so great that it broke through the boundary between the acoustic and the physical to leave a tangible residue behind. In any case, it is a clear sign that Walther's song will cling stubbornly to Sachs's psyche, borne out by his reflection in the second act: "I feel it - and can't understand it; can't retain it - nor forget it either; and if I grasp it entirely, I can't take its measure." ${ }^{58}$ Walther's song is both

would tend to bear out the distinction Wagner makes between private and public ceremonies: one inciting conflict, the other concurrence.

${ }^{58}$ Quoted in Dahlhaus, 70. 
heard and "felt," both sonic and tactile; it exists simultaneously as a vivid memory and a hazy impression, at once accessible and beyond comprehension.

Sachs's conflicting reactions to the Trial Song suggest several Lacanian perspectives: as an evanescent "hazy impression" that cannot be retained, the song and Walther's singing voice come across as examples of a "lost object," the "unattainable but always desire vocal object, hidden somewhere behind and beyond the signifying voice" that "operatic song" periodically manifests "in ecstatic moments of vocal jouissance." 59 Sachs longs for that joy that the song brought him, but having been "lost," he cannot fully assimilate it. ${ }^{60}$ But as a vivid memory that appears to have fundamentally altered Sachs's perspective, even if he cannot "take its measure," one might view his experience of the Trial Song as an eruption of "the Real," that "outside" realm that "remains foreclosed from analytic experience" and cannot be assimilated into language and conventional understanding. ${ }^{61}$ The Real remains as an unprocessed "residue" post-entry into the Symbolic order of language and its periodic return of the Real serves to destabilize the subject. $^{62}$ For Sachs, his experience of Walther's singing has irrevocably changed his preconceptions and perceptions, the memory of that event serving as a "remainder" that has stuck with him even if he cannot fully accommodate it. For Sachs at that present time, Walther's artistry is such that its greatness is completely ungraspable, impossible to

\footnotetext{
${ }^{59}$ Gary Tomlinson, Metaphysical Song: An Essay on Opera (Princeton, NJ: Princeton University Press, 1999), 86.

${ }^{60}$ Michel Poizat discusses "lost voices" in The Angel's Cry: Beyond the Pleasure Principle in Opera, trans. Arthur Denner (Ithaca, NY: Cornell University Press, 1992), 93-95.

${ }^{61}$ Alan Sheridan, "Translator's Note," in Jacques Lacan, The Four Fundamental Concepts of Psychoanalysis (1977), trans. Alan Sheridan, ed. Jacques-Alain Miller (New York and London: W.W. Norton, 1981), 280.

${ }^{62}$ Bruce Fink discusses the relationship between the Symbolic and the Real in The Lacanian Subject: Between Language and Jouissance (Princeton, NJ: Princeton University Press, 1995), 24-34.
} 
fully assimilate. ${ }^{63}$ As such, the heretofore untrained Walther resembles an artistic imago figure. However, with proper guidance that greatness can be refined in order to produce a work of art that contains the same sense of invention and vitality, yet is also fully accessible to the Volk. Act Three of Meistersinger will devote itself to bringing just such a work about, thereby conclusively situating Walther and Sachs as the ideals of German art.

\section{Walther Wins}

When Walther steps forward to deliver his Prize Song, it is the moment to which the story has been building ever since the vociferous rejection of his Trial Song. Walther's entry into the contest is the final iteration of a consistent trope throughout the work: as James Treadwell points out, "each act in centred around a scene of 'marking' and judging...." ${ }^{64}$ In the first act, it is Walther's Trial Song; in the second, Sachs evaluates Beckmesser's composition; the third act features Sachs counselling Walther through the creation of the morning-dream melody, and then occurs the final song contest. But by the third act, the nature of the judging has changed. During the song contest,

[I]t is not only the individual performers who are tested. Via Sachs's ingenious stage-management, the institution of music itself is put on trial before the public (he refers to Walther as his 'Zeuge', a witness in the judicial sense), so that in the final scene the people of Nuremberg judge the Masters, rather than the Masters judging each other. The opera thus becomes a story of art in transition, moved back (to use Sachs's terms) into proper alignment with nature. ${ }^{65}$

Sachs arranges for this to occur by allowing Beckmesser to attempt to sing Walther's song, humiliating himself in the process. Sachs then proclaims that the song

\footnotetext{
${ }^{63}$ Slavoj Žižek further discusses the Lacanian resonances in Wagner's work in "'There is No Sexual Relationship': Wagner as a Lacanian," New German Critique 69 (Autumn 1996): 7-35.

${ }^{64}$ Treadwell, 143.

${ }^{65}$ Ibid.
} 
will be proven to be beautiful if sung correctly and elicits Walther as a volunteer. In doing so, Sachs has strategically constructed a scenario where the crowning of the victor becomes a purely public rather than private spectacle: the Volk and the Masters become united in dismissing Beckmesser's jumbled attempt and anointing Walther the unquestioned champion, as opposed to the Masters simply imposing their judgment upon the public without challenge. As Sachs made clear in the first act, only in a "trial" where truly all and sundry cast a vote can a genuinely fair verdict be handed down. ${ }^{66}$

The first such verdict comes in the form of a rebuke, as Beckmesser's ineptitude in interpreting the song that he had surreptitiously purloined from Sachs's shop causes him to be essentially laughed off the stage by the Masters and Volk alike. In Beckmesser's attempts to memorize the words and meter of Walther's poem, he thoroughly mangles the text (even after sneaking a few glances at the paper) into a grotesque distortion of the poem's intended meaning that leaves Masters and Volk alike stupefied. Beckmesser's first attempt at a Stollen is representative:
Morgen ich leuchte in rosigem Schein, von Blüt und Duft geht schnell die Luft;

[In the morning I shine in a rosy light, with blood and scent the air moves fast; probably soon won as if

\footnotetext{
${ }^{66}$ The persistence of scenes of judgment, both private and public, throughout the work brings to mind Michel Foucault's influential exegesis on the mechanisms of discipline, incarceration, and punishment and the infiltration of those mechanisms into various social and cultural institutions in Discipline and Punish. For Foucault, forms of judgment such as examinations served as the "means of correct training" in order to produce "docile bodies" whose behaviours could be moulded in ways deemed "beneficial" to society. In the various scenes of marking and judgment in Die Meistersinger, we are witness to versions of these principles in action: singers are brought before systems of observation and judgment in which the quality of their melodies and poetry are subject to private and/or public evaluation. During the song contest, "incorrect" singing is punished (public mockery of Beckmesser), while "correct" singing is rewarded (Walther's acceptance as a Mastersinger, public validation of his art, and the winning of Eva's hand in marriage). Clearly, Wagner casts all of this in a much more benign light than Foucault, and all of the discussion of the necessity of the freedom to deviate from rules grants the proceedings a decidedly less conformist patina, but nonetheless one still discerns a scenario in which performing bodies are made into public figures, objects of knowledge, where forms of observation and judgment are mobilized in order to identify the forms of "behaviour" (read: singing) that are considered most potentially beneficial to society. See Discipline and Punish: The Birth of the Prison (1977), trans. Alan Sheridan (New York: Vintage Books, 1995), 170-228.
} 
wohl bald gewonnen, wie zerronnen;

im Garten lud ich ein garstig und fein (III, v) dissolved; in the garden I invited horrid and fine.]

As Beckmesser becomes continually more flustered in the face of the gathered crowd's incredulity and struggles all the more to remember the words, the increasing substitutions of incorrect words and phrases renders the text even more risible. The grotesque travesty of Beckmesser's text is matched by its musical setting, which is rife with meaningless coloratura and accents (metrical and articulated) frequently placed on the wrong beats and syllables. Beckmesser's offering would appear to be an attempt at just the type of empty technical display that Wagner considered to be intrinsic to inferior "foreign" musics.

To reiterate, it is a popular hermeneutic strategy to put forth Beckmesser's unmusicality and overall buffoonery as an example of an anti-Jewish caricature. Certainly the fact that Beckmesser is attempting to triumph in the song contest with a composition stolen from another ${ }^{67}$ is suggestive when considered within the context of Wagner's claim in "Jewishness in Music" that the Jewish musician is only capable of artistic mimicry (often at a highly skilled level, he concedes), not true originality. ${ }^{68}$ Millington takes takes things further, arguing that the copious melismas in both this and Beckmesser's Act Two "serenade" function as Wagner's caricature of "synagogue" singing and the Jewish musician's overall unidiomatic treatment of language and

\footnotetext{
${ }^{67}$ As Vazsonyi notes, Beckmesser's most significant aesthetic transgression is the fact that he forms music to go along with the words of another, rather than originating both himself, as is supposed to be the custom of the Mastersingers. Beckmesser's actions position him as a composer in the vein of the despised Italian and French opera, in which music and words are provided by two different persons. The separation of the two elements of opera is what results in its inevitable decline into empty spectacle. Vazsonyi observes that Beckmesser's separation rather than integration of music and words is part of what frames him as the lone "outsider" in the Nuremberg community. See Vazsonyi, Richard Wagner, 163.

${ }^{68}$ SSD V, 78-81; PW III, 92-96
} 
melody. ${ }^{69}$ Even if one is not inclined to accept the anti-Semitic readings that Millington and Weiner among others offer, there still appears to be little doubt that Beckmesser's musical ideas are clearly coded as antithetical to the Volk, a coding made most apparent by his complete rejection by the crowd gathered at the Festival Meadow. The Volk recognizes that Beckmesser's singing is alien to their collective spirit.

But even before that, Beckmesser is conspicuously portrayed as an outsider to what is ostensibly a harmonious community. David Levin points out that the stage directions clarify that Beckmesser is not involved in the public's unified greeting of Sachs, the "community cobbler and, more important, community hero," 70 in part because he is busy trying to learn the song he pilfered from Sachs's shop. Even taking that into account, Beckmesser's absence from the greeting "crystallizes his atomization in the face of the consolidation of the group identity."71 While the rest of the crowd coalesces into a unified display of public acclamation, Beckmesser is outside, not involved with the group as if he clearly did not belong. Beckmesser's otherness, according to Weiner, is also made somatic: the music and the text work to construct Beckmesser's physical body as grotesque so as to appropriately match his acoustic body. Weiner points to the orchestration accompanying Beckmesser's music in the opera, where a high "nasal" bassoon is prominent to complement his nasal singing. ${ }^{72}$ The gambit serves to construct Beckmesser as an oafish, comedic figure deserving of mockery. When Beckmesser makes his way to the stage at the Festival Meadow, the onlookers devote a significant portion of their scorn to Beckmesser's appearance, proclaiming that he does not look like

\footnotetext{
${ }^{69}$ Millington, "Nuremberg Trial," 251-254.

${ }^{70}$ David J. Levin, Unsettling Opera: Staging Mozart, Verdi, Wagner, and Zemlinsky (Chicago and London: University of Chicago Press, 2007), 55.

${ }^{71}$ Ibid.

${ }^{72}$ Weiner, 123-124.
} 
the "right man" to woo Eva, that were Eva their daughter, they would not wish for Beckmesser as a potential suitor. They then add that he cannot even stand up straight. The crowd is made to observe Beckmesser's physical deficiencies, which will presently be matched with his artistic bankruptcy.

To resurrect a point from earlier in the chapter, Beckmesser's predilection for ostensibly "foreign" coloratura was shown to have also appeared in the vocal lines of some of the other Masters during the guild meeting in the first act, one possible explanation being that Beckmesser is a "corrupting" influence on the guild. A "foreign" agent has implanted itself within the culture and is facilitating its deterioration from within. For the moment, let us presume this to be true and consign any potential critiques of that position to the backs of our minds: it would be possible to argue that through the combination of Beckmesser's physical and artistic shortcomings and his deleterious impact on Nuremberg's artistic culture, Wagner has positioned Beckmesser as "degenerate" in the vein of the discussion of the decline of Parsifal's Grail kingdom in Chapter Four. Like in Parsifal, the "race" of the Volk can only be rescued from the infection of its "purity" through an exscription of that infection, which is carried out when the Volk effectively chases him off of the stage, not to return for the rest of the work.

The framing of Beckmesser as a source of degeneration lends a certain suggestive streak to the interpretation of some of Wagner's own writings: as Levin notes, in Wagner's essay "Actors and Singers," he describes an occurrence after the dress rehearsal for the 1868 premiere of Die Meistersinger where he assured all and sundry present that the work would serve to revitalize the German drama after having been 
"ruined" by the commercial trappings of "opera.", Commenting upon Wagner's characterization of the incident, Levin refers to the "regeneration" of German art through the "artwork of the future." Levin's invocation of that particular term is significant: if Wagner felt his efforts were "regenerating" art (in Levin's words), then it stands to reason that something degenerated it. Levin's word choice suggests that Wagner's theories of degeneration and regeneration has had some influence on the interpretation of his dramatic works and prose writings. I make this point to bolster the contention that Beckmesser's pernicious presence resonates as another example of Wagner's concerns about the supposed degeneration of the German race due to foreign influences that he observed as early as the "Die Wibelungen" essay (1848). In any case, the failure of Beckmesser's own "Trial Song" represents the mobilization of the grand opera ceremonial and crowd scene to create a scenario where a unified public comes together to identify and excommunicate that which is other to their community. When Walther steps up to correctly sing the song, ceremony will be used to publicly crown an individual performance.

Walther, the man who Eva initially saw as possessing the youthful physical beauty of Dürer's "David," will now complete the prophecy introduced at the work's opening, use his complementing acoustic beauty to slay his own Goliath. Even before getting into the details of Walther's song, there are a number of telling contrasts between Walther's performance and that of Beckmesser, which serve to emphasize the elevated nature of the former and debasement of the latter. Goehr points to the fact that Beckmesser accompanies himself on his lute (an instance of diegetic instrumentation) as

\footnotetext{
73."Actors and Singers," quoted in Levin, 42.

${ }^{74}$ Levin, 42.
} 
a compositional strategy that makes plain his musical othering. Walther on the other hand has no diegetic accompaniment, and instead is accompanied by the orchestra. Goehr speculates that Wagner denies Walther an instrument (as she notes, the historical mastersingers likely did accompany themselves on lute or harp) in order "to reflect Walther's status as a singer-poet who finally becomes the true mastersinger." ${ }^{\text {75 }}$ Goehr continues,

Wagner wanted to show Walther less as a mastersinger than as a modern singerpoet who wins his contest by voice alone. Still, one might claim that, contrary to appearance, Walther does play a lute although it is one unseen given its absorption into the orchestra that, though concealed beneath the stage, nevertheless accompanies his song. This claim, however, only fortifies the paragon of eye and ear in Wagner's opera that is designed to show how music is rendered pure for the ear only when the vision of a musician playing an instrument is removed. For, the purer the image of the singer, the purer the song produced. Thus, whereas Walther, qua pure singer, proves himself a pure musician, Beckmesser with his instrument is shown to be no better than a Musikant: a mere instrumentalist. ${ }^{76}$

According to Goehr, Beckmesser's lute (already coded with notions of the arcane and obsolete) is central to theorizing his debased difference because its presence demarcates him as something akin to a mere technician without a hint of inspiration, as opposed to Walther's "pure musicianship." In fact, one can expand upon Goehr's reading in order to locate additional subtexts regarding Walther's idealized musicianship: in stating that Walther's musical talents obviate the need for him to provide an instrumental accompaniment and further speculating that any supposed self-provided instrumentation is effaced from the diegesis and migration into the orchestral setting, Goehr might be implicitly making the case that Walther's musical gifts are portrayed as so significant that they effect a form of slippage of the boundaries between diegetic and

\footnotetext{
${ }^{75}$ Goehr, "Contest, Myth, and Prophecy," 69.

${ }^{76}$ Ibid., 69-70.
} 
non-diegetic instrumental accompaniment. To continue extrapolating from Goehr's starting point, Walther's performing body produces a vocal sonority so potent, so musically coruscating that it produces its own accompaniment out of seeming nothingness through the force of its beauty. To be sure, the orchestral setting is not music that the Nuremberg Volk can hear, so this is not quite an example of an "unsung voice" as discussed in Chapter Four. Also, the accompaniment of an "unseen" and "unheard" (by the characters) orchestra is a persistent feature of opera. But consider that during Beckmesser's performance, Wagner strips away the orchestra and leaves the lute on its own, constructing the instrument as a comically pathetic device that underlines its inadequacy in comparison to the rich sonorities of the full orchestra. The lute's instrumental solitude assists in exposing for all to see the reality that for all his bluster about rules, Beckmesser is nothing more than a hack. In direct contrast, Walther's voice alone seems to re-conjure the orchestra that had fallen by the wayside when Beckmesser had commenced his ill-fated performance. The pure musician that eschews instrumentation possesses such a significant voice that it provokes the materialization of the orchestral texture that had vanished, while the "mere instrumentalist" directly caused its disappearance. The seeming "magical" properties of Walther's voice that summons the orchestra from nothing and bends it to the will of his singing is granted to his specific tenor sonority, granting the sound a "heroic" quality as it rescues the orchestra from the void, which in turn assists in making his musical talent manifest.

Levin identifies another example (this time derived directly from the libretto, rather then dependent on readings of potential subtexts) of differences between Beckmesser's and Walther's respective recitals that serve to underline the significance of 
the talent of the latter performer and the alien nature of the former. With regards to the poem as written on the paper,

Beckmesser needed the text but could not read it; Walther can read it but does not need it: his performance...supplants reading in the transfigurative sublation of natural, inspirational enactment. Rather than simply rendering the poetry - let alone imitating it, as Beckmesser does - Walther overcomes the text by dropping it. $^{77}$

Walther does not need to rely on the manuscript, because the poetry has been completely internalized; the song is an '“organic' creation, a spontaneous and symbiotic combination of music and poetry welling from the depths of his being."78 Moreover, because the song's beauty so enraptures everyone, he allows himself the creative freedom to deviate from the written text, relying on his artistic sense to carry him through. By performing a text and a melody that is self-composed (rather than fitting a melody to a pilfered poem, as Beckmesser does), Walther integrates the two into a seamless whole. This leads Köhler to write that the Prize Song "is the work that Wagner had once described as the 'artwork of the future', a work in which the masculine word plunges into the sea of feminine music." ${ }^{, 79}$ It is this work of art that the Volk receive so rapturously.

\footnotetext{
${ }^{71}$ Levin, 57.

${ }^{78}$ Vazsonyi, 162.

${ }^{79} \mathrm{Kohler}, 500$. This is borne of one of Wagner's central metaphors elucidated in "Opera and Drama," which theorized the music drama as the offspring that comes out of music's ("female") impregnation by poetry ("male"). Jean-Jacques Nattiez identifies this framework as central to the metaphor of androgyny that runs throughout Wagner's work, where the Wagnerian drama is supposedly neither fully poetic nor musical, but a new hybrid. Grey also examines the reproductive metaphor in "Opera and Drama" to reveal the inconsistencies in Wagner's construct, namely that the "intercourse" between dramatic poetry and music is supposed to result in a new being, but it is at this point that the metaphor fails because the joining does not produce a separate offspring as it would biologically, but the result is a hybrid of "male" and "female," where both are changed by the other. See Jean-Jacques Nattiez, Wagner Androgyne: A Study in Interpretation, trans. Stewart Spencer (Princeton, NJ: Princeton University Press, 1993) and Thomas S. Grey, Wagner's Musical Prose: Texts and Contexts (Cambridge: Cambridge University Press, 1995), 138151 .
} 
The story-driven needs regarding the public reception of the Prize Song dictate the musical content that Wagner creates for the piece. In her exploration of the philosophical underpinnings of the opera, Goehr states as much, writing that

because Die Meistersinger contains within it a singing competition, then, if the winning is actually to sound worthy of winning, it must immediately please contemporary ears at the same time that its philosophical message challenges them. These ears, after all, are intended to be Wagner's own public symbolized in the masters' ears, and the latter have to hear the 'Prize Song' of the contest as breaking new ground. ${ }^{80}$

As Goehr notes, the strategy of constructing the Prize Song to sound pleasing to contemporary ears, while the denizens of the drama proclaim it as sounding bold and fresh, is borne of a necessity that arises from the work's philosophical views on the preservation of the old while forging ahead with the new, because

for Wagner's suggested modern to bear the quality of historical inevitability, it must convey the feeling that it emerges naturally out of the past in a way the present 'corrupted' and 'artificial' modern does not. In other words, the archaic forms employed in the opera must show their progressive musical potential. Adapting words sung by Sachs, for the 'music of the future' to emerge out of the 'true' German past the music must 'seem so old and yet sound so new.",81

One cannot help but infer that she is insinuating that Wagner has employed a somewhat disingenuous sleight of hand in projecting conventionally pleasing music of the nineteenth century back into the sixteenth century in order to recover a modernity that has lineage to a preferred past, while suggesting that the Prize Song, a traditional operatic aria if there ever was one, represents something new. Such a suspicion is lent credibility by remarks that she makes in a later essay where she suggests that "Wagner's project in Die Meistersinger was guided doubly, by his desire to write a successful opera, to receive quick applause, and by the desire to prepare the audience to listen to his already

\footnotetext{
${ }^{80} \mathrm{Goehr}$, The Quest for Voice, 60.
}

${ }^{81}$ Ibid. 
composed Tristan." ${ }^{82}$ She invokes Theodor Adorno's critique of Wagner's use of repetition as leaving the work vulnerable to Fascist appropriation, and then extends the point to suggest that Wagner knowingly created a work that was steeped in the past, almost as a "farewell" to traditional opera, while Tristan pushed the form into radical new directions. ${ }^{83}$ Goehr continues,

Tristan's anticonventional form demonstrates something Die Meistersinger's conventional form does not, namely Wagner's commitment to releasing his works from the tradition that had defined opera's conventions and terms of critical judgment. In this sense, Wagner's gestures certainly seem bigger in Tristan than in Die Meistersinger. But is the difference as simple as that? Suppose Die Meistersinger's argument is that if the Volk responded properly to the Preislied, and the audience properly to the opera, then each would show an openness to hearing what was truly new, not in what was being presented as such, in the song actually heard, but, rather, in the promise of new possibilities. ${ }^{84}$

Such words tend to suggest a dim view of Meistersinger's purported conventionality, functioning merely as a test case to determine if audiences are ready to hear something truly innovative. Her words draw a binary where the aesthetically and structurally challenging (Tristan) is portrayed as superior to the comfortable (Meistersinger), more or less solely for being challenging. I tend to agree with Vazsonyi's argument that Goehr's paradigm is problematically elitist, even though he agrees with her point that while Meistersinger thematizes innovation, Tristan genuinely innovates. ${ }^{85}$ Where Vazsonyi and I depart from Goehr is that our positions are that the "mere" thematization of aesthetic advancement need not carry a pejorative connotation, and that the potential alienating effect of radicalism is not an automatic guarantor of superiority.

\footnotetext{
${ }^{82}$ Lydia Goehr, "The Dangers of Satisfaction: On Songs, Rehearsals, and Repetition in Die Meistersinger," Wagner's Meistersinger: Performance, History, Representation, ed. Nicholas Vazsonyi (Rochester: University of Rochester Press, 2003), 67.

${ }^{83}$ Ibid.

${ }^{84}$ Ibid., 68.

${ }^{85}$ Vazsonyi, Richard Wagner, 151.
} 
But it cannot be denied that despite the assembly's plaudits, the song veers off in uncharted aesthetic and structural directions, while retaining at least one foot in the realm of the familiar; the Prize Song, at least on the surface, is in Dahlhaus's words "anything but 'new' music." ${ }^{86} \mathrm{He}$ argues further that the Prize Song takes on the appearance of a lyrical cantabile, "but in the second half of the nineteenth century 'new' music was not cantabile but descriptive," with the opera's apex of musical description coming ironically in the "third-act pantomime for Beckmesser the traditionalist: music which treats musical tradition, or its remnants, as cavalierly as the plot treats Beckmesser the censor." ${ }^{87}$ So the Prize Song does not represent a radical break from tradition. But the opera's overall theme of integrating the conventional and the pioneering gives Wagner an "out" for presenting comparatively old-fashioned music within a drama that advocates for the value of new ideas. The work functions as Wagner's implicit justification for permitting him to pleasurably indulge himself in conventionally pretty tunes.

It is that melodic (if conventional) beauty, combined with its superior poetry that incites the chorus of this grand opera ceremonial scene to publicly proclaim its superlative quality. Comparing the first Bar with that of Beckmesser's attempt will reveal much in terms of how greatly it was distorted:

Morgenlich leuchtend im rosigem Schein, von Blüt und Duft geschwellt die Luft, voll aller Wonnen, nie ersonnen, ein Garten lud mich ein, dort unter einern Wunderbaum, von Früchten reioh behangen zu schaun in sel'gem Liebestraum Erfüllung kühn verhieß
[Shining in the rosy light of morning, the air heavy with blossom and scent, full of every unthought-of joy, a garden invited me, and beneath a wondrous tree there, richly hung with fruit, to behold in blessed dream of love, boldly promising fulfillment to the highest of joy's desires, the most beautiful woman: Eva in Paradise.]

\footnotetext{
${ }^{86}$ Dahlhaus, 74.
}

${ }^{87}$ Ibid. 
Das schönste Weib:

Eva im Paradies.

(III, v)

Obviously, Walther's version features more sensible phrases in addition to more inviting imagery. More importantly, the Biblical allusions of the text set the stage for the Prize Song to become an example of Kunstreligion: Walther invokes the imagery of the Garden of Eden and characterizes Eva as Eve. Further, the "wondrous tree" suggests the forbidden Tree of Knowledge from Judeo-Christian tradition. But Walther re-frames the meaning of the tree for more optimistic ends: taking of the fruit does not appear to be grounds for expulsion. In the subsequent Bars, the tree becomes part of the domain of the woman who is revealed to be the Muse of Parnassus. Her inspirational beauty brings about the creation of the Prize Song, which in the final Abgesang is revealed to have allowed Walther to claim Parnassus in Paradise. Walther's use of Biblical references aligns art with religion, but the narrative trajectory of the poem recasts the story as leading not to the expulsion from Paradise, but to personal fulfillment in Paradise. I submit that Walther's use of poetry to reframe the implications of religious imagery is part of the transition of art into Kunstreligion: the Prize Song demonstrates the power of art to transform the Biblical mythos itself, and in doing so reveals art to be a far more potent and positive cultural force than the traditional church. Such benevolent power essentially allows art to supplant the church as Nuremberg's (and Germany's) primary religious institution. 
Ex.2

(Die Meistersinger III/v, mm.825-841)
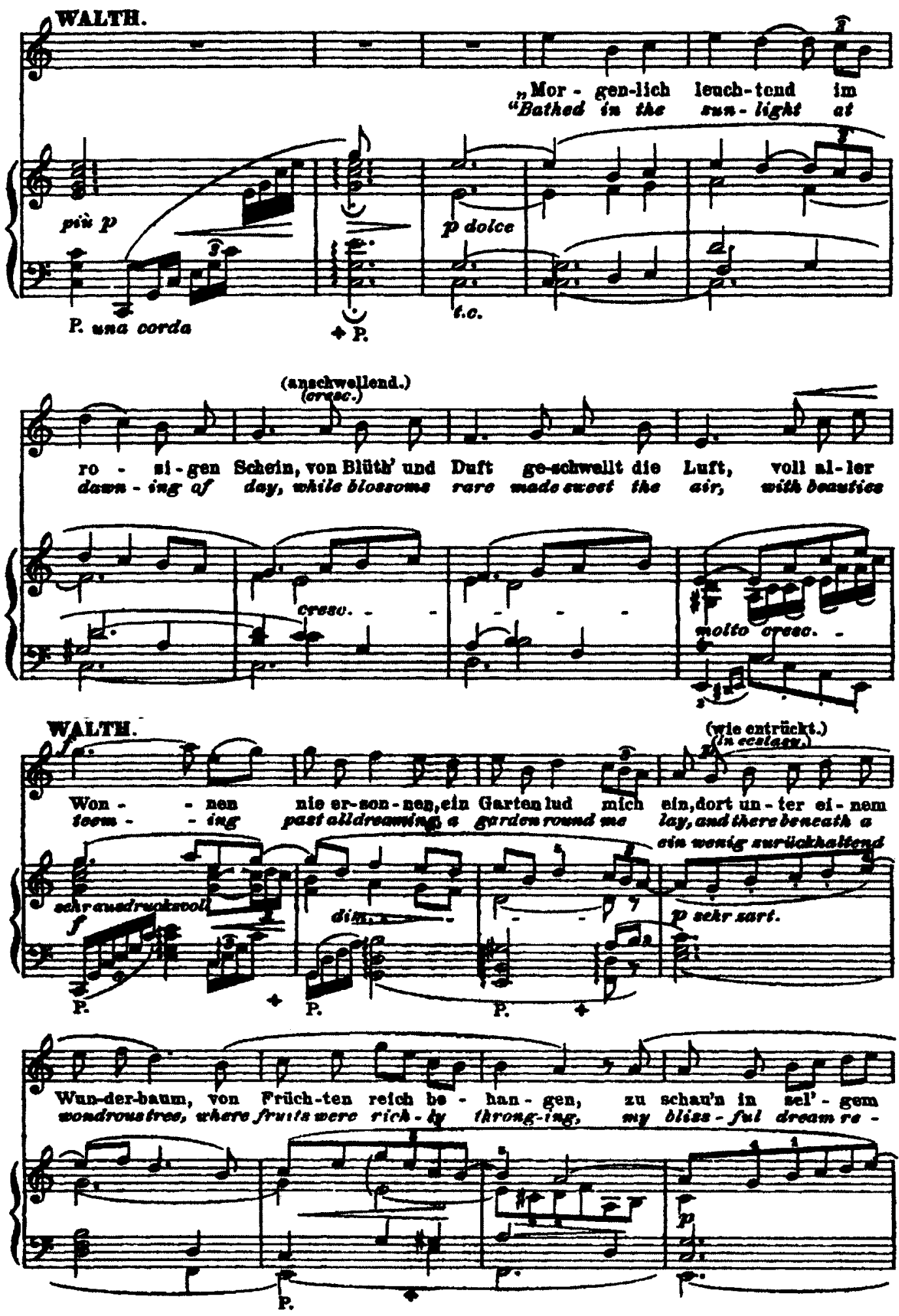
Turning to Walther's vocal line (Ex. 2), the song is characterized by its graceful and lyrical melodic flow with apposite text-setting that favours clarity over ornament. The frequent ascending eighth-note figures create the feeling of a rush of excitement, a musical gesture created by the performing body that incites a bodily response in the listener. The light orchestral scoring foregrounds the vocal line, the upper voices doubling the melody, essentially demanding that attention is paid to the singing. The first two Bars conclude on a sustained $g^{\prime}$, and the final Bar contains a lengthy $a^{\prime}$ near its conclusion. These two pitches are also quite prominent throughout the body of the song. These prominent high notes are examples of the types of musical virtuosity that Wagner normally eschewed in his vocal writing, but it is also the type of showmanship that foregrounds the beautiful tone of the singer, and as such is pleasing to the listener. It is perhaps telling that the choral acclamations of the public immediately follow the final flourishes that are Walther's sustained high notes: pitches that appear designed to maximize the sonorous and melodic splendour seem to provoke, if only by their direct proximity, a mass expression of marked enjoyment from the crowd. These sustained high notes come across as Wagner's exclamation point, highlighting the beauty of the morning-dream melody, which is then duly praised by the crowd.

Although the Prize Song's melodic and harmonic construction bequeath it the veneer of convention that led Dahlhaus to distance it from notions of "new" music, the song's formal properties lend it some complexities that complicate the discussion. As Warrack notes, the song as presented in Sachs's shop is structured not as a true AAB Bar form, but as an AAA form with each A-section consisting of an internal Bar. ${ }^{88}$ But even that is not the final version performed at the Festival Meadow: once Walther has noticed

\footnotetext{
${ }^{88}$ Warrack, 115.
} 
that Kothner has allowed the paper to drop from his hands and is no longer closely following the poem, he allows his song to "[proceed] in a more free manner," ${ }^{89}$ which includes a modulation into the distant key of B major during the second stanza. This represents a crucial element of Wagner's thematization of the necessity of integrating tradition and innovation into a seamless whole: "having reconciled his natural skills to the Masters' rules, and learnt the benefits of their sense of order, Walther is able to create on the spur of the moment an inspired but disciplined Mastersong that wins their wholehearted professional understanding. $" 90$ That the Prize Song couches formal complexities within a presentation that appears steeped in the old-fashioned causes it to register as the moment that conclusively demonstrates that Walther has successfully integrated Sachs's tutelage into his own artistic instincts. The former accordingly demonstrates that through Sachs's mentorship, Walther has acquired a measure of the cobbler-poet's wisdom to temper his "heroism." The "old" aspects account for the song's melodic attractiveness, its "well-rhymed and singable" quality, while the intricate formal plan represents the "bold and strange" aspect that the crowd discerns. As the crowd's reverential praise for the song clearly designates, the artistic sensibilities of both Sachs and Walther have been vindicated in the most public manner.

The Volk's instantaneous appreciation for the Prize Song is significant in terms of framing the piece as communicative to the "spirit" of the German people. The Volk make the Prize Song's perceived connection to the collective public spirit apparent when they declaim "So hold und traut, wie fern es schwebt, doch ist es grad, als ob man selber alles miterlebt!" (So gracious and familiar, however far off it soars, but we seem to be

\footnotetext{
${ }^{89} \mathrm{Ibid}$.

${ }^{90}$ Tbid.
} 
experiencing it with him!) That the Volk position the performance of the Prize Song as a simultaneous, shared experience between performer and spectator tends to situate the song as a site where both are in tune with each other artistically and spiritually. In enjoying such pronounced public acclaim, Walther is conspicuously positioned as possessing the instinctive ability to create art that is directly attuned to the Volksgeist. Moreover, Walther's inherent affinity with the Volksgeist is such that he is able to tap into it before the Volk becomes aware of what Volksgeist art truly sounds like: as Williams notes, Wagner's conception of the organizing principle of the Volk is such that "the folk may not always be aware of their common need or identity, [and] in fact they may only recognize it through the art produced in their name."91 The operative word is that they recognize art as being expressive of the Volk spirit; they do not necessarily know what appearances such art would/should take beforehand. Vazsonyi observes that Eva's initial hearing of the Prize Song in Sachs's shop leads her to intuit that it is truly a Mastersong, her response of knowing it when she hears it effectively anticipating the Volk's reception at the subsequent competition. ${ }^{92}$ Even though the Volk may not have foreknowledge of what constitutes Volk-like art, they too know it when they hear it. Walther's success is thus constructed as a testament to his genius, his intuitive artistic sense (facilitated by Sachs's tutelage) connects him to the shared identity of the Volk even before they are aware of its nature. The Volk did not know what their shared heritage sounded like until Walther presented it to them on the Festival Meadow. In clarifying for the Volk how their collective spirit manifests in song, Walther's morning-

\footnotetext{
${ }^{91}$ Williams, 117.

${ }^{92}$ Vazsonyi, 160.
} 
dream melody is constructed by Wagner to demonstrate its fundamental connection to the essence of German art.

Walther's song transmits bodily-produced sonorities to the assembled masses, sonorities that the Volk find intensely beautiful. In essence, Walther is transmitting a part of his own body to the crowd, and it is that body that registers as a splendorous expression of Volk spirit. But it is not just Walther's own performance that reveals the bodily dimension of the Prize Song: as Wagner's stage direction specifies, Kothner (ostensibly following the written-down poem while Walther sings) is so struck by the staggering beauty of the song's first strain that he involuntarily drops the paper. In describing Kothner's reaction as such, Wagner submits the bodily-produced Prize Song as that which has a distinct effect on the bodies of those who hear it: its sonorous and melodic exquisiteness infuses the listener with pleasures of such intensity that it is sufficient to effectively "overload" the body's capacity to control its movements. In this context, such loss of control is an outward manifestation of bliss, as opposed to a moment of terror. I do not intend to analyze the implications of such a statement, but I invoke it to make the point that in his stage direction, Wagner foregrounds the body as vital in both the performance and reception of his "holy German art."

The sounds that emanate from Walther's performing body consequently form connections with other bodies, and those bodies become connected to each other through their reception of the Prize Song, resulting in a continuously expanding circuit. As such, the music produced by Walther's performing body does not simply become disembodied sonority once it has exited the singer's lips: under the theoretical paradigms of Gilles Deleuze and Félix Guttari, Walther's acoustic dissemination functions as a body of its 
own, in the form of their concept of the "body without organs," which they characterize as the body of "desire" itself. ${ }^{93}$ The body without organs (BwO) represents a virtual body comprised of a seemingly infinite series of potential actions and connections to be made with other bodies. For Deleuze and Guattari, a "full" BwO facilitates desire's drive to traverse from body to body, forming an ever-spreading circuit of connections. The full $\mathrm{BwO}$ represents the $\mathrm{BwO}$ at its most healthy, actively producing flows of desire that seek out connections while not being strictly systematic in directing those connections. The full BwO is not exactly "random" in its production of connections, but at the same time, it is not rigid in its directives, allowing connections to proceed along its "natural" unpredetermined course. ${ }^{94}$

Walther's Prize Song is the type of "virtual body" that emanates from a physical body, flowing outwards and seeking out connections with the various individuals assembled on the Festival Meadow. The Prize Song's demonstrates its productivity as a BwO in that the connections it makes with the sundry spectators produces a new flow of desire; upon making connection with each new body, the Prize Song activates the populace's collective desire for a sense of shared heritage. From that desire, the concept of the Volk becomes defined and normalized, with the Prize Song being collectively identified as a direct engagement with that shared desire for cultural commonality. In a sense, the BwO that is the Prize Song at once speaks to a pre-existing cultural desire for a Volk shared by the populace, and instantly (re)produces that desire by making a series of simultaneous connections with a mass body, the result of a supple outward flow of desire

\footnotetext{
${ }^{93}$ Gilles Deleuze and Félix Guttari, Anti-Oedipus: Capitalism and Schizophrenia, trans. Robert Hurley, Mark Seem, and Helen R. Lane (Minneapolis: University of Minnesota Press, 1983) and A Thousand Plateaus: Capitalism and Schizophrenia, trans. Brian Massumi (Minneapolis: University of Minnesota Press, 1987).

${ }^{94}$ A Thousand Plateaus, 149-166.
} 
producing new forms of desire that seek out new forms of connection between subjects. ${ }^{95}$ These connected masses can then be framed as a coherent Volksgeist, devoted to German art as the primary organizing principle of the community/nation. It could be said that within the context of Wagner's Nuremberg, the Volk could not exist without an outstanding work(s) of art to trigger and cultivate the need for cultural solidarity that forms the basis for the very idea of the Volk. Walther's body - both his physical performing body and the migrating BwO that emerges from that physical body functions as the very instrument that (re)introduces the concept of the Volk to the Nuremberg (German) population, creating the conditions of possibility for their cultural unification under the banner of German art. ${ }^{96}$

In his attainment of both the Masters and the Volk's commendation as the newly outstanding example of Nuremberg's artistic life, Walther becomes a "sterling moral example" for the Mastersingers and Volk alike, a premise borne out by the fact that the chorus takes up the morning-dream melody in unanimously proclaiming Walther the victor. The Prize Song's migration into the vox populi signals that the opera "ends with the energies of Walther's art filling and transforming Nuremberg, a utopian conclusion that enacts with overwhelming confidence the fulfillment of one of the most persistently

\footnotetext{
${ }^{93}$ Compare the ideas that I have just postulated with Carolyn Abbate's notion of a "metempsychotic Wagner." As Abbate notes, "metempsychosis" is predicated on the idea that "an individual soul's eternal essence is imagined to travel unchanged through its residence in this body or that, human or animal" (107). The "metempyschotic" Wagner is an "essence" of Wagner that that migrates in and out of successive performing bodies. One of her examples is the film The Lady Eve (1941), which which traces the plot of Tannhäuser; Abbate argues that the bodies of the film's characters become inhabited by Wagner's essence, speaking in Wagner's "voice." I would propose that the "body without organs" that is the Prize Song could be similarly framed as metempsychotic in that its "essence" traverses the sundry bodies of the Volk and taking up residence within them, demonstrated by the fact that the chorus adopts the principal Prize Song motif and repeats it back to Walther in order to demonstrate the inate connection between Walther's artistry and the Volksgeist. See In Search of Opera (Princeton, NJ and Oxford: Princeton University Press, 2001), 107-144.

${ }^{96}$ Deleuze's theories on music are discussed in detail in Brian Hulse and Nick Nesbitt, eds. Sounding the Virtual: Gilles Deleuze and the Theory and Philosophy of Music (Farnham, UK and Burlington, VT: Ashgate, 2010).
} 
held ideals of the romantic age, the elevation of the artist-hero to supreme influence over society."97 Emanating from the beautiful body that has just heroically slain the giant are the heroic sounds that will serve to unify the populace in praise of the new artistic "leader" that has just shown all witnesses the way forward. Furthermore, the BwO that is the sonority of the Prize Song produces fulfillment and transformation of the community by making its various connections with the receiving bodies of the populace. In all cases, Walther's performing body is the focal point that permits his crowning as the instrument of Nuremberg's artistic transformation.

In ascending to the level of "supreme" artistic influence over an entire society, Walther represents, according to Williams, the first of Wagner's heroic characters who "has achieved messianic status, as society has been regenerated by the power that speaks through his poetry. Their future welfare, even survival, hangs upon Walther's presence. For the first time in the mature music-dramas, the authority embodied in the hero is incorporated into society." 98 Whereas characters such as the Dutchman, Tannhäuser, Lohengrin, and Siegfried were consigned to remain alienated in one manner or another from their respective societies, in Walther, a Wagnerian hero becomes accepted as a valued member of the culture and indeed actively chooses to remain with that culture, ${ }^{99}$ paving the way for Parsifal, arguably the pinnacle of Wagner's messianic heroes. As Williams notes in the above quote, Walther solidifies his messianic status by "regenerating" the art of Mastersong, giving it new life and a refreshed sense of vitality by introducing an entrancing new model for others to follow. In characterizing the climax of the opera as a "fertility rite" heralding the rebirth of German art and the

\footnotetext{
${ }^{97}$ Williams, 126.

${ }^{98}$ Ibid.

${ }^{99}$ Albeit following some soft chiding from Sachs after he initially rejects admittance into the guild. 
concomitant renewal of solidarity of the German race through that art, Paul Lawrence Rose essentially concurs with such a reading. ${ }^{100}$ Rose does not draw out the "heroic" aspect of Walther's engineering of the culture's artistic rebirth, but suffice it say that in performing the Prize Song, Walther's artistic heroism is put forth as "redeeming" the art of Mastersinging and in so doing, situates himself as the exemplary "moral" example to be followed by future practitioners and consumers of German art. ${ }^{101}$

Walther's "heroism" being carried out in the name of art helps siginificantly in solidifying Nuremberg's status as an "aesthetic utopia." In its prophetic connection to David's slaying of Goliath by Eva, Walther's composition and performance of the Prize Song is constructed as an act of artistic intrepidity that stands in for the act of physical derring-do carried out by Walther's mythological forebear. Similarly, Walther's "sterling moral example" arises out of his artistry, rather than the ostensible racial "purity" that will characterize Parsifal's superiority. Neither are outward concerns for the denizens of Wagner's Nuremberg, who "live in a kind of aestheticized state that regulates itself without any need for a social contract." 102 Chapter Two has already expounded upon the notion of the artistic utopia in some detail, but it bears repeating that in this milieu, issues of politics and morality seem not to remotely enter into the Nurembergers consideration; art is the sole lifeblood of their being. Therefore, for Walther to heroically "save" Meistergesang is to save the entire community. The aesthetic utopia of Nuremberg naturally also creates the conditions of possibility for Kunstreligion. Indeed, Claus-

\footnotetext{
${ }^{100}$ Rose, 111.

${ }^{101}$ In fact, Claus-Dieter Osthővener states that Die Meistersinger is "the only music drama in which Wagner is explicitly dedicated to representing his aesthetics beliefs of the Zurich era: the redemption of the arts" ("Die Meistersinger sind damit das einzige Musikdrama, in welchem sich Wagner der explitziten Darstellung seiner åsthetischen Überzeugungen der Zürcher Zeit widmet; der Erlösung der Künste"). He makes this observation in the context of a wider discussion of the pervasivness of the theme of redemption throughout Wagner's work in "Konstellationen des Erlösungsgedankens," Wagnerspectrum 5/2 (2009): 72.

${ }^{102}$ Borchmeyer, Drama and Richard Wagner, 181.
} 
Dieter Osthövener's discussion of redemption in Meistersinger concludes by positing that the work fulfills the "spiritual world" of the Zurich essays, specifically The Artwork of the Future, quoting that essay's proclamation that "the work of art is the living depiction of religion; but religions are not invented by the artist; they only find their origins in the Folk."103 Sachs's subsequent monologue, venerating as it does "holy German art," will endeavour to make explicit in the opera's text the connection between the religiosity of art and the German people.

All of the above elements contributing to the Prize Song's and Walther's public canonization occur as parts of a grand opera ceremonial crowd scene. Indeed, it is the opulent spectacle of a public celebration that plays a substantial role in consecrating Walther, specifically his tenor sonority, as the messianic redeemer of German art and artistic hero of the Volk. ${ }^{104}$ Walther's aestheticized body steps before the choral crowd that is the Volk to deliver an oration in his "heroic" tenor sonority that enraptures the Volk and prompts them to collectively anoint this sound and this performer as their new ideal of Meistergesang. Placed in the context of a large-scale public ceremony, grand opera and the performing body of the Wagnerian tenor interact to "save" the art of Mastersinging, paving the way for Nuremberg to definitively ascend to an aesthetic utopia, and for German art to be officially sanctioned by Sachs as Kunstreligion. By

\footnotetext{
${ }^{103}$ Osthövener, 75: "Denn es filgen sich die Meistersinger so noch einmal neu in die geistige Welt der Zürcher Schriften ein: 'Das Kunstwerk ist die lebendig dargestellte Religion; - Religionen aber erfindet nicht der Kulnstler, die entstehung nur aus dem Volke."'

${ }^{104}$ As Barry Millington and Stewart Spencer note, the situation of the character of Walther as a stand-in for the intersection between German art and the national identity became especially prevalent in Ludwig II's stated feelings of affinity with the character. Indeed, they point to a particular incident when the King arrived at Wagner's home on his birthday in 1866, and announced himself as "Walther von Stolzing." In this occurrence, we see an example of a German monarch moving to cultivate a personal narrative for himself as an enlightened "messianic" leader that provides the moral example of valorizing art - Wagnerian art, specifically - as an expression of national character by appropriating the identity of an operatic character who accomplishes just such a goal. See SL, 592 .
} 
placing the Prize Song in the context of the ceremonial scene, Wagner conspicuously transforms the role of the individual in grand opera's dramaturgy: whereas even the most outstanding characters in traditional grand opera are frequently swallowed up by the inexorable progression of external historical events, in Meistersinger, grand opera's historical backdrop provides the stage for the outstanding individual's greatest triumph.

\section{And So Does Sachs}

Walther and his Prize Song might represent the "saviour" of the art of Meistergesang, but Walther's "heroic" tenor is not permitted the last word; that privilege is reserved for Sachs. As Williams observes, this sheds some intriguing light on the heroic status of both Walther and Sachs. As Walther has ascended to a messianic status, he

[R]uns the danger of committing hubris, which will lead to his downfall, or he will take a position of authority that will require unquestioning loyalty from others. But this is a comedy where tragic categories will not prevail. At the last moment Wagner engineers the action so that Walther's messianic influence and institutional sanction are avoided. As Pogner places the chain of the Mastersinger around Walther's neck, Eva removes the myrtle wreath from Walther's head and places it instead on Sachs'. Social acclaim goes, therefore, to the man whose poetry binds society together, and while romantic art has been recognized by the guild and the people of Nuremberg, it still lies, where it should do, outside the limits of authority. ${ }^{105}$

I am not so sure that Wagner's dramatic gambit effaces Walther's "messianic influence," especially since he has been specifically put forth as the individual who cohesively integrates "old" and "new" and in doing so, revitalizes the Mastersinger guild and the artistic life of Nuremberg as a whole. However, it cannot be denied that in transferring the public's acclamation from Walther to Sachs, Walther's artistic example is prevented from transforming into political or juridical leadership: it is the art that matters, not the

\footnotetext{
${ }^{105}$ Williams, 126-127.
} 
personality. One could profitably dispute such a notion by pointing to the chorus's declaration of "Heil! Sachs! Nürnberg's teurem Sachs!" as the erection of a cult of personality around the cobbler-poet, and Sachs's exhortation to the crowd to "honour your German Masters" comes across as rather self-serving given his prominent position in the guild. Certainly, there is an aspect of the conclusion that is specifically designed to glorify Sachs himself as an outstanding individual. ${ }^{106}$ On the other hand, it could just as plausibly be argued that the crowd's veneration of Sachs is in response to the content of his oration rather than a response to any personal magnetism on his part. If we accept that Wagner's Nuremberg is constructed as an aesthetic utopia, then Sachs's veneration of "holy German art" as the bedrock of society envoices the collective beliefs of the entire Nuremberg community. Even so, the finale centralizes an individual as being held up for prominent public acclaim, with Sachs's performance setting him up as a synecdochal stand-in for the entire community, the expression of the one representing the feelings of the whole.

Several commentators have noted that the finale's transfers the Volk's approbation from Walther to Sachs. Goehr's analysis goes so far as to argue that when Eva removes the wreath from Walther's head and places it on Sachs's, "she crowns Sachs to render him the winner of the contest of art, leaving Walther the winner of the contest of love."107 As Goehr sees it, Eva's response to Sachs's tribute to the endurance of German art is to anoint him as the supreme artistic figure in Nuremberg in place of Walther (the Eva/Eve

\footnotetext{
${ }^{106}$ Indeed, the stage direction for the finale clearly places Sachs in a role suggesting that of benevolent authority figure for the entire city when it specifies that "Pogner läß sich, wie huldigend, auf ein Knie vor Sachs nieder" (Pogner sinks on his knee before Sachs as if in homage) and that "die Meistersinger deuten mit erhobenen Händen auf Sachs, als auf ihr Haupt" (the Mastersingers point to Sachs, with outstretched hands, as to their chief). However, it bears reminding that the bequeathing of such authority is kept strictly metaphorical by the libretto; clearly the intention is not to explicitly frame Sachs as possessing actual political or juridical authority over the town.

${ }^{107}$ Goehr, "Contest, Myth, and Prophecy," 98.
} 
confluence expounded upon in the Prize Song apparently grants her the Biblical authority to carry out this act of benediction in the name of the entire community). This division of the spoils of victory is efficacious in accomplishing the previously stated goal of preventing either Walther or Sachs from attaining absolute messianic influence over the Volk: since neither "wins" completely and thus must share the victory, neither will achieve complete cultural power, leaving themselves vulnerable to corruption as a consequence. Of course, the transfer of artistic triumph from Walther to Sachs suggests that the latter has ended up in possession of "first prize" given the import granted to art above practically all else in Nuremberg. Following Goehr's interpretation, we are led to conclude that in taking the wreath from Walther, Eva effectively communicates to him that he must content himself (as he surely will) with Eva's love because even the manifest greatness of the Prize Song cannot wrest the artistic hearts and minds of the Volk from Sachs. After all, if not for Sachs's recognition and cultivation of Walther's talent and clever strategizing, Walther could not have succeeded. In contending that Sachs exits the opera as the artistic champion of Nuremberg, Goehr suggests that it is Sachs who is positioned at the opera's close as the true "hero" of German art. In an earlier analysis, Groos suggests just that: in stating that through the characterization of Sachs as valuing both innovation and tradition, Wagner constructs Sachs as his own avatar. $^{108}$

Although it is clear that in allowing him to provide the "moral of the story," Wagner has privileged Sachs's position both as a beloved fixture of Nuremberg's culture and as a spokesperson, both within the narrative and without, for the importance of art to the German character, I cannot completely subscribe to either Goehr's or Groos's

${ }^{108}$ Groos, 32 . 
readings of Sachs's relationships to either Nuremberg society or Wagner himself. Principally, I find it difficult to wholly accept the notion that Wagner would foreground as a singular representative of German art and/or a stand-in for himself an individual who, as Goehr herself notes, "ends up with the authority of a critic who no longer performs." 109 Would Wagner assign sole domain over the protection of the sanctity of German art and furthermore, the role of his own personal avatar, to a character whose primary role in the narrative is as a critic and pedagogue, especially when Wagner himself is a composer? Rose's reading takes this into account when he assigns the role of Wagner's stand-in to Walther: the fictional composer/performer rejuvenates German art by renewing its spiritual connection to the Volk, a complementary act to what the real-life composer purports to accomplish within this very work. ${ }^{110}$ On that level, it would appear to make more sense to consider the composer to be Wagner's avatar and representative of the ideal of German art. But the fact that the opera's most triumphant moment revolves around Sachs cannot be ignored, which prompts me to propose a modification of Goehr's and Groos's points: rather than dividing the triumph between artistic (Sachs) and romantic (Walther), I would argue that Wagner sets up the conclusion so that the artistic triumph is shared between Walther and Sachs, with the former the champion practitioner and the latter serving as the reigning philosopher. Such a compartmentalization of acclaim effectively carries out Williams' paradigm of Wagner ensuring that neither character ascends to an absolute messianic influence over the culture; only taken together do Walther and Sachs stand as a complete sterling example of German musical practice

\footnotetext{
${ }^{109}$ Goehr, 99.

${ }^{110}$ Rose, 111.
} 
and appreciation to the Volk. ${ }^{111}$ Since Sachs shares in the public commendation (and one could argue he in fact appropriates Walther's glory) as a protector of German art, it stands to reason that Sachs carves out a heroic role of his own in relation to the promotion of the national identity, a supposition that goes back to Wagner's conception of the character as laid out in A Communication to My Friends, where he framed the cobbler-poet as what amounts to the proverbial "last line of defence" in terms of preserving the artistic spirit of the Volk. In accepting that Walther has now earned the mantle of creative force of Meistergesang, Sachs acquiesces to the role of "elder statesmen," advocating for the preservation of the Mastersinger guild as representative of the essential goodness of German culture. In his "protectionist" role, Sachs attains a heroic stature to the Volk that complements that of Walther; whereas Walther's heroism is based on his intuitive creative genius, Sachs's is based upon the intrinsic wisdom of his philosophy.

We find in Sachs's final address what Stephen McClatchie refers to as "the primary locus of [the opera's] activity of nation-building."112 This is the case because contained in this monologue is the most unequivocal advocacy for art as the foundation of German society, which will outlast such evanescent notions as imperialism, militarism, and even nation-states themselves. As Sachs's summational couplet clearly states: "zerging in Dunst, das heil'ge röm'sche Reich, uns bliebe gleich die heil'ge deutsche Kunst!" ("even if the Holy Roman Empire should dissolve in mist, for us there would yet

\footnotetext{
${ }^{111}$ As an aside, in having created both characters and the scenario that they take part in, Wagner essentially reserves both practical and philosophical roles for himself, leading Goehr to conclude that the opera's resolution "promotes the feeling that the trickiest of all tricks has been played, leaving Wagner the winner of all overall" (99). The triumphs of both Walther and Sachs have been engineered by Wagner, in order to bequeath himself the status of messianic hero of German art.

${ }^{112}$ Stephen McClatchie, "Performing Germany in Wagner's Die Meistersinger von Nürnberg," The Cambridge Companion to Wagner, ed. Thomas S. Grey (Cambridge: Cambridge University Press, 2008), 142.
} 
remain Holy German Art!") As Grey aptly states, through this statement "Wagner stresses the enduring 'spiritual' legacy of art over and against the temporal aims of government and politics."113 Grey adds

The art of song, says Sachs, has always been the best means of achieving civic harmony - hence the special honor due to the mastersingers among all the guilds. Wagner's ideal state is an aesthetic one, in which private and public life alike are subject to the beneficient rule of art. ${ }^{114}$

Grey makes the same contention that Borchmeyer does in identifying Wagner's Nuremberg as an aesthetic utopia. Moreover, the implication that art supplants institutions such as legislature and the church as the culture's organizing principle is intrinsic to art's transformation into Kunstreligion. In this inspirational address "Sachs clearly links the art of the Meistersinger with national culture and, in lecturing Walther, is in fact exhorting the Volk (and the audience) to honor the legacy of holy German art."115 But as Vazsonyi argues, there is a pronounced self-serving streak to Wagner's conflation of the Mastersinger guild with the essence of German identity: in creating a narrative where the fusion of poetry and music is identified as an expression of the very essence of the German people and mobilizing that narrative in a self-composed work that similarly joins text and music, Vazsonyi contends that in Die Meistersinger Wagner has clearly endeavoured to cultivate a brand for himself, where "Wagner" becomes equated with "German."116 By mobilizing this subject matter, Wagner moves to align his opera, and therefore himself, with a vital part of the nation's heritage. Wagner situates the work (and by extension, himself) as an example of a contemporaneous artwork that bears direct

\footnotetext{
${ }^{113}$ Thomas S. Grey, "Wagner's Die Meistersinger as National Opera (1868-1945)," Music \& German National Identity, eds. Celia Applegate \& Pamela Potter (Chicago and London: University of Chicago Press, 2002), 82.

${ }^{114}$ Ibid.

${ }^{115}$ McClatchie, 142.

${ }^{116}$ Vazsonyi, Richard Wagner, 165-168.
} 
lineage to that heritage. As such, both it and Wagner are branded as inherently "German."

During the initial strains of his monologue, Sachs entreats Walther and the Volk to pay appropriate deference to the Mastersingers guild, for it is they, according to Sachs, who have preserved the heritage and sanctity of Nuremberg's art, and protected the noblest aspects of the culture. Sachs's sponsorship of the guild's preservationist practices falls in line with his earlier remarks to Walther that he must fit his innovations within the guild's traditions in order to produce a genuine Mastersong. The musical content of Sachs's monologue acts as the resolution to the issue of integrating innovation and tradition: once Sachs concludes his initial exhortation to Walther to not disparage the Masters, the violins proceed with the Prize Song theme (reprising a similar passage from the overture), carrying the clear implication that Walther's song is now conclusively integrated into Nuremberg's musical culture, a true piece of German art. Concurrent with this statement of the Prize Song melody is the articulation of the theme associated with the Mastersinger guild in the basses. This gesture is a clear case of "innovation quite literally supported by tradition, sounding magnificent together in perfect contrapuntal harmony...."117 The comparative treatment of Sachs's vocal line is interesting: the vocal part vacillates between loosely following the thematic material as declaimed by the orchestra and descanting against the orchestra. As John Deathridge has written, the descant technique was prominently employed for Isolde's final "transfiguration," the voice functioning as counterpoint to the already cohesive musical argument of the

\footnotetext{
${ }^{117}$ Ibid., 166.
} 
orchestra. ${ }^{118}$ Deathridge's analysis posits the lack of "memorable" vocal melody as an example of the gradual destabilization of the voice and situates that notion within a larger framework regarding the dissipation of the self and theories of the noumenal and the musically "absolute." In Meistersinger, I would thematize Sachs's descants quite differently: in ceding the central "musicality" of the passage to the orchestra, Sachs does not efface the necessity of the vocal line. Rather, it foregrounds the text as carrying vital importance. The orchestra can be left to provide the thematic material because the vocal is required to communicate a specific message. Which is not to say that Sachs's oration is confined to dry recitative: his address is certainly musically engaging, but the point is that its deviations from thematic material should not be taken to indicate a disengagement of the voice like in Isolde's soliloquy.

At various points throughout the chapter, I have made the case for Sachs's "low" bass-baritone sonority as an acoustic marker of his "depth" and "wisdom." During this monologue, those low sounds combine with the unhurried rhythms of the vocal line and generally smooth melodic contour in order to acoustically frame Sachs as the wise elder statesmen. The final portion of the monologue is the most explicit in its tying of the Mastersinger guild in with the essence of German art in general, and the spiritual import of both:

Drum sag ich Euch: ehrt Eure deutschen Meister! Dann bannt ihr gute Geister: und gebt ihr ihrem Wirken Gunst, zerging in Dunst das heil'ge röm'sche Reich, uns bleibe gleich die heil'ge deutsche Kunst!
[Therefore I say to you: honour your German Masters, then you will conjure up good spirits! And if you favour their endeavours, even if the Holy Roman Empire should dissolve in mist, for us there would yet remain Holy German Art!]

\footnotetext{
${ }^{118}$ John Deathridge, Wagner - Beyond Good and Evil (Berkeley: University of California Press, 2008), 141142.
} 
As previously discussed in Chapter Two, this passage is the most significant in the opera in terms of framing German art as religious, and as such it serves as Meistersinger's most prominent display of the Kunstreligion aesthetic. By contextualizing his exhortation to honour the Masters within a reverential paean to the enduring power and religiosity of German art, Sachs discursively situates the guild as essentially religious (and messianic) figures in the community.

As it turns out (and as the discussion of this section of the opera in Chapter Two attempted to make clear), this is exactly what the Volk want to hear, as they, in the form of the grand opera chorus, triumphantly repeat Sachs's words as the public benediction of the spiritual power of German art that bonds them together as German people, whose "essence" will endure all forms of political and social upheaval. As Walther accomplished with the Prize Song, Sachs as a solo figure steps into the dramaturgy of the grand opera ceremonial scene to communicate a sonorous message that will serve to unify the Volk, the enhanced spectacle of grand opera giving the message the appropriate mythic weight to accomplish such a monumental task. As with Walther's performance, it can be argued that once the sound/words has escaped from Sachs's lips, his monologue as both text and sonority becomes a "Body Without Organs" that seeks out and initiates connections with its spectators. Those connections serve to unite the Volk with Sachs and with each other through a shared desire: their common belief in the spiritual power of art (specifically song) as the foundation of their society and the status of its practitioners as noble guardians of the best elements of their culture. That shared desire and the connections it forms is what is efficacious in turning Nuremberg into a supple, vital 
community. In functioning alongside Walther as one of the instruments that solidifies and enhances the community/nation's unity through art, Sachs joins Walther in serving as a "heroic" example for the Volk, an outstanding representative of German culture. But like Walther, Sachs's artistic heroism is very much embraced by the community, and both "heroes" accept their roles and remain ensconced within the culture. As such, Walther and Sachs may be foregrounded as "ideals" of German culture, but they manage not to be unattainable, perpetually out-of-reach imago figures; their respective talent and wisdom may be superior to those of the "common" citizenry, but that does not obviate their capacity to be integrated into the Volk. They are simply the most "in touch" with the so-called Volksgeist. It is the reality of being a part of that community that enables them to transmute that spirit into art, and into a philosophy of that art.

Backtracking to the middle of Sachs's monologue, we find the most provocative statement in the piece, where Sachs's advocacy for the sanctity of German art, and the guild's practices in terms of preserving that sanctity turn to outright cultural chauvinism:

Habt Acht! Uns dräuen üble Streich: zerfällt erst deutsches Volk und Reich, in falscher wälscher Majestät kein Fürst bald mehr sein Volk versteht, und wälschen Dunst mit wälschem Tand sie pflanzen uns in deutsches Land; was deutsch und echt, wüßt keener mehr, lebt's nicht in deutscher Meister Ehr. (III, v)
[Beware! Evil tricks threaten us: if the German people and kingdom should one day decay, under a false, foreign rule soon no prince would understand his people; and foreign mists with foreign vanities they would plant in our German land; what is German and true none would know, if it did not live in the art of the German Masters.]

The quoted portion underlines the importance of the Masters in protecting German art and culture from being diluted by ever-present foreign threats. As both Groos and Grey 
observe, ${ }^{119}$ such warnings against potential cultural contamination find resonance within remarks Wagner makes in his 1868 essay "German Art and German Politics," namely that German culture is under constant threat from corrupting influences of foreign cultures, particularly from France. ${ }^{120}$ As Grey notes, the publication of the essay was preceded the Franco-Prussian War by only a few years, giving both Wagner's and Sachs's words a clear subtext. ${ }^{121}$

Wagner's stated disdain for French culture's corrosive effect on German culture feeds into his well-established written censures against grand opera. As Levin notes, in Opera and Drama and even as late as the essay "A Glance at the German Opera-Stage of Today" (1873), ${ }^{122}$ Wagner laments the devolution of opera into meaningless spectacle and stage-trickery as the result of the deleterious influence of foreign (read: French) operatic traditions, "the proliferation of mindless effects on the operatic stage testif[ying] to the predominance of an unnatural, cosmopolitan culture...."123 Wagner's rebuke of operatic cosmopolitanism and "mindless" effects are of course reminiscent of his own "effects without causes" dismissal of Parisian grand opera in Opera and Drama. ${ }^{124}$ So, what does it mean when Wagner clearly mobilizes grand opera dramaturgy in Die Meistersinger to stage German nationhood while warning against the encroachment of French culture? I would submit that this seeming contradiction represents a specific strategy on Wagner's part: rather than allowing German culture to be "colonized" by foreign influences and transformed into something grotesquely unrecognizable as

\footnotetext{
${ }^{119} \mathrm{Groos}, 32$ and Grey, "Meistersinger as National Opera," 83-84.

${ }^{120}$ SSD VIII, 30-35 and 91-97; PW IV, 37-42 and 102-108.

${ }^{121}$ Grey, 84.

${ }^{122}$ SSD IX, 264-287; PW V, 263-284.

${ }^{123}$ Levin, 41.

${ }^{124}$ SSD III, 301; PW II, 95.
} 
German, Wagner will instead "colonize" French culture, appropriating elements of its own musical heritage (grand opera) and transform its ostensibly ruinous excess into that which can successfully represent the German Volksgeist. Whether or not he was conscious of it, it can be argued that Wagner essentially uses Sachs's address to premptively fight the forthcoming Franco-Prussian conflict on an artistic front, with Germany achieving clear cultural conquest.

Sachs's/Wagner's warning also feeds back into the issue of the opera staging sixteenth-century Nuremberg as a proleptic community. As elucidated in Chapter Two, the Festival Meadow registers as an approximation of nineteenth-century festival culture, transplanted into sixteenth-century Nuremberg. The earlier discussion centralized the chorus's reception of the Prize Song as an integral element in the public benediction of German art. Sachs's decree comes in the aftermath of that "festival," but as Groos implies, it is similarly proleptic in projecting the nineteenth century back into the past. ${ }^{125}$ Wagner's contemporaneous concerns about the harmful infiltration of the foreign into German culture are placed in the mouth of Hans Sachs, creating the impression that an aspect of nineteenth-century German nationalist thought is already part of Germany's history by being presented as an expression of sixteenth-century ideology. While Walther performs the Prize Song within the context of a nineteenth-century festival in order to rejuvenate German song, Sachs envoices nineteenth-century political concerns in order to promote vigilance in the protection of the nation's artistic legacy. Both take part in what amounts to a grand opera crowd scene as proleptic community in order to provide the aspirational model for the "regeneration" and preservation of German art.

${ }^{125}$ Groos, 32-34. 
In employing prolepsis in order to project the nineteenth century into the sixteenth century, Die Meistersinger functions as an example of an "invention of tradition." ${ }^{126}$ In this case, the invented tradition is the troping of the sixteenth-century Mastersingers as at once attuned to the Volksgeist, elevating art to the level of the sacred, and protecting German art from foreign corruption, modern narratives that are framed as already part of history so that "the past presumably takes on a double character: it functions with both its traditional and invented interpretation." 127 In employing prolepsis to implant the contemporary nineteenth century into a specific point in German history, it can be contended that Die Meistersinger offers a different angle on the "always-already" paradox that was raised in Chapter Four. In that chapter, I argued that the "Christian" operas tacitly acknowledged the fundamental impossibilities of the consecration and regeneration of German art and the German nation, by framing that which had not yet happened in contemporary society as having already occurred in the mythologized past. These impossibilities were emphasized through the centrality of perpetually deferred male imago figures as embodiments of the redemption of the nation's art with those redemptions being further displaced into temporally and/or geographically removed locales. In contrast, I propose that Meistersinger does not place a constantly postponed future inside a mythical past: the shift from the unattainable male imago figures of Lohengrin and Parsifal to the more easily assimilated Walther and Sachs functions as the first step towards a transition from the deferred future to the living present. Through the performance of Die Meistersinger on the contemporary nineteenth-century stage, the

\footnotetext{
${ }^{126}$ Eric Hobsbawm and Terence Ranger, eds. The Invention of Tradition (Cambridge and New York: Cambridge University Press, 1983).

${ }^{127}$ Goehr, The Quest for Voice, 52.
} 
regeneration of German art through its renewed connection to the Volksgeist is happening right now.

But that "right now" also registers as a form of cultural atavism: the consecration of German art that is currently happening on stage is presented as having already happened. The consecration is taking place in a past that is ostensibly less "mythologized" than the past of the "Christian" works due to sixteenth-century Nuremberg's greater temporal proximity to the present and the greater documentation of the culture of the Mastersingers. Of course, this "Nuremberg" is in reality very much a mythologized past, owing to the invented tradition being played out. From the perspective of the nineteenth century, German art and the nation is simultaneously being and has already been reinvigorated and preserved through the heroic examples of the performing bodies of Walther and Sachs. Meanwhile, from the vantage point of sixteenth-century Nuremberg, German art is at once being consecrated and will be consecrated again in the future through those same performing bodies. In addition to the "always-already" paradox, Die Meistersinger's invention of tradition through the proleptic community also sheds some new light on Nietzsche's "yesterday and tomorrow, but no today" paradigm about German culture, as expounded upon in Chapter Two. Through the intersection of the history (documented and mythologized) of the Mastersingers of Nuremberg and their depiction on Wagner's operatic stage, present, past, and future circle back on each other in a feedback loop: the opera's has been/is/will be paradigm with regards to the rebirth of German art creates something of a cultural Moebius Strip, the beginning and ending of the circuit difficult to distinguish. Whether 
this truly constitutes "no today" and the question of how the past, present, and future of German art relate to each other in this context are logical and philosophical problems I am not equipped to solve. Nonetheless, the salient point that I wish to take from this discussion is that Wagner's Nuremberg as stage for the German nation distinguishes itself from the nation as thematized in Lohengrin, and Parsifal: where those works acknowledged a fundamental unattainability of the nation, Die Meistersinger posits what could be called a "over-attainability" by demonstrating its simultaneous realization in its past, that past's future, and the present.

In situating his musical works (whether we call them operas, music dramas, or Bühnen(weih)festspiele) as vital expressions of German identity, and through those works locating the German nation somewhere on a continuum between "unattainable" and "over-attainable," Wagner (unknowingly) demonstrates that the performance and production of the nation is more fraught than he ever could have realized. This can be amply shown through the lack of continuity and linearity in terms of where his works fall on that continuum: Parsifal, Wagner's "last card," presents the "regeneration" of the German race as a perpetually deferred event, while Die Meistersinger, completed earlier, presents the renewal of the German nation as very much within grasp. These types of discontinuities between perspectives on the (im)possibility of a stable and supple nation throughout the corpus of Wagner's work should not necessarily be written off as mere inconsistency of thought, or even as simply leaps of imagination, for from our contemporary theoretical and hermeneutical perspective, it is those very inconsistencies and discontinuities that demonstrate to us the contingent nature of narratives of nationhood. In vacillating between the nation of differance as staged upon the 
performing body of the unattainable male imago, and the attained nation as presented through the invented tradition of the proleptic community, Wagner's dramatic works clearly illuminate for us that the nation is subject to persistent flux, subject to constant redefinition and thus must be continually brought into being, performed over and over again in order to prop up a fantasy of stability. And as the preceding discussion should have made abundantly apparent, the mobilization of grand opera plays no small part in Wagner's endeavours to stabilize his own phantasmatic(s) of performing bodies and of German art and nationhood. 


\section{BIBLIOGRAPHY}

Abbate, Carolyn. "The Parisian 'Venus' and the 'Paris' Tannhäuser," Journal of the American Musicological Society 36/1 (Spring 1983): 73-123.

. “The 'Parisian' Tannhäuser.” Ph.D. diss., Princeton University, 1984.

. "Opera as Symphony, a Wagnerian Myth." In Analyzing Opera: Verdi and Wagner, eds. Carolyn Abbate and Roger Parker, 92-124. Berkeley: University of California Press, 1989.

. Unsung Voices: Opera and Musical Narrative in the Nineteenth Century. Princeton, NJ: Princeton University Press, 1991.

. In Search of Opera. Princeton, NJ: Princeton University Press, 2001.

and Roger Parker. A History of Opera. New York and London: W.W. Norton, 2012.

Adorno, Theodor W. "On the Score of 'Parsifal" (1956). Translated by Anthony Barone. Music \& Letters 76/3 (August, 1995): 384-397.

. Essays on Music, ed. Richard Leppert. Berkeley: University of California Press, 2002.

. In Search of Wagner (1952). Translated by Rodney Livingstone. London: Verso, 2005.

and Max Horkheimer. Dialectic of Enlightenment. Translated by Edmund Jephcott. Stanford, CA: Stanford University Press, 2002.

Altenburg, Detlef. "Franz Liszt and the Legacy of the Classical Era," $19^{\text {th }}$-Century Music 18/1 (Summer 1994): 46-63.

. "Franz Liszt und das Erbe der Klassik." In Liszt und die Weimarer Klassik, ed. Detlef Altenburg, 8-32. Laaber: Laaber-Verlag, 1997.

, ed. Liszt und die Neudeutche Schule. Laaber: Laaber-Verlag, 2006.

Althusser, Louis. "Ideology and Ideological State Apparatuses." In Lenin and Philosophy and Other Essays, 121-173. London: New Left Books, 1971.

Anderson, Benedict. Imagined Communities: Reflections on the Origin and Spread of Nationalism - Revised Edition. London: Verso, 1991. 
André, Naomi. Voicing Gender: Castrati, Travesti, and the Second Woman in Early Nineteenth-Century Opera. Bloomington: University of Indiana Press, 2006.

Applegate, Celia. A Nation of Provincials: The German Idea of Heimat. Berkeley: University of California Press, 1990.

. Bach in Berlin: Nation and Culture in Mendelssohn's Revival of the St. Matthew Passion. Ithaca, NY: Cornell University Press, 2005.

and Pamela Potter. "Germans as the 'People of Music': Genealogy of an Identity," in Music \& German National Identity, eds. Celia Applegate and Pamela Potter, 1-35. Chicago and London: University of Chicago Press, 2002.

Austen, J.L. How to Do Things With Words. Cambridge, MA: Harvard University Press, 1962.

Bakhtin, Mikhail. Rabelais and His World. Translated by Hélène Iswolsky. Bloomington and Indianapolis: Indiana University Press, 1984.

Barone, Anthony. "Richard Wagner's Parsifal and the Theory of 'Late' Style," Cambridge Opera Journal 7/1 (March 1995): 37-54.

Barth, Herbert, Dietrich Mack, and Egon Voss, eds. Wagner: A Documentary Study. New York: Oxford University Press, 1975.

Barthes, Roland. Mythologies (1957). Translated by Annette Lavers. London: J. Cape, 1972.

. Image/Music/Text. Translated by Stephen Heath. New York: Hill \& Wang, 1977.

Bartlet, M. Elizabeth C. "Grand Opera." In Oxford Music Online. Accessed July 15, 2012.

Baudelaire, Charles. The Painter of Modern Life and Other Essays $-2^{\text {nd }}$ Edition. Translated and edited by Jonathan Mayne. London: Phaidon Press, 1995.

Beckett, Lucy. Richard Wagner: Parsifal. Cambridge: Cambridge University Press, 1981.

Beecher, Jonathan. Charles Fourier: The Visionary and His World. Berkeley: University of California Press, 1986.

Benjamin, Walter. The Origin of German Tragic Drama. Translated by John Osborne. London: New Left Books, 1977.

. The Arcades Project (1999). Translated by Howard Eiland and Kevin McLaughlin. Cambridge, MA and London: Belknap Press, 2002. 
. The Writer of Modern Life: Essays on Charles Baudelaire. Translated by Howard Eiland, Edmund Jephcott, Rodney Livingstone, and Harry Zohn, ed. Michael W. Jennings. Cambridge, MA and London: Belknap Press, 2006.

. The Work of Art in the Age of Its Technological Reproducibility and Other Writings on Media. Translated by Edmund Jephcott, Rodney Livingstone, and Howard Eiland, ed. Michael W. Jennings, Brigid Doherty, and Thomas Y. Levin. Cambridge, MA and London: Belknap Press, 2008.

Berman, Marshall. All That is Solid Melts into Air: The Experience of Modernity. New York: Penguin, 1988.

Bernstein, Susan. "In Formel: Wagner and Liszt." New German Critique 69 (Autumn, 1996): 85-97.

Bertagnolli, Paul A. "Amanuesis or Author? The Liszt-Raff Collaboration Revisisted," $19^{\text {th }}$-Century Music 26/1 (Summer 2002): 23-51.

. "Liszt, Goethe, and a Musical Cult of Prometheus." In Liszt and the Birth of Modern Europe: Music as a Mirror of Religious, Political, Cultural, and Aesthetic Transformations, ed. Michael Saffle, 169-196. Hillsdale, NY: Pendragon Press, 2003.

Berry, Mark. Treacherous Bonds and Laughing Fire: Politics and Religion in Wagner's Ring. Aldershot, UK: Ashgate, 2006.

Bhabha, Homi K. "Narrating the Nation." In Nationalism, eds. John Hutchinson and Anthony D. Smith, 306-312. Oxford and New York: Oxford University Press, 1994.

. The Location of Culture (1994). London: Routledge, 2004.

Biddle, Ian. Music, Masculinity, and the Claims of History. Burlington, VT: Ashgate, 2011.

and Kirsten Gibson. "Section Two: Introduction." In Masculinity and Western Musical Practice, eds. Ian Biddle and Kirsten Gibson, 135-140. Farnham, UK and Burlington, VT: Ashgate, 2009.

Björnsson, Árni. Wagner and the Volsungs: Icelandic Sources of Der Ring des Nibelungen. University College London: Viking Society for Northern Research, 2003.

Bohlman, Philip Vilas. The Music of European Nationalism: Cultural Identity and Modern History. Santa Barbara: ABC-CLIO, 2004. 
Borchmeyer, Dieter. Richard Wagner: Theory and Theatre. Translated by Stewart Spencer. Oxford: Clarendon Press, 1991.

. "Wagner and Nietzsche." In Wagner Handbook. Translated by John Deathridge, ed. Ulrich Müller and Peter Wapnewski, 327-342. Cambridge MA and London: Harvard University Press, 1992.

. Weimarer Klassik: Portrait einer Epoche. Weinheim: Beltz Athenäum, 1994.

. Drama and the World of Richard Wagner. Translated by Daphne Ellis. Princeton and Oxford: Princeton University Press, 2003.

Bourdieu, Pierre. The Field of Cultural Production: Essays on Art and Literature, ed. Randal Johnson. New York: Columbia University Press, 1993.

Breig, Werner. "Der 'Rheintöchtergesang' in Wagners Rheingold," Archiv für Musikwissenschaft 37/4 (1980): 241-263.

. "The Musical Works." In Wagner Handbook. Translated by John Deathridge, eds. Ulrich Müller and Peter Wapnewski, 397-482. Cambridge, MA and London: Harvard University Press, 1992.

Brendel, Franz. Gesammelte Aufsätze zur Geschichte und Kritik der neueren Musik, ed. Allgemeiner Deutscher Musikverein. Leipzig: C.J. Rahnt Nachfolger, 1888.

. Geschichte der Musik in Italien, Deutschland und Frankreich von den ersten christlichen Zeiten bis auf die Gegenwert - Siebente, neu durchgesehene und vermehrte Auflage. Leipzig: Heinrich Matthes, 1889.

Brockmann, Stephen. Nuremberg: The Imaginary Capital. Rochester, NY: Camden House, 2006.

Brumlik, Mischa. "Erlösung von der Erlösung: Richard Wagners Christologie," Wagnerspectrum 5/2 (2009): 81-104.

Bryson, Norman. "Géricault and 'Masculinity." In Visual Culture: Images and Interpretations, eds. Norman Bryson, Michael Ann Holly, and Keith Moxey, 228259. Hanover and London: Wesleyan University Press, 1994.

Bujic, Bojan, ed. Music in European Thought, 1851-1912. Cambridge and New York: Cambridge University Press, 1988.

Burnham, Scott G. Beethoven Hero. Princeton, NJ: Princeton University Press, 1995.

Butler, Judith. Bodies That Matter: On the Discursive Limits of "Sex." New York and London: Routledge, 1993. 
. Gender Trouble: Feminism and the Subversion of Identity (1990). New York and London: Routledge, 1999.

Carlyle, Thomas. On Heroes, Hero-Worship, \& the Heroic in History. London: James Fraser, 1841.

Carnegy, Patrick. Wagner and the Art of the Theatre. New Haven and London: Yale University Press, 2006.

Cicora, Mary A. Parsifal Reception in the Bayreuther Blätter. New York: Peter Lang, 1987.

. From History to Myth: Wagner's Tannhäuser and its Literary Sources. Bern and New York: Peter Lang, 1992.

. Mythology as Metaphor: Romantic Irony, Critical Theory, and Wagner's Ring. Westport, CT: Greenwood Press, 1998.

.Wagner's Ring and German Drama: Comparative Studies in Mythology and History in Drama. Westport, CT: Greenwood Press, 1999.

. Modern Myths and Wagnerian Deconstructions: Hermeneutic Approaches to Wagner's Music Dramas. Westport, CT: Greenwood Press, 2000.

Citron, Marcia J. Gender and the Musical Canon. Cambridge and New York: Cambridge University Press, 1993.

"Gendered Reception of Brahms: Masculinity, Nationalism and Musical Politics." In Masculinity and Western Musical Practice, eds. Ian Biddle and Kirsten Gibson, 141-159. Farnham, UK and Burlington, VT: Ashgate, 2009.

Clark, Maribeth. "The Body and the Voice in La Muette de Portici," $19^{\text {th }}$-Century Music (Autumn 2003): 116-131.

Clément, Catherine. Opera, or, The Undoing of Women. Translated by Betsy Wing. Minneapolis: University of Minnesota Press, 1988.

Cooke, Deryck. I Saw the World End: A Study of Wagner's Ring. London: Oxford University Press, 1979.

Dahlhaus, Carl. Richard Wagner's Music Dramas. Translated by Mary Whittall. Cambridge: Cambridge University Press, 1979. . Between Romanticism and Modernism: Four Studies in the Music of the Later Nineteenth Century. Translated by Mary Whittall. Berkeley: University of California Press, 1980. 
. Nineteenth-Century Music. Translated by J. Bradford Robinson. Berkeley: University of California Press, 1989.

Danuser, Hermann. "Musical Manifestations of the End in Wagner and in PostWagnerian Weltenschauungsmusik," $19^{\text {th }}$-Century Music 18/1 (Summer 1994): 64-82.

Daub, Adrian. "Mother Mime: Siegfried, the Fairy Tale, and the Metaphysics of Sexual Difference," $19^{\text {th }}$-Century Music 32/2 (Fall 2008): 160-177.

Deathridge, John. Wagner's Rienzi: A Reappraisal Based on a Study of Sketches and Drafts. Oxford: Clarendon Press, 1977.

.Wagner - Beyond Good and Evil. Berkeley: University of Califomia Press, 2008.

Deaville, James. "Franz Brendel's Reconciliation Address." In Richard Wagner and His World, ed. Thomas S. Grey, 311-332. Princeton, NJ and Oxford: Princeton University Press, 2009.

. "Joachim Raff." Oxford Music Online. Accessed December 18, 2012.

Deleuze, Gilles and Félix Guattari. Anti-Oedipus: Capitalism and Schizophrenia. Translated by Robert Hurley, Mark Seem, and Helen R. Lane. Minneapolis: University of Minnesota Press, 1983.

. Kafka: Toward a Minor Literature. Translated by Dana Polan. Minneapolis: University of Minnesota Press, 1986.

. A Thousand Plateaus: Capitalism and Schizophrenia. Translated by Brian Massumi. Minneapolis: University of Minnesota Press, 1987.

Dellamora, Richard and Daniel Fischlin. "Introduction." In The Work of Opera: Genre, Nationhood, and Sexual Difference, eds. Richard Dellamora and Daniel Fischlin, 1-23. New York: Columbia University Press, 1997.

du Quenoy, Paul. Wagner and the French Muse: Music, Society, and Nation in Modern France. Bethesda, MD. Academica Press, 2011.

Derrida, Jacques. Margins of Philosophy. Translated by Alan Bass. Chicago: University of Chicago Press, 1982.

Downes, Stephen C. Music and Decadence in European Modernism: The Case of Central and Eastern Europe. Cambridge and New York: Cambridge University Press, 2010. 
Dreyfus, Laurence. "Siegfried's Masculinity," The Wagner Journal 4/3 (November, 2010): 4-26.

. Wagner and the Erotic Impulse. Cambridge, MA and London: Harvard University Press, 2010.

Edwards, Cyril, trans. The Nibelungenlied: The Lay of the Nibelungs. Oxford and New York: Oxford University Press, 2010.

Ellis, Katharine. "Wagnerism and Anti-Wagnerism in the Paris Periodical Press, 18521870." In Wagner zum Wagnérisme: Musik, Literatur, Kunst, Politik, eds. Annegret Fauser and Manuela Schwartz, 51-83. Leipzig: Leipziger Universitätsverlag, 1999.

Emslie, Barry. "Wagner: Race, Nation, Culture," The Wagner Journal 2/1 (March, 2008): 3-19.

- Richard Wagner and the Centrality of Love. Woodbridge, Suffolk and Rochester, NY: Boydell Press, 2010.

Erlich, Lothar. "Liszt und Goethe." In Franz Liszt und die Weimarer Klassik, ed. Detlef Altenburg, 33-45. Laaber: Laaber-Verlag, 1997.

Everist, Mark. Giacomo Meyerbeer and Music Drama in Nineteenth-Century Paris. Aldershot: Ashgate, 2005.

. "Grand Opéra - Petit Opéra: Parisian Opera and Ballet from the Restoration to the Second Empire," $19^{\text {th }}$-Century Music 33/3 (Spring 2010): 195-231.

Fauser, Annegret. “Cette musique sans tradition: Wagner's Tannhöuser and Its French Critics." In Music, Theater, and Cultural Transfer: Paris, 1830-1914, eds. Annegret Fauser and Mark Everist, 228-255. Chicago and London: University of Chicago Press, 2009.

and Thomas S. Grey. "Debacle at the Paris Operra: Tannhäuser and the French Critics, 1861." In Richard Wagner and His World, ed. Thomas S. Grey, 347-371. Princeton, NJ: Princeton University Press, 2009.

Fink, Bruce. The Lacanian Subject: Between Language and Jouissance. Princeton, NJ: Princeton University Press, 1995.

Fischer, Jens Malte. "Sprechgesang or Bel Canto: Toward a History of Singing Wagner." In Wagner Handbook. Translated by John Deathridge, eds. Ulrich Müller and Peter Wapnewski, 524-546. Cambridge, MA and London: Harvard University Press, 1992. 
Foucault, Michel. The Archaeology of Knowledge \& The Discourse on Language. Translated by A.M. Sheridan-Smith. New York: Pantheon Books, 1972. . The Foucault Reader, ed. Paul Rabinow. New York: Pantheon Books, 1984.

.The History of Sexuality Volume I: An Introduction (1978). Translated by Robert Hurley. New York: Vintage Books, 1990.

.The Order of Things: An Archaeology of the Human Sciences (1970). New York: Vintage Books, 1994.

. Discipline and Punish: The Birth of the Prison (1977). Translated by Alan Sheridan. New York: Vintage Books, 1995.

. "Of Other Spaces (1967), Heterotopias." Translated by Jay Miskowiec. http://foucault.info/documents/heteroTopia/foucault.heteroTopia.en.html. Accessed November 20, 2012.

Foster, Daniel H. Wagner's Ring Cycle and the Greeks. Cambridge and New York: Cambridge University Press, 2010.

Frank, Roberta. "Wagner's Ring, North-by-Northwest," University of Toronto Quarterly 74/2 (Spring 2005): 671-676.

Freud, Sigmund. The Standard Edition of the Complete Psychoanalytic Works of Sigmund Freud, 24 vols. Translated and edited by James Strachey. London: Hogarth Press, 1953-1974.

Fricke, Richard. Wagner in Rehearsal, 1875-1876: The Diaries of Richard Fricke. Translated by George R. Fricke, eds. James Deaville and Evan Baker. Stuyvesant, NY: Pendragon Press, 1998.

Frisch, Walter. German Modernism: Music and the Arts. Berkeley: University of California Press, 2005.

Fulcher, Jane F. "French Grand Opera and the Quest for a National Image: An Approach to the Study of Government-Sponsored Art," Current Musicology 35 (1983): 3445 .

. The Nation's Image: French Grand Opera as Politics and Politicized Art. Cambridge: Cambridge University Press, 1987.

Gabriel, Barbara. "The Wounds of Memory: Mavis Gallant's 'Baum, Gabriel (1935- ),' National Trauma, and Postwar French Cinema," Essays on Canadian Writing 80 (Fall 2003): 189-216. 
Garratt, James. Music, Culture and Social Reform in the Age of Wagner. Cambridge: Cambridge University Press, 2010.

Gerhard, Anselm. The Urbanization of Opera: Music Theater in Paris in the Nineteenth Century. Translated by Mary Whittall. Chicago and London: University of Chicago Press, 1998.

Gibbons, William. "Music of the Future, Music of the Past: Tannhäuser and Alceste at the Paris Opéra," $19^{\text {th }}$-Century Music 33/3 (Spring 2010): 232-246.

Gilman, Sander. The Jew's Body. New York and London: Routledge, 1991. . Freud, Race, and Gender. Princeton, NJ: Princeton University Press, 1993.

Gilloch, Graeme. Myth and Metropolis: Walter Benjamin and the City. Cambridge: Polity Press, 1996.

Goehr, Lydia. The Quest for Voice: On Music, Politics, and the Limits of Philosophy. Berkeley: University of California Press, 1998.

. "The Dangers of Satisfaction: On Songs, Rehearsals, and Repetition in Die Meistersinger." In Wagner's Meistersinger: Performance, History, Representation, ed. Nicholas Vazsonyi, 56-70. Rochester: University of Rochester Press, 2003.

. "From Opera to Music Drama: Nominal Loss, Titular Gain." In Richard Wagner and His World, ed. Thomas S. Grey, 65-86. Princeton, NJ and Oxford: Princeton University Press, 2009.

."-wie ihn uns Meister Dürer gemalt!' Contest, Myth, and Prophecy in Wagner's Die Meistersinger," Journal of the American Musicological Society 64/1 (Spring 2011): 51-117.

Gogröf-Vorhees, Andrea. Defining Modernism: Baudelaire and Nietzsche on Romanticism, Modernity, Decadence, and Wagner. New York: Peter Lang, 1999.

Gossett, Philip. "Becoming a Citizen: The Chorus in Risorgimento Opera," Cambridge Opera Journal 2/1 (March 1990): 41-64.

Gramit, David. Cultivating Music: The Aspirations, Interests, and Limits of German Musical Culture, 1770-1848. Berkeley: University of California Press, 2002.

Grey, Thomas S. Wagner's Musical Prose: Texts and Contexts. Cambridge: Cambridge University Press, 1995. 
. "Bodies of Evidence," review of Richard Wagner and the Anti-Semitic Imagination, by Marc A. Weiner. Cambridge Opera Journal 8/2 (July, 1996): 185-197.

, ed. Richard Wagner: Der fliegende Holländer. Cambridge: Cambridge University Press, 2000.

. "Wagner's Die Meistersinger as National Opera (1868-1945)." In Music \& German National Identity, eds. Celia Applegate \& Pamela Potter, 78-104. Chicago and London: University of Chicago Press, 2002.

. "Richard Wagner and the Legacy of French Grand Opera." In The Cambridge Companion to Grand Opera, ed. David Charlton, 321-343. Cambridge: Cambridge University Press, 2003.

- "Masters and Their Critics: Wagner, Hanslick, Beckmesser, and Die Meistersinger." In Wagner's Meistersinger: Performance, History, Representation, ed. Nicholas Vazsonyi, 165-189. Rochester, NY: University of Rochester Press, 2003.

. "Meister Richard's Apprenticeship: The Early Operas (1833-1840)." In The Cambrige Companion to Wagner, ed. Thomas S. Grey, 18-46. Cambridge: Cambridge University Press, 2008.

. "Leitmotif, Temporality, and Musical Design in the Ring." In The Cambridge Companion to Wagner, ed. Thomas S. Grey, 85-114. Cambridge: Cambridge University Press, 2008.

- "Wagner Introduces Wagner (and Beethoven): Program Notes Written for Concert Performances by and of Richard Wagner, 1846-1880." In Richard Wagner and His World, ed. Thomas S. Grey, 479-520. Princeton, NJ: Princeton University Press, 2009.

Groos, Arthur. "Constructing Nuremberg: Typological and Proleptic Communities in Die Meistersinger," $19^{\text {th }}$-Century Music 16/1 (Summer 1992): 18-34.

. Romancing the Grail: Genre, Science, and Quest in Wolfram's Parzival. Ithaca, NY and London: Cornell University Press, 1995.

Gunning, Tom. "An Aesthetic of Astonishment: Early Film and the (In)Credulous Spectator," Art and Text 34 (Spring 1989): 31-45.

- "The Cinema of Attractions: Early Film, Its Spectator, and the Avant-Garde" (1986). In Early Cinema: Space, Frame, Narrative, ed. Thomas Elsaesser, 56-62. London: BFI, 1990. 
Hamilton, Kenneth. "Wagner and Liszt: Elective Affinities." In Richard Wagner and His World, ed. Thomas S. Grey, 27-64. Princeton, NJ: Princeton University Press, 2009.

Hanslick, Eduard. Music Criticisms - 1846-99. Translated and edited by Henry Pleasants. Harmondsworth, UK: Penguin, 1963.

. On the Musically Beautiful: A Contribution Towards the Revision of the Aesthetics of Music (1891). Translated and edited by Geoffrey Payzant. Indianapolis: Hackett, 1986.

Hartford, Robert, ed. Bayreuth - The Early Years: An Account of the Early Decades of the Wagner Festival as seen by the Celebrated Visitors \& Participants. Cambridge: Cambridge University Press, 1980.

Harvey, David. Paris, the Capital of Modernity. New York and London: Routledge, 2003.

Hegel, Georg Wilhelm Friedrich. Phenomenology of Spirit (1807). Translated by A.V. Miller. Oxford: Clarendon Press, 1977.

Herder, Johann Gottfried. Philosophical Writings. Translated and edited by Michael N. Foster. Cambridge: Cambridge University Press, 2002.

Hartwich, Wolf-Daniel. "Deutsche Mythologie": Die Erfindung einer nationalen Kunstreligion. Berlin: Philo Verlagsgesellschaft, 2000.

. "Musik und Religion: Richard Wagners Parsifal," Wagnerspectrum 5/2 (2009): 185-197.

Hibberd, Sarah. French Grand Opera and the Historical Imagination. Cambridge: Cambridge University Press, 2009.

Higonnet, Patrice L.R. Paris: Capital of the World. Translated by Arthur Goldhammer. Cambridge, MA: Belknap Press, 2002.

Hobsbawm, Eric and Terence Ranger, eds. The Invention of Tradition. Cambridge: Cambridge University Press, 1983.

Hobsbawm, Eric. "The Nation as Invented Tradition." In Nationalism, eds. John Hutchinson and Anthony D. Smith, 76-83. Oxford and New York: Oxford University Press, 1994.

Hoeckner, Berthold. "Elsa Screams, or The Birth of Music Drama," Cambridge Opera Journal 9/2 (July, 1997): 97-132. 
Hohendahl, Peter Uwe. "Reworking History: Wagner's German Myth of Nuremberg." In Re-Reading Wagner, eds. Reinhold Grimm and Jost Hermand, 39-60. Madison, WI: University of Wisconsin Press, 1993.

Huckel, Oliver. Parsifal: A Mystical Drama by Richard Wagner Retold in the Spirit of the Bayreuth Interpretation by Oliver Huckel. New York: T.Y. Crowell, 1903.

Huebner, Steven. "Opera Audiences in Paris 1830-1870," Music \& Letters 70/2 (May 1989): 206-225.

. French Opera at the Fin-de-siècle: Wagnerism, Nationalism, and Style. Oxford and New York: Oxford University Press, 1999.

. "After 1850 at the Paris Opéra: Institution and Repertory." In The Cambridge Companion to Grand Opera, ed. David Charlton, 291-317. Cambridge: Cambridge University Press, 2003.

Hutcheon, Linda and Michael Hutcheon: Opera: Desire, Disease, Death. Lincoln and London: University of Nebraska Press, 1996.

. Bodily Charm: Living Opera. Lincoln and London: University of Nebraska Press, 2000.

Huymans, J.K., Teodor de Wyzewa, and Edouard Dujardin. "The Revue wagnérienne: Symbolism, Aestheticism, and Germanophilia." In Richard Wagner and His World, ed. Thomas S. Grey, 372-387. Princeton, NJ: Princeton University Press, 2009.

Huyssen, Andreas. "Monumental Seduction," New German Critique 69 (Autumn 1996): 181-200.

Jander, Owen and Ellen T. Harris. "Heldentenor." In Oxford Music Online. Accessed December 4, 2012.

Jay, Martin. Downcast Eyes: The Denigration of Vision in Twentieth-Century French Thought. Berkeley: University of California Press, 1994.

Jones, Colin. Paris: The Biography of a City. New York: Viking, 2005.

Jordan, David P. Transforming Paris: The Life and Labors of Baron Haussmann. New York: Free Press, 1995.

Jung, C.G. Psychology of the Unconscious: A Study of the Transformations and Symbolisms of the Libido (1911). Translated by Beatrice M. Hinkle. New York: Dodd, Mead, and Company, 1925. 
Jung Emma and Marie-Louise von Franz. The Grail Legend (1970). Translated by Andrea Dykes. Princeton, NJ: Princeton University Press, 1998.

Keiler, Allan. "Liszt and the Weimar Hoftheater," Studia Musicologica Academiae Scientarium Hungaricae 28 (1986): 431-450.

Kennaway, James. "Degenerate Religion and Masculinity in Parsifal Reception," Current Musicology 88 (Fall 2009): 35-62.

Kienzle. Ulrike. "Parsifal and Religion: A Christian Music Drama?" In A Companion to Wagner's Parsifal, eds. William Kinderman and Katherine R. Syer, 81-130. Rochester, NY: Camden House, 2005.

Kinderman, William. "Die Entstehung der 'Parsifal' - Musik," Archiv für Musikwissenschaft 52/1 (1995): 66-97.

. "Die Entstehung der 'Parsifal' - Musik (Fortsetszung und Schluß)," Archiv für Musikwissenschaft 52/2 (1995): 145-165.

. "Introduction: The Challenge of Wagner's Parsifal." In A Companion to Wagner's Parsifal, eds. William Kinderman and Katherine R. Syer, 1-28. Rochester, NY: Camden House, 2005.

Knittel, K.M. "Wagner, Deafness, and the Reception of Beethoven's Late Style," Journal of the American Musicological Society 51/1 (Spring 1998): 49-82

Knapp, Raymond. "Reading Gender in Late Beethoven: An die Freude and An die ferne Geliebte," Acta Musicologica 75/1 (2003): 45-63.

Koepnick, Lutz. "Stereoscopic Vision: Sight and Community in Die Meistersinger." In Wagner's Meistersinger: Performance, History, Representation, ed. Nicholas Vazsonyi, 73-97. Rochester, NY: University of Rochester Press, 2003.

Köhler, Joachim. Richard Wagner: The Last of the Titans. Translated by Stewart Spencer. New Haven and London: Yale University Press, 2004.

Kolb, Katherine. "Flying Leaves: Between Berlioz and Wagner," $19^{\text {th }}$-Century Music 33/1 (Summer 2009): 25-61.

Koshar, Rudy. Germany's Transient Pasts: Preservation and National Memory in the Twentieth Century. Chapel Hill: University of North Carolina Press, 1998.

. From Monuments to Traces: Artifacts of German Memory, 1870-1990. Berkeley: University of California Press, 2000. 
Kraft, G. and Dieter Härtwig. "Weimar." In Oxford Music Online. Accessed December 30,2012

Kramer, Lawrence. Classical Music and Postmodern Knowledge. Berkeley: University of California Press, 1995.

. Opera and Modern Culture: Wagner and Strauss. Berkeley: University of Califormia Press, 2004.

. "The Talking Wound and the Foolish Question: Symbolization in Parsifal," The Opera Quarterly 22/2 (Spring 2006): 208-229.

. "Wagner's Gold Standard: Tannhäuser and the General Equivalent," Cambridge Opera Journal 21/2 (2010): 139-158.

Kreuzer, Gundula. "Wagner-Dampf: Steam in Der Ring des Nibelungen and Operatic Production," The Opera Quarterly 27/2-3 (Spring/Summer 2011): 179-218.

Kühnel, Jürgen. "The Prose Writings." In Wagner Handbook. Translated by John Deathridge, eds. Ulrich Müller and Peter Wapnewski, 565-651. Cambridge, MA and London: Harvard University Press, 1992.

Lacan, Jacques. The Four Fundamental Concepts of Psychoanalysis (1977), ed. JacquesAlain Miller. Translated by Alan Sheridan. New York and London: W.W. Norton, 1981.

. Ecrits: A Selection. Translated by Bruce Fink. New York and London: W.W. Norton, 2004.

Lacombe, Hervé. The Keys to French Opera in the Nineteenth Century. Translated by Edward Schneider. Berkeley: University of California Press, 2001.

Laplanche, Jean and J.B. Pontalis. The Language of Psycho-Analysis. New York: W.W. Norton, 1973.

Leppert, Richard. The Sight of Sound: Music, Representation, and the History of the Body. Berkeley: University of California Press, 1995.

Levin, David J. "Reading Beckmesser Reading: Antisemitism and Aesthetic Practice in The Mastersingers of Nuremberg," New German Critique 69 (Autumn, 1996): 127-146.

. Unsettling Opera: Staging Mozart, Verdi, Wagner, and Zemlinsky. Chicago and London: University of Chicago Press, 2007.

Lincoln, Bruce. Theorizing Myth: Narrative, Ideology, and Scholarship. Chicago and London: University of Chicago Press, 1999. 
Linke, Uli. Blood and Nation: The European Aesthetics of Race. Philadelphia: University of Pennsylvania Press, 1999.

Liszt, Franz. Sämtliche Schriften - Band 3: Die Goethe-Stiftung, ed. Detlef Altenburg and Britta Schilling-Wang. Wiesbaden: Breitkopf \& Härtel, 1997.

. Sämtliche Schriften - Band 4: Lohengrin und Tannhäuser von Richard Wagner, ed. Rainer Kleinertz. Wiesbaden: Breitkopf \& Härtel, 1989.

."Liszt on Lohengrin (or: Wagner in Absentia)," ed. David Trippett, The Wagner Journal 4/1 (March, 2010): 4-21.

. "Liszt on Lohengrin (or: Wagner in Absentia): Part 2," ed. David Trippett, The Wagner Journal 4/2 (July, 2010): 28-41.

. "Liszt on Lohengrin (or: Wagner in Absentia): Part 3," ed. David Trippett, The Wagner Journal 4/3 (November, 2010): 43-57.

Magee, Elizabeth. Richard Wagner and the Nibelungs. Oxford: Clarendon Press, 1990.

Magee, Bryan. The Tristan Chord: Wagner and Philosophy. New York: Metropolitan Books, 2000.

Mann, Thomas. Pro and Contra Wagner. Translated by Allan Blunden. London: Faber and Faber, 1985.

McClatchie, Stephen. Analyzing Wagner's Operas: Alfred Lorenz and German Nationalist Ideology. Rochester, NY: University of Rochester Press, 1998.

. "Performing Germany in Wagner's Die Meistersinger von Nürnberg." In The Cambridge Companion to Wagner, ed. Thomas S. Grey, 134-150. Cambridge: Cambridge University Press, 2008.

McClary, Susan. Feminine Endings: Music, Gender, \& Sexuality. Minneapolis and London: University of Minnesota Press, 1991.

Meinecke, Friedrich. Cosmopolitanism and the National State. Translated by Robert B. Kimber. Princeton, NJ: Princeton University Press, 1970.

Mertens, Volker. Der Gral: Mythos und Literatur. Stuttgart: Reclam, 2003. . "Wie christlich ist Wagners Gral?" Wagnerspectrum 4/1 (2008): 91-115. 
Metzger, Reinhard. "Eine geheime Botschaft in Die Meistersinger und Parsifal: Jüdisches, Christliches und Antisemtisches in zwei Werken von Richard Wagner," The German Quarterly 80/1 (Winter 2007): 20-41.

Meyer, Stephen C. Carl Maria von Weber and the Search for a German Opera. Bloomington and Indianapolis: Indiana University Press, 2003.

. "Illustrating Transcendence: Parsifal, Franz Stassen, and the Leitmotif," The Musical Quarterly 92/1-2 (2009): 9-32. . "Parsifal's Aura," 19 $9^{\text {th }}$-Century Music 33/2 (Fall 2009): 151-172.

Millington, Barry. "Nuremberg Trial: Is There Anti-Semitism in Die Meistersinger?" Cambridge Opera Journal 3/3 (November 1991): 247-260.

, ed. The Wagner Compendium. London: Thames \& Hudson, 1992.

.Wagner - Revised Edition. Princeton, NJ: Princeton University Press, 1992.

. "After the Revolution: The Ring in the Light of Wagner's Dresden and Zurich Projects," University of Toronto Quarterly 74/2 (Spring 2005): 677-692.

. "Der Ring des Nibelungen: Conception and Interpretation." In The Cambridge Companion to Wagner, ed. Thomas S. Grey, 74-84. Cambridge: Cambridge University Press, 2008.

. "Tannhäuser." In Grove Music Online. Accessed January 16, 2013.

Minor, Ryan. "National Memory, Public Music: Commemoration and Consecration in Nineteenth-Century German Choral Music." Ph.D. diss., University of Chicago, 2005.

. "Wagner's Last Chorus: Consecrating Space and Spectatorship in Parsifal," Cambridge Opera Journal 17/1 (2005): 1-36.

- Choral Fantasies: Music, Festivity, and Nationhood in Nineteenth-Century Germany. Cambridge: Cambridge University Press, 2012.

Mosse, George L. The Nationalization of the Masses: Political Symbolism and Mass Movements in Germany from the Napoleonic Wars Through the Third Reich. New York: Howard Fertig, 1975.

. Nationalism and Sexuality: Respectability and Abnormal Sexuality in Modern Europe. New York: Howard Fertig, 1985. 
Nattiez, Jean-Jacques. Wagner Androgyne: A Study in Interpretation. Translated by Stewart Spencer. Princeton, NJ: Princeton University Press, 1993.

Nietzsche, Friedrich Wilhelm. Nietzche Contra Wagner. In The Portable Nietzsche. Translated and edited by Walter Kauffmann. New York: Penguin Books, 1982.

. Untimely Meditations. Translated by R.J. Hollingdale. Cambridge: Cambridge University Press, 1983.

. The Birth of Tragedy and The Case of Wagner. In The Basic Writings of Nietzsche. Translated and edited by Walter Kauffmann. New York: Modern Library, 2000.

Nora, Pierre. "Between Memory and History: Les Lieux de Mémoire," Representations 26 (1989): 7-25.

. Realms of Memory: Rethinking the French Past, 3 vols. Translated by Arthur Goldhammer, ed. Lawrence D. Kritzman. New York: Columbia University Press, 1996-1998.

Nowak, Adolf. "Wagners Parsifal und die Idee der Kunstreligion." In Richard Wagner: Werk und Wirkung, ed. Carl Dahlhaus, 161-175. Regensburg: G. Bosse, 1971.

Osthövener, Claus-Dieter. "Konstellation der Erlösungsgedankens," Wagnerspectrum 5/2 (2009): 51-80.

Papayanis, Nicholas. Planning Paris Before Haussmann. Baltimore: Johns Hopkins University Press, 2004.

Parakilas, James. "Political Representation and the Chorus in Nineteenth-Century Opera," $19^{\text {th }}$.Century Music 16/2 (Fall 1992): 181-202.

. "The Chorus." In The Cambridge Companion to Grand Opera, ed. David Charlton, 76-92. Cambridge: Cambridge University Press, 2003.

Parker, Andrew and Eve Kosofsky Sedgwick, eds. Performativity and Performance. New York and London: Routledge, 1995.

Pasler, Jann. Composing the Citizen: Music as Public Utility in Third Republic France. Berkeley: University of California Press, 2009.

Pederson, Sanna. "Beethoven and Masculinity." In Beethoven and His World, ed. Scott Burnham and Michael P. Steinberg, 313-331. Princeton, NJ: Princeton University Press, 2000. 
Pendle, Karin. Eugène Scribe and French Opera of the Nineteenth Century. Ann Arbor, MI: UMI Research Press, 1979.

Poizat, Michel. The Angel's Cry: Beyond the Pleasure Principle in Opera. Translated by Arthur Denner. Ithaca, NY: Cornell University Press, 1992.

Porges, Heinrich. Wagner Rehearsing the Ring: An Eye-Witness Account of the Stage Rehearsals of the First Bayreuth Festival (1881-1896). Translated by Robert L. Jacobs. Cambridge: Cambridge University Press, 1983.

Potter, John. Tenor: History of a Voice. New Haven and London: Yale University Press, 2009.

Prendergast, Christopher. Paris and the Nineteenth Century. Oxford and Cambridge, MA: Blackwell, 1992.

Raff, Joachim. Die Wagnerfrage, kritisch beleuchtet, vol. 1. Braunschweig: Friedrich Vieweg und Sohn, 1854.

Rehding, Alexander. Music and Monumentality: Commemoration and Wonderment in Nineteenth-Century Germany. Oxford and New York: Oxford University Press, 2009.

Richter, Simon, ed. The Literature of Weimar Classicism. Rochester, NY: Camden House, 2005.

Rieger, Eva. Richard Wagner's Women. Translated by Chris Walton. Woodbridge, UK and Rochester, NY: Boydell Press, 2011.

Rose, Paul Lawrence. Wagner: Race and Revolution. New Haven and London: Yale University Press, 1992.

Salmi, Hannu. Imagined Germany: Richard Wagner's National Utopia. New York: Peter Lang, 1999.

Schleiermacher, Friedrich. On Religion: Speeches to its Cultural Despisers. Translated by John Oman. New York: Harper \& Brothers, 1958.

Schulze, Hagen. The Course of German Nationalism from Frederick the Great to Bismarck, 1763-1867. Translated by Sarah Hanbury-Tenison. New York: Cambridge University Press, 1991.

Seedorf, Thomas. "Ein neuer Held! - Ein neuer Held? Zur aktuellen Diskussion über ein Stimmfach," Wagnerspectrum 8/1 (2012): 55-67. 
Shaw, George Bernard. "The Perfect Wagnerite: A Commentary on The Nibelung's Ring." In Shaw's Music: The Complete Music Criticism in Three Volumes Volume III, ed. Dan H. Laurence, 408-545. London: Bodley Head, 1981.

Sheridan, Daniel. Review of Wagner - Beyond Good and Evil, by John Deathridge. Intersections: Canadian Journal of Music 30/1 (2010): 137-142.

Silverman, Kaja. The Subject of Semiotics. New York and Oxford: Oxford University Press, 1983.

- The Acoustic Mirror: The Female Voice in Psychoanalysis and Cinema. Bloomington: Indiana University Press, 1988.

Simmel, Georg. "The Metropolis and Mental Life" (1903). In The Sociology of Georg Simmel. Translated and edited by Kurt H. Wolff. New York: The Free Press, 1964.

Smart, Mary Ann. "Roles, Reputations, Shadows: Singers at the Opéra, 1828-49." In The Cambridge Companion to Grand Opera, ed. David Charlton, 108-128. Cambridge: Cambridge University Press, 2003.

. Mimomania: Music and Gesture in Nineteenth-Century Opera. Berkeley: University of California Press, 2004.

Smith, Marian. "Dance and Dancers." In The Cambridge Companion to Grand Opera, ed. David Charlton, 93-107. Cambridge: Cambridge University Press, 2003.

Spencer, Stewart. "Wagner's Nuremberg," Cambridge Opera Journal 4/1 (March, 1992): 21-41.

Spotts, Frederic. Bayreuth: A History of the Wagner Festival. New Haven: Yale University Press, 1994.

Stanley, Glenn. "Parsifal: Redemption and Kunstreligion." In The Cambridge Companion to Wagner, ed. Thomas S. Grey, 151-175. Cambridge: Cambridge University Press, 2008.

Steane, J.B. "Fach." In Grove Music Online. Accessed May 9, 2012.

Steinberg, Michael P. "Music Drama and the End of History," New German Critique 69 (Autumn, 1996): 163-180.

Stollberg, Ame, “'Hartnäcking auf dem Christlichen Standpunkte': Wagners Lohengrin am Ende der absoluten Musik," Archiv für Musikwissenschaft 65/1 (2008): 45-60. 
Syer, Katherine Rae. "Altered States: Musical and Psychological Processes in Wagner." Ph.D. diss., University of Victoria, 1999.

. "Unseen Voices: Wagner's Musical-Dramatic Shaping of the Grail Scene of Act

I." In A Companion to Wagner's Parsifal, eds. William Kinderman and Katherine R. Syer, 177-214. Rochester, NY: Camden House, 2005.

. "From Page to Stage: Wagner as Regisseur." In Richard Wagner and His World, ed. Thomas S. Grey, 3-26. Princeton, NJ and Oxford: Princeton University Press, 2009.

Tambling, Jeremy. Opera and the Culture of Fascism. New York: Oxford University Press, 1996.

Taruskin, Richard. The Oxford History of Western Music - Volume 2: Music in the Seventeenth and Eighteenth Centuries (2005). Oxford and New York: Oxford University Press, 2010.

. The Oxford History of Western Music - Volume 3: Music in the Nineteenth Century (2005). Oxford and New York: Oxford University Press, 2010.

Theile, Gert. "The Weimar Myth: From City of the Arts to Global Village." In Unwrapping Goethe's Weimar: Essays in Cultural Studies and Local Knowledge, ed. Burkhard Henke, Susanne Kord, and Simon Richter, 310-327. Rochester, NY: Camden House, 2000.

Theweleit, Klaus. Male Fantasies, 2 vols. Translated by Stephen Conway, Erica Carter, and Chris Turner. Minneapolis: University of Minnesota Press, 1987-1989.

Tomlinson, Gary. Metaphysical Song: An Essay on Opera. Princeton, NJ: Princeton University Press, 1999.

Treadwell, James. Interpreting Wagner. New Haven, CT and London: Yale University Press, 2003.

Trippett, David. "Lohengrin at the Weimar Hoftheater: the Politics of a Premiere," Journal of the American Liszt Society 61-62 (2010-2011): 135-158.

Turbow, Gerald D. "Art and Politics: Wagnerism in France." In Wagnerism in European Culture and Politics, eds. David C. Large and William Weber, 134-166. Ithaca, NY and London: Cornell University Press, 1984.

Tusa, Michael C. "Cosmopolitanism and the National Opera: Weber's Der Freischütz," The Journal of Interdisciplinary History 36/3 (Winter 2006): 483-506. 
Uhlig, Theodor. Musikalische Schriften, ed. Ludwig Frankenstein. Regensburg: G. Bosse, 1913.

Vaget, Hans Rudolf. “'Du warst mein Feind von je': The Beckmesser Controversy Revisited." In Wagner's Meistersinger: Performance, History, Representation, ed. Nicholas Vazsonyi, 190-208. Rochester, NY: University of Rochester Press, 2003.

Vazsonyi, Nicholas. "Eine Pilgerfahrt zu Wagner: Kunstreligion und ihre Vermarktung," Wagnerspectrum 5/2 (2009): 199-218.

. Richard Wagner: Self-Promotion and the Making of a Brand. Cambridge: Cambridge University Press, 2010.

Verdino-Süllwold, Carla Maria. "The Heldentenor in the Twentieth Century: Refining a Rare Breed," The Opera Journal 20/3 (1987): 24-40.

Wagner, Wolfgang. Carl Maria von Weber und die deutsche Nationaloper. Mainz: Schott, 1994

Walker, Alan. Franz Liszt - Volume Two: The Weimar Years 1848-1861 (1989). Ithaca, NY: Cornell University Press, 1993.

Warrack, John. Richard Wagner: Die Meistersinger von Nümberg. Cambridge: Cambridge University Press, 1994.

- German Opera: From the Beginnings to Wagner. Cambridge: Cambridge University Press, 2001.

Weber, William. Music and the Middle Class: The Social Structure of Concert Life in London, Paris and Vienna between 1830 and 1848 (1975). Aldershot: Ashgate, 2004.

Weiner, Marc A. Richard Wagner and the Anti-Semitic Imagination. Lincoln: University of Nebraska Press, 1995.

Webb, Allen-Cary. Making Subject(s): Literature and the Emergence of National Identity. New York and London: Garland Publishing, 1998.

Weber, Samuel. "The Ring as Deconstruction of Modernity: Reading Wagner With Benjamin." In Sound Figures of Modernity: German Music and Philosophy, eds. Jost Hermand and Gerhard Richter, 106-123. Madison, WI: University of Wisconsin Press, 2006. 
Williams, Simon. "The Spectacle of the Past in Grand Opera." In The Cambridge Companion to Grand Opera, ed. David Charlton, 58-75. Cambridge: Cambridge University Press, 2003.

Wagner and the Romantic Hero. Cambridge: Cambridge University Press, 2004.

Williamson, George, S. The Longing for Myth in Germany: Religion and Aesthetic Culture from Romanticism to Nietzsche. Chicago and London: University of Chicago Press, 2004.

Winkler, Gerhard J. "Liszt und Wagner: Notizen zu einer problematischen Beziehung," Österreichische Musikzeitschrift 41/2 (1986): 83-89.

. "Liszt's 'Weimar Mythology."' In Liszt and His World, ed. Michael Saffle, 6173. Stuyvesant, NY: Pendragon Press, 1998.

Wolfram, von Eschenbach. Parzival and Titurel. Translated by Cyril Edwards. Oxford and New York: Oxford University Press, 2006.

Zika, Charles. Exorcising Our Demons: Magic, Witchcraft, and Visual Culture in Early Modern Europe. Leiden and Boston: Brill, 2003.

Žižek, Slavoj. "'The Wound Is Healed Only by the Spear That Smote You': The Operatic Subject and Its Vicissitudes." In Opera Through Other Eyes, ed. David J. Levin, 177-214. Stanford, CA: Stanford University Press, 1994.

. "There is No Sexual Relationship': Wagner as a Lacanian," New German Critique 69 (Autumn, 1996): 7-35.

and Mladen Dolar. Opera's Second Death. New York: Routledge, 2002. 